\author{
Universidade de São Paulo \\ Escola de Comunicações e Artes
}

Silvia Noriko Tagusagawa

\title{
A Cerâmica e suas poéticas \\ Transcender limites
}

\author{
Área de concentração: Poéticas visuais \\ Linha de Pesquisa: L1 Processos de criação em artes visuais
}




\title{
Silvia Noriko Tagusagawa
}

\section{A Cerâmica e suas poéticas: Transcender limites}

\author{
Área de concentração: Poéticas visuais \\ Linha de Pesquisa: L1 Processos de criação em artes visuais
}

Tese de doutorado apresentado ao Programa de Pós-Graduação em Artes, Área de Concentração em Poéticas Visuais, Linha de Pesquisa Processos de Criação em Artes Visuais, da Escola de Comunicações e Artes da Universidade de São Paulo, como exigência parcial para obtenção do Título de Doutor em Artes, sob a orientação da Profa. Dra. Norma Tenenholz Grinberg.

Apoio:

FAPESP - Fundação de Amparo à pesquisa do Estado de São Paulo (Processo nº 2012/05044-3) 
São Paulo, de de 2015 . 
Dedico este trabalho Aos grandes artistas André Yassuda, Kimi Nii, Laerte Ramos, Marco Paulo Rolla, Máyy Koffler, Miguel dos Santos e Norma Grinberg. Aos amores da minha vida: Eduardo, Ana e Carol. 


\section{Agradecimentos}

À Profe. . Norma Grinberg, grande mestre que muito me ensina, apoia e inspira, contribuindo para meu crescimento artístico, profissional e pessoal.

Aos artistas André Yassuda, Kimi Nii, Laerte Ramos, Marco Paulo Rolla, Máyy Koffler, Miguel dos Santos e Norma Grinberg pela generosidade em doar preciosos momentos de suas vidas em colaborações fundamentais para esta pesquisa e, por terem mostrado a nós a riqueza poética de seus universos.

À FAPESP - Fundação de Amparo à pesquisa do Estado de São Paulo (Processo no 2012/05044-3) - cujo apoio foi fundamental para o desenvolvimento desta pesquisa.

À Prof ${ }^{a}$ Dr ${ }^{a}$ Cristiane Aun Bertoldi, pela amizade, conhecimento e motivação.

À Prof ${ }^{a} \mathrm{Dr}^{\mathrm{a}}$ Lalada Dalglish que ajudou a abrir meus horizontes durante a graduação e despertou em mim a paixão pela Cerâmica.

À Prof $\stackrel{a}{a}$. Dr ${ }^{a}$. Cecília Almeida Salles cujos ensinamentos foram grandes inspirações para a realização deste trabalho.

Ao Prof. Dr. Evandro Carlos Jardim pelas palavras inspiradoras e motivadoras que contribuem à poética e ao fazer artístico.

À Rita Braga, pelo precioso apoio, dedicação, incentivo e revisão deste trabalho.

À Pinacoteca do Estado de São Paulo e ao Centro Cultural Banco do Brasil de São Paulo que autorizaram o registro fotográfico das obras de Laerte Ramos e Kimi Nii.

À Cláudia e Marcia que sempre estiveram presentes nos momentos felizes e desafiadores.

À Rosilene e Dona Magali, pela acolhida e pelas deliciosas conversas que tivemos durante minha estadia em João Pessoa.

Ao Luíz Puntel pelas deliciosas conversas que ajudaram nas reflexões. 
O apoio de Solange, Stela e Regina do Departamento de Artes Plásticas da ECA.

À minha mãe Idalina e meu pai Edmundo (in memoriam) que sempre estiveram ao meu lado apoiando.

À Dona Eliane e à Lila pelo carinho e dedicação à minha família.

Ao Eduardo, meu amor e companheiro que ajuda a completar a minha existência e sempre me animou, aconselhou e apoiou incondicionalmente todos os meus projetos.

Às minhas queridas e amadas Ana e Carol, pela compreensão, alegria e paciência que tiveram durante todo processo deste trabalho. 
"Preservar é aprender Aprender é praticar Praticar é repetir Repetir é vivenciar Vivenciar é crise Crise é prova

Prova é fortalecimento Fortalecimento é criar no novo Criar no novo é transformar Transformar é início e fim ao mesmo tempo"

Rudolf Steiner 


\section{Resumo}

Esta pesquisa tem como objetivo refletir sobre a Poética e sobre a Técnica que envolvem a Cerâmica como meio de expressão. Tal reflexão foi feita por meio da análise de depoimentos de sete artistas, bem como da observação das singularidades de seus trabalhos em cerâmica. Entre os critérios para seleção dos artistas estão o reconhecimento no meio artístico e a ousadia ao transcenderem os limites técnicos conhecidos.

\section{Palavras-chave}

Cerâmica, arte contemporânea, poética, escultura, instalação, tridimensional, universo artístico, processo de criação, transcender limites. 


\section{Abstract}

This research aims to reflect about the Poetics and the Technical which involve Ceramics as a means of expression. This reflection was made by analyzing seven artists' testimonies as well as the observation of singularities of their ceramic works. Among the criteria for the artists selection is their recognition in the artistic world and the daring to transcend the known technical limits.

\section{Keywords}

Ceramics, contemporary art, poesy, sculpture, installation, three-dimensional, artistic world, creative process, transcending limits. 
INTRODUÇÃO.................................................................................................................12

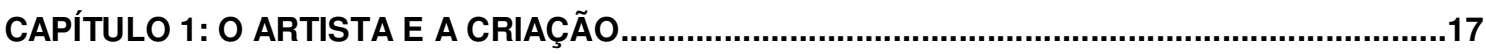

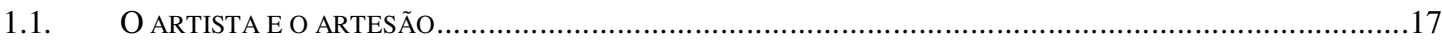

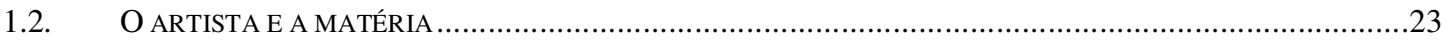

\section{CAPÍTULO 2: O ARTISTA E A MÃO INTELIGENTE - PROCESSO DE CRIAÇÃO NA CERÂMICA28}

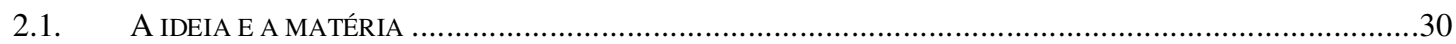

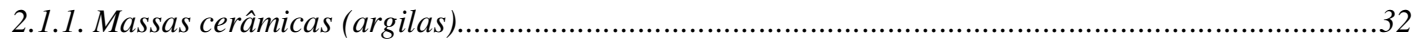

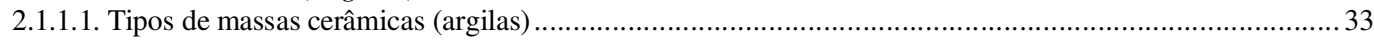

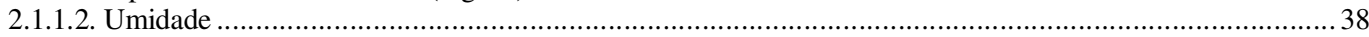

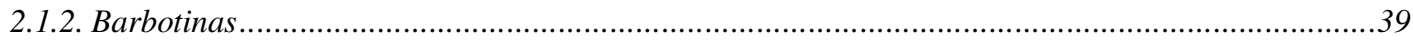

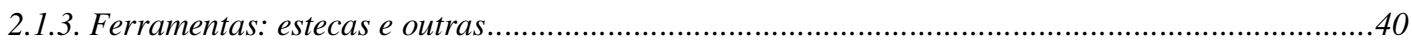

2.2. TÉCNICAS DE MODELAGEM, APLICAÇÃO DE CORES E TEXTURAS NA CERÂMICA ……..............................41

2.2.1. Técnicas de modelagem manual ..............................................................................................42

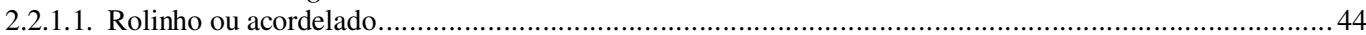

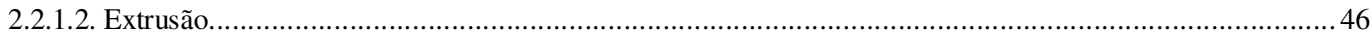

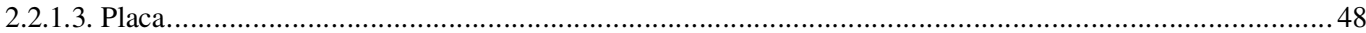

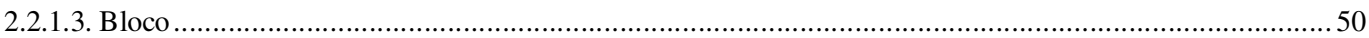

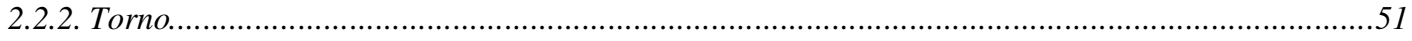

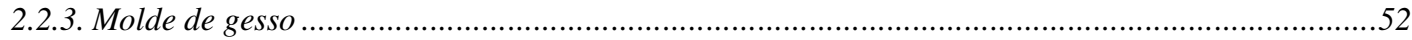

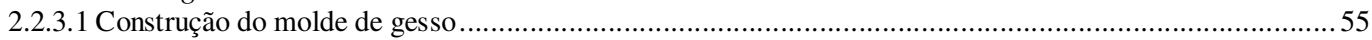

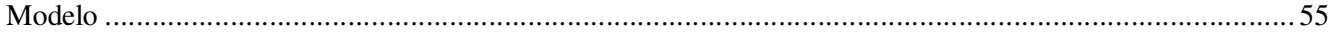

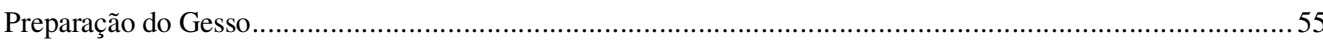

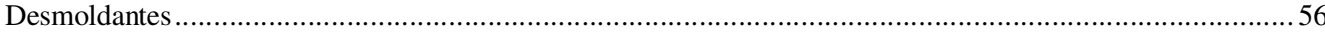

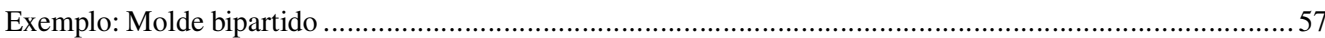

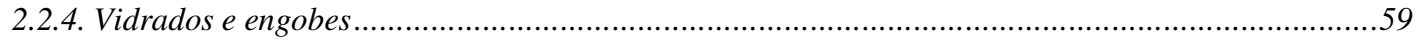

2.2.4.1. Vidrados Cerâmicos ................................................................................................. 59

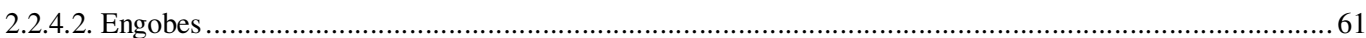

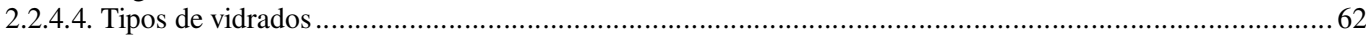

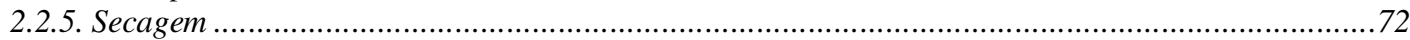

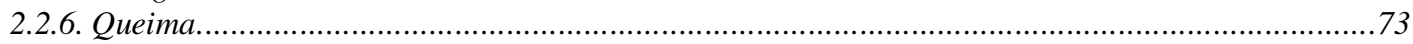

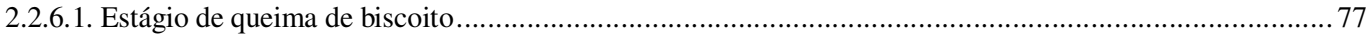

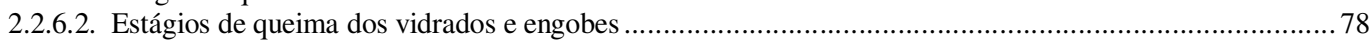

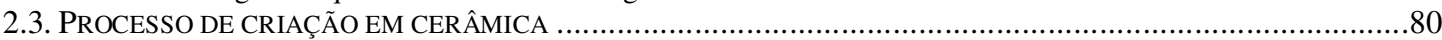

\section{CAPÍTULO 3: SETE ARTISTAS - HISTÓRIAS DE VIDA E O UNIVERSO DA CERÂMICA ..............85}

3.1 ANDRÉ YASSUdA (PINDAMONHANGABA, SÃo PAUlO, 1969): O GESTUAL NO BARRO E A ESSÊNCIA DA

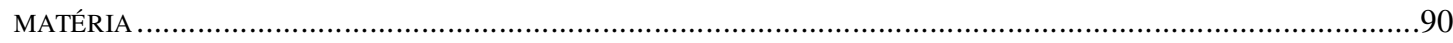

3.1.1. Poética e processo de André Yassuda ..............................................................................99

3.1.2. Entrevista com André Yassuda (São Paulo, 08/05/2013) .........................................................103

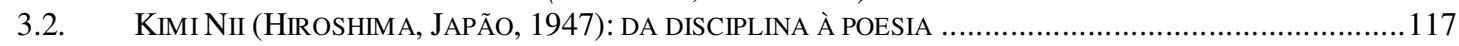

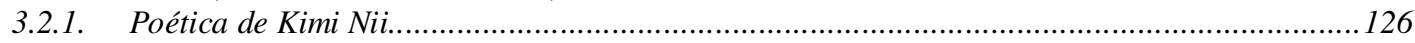

3.2.2. Entrevista com Kimi Nii (São Paulo, 12/06/2013)........................................................... 130

3.3. Laerte Ramos (SÃo PAulo, SÃo PAulo, 1978) : ÍCONES CERÂMicos .......................................152

3.3.1. Poética de Laerte Ramos.................................................................................................... 160

3.3.2. Entrevista com Laerte Ramos (São Paulo, 04/12/2013)....................................................... 166

3.4. Marco Paulo Rolla (São Domingos do Prata, Minas Gerais, 1967) : Simbologias, drama

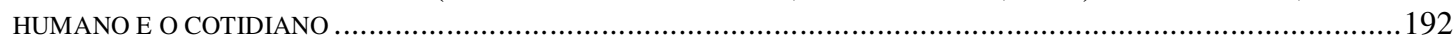

3.4.1. Poética de Marco Paulo Rolla................................................................................................... 199

3.4.2. Entrevista com Marco Paulo Rolla (Belo Horizonte, 22/05/2013) .............................................206

3.5. MÁYY KOFFler (ASSUnÇÃO, PARAGUAi, 1952): O SUBliME E DELICADO....................................224

3.5.1. Poética de Máyy Koffler..................................................................................................231

3.5.2. Entrevista com Máyy Kóffler (São Paulo, 19/08/2013)..........................................................240

3.6. Miguel dos Santos (CARuaru, Pernambuco 1944): Totens E GUERREIROS.............................262

3.6.1. Poética de Miguel dos Santos.................................................................................................2 271

3.6.2. Entrevista com Miguel dos Santos (João Pessoa, 27/09/2013) ...............................................276 
3.7. NORMA GrinBerg (COChabAMBA, Bolívia, 1951): Formas EM INFINITA METAMORFOSE............294

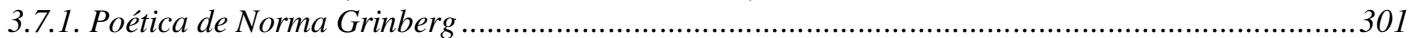

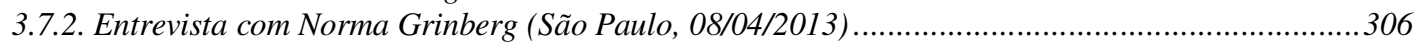

CAPITULO 4: CONEXÕES........................................................................................................319

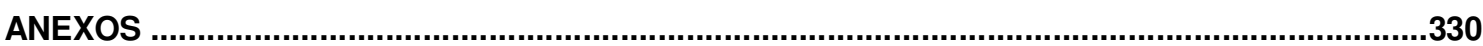

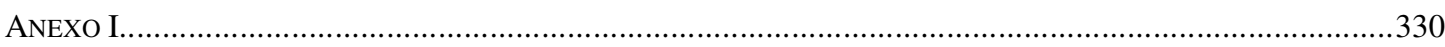

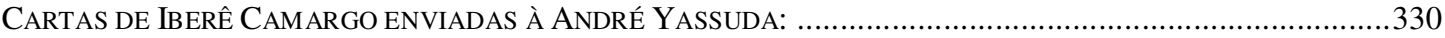

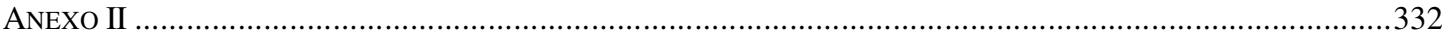

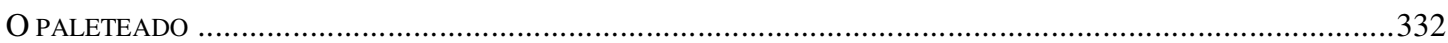

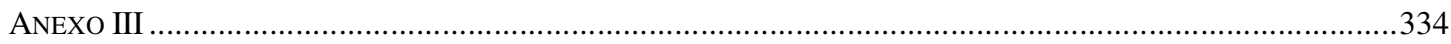

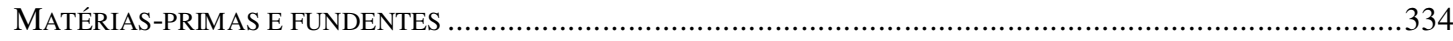

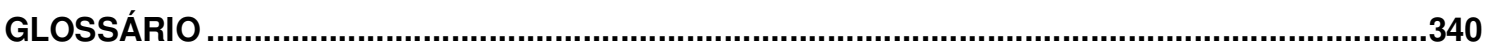

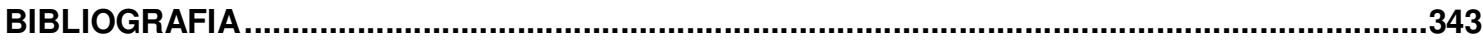




\section{Introdução}

"É notável que toda a obra de fôlego, pelo qual um indivíduo se institui mestre na sua categoria, é, ao mesmo tempo, obra de emoção e de pensamento, contém tanto uma forma de arte como uma fórmula de filosofia." ${ }^{1}$

Em minha experiência como artista e pesquisadora, percebo que o fazer artístico é movido por inquietações, experiências de vida, estímulos produzidos pelo mundo à nossa volta e por uma paixão. Como diz Mário de Andrade: "A arte é uma doença, é uma insatisfação humana e o artista combate a doença fazendo mais arte, outra arte. Fazer outra arte é a única receita para a doença estética da imperfeição".

Quando o artista entra em contato físico com a matéria, uma série de emoções, ideias e percepções são desencadeadas. É o início da criação de uma obra de arte: não há rumos certos. Nas palavras de Salles: "intuição amorfa, conceito ou premissa geral e miragem são alguns modos de descrever o elemento direcionador do processo". 3

Persistentemente, o artista se esforça tanto mental como fisicamente. Salles também comenta que "o artista é visto em seu ambiente de trabalho, em seu esforço de fazer visível aquilo que está por existir: um trabalho sensível e intelectual executado por um artesão."

Em minha dissertação de mestrado, defendida em fevereiro de 2010, fiz um memorial descritivo do meu percurso artístico, que se baseou na reflexão sobre o fascínio pelo corpo humano, sobre as experiências vividas pelo meu próprio corpo, e sobre a percepção acerca do corpo do outro. Utilizei a cerâmica como principal meio de expressão poética. Foram produzidas séries de esculturas, nas quais foram

\footnotetext{
${ }^{1}$ PESSOA, F. "Caracterização individual dos heterônimos". In: Obras em Prosa. $1^{\circ}$ Ed. Rio de Janeiro: Nova Aguilar, 1974.

2 ANDRADE, Mário (1989). Apud SALLES, Cecília Almeida. Gesto inacabado: Processo de criação artística. São Paulo: Annablume, 2001, p. 30.

${ }^{3}$ SALLES, Cecilia Almeida. Gesto inacabado: Processo de criação artística. São Paulo: Annablume, 2001, p. 28.

${ }^{4}$ Idem, p. 26
} 
empregados diferentes processos construtivos, entre eles: modelagem por placa, acordelado, extrusão. Passei também pela pintura em cerâmica: terra sigilata ${ }^{5}$, engobe, vidrados, além de técnicas de gravura e serigrafia aplicadas sobre alguns dos trabalhos. Portanto, meu processo criativo e a minha poética foram o foco daquela pesquisa de Mestrado.

Como o trabalho do artista é algo que está sempre em mutação, com o passar dos anos, outras questões foram surgindo e, durante toda a minha formação acadêmica, observei que a Cerâmica sempre foi minha aliada na expressividade. $O$ aumento da experiência técnica e a prática conduziram-me a buscar e descobrir novas possibilidades, e este desenvolvimento me ajudou a materializar com maior agilidade e fluidez minhas ideias e reflexões.

Há uma infinidade de meios técnicos dos quais o artista faz uso para expressar a sua poética. Ele elege um ou vários deles e quando isso ocorre são as experiências, suas ideias, as experimentações, os erros, os acasos que vão compondo o fazer do artista, que vão se transformando em obra de arte. $\mathrm{O}$ artista de maneira persistente, ou até mesmo obsessiva, vai buscando maneiras de exteriorizar aquilo que o inquieta.

Nessa incessante busca, a prática e produção constantes fazem com que determinados artistas transcendam os limites técnicos conhecidos, criando novos paradigmas e conceitos. Independentemente da técnica ou do material, a obra fala por si só. A força de um trabalho está na poética do artista. Já dizia Fayga Ostrower: “[...] nas obras de arte, as técnicas acabam se tornando 'invisíveis', sendo absorvidas inteiramente pelas formas expressivas [...]"6. Pode-se dizer, então, que a força do trabalho artístico reside no conteúdo simbólico e conceitual empregado pelo artista, um conteúdo que prevalece e se sobressai sobre os meios que utiliza para tal fim.

\footnotetext{
${ }^{5}$ Terra sigilata: termo usado para nomear uma mistura dos grãos mais finos da argila com a água. Com o auxílio de um pincel, a terra sigilata é aplicada sobre uma peça cerâmica, em estado de couro. Depois de brunido, a peça é queimada até $980^{\circ} \mathrm{C}$, resultando em um aspecto acetinado e sedoso. Podem ser coloridos com corantes minerais ou óxidos colorantes, com possibilidade de formação de uma gama de cores e tons pastéis.

${ }^{6}$ OSTROWER, Fayga. Acasos e criação artística. Rio de Janeiro: Elsevier Editora, 1999, p.18.
} 
Especificamente quando falamos de cerâmica, podemos destacar o ato de transformar uma massa amorfa em algo que visualmente nos causará alguma reação. Ter a maestria de saber o ponto de umidade ideal para fazer determinado corte ou modelar é fundamental para que o artista tenha sucesso na realização de seus projetos. Porém, ele pode se sentir livre para incorporar certos "acidentes". Concordo com Fayga Ostrower quando ela diz que o conhecimento técnico é importante, mas devemos vê-lo como um instrumento facilitador para a expressividade: "[...] Jamais a arte será mera questão de habilidade ou se limitará a meros problemas técnicos [...] A técnica representa um instrumento de trabalho $[\ldots]]^{7}$.

Pensar na obra de um artista leva-nos a questionar as razões pelas quais ela passou a existir. Uma obra construída passou por um processo longo de experiências vividas, reflexões, experimentações, práticas entre tantas outras atividades relacionadas ao fazer artístico. Acima da valorização da habilidade técnica, está a da Arte. A poética do artista é que dá o tom a um trabalho.

Refletindo sobre estes dois pontos, a poética e a técnica, questionamos: Quais são as motivações que levam um artista a escolher determinada técnica? Por que alguns artistas escolheram a Cerâmica como meio de expressão? O que leva um artista a desafiar os limites técnicos e quebrar paradigmas e conceitos?

Levantando as possíveis hipóteses para tais questões, iniciei minhas reflexões sobre o papel do artista em diferentes tempos. Entre outros fatores, considerei a relação entre 0 artista e a matéria selecionada para construir sua poética e a importância do conhecimento técnico no processo de criação em cerâmica. Depois parti para a apresentação de parte da vida e de obras de sete artistas brasileiros que utilizam a cerâmica, entre outros meios, para se expressar. Além das entrevistas, fiz uma análise bibliográfica e documental, e realizei visita aos seus ateliers e exposições, buscando conexões que pudessem nos ajudar a entender como um artista pode ir muito além dos limites impostos pela técnica.

\footnotetext{
${ }^{7}$ OSTROWER, Fayga. Acasos e criação artística. Rio de Janeiro: Elsevier Editora, 1999, p.18.
} 
Os sete artistas que fazem parte desta pesquisa e que se destacam no cenário nacional de Arte são:

André Luiz Yassuda;

Kimi Nii;

Laerte Ramos;

Marco Paulo Rolla;

Máyy Kóffler;

Miguel dos Santos;

Norma Grinberg.

O presente texto é formado por quatro capítulos e um anexo. O primeiro capítulo, intitulado $O$ Artista e a criação na Cerâmica, engloba duas partes: a primeira, $O$ artista e o artesão, onde inicio minhas reflexões sobre como o artista se configurava na Idade Média, época em que era na realidade o que hoje chamamos de "artesão". Ele atendia às necessidades de uma sociedade, mas com o passar do tempo, voltou-se para si próprio. Assim, aparentemente, para o artista o que era mais importante eram suas inquietações perante o mundo em que vivia. Na segunda parte, sob o título $O$ artista e a matéria, falo sobre a necessidade de materializar sua poética através de uma determinada matéria. Para que isso ocorra, ele precisa conhecê-la, criar uma intimidade com ela, conhecer técnicas, materiais e ferramentas que auxiliam nessa materialização.

No segundo capítulo $O$ artista e a mão inteligente: o processo de criação na Cerâmica, são levantadas questões relacionadas à necessidade do domínio técnico dentro do processo de criação e as especificidades do fazer artístico dentro da Cerâmica. Este capítulo foi dividido em: $A$ ideia e a matéria, onde são apresentados os materiais utilizados, os tipos de massas de cerâmicas, vidrados e matériasprimas. Além disso, comento algumas ferramentas que são fundamentais para a construção dos trabalhos em cerâmica. Adiante, apresento Técnicas de modelagem, aplicação de cores e texturas na cerâmica e O processo de criação na Cerâmica, 
com um comentário sobre a relação entre as ideias do artista, técnicas, materiais e ferramentas.

No terceiro capítulo, Sete artistas: Histórias de vida e o universo da cerâmica são apresentados os critérios de seleção dos setes artistas escolhidos para esta pesquisa. Nele também está descrito o processo que envolveu o contato com os mesmos, além de impressões que tive durante as visitas. Em seguida, é exposta a trajetória, a poética e o processo de criação de cada um deles. Neste capítulo, além de um pouco da vida e das obras, são exploradas as suas perspectivas sobre a relação entre a poética e a técnica.

Com o objetivo de tornar mais evidente as conexões e o peso das histórias de vida no desenvolvimento singular e na formação de cada um dos artistas, optou-se por colocar as entrevistas no corpo do texto (e não separá-las em um anexo, como geralmente se faz em dissertações acadêmicas).

Finalmente, no quarto capítulo, Conexões, tem-se o intuito de levantar quais são os pontos em comum entre os artistas e responder à questão: O que leva um artista a desafiar os limites técnicos e quebrar paradigmas e conceitos?

Cabe ressaltar que a ferramenta metodológica da História Oral, onde os artistas narram suas próprias histórias, foi utilizada para trazer mais riqueza e detalhes à pesquisa. Acredito que ouvir os depoimentos do artista, falando sobre suas inquietações, experiências, ou, o que o levou a escolher a cerâmica para materializar alguma ideia; sua visão pessoal sobre a técnica e criação, tudo isso pode dar margem a uma maior reflexão acerca das técnicas apresentadas, bem como às obras em si. Esses depoimentos também podem abrir portas para pesquisas mais apuradas sobre os mesmos, no entanto, não cabe a esta pesquisa detalhar a vida de cada um deles, nem tão pouco fazer um levantamento de todos os trabalhos realizados, mas sim, priorizar as obras em cerâmica e suas particularidades. 


\section{Capítulo 1: 0 artista e a criação}

\subsection{O artista e 0 artesão}

O que diferencia o Homem dos demais seres vivos, entre outras coisas, é a capacidade de criar, e para definir tal capacidade, recorremos a Ostrower:

"Criar é, basicamente, formar. É poder dar uma forma a algo novo. Em qualquer que seja o campo de atividade, trata-se, nesse 'novo', de novas coerências que se estabelecem para a mente humana, fenômenos relacionados de modo novo e compreendidos em termos novos. $O$ ato criador abrange, portanto, a capacidade de compreender; e esta por sua vez, a de relacionar, ordenar, configurar, significar."8

Ostrower acrescenta que criar é uma necessidade humana, pois somente desta maneira o Homem evolui. Ele vem criando objetos, máquinas, vestimentas, músicas, fórmulas, enfim, infinitas coisas. Cada indivíduo tem uma capacidade criadora e isso irá variar conforme suas aptidões e motivações internas e externas. Dentro deste contexto, o artista é o primeiro indivíduo que relacionamos quando falamos de criação.

A figura do artista ilustra inúmeros momentos da história, tendo ele exercido vários papéis: de um artesão, cujo trabalho é dedicado a uma sociedade com suas crenças e necessidades, ou como um ser dotado de virtudes, criador, chegando a ser "divino". De acordo com Sennett", na Idade Média, objetos do dia-a-dia, vestimentas, ourivesarias e armas, entre outros, eram fabricados nas oficinas, denominadas guildas. Essas oficinas eram, ao mesmo tempo, comandadas por chefes artesãos - os artífices - que faziam delas suas residências e abrigavam várias pessoas, mas visavam à produtividade e o lucro. Além disso, havia uma

${ }^{8}$ OSTROWER, Fayga. Criatividade e processos de criação. Rio de Janeiro: Editora Vozes, 2012, p. 9. 
hierarquia dentro das guildas, a qual era dividida em três níveis: mestres, jornaleiros e aprendizes.

"Os contratos especificavam a duração do aprendizado, geralmente sete anos, e o custo, em geral assumido pelos pais do jovem. As etapas do progresso na guilda eram assinaladas inicialmente pela apresentação, ao cabo desses sete anos, do chef d'oeuvre, um trabalho que demonstrava as habilidades fundamentais absorvidas pelo aprendiz. Obtendo êxito, o artífice, já agora um jornaleiro, trabalharia por mais cinco ou dez anos até ser capaz de demonstrar, num chef d'oeuvre élevé, que estava em condições tomar o lugar do mestre. ${ }^{10}$

Ainda segundo Sennett ${ }^{11}$, a questão de autoridade nas guildas estava relacionada com a qualidade de habilidades, ou seja, o mestre tinha a autoridade e maior habilidade. Assim, as inúmeras horas e anos de práticas determinavam a hierarquia nesses locais também. O aprendizado era feito através da observação e se iniciava com as práticas mais simples até chegar às mais complexas: o manuseio do material, técnicas de transformar esse material, cuidados com esse material, o rigor da seleção do material.

"O trabalho apresentado por um aprendiz centrava-se no princípio da imitação: a cópia como aprendiz. O trabalho apresentado pelo jornaleiro tinha um escopo maior. Ele tinha de demonstrar competência gerencial e dar mostra de merecer confiança como um futuro líder."

Sennett conclui que, até hoje, a prática é algo extremamente importante nas diversas profissões existentes, principalmente aqueles que utilizam as mãos para desenvolver determinado produto:

"Toda habilidade artesanal baseia-se numa aptidão desenvolvida em alto grau. Uma das medidas mais habitualmente utilizadas é a de que cerca de 10 mil horas de experiência são necessárias pra produzir um mestre carpinteiro ou músico. Vários estudos demonstram que

\footnotetext{
${ }^{9}$ SENNETT, Richard. O artífice. Rio de Janeiro: Editora Record, 2012, p. 72.

${ }_{11}^{10}$ SENNETT, Richard. O artífice. Rio de Janeiro: Editora Record, 2012, p. 72.

${ }^{11}$ Idem, Ibidem.
} 
progredindo, a habilidade torna-se mais sintonizada com os problemas [...]."12

Problemas esses enfrentados seja por artistas, músicos ou qualquer outro profissional que utiliza as mãos para elaborar seu trabalho. Sennett acrescenta ainda que:

\begin{abstract}
"A habilidade é uma prática decorrente de treinamento; a tecnologia moderna está sendo mal empregada quando priva seus usuários precisamente desse treinamento concreto e repetitivo da mão na massa."13
\end{abstract}

Como se percebe nas palavras de Sennett, na Idade Média, o artesão se orgulhava em desempenhar toda a sua perícia na satisfação de qualquer encomenda. Já no Renascimento, há uma evidência maior do artista em busca de algo além de qualidade ou serventia, preocupando-se em dotar suas obras de subjetividade ou identidade:

"A arte carrega uma responsabilidade bem pesada nessa versão da mudança cultural. Para começo de conversa, representa a concessão de um novo e mais amplo privilégio à subjetividade na sociedade moderna, com o artífice voltado para a sua comunidade e o artista voltado para si mesmo." ${ }^{14}$

De acordo com os Wittkower ${ }^{15}$, dotando suas obras de originalidade, o artista passa se situar numa posição mais autônoma, se comparado ao artesão.

Sennet diz que o conceito de originalidade (do grego poesis ou poiesis), tão almejado pelos artistas renascentistas não é um conceito inédito, mas já havia sido apontado nas obras de Platão para denominar "algo onde antes nada havia". De acordo com Reale ${ }^{16}$, Platão define como poeisis todas as formas de atividade produtiva capazes de levar do não-ser ao ser. Assim, Reale acrescenta:

\footnotetext{
12 Idem, p. 30.

${ }^{13}$ SENNETT, Richard. O artífice. Rio de Janeiro: Editora Record, 2012, p. 64

${ }^{14}$ Idem, p. 80

15 WITTKOWER, Margot e Rudolf Apud SENNETT, Richard. O artífice. Rio de Janeiro: Editora Record, 2012, p. 80.

${ }^{16}$ REALE, Giovanni. Para uma nova interpretação Platão. São Paulo: Edições Loyola, 1997, p. 397.
} 
'Todavia, observa Platão, passou-se a chamar de 'poetas', ou seja, 'criadores', apenas os que se ocupam de poesia e de música, mesmo se, na realidade, o termo poiesis valha para toda a esfera da arte produtiva [...] Mais adequada é a tradução de 'poiesis' por criação, porque também para nós modernos a poesia é criação; e ademais todo tipo de atividade produtiva é considerado comumente uma forma de criação."17

Pervsner ${ }^{18}$ aponta a superioridade do artista renascentista como um portador de uma mensagem sublime, visto como um indivíduo dedicado às questões científicas e filosóficas, e não mais como um trabalhador, fabricante de objetos. Sennett acrescenta que no Renascimento, ocorre a separação arte e o artesanato. ${ }^{19}$

No século XVIII, surgem filósofos como Schiller ${ }^{20}$ que foi um dos primeiros a elaborar uma filosofia da arte considerando o artista um indivíduo de sabedoria e maestria. Daí por diante, surgiram outros teóricos que exaltavam este papel do artista: "os legisladores não reconhecidos do mundo"; "o artista já não é um artesão, já não é um servo, é um sacerdote"

Assim, o artista torna-se um indivíduo independente, dando maior importância à sua liberdade, sendo seu interior algo sagrado. E dentro deste contexto, seu maior anseio é materializar suas ideias, paixões e inquietações, e ter como resultado a obra de arte. Essa obra de arte que traduz um universo particular: "Uma obra de arte é um mundo em si que reflete as percepções e emoções do mundo do artista."21

No entanto, vale ressaltar o que Ostrower defende sobre o fato de a Arte não ser somente uma área, onde o artista desagua suas emoções:

"Embora exista no ato criador uma descarga emocional, ela representa um momento de libertação de energias - necessário, mas de menos importância do que certos teóricos talvez o acreditem ser. Mais fundamental e gratificante, sobretudo para o indivíduo que está criando, é o sentimento concomitante de reestruturação, de

\footnotetext{
${ }^{17}$ REALE, Giovanni. Para uma nova interpretação Platão. São Paulo: Edições Loyola, 1997, p. 397.

${ }^{18}$ PEVSNER, Nikolaus. Os pioneiros do desenho moderno. São Paulo: Martins Fontes, 2002, p.3.

${ }^{19}$ SENNETT, Richard. Op. cit., p. $165 .$.

${ }^{20}$ SCHILLER citado em PERVSNER, Nikolaus. Os pioneiros do desenho moderno. São Paulo: Martins fontes, 2002. ( p. 3)

${ }^{21}$ CHIPP, H.B. Teorias da Arte Moderna. São Paulo: Editora Martins Fontes, 1999, p. 544.
} 
enriquecimento da própria produtividade, de maior amplitude do ser, que se libera no ato de criar"22.

Ela ainda acrescenta:

"Criar não representa um relaxamento ou um esvaziamento pessoal, nem uma substituição imaginativa da realidade; criar representa uma intensificação do viver, um vivenciar-se no fazer; e, em vez de substituir a realidade, é a realidade; é uma realidade nova que adquire dimensões novas pelo fato de nos articularmos, em nós e perante nós mesmos, em níveis de consciência mais elevados e mais complexos. Somos, nós, a realidade nova. Daí o sentimento do essencial e necessário no criar, o sentimento de um crescimento interior, em que nos ampliamos em nossa abertura para a vida". ${ }^{23}$

Dentro da Arte criou-se um debate entre a relevância ou não da valorização da habilidade manual dentro da Arte. No século XIX, William Morris ${ }^{24}$ defendia a ideia utópica de que a arte deveria ser acessível a todas as classes sociais e a maestria artesanal na sua realização valorizava o trabalho medieval de fazer arte. Defendia a ideia de que arte é simplesmente uma maneira do Homem exprimir o prazer que lhe vem do trabalho, desprezando o orgulho do artista criador como algumas formas especiais de inspiração. Suas ideias foram bastante rebatidas pelos defensores da modernidade e do avanço industrial, que de outro lado, viam beleza nas máquinas e exaltavam as maravilhas da indústria moderna:

"Todas as máquinas podem ser belas mesmo sem ornamentação. Não vos preocupeis com a decoração. Não podemos deixar de pensar que qualquer boa máquina é graciosa, pois a linha da força e a linha de beleza são uma só." 25

${ }^{22}$ OSTROWER, Fayga. Criatividade e processos de criação. Petrópolis: Editora Vozes, 2012, p. 28.

${ }^{23}$ Idem, Ibidem.

${ }^{24}$ William Morris, artista, poeta e escritor inglês, era defensor das ideias do também artista, poeta e crítico social John Ruskin (1819-1900): " A verdadeira arte deve ser feita pelo povo e para o povo, como uma bênção para quem a faz e para quem a desfruta". Apud PERVSNER, Nikolaus. Os pioneiros do desenho moderno, 2002, p. 5.

${ }^{25}$ WILD, Oscar. Apud PEVSNER, Nikolaus. Os pioneiros do desenho moderno. São Paulo: Martins Fontes, 2002, p. 11. . 
Assim, no decorrer da História, o artista exercitou múltiplos papéis: de cientista, filósofo, de arquiteto, poeta, pensador - para assim alcançar seus objetivos de criar. Ele poetiza sobre materiais diversos desde tinta, argila, vídeo, até ocupando espaços abertos na natureza, transformando-os em obra de arte. De acordo com Coli $^{26}$, a obra de arte é um agregador de elementos que escapam ao domínio do racional e sua comunicação com o espectador se faz por outros canais: emoção, espanto, intuição, associações, evocações, seduções.

Atualmente, o mundo globalizado é diversificado, com total liberdade e aceitação de opiniões e ideias, sendo difícil e limitado categorizar o que é certo e errado. Assim, em seu livro Após o fim da Arte, Danto diz:

"E é de maneira similar que os artistas, no fim da arte, estão livres para ser o que quiserem ser - livre para ser alguma coisa ou mesmo para ser todas as coisas. ${ }^{27}$

O papel do artista e a definição do que é de fato obra de arte também se tornou ainda mais diversificado: "Não há nenhuma limitação a priori de como as obras de arte devem parecer - elas podem assumir a aparência de qualquer coisa." ${ }^{28}$ Sempre atento ao que está ao seu redor, o artista se interessa por um determinado material, o conhece, experimenta e aprende a domá-lo, para assim, poetizar sobre este. O artista respira arte e isto se reflete como o exercício do pensar, conectado com o artesanato, que seria a ação, a prática e materialização deste pensar. Neste caso, a Arte é tratada como algo que faz parte do espírito do artista, seria como sua motivação para viver. Materializar sua arte é como dar vida a um material.

No caso da cerâmica, o contato físico com a matéria, as habilidades técnicas para lidar com ela e lado poético estão em jogo. Ou seja, manipular o material e perceber as transformações físicas da matéria, também deve entrar em sintonia com a poética do artista. Assim, este meio, a Cerâmica, alia o exercício do pensar, das

${ }^{26}$ COLI, Jorge. O que é Arte? São Paulo: Editora Brasiliense, 1995, p. 107

${ }^{27}$ DANTO, Arthur: Após o fim da Arte: A arte contemporânea e os limites da história. São Paulo: Edusp, 2010, p. 50.

${ }_{28}$ Idem, p. 19. 
emoções e inquietações do artista à prática de manipular os materiais, típica do artesanato. Mas, como diz Mário de Andrade ${ }^{29}$ :

"[...] nos processos de movimentar o material, a arte se confunde quase inteiramente com o artesanato. Pelo menos naquilo que se aprende."

\subsection{O artista e a matéria}

Para Bachelard, nosso psiquismo é regido por imagens, que por sua vez buscam uma realidade. Assim, o artista exerce bem este papel, trabalhando a imaginação reprodutora e a imaginação criadora. Bachelard ${ }^{30}$ define imaginação reprodutora como aquela geradora de imagens produzidas através das percepções e da memória, e a imaginação criadora, como a que busca imagens através do irreal.

Assim como as palavras são os meios que o poeta se utiliza para criar tais imagens, o artista se utiliza de diversos materiais para fazer o mesmo. Criando imagens, o artista se expressa. O artista trabalha o tempo todo com imagens, através da linguagem poética. Linguagem que, segundo Bachelard, "quando traduz imagens materiais, é um verdadeiro encantamento de energia"31.

Em contato com um determinado material e as ferramentas apropriadas para a sua manipulação, o artista trava uma batalha imaginativa, sendo a sua mente, mãos, e olhos contra a matéria que está diante dele:

"[...] temo-las sob os olhos; sentimo-las nas mãos, despertam em nós alegrias musculares assim que tomamos o gosto de trabalhálas"32.

É com prazer, sofrimento, força, necessidade e curiosidade que o artista é tomado pela vontade de materializar suas ideias, fato que, obviamente, ocorre através de seu trabalho.

\footnotetext{
${ }^{29}$ ANDRADE, Mário de. O baile das quatro artes. Rio de Janeiro: Editora Nova Fronteira, 2012, p. 2. ${ }^{30}$ BACHELARD, Gastón. A terra e os devaneios da vontade. São Paulo: Editora Martins Fontes, 2008, p.3 
"[...] Existe, é certo, dentro da arte, um elemento, o material, que é necessário pôr em ação, mover, para que a obra de arte se faça ${ }^{\text {,33. }}$.

No momento em que o artista movimenta a matéria, ele conhece profundamente suas possibilidades e seus limites. Com relação aos fatores limitadores da matéria, assim como havia dito anteriormente, há uma batalha que Bachelard define como a "imaginação da resistência", a substancialidade imaginária do contra. Ou seja, o artista vive uma relação de adversidades provocada pela imaginação material e dinâmica:

"[...] uma psicologia do contra que não se contenta com a pancada, com o choque, mas que se promete a dominação sobre a própria intimidade da matéria". ${ }^{34}$

Para dominar a matéria o artista se utiliza de seu trabalho, onde o seu corpo atua ativamente sobre a mesma:

"A consciência do trabalho aí se precisa simultaneamente nos músculos e nas articulações do trabalhador e nos progressos regulares da tarefa. A luta do trabalho é a mais cerrada das lutas". ${ }^{35}$

Essa luta é mantida a cada projeto, no anseio de se criar uma obra de arte. Algo que Novalis ${ }^{36}$ enfatiza quando reflete sobre essa relação das mãos com a matéria:

"É o mesmo que dizer que a substância é dotada do ato de nos tocar. Ela nos toca assim como a tocamos, dura ou suavemente".

E continua:

"[...] é o ser humano que desperta a matéria, é o contato da mão maravilhosa, o contato dotado de todos os sonhos do tato imaginante que dá vida as qualidades que estão adormecidas nas coisas".

\footnotetext{
${ }^{33}$ ANDRADE, Mário de. O baile das quatro artes. Rio de Janeiro: Editora Nova Fronteira, 2012, p. 2.

${ }^{34}$ BACHELARD, Gastón. A terra e os devaneios da vontade. São Paulo: Editora Martins Fontes, 2008, p. 18.

${ }^{35}$ Idem, Ibidem.

${ }^{36}$ Apud BACHELARD, Gastón, 2008. Op. cit., p. 20.
} 
De acordo com Ostrower, para que a obra aconteça, o artista alia uma imaginação criativa específica para cada tipo de matéria e ela diz:

"Formulamos aqui a ideia de a imaginação criativa vincula-se à especificidade de uma matéria [...]". ${ }^{37}$

Bachelard refere-se a cada material como algo único na maneira de trabalhar, ele é quem nos direciona e nos instrui. Ele ainda acrescenta que a prática de lidar com diferentes materiais possibilita que o artista adquira tipos individualizados de flexibilidade e decisão:

"Não só nos tornamos destros na feitura das formas, mas também nos tornamos materialmente hábeis ao agir no ponto de equilíbrio de nossa força e da resistência da matéria. Matéria e mão devem estar unidas para formar o ponto essencial do dualismo enérgico. [...] a mão que trabalha põe o objeto numa ordem nova, na emergência de sua existência dinamizada". ${ }^{38}$

$\mathrm{Na}$ sua sede de materializar sua poesia, o artista entra em profunda sintonia com a matéria: "Tudo me é massa, eu sou massa em mim mesmo, meu devir é minha própria matéria, minha própria matéria é ação e paixão, sou verdadeira uma massa primordial." ${ }^{39}$ Bachelard ainda acrescenta que essa relação artista e matéria se faz de maneira profunda e intensa:

"O ser humano, que abandona os homens e vai até o fundo de seus devaneios, olha enfim as coisas. Devolvido assim à natureza, o homem é devolvido às suas potências transformadoras, à sua função de transformação material, mas somente se ele vai à solidão não como a um retiro longe dos homens, mas com as próprias forças do trabalho. [...] Na solidão ativa, o homem quer cavar a terra, furar a pedra, talhar a madeira. Quer trabalhar a matéria, transformar a matéria. Então o homem não é mais um simples filósofo diante do universo, é uma força infatigável contra o universo, contra a substância das coisas. ${ }^{40}$

\footnotetext{
${ }^{37}$ OSTROWER, Fayga. Criatividade e processos de criação. Petrópolis: Editora Vozes, 2012, p. 32.

${ }^{38}$ BACHELARD, Gastón, 2008. Op. cit., p. 21.

${ }^{39}$ Idem, p. 65

${ }^{40}$ Idem, p. $23-24$.
} 
Para Ostrower ${ }^{41}$, o artista quando age sobre determinada matéria, ele o faz de maneira a criar novas ordenações, assim, essa matéria é vista de um jeito novo. Desta maneira, o artista, criando novas ordenações, compõe novas poesias. Das novas possibilidades e poesia, o artista tenta transcender os limites dessa matéria.

No que se refere à relação do artista com a sua matéria, a massa ou a argila, Bachelard $^{42}$ explica que a interação matéria/artista deve ser analisada de uma maneira própria. Cada matéria e técnica seja madeira ou gravura; tela ou pintura possuem o seu onirismo, ou melhor, uma linguagem poética. A linguagem poética, segundo Bachelard, seria uma tradução de imagens materiais, resultando naquele encantamento de energia.

"Se a poesia deve reanimar na alma as virtudes da criação, se deve nos ajudar a reviver, em toda a sua intensidade e em todas as suas funções, nossos sonhos naturais, precisamos compreender que a mão, assim como o olhar, tem seus devaneios e sua poesia. Deveremos, portanto, descobrir os poemas do tato, os poemas da mão que amassa,43

Na Cerâmica, o esforço físico, no amassar o barro, reforça a intensidade das mãos, do toque mais forte na massa, provando a sua própria existência:

"[...] Falam-nos particularmente do cogito biraniano no qual o ser encontra a prova da sua existência no próprio ato de seu esforço.[...]"44

Assim, o próprio fazer ou o contato com a matéria dá a prova da existência do ser.

"Assim, encontrando sei lá que massa primordial em minhas mãos vazias, todo o meu sonho manual, murmuro: Tudo me é massa, eu sou massa em mim mesmo, meu dever é minha própria matéria,

${ }^{41}$ OSTROWER, Fayga. Criatividade e processos de criação. Rio de Janeiro: Editora Vozes, 2012, p. 34.

${ }^{42}$ BACHELARD, Gastón, 2008. Op. cit., p. 6.

${ }^{43}$ Idem, p. 65.

${ }^{44}$ Idem, Ibidem. 
minha própria matéria é ação e paixão, sou verdadeiramente uma massa primordial. ${ }^{, 45}$

Essa relação do artista com a matéria é forte na Cerâmica. Sendo a matéria um meio de expressão poética, a compreensão do seu comportamento é fundamental.

Sendo a Cerâmica uma linguagem, o artista deve conhecer a sua "gramática" para escrever a sua poesia.

Portanto, essa relação do artista com a matéria é estimulada pelo potencial criador. Esse potencial criador significa trabalho. Não há obra de arte sem trabalho, ou seja, deve haver o fazer concreto que é o artista agindo sobre uma matéria ou materialidade ${ }^{46}$.

${ }^{45}$ BACHELARD, Gastón, 2008. Op. cit., p. 65.

${ }^{46}$ Fayga Ostrower utiliza o termo materialidade, ao invés de matéria, com objetivo de não somente abranger determinada substância, e sim tudo o que está sendo formado e transformado pelo homem. (OSTROWER, Fayga. Criatividade e processos de criação. Rio de Janeiro: Editora Vozes, 2012, p. 31) 


\section{Capítulo 2: 0 artista e a mão inteligente - processo de criação na Cerâmica}

Falamos anteriormente sobre a relação entre a habilidade manual e a criação em arte. Vimos que em cerâmica é inevitável o contato tátil do artista com alguma matéria para se expressar. $O$ artista é ao mesmo tempo artífice neste sentido: "focaliza a relação íntima entre a mão e a cabeça"47

Mário de Andrade faz uma reflexão sobre a Arte em sua obra $O$ baile das quatro $\operatorname{artes}^{48} \mathrm{e}$ argumenta sobre a importância da habilidade manual:

"O artesanato, os segredos, os caprichos, as exigências do material, isto é assunto ensinável, e de ensinamento por muitas partes dogmático, a que fugir será sempre prejudicial para a obra de arte. $\mathrm{E}$ se um artista é verdadeiramente artista, quero dizer, está consciente do seu destino e da missão que se deu para cumprir no mundo, ele chegará fatalmente àquela verdade de que, em arte, o que existe de principal é a obra de arte." ${ }^{49}$

Sennett que diz a habilidade artesanal se baseia no desenvolvimento em alto grau da aptidão. A técnica, segundo ele, não é algo meramente mecânico: "as pessoas são capazes de sentir plenamente, pensar profundamente o que estão fazendo quando o fazem bem". ${ }^{50}$ Sobre a questão do treino e da prática para se adquirir habilidade artesanal, ele dá o exemplo de um mestre carpinteiro que necessita de pelo menos 10 mil horas de experiência para que ele seja habilidoso em sua área.

\footnotetext{
${ }^{47}$ SENNETT, Richard. Op. Cit., p. 20.

48 Na mesma página, Mário de Andrade usa as seguintes palavras na nota de rodapé: "Está claro: prejudicial para a obra de arte, eu digo, e não para o artista. O artista prescinde das leis técnicas, não em benefício da obra de arte, mas de si mesmo. É a frase de Beethoven: 'não há regra que não possa ser superada em benefício da expressão.' E não virá disto a degringolada da arte, do Romantismo para cá? Um artista cada vez mais expressivo de si mesmo, e uma obra de arte cada vez mais pessoal e inatingível ao povo?' (ANDRADE, 2012, p. 3)

${ }^{49}$ ANDRADE, Mário de. Op. Cit., p. 3.

50 SENNETT, Richard. Op. Cit., p. 30.
} 
Assim, o conhecimento das técnicas que irão facilitar ou agilizar o trabalho com determinada matéria é essencial. A técnica elimina procedimentos que não atendem a um fim determinado. "Mourejar no trabalho artesanal é uma forma de descobrilas." 51

Vale dizer ainda, que, desde a Antiguidade, já havia uma preocupação em aliar a teoria e a prática, pois de acordo com Sennett, "as várias artes são compostas de duas coisas: perícia artesanal e teoria" ${ }^{52}$. Partilhar o conhecimento técnico era uma grande preocupação, como Sennett constata nos textos de Vitrúvio (anos 20-30 a.C.) sobre arquitetura reunidos em dez livros. Os registros das técnicas ou os procedimentos de realização de determinada obra, era também uma maneira de um artífice deixar a marca de seu trabalho. Outro exemplo são os 35 volumes editados por Denis Diderot conhecidos como Enciclopédia ou Dicionário de artes e ofícios, publicados entre 1751 e 1772. Neles estão contidas imagens e palavras que descrevem detalhadamente como as coisas são feitas..$^{53}$

No caso da Cerâmica, há uma vasta bibliografia internacional que explica e ilustra detalhadamente todos os materiais, ferramentas, técnicas de construção, conformação, coloração e queima. Há também um vasto material sobre a história deste meio, como podemos verificar na bibliografia apresentada nesta pesquisa. No entanto, convém citar e apresentar tais técnicas para que todo leitor ou pesquisador tenha pelo menos o entendimento básico dos processos utilizados pelos sete artistas entrevistados. Adiante, para melhor compreensão do processo criativo de cada um, passamos a considerar as técnicas, materiais e ferramentas utilizadas, afinal, 0 argumento de Sennett sobre o trabalho manual ilustra bem essa importância:

\footnotetext{
"O trabalho artesanal cria um mundo de habilidade e conhecimento que talvez não esteja ao alcance da capacidade verbal humana explicar; mesmo o mais profissional dos escritores teria dificuldade de descrever com precisão como atar um nó corrediço." ${ }^{24}$
}

\footnotetext{
51 SENNETT, Richard. Op. Cit., 147

52 Idem, p. 152.

53 Idem, p. 107.

${ }^{54}$ Idem, p. 111.
} 


\subsection{A ideia e a matéria}

Certa vez, Immanuel Kant disse: "A mão é a janela que dá para a mente"55. $\mathrm{E}$ como já vimos, é assim, através das mãos, que o artista materializa sua poesia. Essa relação da mão com a matéria, estimulada pelas ideias, gera uma transformação e o surgimento de algo novo.

"O artista é visto em seu ambiente de trabalho, em seu esforço de fazer visível aquilo que está por existir: um trabalho sensível e intelectual executado por um artesão." 56

Segundo Sennett, quando as máquinas dominaram espaço na sociedade industrial, daria a entender que tal fato seria o início do desaparecimento da habilidade artesanal, mas isso é um engano. A habilidade artesanal, segundo Sennett, é um impulso humano básico e permanente, o desejo de um trabalho bem feito por si mesmo ${ }^{57}$.

Sennett ainda aponta que em várias áreas, principalmente no meio artístico, tem-se dado menor importância ao aprendizado das técnicas. Ele diz:

"A técnica tem má fama; pode parecer destituída de alma. Mas não é assim que é vista pelas pessoas que adquirem nas mãos um alto grau de capacitação. Para elas, a técnica estará sempre ligada à expressão." 58

A Cerâmica é a arte que tem como característica marcante a relação íntima das mãos do artista com a sua matéria principal, a argila. Há uma ligação inseparável. Conhecer as técnicas e as ferramentas da Cerâmica é fundamental para que a poética possa fluir.

\footnotetext{
${ }^{55}$ KANT, Immanuel, Apud SENNETT, Richard. O artífice. Rio de Janeiro: Editora Record, 2012, p. 169.

${ }^{56}$ SALLES, Cecília Almeida. Gesto inacabado: processo de criação artística. São Paulo: Annablume, 2004, p. 26.).

${ }^{57}$ SENNETT, Richard. Op.Cit., p. 19

${ }^{58}$ Idem, p. 169.
} 
No processo da cerâmica devemos compreender as mudanças drásticas que ocorrem durante os diversos estágios: da argila úmida e mole até a sua queima a altas temperaturas ${ }^{59}$.

Em sua larga experiência no European Ceramic Work Centre, Reijnders ${ }^{60}$ diz que para ter um trabalho bem sucedido na Cerâmica é necessário:

1. Compreender os materiais e processo;

2. Conhecer as consequências da forma;

3. Escolher o(s) método(s) mais adequado(s) para realizar um trabalho.

Tendo estes três pontos em mente, o artista sofrerá menos perdas e terá mais sucesso naquilo que deseja materializar. Cada técnica possui suas características, possibilidades e também limitações. Por isso, cabe-nos conhecer seus limites e experimentar. Assim como o poeta que, antes de tudo, precisa aprender as regras fundamentais da escrita e da gramática, para depois utilizar sua intuição e intelecto para poetizar. Dentro dos processos de seleção dos materiais cerâmicos a serem trabalhados, técnicas de construção, de queima e coloração, existem inúmeras possibilidades poéticas.

A Cerâmica é uma das áreas que atua em diversas frentes desde a arte e design até na medicina e odontologia. As possibilidades ampliaram-se ainda mais, com novos materiais, ferramentas e equipamentos que facilitam a construção de peças ou objetos cerâmicos.

As técnicas, juntamente com as ferramentas e equipamentos, auxiliam na eliminação de procedimentos que não atendam a um fim predeterminado, visam facilitar o trabalho. ${ }^{61}$

\footnotetext{
${ }^{59}$ REIJNDERS, Anton. "The ceramic process: a manual and source of inspiration for ceramic art and design". In: ECWC - European Ceramic Work Centre London: A\&C Black, 2005, p. 17.

${ }^{60}$ O European Ceramic Work Centre é um centro de formação na área de cerâmica que reúne artistas visuais, designers, arquitetos e ceramistas para explorar possibilidades artísticas e técnicas da cerâmica como meio (ver bibliografia: ECWC, 2005, p. 10).

${ }^{61}$ SENNETT, Richard. Op.Cit, p. 181
} 


\subsubsection{Massas cerâmicas (argilas)}

"Descobrir que a argila torna-se rígida e durável quando queimada é um dos feitos mais importantes do Homem. A vida doméstica do homem primitivo foi imensuravelmente enriquecida com a aquisição dos contêineres para armazenamento de grãos, água, para cozinhar, lavar, e carregar alimentos - sem falar nos usos em cerimoniais e puramente estéticos nos quais os objetos em cerâmica eram colocados." ${ }^{62}$

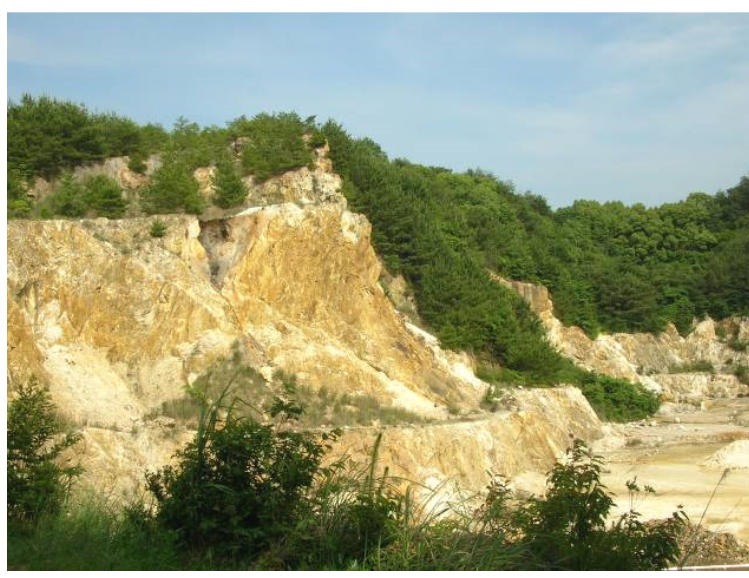

Figura 1

Arita, Japão. Depósito de extração de caulim. (utilizado na fabricação da porcelana) Foto: Silvia Tagusagawa

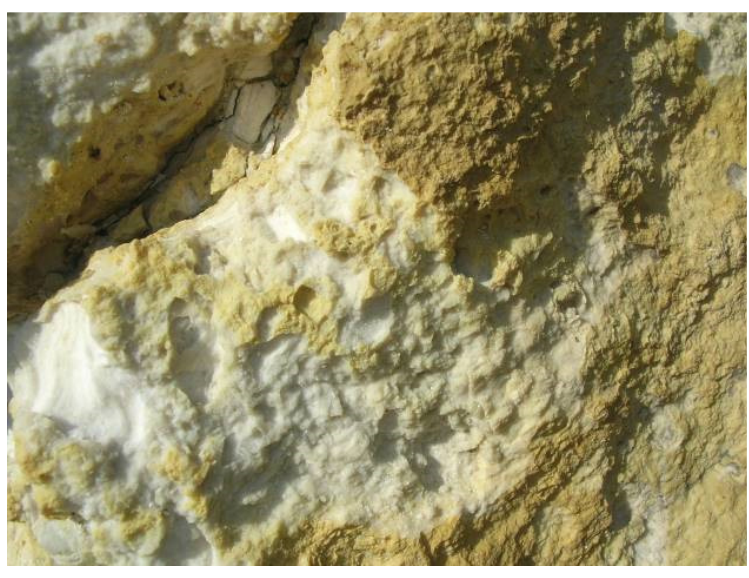

Figura 2

Arita, Japão.

Depósito de extração de caulim. (utilizado na fabricação da porcelana) Foto: Silvia Tagusagawa

A partir da definição apresentada por Rhodes $^{63}$, vemos que a argila, o principal material para a cerâmica, é um silicato de alumínio hidratado pesado, úmido e plástico que se conforma quando seca e muda suas características químicas e físicas quando sofre aquecimento. Origina-se das rochas ígneas formadas na crosta terrestre que por sua vez, são compostas por vários metais e minerais tais como: quartzo, alumina, ferro, cálcio, sódio, magnésio, potássio, água, titânio entre outros. De acordo com Norton ${ }^{64}$, a composição química aproximada de uma argila é:

\footnotetext{
${ }^{62}$ RHODES, Daniel. Clay and glazes for the potter. Pennsylvania : Chilton,1973., p. 13.

63 Idem, p. 3.

${ }^{64}$ NORTON, F. H. Ceramics for the artist potter. Massachusetts: Addison-Wesley Publishing Company, 1956, p. 126.
} 
$47 \%$ sílica $\left(\mathrm{SiO}_{2}\right)$

$39 \%$ alumina $\left(\mathrm{Al}_{2} \mathrm{O}_{3}\right)$

$14 \%$ água $\left(\mathrm{H}_{2} \mathrm{O}_{3}\right)$

\subsubsection{Tipos de massas cerâmicas (argilas)}

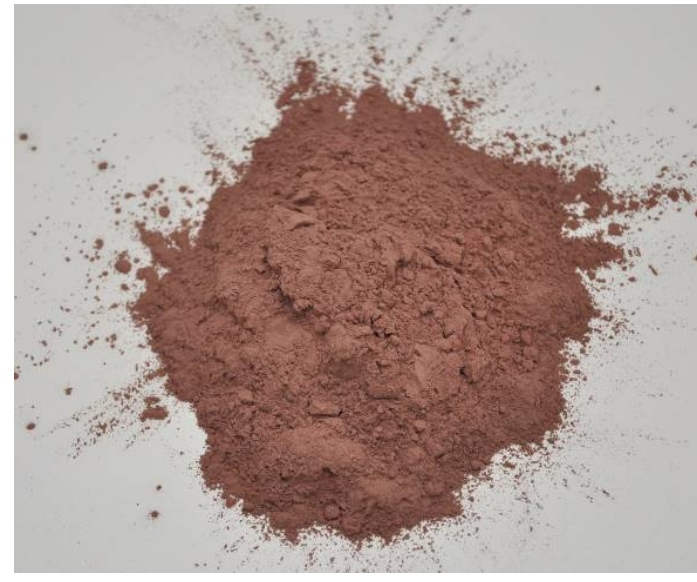

Figura 3

Argila em pó vermelha beneficiada

Foto:Silvia Tagusagawa

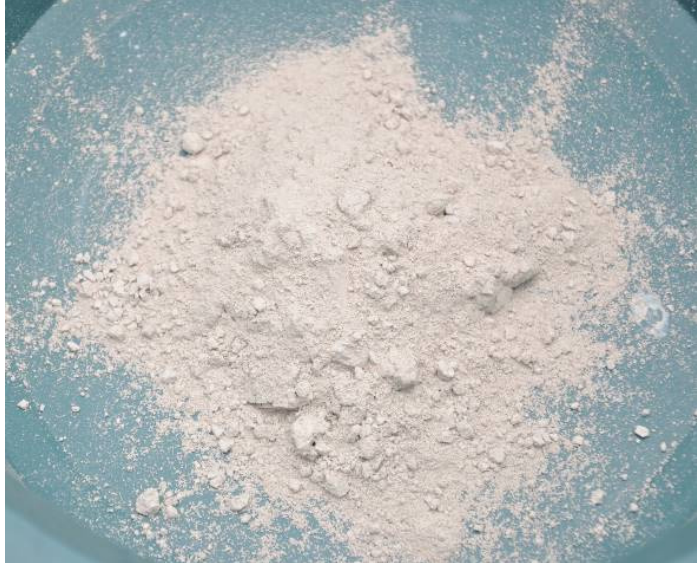

Figura 4

Argila em pó branca beneficiada

Foto: Silvia Tagusagawa

Conforme Norton e Rhodes, as argilas podem ser classificadas como:

- Caulim $\left(\mathrm{Al}_{2} \mathrm{O}_{3} \cdot 2 \mathrm{SiO}_{2} 2 \mathrm{H}_{2} \mathrm{O}\right)$ : uma argila altamente refratária cujo ponto de fusão está acima de $1800^{\circ} \mathrm{C}$. É uma argila pouco plástica e difícil de ser modelada. Para que se torne plástica são necessárias matérias-primas mais plásticas. Normalmente, encontram-se livres de óxido ou com quantidade insignificativa;

- Ball clay ou argila branca plástica: é oposta ao caulim, pois apresenta uma grande quantidade de ferro, é mais fundente e muito plástica. Normalmente, combina-se caulim e ball clay no preparo de massas cerâmicas. Ele sozinho é difícil de ser trabalhado já que sua porcentagem de encolhimento é de mais de $20 \%$ quando queimado e seu ponto de fusão é de $1300^{\circ} \mathrm{C}$. 
- Argila de alta temperatura: é uma argila rica em feldspato e é combinado com argila plástica.

- Argilas vermelhas: essas argilas têm ponto de fusão de $1000^{\circ} \mathrm{C}$ a $1200^{\circ} \mathrm{C}$ e são ricas em óxido de ferro. Normalmente, são argilas bem plásticas.

Existem argilas de vários tipos na natureza, podendo ser encontradas em rios ou encostas. Caso seja encontrada uma fonte delas, é necessário beneficiá-las e testá-las para o uso.

Quando as argilas são extraídas de suas fontes, normalmente, elas precisam ser processadas, ou seja, devem ser secadas, moídas, peneiradas e misturadas ${ }^{65}$. Segundo Rhodes ${ }^{66}$, é possível utilizar a argila em seu estado puro, mas normalmente é necessário a adição de pelos menos dois ou mais materiais minerais para se obter um material cerâmico ideal para o trabalho. Pode-se desejar melhorar um tipo de argila nos seguintes casos:

1. Mudança de cor e textura: Talvez seja necessário mudar a cor da argila, para deixá-la mais clara ou escura. Ou quando se deseja uma superfície mais ou menos rugosa;

2. Alteração de plasticidade: existem argilas extremamente plásticas e outras nem tanto. Por isso, em alguns casos, há necessidade de ajuste nesta parte. A plasticidade de uma argila é a capacidade que ela tem de se deformar sem rachar;

3. Diminuição na porcentagem de encolhimento ou melhoria na secagem e queima com o mínimo de empenamento e rachaduras;

4. Aumento ou diminuição do ponto de sinterização da argila;

5. Melhor adequação de vidrado à argila.

${ }^{65}$ ECWC - European Ceramic Work Centre/REIJNDERS, Anton . "The ceramic process: a manual and source of inspiration for ceramic art and design". London: A\&C Black, 2005, p. 31

${ }^{66}$ RHODES, Daniel. Clay and glazes for the potter. Pennsylvania : Chilton,1973., p. 25 
O mercado disponibiliza vários tipos de massas cerâmicas para determinadas formas de modelagem tais como: torno, modelagem, colagem, queima de Raku, modelagem de peças cerâmicas de grandes dimensões. Cores e texturas diferenciadas também podem ser encontradas nas massas cerâmicas comercializadas.
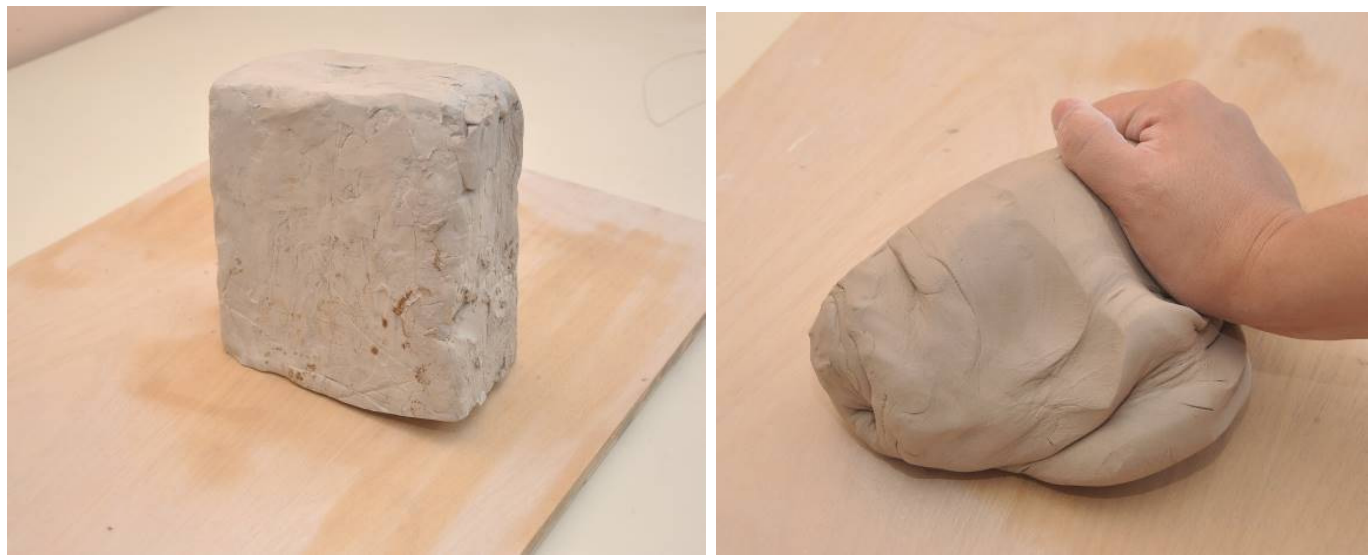

Figura 5 - Massa cerâmica grês branca Fotos: Silvia Tagusagawa

Além de pensar no tipo de trabalho que será realizado, a temperatura de queima é essencial para determinar que tipo de massa cerâmica é mais adequado.

Basicamente, as massas cerâmicas são divididas em dois grandes grupos:

- Baixa temperatura: as massas relacionadas nesta temperatura atingem ponto de fusão abaixo de $\operatorname{cone}^{67} 6\left(1190^{\circ} \mathrm{C}\right)^{68}$. As massas de baixa temperatura tem um toque suave quando modeladas e são mais frágeis do que as massas de alta temperatura, mas não são quebradiças. Como se confirma em Rhodes ${ }^{69}$, a gama de cores das massas de baixa temperatura variam de vermelhas, laranjas, ocres até marrons. Esses tons são adquiridos graças à quantidade de óxidos de ferro presente nas argilas.

\footnotetext{
${ }^{67}$ Ver sobre cones pirométricos nos Anexos.

${ }^{68}$ RHODES, Daniel. Clay and glazes for the potter. Pennsylvania : Chilton, 1973., p. 315.

${ }^{69}$ Idem, p. 47.
} 
As massas mais comuns são conhecidas como Terracota (palavra de origem italiana, que significa "terra queimada") e são feitas com argilas com alto teor de óxido de ferro. No mercado, são conhecidas massas vermelhas para baixa temperatura e também há as massas brancas - que são conhecidas como faianças.

- Alta temperatura: essas massas são mais resistentes em comparação às de baixa. O ponto de fusão está entre os cones 6 a 14 (entre $1190^{\circ} \mathrm{C}$ a $\left.1390^{\circ} \mathrm{C}\right)^{70}$. As massas de alta temperatura são bem duras, resistentes e impermeáveis. Normalmente, são utilizadas para modelagem de grandes esculturas e utilitários.

- As massas de porcelana também são bastante refratárias, tendo ponto de fusão aproximado entre $1280^{\circ} \mathrm{C}$ e $1300^{\circ} \mathrm{C}$.

Fotos: Silvia Tagusagawa

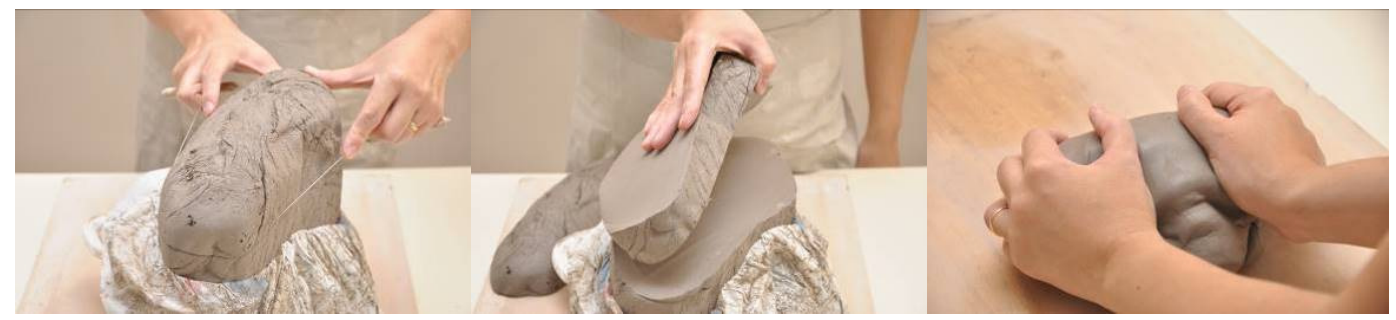

\section{Massas para torno}

Assim como foi dito anteriormente, as massas cerâmicas também são elaboradas para a construção de determinadas peças ou objetos. No caso do torno, por exemplo, as massas são, preferencialmente, plásticas o suficiente para deslizar por entre as mãos, não devem reter água rapidamente e precisam manter sustentação à medida em que as paredes da peça se elevam. Normalmente, utilizam-se massas de baixa temperatura como a terracota e a faiança. Em alta temperatura, existem massas grês e porcelana, cuja plasticidade é ajustada através da adequação de matérias primas.

\footnotetext{
${ }^{70}$ RHODES, Daniel. Clay and glazes for the potter. Pennsylvania : Chilton,1973., p. 315
} 


\section{Massas para modelagem}

Trabalhos de grandes dimensões ou peças planas como azulejos, por exemplo, possuem paredes grossas e a massa utilizada deve secar sem deformações e rachaduras. Sua queima deve ser segura.

Esculturas cerâmicas de grandes dimensões são construídas e ocas por dentro. Sendo assim, sua secagem ocorre de forma irregular, podendo sofrer tensões em certas partes. Para evitar tais inconvenientes, Reijnders ${ }^{71}$ aconselha a utilizar quantidade baixa ou moderada de quartzo na massa, um chamote com alto teor de alumina e uma estrutura aberta.

É importante a utilização de cargas para este tipo de massa, tais como chamote (argila queimada e triturada) e alguns tipos de fibras ou polpa de papel, dependendo da textura desejada. Alguns tipos de carga, como polpa de papel, por exemplo, deixam a peça mais leve após a queima. Já os chamotes e outras cargas similares têm a função de dar maior resistência mecânica à peça.

Com relação às cargas utilizadas em massas cerâmicas, há pesquisas que relatam o uso de diversos tipos delas como areia, granilhas e grãos que proporcionam texturas e cores diversas. Há algumas obras bibliográficas que podem ser consultadas a respeito de cargas em massas.

\section{Porcelana}

Porcelana é uma massa branca que, quando queimada a cone $9\left(1280^{\circ} \mathrm{C}\right)$ ou mais, vitrifica-se criando uma superfície translúcida. A massa de porcelana é a combinação de argilas com feldspato e quartzo.

A palavra porcelana ou porcelain é de origem inglesa, mas possivelmente deriva do francês porcelaine ou do italiano porcelana. Antes do nome dado pelos ingleses, era definida como "china", pois as primeiras peças em porcelana surgiram na China. Por volta de 618-907 d.C., na Dinastia Tang, a porcelana foi desenvolvida e a partir desta época os chineses foram alcançando um alto grau de refinamento quanto às formas das peças, as queimas e materiais. A porcelana chinesa foi

\footnotetext{
${ }^{71}$ EKWC/Reijnders, Op.cit., 2005, p. 42.
} 
amplamente apreciada na Europa e com preços elevados, por isso, era conhecida também como "ouro branco"72. Fábricas de cerâmica em Sèvres (França) e em Worcester (Inglaterra) também se tornaram famosas pela produção de peças em porcelana.

As massas de porcelanas apresentam grande quantidade de material refratário e pouco plástico, o que dificulta, para alguns, seu manuseio durante a modelagem. De qualquer forma, a indústria desenvolveu massas de porcelana para temperaturas inferiores a $1280^{\circ} \mathrm{C}$ e com plasticidade adequada, tanto para torno como modelagem.

Como a porcelana se destaca pela sua translucidez, espessura fina e delicada, há no mercado uma massa de porcelana que é vendida sob a forma de folha retangular, cuja espessura variar entre $0,3 \mathrm{~cm}$ a $0,5 \mathrm{~cm}$, comercialmente conhecida como Keraflex. A vantagem na utilização dessa folha de porcelana é que não há necessidade de esticar a massa, podendo ser cortadas na forma desejada.

\subsubsection{Umidade}

Segundo Rhodes, para que uma massa cerâmica seja adequadamente plástica, ela necessita de aproximadamente 35 partes de água, para 100 partes de $\operatorname{argila}^{73}$. Reijnders ${ }^{74}$ sugere que massas utilizadas para a construção de esculturas e que contenham cargas como chamote, por exemplo, tenham $16 \%$ de água em relação ao peso total de massa em pó. Já massas com quantidade predominante de argila deveriam conter até $23 \%$ de água.

\footnotetext{
${ }^{72}$ COOPER, Emmanuel. Ten thousand years of pottery. Philadelphia: University of Pennsylvania, 2000 , p. 160.

${ }^{73}$ RHODES, Daniel. Clay and glazes for the potter. Pennsylvania : Chilton,1973, p. 13.

${ }^{74}$ EKWC/Reijnders. Op.cit., 2005, p. 51.
} 


\subsubsection{Barbotinas}

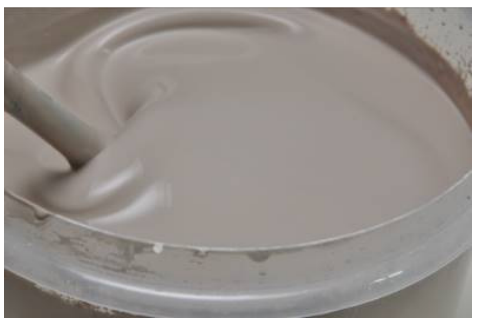

Figura 6

Barbotina grês branca

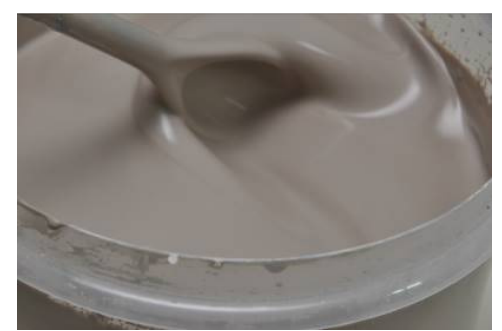

Figura 7

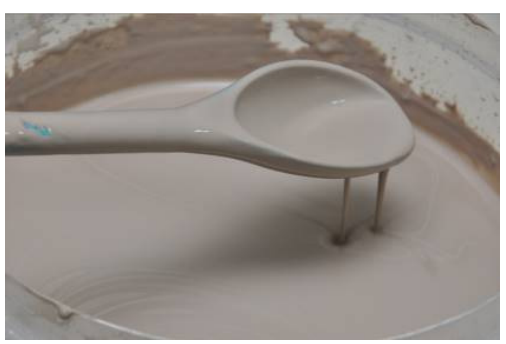

Figura 8

Fotos: Silvia Tagusagawa

A barbotina é uma suspensão de matérias-primas cerâmicas em água, a mistura é suficientemente líquida para poder ser vertida ${ }^{75}$. As barbotinas são similares às massas cerâmicas com relação aos tipos e temperaturas, mas são diferentes quanto à sua viscosidade. Assim como as massas cerâmicas, há barbotinas de alta e baixa temperatura:

- Alta Temperatura: porcelanas, com grês variando entre as cores brancas, cremes até vermelhas;

- Baixa temperatura: as faianças (brancas) e terracotas.

É possível trabalhar com barbotinas de outras cores, para tanto é necessário um estudo prévio de cores, empregando corantes minerais ou óxidos.

Para que uma barbotina tenha fluidez, é necessário adicionar água e defloculante aos ingredientes em pó.

75 AUN, Cristiane Rodrigues. Proposta de uma nova linguagem de projeto para o revestimento cerâmico aplicado às fachadas para o uso doméstico e/ou comercial. Tese de Doutorado apresentada à Faculdade de Arquitetura e Urbanismo da USP, São Paulo, 2005, p. 24. 


\subsubsection{Ferramentas: estecas e outras}

Fotos: Silvia Tagusagawa

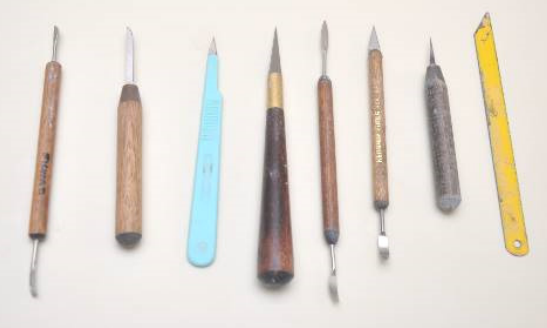

Figura 9

Ferramentas e estecas para corte e furos

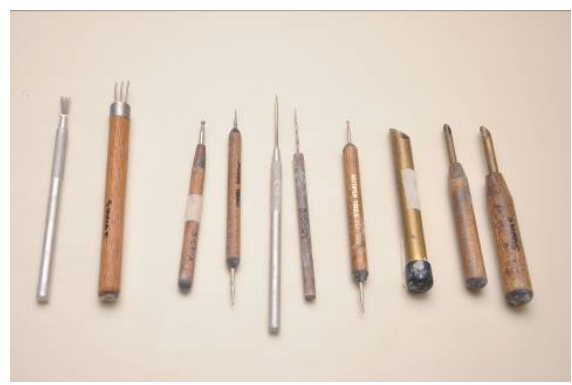

Figura 11 - Estecas para furar

e arranhar superfícies

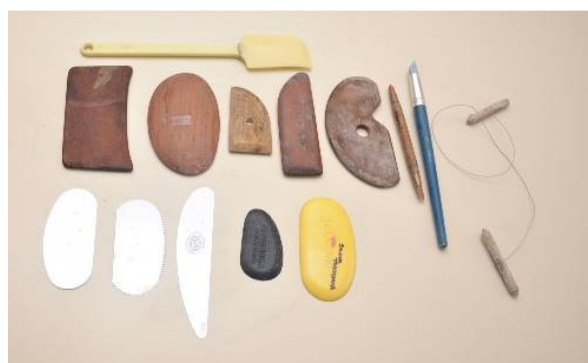

Figura 13 - ferramentas em madeira, aço inox e silicone - utilizados para alisar, brunir e raspar Fio de nylon utilizado para corte de massa

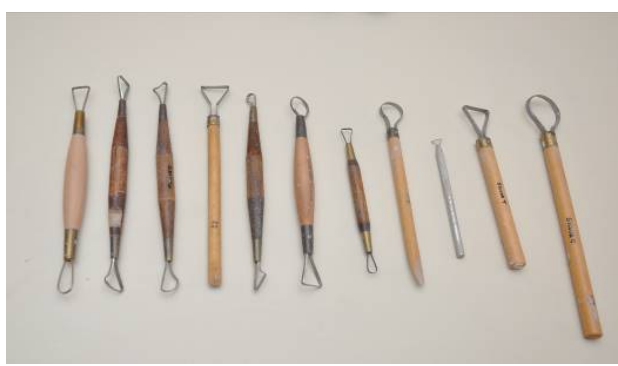

Figura 10

Estecas para desbaste e cavar

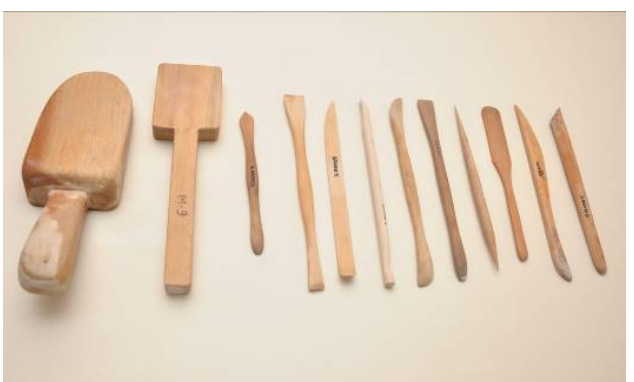

Figura 12 - Estecas em madeira

para acabamento e modelagem

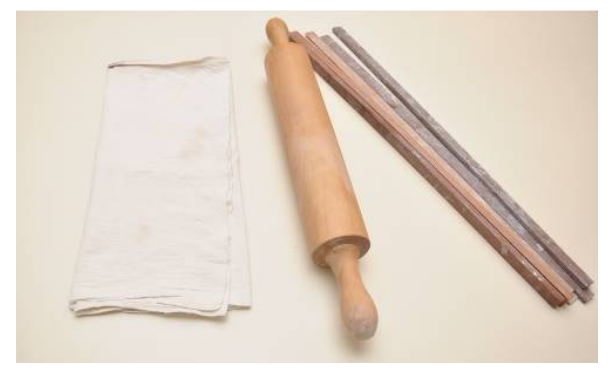

Figura 14 - Lona, rolo e guias de madeira utilizados para abrir placas.

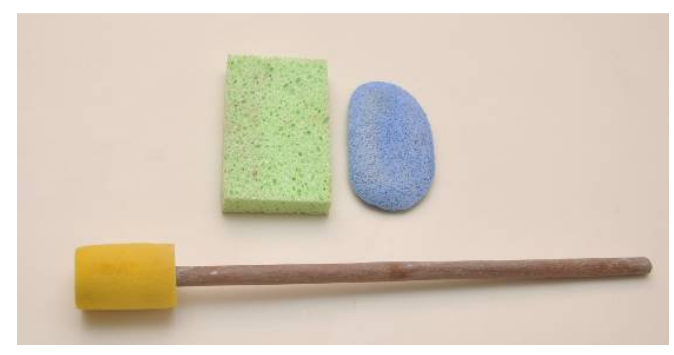

Figura 15

Esponjas 
As ferramentas para cerâmica, conhecidas como estecas, são utilizadas na modelagem e acabamento das peças. Podemos utilizá-las para cortar, cavar, extrair, fazer texturas, alisar e juntar a massa cerâmica. Além das estecas, é possível adaptar outros tipos de utensílios para dar forma e acabamento aos trabalhos como colheres e pequenas facas. Há quem adapte ferramentas de dentista para a realização de trabalhos em cerâmica. Existem ainda vários tipos de estecas feitas em madeira, fios de aço e plásticos.

"Assim uma ferramenta deve ser considerada em ligação com o seu complemento de matéria, na exata dinâmica do impulso manual e da resistência material. ${ }^{, 76}$

Para cada tipo de trabalho, seja cavar, alisar, desbastar, molhar ou cortar, o artista irá escolher uma ferramenta específica. Assim Bachelard acrescenta:

"E é em função da matéria, de sua resistência, de sua dureza que se forma na alma do trabalhador, ao lado de uma consciência de destreza, uma consciência de poder. Destreza e poder não andam uma sem o outro, no onirismo do trabalho, nos devaneios da vontade. A ferramenta lhes estabelece a união de uma matéria tão nítida que se pode dizer que, se cada matéria tem um coeficiente de adversidade, cada ferramenta determina na alma do operário um coeficiente de domínio"ק7

\subsection{Técnicas de modelagem, aplicação de cores e texturas na cerâmica}
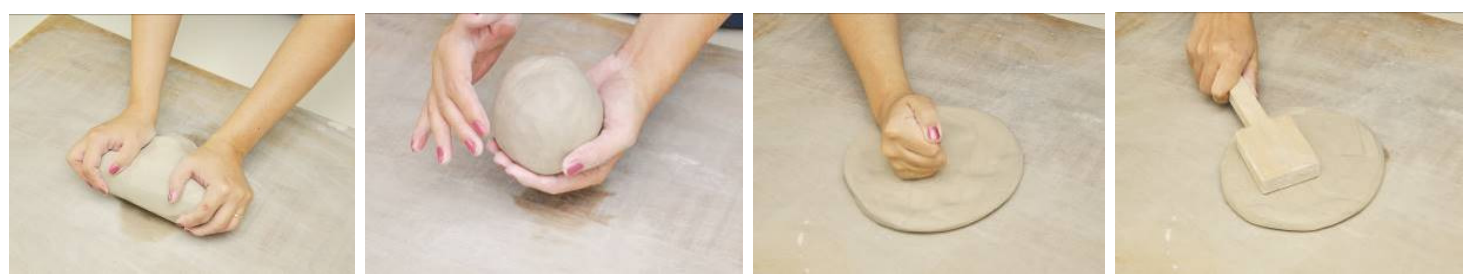

\footnotetext{
${ }^{76}$ BACHELARD, Gastón. Op. cit., 2008, p. 42

77 Idem, ibidem.
} 


\subsubsection{Técnicas de modelagem manual}

O simples movimento de empurrar, espremer ou rolar a argila com as mãos são sentidos institivamente e estabelecem uma forte conexão entre o indivíduo que manipula e a matéria. O que chama a atenção é esse contato constante e íntimo entre as mãos do artista e a matéria durante a elaboração do trabalho em cerâmica. Diversas técnicas foram desenvolvidas para facilitar e agilizar o trabalho. Além disso, inovações tecnológicas têm sido atuantes nesta área. Como por exemplo, os tornos manuais que já eram utilizados para agilizar a construção de potes e atualmente possuem motores potentes e silenciosos, além de serem funcionais e ergonômicos quanto ao seu uso.

Mesmo com o surgimento das máquinas que auxiliam na construção de peças cerâmicas, a intimidade com a matéria proporcionada pelas técnicas de modelagem manual é sempre recorrente entre os artistas dessa área. Por isso, entender como são utilizadas é importante para compreender o processo de criação em cerâmica.

Antes de iniciar a construção de uma peça cerâmica devemos levar em consideração a consistência da massa cerâmica. Sabe-se que em contato com o ar e à temperatura do ambiente, essa massa vai perdendo líquido e endurece. Respeitando e conhecendo os diversos estágios de secagem da massa, as chances de sucesso do projeto serão maiores. Por isso, conforme a orientação de Rhodes ${ }^{78}$, devemos levar em consideração que:

- Uma massa em condição extremamente plástica pode ser interferida com maior facilidade e qualquer pressão sofrerá deformação. No entanto, não suporta sustentar grande peso, pode deformar-se e ceder;

- Numa condição média de secagem, a massa pode ser modelada, mas com certas restrições. Essa consistência é a ideal na modelagem de escultura de maiores dimensões;

\footnotetext{
${ }^{78}$ RHODES, Daniel. Op. cit.,1973, p. 4
} 
- A massa pode ser interferida, sem sofrer grandes alterações quanto a sua deformação, quando está num estado que definimos como ponto de couro (a massa está firme e dura, porém, pode ser interferida com cortes ou incisões);

- Há o estágio de secagem da massa em que ela está extremamente dura e seca, pode ser pouco interferida. Deve-se tomar cuidado ao manusear a peça nesta fase, pois ela pode se romper. A massa fica com a cor mais clara.

Há quatro técnicas básicas de modelagem manual: rolinho, extrusão, placa e modelagem de peça sólida ou bloco:

- Rolinho ou acordelado: rolos de argila podem ser construídos com as mãos ou através de uma extrusora. Esses rolos são unidos, um sobre o outro, para construção de uma parede;

- Extrusão: envolve pressionar a argila através de um bocal que pode ter formas cilíndricas, cubicas, entre outras, com o intuito de construir formas contínuas;

- Placas: paredes de peças ou objetos cerâmicos podem ser formadas por placas de argilas. Essas placas são construídas quando um rolo de madeira é pressionado, com as mãos, sobre um pedaço de argila, até adquirir uma espessura desejada;

- Bloco: é possível interferir num bloco de massa cerâmica úmida, com as mãos e ferramentas, pressionando-os, retirando pedaço ou acrescentando, até adquirir a forma desejada.

Taylor $^{79}$ acrescenta outro meio de modelagem manual que ela define como pinching (ou "beliscar") que na realidade se trata de pressionar os dedos sobre um pedaço de argila mole, proporcionando uma nova forma a essa massa amorfa.

\footnotetext{
${ }^{79}$ TAYLOR, Louisa. The Ceramics Bible. San Francisco: Chronicle books, 2011, p. 60.
} 


\subsubsection{Rolinho ou acordelado}

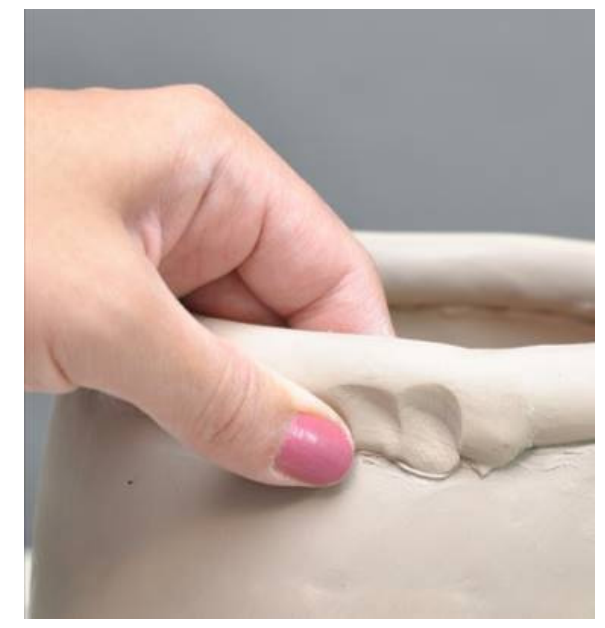

Figura 16

Construção com rolinho ou acordelado Foto: Silvia Tagusagawa

A técnica do "rolinho" ou acordelado é uma das técnicas mais utilizadas na modelagem de objetos ou peças cerâmicas. Tradicionalmente, rolinhos são modelados com as mãos, dispostos de maneira a construir a parede da peça.

Com a técnica do "rolinho" ou acordelado é possível construir esculturas ou objetos ocos e de tamanhos diversos. Utilizam-se rolos feitos de massa cerâmica, que são posicionados um sobre o outro e com o auxílio das mãos e ferramentas adequadas, são unidos formando uma parede regular firme.

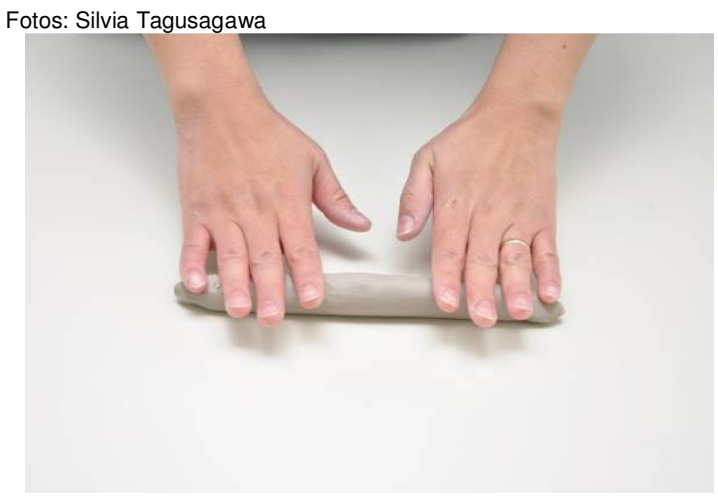

A 1

Modelagem manual - rolinho ou acordelado

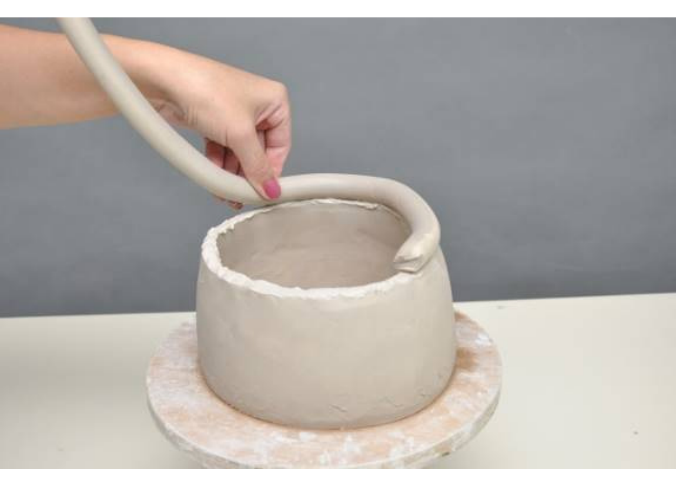

A 2

Os rolinhos são acomodados sobre a outra parte. 


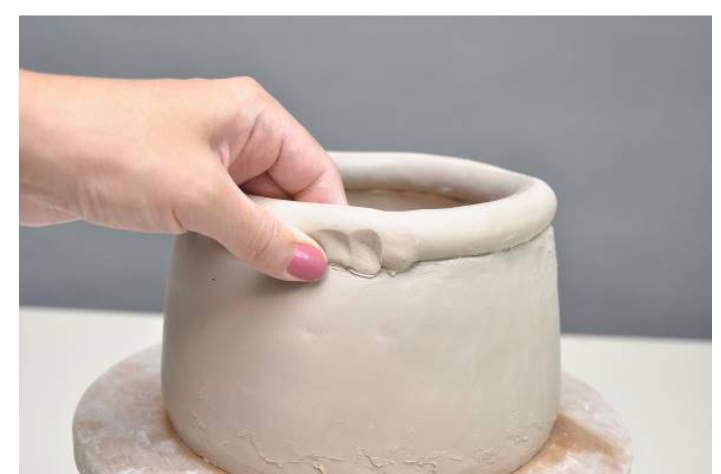

A 3

Com auxílio dos dedos e ferramentas os rolinhos são pressionados e comprimidos para formar a parede da peça cerâmica

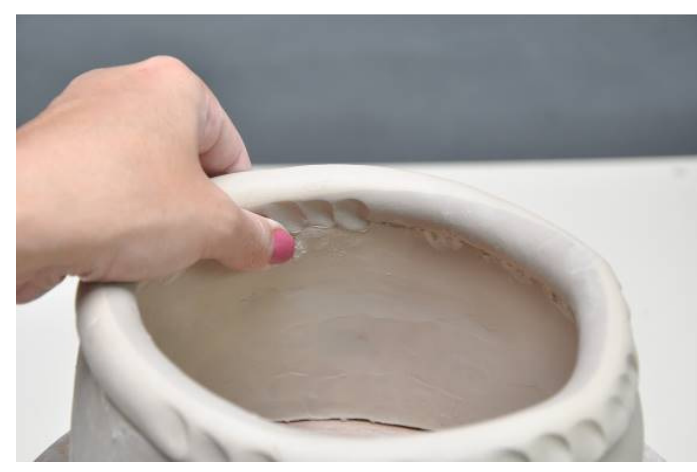

A 4

Pressionar e comprimir os rolinhos nas partes externa e interna da peça.

Atualmente, algumas impressoras 3D utilizam o mesmo princípio do rolinho. Como, por exemplo, na pesquisa desenvolvida por Brian Peters ${ }^{80}$ com o objetivo de construir, de maneira rápida e eficiente, tijolos leves e com encaixes precisos. Peters desenvolveu uma impressora que primeiramente, recebe informações sobre o desenho do tijolo vindo de um software, que é utilizado para desenhar o modelo que se deseja reproduzir tridimensionalmente. Existem impressoras 3D que reproduzem ou imprimem objetos, sendo que os cartuchos dessas máquinas são carregados de plásticos em estado pastosos e que vão liberando rolinhos conforme o desenho programado. No caso de Peters, ele desenvolveu uma massa cerâmica, cuja consistência pastosa foi devidamente adequada após inúmeros testes e vai caindo a partir de um tubo. Este tubo possui uma espécie de braço mecânico comandado pelo computador.

80 Brian Peters é arquiteto e co-fundador do Design Lab Studio. Adaptou uma impressora 3D para a produção de tijolos para a construção de estruturas arquitetônicas (http://www.dezeen.com Acesso em: 02/02/2013. 


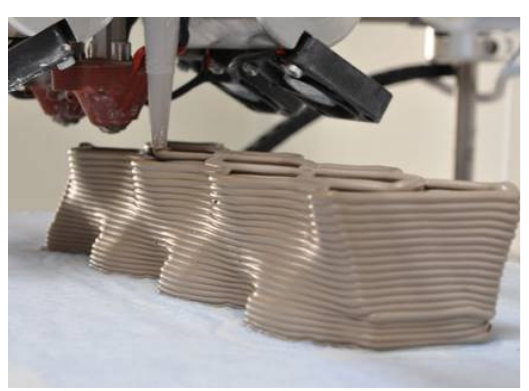

Figura 17

Brian Peters - Impressão 3D

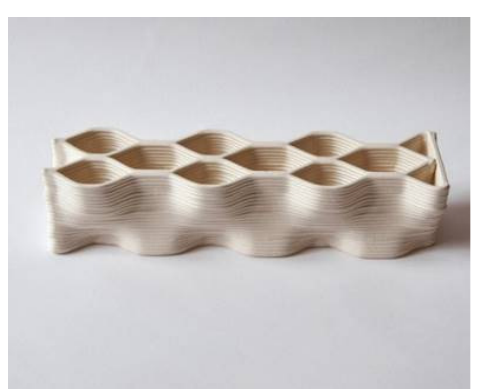

Figura 18

Tijolo desenvolvido por Peters com massa cerâmica adaptada à

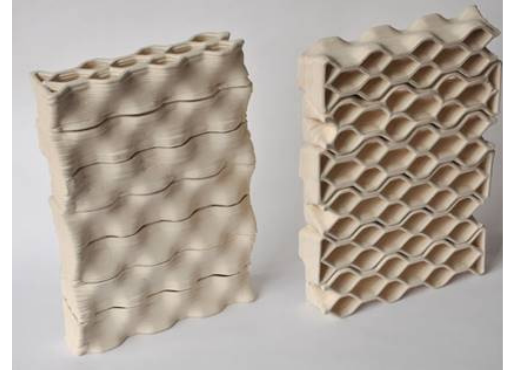

Figura 19

Tijolos feitos em impressora 3D.

Historicamente, sabe-se que o acordelado ou rolinho foi uma técnica utilizada pelos povos na Era Neolítica e na Idade do Bronze na produção de potes ou contêineres para armazenamento de água e alimentos. Há registros de artefatos similares na Era da América Pré-Colombiana, no Oeste Africano, na Ásia e no Mediterrâneo. Exemplos de peças cerâmicas antigas originárias do Japão Antigo também foram construídas, muito provavelmente, pela técnica do rolinho ou acordelado ${ }^{81}$.

\subsubsection{Extrusão}

O método de extrusão consiste em forçar um pedaço de massa cerâmica através de um tubo cilíndrico ou cubico e que passa por um bocal ou matriz para se obter uma forma desejada. Normalmente, numa extrusora podemos utilizar bocais ou matrizes com desenhos variados como círculos, quadrados, retângulos, entre outros. Ao passar pelo bocal, a extrusora produz formas tubulares, em tiras de qualquer comprimento.

\footnotetext{
${ }^{81}$ COOPER, Emmanuel. Ten thousand years of pottery. Philadelphia: University of Pennsylvania, 2000 , p. 9.
} 


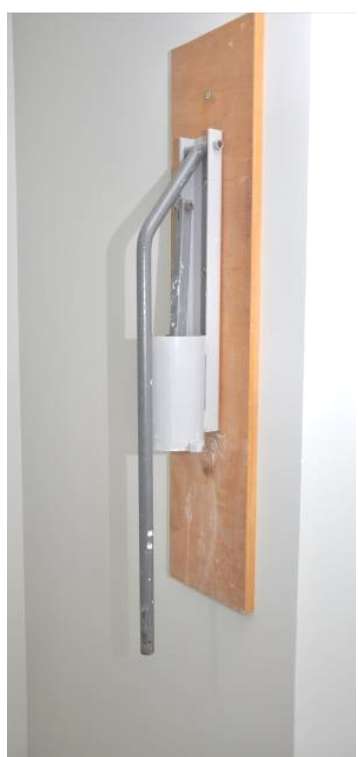

\section{Extrusora}

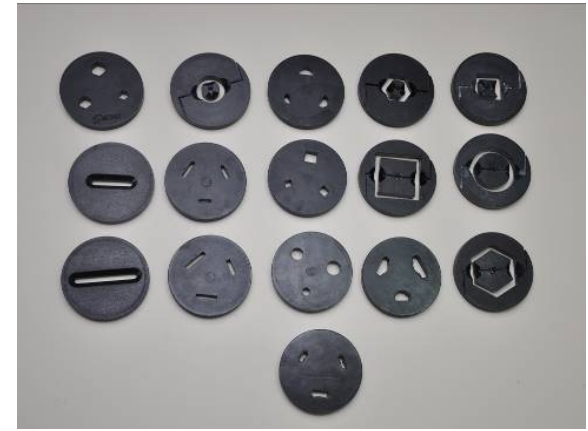

Figura 21

Bocais ou matrizes da extrusora

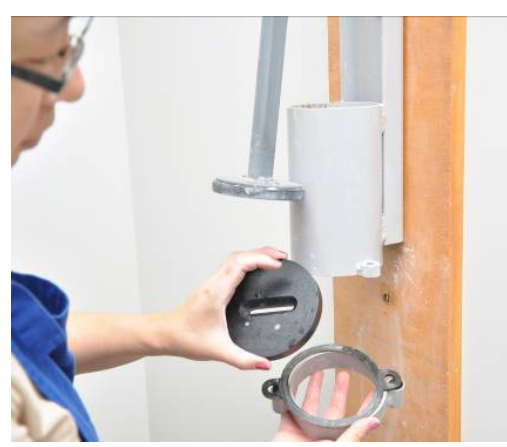

Figura 22

Figura 20

O método de extrusão utiliza o mesmo princípio de uma seringa, em que a massa é colocada dentro de um tubo. A massa é pressionada manualmente de cima para baixo com a ajuda de uma alavanca, como se percebe nas figuras abaixo.

Fotos: Silvia Tagusagawa)

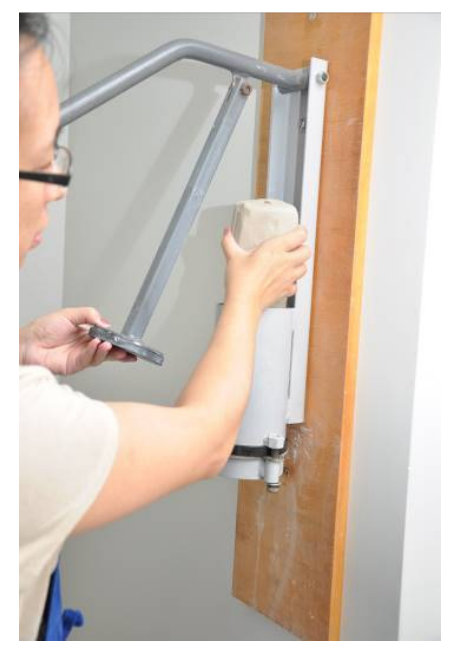

Figura 23

Coloque a massa dentro do cilindro
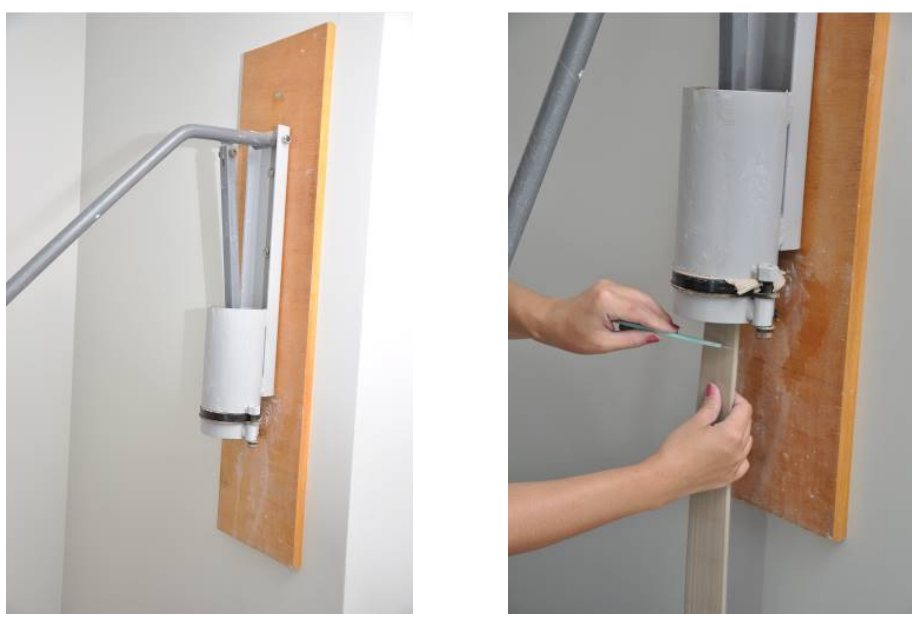

Figura 24

Pressionar para baixo o êmbolo da extrusora dentro do cilindro
Figura 25

Cortar 


\subsubsection{Placa}

Peças ou objetos cerâmicos podem ser desenvolvidos por meio de construção de placas de argila. Para isso, deve-se ter uma ideia das dimensões da peça, pegar uma peça de massa cerâmica úmida para cada parte da peça a ser confeccionada. Pressionando a massa cerâmica com um rolo pode-se formar "folhas" de massa com espessura que pode variar de $0,5 \mathrm{~cm}$ a $2 \mathrm{~cm}$.

Fotos: Silvia Tagusagawa

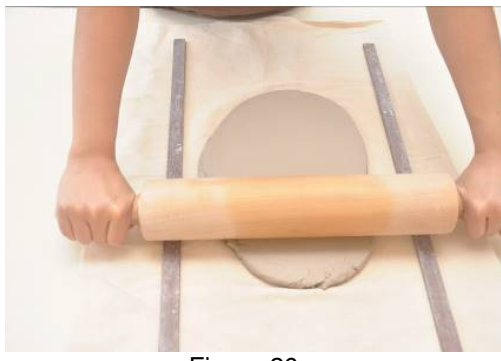

Figura 26

Duas guias são posicionadas sobre uma superfície plana. A massa é colocada entre as duas guias e pressionada com um rolo de madeira

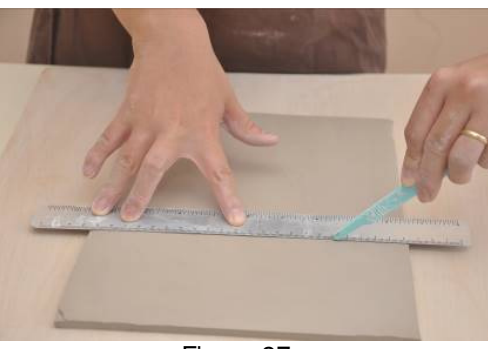

Figura 27

Cortar da placa formada da maneira desejada.

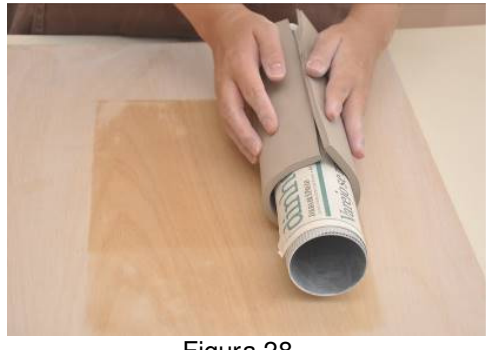

Figura 28

A consistência da massa é diferente para cada tipo de trabalho. Por exemplo, em peças geométricas, recomenda-se trabalhar com as placas em ponto de couro.

A construção por meio de placas de massa cerâmica permite que as peças tenham paredes mais uniformes e com espessuras regulares.

As placas podem ser facilmente manipuladas e deformadas quando estão úmidas. Por isso, peças em forma de cones e cilindros, por exemplo, podem ser construídas através deste método.

Para peças geométricas, em forma de cubo, por exemplo, as placas devem estar firmes para serem cortadas nos formatos desejados. Se o teor de umidade for alto, as placas podem ceder ou sofrer deformações durante a montagem ou secagem.

Reijnders ${ }^{82}$ aconselha atenção redobrada para peças de grandes dimensões, utilizando o método de placas, como:

82 REIJNDERS, Anton. "The ceramic process: a manual and source of inspiration for ceramic art and design". In: ECWC - European Ceramic Work Centre London: A\&C Black, 2005, p. 76 
- Secagem uniforme e lenta das placas (a diferença resultará em encolhimento desigual, aumentando as chances de rachaduras);

- Quando as placas tiverem espessura inferior a $1,5 \mathrm{~cm}$, o ponto de junção de suas placas deve ter um ângulo de $45^{\circ}$ ao invés de $90^{\circ}$ (como normalmente é);

- As áreas de junção devem ser "arranhadas", para assim serem demarcadas, com uma ferramenta similar a um garfo e umedecidas com água;

- Ao unir duas placas, a área de junção deve ser umedecida com barbotina, preparada a partir da argila utilizada no trabalho;

- Para unir as extremidades dos segmentos, empurra-se a argila com a ponta de uma faca ou com o polegar. Faz-se um "tipo" de costura nas junções com o auxílio de uma ferramenta de madeira e, depois, preenche-se com argila de uma consistência semelhante.

As placas em seu estado de couro são mais fáceis de trabalhar e de serem controladas, principalmente na construção de peças geométricas.

As placas podem ser dobradas, modeladas e cortadas

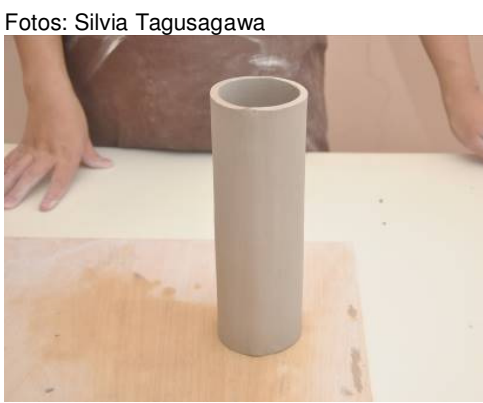

B 1

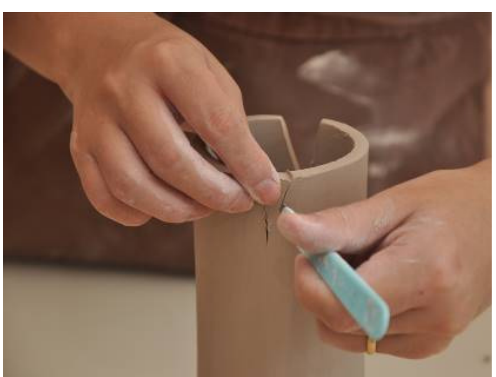

B 2

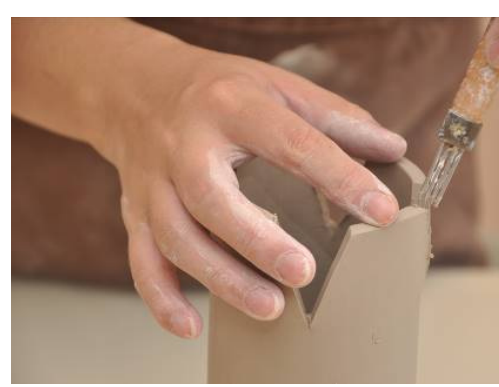

B 3 

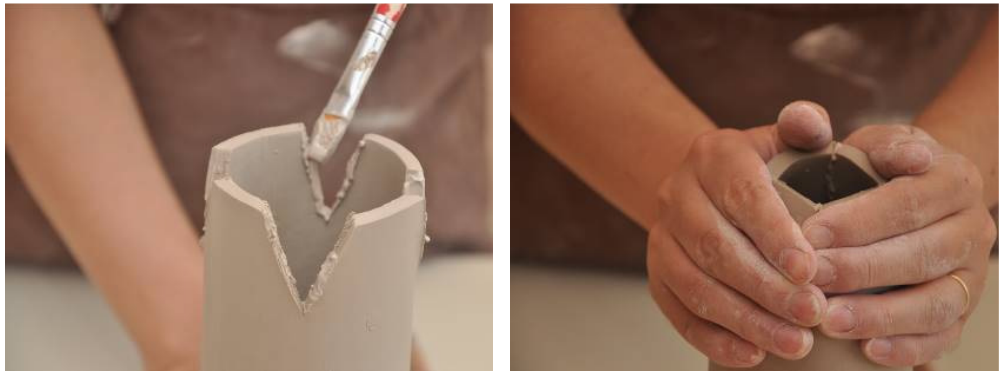

B 5

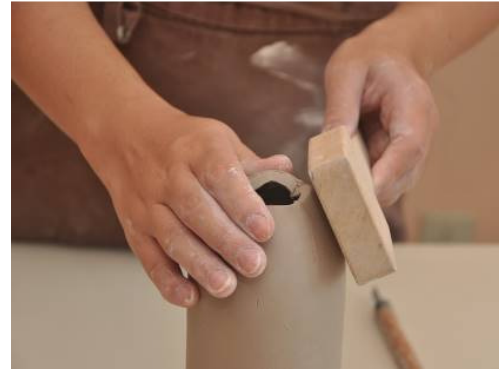

B 6

\subsubsection{Bloco}

A modelagem de um pedaço ou bloco de massa cerâmica pode ser realizada com as mãos e utilizando ferramentas apropriadas. Pedaços de argila são acrescentados, deslocados ou retirados até adquirir a forma desejada.

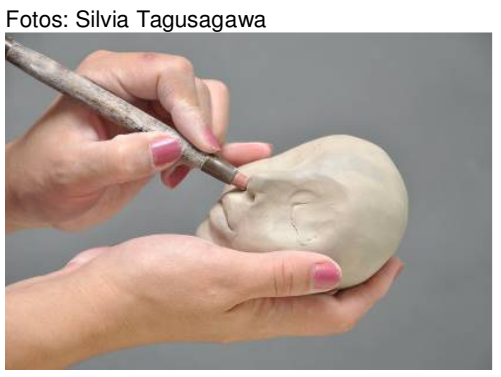

C 1- Modelar um bloco ou pedaço de massa cerâmica

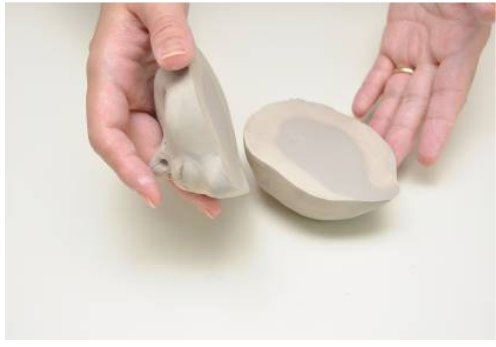

C 2 - Após adquirir certa consistência a peça pode ser cortada

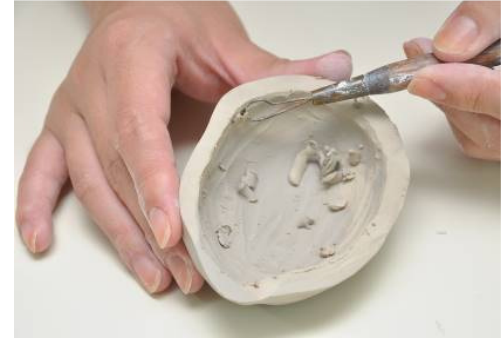

C 3- As peças cerâmicas normalmente devem ser ocas por dentro. Por isso, deve-se esvazia-la com uma esteca de arame.

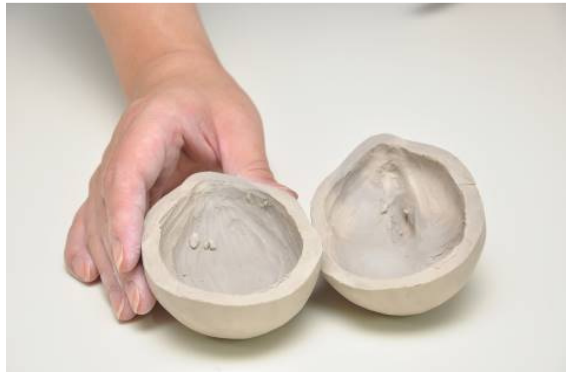

C 4

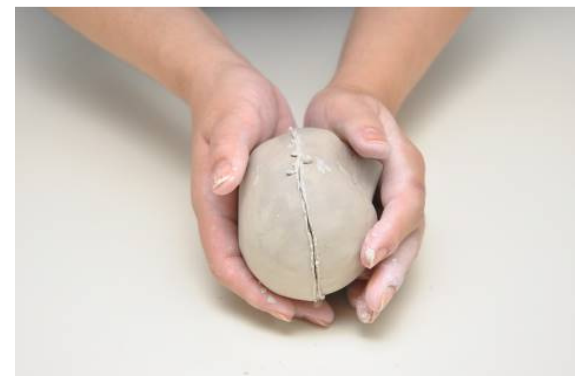

C 5

A peça deve permanecer úmida até o final da modelagem, e ao mesmo tempo, deve estar firme para receber mais peso, caso seja necessário, principalmente no 
caso de escultura de grandes dimensões. Suportes temporários são necessários, por vezes, para sustentar o peso ou dar equilíbrio para que a peça não ceda.

Essas peças não devem ir maciças ao forno, necessitando esvaziar o seu interior. Após a peça passar por uma leve secagem, em ponto de couro ou um pouco antes, ela deve ser aberta com uma ferramenta de corte como um fio nylon e o seu interior deve ser escavado com uma ferramenta apropriada. Esse processo deve se ater ao estágio de secagem, pois se a peça estiver demasiadamente dura, fica mais difícil deixá-la oca.

Reijnders $^{83}$ faz uma importante orientação com relação às esculturas ou peças feitas com massas que contenham cargas como fibras ou polpa de papel. Neste caso, as peças devem ter seu esvaziamento iniciado em ponto mais úmido, pois conforme a secagem, este trabalho torna-se também difícil.

\subsubsection{Torno}

É na práxis, que o artista vai desvendando novas possibilidades para a sua criação. No contato da matéria com as mãos, no simples ato de pegar uma ferramenta e manuseá-la sobre a massa cerâmica, pressionando, dobrando, beliscando, cavando, cortando e em toda e qualquer intervenção, descobre-se e são reinventadas novas formas de poesia. Assim é com o torno. Quando se fala em cerâmica, muitos relacionam com a imagem de um oleiro sobre seu torno, levantando um vaso ou um pote. O movimento circular do torno e velocidade constante faz com que a massa cerâmica seja distribuída uniformemente, com a ajuda das mãos do artista, de baixo para cima, de forma sincronizada, elevando assim uma parede uniforme. Com o toque sutil dos dedos, das palmas das mãos e ferramentas, a partir da forma cilíndrica, surgem outras formas esféricas e sinuosas.

O torno utilizado atualmente funciona em energia elétrica, possui controle de velocidade e rotação bilateral, permitindo maior eficiência na produção de peças ou objetos cerâmicos. É necessário o aprendizado prévio de seu manuseio e seu

${ }^{83}$ EKWC. Op. Cit,.2005 ,p. 80. 
domínio é adquirido com a prática. Há muitos ceramistas que dedicam totalmente a sua produção por esse meio.

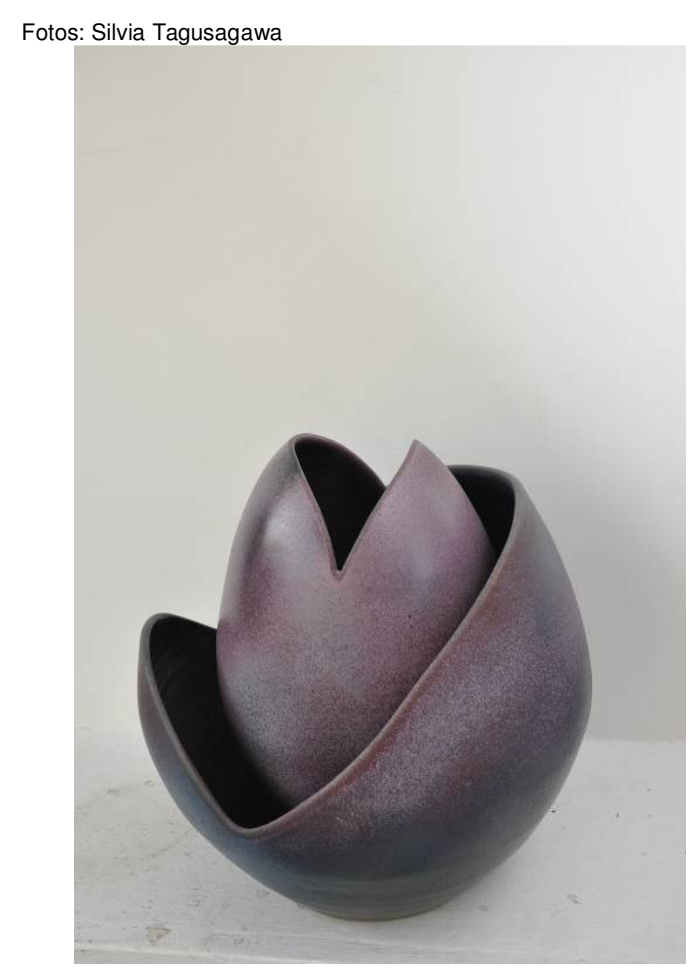

Figura 29

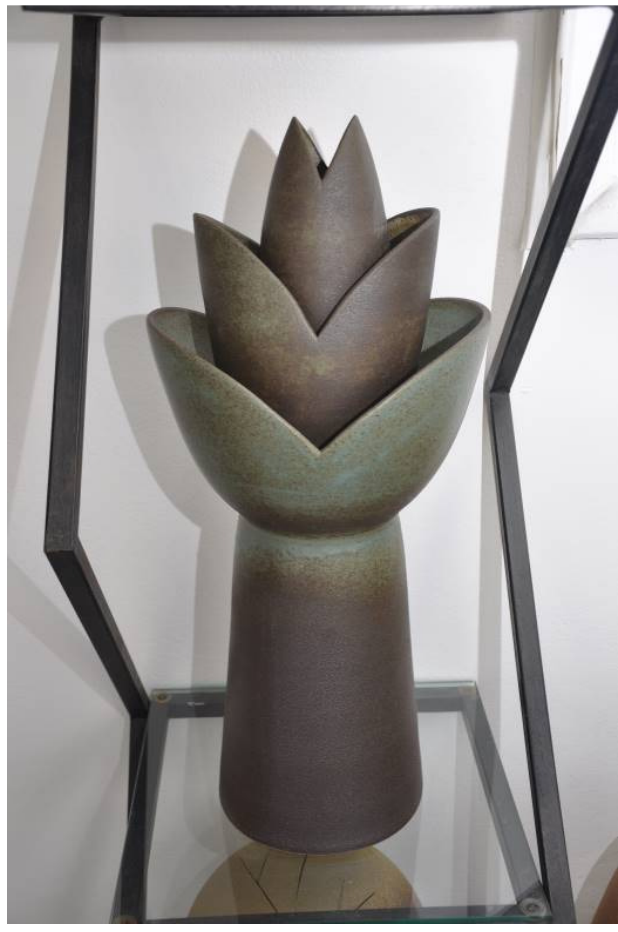

Figura 30

Cada parte desta peça foi torneada e depois reunida

\subsubsection{Molde de gesso}

O molde de gesso é muito utilizado na indústria cerâmica para a reprodução de peças ou objetos em grande quantidade. De acordo com Chavarria ${ }^{84}$, os tipos mais comuns de moldes de gesso utilizados na cerâmica são:

- Molde perdido;

- Molde para colagem;

- Molde para moldagem.

${ }^{84}$ CHAVARRIA, Joaquim. Moldes. Barcelona: Parromón Ediciones, 2008, p.6. 
Molde perdido: com este tipo de molde é possível reproduzir uma peça e o molde geralmente é produzido em gesso. De acordo com Chavarria, o modelo pode ser feito de massa cerâmica ou em outros materiais. Quando é feito em massa cerâmica, o modelo deve ser retirado cuidadosamente com uma esteca. Portanto, antes de cada moldagem é preciso que o molde esteja completamente limpo e impermeabilizado com o desmoldante. $\mathrm{O}$ molde perdido pode ter duas ou mais partes, dependendo da complexidade do modelo.

Molde para colagem: denomina-se colagem, o método no qual a barbotina é despejada num molde de gesso e após certo período, parte da água da barbotina é absorvida pelas paredes do molde, formando assim uma sólida camada, como se fosse uma espécie de "casca" junto à parede do molde. O excesso de barbotina é despejado novamente no balde em que estava armazenada. Após a secagem do excesso de água depositada na casca, o molde é aberto. A peça passa por um acabamento e é colocada para secagem total.

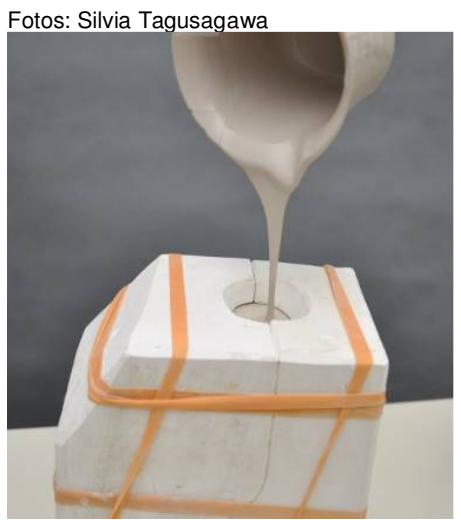

E 1

Preenchimento com barbotina

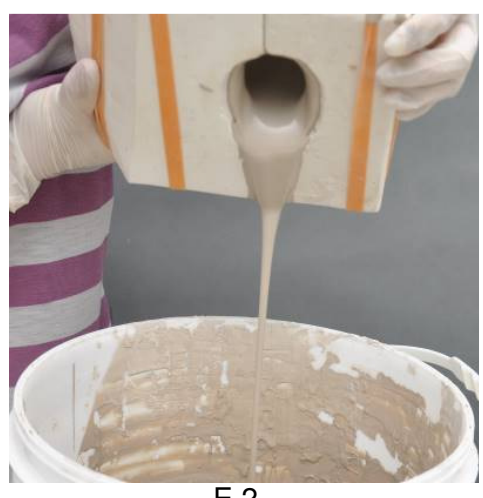

E 2

Retirada do excesso de barbotina

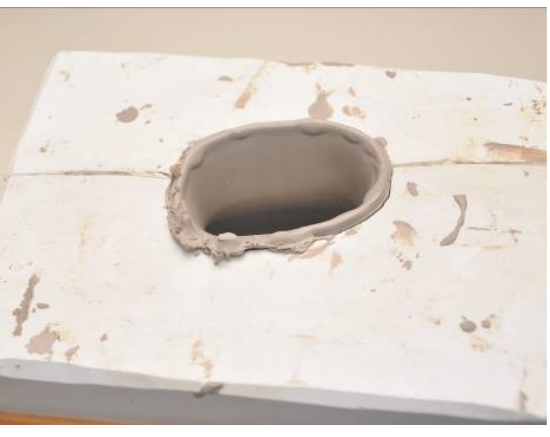

E 3

Formação de parece sólida de barbotina rente às partes internas do molde 


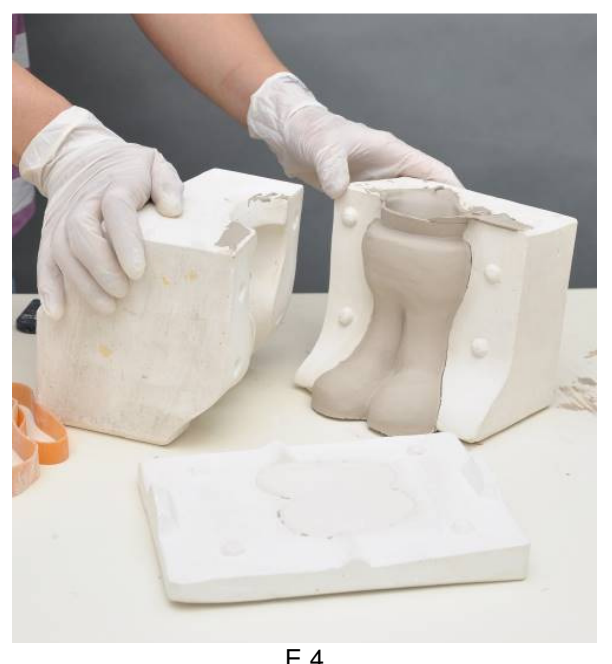

Molde de gesso com 3 partes

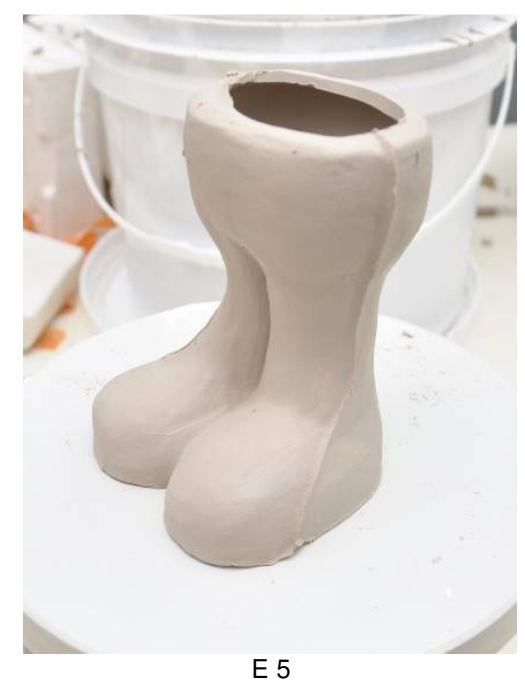

Peça em barbotina

Molde para moldagem: este método denominado moldagem, pedaços ou placas feitos com massa cerâmica são pressionados no interior do molde. ${ }^{85} \mathrm{~A}$ massa cerâmica deve estar úmida e plástica.

Para Reijnders' ${ }^{86}$, a construção de escultura, pelo processo de pressionar massa cerâmica sobre a superfície do molde, se mostra eficiente, principalmente para peças de médias e grandes dimensões. Os moldes podem ter uma, duas ou mais partes dependendo da complexidade.

Fotos: Silvia Tagusagawa

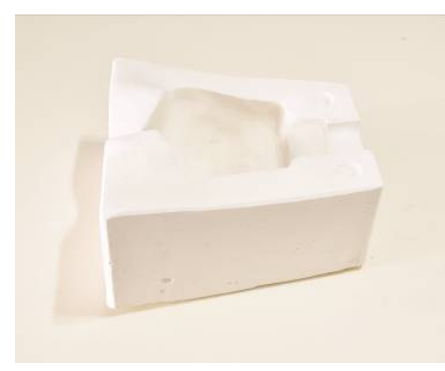

F 1
Moldagem

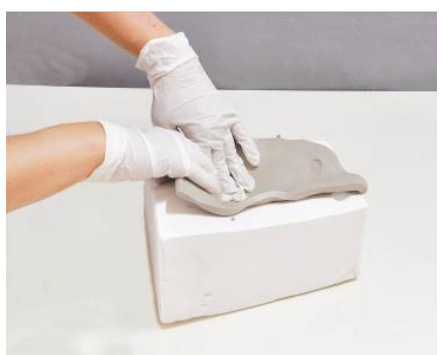

F 2

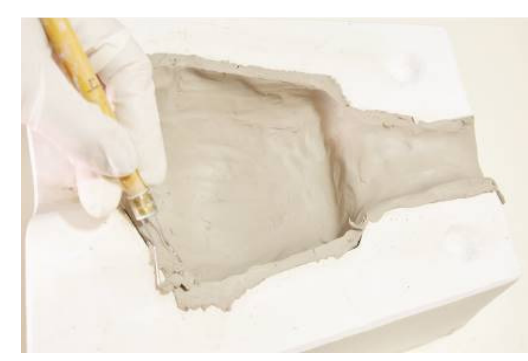

F 3

${ }^{85}$ EKWC. Op. cit.,2005, p. 77.

${ }^{86}$ Idem, pp. 77-88. 


\subsubsection{Construção do molde de gesso}

\section{Modelo}

De acordo com Reijnders ${ }^{87}$, um molde de gesso deve ser feito a partir de um modelo. Podemos eleger como modelo qualquer objeto em qualquer material. Ele nos alerta que para a construção de um molde de gesso é aconselhável levar em consideração as dimensões finais do objeto reproduzido em cerâmica, pois este ficará menor que o modelo original. Isso dependerá da porcentagem de encolhimento após a queima, que pode variar de $4 \%$ a $17 \%$, dependendo da massa ou barbotina. Assim, se o objeto deve ter um tamanho exato, a porcentagem de encolhimento deve ser levada em consideração durante a construção do modelo. Portanto, se a porcentagem de encolhimento, durante a secagem e queima for de $10 \%$, por exemplo, o modelo deve ser ampliado na proporção 1.11 (dividindo $100 \%$ por $90 \%=1.11$ ) aproximadamente.

Outro ponto importante levantado por Reijnders é o processo de secagem da peça cerâmica, que normalmente ocorre de maneira irregular: "como o encolhimento vertical nunca será o mesmo que o horizontal (altura versus largura) fica difícil predeterminar as exatas dimensões do objeto." ${ }^{\prime 8}$

\section{Preparação do Gesso}

Com relação à preparação do gesso, Reijnders ${ }^{89}$ orienta para alguns cuidados tais como:

1. Adicionar água num recipiente de plástico;

2. Polvilhar o gesso sobre a água de maneira uniforme, com cuidado para não despejar o gesso em torrões;

3. Quando o gesso for totalmente acrescentado, aguardar por 1 minuto. Tempo suficiente para a água absorver o gesso;

\footnotetext{
${ }^{87}$ EKWC. Op. cit.,2005, p. 96.

88 Idem, Ibidem.

${ }^{89}$ Idem, p. 91.
} 
4. Misturar por um minuto com movimentos delicados de maneira a remover os grumos e as bolhas de ar. Esses grumos e bolhas podem prejudicar a vida útil do molde, bem como alterar a forma.

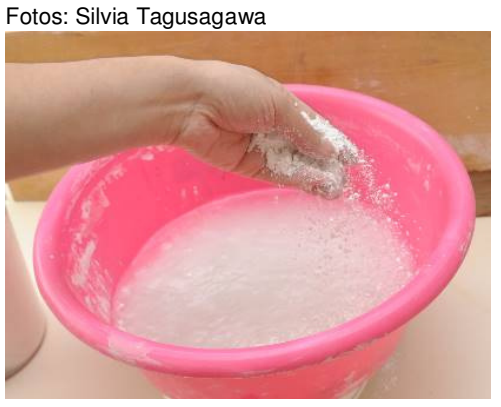

Figura 31

Gesso: despejando aos poucos sobre na água de maneira uniforme

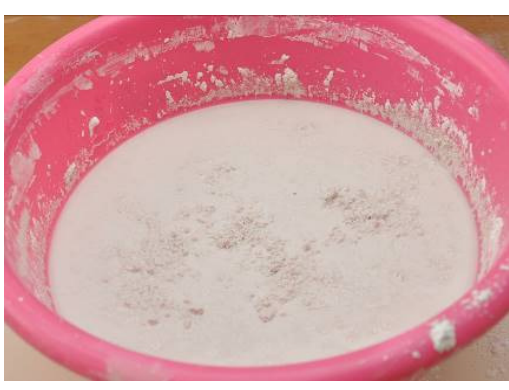

Figura 32 Ao ser acrescentado todo o gesso, serão percebidas pequenas "ilhas" sobre a água

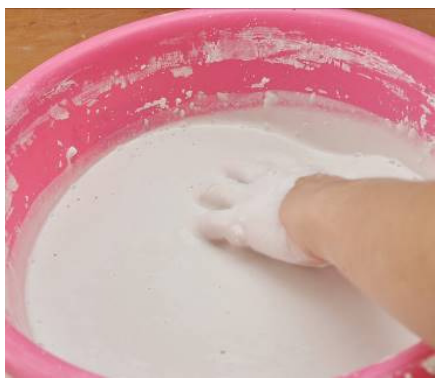

Figura 33

Misturar o gesso e a água com movimentos uniformes para homogeneização e retirada de bolhas de ar

\section{Desmoldantes}

Para moldes de duas ou mais partes, Chavarria ${ }^{90}$ orienta que as partes onde ocorrem as junções sejam impermeabilizadas com desmoldantes para que elas não se unam.

Desmoldantes são agentes que impedem que as superfícies das partes do molde unam-se uma à outra. De acordo com Chavarria ${ }^{91}$, pode-se utilizar como desmoldante uma solução de sabão em pasta (ou um sabão potássico) diluído em água (cuja proporção aproximada seria: $500 \mathrm{~g}$ de sabão para 1 litro de água), devendo ser aplicada diretamente sobre as partes dos moldes e modelo que deverão entrar em contato. A solução deve ser aplicada com um pincel ou brocha, dependendo das dimensões da superfície do molde.

\footnotetext{
${ }^{90}$ CHAVARRIA, Joaquim. Moldes.Barcelona: Parramón Ediciones, 2008, p. 9

${ }^{91}$ Idem, Ibidem.
} 


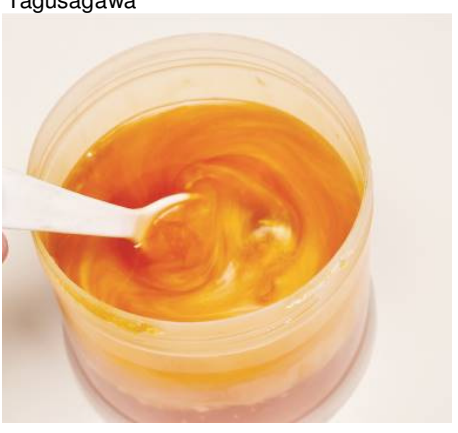

Figura 34

Sabão em pasta

\section{Aplicação do desmoldante}

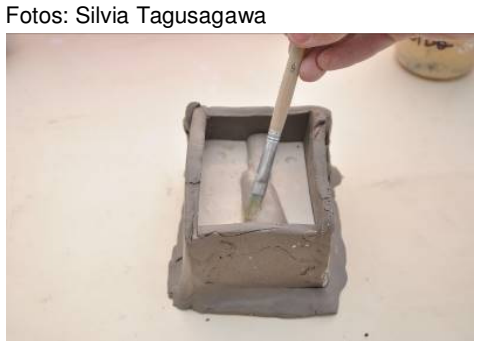

Figura 36

Com a prim eira parte do molde feita, aplica-se o desmoldante.

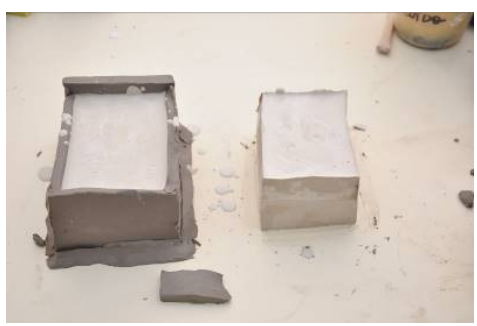

Figura 37

Despejar a segunda parte do gesso. Depois de seca, retirar os cercados.

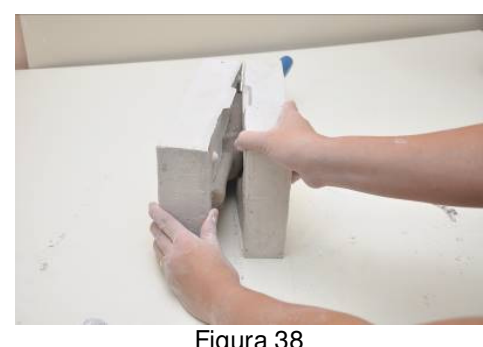

Com as duas partes feitas, abre-se 0 molde e retira-se o modelo.

\section{Exemplo: Molde bipartido}

Como havíamos discutido no início, primeiramente devemos fazer um estudo do modelo para verificar quantas partes o molde de gesso possuirá. No exemplo a seguir, é apresentada a construção de um molde de duas partes.

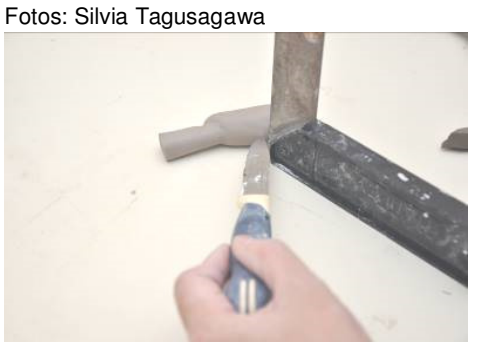

G 1

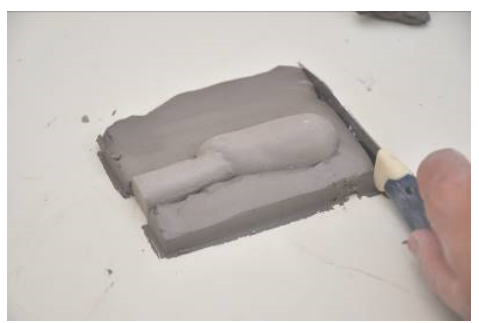

G 2

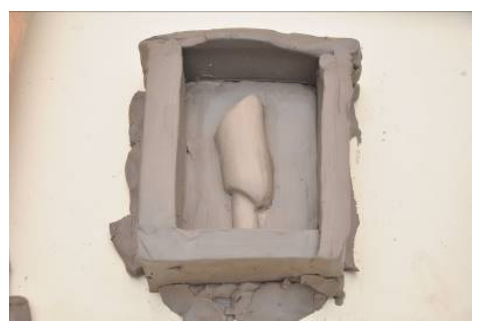

G 3 


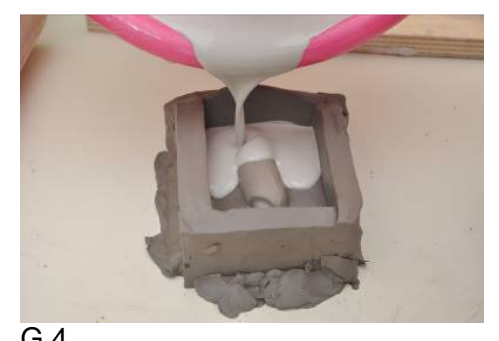

G 4

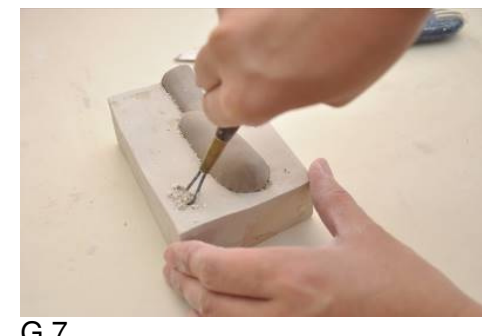

G 7

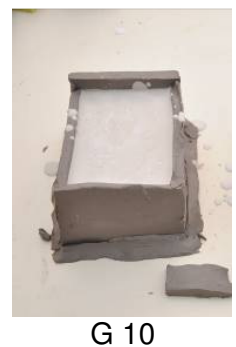

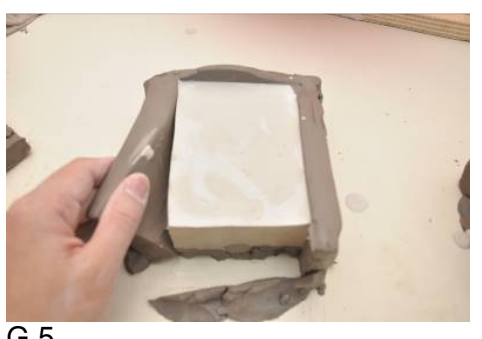

G 5

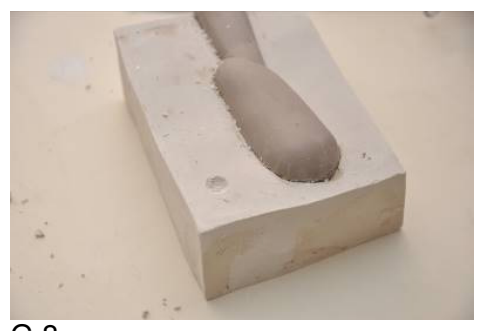

G 8

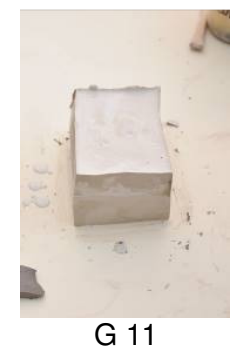

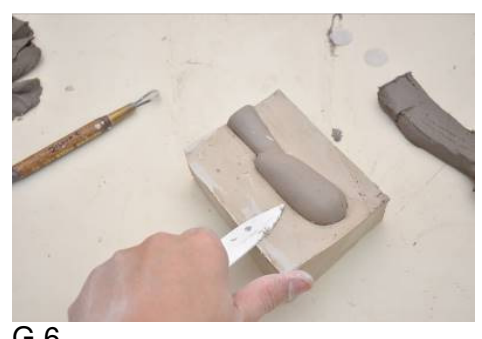

G 6

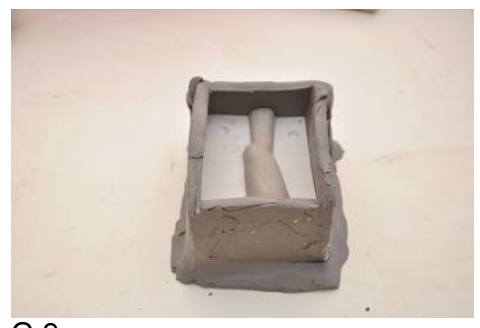

G 9

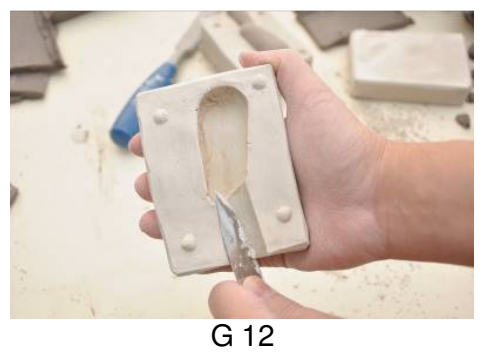




\subsubsection{Vidrados e engobes}

\subsubsection{Vidrados Cerâmicos}

"Assim como as roupas são para o corpo humano, os vidrados são para a cerâmica'92

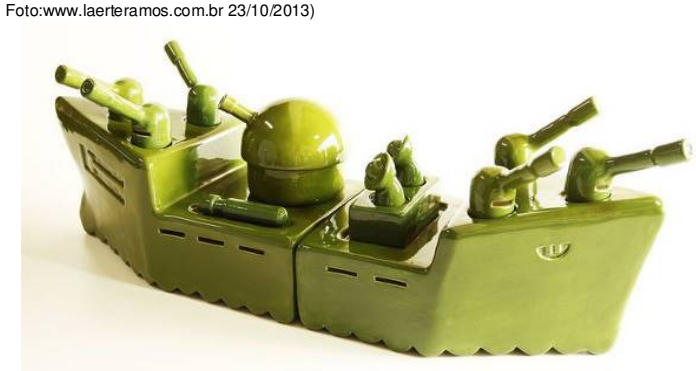

Figura 39 Laerte Ramos Lastlândia (detalhe) Dimensões variadas 2013

Cerâmica esmaltada (baixa temperatura)

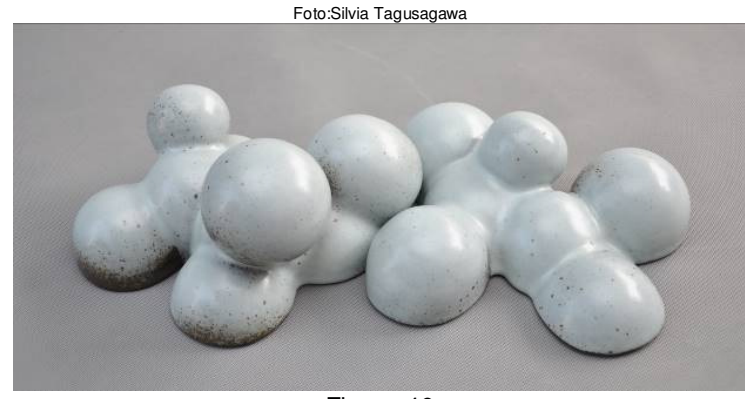

Figura 40

Kimi Nii

Nuvens e Ilhas (detalhe)

Dimensões variadas 2014

Cerâmica esmaltada (Alta temperatura)

Um vidrado cerâmico é uma camada vítrea aplicada sobre um corpo cerâmico. Além de impermeabilizar a superfície cerâmica, os vidrados têm funções estéticas como dar brilho, opacidade, textura, efeitos e cores.

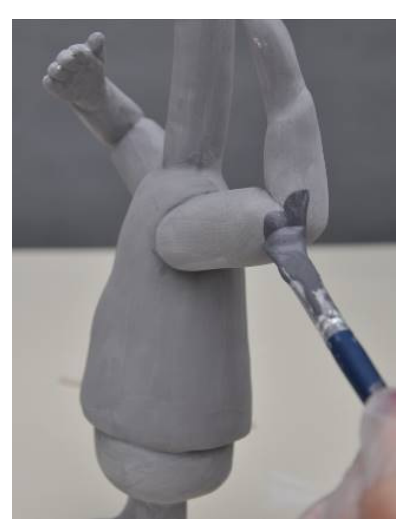

Figura 41 - Aplicação de vidrado sobre a peça cerâmica biscoitada
Fotos: Silvia Tagusagawa

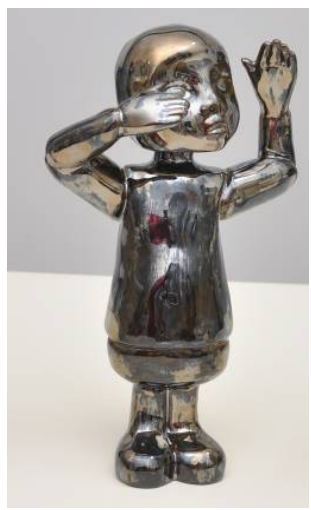

Figura 42 - Resultado final de vidrado após a queima

${ }^{92}$ LEACH, Bernard Apud PERRYMAN, Jane. Naked clay: ceramics without glaze. London: A \& C Black, 2004, p. 1. 
De acordo com Hamer ${ }^{93}$, os vidrados são compostos por álcalis e ácidos que, por sua vez, são óxidos. A interação de álcalis e ácidos na presença de calor produz um material fluido. Os óxidos são extraídos das rochas, que são trituradas até ponto de pó. Mudanças físicas e químicas ocorrem durante a queima dos vidrados.

Há três elementos básicos que são essenciais para a composição de um vidrado: formadores de vidro, fundentes e estabilizantes que durante a queima, fundem-se para formar uma camada compacta de material derretido ${ }^{94}$.

Os formadores de vidro são indispensáveis na cerâmica. Eles formam uma massa de vidrado e fornecem um cimento vítreo que dá resistência à massa cerâmica. As fontes de formadores de vidros são: sílica, óxido bórico, óxido fosfórico, óxido de antimônio, óxido de arsênico, óxido de germânio e óxido de selênio. A sílica é a mais utilizada, por ser facilmente encontrada. Os quatro últimos óxidos são altamente tóxicos, mas podem ser encontrados na forma de fritas que possuem o teor de toxicidade menor.

A sílica é utilizada na forma de quartzo, sendo uma substância vítrea que tem ponto de fusão a $1710^{\circ} \mathrm{C}$ para se tornar um vidro transparente. Esta temperatura é elevada demais e fornos cerâmicos comuns não chegam a essa temperatura.

Fundentes: os fundentes ajudam a baixar o ponto de fusão da sílica para $800^{\circ} \mathrm{C}$ a $1300^{\circ} \mathrm{C}$. Em forma de óxidos ou dióxidos, os elementos utilizados como fundentes são: lítio, sódio, potássio, berílio, magnésio, cálcio, zinco, estrôncio, bário, chumbo, boro, bismuto, manganês, ferro, cobalto, níquel e cobre.

Cada um dos óxidos possui propriedades distintas, alguns deles funcionam para vidrados de baixa temperatura e que podem chegar a volatizar em alta temperatura. Já outros fundentes funcionam bem em alta temperatura. Para compreender melhor os óxidos fundentes, consultar anexo.

A alumina ou óxido de alumínio $\left(\mathrm{Al}_{2} \mathrm{O}_{3}\right)$ é uma matéria-prima importante que compõe um vidrado, pois ele oferece estabilidade para o vidrado. De acordo com

\footnotetext{
${ }^{93}$ HAMER, Frank e HAMER, Janet. The potter's dictionary of materials and techniques. Philadelphia: University fo Pennsylvania Press, 2004, p. 163.

${ }^{94}$ Idem, Ibidem.
} 
$A^{95}{ }^{95}$, a interação da sílica com a alumina fazem com que o vidrado fique unido à massa após a queima.

\subsubsection{Engobes}

Os engobes têm a argila como base em seu composto. Uma argila misturada com certa quantidade de água pode ser um tipo de engobe, mas normalmente acrescentam-se outros óxidos ou matérias primas para adequação do seu encolhimento, para melhor aderência, evitar rachaduras e até elaborar uma gama de cores. Uma vez preparados, os engobes podem ser aplicados com pincel, imersão, ou spray.

Os engobes possuem formulações especificas, em forma de pó e misturadas à água. Podem ser aplicados quando estão mais espessos ou densos como uma geleia sobre a superfície cerâmica úmida, seca ou queimada. No anexo desta pesquisa, apresentam-se formulações de engobes extraídas do livro de Daniel Rhodes, Clay and Glazes for the potter.

Quando são queimados não chegam a fundir ao ponto de vidro. Produzem uma aparência opaca e sem brilho.

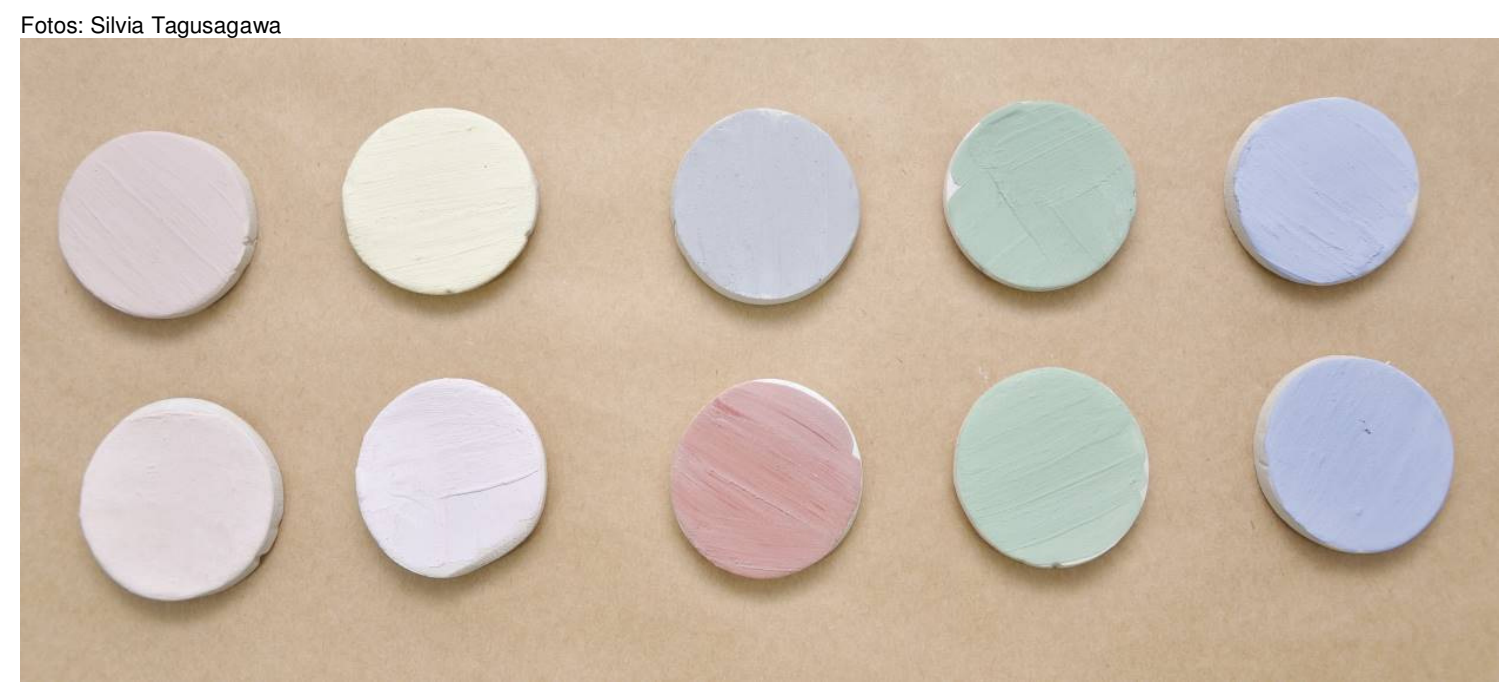

Figura 43 - Testes de engobes - coloridos com corantes cerâmicos e queimados a $1200^{\circ} \mathrm{C}$

\footnotetext{
${ }^{95}$ AUN, Subsídios técnicos para o projeto de vidração e decoração em cerâmica branca - louças de mesa. Dissertação apresentada à FAU-USP, 2000, p. 13.
} 


\subsubsection{Tipos de vidrados}

Os vidrados podem ser adquiridos prontos para o uso em lojas especializadas ou podem ser preparados a partir de uma receita.

De maneira geral, os vidrados são classificados tendo em vista seus aspectos físicos, com inúmeras cores e texturas, podendo ser:

- Brilhantes ou foscos;

- Transparente ou opacos;

- Com cores, texturas e efeitos.

Aun ${ }^{96}$ aponta três fatores que interferem na coloração do vidrado:
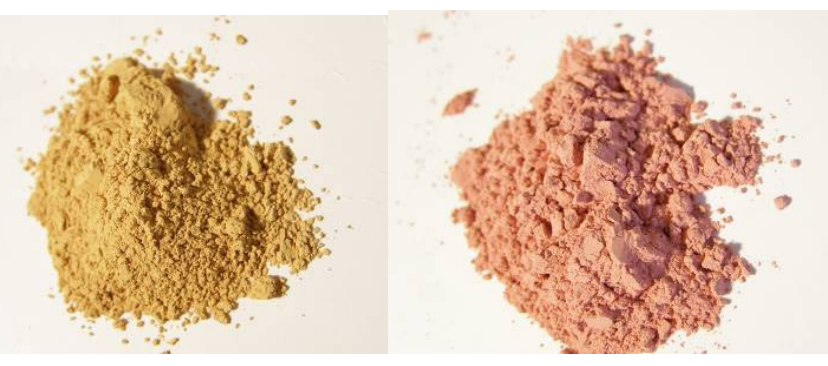

Figura 44 - Corantes cerâmicos

Agente corante: quando adicionado óxidos corantes e corantes minerais, os vidrados podem ter cores variadas;

Atmosfera do forno: de acordo o tipo de forno, sua atmosfera pode ser oxidante ou redutora. Alguns agentes corantes irão reagir e produzir cor em uma das atmosferas. Há outros que irão apresentar resultados distintos em ambas as atmosferas.

Temperatura de queima: alguns agentes corantes podem atuar até certa faixa de temperatura, podendo volatizar ou desaparecer se a temperatura por ultrapassada.

\footnotetext{
${ }^{96}$ AUN, Cristiane Rodrigues. Op. cit., 2000, p. 16.
} 


\section{Cores e efeitos}

Há uma gama variada de cores, texturas e efeitos que podemos obter com os vidrados cerâmicos. De acordo com Aun ${ }^{97}$, após definirmos uma base, normalmente um vidrado incolor transparente ou opaco, devemos adicionar óxidos corantes ou corantes cerâmicos sobre esta. Aun também apresenta as diferenças quanto aos efeitos obtidos tanto pelos óxidos como pelos corantes cerâmicos.

Aun ${ }^{98}$ comenta que a partir do momento que estabelecemos um vidrado base, podemos fazer algumas modificações quanto a sua:

Opacidade: componentes que dificultam a passagem de luz são introduzidos no vidrado base, não sendo possível ver a superfície cerâmica, a camada vítrea fica difusa graças aos cristais que se formam através dela. De maneira geral, para obtermos vidrados opacos devemos acrescentar matérias-primas que contenham um destes elementos: zircônio, titânio, estânio, antimônio e zinco

Matização: De acordo com Rhodes ${ }^{99}$, um vidrado fosco ou mate, que é um esmalte sem brilho, está relacionado com opacidade. O simples fato de adicionarmos alguma matéria-prima refratária que contenha elementos como magnésio ou alumina e que não atinjam o ponto de fusão de tais elementos obteríamos um vidrado com estas características. Outros fatores que, segundo Rhodes, também favorecem uma superfície mate são:

- Queima que não atinja o ponto de fusão;

- Aumento a alumina, cálcio ou magnésio;

- Aumento da sílica ao ponto de ocorrer a devitrificação durante o resfriamento. Neste caso, o vidrado se apresentará cristalizado, sem brilho. A formação de cristais é favorecida pelo resfriamento lento após a queima de vidrados que contenham zinco, por exemplo.

\footnotetext{
${ }^{97}$ AUN, Cristiane Rodrigues. Op. cit., 2000, p.15.

${ }^{98}$ Idem, p.21.
} 
Coloração: Os óxidos corantes ou cromóforos são compostos por elementos metálicos de transição (cobalto, cobre, cromo, ferro, manganês, níquel, vanádio e titânio. Aun ${ }^{100}$ acrescenta que os óxidos podem apresentar irregularidades na cor devido à cristalização ou formação de colônias de cores, além da instabilidade química.

Já os corantes cerâmicos são resultantes da calcinação feita industrialmente, de um ou mais óxidos corantes com agentes estabilizantes. Eles são fritados (queimados) e moídos, o que garante uma homogeneidade na coloração.

Aun aponta três fatores que interferem na coloração do vidrado. Primeiro, é o agente corante que é obtido através dos óxidos e corantes cerâmicos. O segundo fator é a atmosfera do forno que pode ser oxidante ou redutora, onde os agentes corantes agem de formas distintas nas duas atmosferas, por exemplo, um vidrado com adição de óxido de cobre pode resultar em tons verdes em ambiente oxidante e avermelhados em ambiente redutor.

O terceiro fator que interfere tanto na coloração como na textura de um vidrado é a temperatura.

\section{Vidrados crus}

De acordo com Norton ${ }^{101}$, os vidrados são compostos por vários óxidos. Os óxidos, por sua vez, são encontrados em várias matérias-primas. Há uma proporção adequada de cada matéria-prima para que se obtenha um vidrado cerâmico na cor e textura desejada. Para isso, deve-se seguir algumas receitas ou formulações. Essas receitas são obtidas em livros e revistas especializadas de cerâmica e devem ser testados antes de se aplicar diretamente numa peça cerâmica. Conhecendo o comportamento de cada matéria-prima e seu ponto de fusão, é possível formular um vidrado. Há vários métodos de cálculo e proporção para formular um vidrado. Entre os mais conhecidos estão o Método de Seger e o Método triaxial.

\footnotetext{
99 RHODES, Daniel. Op. Cit., 1973, p. 204.

100 AUN, Cristiane Rodrigues. Op. Cit., 2000, p.15.

${ }^{101}$ NORTON, F. H. Ceramics for the artist potter. Massachusetts: Addison-Wesley Publishing Company, 1956, p. 219.
} 
No Método de Seger, a formulação de um vidrado é feita a partir do cálculo do peso molecular de cada matéria-prima. De acordo com Aun ${ }^{102}$, Seger dividiu os óxidos cerâmicos em três famílias ou grupos: RO-RO2O, R2O3 e RO2.

\begin{tabular}{|c|c|c|}
\hline RO & $\mathrm{R}_{2} \mathrm{O}_{3}$ & $\mathrm{RO}_{2}$ \\
\hline $\begin{array}{c}\text { Grupo dos fundentes } \\
\text { Atuam como fundentes } \\
\text { ou modificadores da } \\
\text { silica. }\end{array}$ & $\begin{array}{c}\text { Intermediários ou } \\
\text { anfotéricos } \\
\text { Óxidos ácidos ou } \\
\text { básicos } \\
\text { Estabilizante da rede } \\
\text { vítrea, evitando a } \\
\text { recristalização do } \\
\text { vidrado }\end{array}$ & $\begin{array}{c}\text { Ácidos } \\
\text { Formadores de rede } \\
\text { vítrea }\end{array}$ \\
\hline $\begin{array}{l}\text { - Óxido de lítio }\left(\mathrm{Li}_{2} \mathrm{O}\right) \\
\text { - Óxido de sódio }\left(\mathrm{Na}_{2} \mathrm{O}\right) \\
\text { - } \\
\text { Óxido de potássio } \\
\left(\mathrm{Na}_{2} \mathrm{O}\right) \\
\text { - } \\
\text { Oxido de magnésio } \\
\text { (MgO) } \\
\text { - Óxido de cálcio }(\mathrm{CaO}) \\
\text { - Óxido de zinco }(\mathrm{ZnO}) \\
\text { - Óxido de estrôncio } \\
\text { (SrO) } \\
\text { - Óxido de bário }(\mathrm{BaO}) \\
\text { - Óxido de chumbo } \\
(\mathrm{PbO})\end{array}$ & $\begin{array}{l}\text { - Alumina } \mathrm{Al} 2 \mathrm{O} 3 \\
\text { Atua como formador da } \\
\text { rede vítrea e estabilizante }\end{array}$ & - Quartzo ou sílica $\mathrm{SiO}_{2}$ \\
\hline & - Óxido de boro $\left(\mathrm{B}_{2} \mathrm{O}_{3}\right)$ & - Óxido de boro $\left(\mathrm{B}_{2} \mathrm{O}_{3}\right)$ \\
\hline
\end{tabular}

A coluna $\mathrm{RO}$ que representa a combinação radical com um átomo de oxigênio, já a R2O3 corresponde aos elementos com oxigênio na proporção de dois para três. A coluna RO2 representa os elementos com dois átomos de oxigênio.

${ }^{102}$ AUN, Cristiane Rodrigues. Op. Cit., 2000, p. 9. 
Rhodes ${ }^{103}$ descreve o método de Séger que consiste em reportar a quantidade de cada óxido presente num vidrado. As quantidades são representadas pelo peso molecular de cada óxido e depois eles são convertidos ao peso em gramas ou quilos ou porcentagem.

Os óxidos são normalmente encontrados nas matérias-primas e não em seu estado puro. Um feldspato potássico (K2O.Al2O3.6SiO2), por exemplo, possui: potássio, sílica e alumina.

Já o método triaxial, consiste em combinar três matérias-primas em diferentes porcentagens, normalmente composto por fundente, estabilizante e formador de rede vítrea. O triaxial tem como base um triângulo que tem vários pontos que se cruzam formando 66 intersecções. Cada intersecção é uma amostra de vidrado (conforme figura 45) e as extremidades, A B e C, correspondem a uma matériaprima. Por exemplo:

$$
\begin{aligned}
& A=\text { Carbonato de cálcio } \\
& B=\text { Feldspato Potássico } \\
& \text { C }=\text { Quartzo }
\end{aligned}
$$

${ }^{103}$ RHODES, Daniel. Clay and glazes for the potter. Pennsylvania: Chilton, 1973 


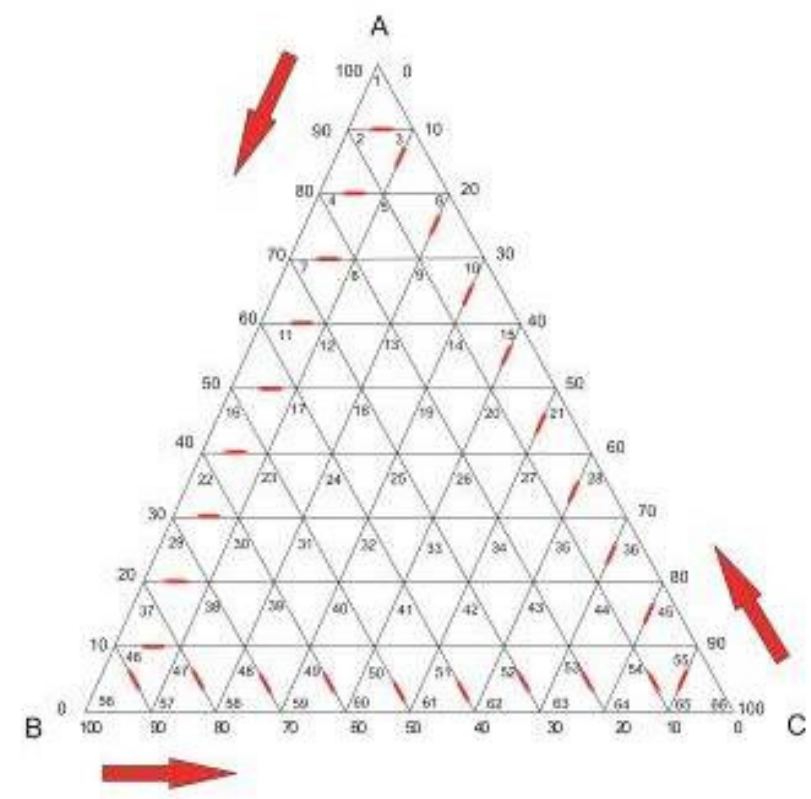

Figura 45 - Método triaxial

Fonte: HOPPER, Robin. The ceramic spectrum. Ohio: The American Ceramic Society, 2004.

$\mathrm{Na}$ tabela 1 são apresentadas as proporções, em porcentagem, de cada amostra de vidrado. Por exemplo: Na amostra 3 temos:

$$
\begin{aligned}
& A=90 \% \text { Carbonato de cálcio } \\
& B=0 \% \text { Feldspato Potássico } \\
& C=10 \% \text { Quartzo }
\end{aligned}
$$

Tabela 1 - Proporção em \% de cada matéria-prima para 66 amostras

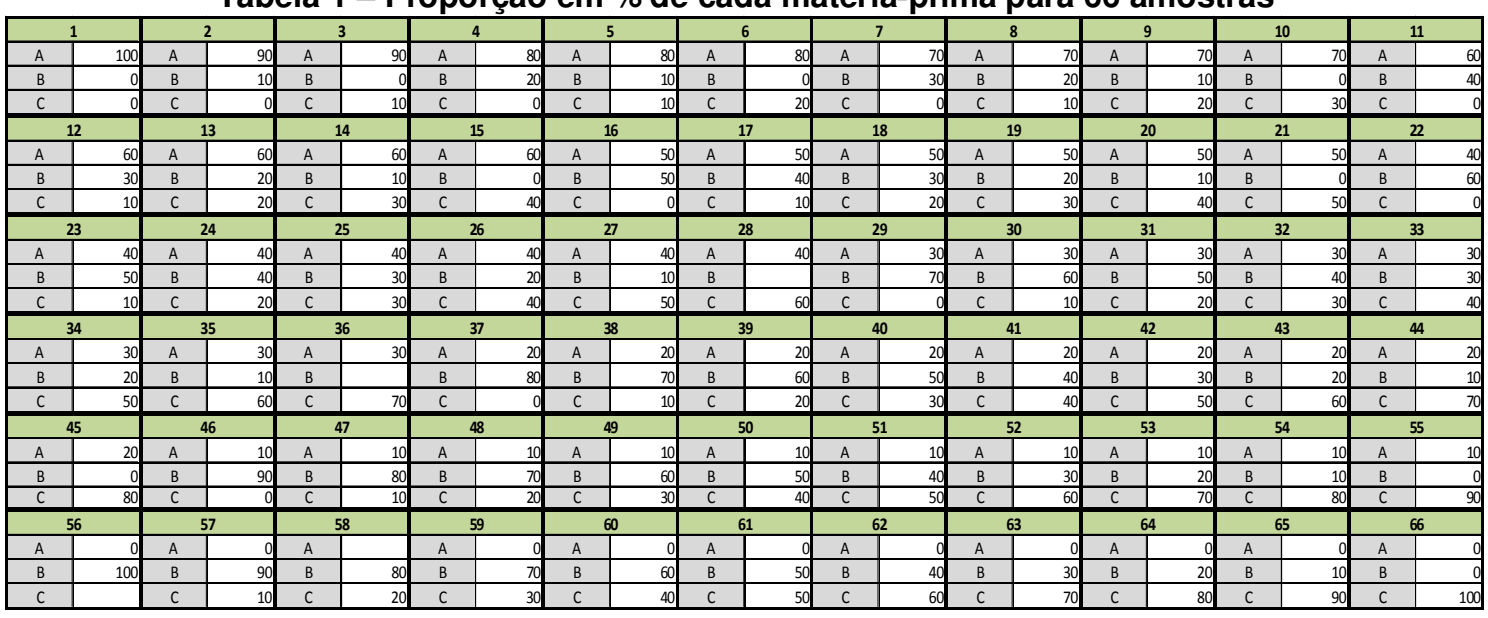

Fonte: HOPPER, Robin. The ceramic spectrum. Ohio: The American Ceramic Society, 2004. 


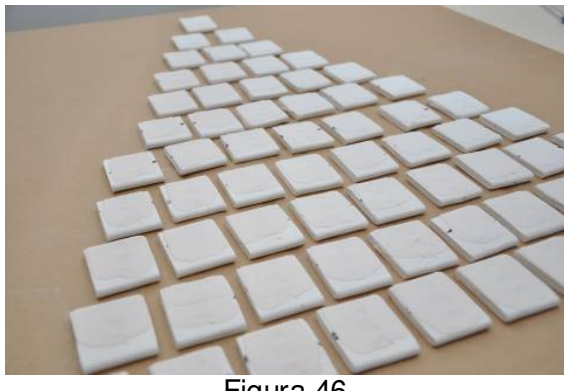

Figura 46

Triaxial - Amostras com vidrados crus (Massa de grês branca $1260^{\circ} \mathrm{C}$

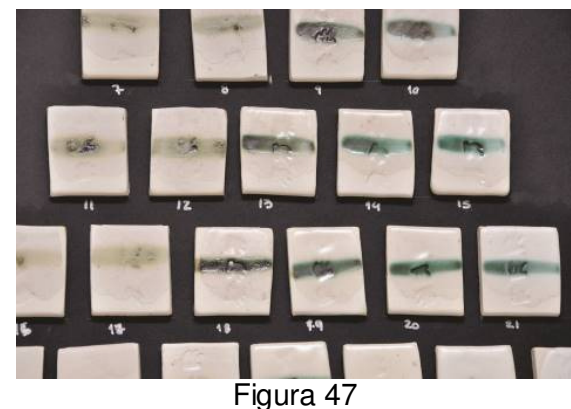

Triaxial - Amostras queimadas a $1260^{\circ} \mathrm{C}$

O método triaxial é muito utilizado no aprendizado de formulação de vidrados, facilitando a visualização dos efeitos e comportamento de cada matéria-prima testada.

Além de utilizar tais métodos é preciso definir uma temperatura de queima. Atualmente, o mercado dispõe de eficientes softwares para calcular e formular vidrados cerâmicos. De acordo com Hamer ${ }^{104}$, além de agilizar o cálculo das proporções necessárias de cada matéria-prima, os programas utilizados na elaboração de vidrados ajudam a reformular receitas, a fazer um comparativo de uma receita com outra, informam a densidade relativa de cada receita com ingredientes secos e nos auxiliam a diagnosticar alguns problemas que possam ocorrer.

\section{CMF - Compostos moídos de fritas}

Os compostos moídos de fritas são vidrados comercializados e vendidos em pó ou líquido. Essas fritas cerâmicas são processadas industrialmente a partir de uma receita de vidrados que são misturados, queimados, resfriados e triturados. As fritas precisam ser bem moídas, já que os vidrados devem estar em pó para serem utilizados, Esses compostos moídos de fritas são adicionados à água e podem ser aplicados sobre peças cerâmicas. É comum também a utilização de CMF na composição de outras receitas de vidrados.

\footnotetext{
${ }^{104}$ HAMER, Frank \& HAMER, Janet. Op. cit.,2004, p. 48.
} 
Existem os compostos moídos de fritas que são vidrados que foram industrialmente derretidos, resfriados e triturados até virar pó. Esses compostos podem ser aplicados diretamente em peças cerâmicas, acrescentados em receitas de vidrados ou ainda ser misturados a outros compostos para obtenção de outras cores ou texturas. A vantagem do uso de CMF é que durante o processo industrial, boa parte da toxidade é eliminada. Este fato é importante, principalmente aos vidrados que possuem o chumbo como fundente.

Existe no mercado uma gama variada de CMFs que oferecem cores vibrantes e efeitos variados. Normalmente, são dispersos em água e aplicados com pincel, ou compressor, imersão ou banho (ver Método de aplicação de vidrados).

De acordo com Aun ${ }^{105}$, normalmente, os CMFs são compostos quimicamente por:

Silicato de chumbo (SiO2PbO)

Borossilicato de chumbo (SiO2.PbO.B2O3)

Borossilicato (SiO2.B2O3)

A aplicação de CMF exige certa habilidade e treino, pois há uma quantidade correta de água para sua dispersão, bem como a camada a ser aplicada não pode ser demasiadamente fina ou grossa. Uma camada fina demais não cobrirá a peça o suficiente, não possibilitando sua impermeabilização. Se a camada for grossa demais, a mistura escorrerá durante a queima ou haverá a formação de bolhas.

Normalmente, os CMFs são vendidos em pó e a aplicação deles exige certa habilidade e treino, pois há uma quantidade correta de água para sua dispersão, bem como a camada a ser aplicada não pode ser demasiadamente fina ou grossa. Uma camada fina demais não cobrirá a peça o suficiente, não possibilitando sua impermeabilização. Se a camada for grossa demais, a mistura escorrerá durante a queima ou haverá a formação de bolhas.

105 AUN, Cristiane Rodrigues. Op. cit. 2000, p.10. 
Há disponível no mercado vidrados já acrescidos de veículo, com viscosidade e densidade adequada e pronta para uso. De acordo com os Hamer ${ }^{106}$, a vantagem de utilizar vidrados prontos está no fato de serem fáceis de aplicar. Podendo ser utilizados como tintas a frio com pincel e, em alguns casos, por imersão e banho. Eles são vendidos em potes ou tubos, em forma líquida.

Há uma paleta de cores e efeitos que o mercado disponibiliza e há marcas nacionais e importadas. São mais caros se comparados aos vidrados feitos a partir e matérias-primas cruas. Por isso, é interessante planejar para ver o que compensa utilizar.

\section{Vidrados híbridos}

De acordo com Aun ${ }^{107}$, os vidrados híbridos são compostos por matérias-primas cruas e fritadas (os CMFs). São muito utilizadas para médias temperaturas (1100$\left.1200^{\circ} \mathrm{C}\right)$. Os compostos moídos de fritas ajudam a abaixar o ponto de fusão quando unidos às matérias-primas cruas refratárias.

\section{Preparo e aplicação}

De acordo com Taylor ${ }^{108}$, após a definição de uma receita de vidrado, é necessária a pesagem correta de cada matéria-prima que a compõe. Para isso, fazse necessário uma balança para pesar cada ingrediente, um pote para armazenagem devidamente identificado, água, peneira, almofariz ${ }^{109}$ e um pistilo para moagem (conforme ilustração a seguir).

\footnotetext{
${ }^{106}$ HAMER, Frank \& HAMER, Janet. Op. cit. 2004, p. 156.

${ }^{107}$ AUN, Cristiane Rodrigues. Op. cit. 2000, p.10.

108 TAYLOR, Louisa. The ceramics bible. San Francisco: Chronicle Books, 2011, p. 144.

${ }^{109}$ Para a quantidade acima de $1 \mathrm{~kg}$, podemos utilizar um moinho de bolas para moagem e homogeneização do vidrado. Trata-se de um cilindro rotativo com esferas de alumina em seu interior. Este cilindro gira com o impulso de um motor.
} 


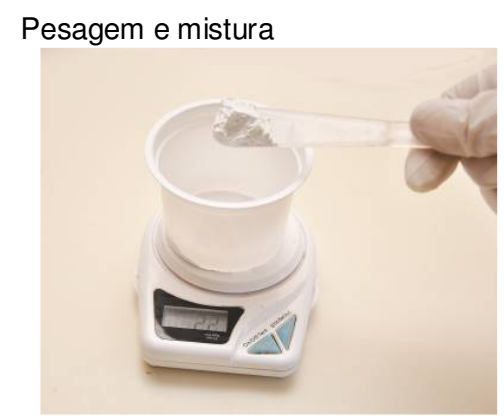

$\mathrm{H} 1$

Pesagem das matérias-primas

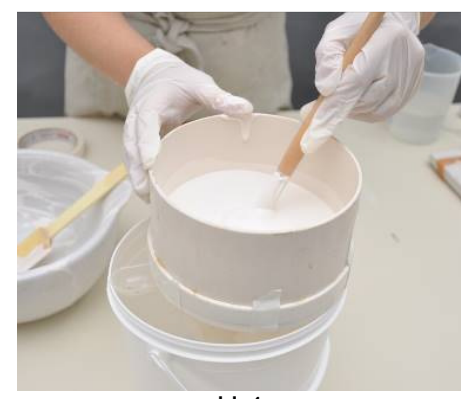

$\mathrm{H} 4$

Passar em peneira (malha 100 ou 200)

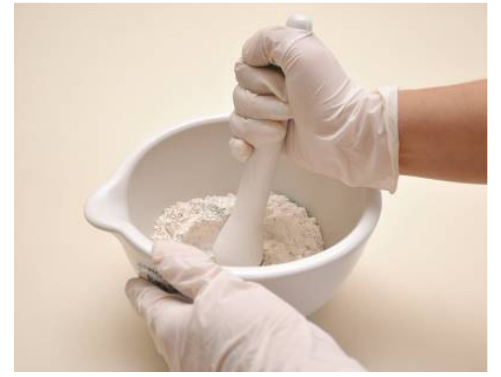

$\mathrm{H} 2$ Moagem das matérias-primas

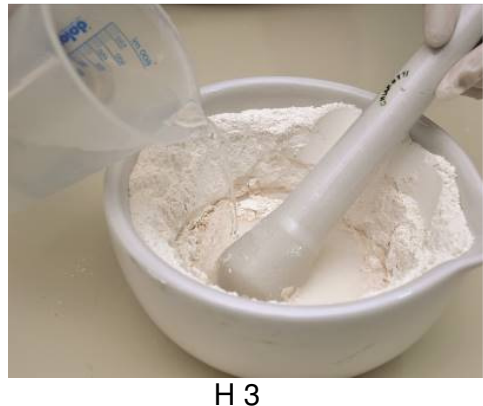

Mistura os ingredientes em pó com água

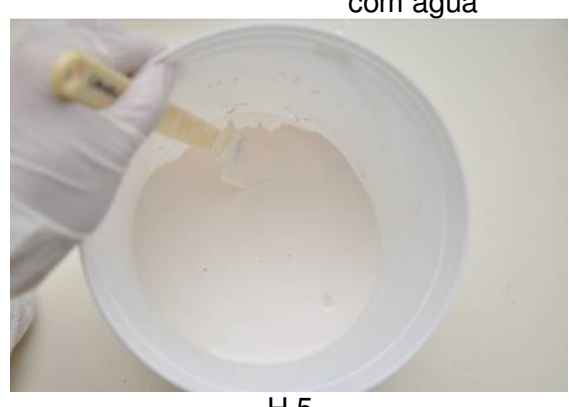

$\mathrm{H} 5$

Armazenagem em pote com tampa devidamente identificada.

Basicamente, deve-se adicionar água à mistura em pó. Taylor acrescenta que a consistência da suspensão (água e pó) de um vidrado será determinada pela quantidade de água adicionada à mistura em pó. Quando aplicado sobre uma peça, a água é imediatamente absorvida e o pó se instalará sobre a superfície cerâmica. Se a quantidade de água for pequena, a camada de vidrado ficará muito grossa, o que causará problemas técnicos como rachaduras, por exemplo, podendo se soltar ou durante a queima, poderá se escorrer. Taylor sugere a proporção aproximada de 1,2 litros de água para $1 \mathrm{~kg}$ de pó de vidrado. Logicamente, a absorção de água será determinada também pela porosidade da peça cerâmica.

De acordo com Aun ${ }^{110}$, há cálculos específicos tanto para pesagem e adição de água em vidrados que são utilizados na indústria cerâmica. Aun diz que para determinar a quantidade água necessária, deve-se conhecer a densidade ideal da

${ }^{110}$ AUN, Cristiane Rodrigues. Proposta de uma metodologia de projeto para a louça utilitária de uso doméstico. Dissertação de Mestrado apresentada à Faculdade de Arquitetura e Urbanismo da USP, São Paulo, 2000.p. 27 
suspensão que pode variar de 1,30 a $1,40 \mathrm{~g} / \mathrm{cm}^{3}$ e que dependerá do método de aplicação.

\section{Métodos de aplicação de vidrados}

De acordo com Taylor ${ }^{111}$, os vidrados cerâmicos são melhores aplicados sobre as peças cerâmicas biscoitadas. No entanto, nada impede que a aplicação seja feita sobre peças ainda não biscoitadas, ou seja, peças que estão em processo de secagem e ainda não passaram por alguma queima.

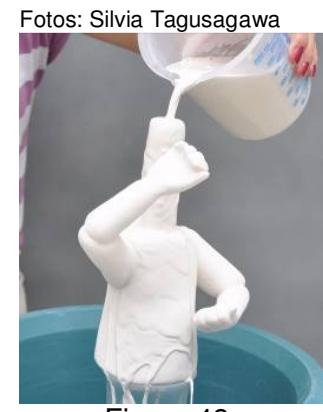

Figura 48

Aplicação por banho

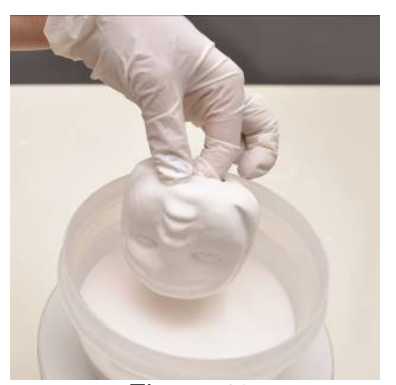

Figura 49

Aplicação por imersão

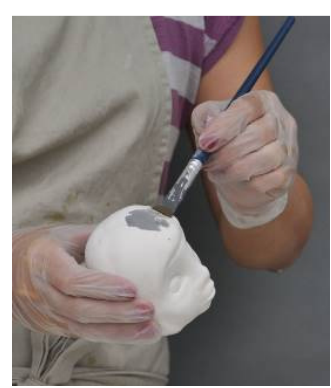

Figura 50

Aplicação com pincel

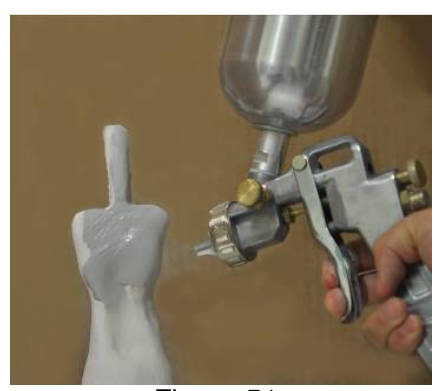

Figura 51

Aplicação com compressor

\subsubsection{Secagem}

De acordo com Rhodes ${ }^{112}$, quando a argila está em processo de secagem, ela encolhe aproximadamente $5 \%$ e as mais plásticas chegam a $8 \%$. A secagem sempre é acompanhada pelo encolhimento da massa. Materiais ou matérias-primas não plásticas como vermiculitas ou chamotes (argila ou massa cerâmica queimada e triturada) podem ser adicionados à argila, diminuindo a porcentagem de encolhimento e consequentemente as rachaduras. Esses materiais permitem também que peças ou esculturas de grande porte tenham secagem segura e resistência mecânica.

\footnotetext{
${ }^{111}$ TAYLOR, Louisa. The ceramics bible. San Francisco: Chronicle Books, 2011, p. 148.

112 RHODES, Daniel. Op. cit.1973, p. 13.
} 


\subsubsection{Queima}

$\mathrm{Na}$ conversão de argila para cerâmica, as mudanças ocorridas fazem com que os materiais tenham transformações químicas e físicas ${ }^{113}$, tornando-se resistentes à água e com aparência de rocha. Para que haja essas transformações, a temperatura mínima envolvida é de aproximadamente $600^{\circ} \mathrm{C}$, chegando a $1300^{\circ} \mathrm{C}$ dependendo do tipo de forno.

A queima é uma das partes mais importantes do processo da cerâmica, sendo assim, um forno de boa qualidade é muito importante.

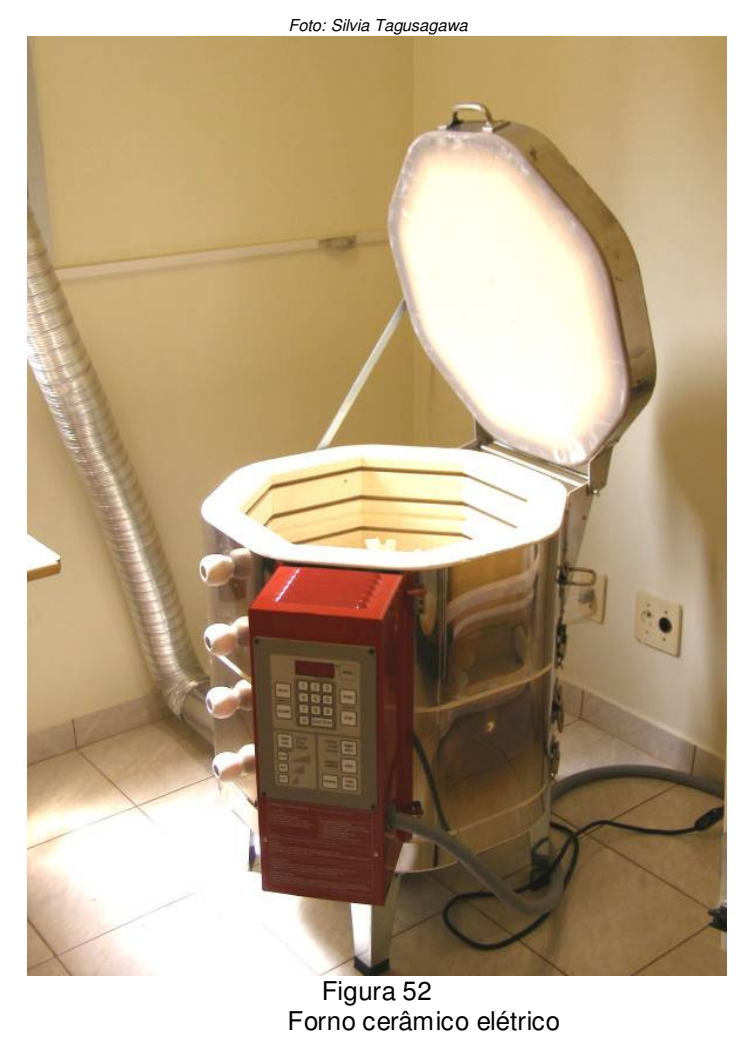

Tipos de fornos e temperaturas

Como havia dito anteriormente, há vários tipos de argilas, bem como massas cerâmicas. Elas se diferenciam tanto pela textura, cores e temperatura de sinterização. Conforme a composição da massa, sua temperatura de sinterização

${ }^{113}$ HAMER \& HAMER. Op. cit, 2004,. p. 138 
será maior ou menor. Os fornos utilizados para a queima de peças cerâmicas se diferenciam pelo design, tamanho e energia para aquecimento.

Normalmente, os fornos podem ter dois tipos de ambiente em seu interior:

Ambiente oxidante: Na queima oxidante, há circulação e interação do oxigênio durante todo o período de queima, liberando carbono e sulfatos provenientes das peças cerâmicas e dos vidrados. O oxigênio atua sobre os óxidos metálicos resultando em determinados tipos de cores e efeitos.

Ambiente redutor: $\mathrm{Na}$ queima redutora, o fluxo de oxigênio é reduzido, circulando gás carbônico em seu interior. Isso resulta em diferentes cores e efeitos à superfície cerâmica, seja ela esmaltada ou não. Hamer ${ }^{114}$ exemplifica tais efeitos em vidrados à base de óxido de estanho, que em ambiente oxidante produz tonalidades brancas e em redutor, proporciona lustres metálicos. Ou ainda, vidrados com óxido de ferro que, queimados em redução, produzem os chamados Celadons. Os Celadons são vidrados de tons cinzas-esverdeados a azuis cinzentos que são muito apreciados na China, Japão e Coréia. O óxido de ferro queimado em ambiente oxidante produz tons avermelhados, ocres, marrons e até pretos.

De acordo com registros históricos, os primeiros fornos de cerâmica surgiram por volta de 8000 a.C. ou antes disso. Os mais antigos tratavam-se de uma espécie de fogueira ao ar livre, como um buraco cavado no chão ${ }^{115}$. Esses fornos, cavados no chão, tinham suas bases e topos revestidos de pedaços de madeira, galhos e folhas secas e entre essas camadas as peças eram empilhadas e queimadas. Em algumas localidades pratica-se este tipo de queima até os dias atuais.

Os fornos foram adquirindo outras formas com o intuito de armazenar mais calor durante a queima e assim obter temperaturas mais elevadas. Na China, foram muito eficientes para queima de porcelana, por exemplo.

Normalmente, os fornos funcionam com eletricidade, gás ou lenha. A escolha de um forno, ou a construção dele, dependerá do local de trabalho, da necessidade

\footnotetext{
114 HAMER \& HAMER. Op. cit..2004, p. 299.

${ }^{115}$ RHODES, Daniel. Kilns. Philadelphia: Chilton Book Company, 1968, p. 3.
} 
do ceramista e o dos tipos de efeitos deseja. Queimas oxidantes podem ser feitas em todos os tipos de fornos mencionados. Já as queimas redutoras só são possíveis em fornos a gás e a lenha.

Os fornos elétricos são os mais populares, principalmente em zonas urbanas onde a energia limpa se faz mais presente. Eles se adequam bem às necessidades de qualquer ambiente de ateliê, seja em zona urbana ou no campo. O mais importante é ter energia elétrica disponível e instalações adequadas para o seu funcionamento. Basicamente os fornos elétricos são construídos com tijolos refratários que possuem encaixes que, por sua vez, acomodam as resistências elétricas. O controle da temperatura é feito através de um termopar ${ }^{116}$ que é uma espécie de sonda introduzida no interior do forno, através de sua parede, para medir a temperatura interna. Além do controle de temperatura, os fornos elétricos mais modernos possuem em seu painel digital, programas de queima e controle para aumento e diminuição de temperatura.

Os fornos a gás também podem ser construídos com tijolos refratários. Neles são acoplados maçaricos que, quando ligados, lançam chamas que aquecem os tijolos. Um termopar também é instalado no interior do forno e que é controlado através de um painel que monitora a temperatura. Assim, como em um fogão convencional, é possível aumentar ou diminuir as chamas. Um grau de conhecimento é necessário para manusear um forno deste tipo, mas atualmente há modernos fornos a gás que são automatizados, como os fornos elétricos, o que facilita o seu uso.

Os fornos a gás possuem chaminé para que haja circulação de ar, são muito apreciados por aqueles que desejam queimas em ambiente redutor.

116 HAMER \& HAMER. Op. cit. p. 362 


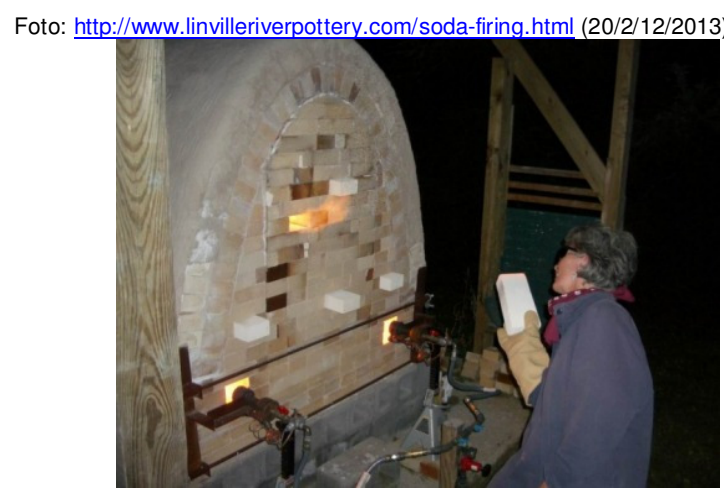

Figura 53 - Forno à gas

Há fornos que utilizam como combustíveis lenhas e galhos. Esses tipos de fornos exigem espaços abertos e geralmente distantes das grandes cidades, pois produzem bastante fumaça. Geralmente, são construídas várias câmaras como é o caso do forno Noborigama. No entanto, ao redor do mundo há uma variedade quanto às formas de construção deste tipo de forno. Esse tipo de queima exige acompanhamento durante todo o processo para que a temperatura seja monitorada. Pode-se realizar queimas oxidantes e redutoras. O diferencial deste tipo de forno são os efeitos criados durante a redução e normalmente as chamas de fogo podem criar interessantes efeitos sobre a superfície cerâmica.

Foto: Silvia Tagusagawa

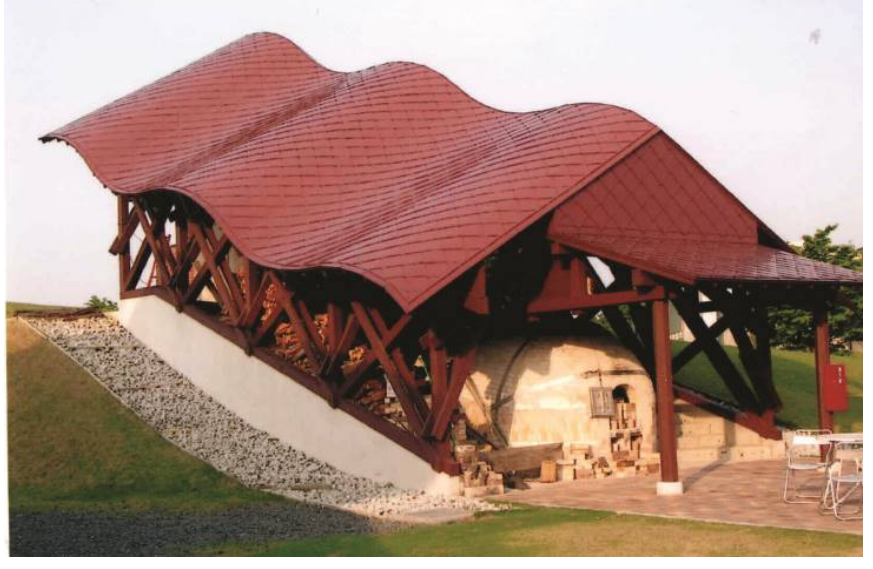

Foto: http://www. ateliesj.com.br/ (02/01/2015)

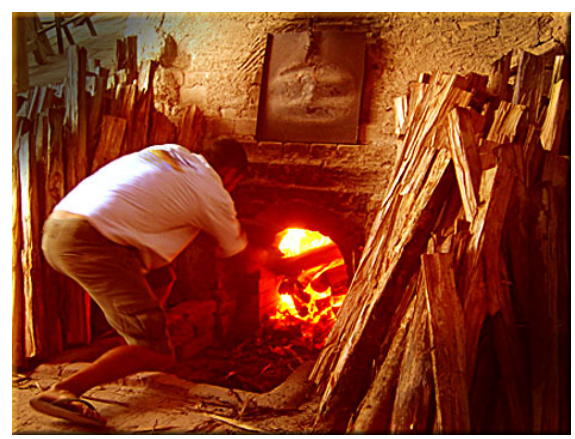

Figura 55 - Queima em forno Noborigama no Ateliiê de Cerãmica Suenaga e Jardineiro

Figura 54

Forno Noborigama - Cidade de Kasama, Japão 


\subsubsection{Estágio de queima de biscoito}

De acordo com Reijnders ${ }^{117}$, normalmente a peça cerâmica passa por dois ciclos de queima: a queima de biscoito e a queima de vidrados. Uma vez biscoitada, a peça pode ser manipulada facilmente durante a aplicação de vidrados e reduz as chances de ocorrer problemas de interação entre a superfície cerâmica e o vidrado.

A cerâmica biscoitada também tem as suas paredes porosas o suficiente para receber o vidrado cerâmico. No entanto, as peças cerâmicas podem ser queimadas uma vez ou várias vezes, dependendo do projeto.

De acordo com Hamer ${ }^{118}$, durante o processo de queima de biscoito, as peças passam pelos seguintes estágios:

- Evaporação da água: A água residual entra em ebulição quando aquecida a $100^{\circ} \mathrm{C}$ e evapora a $120^{\circ} \mathrm{C}$. A elevação da temperatura deve ocorrer de maneira cuidadosa, caso contrário, a rápida elevação causará pressão do vapor, rachaduras ou até uma explosão da peça.

- Decomposição dos materiais orgânicos contidos na massa: as argilas se originam de diferentes localidades que podem apresentar todos os tipos de materiais orgânicos, principalmente vegetais. A partir de $200^{\circ} \mathrm{C}$, todo material orgânico se volatiza. Ocorre também a dilatação da peça e das mobílias internas do forno, por isso, deve-se tomar o cuidado de deixar um espaço entre as paredes do forno e as peças para que não haja atrito e possíveis choques.

- Mudanças químicas da cerâmica: entre $300^{\circ} \mathrm{C}$ a $450^{\circ} \mathrm{C}$, ocorrem mudanças químicas, transformando a massa em cerâmica de fato. Essa vai até $600^{\circ} \mathrm{C}$ aproximadamente. No entanto, ainda não ocorre a fusão, mas a peça fica incandescente e as partículas menores se unem.

- Queima ou oxidação do carbono e sulfatos contidos na massa: Durante o processo de oxidação, carbono e sulfatos são eliminados e isso ocorre

${ }^{117}$ EKWC/Reijnders, Op.cit., 2005, p. 151.

${ }^{118}$ HAMER, Frank \& HAMER, Janet. Op. cit.,2004, p. 139. 
a partir de $700^{\circ} \mathrm{C}$ até $1150^{\circ} \mathrm{C}$. É importante a eliminação desses gases, por isso, Hamer sugere que se faça uma queima lenta nesta fase.

- Vitrificação progressiva: A vitrificação se inicia a partir de $800^{\circ} \mathrm{C}$ quando os óxidos de sódio e o potássio que estão contidos na massa começam a fundir a sílica. A vitrificação é evoluída durante toda a queima até chegar a temperatura desejada de 980 a $1000^{\circ} \mathrm{C}$.

\section{Estágios de queima de biscoito}

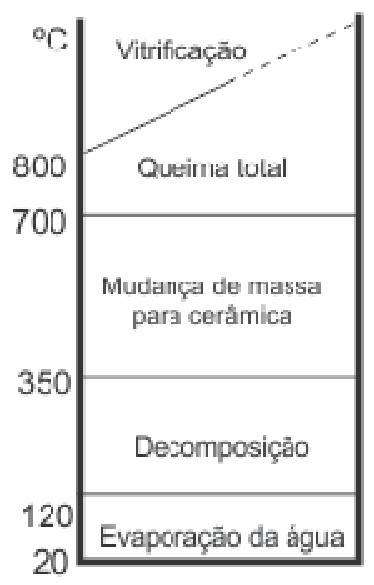

Figura 56 - fonte: Hamer, F. \& Hamer, J. 2004

\subsubsection{Estágios de queima dos vidrados e engobes}

De acordo com Hamer ${ }^{119}$, tanto os engobes como os vidrados são compostos por inúmeras partículas de moléculas que durante a queima passam pelos seguintes estágios:

- Da temperatura ambiente até $100^{\circ} \mathrm{C}$ : é o período de secagem da água remanescente presente no vidrado ou engobe;

${ }^{119}$ HAMER, F. \& HAMER, J. Op. cit.,, p. 142. 
- De $100^{\circ} \mathrm{C}$ a $570^{\circ} \mathrm{C}$ : os vidrados preparados com matérias-primas cruas, quando queimados e atingem a temperatura entre $350^{\circ} \mathrm{C}$ a $900^{\circ} \mathrm{C}$ (para algumas matérias-primas) convertem-se de minerais para óxidos.

- A partir de $600^{\circ} \mathrm{C}$ : o material cerâmico que se encontra biscoitado sofre repentina dilatação devido a quantidade de sílica cristalina e inicia-se a fusão dos vidrados. Primeiramente, as matérias-primas contendo óxidos de potássio e cálcio começam derreter.

- De $600^{\circ} \mathrm{C}$ a $1300^{\circ} \mathrm{C}$ : Até $1000^{\circ} \mathrm{C}$ o corpo cerâmico não sofre alterações significativas, mas as matérias-primas que compõe o vidrado continuam o processo de vitrificação. Ocorre tanto a liberação dos gases dos vidrados como também da massa, formando bolhas na superfície. A fusão total vai ocorrer na temperatura determinada para aquele tipo de vidrado que pode ser entre $1000^{\circ} \mathrm{C}$ a $1300^{\circ} \mathrm{C}$.

- Quando chegar a temperatura determinada, seja um vidrado de baixa ou de alta temperatura, as matérias-primas tornam-se vidro. E ao alcançar temperatura ideal, o vidrado se integra à superfície cerâmica. Em queimas redutoras, para alta temperatura $\left(1300^{\circ} \mathrm{C}\right)$, é interrompido o fluxo de oxigênio, favorecendo um ambiente rico em gás carbônico. A redução deve ser feita caso queira esmaltes com efeitos para tal tipo de queima, normalmente, para porcelanas e massas de alta temperatura.

No caso dos engobes, as partículas não chegam a derreter-se totalmente para formar a camada vítrea, por isso, ficam com a aparência opaca e sem brilho.

Quando a temperatura se eleva acima do exigido, as partículas, que agora se encontram em estado líquido, podem escorrer e até mesmo volatizar, dependendo dos óxidos. O tempo de queima e resfriamento também deve ser considerado, principalmente para obtenção de cristais em determinadas superfícies vítreas.

Outros pontos que podem alterar a transformação da combinação de óxidos ou matérias-primas em um vidrado cerâmico são as variações nos ingredientes. Essas variações estão relacionadas às condições geológicas e tamanho das partículas que 
compõem essas matérias primas. No que se referem às condições geológicas, essas matérias-primas são encontradas e se formaram de maneiras variadas: alterações de temperatura, interferências de outros materiais como matérias orgânicas e minerais. Além disso, o tamanho das partículas, que compõe as matérias-primas, também pode interferir no resultado final do vidrado. Quanto maior o tamanho das partículas, maior a temperatura exigida, além de maior dificuldade no derretimento para se alcançar o ponto de fusão ${ }^{120}$.

\subsection{Processo de criação em cerâmica}

A compreensão das mudanças físicas e químicas da matéria e o uso das ferramentas e técnicas da Cerâmica facilitará o processo de criação através deste meio.

De modo geral, o processo de criação em Artes envolve intuição, sensibilidade e intelecto. Como já foi dito, o artista é impulsionado por uma motivação, seja ela proveniente do cotidiano, de um estímulo visual qualquer ou até mesmo um som, o artista, no mundo e no dia a dia, busca a si próprio. Nessa constante busca, o artista experimenta e cria suas obras:

"Ensaiando e experimentando com diversos materiais e técnicas, segue determinados caminhos - sempre à procura de formas de identificação."121

Nas experiências vividas criam-se novas possibilidades:

"Todos os conteúdos expressivos na Arte, quer sejam de obras figurativas ou abstratas, são conteúdo essencialmente vivenciais e existenciais." ${ }^{122}$

Assim, com suas experiências, inquietação, possibilidades técnicas e ferramentais, o artista busca saciar seu desejo de materializar sua poesia.

120 EKWC/Reijnders, 2005, p. 173.

${ }^{121}$ OSTROWER, Fayga. Acasos e criação artística. Rio de Janeiro: Elsevier Editora, 1999, p. 6.

122 Idem, p. 7. 
"O artista observa o mundo e recolhe aquilo que, por algum motivo, o interessa. Trata-se de um percurso sensível."123

No caso da cerâmica, o processo de criação, inevitavelmente, envolve o contato quase visceral do artista com a matéria, no caso, a argila. Além da argila, outros materiais e ferramentas que incorporam a Arte Cerâmica fazem parte desta relação o artista. Além desse contato com a matéria, há também a importância de se conhecer as técnicas e os limites impostos pelos materiais e ferramentas. De acordo com Salles, essa arte é influenciada pelos sentimentos, percepções e experiências vividas pelo artista:

"A arte está sendo abordada sob o ponto de vista do fazer, dentro de um contexto histórico, social e artístico. Um movimento feito de sensações, ações e pensamentos, sofrendo intervenções do consciente e do inconsciente." [...]

"A arte [...] sob o ponto de vista do fazer, dentro de um contexto histórico, social e artístico. Um movimento feito de sensações, ações e pensamentos, sofrendo intervenções do consciente e do inconsciente." ${ }^{124}$

O artista nipo-americano Jun Kaneko aponta, em uma de suas entrevistas concedidas a um canal televisivo canadense, a fragilidade existente entre a pouca habilidade técnica ou a falta dela e o fazer artístico:

"Lembro-me ainda de quando comecei na Cerâmica. Eu não podia lidar com tudo. Eu achava que havia uma grande ideia em minha mente, mas quando eu via o que eu estava fazendo, diante dos meus olhos era um desastre! Portanto, há uma lacuna, uma lacuna enorme, entre a ideia e a habilidade técnica." ${ }^{125}$

Portanto, o artista consegue sintonizar suas ideais, mãos, matérias, ferramentas e técnicas após muitas tentativas, acidentes, experimentações e aprendizado. Concordamos, portanto, com Ostrower:

\footnotetext{
${ }^{123}$ SALLES, Cecília Almeida. Redes da criação: construção da obra de arte. São Paulo: Editora Horizonte, 2006, p. 51.

${ }^{124}$ SALLES, Cecília Almeida. Gesto inacabado: processo de criação artística. São Paulo: Annablume, 2004, pp. 26- 27.

${ }_{125}$ Trecho da entrevista de Jun Kaneko (https://www.youtube.com/watch?v=HvmU5Vm6iol Acesso: 16/06/2011.
} 
"Assim, a criação é uma conquista de maturidade. Só ela dará ao artista a liberdade de formular novos conteúdos expressivos, de crescente complexidade estilística e sutileza de nuances emocionais." ${ }^{\text {"126 }}$

Assim como diz o artista Jun Kaneko, na entrevista citada, com essa liberdade nas mãos, o artista tenta ultrapassar os limites do conhecido: "[Trata-se de] como lidar com as coisas desconhecidas e tentar encontrar algo que você nunca viu".

Tenta-se fazer, transformar, recombinar, fazer releituras, criar novas possibilidades para obter algo único. Para isso, o artista tem a liberdade de escolher por onde quer percorrer para chegar a algum lugar. Às vezes, nem sabe aonde quer chegar. Cada um escolhe sua maneira de trabalhar, tem seu processo de criação particular. Esse processo criador entendido por Salles ${ }^{127}$ da seguinte maneira:

"O processo criador é um percurso com 'um objetivo a atingir, um mistério a penetrar', de acordo com Picasso (1985). A intenção do artista é pôr obras no mundo. Ele é, nessa perspectiva, portador de uma necessidade de conhecer algo, que não deixa de ser conhecimento de si mesmo, como veremos, cujo alcance está na consonância do coração com o intelecto. Desejo que nunca é completamente satisfeito e que, assim, se renova na criação de cada obra."

Para Salles ${ }^{128}$, essa liberdade na criação artística tem uma relação de tensão com o limite. Esse limite é composto por certas leis existentes. É importante ressaltar ainda, que esses limites, dentro do processo de criação, não são deixados de lado pelo artista. Pelo contrário, para Ostrower, o artista irá amplia-los ou reformulá-los, recolocando-os em outro lugar e com novos significados. Ostrower acrescenta:

"[...] os limites são indispensáveis, estabelecendo cada vez as referências. $E$ tudo o que se torna significativo só pode ser avaliado através de referências. [...] Permitindo a avaliação do "novo" nas

\footnotetext{
${ }^{126}$ OSTROWER, Fayga. Op. cit. 1999, p. 13.

${ }^{127}$ SALLES, Cecília Almeida. Gesto inacabado: processo de criação artística. São Paulo: Annablume, 2004, p. 30

${ }^{128}$ Idem, p. 63
} 
formas novas, o referencial também permitirá avaliar o conteúdo incorporado nestas formas. Portanto, é justamente esta compreensão, e a plena aceitação do fato, o respeito pelos limites reais de fenômenos reais), que dão ao artista, ou ao cientista, a liberdade de se aprofundar na matéria sem medo de se perder, sondar sua essência sem medo de violenta-la, com vistas à descoberta, em novas formas, de novos relacionamentos significativos. " 129

Também segundo Salles, a Cerâmica possui suas regras e o conhecimento destas seria a verdadeira liberdade.

"Músicos, arquitetos, pintores, poetas ou quaisquer outros artífices não podem ter somente suas próprias técnicas sem estudar primeiro as leis básicas de suas respectivas artes. Inevitáveis são as regras em que eles devem, em última instância, basear a construção de suas técnicas." ${ }^{130}$

Dentro da Cerâmica, a poética está intimamente ligada com o contato com a matéria, as percepções táteis, visuais e até sonoras sobre esta: fria, mole, amorfa, dura, lisa, brilhante, opaca, colorida, áspera, fina, grossa, etc. Jun Kaneko, descreve algo marcante na Cerâmica, que é a relação do imprevisível.

“ [...] A pintura é coisa realmente interessante, você sabe, podemos adicionar, apagar, fazer um monte de coisas e você sabe o que acontece de imediato. Em Cerâmica, você não pode (ter tudo isso). Você tem que imaginar o que você vai ver mais à frente (no futuro). $\mathrm{Na}$ fase de queima, o que você imagina obter não é o que realmente vai conseguir. Esta sabedoria é completamente diferente."131

Dentro do processo de criação, há uma questão ligada à relação entre as ideias do artista e como materializar tudo isso: o pensar e o fazer. Particularmente na Cerâmica, há uma relação de intimidade muito forte entre a poética, o contato com matéria, as ferramentas e seu uso.

\footnotetext{
129 OSTROWER, Fayga. Op. cit. 1999 , p. 55

${ }^{130}$ SALLES, Cecília Almeida. Op. cit. 2004, p. 63.

131 Trecho da entrevista de Jun Kaneko (https://www.youtube.com/watch?v=HvmU5Vm6iol). Acesso em 28/01/2013.
} 
Assim como um poeta que, antes de compor seus poemas, compreendeu os mecanismos da linguagem, aprendendo e vivenciando elementos do fazer no contato direto com a poesia de outros, com o tempo, constrói-se uma relação íntima - tão intima que as regras são meros meios, dando lugar ao que mais importa: a poesia. O poeta extrapola os limites da gramática, pois o que importa são suas ideias.

Há um paradoxo da Cerâmica, pois o artista que a elege como meio expressão, constantemente depara com a limitação e, ao mesmo tempo, as infinitas possibilidades que ela pode oferecer. $\mathrm{O}$ artista deve conhecer a sua técnica e para Fayga Ostrower esse fato é evidente: "É claro que os artistas dominam sua técnica"132.

${ }^{132}$ OSTROWER, Fayga. Acasos e criação artística. Rio de Janeiro: Elsevier Editora, 1999. p. 18. 


\title{
Capítulo 3: Sete artistas - Histórias de vida e o universo da cerâmica
}

\author{
"Todo o segredo da arte é talvez saber ordenar as emoções \\ desordenadas, mas ordená-las de tal modo que se faça sentir ainda \\ melhor a desordem." Charles Ramuz ${ }^{133}$
}

A Cerâmica sempre esteve presente no meu percurso artístico e tudo que está ligado às pesquisas técnicas e poéticas é de grande interesse para mim. Fico fascinada ao ver uma peça cuja forma e cores estão em perfeita sintonia, ao ver como alguns artistas ousam e, sem medo, fazem grandes obras com a cerâmica. Tenho grande admiração pelos artistas que trilham os caminhos da cerâmica que, assim como as outras artes, possuem seus desafios e também brilhantismos. Tenho para mim alguns artistas como referência e exemplo de vida, trabalho e poesia. Vejo que não há como separar vida e obra de um artista. Por isso, na minha percepção, falar somente da cerâmica pura e simples não teria sentido se não a contextualizássemos em sua vida.

Houve muitos questionamentos sobre quais critérios poderiam ser utilizados e o porquê de ter escolhido estes sete artistas para a presente pesquisa. Também tive minhas dúvidas, pois há muitos artistas igualmente importantes para a Arte Cerâmica Brasileira, mas procurei delimitar minhas escolhas subjetivamente, já que para a escrita desta tese o tempo e o espaço são limitados. Como comentarei a seguir, isso não significa que não houve critérios. Apresentados aqui em ordem alfabética, os selecionados foram: André Yassuda, Kimi Nii, Laerte Ramos, Marco Paulo Rolla, Máyy Kóffler, Miguel dos Santos e Norma Grinberg.

Primeiramente, o critério utilizado foi a intuição e a emoção. Ao ver e conhecer de perto as obras destes artistas e suas histórias levantaram reações de curiosidade, entusiasmo, admiração, fascinação e por vezes espanto. Principalmente

\footnotetext{
${ }^{133}$ RAMUZ, Charles. Journal, 1906. (http://www.dicocitations.com/reference citation/90548/Journal 1906.php). Acesso em: 28/11/2014.
} 
na maneira como aliam de forma tão diversa a cerâmica e suas poéticas. Para Chipp, a arte é demasiadamente emocional para ser coagida ou disciplinada e não poderá ser bem-sucedida, tornando-se um capricho. ${ }^{134}$

Sabe-se que em todas as áreas do conhecimento, estudos costumam ser feitos com base em explicações racionais e lógicas. Assim sendo, as habilidades ligadas ao raciocínio lógico e concreto sempre foram consideradas base de todo sucesso do ser humano. Um homem bem sucedido era aquele considerado com elevada habilidade racional, assim como a criança que tirava as melhores notas na escola. No entanto, o psicólogo americano Daniel Goleman agitou o mundo quando lançou seus estudos que mostram a importância da inteligência emocional como uma das habilidades humanas para seu sucesso. A inteligência emocional está vinculada aos sentimentos, caráter, instintos morais e intuição além de controle dos impulsos. "Isso indica que nossos mais profundos sentimentos, as nossas paixões e anseios são diretrizes essenciais." 135

Desde Platão, sempre se buscou explicações lógicas a todas as coisas e fenômenos, devendo ser, por princípio, visto sob a luz da razão. A partir de 1912, surgem os testes de QI (Quociente de inteligência) que passam a avaliar a capacidade dos indivíduos. O raciocínio lógico, habilidades matemáticas, por exemplo, deveriam ser considerados fatores preponderantes para sucesso de um indivíduo. Os testes de QI eram referências para determinar o quanto uma criança era habilidosa, em termos de raciocínio, nas questões de linguagem e lógica, acreditando-se que tais habilidades bastavam para dizer que ela seria uma pessoa bem sucedida futuramente. No entanto, através de estudos de caso por diversos profissionais da área da Psicologia e Medicina, se constatavam que tais afirmações contradiziam com a realidade: muitas pessoas, mesmo sendo extremamente habilidosas na escola e até as primeiras da classe, tinham sérios problemas com o controle de suas emoções. Para Goleman ${ }^{136}$, as emoções são manifestadas

\footnotetext{
${ }^{134}$ CHIPP, H.B. Teorias da Arte Moderna. São Paulo: Editora Martins Fontes, 1999, p. 527.

135 GOLEMAN, Daniel. Inteligência emocional. Rio de Janeiro: Editora Objetiva, 1995.

136 Idem, p. 42.
} 
primeiramente, antes dos pensamentos organizados, ditos racionais e as emoções são importantes para a racionalidade. Assim, razão e emoção andam juntas.

Goleman também define como o racional algo relacionado com o cérebro. Já o sensível, com o coração. Assim, o ser humano é regido pelas suas emoções e pensamentos. Neste caso, a Arte parece ser a área do conhecimento que lida com ambos e não há como negar que deva ser vista e compreendida tanto pela luz da razão como também pela emoção e intuição. Segundo Coli:

"O artista nos dá a perceber sua obra por modos que posso talvez nomear, mas que escapam ao discurso, pois jamais deixarão de pertencer ao campo do não racional."137

Outro ponto importante levantado por Goleman é a importância da intuição no comportamento humano. Em seu livro, Inteligência emocional, ele relata a experiência de um neurologista que retirou um tumor localizado um pouco atrás da testa de um paciente. Esse paciente era um excelente advogado que, depois da cirurgia, parecia indiferente a qualquer questão de sua vida, mesmo que intelectualmente continuasse brilhante. Ele tinha a capacidade de listar pontos bons e ruins de qualquer fato, mas quando era para escolher algo, era incapaz de fazê-lo, pois as escolhas são feitas com o sentimento, a intuição. Goleman conclui que os sentimentos desempenham um importante papel na tomada de decisões, que não podem ser tomadas apenas à luz da razão. "[...] exigem intuição e a sabedoria emocional que acumulamos de experiências passadas".. ${ }^{138}$

Os artistas apresentados são profissionais cujas obras apresentam singularidade em seus processos e em sua produção na Cerâmica, seja incorporando a Cerâmica na sua poética, seja ultrapassando os limites técnicos conhecidos. Como já foi dito, o psicólogo americano Daniel Goleman ${ }^{139}$ explica que tanto a mente racional como a emocional possuem importância equivalente. A mente racional é mais destacada na consciência, mais atenta e capaz de ponderar e refletir. Já a emocional é ilógica, impulsiva e poderosa. Ambas funcionam em

\footnotetext{
137 COLI, Jorge. O que é Arte? São Paulo: Editora Brasiliense, 1995, p. 107.

138 GOLEMAN, Daniel. Op. cit., 1995, p. 66.

139 GOLEMAN, Daniel. Op. cit., 1995, p. 23.
} 
perfeita harmonia, uma alimentando a outra, sendo cada uma delas essenciais para a vida humana. A Arte é a área do conhecimento que nos permite utilizar os dois lados humanos: racional e emocional. Apreciar, tentar compreender e analisar a obra de arte são ações incompletas sem o emocional. O emocional utiliza de outros meios para produzir e desfrutar de uma obra de arte, que, muitas vezes, não conseguimos explicar por meio de palavras ou fórmulas. Segundo Coli:

"A razão está assim intrinsecamente presente no objeto artístico, mas a obra enfeixa elementos que escapam do domínio do racional e sua comunicação conosco se faz por outros canais: da emoção, do espanto, da intuição, das associações, das evocações, das seduções." ${ }^{140}$

Para Goleman ${ }^{141}$, pessoas como artistas, poetas, músicos utilizam-se da lógica associativa que organizam elementos que simbolizam uma realidade, através de símiles, metáforas e imagens que têm comunicação direta com a mente emocional. A mente emocional possui suas próprias regras e não fazem sentido do ponto de vista racional.

Por isso, os critérios de seleção dos artistas para esta pesquisa não poderiam ser diferentes. Pode-se dizer que a escolha foi feita pela emoção e em seguida pelos trabalhos produzidos.

Cada um dos sete artistas descritos nesta pesquisa possui um universo imensamente rico e ao mesmo tempo, único. São artistas cujas histórias de vida me emocionaram e de certa forma, começaram a fazer parte da minha vida. De acordo com as palavras de Danto:

"A história de vida de qualquer pessoa nunca é o simples descobrirse no curso do termo de uma narrativa internamente programada, ainda que esta exiba o que se pode chamar de estrutura episódica padrão [...]. O que faz a biografia e a sua leitura valerem a pena são os acidentes, as intersecções e entrecruzamentos de históricas

140 COLI, Jorge. Op. cit. 1995, p. 107

${ }^{141}$ GOLEMAN, Daniel. Op. cit., 1995, p. 308. 
causais, que projetam acontecimentos pouco previsíveis a partir de um encadeamento qualquer". 142

Esses artistas, portanto, me deram a oportunidade de conhecer suas histórias de vida e um pouco mais sobre suas obras por meio de entrevistas feitas com cada um. Falaram sobre o início de suas carreiras, inspirações, desafios, trabalhos, processo criativo e exposições.

142 DANTO, Arthur. Após o fim da Arte: $A$ arte contemporânea e os limites da história. São Paulo: Edusp, 2010, p.45. 


\subsection{André Yassuda (Pindamonhangaba, São Paulo, 1969): 0 gestual no barro e a essência da matéria}

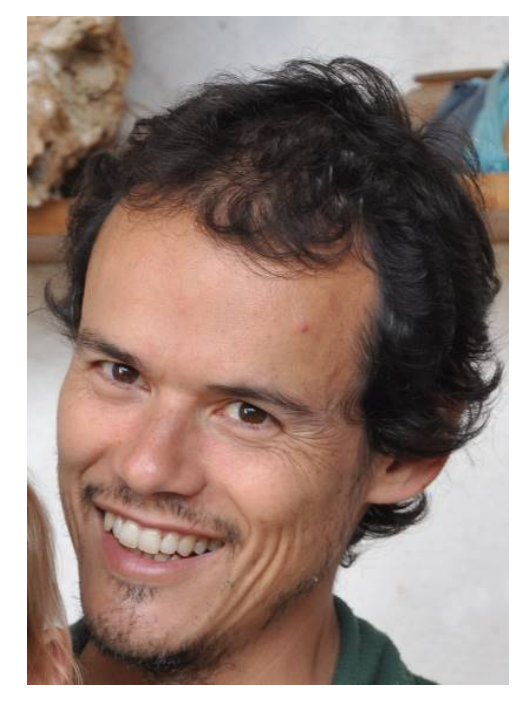

Conheci André Yassuda no curso de Artes Plásticas, na Escola de Comunicações e Artes da Universidade de São Paulo em 2007. Foi em uma das aulas da professora Norma Grinberg - que eu frequentava como aluna especial que o vi pela primeira vez. Naquela época, ele estava pesquisando as argilas da região onde morava para desenvolver massas cerâmicas e por isso procurou orientação da professora. Um ano antes, Yassuda havia se formado em Artes pela mesma instituição e estava desenvolvendo um trabalho em cerâmica. Ao mesmo tempo, ele se dedicava à pintura e à gravura.

O que despertou o meu interesse por suas obras em cerâmica foi a maneira como ele emprega a gestualidade de seus desenhos e pinturas na cerâmica.

Seus trabalhos contrastam com o seu jeito de ser tranquilo e sereno, pois mostram movimentos fortes, decisivos e, ao mesmo tempo, soltos de suas mãos isso, seja na pintura, gravura ou cerâmica. O espírito de tranquilidade e paz contrariam a força e rusticidade dos materiais empregados em suas obras. Há, portanto, força, movimento e transformação. Além da maneira de como emprega as técnicas da cerâmica, foi justamente essa dialética que despertou em mim o interesse em pesquisá-lo. 


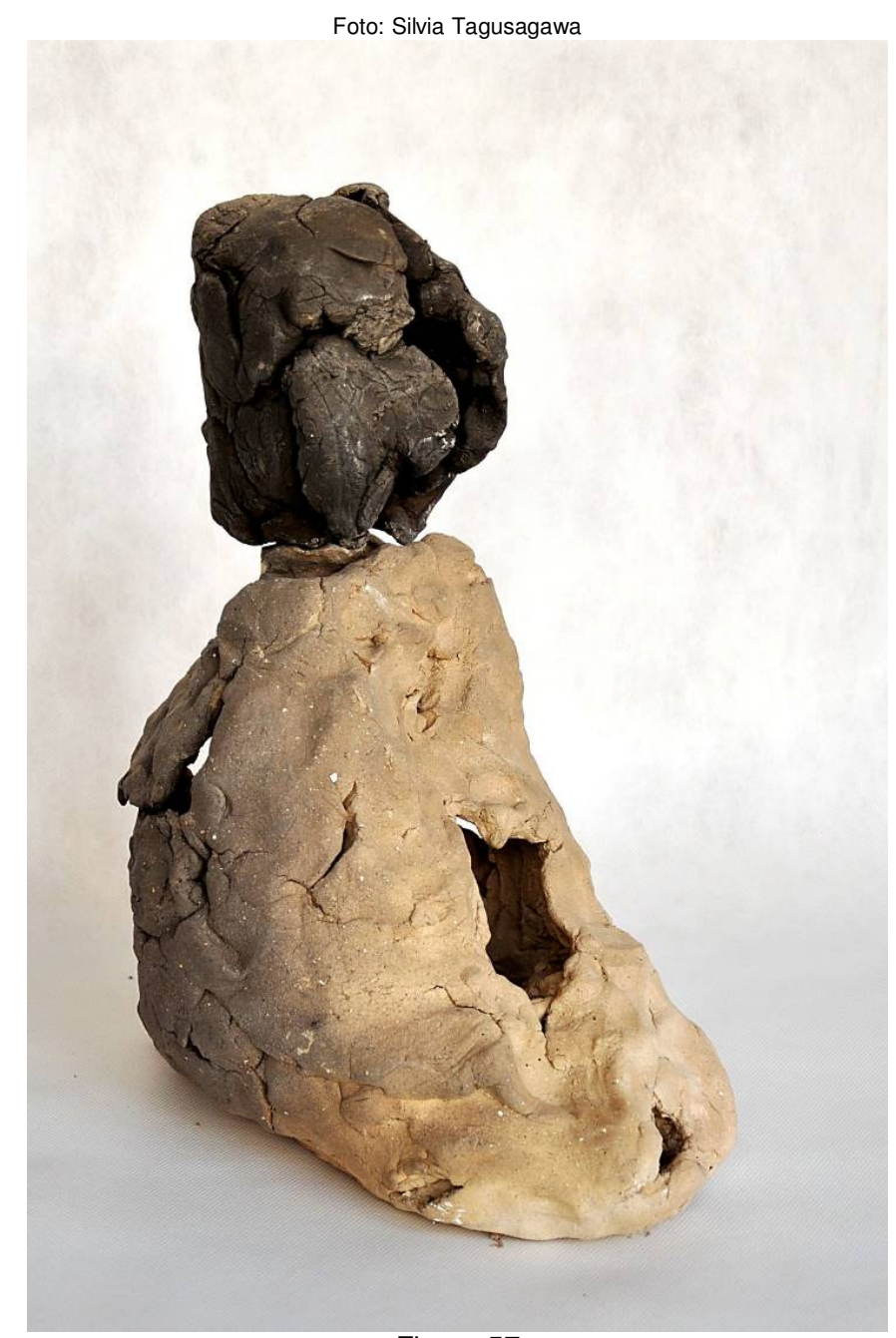

Figura 57

André Yassuda

$$
\text { Seizá }
$$

$65 \times 34 \times 45 \mathrm{~cm}$

Cerâmica de alta temperatura

2013

Em 2009, uma de suas exposições, sob o título Raízes, vozes... Aqui ${ }^{143}$, ele mostrou parte de seus trabalhos bidimensionais e uma escultura cerâmica de grandes dimensões. Essa escultura foi construída numa antiga fábrica de cerâmica a Cerâmica São Geraldo, localizada em Pindamonhangaba, sua cidade natal. Este

\footnotetext{
${ }^{143}$ Este projeto foi apoiado pela Secretaria do Estado da Cultura de São Paulo, por meio do ProaC (Programa de Ação Cultural). Ver: YASSUDA, André L. Passagens. Dissertação de Mestrado apresentada à Escola de Comunicações e Artes da USP, p. 29.
} 
projeto envolveu o uso de matéria-prima local, além da colaboração da comunidade.

\section{Nas palavras do autor:}

"Povoada por pessoas que dependiam dessa atividade (uma antiga olaria), que foi interrompida com a falência da empresa, a comunidade passou por um processo de degradação das condições de vida, o local se transformou em local de despejo de lixo de onde passaram a sobreviver, coletando restos [...] A prefeitura instalou ali um projeto de 'resgate da cidadania' com a construção de um ateliê de cerâmica, produzindo peças de artesanato [...]. Passei a me locomover para esse local para trabalhar, o que possibilitou um intercâmbio com o lugar, a paisagem e as pessoas. A obra que realizei, passou a ser um reflexo deste universo e das condições de trabalho. Grande parte da matéria-prima utilizada para compor as massas cerâmicas e os engobes foi resultado de uma pesquisa realizada na região, que é rica em terrenos argilosos, com grandes monoculturas de arroz em alagados. Após alguns testes de queima no meu ateliê, percebi que o barro recolhido em alguns poços no local era muito bom para a modelagem e para a queima." ${ }^{144}$

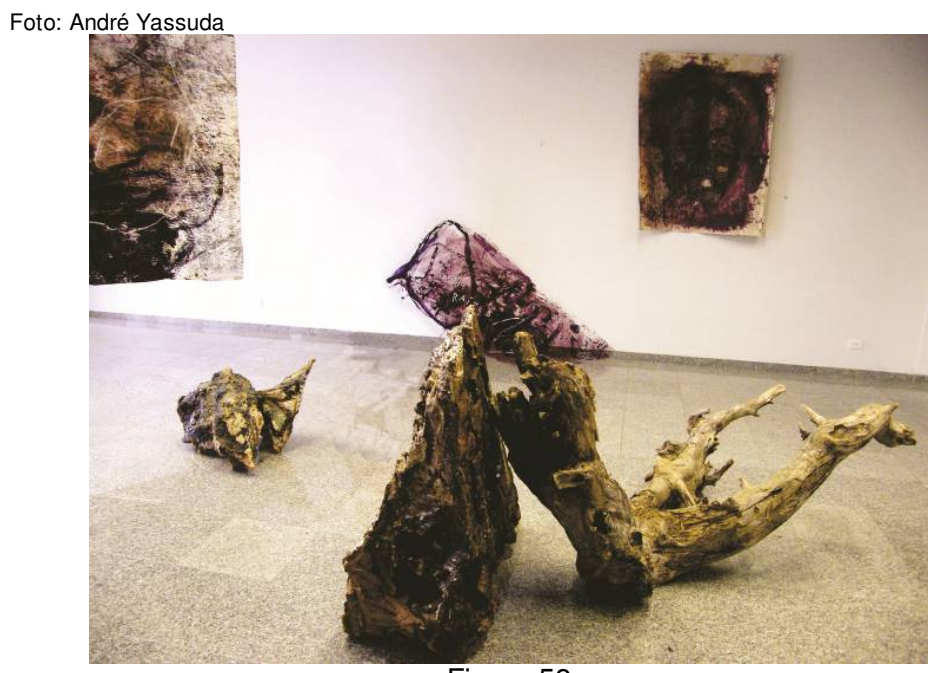

Figura 58

Exposição de André Yassuda - Raízes, vozes...aqui, 2009

Nesta mostra, Yassuda apresentou o resultado do projeto realizado na Cerâmica São Geraldo, bem como trabalhos em pintura e gravura

Prefeitura municipal de Pindamonhangaba, SP

${ }^{144}$ YASSUDA, André L.. Passagens. Dissertação de mestrado apresentada à Escola de Comunicações e Artes da USP, 2011, p. 28. 
Em 2011, Yassuda obteve seu título de mestre pela Escola de Comunicações e Artes da Universidade de São Paulo, sob orientação da professora Norma Grinberg. Em sua dissertação, Yassuda fez um recorte de seu percurso artístico, descrevendo seu processo de criação e o resultado de suas obras em cerâmica.

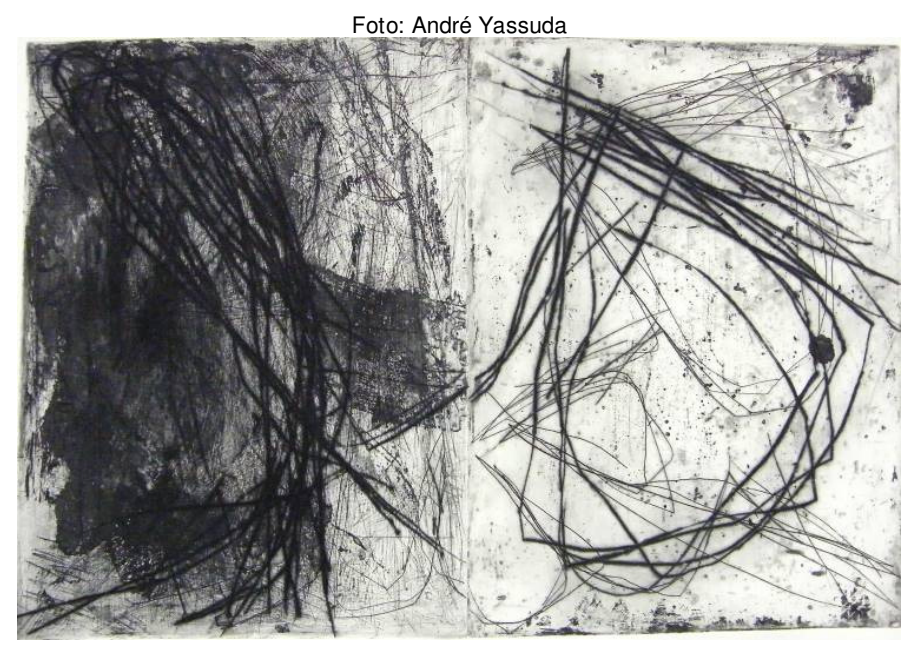

Figura 59

André Yassuda

Lá.

Gravura em metal.

$39 \times 50 \mathrm{~cm}$

2010.

Sua rotina divide-se entres as cidades paulistas de Santo Antônio do Pinhal, São Paulo, Santo André e sua cidade natal, Pindamonhangaba, onde está desenvolvendo um novo projeto apoiado pelo PROAC (Programa de Ação Cultural da Secretaria de Cultura do Estado de São Paulo) para o desenvolvimento de uma exposição individual. Em Santo Antônio do Pinhal, onde mora com sua esposa e filho, também mantém seu ateliê de cerâmica. Durante a semana, divide seu tempo entre as aulas de cerâmica que ministra na Escola Municipal de Iniciação Artística de Santo André, e aproveita o tempo que está em São Paulo para trabalhar em novas pinturas no ateliê de seu amigo e artista plástico Claudinei Roberto da Silva, localizado no bairro do Cambuci. Todas essas atividades demandam tempo e muito esforço, principalmente de locomoção entre as cidades. Esse esforço é transportado 
para os seus trabalhos, em suas cerâmicas, pinturas e gravuras que possuem grande porte e força nas texturas e cores.

Um dos encontros para uma entrevista com Yassuda foi realizado no seu ateliê de pintura do Cambuci. Quando iniciamos a conversa, Yassuda falou de sua vida, infância e como começou sua carreira nas Artes Visuais. Aos poucos, seus olhos começaram a brilhar e seu discurso ficou cada vez mais animado a medida que ele falava sobre suas buscas pessoais, suas experiências artísticas e sua formação.

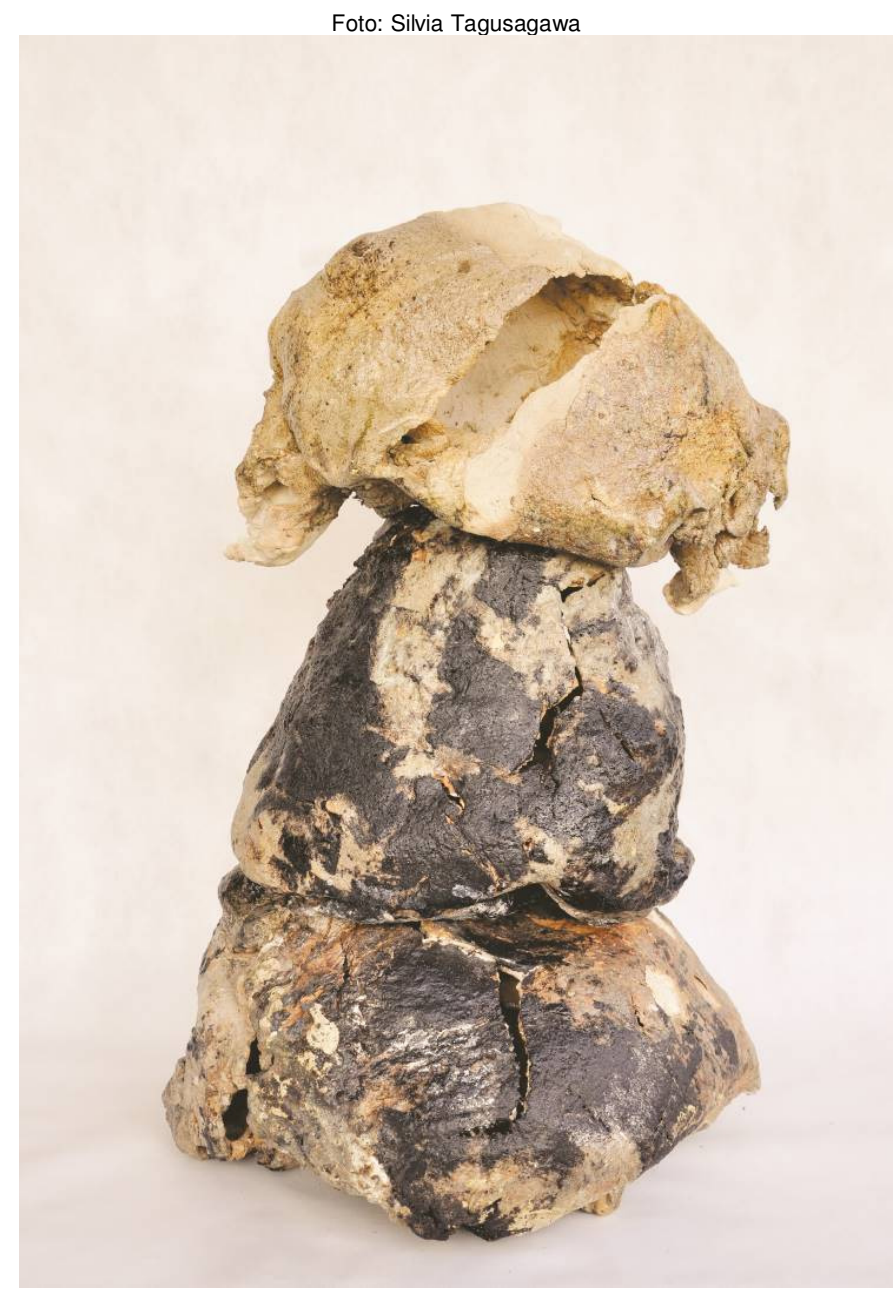

Figura 60

André Yassuda

Figura em Pé (Noh)

$115 \times 44 \times 56 \mathrm{~cm}$

Cerâmica de alta temperatura

2013 
Yassuda conta que nasceu em Pindamonhangaba, em 1969, uma pacata cidade do interior de São Paulo. Em sua infância, já demonstrava interesse pelo desenho. $\mathrm{Na}$ adolescência, teve uma banda de rock e estampava camisetas com imagens ligadas a esse universo. Nesse mesmo período, no colégio, estudou música e na faculdade decidiu cursar Composição e regência no Instituto de Artes da UNESP (Universidade Estadual Paulista). Na faculdade de música, teve aulas de história da Arte e ao mesmo tempo sentiu que deveria retomar sua relação com o desenho. Começou a frequentar, assiduamente, a Pinacoteca do Estado de São Paulo e, lá, passava horas desenhando.

Com o tempo, cresceu também seu interesse pelo estudo da Arte, frequentando exposições, palestras e praticando desenho durante as sessões de modelo vivo que acontecem no Centro Cultural São Paulo. Encantou-se quando viu pela primeira vez as obras de lberê Camargo que, para ele, teve grande importância em seu percurso artístico. Tão grande era a sua admiração que certa vez, conseguiu o endereço do artista, que morava no Rio Grande do Sul. E assim, escreveu-Ihe uma carta e também enviou desenhos seus. Sua maior surpresa foi quando, num belo dia, foi surpreendido com o recebimento de uma carta escrita pelas mãos do próprio Iberê ${ }^{145}$. Segundo ele, todo esse percurso foi mostrando o seu verdadeiro caminho, o do Expressionismo.

Nesta busca incessante, teve contato com Evandro Carlos Jardim, que foi seu grande estimulador e mestre. Com ele, participou de grupos de estudos sobre gravura em diferentes momentos ao longo de todos os anos de sua formação e ainda hoje considera sempre valiosas as oportunidades de ver sua obra e ouvi-lo pessoalmente. A primeira vez que participou de uma oficina orientada pelo mestre foi no "Ateliê Experimental Francesc Domingo Segura", entre 1993 e 1995, no MAC do Ibirapuera e essa experiência foi fundamental para seu pensamento como artista, tanto no que diz respeito à produção artística quanto em relação ao ensino e à função da arte na formação e desenvolvimento humanos.

\footnotetext{
${ }^{145}$ Essas cartas foram gentilmente disponibilizadas pelo artista e encontram-se compiladas nos Anexos.
} 


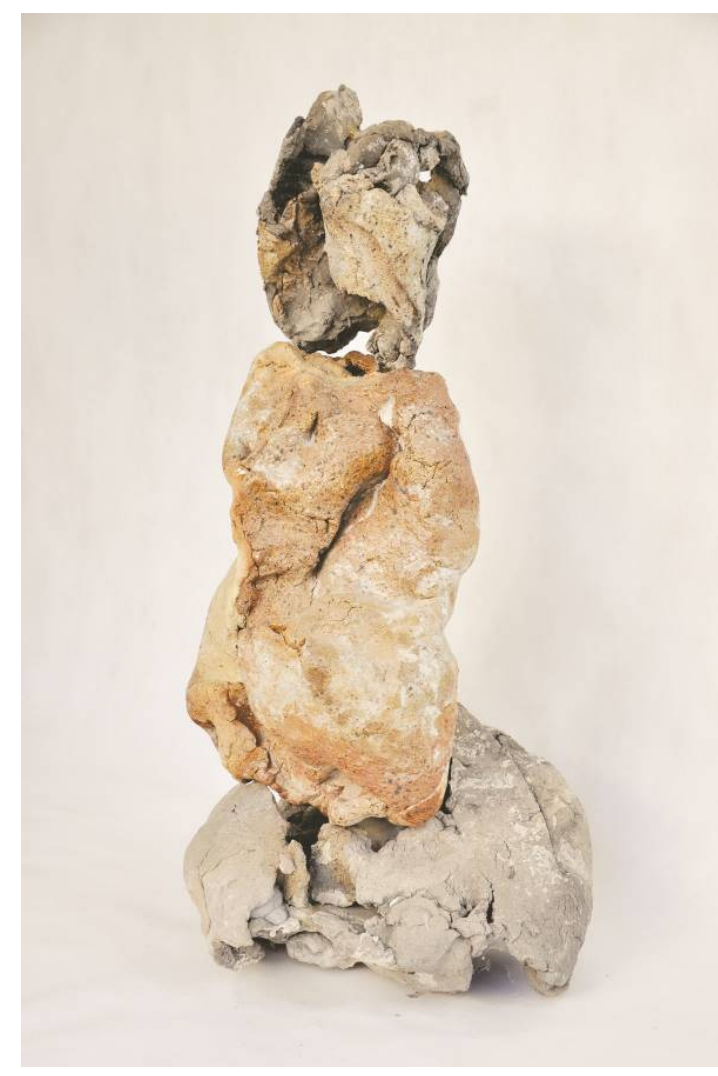

Figura 61

André Yassuda

Meditação

$85 \times 43 \times 38 \mathrm{~cm}$

$$
2012
$$

Cerâmica com engobe (Alta temperatura)

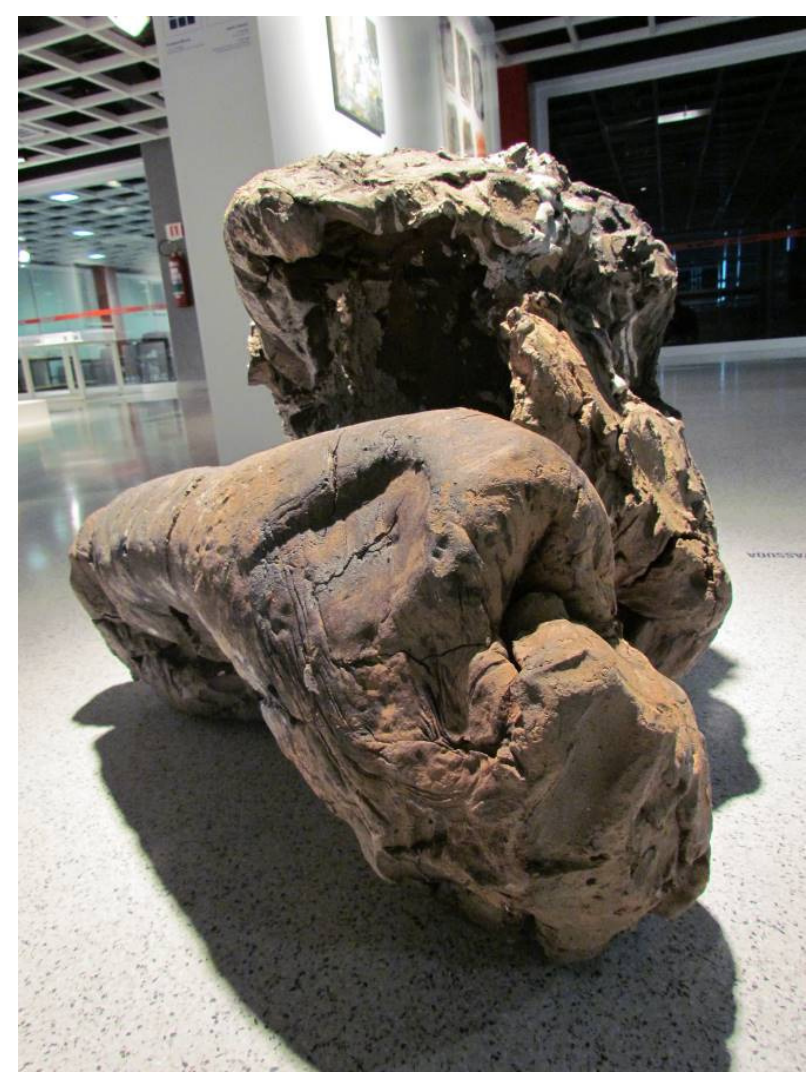

Figura 62

André Yassuda

Sem Título

$100 \mathrm{~cm}^{3}$

2011

Cerâmica com engobe (Alta temperatura)

Morou na Espanha por um ano em 1997, onde passava boa parte do tempo em museus, desenhando e pintando. Segundo ele, em sua temporada na Europa, pôde conhecer de perto as obras de vários mestres como, Velázquez, Goya, Rubens, El Grecco, Rothko, De Kooning, Anselm Kiefer, Picasso, Miró entre outros, enriquecendo seu conhecimento e aumentando sua admiração por eles. 


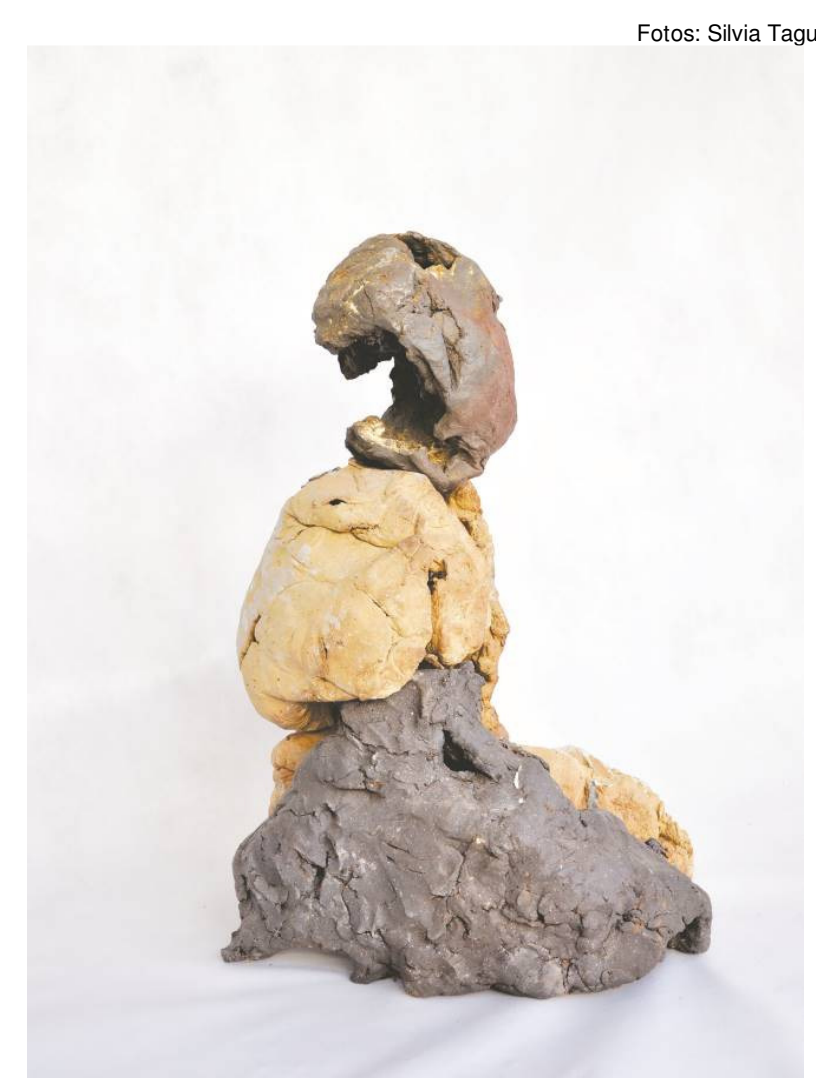

Figura 63

André Yassuda

Figura sentada

$70 \times 30 \times 46 \mathrm{~cm}$

2012

Cerâmica de alta temperatura
Figura 64

André Yassuda

Sem título

$47 \times 35 \times 35 \mathrm{~cm}$

2011

Cerâmica de alta temperatura

Ao regressar ao Brasil, retomou o contato com o professor Jardim em 1998, agora nas aulas de gravura em metal no ateliê do SESC Pompéia. Em 1999 realizou sua primeira exposição individual em São Paulo, no Centro Universitário Maria Antônia. Em 2000, ingressou para a faculdade de Artes Plásticas da ECAUSP. Nesta época, teve um dos seus primeiros contatos com a cerâmica nas aulas com a professora Norma Grinberg. Encantou-se pelas obras de Peter Voulkos e John Mason, ícones da Cerâmica Moderna Norte-Americana. Em 2001, participa do Programa de exposições do Centro Cultural São Paulo com uma exposição individual. Assim, sob forte influência dos expressionistas e em meio a todo um 
universo de novas relações que encontrou na universidade, Yassuda continua sua busca. Como se sabe, o Expressionismo tem como base a emoção do artista, sua visão pessoal com relação ao mundo que o cerca.

Em 2005, em partes por se ver diante de uma experiência totalmente nova - a paternidade (sua primeira filha, que nasceu em 2002 e a segunda em 2004) se interessa pela filosofia macrobiótica e vai morar numa comunidade em Mairiporã, São Paulo, que visava hábitos e alimentação saudáveis, praticando principalmente a agricultura orgânica. Lá, havia uma fábrica de cerâmica desativada e a comunidade se entusiasmou em reativá-la, motivando Yassuda na retomada das pesquisas sobre técnicas cerâmicas. Aprendeu a preparar massas cerâmicas, esmaltes e como queimar as peças para a produção de utilitários. Auxiliando a comunidade, na fabricação de tigelas e potes, ele sentiu a necessidade de explorar a cerâmica em suas potencialidades plásticas. Viu novas possibilidades naqueles materiais que, aos poucos, descobria em meio aquele espaço que antes estava abandonado.

Após sair da comunidade macrobiótica, Yassuda vai morar num sítio que pertencia a uma ceramista no interior de São Paulo. Lá, teve a oportunidade de aprimorar seu conhecimento técnico em cerâmica. Em meio ao verde, Yassuda observa atentamente e quase que diariamente as formas na natureza e os ritmos nas formas dos galhos das árvores, os desenhos criados pelos cipós na mata. Fotografava os cipós na mata que, para ele, tinham formas muitas parecidas com as grafias que utilizada em seus desenhos e pinturas.

Por ocasião de seu trabalho com o grupo de dança e performance, Núcleo Fu $\mathrm{Bu}$ Myo $\ln { }^{146}$, onde atuava como iluminador, iniciou práticas de sensibilização corporal e assim percebeu novas possibilidades de aliar a modelagem e a gestualidade $^{147}$, como uma outra atenção ao próprio gesto, ou ação, como movimento que parte de uma percepção mais ampla do corpo. Assim, Yassuda conectava tudo que estava ao seu redor com o seu trabalho.

\footnotetext{
${ }^{146}$ O Núcleo Fu Bu Myo In é um grupo coordenado por Toshi Tanaka, ator-bailarino japonês, que aplica as metodologias do teatro Nô com as técnicas do Do-Ho. O Do-Ho é uma metodologia de conscientização corporal baseada num tipo de dança japonesa contemporânea.

147 Yassuda, André L. Passagens. Dissertação de mestrado apresentado à ECAUSP, 2011, p. 17.
} 
Nesta fase, traz para suas obras tridimensionais em cerâmica, toda a sua gestualidade e dinamismo que vinha buscando no desenho, pintura e gravura, o que exige que se abram novas áreas de pesquisa, levando a uma aproximação com o universo da dança, das artes do corpo, de textos e práticas ligados à antroposofia, ao zen-budismo, xamanismo. Já entre 2009 e 2011, volta a morar em São Paulo, próximo a USP, onde pôde desenvolver e aprofundar sua pesquisa em cerâmica no mestrado em Poéticas Visuais orientado pela professora Norma Grinberg, do Departamento de Artes Plásticas.

\subsubsection{Poética e processo de André Yassuda}

André Yassuda utiliza a massa cerâmica de alta temperatura em tons de branco a marrons avermelhados, obtida através da mistura de argilas colhidas próximas de sua casa, com outras matérias-primas e cargas como chamotes diversos, vermiculita, materiais ocasionais, como serragem, papel picado, além de óxidos de manganês, ferro e cobre. Frequentemente, também utiliza cinzas de madeira, que retira do fogão a lenha de sua casa, assim como diferentes combinações de matérias-primas fundentes e refratários baseadas no método triaxial de esmaltes, queimadas em alta temperatura no forno a gás construído por ele. Essas provas servem para proporcionar os minerais básicos na composição de esmaltes e também nas massas, alterando o ponto de sinterização. A modelagem ocorre principalmente em forma de placas pesadas e grossas, que vão sendo trabalhadas em diversos estágios de endurecimento, muitas vezes controlando a mudança de umidade, antes de se chegar à secagem completa. Elas precisam ser assim, grossas, pois as dimensões de suas peças tendem a chegar a 1,50 m de altura.

Algumas peças são modulares, podendo ser empilhadas uma sobre a outra. Esses módulos de formas orgânicas, montados um sobre o outro dão a sensação de um corpo único. Durante a modelagem e construção, Yassuda utiliza como estruturas de sustentação galhos de árvore e folhas de jornal.

"Na modelagem, inicialmente trabalhei nos vazios entre os galhos servindo de sustentação à massa de argila e como traçado de um desenho no espaço tridimensional. Os galhos 
desapareceram na queima deixando apenas marcas, vazios e vestígios de sua presença na matéria." ${ }^{148}$

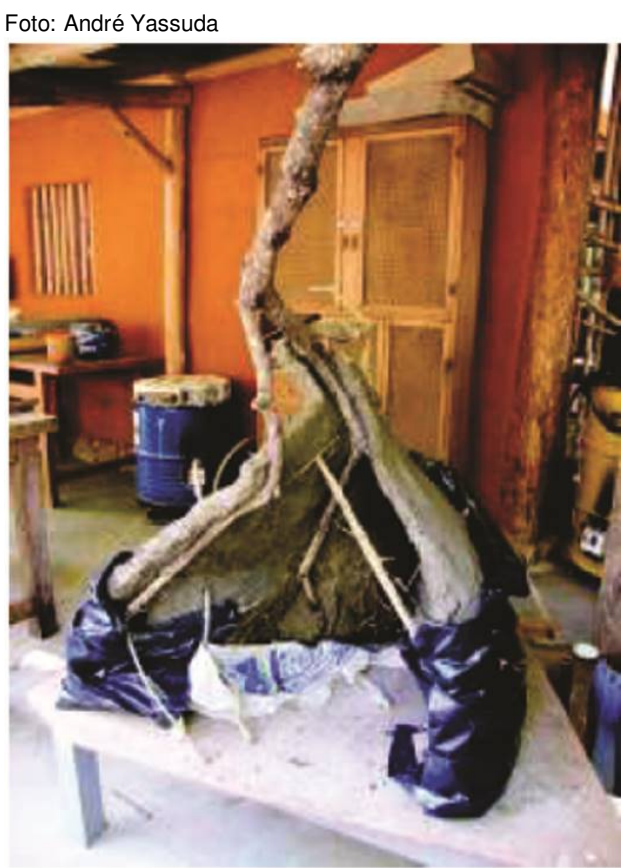

Figura 65

Trabalho em andamento Massa cerâmica e galhos de árvore

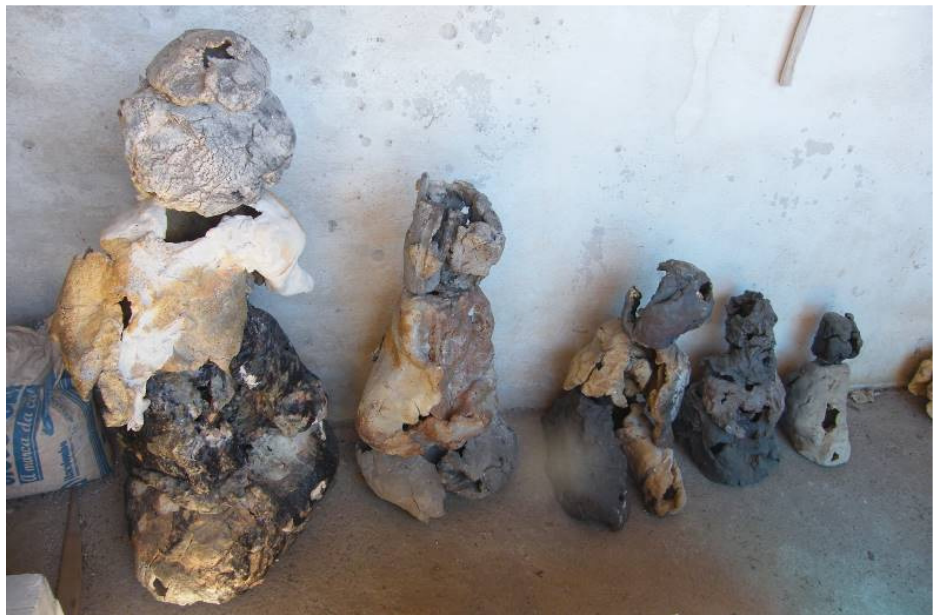

Figura 66

Trabalhos de André Yassuda

Durante a modelagem, Yassuda deixa ressaltar as potencialidades da matéria, a argila, deixando que as mãos e a massa movimentem livremente até chegar numa forma que seja o encontro de algo surgido naquele instante. "Essa forma, lançada nessa ação deve ter a capacidade de se sustentar em diferentes posições que vão sendo experimentadas. Nesse processo, alterações vão sendo incorporadas, fissuras acontecem. Até que algo diz que chegou o momento de deixar assim, mas se nisso a coisa se desfaz, por exemplo, então tudo é amassado de novo e volta ao princípio. Muitas vezes diante de um total colapso, 'jogando tudo no chão', aparece a forma... ", nas palavras do próprio artista.

Seguindo a gestualidade presente em suas pinturas e gravuras, sua intuição, sua vontade de experimentar se dão também no momento da formulação das

${ }^{148}$ YASSUDA, André L. Op. cit., 2011 p. 14. 
massas e óxidos que trabalha. "A possibilidade de construir diferentes camadas que se fundem sob a ação do fogo, incorporando diferentes combinações de minerais, apontava para relações da cerâmica com a poética que vinha desenvolvendo, tanto na pintura como construção em camadas, evidenciando a materialidade dos meios empregados, como na gravura em metal, onde trabalho com gravações profundas utilizando a sobreposição de estampas de diferentes matrizes" ${ }^{149}$ nas placas de cobre pela ação intensa dos ácidos; ou no caso das xilogravuras

"Acredito que a queima é o coração da linguagem da cerâmica.[...] A técnica é o grande meio de descoberta do trabalho, é ali que se descobre o que se pode fazer ${ }^{\prime 150}$

Fotos: Silvia Tagusagawa

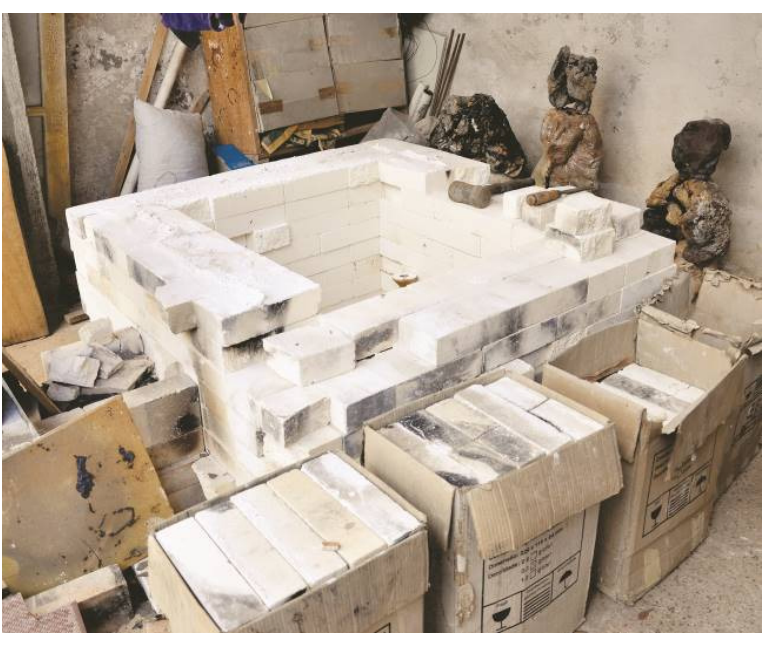

Figura 67

Forno de cerâmica

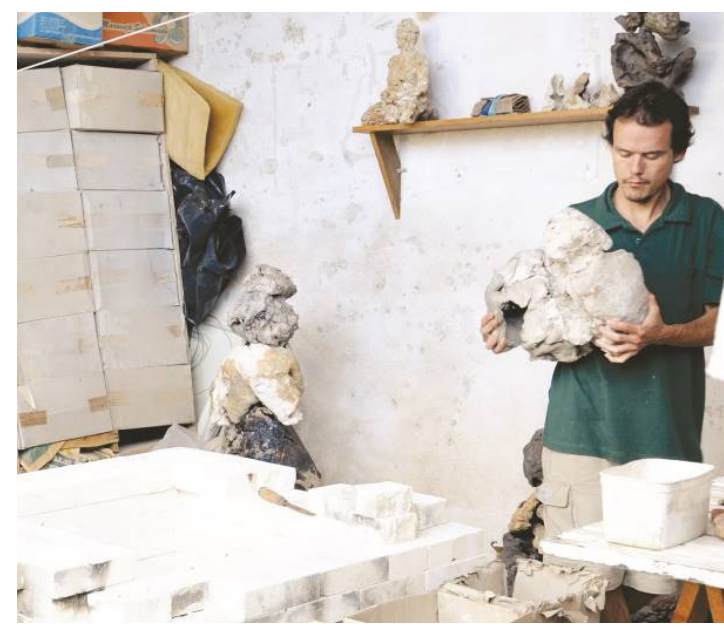

Figura 68 André Yassuda - Ateliê

Na queima, que para ele é um momento fundamental dentro do processo, suas peças passam por grandes transformações físicas e químicas com relação às cores e texturas. "Pelo posicionamento da chama dirigida dos maçaricos a gás, a forma do forno atua diretamente na configuração dos trabalhos, pela ação do fogo."151

\footnotetext{
149 YASSUDA, André L. Op. cit., 2011, p. 13.

${ }^{150}$ Entrevista de André Yassuda concedida a Silvia Tagusagawa

151 YASSUDA, André L. Op. cit., 2011, p. 21.
} 
Para André Yassuda, o conhecimento da técnica ajuda a materializar a sua poética:

"A cerâmica tem alguma coisa que é o conhecimento dos materiais. A maneira de você processar isso (suas ideias) está diretamente ligada ao processo, ou seja, você não consegue concretizar uma poética sem o conhecimento dos materiais, ou melhor dizendo, a partir do diálogo com a matéria, que será sempre um contato com algo desconhecido." ${ }^{152}$

Fotos: André Yassuda

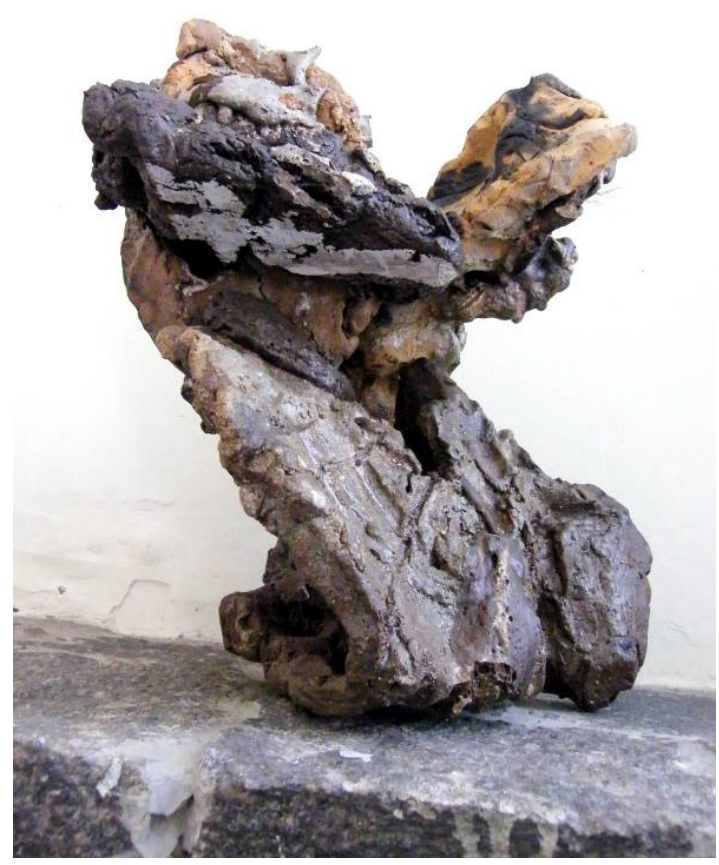

Figura 69 André Yassuda

Dança

$150 \times 40 \mathrm{~cm}$ 2010

Cerâmica de Alta Temperatura

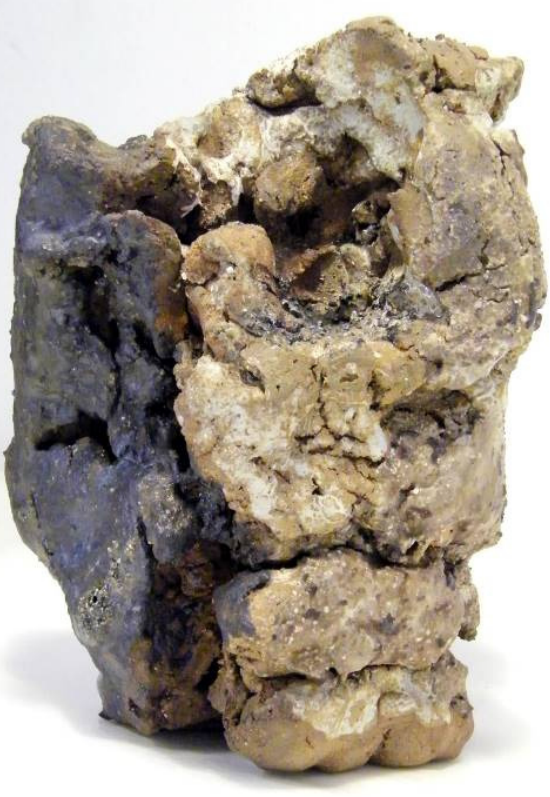

Figura 70 André Yassuda Cabeça $19 \times 22 \times 17 \mathrm{~cm}$ 2009

Cerâmica de Alta Temperatura

\footnotetext{
152 Trecho da entrevista de André Yassuda concedida à Silvia Tagusagawa
} 
O forno é montado ao redor da peça e os maçaricos são posicionados para que a chama atinja toda a escultura. "[...] construído em conformidade com cada nova série de trabalhos, podendo ir adaptando suas formas e dimensões, explorando a queima de forma mais experimental." 153

\subsubsection{Entrevista com André Yassuda (São Paulo, 08/05/2013)}

Silvia: A primeira vez que vi seus trabalhos, fiquei impactada. Tanto as esculturas como a pintura, transmitem muita força. Acredito que seja muito importante conversar com o artista, pois isso enriquece o significado da obra. Por isso, fale-me do seu início.

André: Desde criança, eu sempre gostei de desenhar. Meu pai me estimulava. Quando somos crianças, os pais desenham para nós. Eu achava que meu pai desenhava muito bem. Era dentista. Quando jovem, chegou a ter algum tipo de inclinação artística, mas na família dele, de japoneses, agricultores que trabalhavam de sol a sol, as coisas eram bem determinadas. Todos os irmãos tiveram que estudar algo pensando em ter tudo na mesma família.

Silvia: Que é algo típico das famílias japonesas aqui no Brasil. Tinha que estudar engenharia, medicina, odontologia...

André: Sim. Por isso, um tio meu é agrônomo, outro é engenheiro, outro é médico e meu pai, bem, decidiram que ele seria dentista (risos). Na verdade, acho que isso não foi uma escolha assim tão unilateral. Uma vez ele me disse que gostou dessa profissão, pois tinha um lado artesanal, de trabalhar com as mãos, algo bem minucioso, que exigia paciência.

Lembro-me que sempre pedia para ele, meu pai, desenhar e teve um dia que ele disse que era eu quem deveria fazer meus próprios desenhos. Daí, eu disse que não sabia desenhar como ele. Ele, então, respondeu: "Mas o mais importante é que seja seu desenho e que desenhe como você mesmo". E é engraçado isso, porque quando você é criança, essas coisas marcam. A partir daí, comecei a desenhar mais

\footnotetext{
${ }^{153}$ YASSUDA, André L. Op. cit., 2011, p. 21
} 
e acho que isso funcionou. No primeiro dia que fui para a escola, no jardim da infância, fiquei surpreso quando a certa altura do dia, deram material para desenharmos, as pessoas se impressionaram e até se juntaram para ver enquanto eu desenhava.

$\mathrm{Na}$ adolescência, pintava camiseta de rock, que imitava aquelas capas de disco. Pintava à mão mesmo. Nessa mesma época, eu montei uma banda de rock com mais alguns colegas e tocava guitarra. Estava mesmo muito ligado com a música e a partir daí, comecei estudar. Lá em Pindamonhangaba, havia uma escola muito legal de música que era também um convento. Ali, havia um conservatório de música, dirigido pela Irmã Maria Cecília, como era conhecida, onde regia um coral. Ela estudou música por muito tempo, foi aluna do Osvaldo Lacerda aqui em São Paulo. [Também] tive a sorte de ter aulas de violão com um professor, na época era recém-formado, que atualmente é professor na Faculdade de Música na USP (Universidade de São Paulo), o Paulo de Tarso Sales. Daí, decidi que iria prestar vestibular para música. Na preparação para o vestibular, vinha toda a semana para São Paulo ter aulas particulares de composição com o Paulo. Fui aprovado na UNESP (Universidade Estadual Paulista) e estudei lá durante três anos. No quarto ano, fiquei em dúvida, rolou uma crise e no quinto ano acabei abandonando o curso. Na UNESP, no curso de música, também havia aulas de história da arte, cujo professor era o Spinelli ${ }^{154}$. As aulas eram voltadas para as Artes Plásticas. A partir daí, fiquei motivado em querer aprender mais e voltou aquela vontade de desenhar, a pensar mais sobre a matéria e o espaço.

Silvia: Então, você achou que em Artes, você poderia criar?

André: Eu comecei a achar que poderia ser um caminho mais promissor, ou que eu me expressava melhor. Eu tinha mais familiaridade com o universo das Artes Plásticas. Em música, cheguei a compor, a escrever partitura e gravei uma composição para dois violões. Vendo hoje, acho que poderia ter continuado, mas a vontade de desenhar voltou. Resolvi voltar a fazer desenhos e arriscar na Pintura. A

\footnotetext{
154 José Jurandir Spinelli, artista plástico e docente do Instituto de Artes da UNESP (Universidade Estadual Paulista).
} 
formação musical influenciou e começaram a surgir ideias com a linguagem plástica que não teriam ocorrido sem a experiência na música. Daí, eu comecei a ir semanalmente à Pinacoteca. Desenhava as esculturas. Conversei com o Spinelli e mostrei para ele as coisas que estava fazendo, ele gostou muito. Ele começou a incentivar e disse: "Vamos fazer o seguinte, eu posso te orientar aqui na escola mesmo." Houve uma ocasião, que ele me contou que foi aluno do Bonadei'155, e disse que faríamos como ele trabalhava e ensinava seus alunos. Tinha que fazer uma série desenhos toda semana, uns cem. Muito mesmo, cem desenhos toda semana! Não os cem desenhos, mas desenhava bastante, o máximo que podia. Com o tempo, a linha foi ganhando mais fluência e modulação. O Spinelli falava algumas coisas que foram importantes sobre a linha, a modulação e a luz que vem desde Leonardo Da Vinci e que ajudou a ver essas coisas, "a linha sensível". Comecei a trabalhar bastante neste início e nessa mesma época conheci a pessoa que viria a ser minha companheira por alguns anos. Eu a conheci quando eu frequentava a Pinacoteca do Estado de São Paulo para desenhar. Ela estudava Artes Plásticas. Um dia, haveria uma palestra com Evandro Carlos Jardim na Fundação de Artes de São Caetano, e eu nem sabia quem era ele, daí ela disse: "É um cara super legal... vamos lá assistir...". O Evandro é um mestre, que pensa muito na questão da formação pela arte e a palestra falava justamente sobre isso. Ele estava sempre refletindo e elaborando o seu pensamento com relação ao ensino da arte, nestes contextos em que vinha atuando ao longo de vários anos e estava empenhado naquele momento num projeto que era o ateliê experimental de gravura Francesc Domingo Segura (nome do mestre que o ensinou a trabalhar na gravura em metal) no MAC-USP no Ibirapuera (Museu de Arte Contemporânea da Universidade de São Paulo), que ele coordenava. Lá, havia orientadores que eram seus ex-alunos e alunos da USP, pessoas que até hoje tem uma atuação importante no meio artístico.

[Ao mesmo tempo] eu ainda sem conhecer o trabalho do Evandro, mas ouvindo o que ele falava, pensei que se quisesse aprender algo com alguém seria com ele.

\footnotetext{
${ }^{155}$ Aldo Cláudio Felipe Bonadei (São Paulo, 1906-1974), conhecido como Aldo Bonadei, foi um pintor, integrou o Grupo Santa Helena. Atuou na Pintura, Gravura, Cenografia e, como professor, formou muitos artistas.
} 
Um dia, eu fui ao MAC-USP, falei o que eu fazia; o que estava pintando e mostrei algumas coisas. Daí, ele disse que se eu quisesse ir toda quarta-feira, ele estava com um grupo de estudos sobre pintura, composto por alunos da USP e que poderia frequentar, pois era aberto. Ele disse também que se eu quisesse frequentar o ateliê seria interessante fazer aulas com a Eliana Anghinah ${ }^{156}$ de monotipia. Ela fazia um trabalho poético com papel artesanal. Ela foi uma excelente orientadora e fazendo monotipia com ela, eu aprendi muito sobre pintura, além de ouvir o Evandro. A partir daí, fui cada vez mais mergulhando nas Artes Plásticas.

Um dia, fui a uma exposição incrível do lberê Camargo na galeria Camargo Villaça e foi como um norte para mim.

Certo dia, minha namorada e eu achamos que aquele parecia ser o momento mais propício para empreendermos uma viagem e tentar viver juntos, decidimos ir à Espanha. Moramos em Barcelona, depois passamos um tempo em Madrid e posteriormente fomos a Bilbao. Frequentava o Museu do Prado e ficava desenhando. Uma coisa importante que aprendi que as próprias obras são os maiores mestres e o próprio lberê dizia isso. Outro dia, estava estudando para dar uma aula sobre o Manet e achei interessante que ele também aprendeu indo ao Museu do Louvre. Obviamente, ele tinha uma base, estudou pintura e mergulhou no caminho do contato direto com as obras que mais amava. Mesmo o lberê e os caras que eu admirava fizeram a mesma coisa, foram à Europa estudar com os mestres como Giorgio De Chirico e André Lhote, e eles também orientavam neste sentido: ir aos museus, pegar seus materiais e absorver o que lhes interessava.

Antes de viajar, no começo, frequentei as aulas de modelos vivo no Centro Cultural São Paulo e também, na ocasião, estava tendo uma exposição, que me impressionou muito, do Flávio Shiró no MASP (Museu de Artes de São Paulo). Neste momento, comecei a desenhar a partir de modelo vivo algo mais gestual. Foi uma passagem meio rápida: estudar, ir às exposições, mesmo nas aulas de modelo vivo

\footnotetext{
${ }^{156}$ Eliana Anghinah (São Paulo, 1953) artista plástica formada pela FAAP, atua principalmente na área da Gravura. Nos anos 70 estudou pintura na Itália e com Evandro Carlos Jardim e realizou pesquisas em Litografia, sob a orientação de Otávio Pereira (fonte:

http://enciclopedia.itaucultural.org.br/pessoa8989/eliana-anghinah). Acesso em 15/12/2014.
} 
comecei a experimentar algumas ideias que era meio o que a Anita Malfatti fazia, que tinha a ver com Cubismo, não sei, algo meio "Delaunay" também. A partir daí, começou a sair algo mais gestual e até porque já havia naquilo meio que um caminho com lberê Camargo, Flávio Shiró e vendo as pinturas desses artistas, havia encontrado um caminho.

Eu também frequentava muito a biblioteca do MAM-SP (Museu de Arte Moderna de São Paulo) e lá havia uma bibliotecária que era muito gentil. Certo eu comecei a falar da minha admiração pelos trabalhos do lberê Camargo e ela me deu endereço dele! Disse para eu entrar em contato com ele. Então, eu mandei uns desenhos. Nessa época, o lberê estava sendo muito valorizado. Depois de um tempo, para minha surpresa, ele me respondeu!

$\mathrm{Na}$ época, eu morava numa quitinete em São Paulo. O porteiro avisou que havia uma carta para mim e quando vejo era uma carta do Iberê! Uma carta do Iberê escrita à mão! Então, eu respondi a carta.

O Iberê respondeu novamente, mas com uma carta mais curta. Ele falou que havia demorado a responder porque estava com problemas de saúde. Tempos depois, ele faleceu.

Depois, quando voltei para o Brasil, meu relacionamento entrou em crise e eu me separei. Recomecei minha vida aqui e passei uma temporada na casa de meus pais e depois fui morar em São Paulo. Trabalhei com montagem, monitoria e iluminação. A partir da daí, comecei a me interessar por questões da luz, principalmente porque estava pintando telas em preto. Eu me interessei bastante por essa questão de iluminação, mas não levei adiante em pesquisar. Percebi que esse interesse pela luz era por uma questão da pintura, uma construção da matéria, o que não significa que a luz também não seja matéria.

A experiência do ateliê que o Evandro Carlos Jardim desenvolveu no MAC, em 1995, passou a ser no SESC Pompéia como Ateliê de Gravura em Metal. Em 1998, comecei a frequentar 0 ateliê no SESC. O Jardim via meus trabalhos, conversávamos, e ele perguntou: "Por que você não entra na faculdade?." Ele sempre foi um grande estimulador. Em 1999, continuei na gravura e fiz um tempo de 
Lazar Segal,o professor era o Luís Claudio Mubarac. Em 2000, entrei na USP e lá que, pela primeira vez, entrei em contato com a Cerâmica.

Já na USP, tive maior contato com o material e foi legal. A professora Norma Grinberg também gostou do que eu estava fazendo. Já no final do curso, tínhamos que estudar algum artista, que trabalhasse com cerâmica. Eu gostei muito do Peter Voulkos.

Silvia: Que é expressionista...

André: Sim. Tem aquele outro americano, o John Mason. Os trabalhos destes caras me interessaram bastante. Então, acho que tem a ver com esse cara, 0 Voulkos, a improvisação que ele praticava sobre o trabalho.

Silvia: A motivação veio logo no começo com a cerâmica?

André: Eu comecei a trabalhar com placas de argila, aplicando improvisações, algo gestual, com o objetivo de construir um espaço pela gestualidade. Lembro-me que fiz um trabalho e a professora Norma gostou muito. O mais interessante era que tinha uma coisa no espaço e havia uma relação com os trabalhos do Franz Klein, Soulages, Hartung, com as telas grandes compostas por pinceladas em preto e que tem a ver com as coisas faço. Lembra um pouco da caligrafia oriental, o espaço construído com grandes manchas negras e sendo atravessado pela mancha negra. As placas que eu fazia tinham esse jogo de construção. Eu acho que quando você encontra uma conversa com material, você acaba indo lá no fundo do seu trabalho.

Silvia: Qual é a importância que você dá para o conhecimento técnico no seu trabalho, o conhecimento técnico na cerâmica?

André: A cerâmica tem alguma coisa que é o conhecimento dos materiais. A maneira de você processar isso [suas ideias] está diretamente ligada ao processo, ou seja, você não consegue concretizar uma poética sem o conhecimento dos materiais. Na verdade, não sei até que ponto isso se aplica a outros artistas.

Eu acho que mesmo na pintura tem este caminho, essa história do fazer... Já foi uma coisa da formação mesmo, da técnica. O lberê sempre falava isso também. Eu tinha uma postura meio polêmica com relação ao que via nas tendências de artes plásticas, pois na época havia discussões sobre o fim do suporte. No final, acho que 
não tem nada a ver. Na discussão do lberê, havia uma questão do resgate ou a volta de pintura, que iniciou nos anos 80 e ele dizia que nunca soube disso porque nunca deixou de pintar, por isso, para ele, a pintura nunca deixou de existir. Essas discussões têm a ver com a moda e o mercado. A postura do lberê é a mesma que eu tenho, no sentido de se aprofundar no diálogo com o fazer, ou como diz o Evandro, tendo como aliado "a tradição como transmissão de uma essência vital", ao que nos transmitem as obras. Daí a importância de ver com os próprios olhos, de coração aberto.

Silvia: Você poderia explicar melhor essa parte?

André: Eu acho que a técnica e a expressão poética estão diretamente ligadas, principalmente no caso dele, com a própria visão que o artista tem de si mesmo. 0 trabalho do artista se torna o que ele é e o trabalho é o próprio artista. É uma relação muito direta e eu acho que me interessei por cerâmica também porque o trabalho pedia essa materialidade, mas para mim era uma técnica muito distante, no sentido de que eu deveria aprender muito.

Silvia: Em sua dissertação, você fala que foi morar numa comunidade Macrobiótica e lá você se envolveu bastante com a cerâmica.

André: Quando nasceu a minha primeira filha, em 2002, comecei a me interessar por alimentação natural. Comecei a frequentar restaurante macrobiótico, tive um envolvimento com a proposta e a filosofia. Então, fui morar numa comunidade em Mairiporã, que praticava essa filosofia. Lá, eu encontrei vários equipamentos de cerâmica de uma fábrica desativada. Nessa comunidade, havia vários projetos, desde agricultura orgânica e até cerveja artesanal. Havia muita coisa ligada à cultura japonesa, o líder desta comunidade era um japonês e que trouxe vários conceitos de macrobiótica do Japão. Ele era discípulo de George Ohsawa. ${ }^{157}$ Passei alguns anos lá, trabalhando direto, fazendo todo tipo de coisas para sobreviver. Nos anos 80 ou 90, um dos membros da comunidade se interessou em fazer utilitários e começou a estudar a cerâmica japonesa, as tigelas, aquela coisa

\footnotetext{
${ }^{157}$ George Ohsawa (Quioto, Japão 1893-1966) foi fundador da Macrobiótica.
} 
toda. Produziam as tigelas lá mesmo e lá dentro havia encontros de macrobiótica, onde eles vendiam as cerâmicas.

Silvia: Eles utilizavam somente material local?

André: Não, eles utilizavam a argila de lá, mas também compravam massas e equipamentos de fora. Eles foram longe e até montaram um forno grande lá. Era um forno a gás. A fábrica de cerâmica ficou desativada, muita coisa se perdeu, acabaram destruindo o forno numa reforma do local onde ficava, eu decidi que queria reativá-la.

Silvia: Isso foi em...?

André: Em 2005.

Silvia: Lembro-me de você na USP, conversando com a Norma sobre esse projeto e levando até umas amostras de argila de lá.

André: É verdade. Daí eu comecei a trabalhar nisso e eles propuseram reativar aquilo, a fazer uma produção, pois tinha lá os seminários de Macrobiótica e as pessoas que frequentassem, poderiam comprar as coisas. Aí que eu fui procurar a Norma e perguntei se ela poderia me orientar. Não tinha feito esse tipo de produção e foi aí que comecei a mexer bastante com cerâmica. Eu fiz um monte de tigelas, utilizei moldes e aí comecei a me interessar muito, aprendi a mexer no torno, fazer barbotina, as peças tinham que ter regularidade, ficar as mais simétricas possíveis. Aquilo era bem difícil, mas saiu. Além dos trabalhos com cerâmica, estava com o meus projetos em pintura. Estava trabalhando os dois lados da tela, com a ideia da pintura ficar sempre no espaço. Na época da exposição de formatura foram expostas essas pinturas, não eram mais pinturas de colocar na parede e ficavam no espaço. Eram telas feitas a partir de tecidos que eu encontrava no lugar em que eu morava. Utilizei uma cola utilizada tradicionalmente na pintura desde a época do renascimento, que é a cola de pele de coelho. $E$ eu passava isso sobre o tecido que pousava sobre o chão. O tecido grudava no chão e quando eu puxava, vinham junto algumas manchas (resultantes da sujeira do chão). A própria cola de pele de coelho dava uma textura de couro (ao tecido). Aquele suporte passou a ser uma espécie de pele onde eu inseria uma escrita gestual, trabalhava com a linha e palavras que 
surgiam. A partir daí, tive vontade de trabalhar no espaço tridimensional e nesta mesma época comecei a trabalhar com as coisas de cerâmica. Para mim, era como a pintura se sustentar no espaço, em placas de argila que paravam em pé.

Silvia: Eu vi na sua dissertação que você utiliza alguns galhos para fazer essa sustentação. Explique para mim a relação desses galhos. Eles são meros suportes ou há uma relação com a proposta do trabalho (a relação da pintura, as formas e linhas dos galhos) ou era uma escolha aleatória?

André: Há uma relação sim. Tem algo a ver um pouco com essas pinturas e nessa época também eu comecei a pensar como essa gestualidade poderia de alguma maneira, configurar outro espaço. Os galhos vieram depois, quando fui para Cotia. Como é uma coisa que começou a me inquietar muito, era algo que vem da arte japonesa, traz para a questão da dança também, o Butô, algo que descobri depois. Há uma pesquisa a partir do Butô, na qual o movimento surge a partir de um outro lugar, ou seja, como se a vontade do corpo, da carne e dos ossos. Comecei a me interessar e a fazer algumas práticas com um mestre japonês, Toshi Tanaka, que era professor da PUC de Artes do Corpo. Ele trabalha com isso e traz algumas práticas da caligrafia japonesa em que o movimento ou gesto que parte do centro do corpo. O traço não é feito a partir do punho e da mão, mas de uma relação com o movimento do corpo todo. A performance que ele faz com pintura, em que a ação do corpo está ligada com este universo enorme, influenciou o meu olhar para o movimento. Percebi então que a árvore cria um gesto próprio que é uma coisa regida pela luz, pela natureza e pelo ambiente. Eu começava com certo movimento, as coisas que estava trabalhando na pintura, uma coisa da escrita. Escrevendo assim palavras que vinham de uma ação mais pelo corpo, era um gesto feito mais pela ação. Interessante a pesquisa do Toshi que tinha questão dos sons das vogais e de como elas vibram no corpo. Há uma relação muito forte com as coisas que via na mata, naquele silêncio das formas das árvores.

Depois que eu saí de lá eu fui morar no sítio que era de uma ceramista em Cotia. Na época eu ficava trabalhando lá direto. Ela foi aluna do Jorge Fernández 
Chiti158, na Argentina; a Rosemarie Jensen. Realmente, ela foi uma discípula dele, construiu fornos à maneira dele. Ela iria ficar um ano fora e me deixou usar o ateliê. Lá tinha uma área de mata e tinha argila no terreno. Era um lugar muito bonito, e com uma cachoeira passando por dentro da mata. Comecei a fotografar os cipós na mata e eram formas muitas parecidas com o que eu fazia com as letras das palavras que eu ia escrevendo, ou desenhando soltas no espaço das pinturas e desenhos que fazia naquela época. O que eu buscava era manifestar um espaço surgido de uma não intencionalidade, por assim dizer; uma "intenção sem intenção". Ali eu comecei a pegar esses galhos e incorporar suas formas, acho que neles eu sentia que havia esse sentido que eu buscava em termos de espacialidade, do gesto, do crescimento orgânico da forma, algo que se dá, isto é acontece naturalmente.

Eu comecei a perceber que as coisas que o Toshi falava sobre a relação do corpo e o ar: que o corpo continha ar e que podíamos perceber essa relação. $O$ ar como espaço do movimento que flui através do corpo. Perceber essas sutilezas, aquilo que se dá mesmo num plano da não visibilidade, da presença que fala por si, do silêncio... quanta coisa pode estar contida aí, coisas que não necessitam de definições. As pessoas às vezes buscam algo como milagres, como algo fora do normal, mas a respiração já é um milagre que está bem aí, em cada forma de vida, em nós mesmos. Lá na mata eu vi muito forte isso, em alguns momentos. Era um lugar muito especial, foi um momento que me deu essa possibilidade.

A argila preenchia os espaços vazios, entre os galhos e revelava uma forma neste espaço que ficava entre, onde antes havia o vazio.

Silvia: Interessante que mesmo após a queima ficam as marcas e lembranças da linha. Na trajetória de um artista nada impede que tudo seja algo experimental, aleatório, mas percebo que no seu trabalho, há uma coerência na sua busca, de encontrar, tudo aquilo que você está vivendo.

\footnotetext{
158 Jorge Fernádez Chiti (Buenos Aires,Argentina- 1940) é ceramista, professor e escritor. Em 1970, fundou em Buenos Aires, o Instituto de Ceramología Condorhuasi, onde ministra cursos, palestra e realiza pesquisas na área de cerâmica artística. Chiti contribuiu fortemente na formação de vários ceramistas tanto em seu país como fora dele. Publicou vários livros de técnicas de modelagem e esmaltação. ( http://www.condorhuasi.org.ar/index.htm Data: 23/07/2013)
} 
André: Tudo começou com essa coisa da escrita e partiu para os galhos. Nesse percurso, comecei a perceber como a cerâmica está ligada com essa questão da composição, da matéria. Essa relação da composição e da matéria com a espera, na queima. Como a formulação altera o ponto de fusão da massa, por exemplo. Como a formação da própria massa faz parte do processo de elaboração poética.

Lembro-me de uma queima que fiz num tambor. Comecei a utilizar esses maçaricos utilizados para queimar asfalto, que com o tempo eles não aguentam. Ali, fiz umas tentativas de queima em lata, e comecei a entender o que não funciona e o que funciona.

Acredito que a queima é o coração da linguagem da cerâmica. Fiz as queimas, peguei muitas orientações com a Norma, fiz a triangulação. Comecei a explorar aquilo. A técnica é o grande meio de descoberta do trabalho, é ali que se descobre o que se pode fazer.

Aí, lá em Cotia. Lembro-me que fiz umas queimas e comecei a fazer umas massas, mas nem sabia o que ia dar. Lembro que fiz uma queima e montei varias peças e andares com prateleiras e o medidor de temperatura foi colocado numa altura média do forno, que chegou a uns $1200^{\circ} \mathrm{C}$. Ela tinha aqueles queimadores do Chiti que têm registros que abrindo fazem a óxido-redução de forma muito eficiente. Deixei um tempo assim e as peças que havia deixado embaixo tinham ficado numa temperatura muito além do que eu imaginei e eu nem reconhecia mais as peças e depois desse choque eu fiquei assim fascinado, porque aquilo tinha saído muito melhor que eu esperava.

Silvia: Deformaram muito?

André: Sim, mas criaram-se novas formas! Achei que ficaram muito melhores. Aí eu vi que aquilo ali era uma nova possibilidade. A partir daí, fui buscar algo mais intencionalmente.

Logicamente que na busca de uma queima assim, você começa a ter alguns acidentes que são meio que destrutivos, principalmente com relação ao forno. Depois, com o tempo, eu também continuei com essas coisas da performance, do corpo tal... O Toshi ganhou um prêmio de fomento à dança, ele estava montando 
uma equipe e ele precisava de um iluminador. Ele perguntou se eu não estava interessado e claro que topei e até para fazer as práticas junto com o grupo. Nessa época, eu acabei conhecendo minha atual companheira, que fazia parte do grupo dele. Então comecei a me aproximar mais da dança mesmo e a fazer algumas práticas de contato-improvisação, onde tinha toda uma pesquisa com o corpo, com a questão dos apoios, do peso, de como um peso sustenta o outro, de como se sustenta a partir de qualquer situação do corpo.

E com relação às peças, eu comecei a perceber que muitas das coisas que haviam acontecido naquela queima, as deformações, por exemplo, mudaram a própria leitura do trabalho. O trabalho passou a ter outras posições e acho que isso foi interessante, porque saí um pouco do conceito de que a cerâmica deve estar sempre presa à base. Não significava que estava presa à base sempre, mas costumava construir sempre debaixo para cima e comecei a pesquisar maneiras diferentes de modelar e partir desse momento comecei a usar muito jornais, papéis diferentes.

Silvia: Para dar sustentação?

André: Sim. Inclusive eu até comprei aqueles papéis sanfonados que ajudam bem para parar em pé, mas que compõe e acompanham o movimento.

Silvia: Então, você utilizava o movimento do papel e partir daí que você posicionava a argila ou não?

André: Não, eu primeiro abria algumas placas e colocava os papéis junto com elas e depois parto para uma ação do meu corpo sobre o trabalho. Abro as placas em cima de tecidos em muitos casos, um pano ou lona e então posso trabalhar com engobes. Depois que seca, eu levo para o forno para a queima, às vezes com o próprio tecido e os papéis.

Silvia: São peças imensas!

André: Esses vazios estavam preenchidos com tecido ou papéis. Aqui, por exemplo, tinha muito papel. Até hoje eu faço isso e quando eu dou aula e eu digo: "você quer que uma forma fique em pé, pode colocar jornal, depois que queimar, vira cinza e sai". 
Silvia: Quais são as dimensões dessas esculturas? Você sempre trabalha com esculturas grandes ...

André: Na verdade, varia bastante. Há esculturas que faço [em tamanho] pequeno e depois construo uma maior, mesmo sendo uma coisa da improvisação, tem coisas que se repetem e acontecem de novo.

Essa escultura aqui eu fiz num projeto patrocinado pelo PROAC (Programa de Ação Cultural) e essa madeira era do local onde eu executei o projeto, que era uma antiga fábrica de cerâmica. A antiga olaria de Pindamonhangaba.

Dessas formas feitas com a interferência do corpo, acabou tomando a forma da figura humana. Isso me fez buscar a escultura mesmo, ver as esculturas do Donatello, que são magistrais.

Silvia: Percebo as marcas do fogo e que também tem a ver com o gestual.

André: Algumas das peças foram duas ou três vezes ao forno.

Silvia: Você experimenta, não está muito preocupado com as "regras"...

André: O próprio Manet, na pintura, que na época era um ambiente cheio de "regras", passou a desafiá-las e isso custou muito para ele, mas valeu a pena! O Darcy Ribeiro dizia mais ou menos assim, que tudo o que ele tentou fazer para construir um país digno naquela época (antes do golpe da direita) fracassou, mas que ele jamais preferiria estar do outro lado.

Silvia: E era aquilo que você falou no começo e que o lberê também falou para você, que o artista deve ser orientado até certo ponto e depois ele tem que trilhar sozinho. Vejo que você seguiu isso: depois de certo ponto, você foi experimentando, descobrindo por si só e chegando aos seus objetivos.

André: Na pintura, também sempre houve regras, principalmente na época da academia, que têm a sua importância e todos aprenderam através delas, mas há um momento em alguns artistas não se satisfazem mais com isso e tomam coragem em buscar o seu próprio caminho. Vemos isso em diferentes momentos o Rembrandt, por exemplo, teve uma época em que ninguém queria as obras dele e chegou até a passar grandes dificuldades, foi a falência, mas são trabalhos maravilhosos estão 
além do sucesso ou fracasso. Segundo Jardim, a tradição é uma transmissão da presença viva de alguma coisa e Rembrandt é um exemplo de algo que mais que coragem é essa coisa da relação do artista com os materiais, que é a conversa com o próprio fazer, ir fundo em si mesmo. O Manet foi buscar seu próprio caminho, pois não queria ficar preso as regras e vai utilizar os recursos da pintura com essa profundidade, no material onde ele via outras possibilidades, de ser verdadeiro.

Acredito que deve haver um respeito pela técnica, pois ela não existe gratuitamente. Imagine os primeiros ceramistas, quantas tentativas e erros eles não passaram para se chegar a compreender os princípios que você precisa ter para se realizar uma peça cerâmica. Você já recebeu isso deles, sem isso, você não realiza nada.

Certamente, são conhecimentos que levaram gerações. Imagine os esmaltes, para se chegar aonde se chegou né...

Silvia: Agora temos tudo isso meio pronto (em livros, revistas, etc..).

André: É. O mais importante é você entender o princípio, mas não ser preso à regra. Você deve saber os porquês e como pode usar aquilo, buscando o que se pode fazer. Mesmo quando dá errado, você saber o porquê deu errado e se você pode tirar proveito disto ou não. Por que no fundo, diante das grandes questões, só o silêncio é grande... 


\subsection{Kimi Nii (Hiroshima, Japão, 1947): da disciplina à poesia}

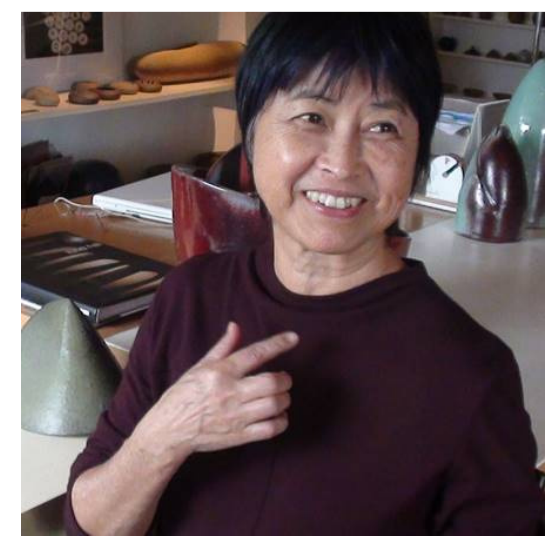

Kimi Nii dedica-se inteiramente à Arte Cerâmica há mais de 30 anos. Formada em desenho industrial, seus trabalhos têm formas limpas, retas e curvas obtidas com perfeição. Algo bem desafiador para um material como a argila, que orginalmente é uma massa amorfa, maleável e difícil de ser controlada, principalmente porque reações químicas e físicas são interferidas pelo próprio meio ambiente em que se encontra. São formas que me instigaram e fascinaram, pois desafiam as próprias leis naturais da cerâmica.

Kimi Nii é centrada, disciplinada e, ao mesmo tempo, sensível, características que são transmitidas para os seus trabalhos.

Durante a entrevista, Kimi se mostrou bastante à vontade e quando começamos a falar sobre seu percurso e a cerâmica, seus olhos brilhavam de alegria em lembrar dos desafios e de como esses foram superados.

Ela me recebeu em seu ateliê que fica numa casa no bairro do Butantã. Todos os espaços possuem peças suas e é um local que você pode ficar contemplando por horas, observando cada peça e detalhe. Você se sente em paz. No fundo casa está seu espaço de trabalho e é onde se localizam seus fornos. 


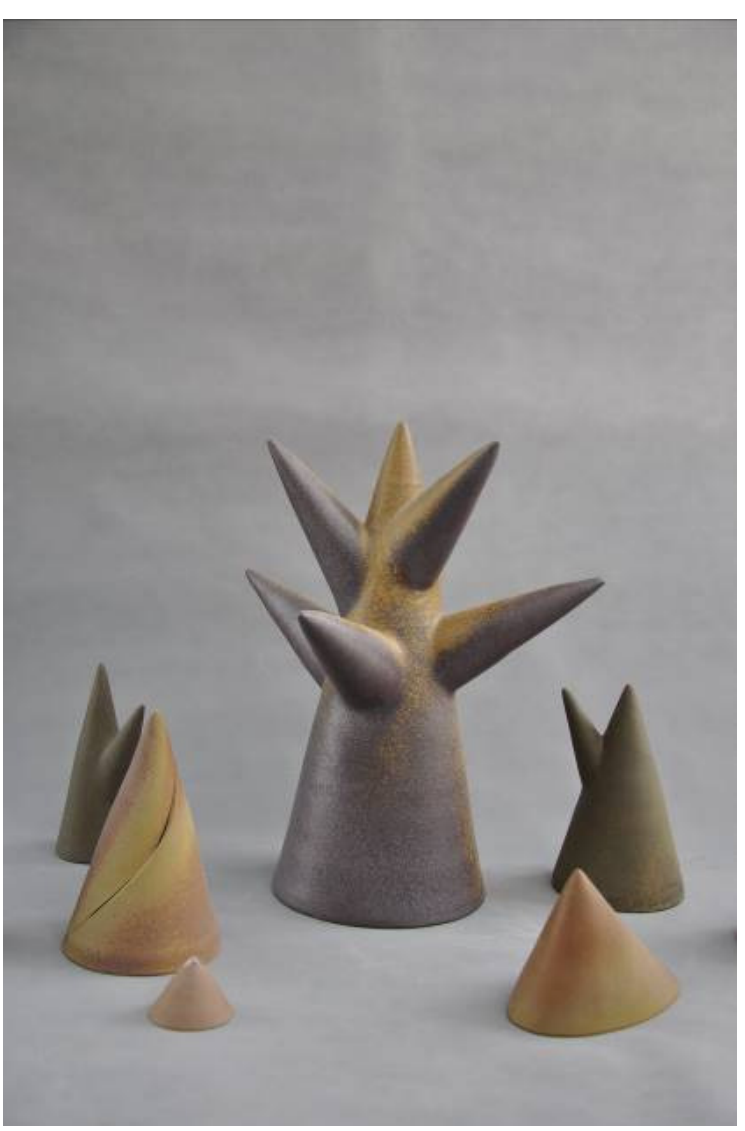

Figura 71

Kimi Nii

De $48 \mathrm{~cm}$ a $25 \mathrm{~cm}$ de altura

$1997 / 2012$

Cerâmica esmaltada (Alta Temperatura)

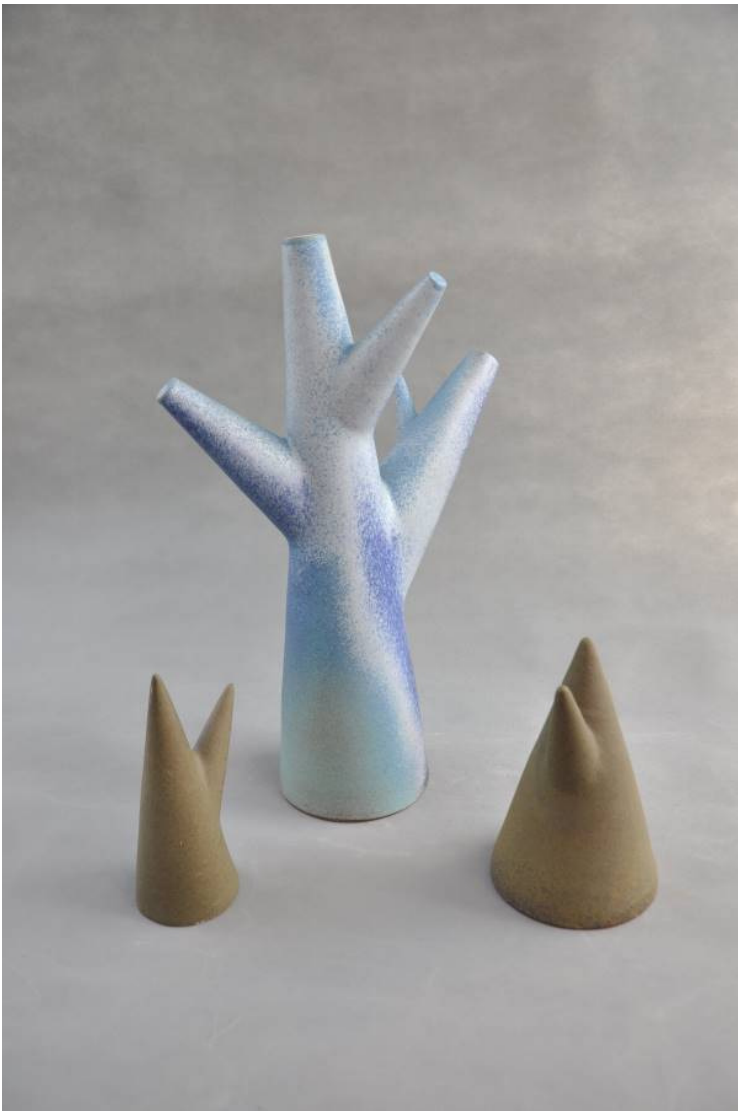

Figura 72

Kimi Nii

De $48 \mathrm{~cm}$ a $25 \mathrm{~cm}$ de altura

$1997 / 2012$

Cerâmica esmaltada (Alta Temperatura)

Lembro-me de que a encontrei informalmente e foi uma conversa muito rica, pois ela falou muito a respeito de sua visão sobre a Arte e a Cerâmica. Nesta conversa, pude perceber que sua disciplina tem raízes em sua educação baseada na cultura japonesa e sua poética, bem como suas emoções que são passadas para os seus trabalhos, vêm de uma tentativa constante de libertação e superação. Segundo Nii, ela sempre teve curiosidade e interesse pela cerâmica, mas o momento de libertação veio quando optou por largar a agência de publicidade para se dedicar inteiramente à sua arte. 


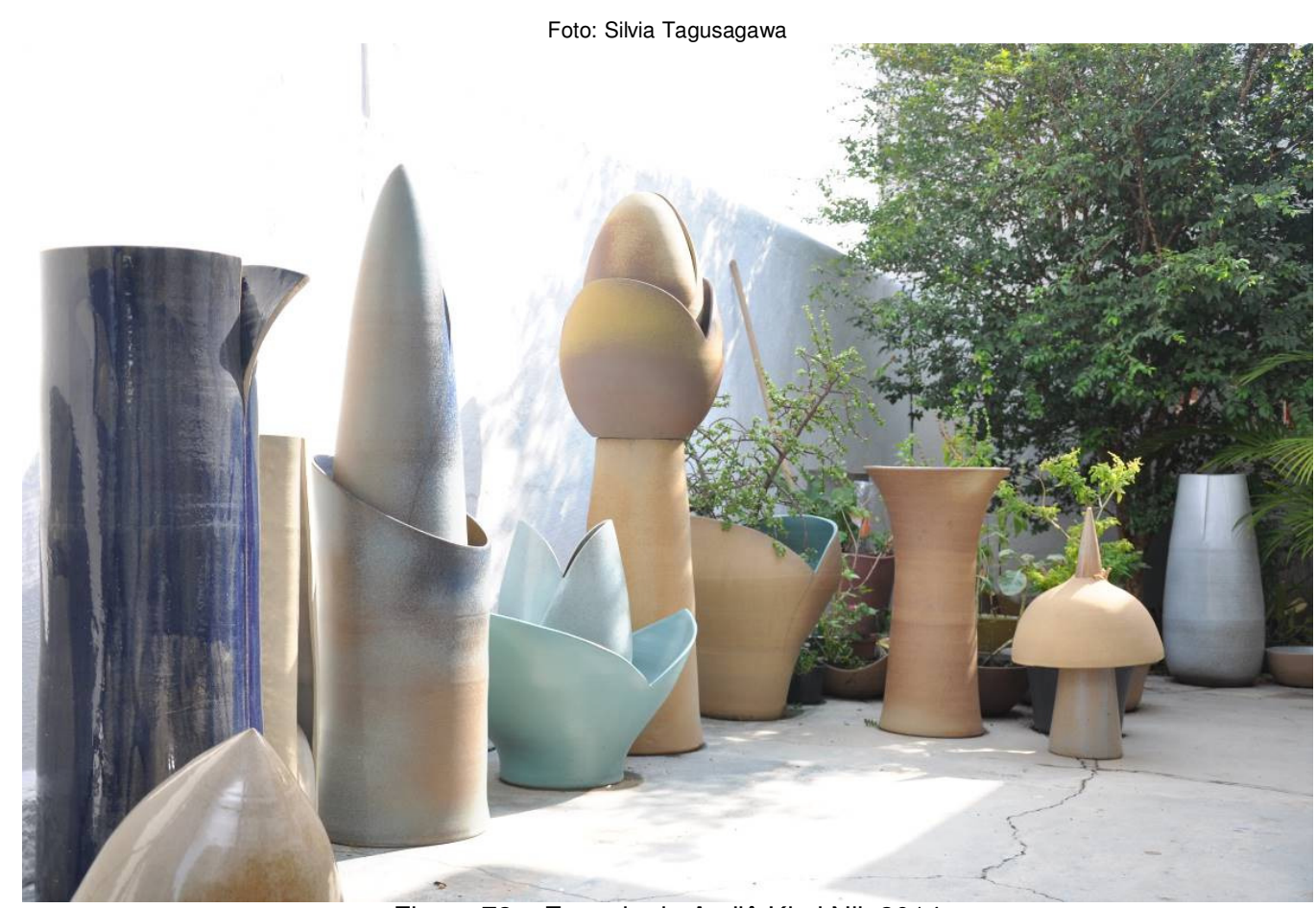

Figura 73 - Entrada do Ateliê Kimi Nii, 2014

Kimi, que aos nove anos veio para o Brasil, tem como cidade natal Hiroshima, no Japão. Tinha no seu pai alguma referência com o mundo da Arte. Ela relata que o contato com a Arte sempre esteve presente em sua família, pois seu pai, que era arquiteto, levava os filhos a museus e, até por causa de seu trabalho, materiais de arte, como lápis de cor e caderno de desenho eram itens comuns em sua casa. Nesse contexto, um olhar especial para as formas e cores foi desenvolvido desde a sua infância. No Japão, onde estudou parte de sua infância, Arte e Música eram tão importantes quanto as outras disciplinas.

Nos anos 70, estudou Desenho Industrial na FAAP-SP (Fundação Armando Álvares Penteado), em São Paulo, e trabalhou em agências de publicidade e design, atuando em comunicação visual e desenvolvimento de embalagens. No entanto, sua paixão e vontade de trabalhar com Arte estiveram sempre latentes.

Seu interesse específico pela cerâmica é de longa data. Foi uma visita à feira da Praça da República que Ihe fez aflorar aquela vontade em explorar este meio. Encantou-se de imediato ao ver as cerâmicas de alta temperatura de Massayuki Sato, que posteriormente foi seu professor. Em sua primeira aula de Cerâmica, sua 
vontade de fazer Cerâmica era algo muito forte e, segundo ela, não a deixava dormir. Ficou eufórica e a partir daí não parou. Sua prima, Yae Takeda, que havia passado uma temporada no exterior, numa viagem ao redor do mundo - com passagem pelo Japão - ao regressar ao Brasil, propõe à Kimi que abrissem juntas um ateliê de Cerâmica. Aceitou de imediato.

Foto: Silvia Tagusagawa
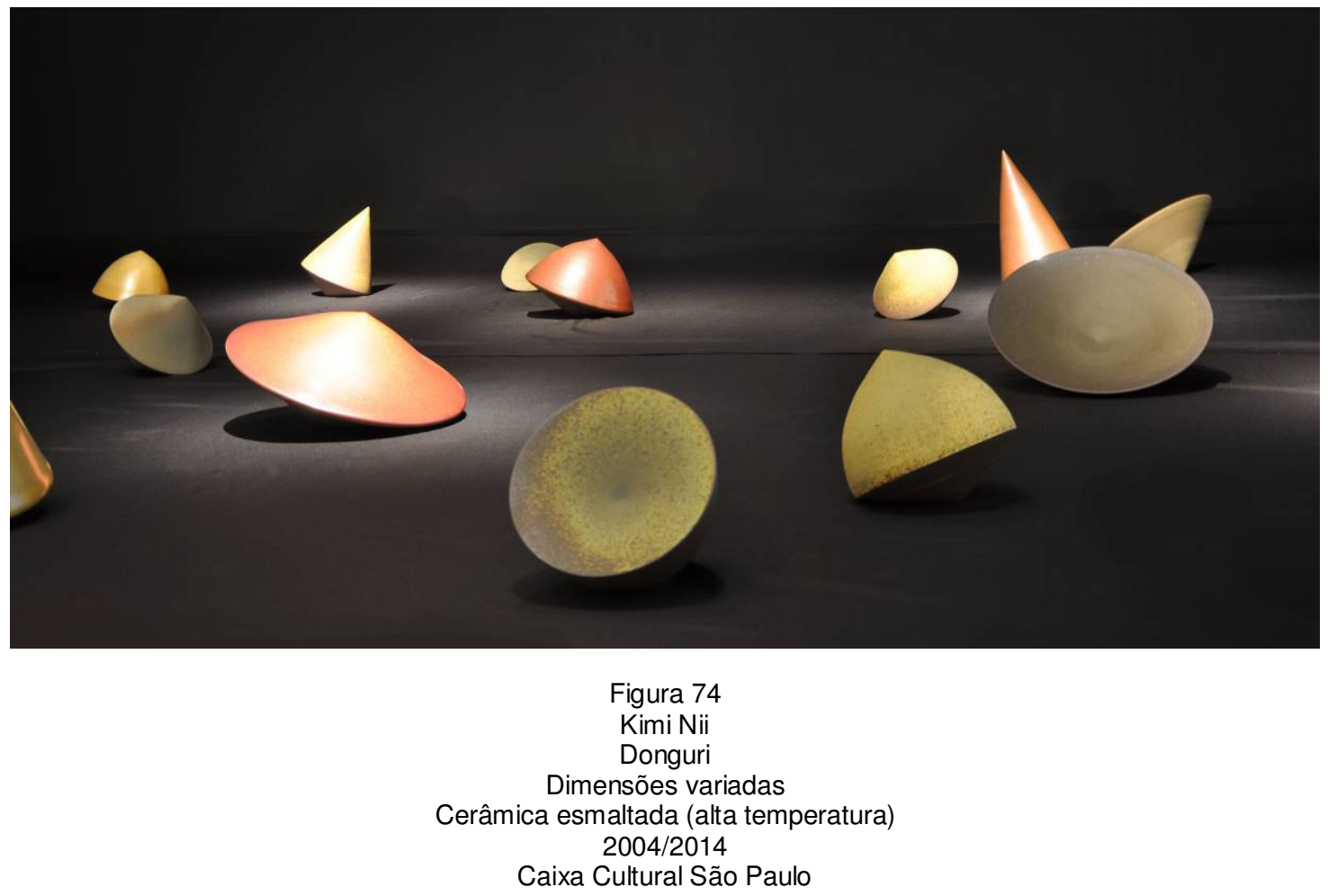

Iniciaram juntas busca de conhecimento técnico, uma boa massa para trabalhar e desejavam construir um forno. Nesse percurso, conhecem Jeremy Fiennes e juntos, montam um ateliê de Cerâmica em Embu das Artes, São Paulo.

Kimi, sua prima Yae e Jeremy mergulharam juntos no mundo da cerâmica, aprenderam juntos, formularam massas e vidrados e construíram um forno Noborigama ${ }^{159}$. Através das tentativas, erros, acidentes e acertos conseguiram, aos poucos, dominar a técnica. Com o passar do tempo, cada um seguiu o seu caminho e Kimi deu continuidade ao seu trabalho em Cerâmica no qual persiste até hoje. 
Com relação às suas influências artísticas e motivações para a produção autoral, Kimi diz que prefere buscar dentre de si mesma, mas nota-se que sua educação em Artes influenciou bastante. Segundo Kimi, sua formação foi baseada nos conceitos pregados pela Bauhaus. Tem grande admiração por movimentos como o Concretismo, o Construtivismo e o Modernismo, de maneira geral.

"Minha formação é da linha Bauhaus, uma coisa mais objetiva e limpa. Isso ajudou muito a desenvolver minha linha de utilitários. Mas isso de ser objetiva e racional não dispensa o outro lado, porque eu aprendi que além de ser tudo isso, tem que ter uma linguagem, uma poesia. Em alguns momentos, quando o racional e o sensível trabalham juntos, as coisas terão maior sentido. Cada detalhe terá um sentido de existir." ${ }^{160}$

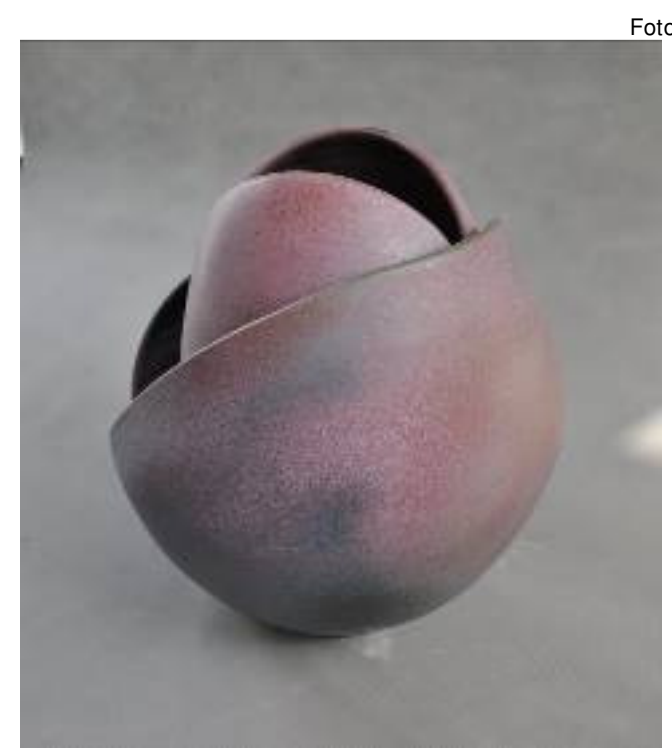

Figura 75

Botão

Cerâmica de alta temperatura

2010

$37 \mathrm{~cm} \times 40 \mathrm{~cm}$

otos: Silvia Tagusagawa

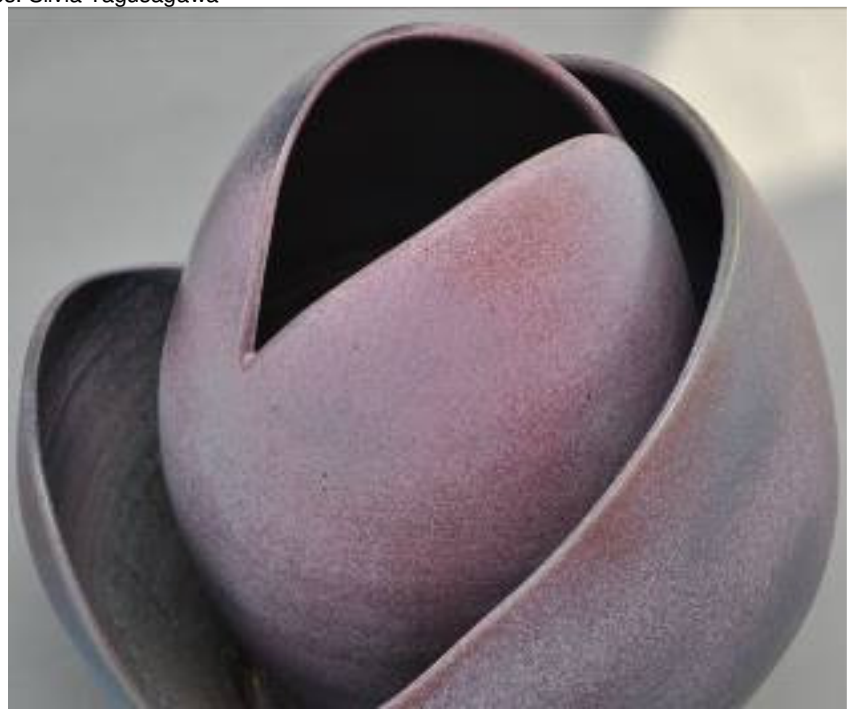

Figura 76

Botão

Cerâmica de alta temperatura

2010

$37 \mathrm{~cm} \times 40 \mathrm{~cm}$

${ }^{159}$ Ver Capítulo 2, item 2.2.6. Queima

160 Trecho da entrevista de Kimi Nii concedida à Silvia Tagusagawa 
De acordo com Gonçalves ${ }^{161}$, Kimi Nii não tinha a intenção de fazer algo decorativo e mesmo que suas obras lembrem algo do Concretismo ou Bauhaus, não era seu objetivo fazer imitar: "seu diálogo com a obra de outros artistas não é imitativo", define o autor. Kimi, em seu relato durante a entrevista, comenta que ela sempre quis fazer algo diferente de seu tempo:

"Eu sempre tive a preocupação com isso, de não fazer algo repetido ou o que já se fez. Eu tinha que tentar algo novo. Tinha muita preocupação com isso, de não ser a mesma. Às vezes pensava: 'eu acho que alguém já fez isso algum lugar...'. Daí, eu parava de fazer."
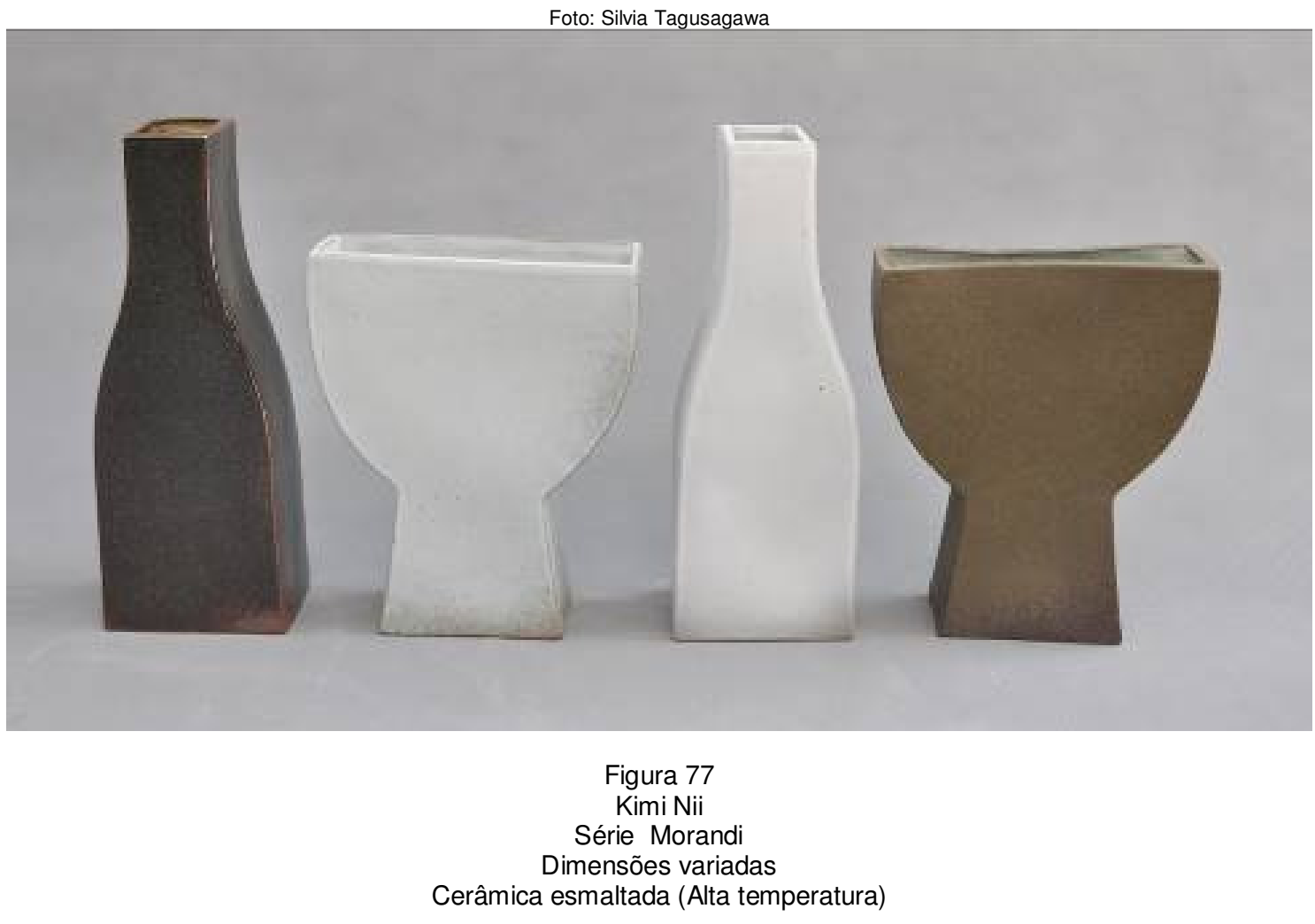

Além disso, para evitar interferências externas em sua poética, parou de consultar livros e revistas de cerâmica. Queria buscar na sua essência a inspiração e alcançar assim a liberdade de se expressar.

${ }^{161}$ GONÇALVEZ FILHO, Antônio Apud MOLINA, Camila. A Cerâmica como Arte, por Kimi Nii. Jornal 
Nas primeiras obras, Kimi busca as formas retas, geometrizadas com exatidão, sem deformações - algo bem desafiador para uma matéria que, como visto em capítulos anteriores, sofre inúmeras transformações desde a modelagem até a queima. Adequar os projetos às condições de produção, bem como aos comportamentos da massa cerâmica trabalhada, à queima e aos outros estágios do processo cerâmico foi um caminho árduo. No entanto, ela não desistiu e seguiu a sua luta firmemente:

"Na verdade, eu sofri muito com as deformações porque eu desenhava as coisas para ficarem retas e nunca ficavam, sempre entortavam. Quando projetava uma curva assim, depois da queima ela não era aquela curva perfeita, mas ficava assim deformada, sinuosa." ${ }^{162}$

Essa luta em adequar a matéria à sua poética foi travada nesta época.

Os vasos Morandi mostram essa busca pela forma exata, essa luta. A cada peça feita, Kimi analisava cuidadosamente onde poderia melhorar, a cada fornada, mesmo não conseguindo o seu objetivo, ela insistia. Ela se deu conta de que não deveria lutar contra, mas aceitar as imposições feitas pela massa e a transformação do fogo. Kimi percebe então, que deveria trabalhar com as forças e os fenômenos físicos impostos pela massa cerâmica, pela umidade, pelo ar e pelo fogo. Ela diz:

"Então, eu sabia que querer aquelas formas era um desafio muito grande e desisti das formas retas demais. Agora eu tenho um controle um pouco maior sobre as deformações. Sei que a peça pode deformar de um lado, por isso faço uma deformação contrária. Assim, as forças se equilibram e a peça fica do jeito que desenhei. Eu desafiava e explorava os limites e verificava até que ponto poderia entortar." 163

Assim, ela começou a trabalhar as forças contrárias e convertê-las a seu favor.

O Estado de São Paulo, São Paulo, 08/02/2012 às 03h09. Disponível em <.http://cultura.estadao.com.br/noticias> Acesso em:20/04/2013.

162 Trecho da entrevista de Kimi Nii concedida à Silvia Tagusagawa.

${ }^{163}$ Idem, Ibidem. 
"O artista, impulsionado a vencer o desafio, sai em busca da satisfação de sua necessidade. Ele é seduzido pela concretização desse desejo que, por ser operante, o leva à ação". ${ }^{164}$

Certamente, quando falamos dos trabalhos de Kimi Nii, remetemo-nos à Cerâmica Japonesa:

'No Japão, a cerâmica está no dia-a-dia das pessoas: um simples almoço é servido em pratos de porcelana ou cerâmica de alta temperatura, assim almoços ou jantares formais ou comemorativos enchem os olhos com a variedade de cores e formas das cerâmicas que as servem. [...] As cerâmicas utilitárias dividem espaço igualitário com o mundo vibrante da cerâmica artística."165

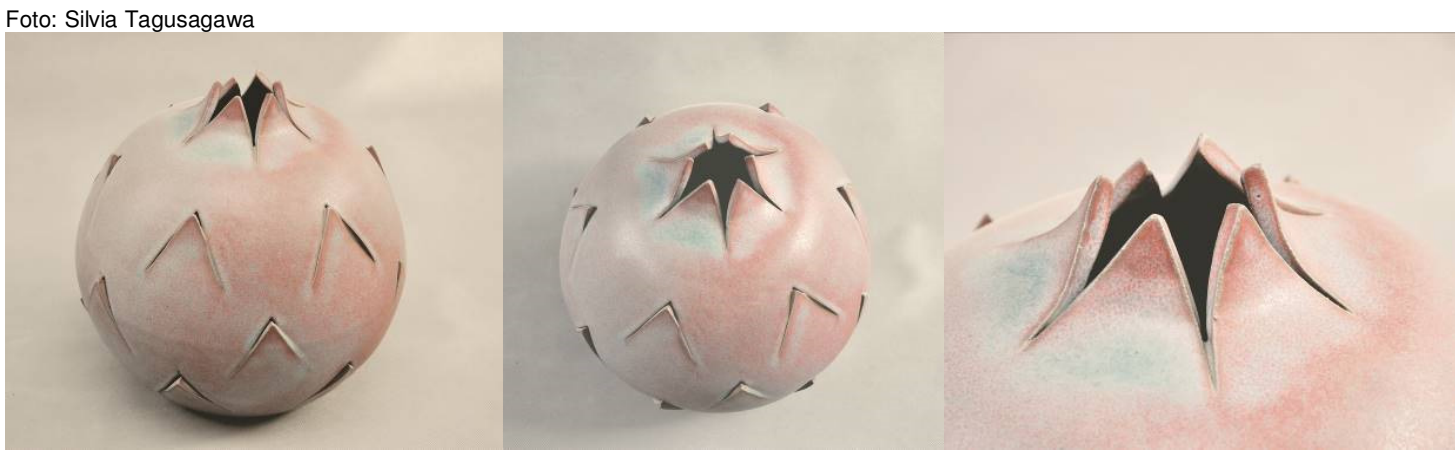

Figura 78

Kimi Nii

Ananás

$30 \mathrm{~cm}$ de diâmetro

2002

Cerâmica esmaltada (Alta temperatura)

Com relação aos artistas japoneses, que trabalham cerâmica, Earle acrescenta:

"Apesar das nomenclaturas como tigelas, jarros ou vasos, que implicam algo com funções práticas, eles foram criados com o mesmo espírito dos artistas ceramistas europeus e americanos contemporâneos, ou seja, seguindo a concepção de realização pessoal e de autoexpressão que são considerados mais importantes do que a utilidade prática ou sucesso comercial." ${ }^{166}$

${ }^{164}$ SALLES, Cecília A. Gesto inacabado: processo de criação artística. São Paulo: Annablume,2004 (p. 29)

${ }^{165}$ EARLE, Joe. Ceramic clay: Japanese ceramics for the new century. Boston: MFA Publications, 2005,p. 6.

${ }^{166}$ Idem, Ibidem 
Assim, a arte de Kimi segue essa mesma tendência, na qual suas peças dividem espaço igualitário:

"Eu chamo de escultura, utilitários e vasos. [...] Na verdade, para mim todos têm o mesmo valor, pois eu tenho carinho pelos três. A única diferença é maneira como eu produzo cada uma delas. Quero dizer, o quanto eu produzo."

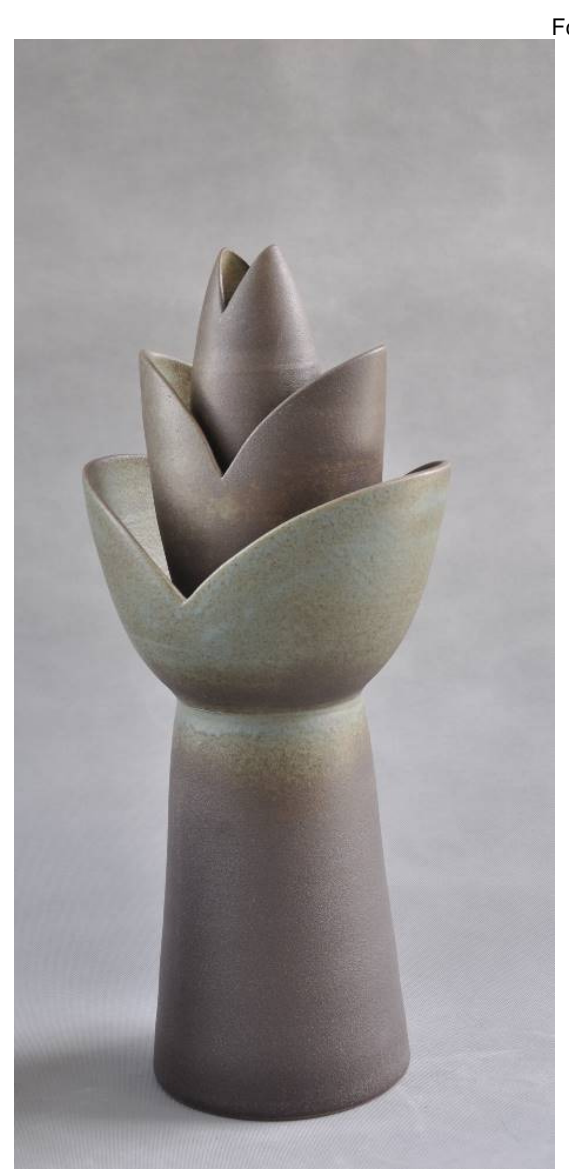

Figura 79

Kimi Nii

Bromélia

$140 \mathrm{~cm}$ de altura

2007

Cerâmica de alta temperatura

Foto: Silvia Tagusagawa

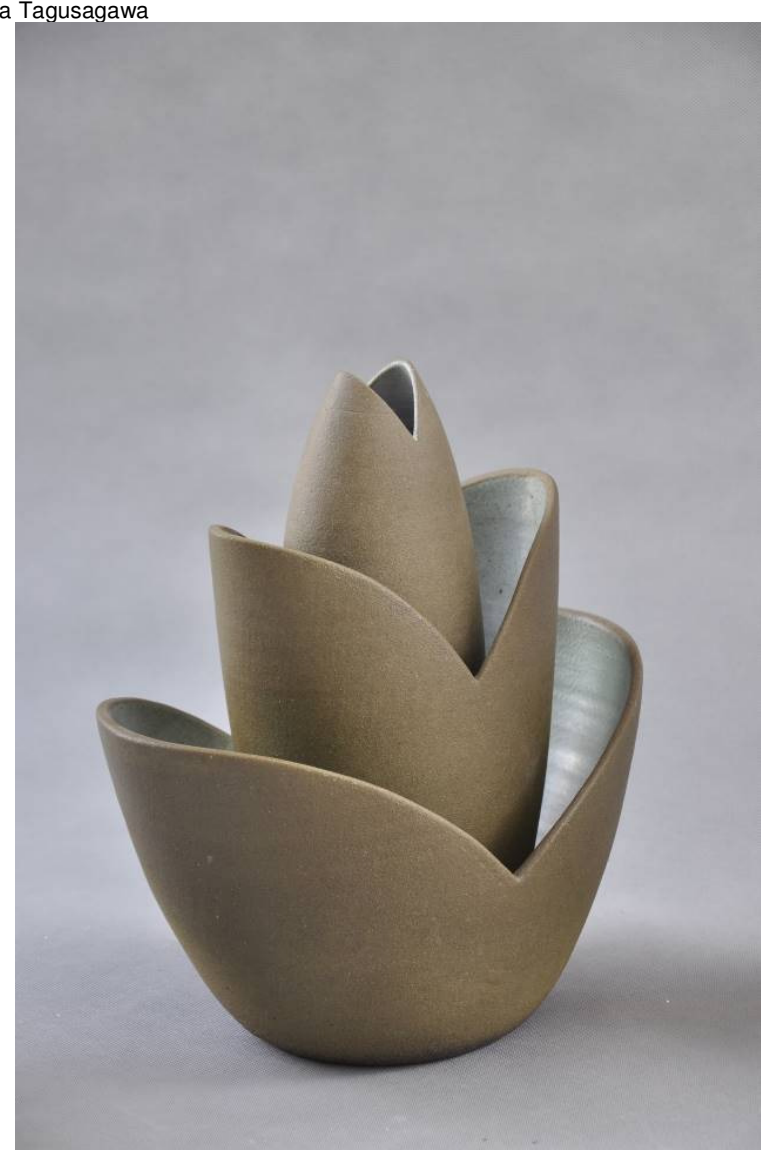

Figura 80

Kimi Nii

Bromélia

$35 \mathrm{~cm}$ de altura

2007

Cerâmica de alta temperatura

Kimi Nii, com anos de prática e persistência, desenvolveu uma sensibilidade única para perceber cada mudança sutil durante o processo da cerâmica. 
"Então, não basta só fazer, dar a forma. A maneira de como você faz, como você seca ou como você queima, tudo isso, faz a diferença

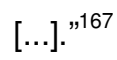

\subsubsection{Poética de Kimi Nii}

Como foi dito, utilitário e suas obras únicas têm o mesmo valor para ela. Inicialmente, Kimi batalhou para aprimorar seu conhecimento técnico em Cerâmica. Seu maior desejo era tornar tridimensionais as formas que imaginava e desenhava. Além de domínio da técnica, Kimi desenvolveu uma sensibilidade para perceber cada mudança sofrida pela massa cerâmica durante a modelagem, secagem e queima, o que permite que ela preveja os resultados finais.

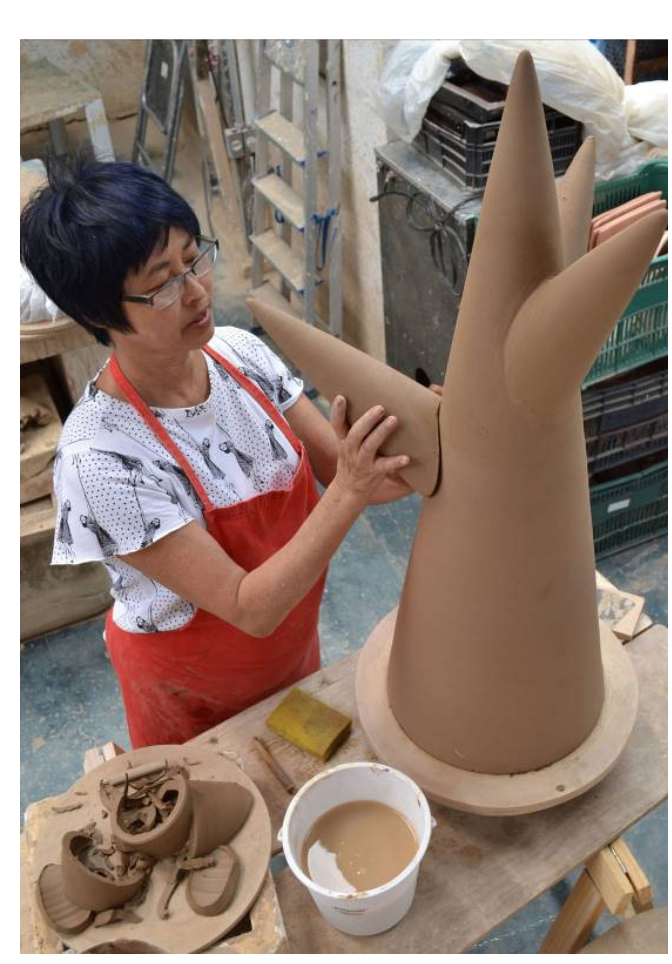

Fotos: Kimi Nii

Figura 81

Kimi Nii em seu ateliê

Montagem de peça

${ }^{167}$ Trecho da entrevista de Kimi Nii concedido a Silvia Tagusagawa 
O comportamento da matéria desafiava aquilo que queria materializar. Por isso, dedicou-se em aprender a teoria e, ao mesmo tempo, pôr em prática. Em tentativas, erros e acertos, ela pôde compreender o comportamento da matéria e assim transcender os seus limites, obedecendo-a em suas especificidades e imposições. A sua poesia está na perseguição pelas formas exatas, puras, em harmonia com as cores dos vidrados, sem rachaduras.

Fotos: Silvia Tagusagawa

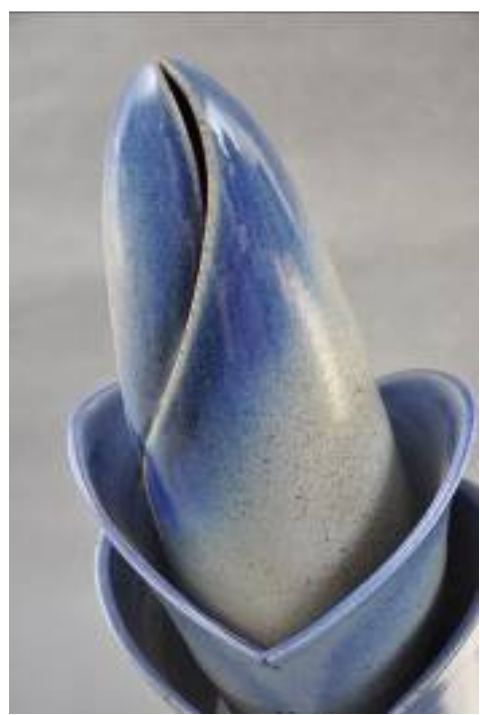

Figura 83

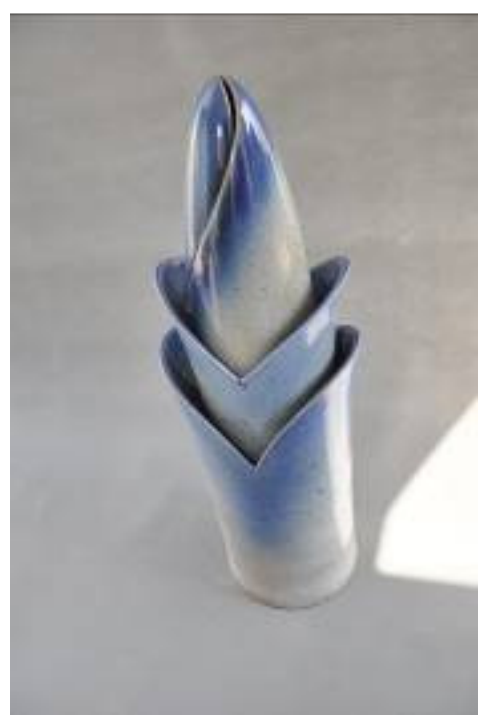

Figura 84

Kimi Nii

Capim

$62 \mathrm{~cm}$ de altura

2002

Cerâmica esmaltada de alta temperatura

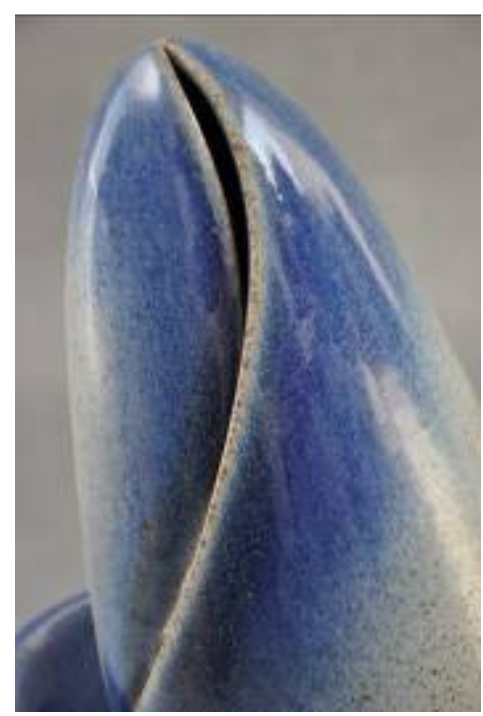

Figura 85

No decorrer de sua carreira Kimi Nii buscou uma perfeição nas formas, na técnica e isso reverteu para a sua poética. Em seus trabalhos posteriores à serie Morandi, Kimi se inspira nas formas de plantas e flores que mostram sua busca pelas formas mais arredondadas e sinuosas. Essa busca resultou nas séries bromélias, por exemplo: 
"Eu acho que me identifico com as plantas, pois elas têm certa ordem, uma geometria, uma sequência de proporção matemática."168

Foto: Silvia Tagusagawa

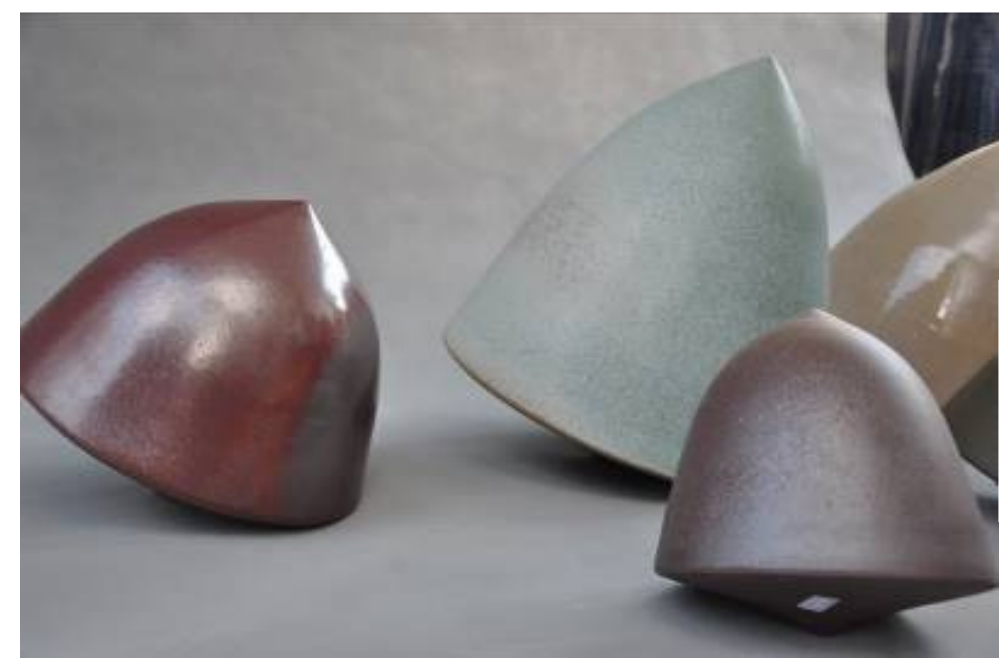

\author{
Figura 86 \\ Kimi Nii \\ Donguri \\ De 44 a 48 cm de diâmetro \\ 2004 \\ Cerâmica de alta temperatura
}

Dos movimentos retos para as curvas, Kimi cria obras com movimento. $\mathrm{Na}$ série Donguri, que se inspira na música japonesa "Donguri, koro, koro, donguri ko" que significa avelãs rolando, rolando..." faz uma instalação com peças torneadas e que giram em torno em si.

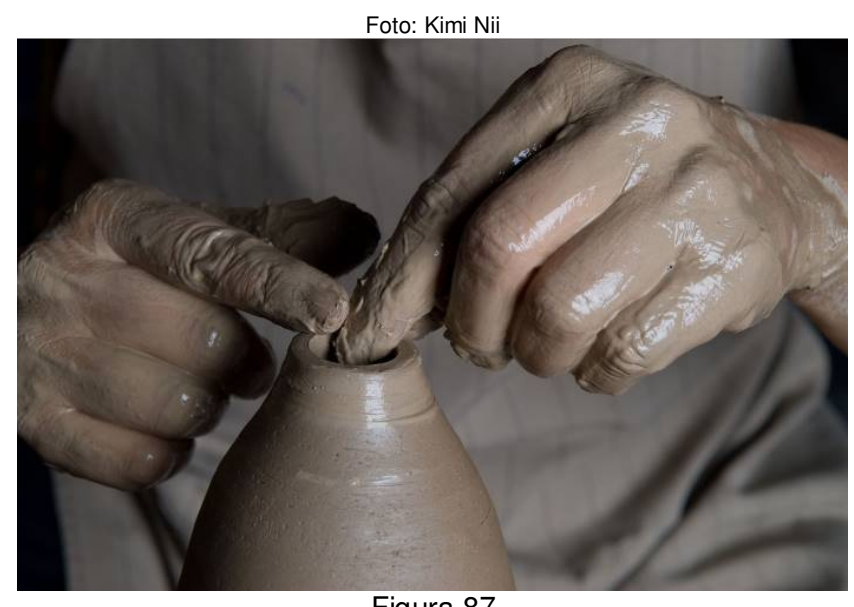

Figura 87

Kimi Nii torneando uma peça

${ }^{168}$ Trecho da entrevista de Kimi Nii concedido a Silvia Tagusagawa 
Assim, em seu percurso, Kimi consegue a liberdade que sonhava há tempos, aliando o seu conhecimento técnico à sua sensibilidade em observar a natureza. Seu olhar se volta para a paisagem e para o céu. As formas torneadas e retas dão lugar às formas extremamente orgânicas como na instalação Nuvens e llhas. Nesta instalação, Kimi Nii construiu as peças utilizando o recurso dos moldes de gesso para reproduzir as inúmeras formas de compõe a instalação.

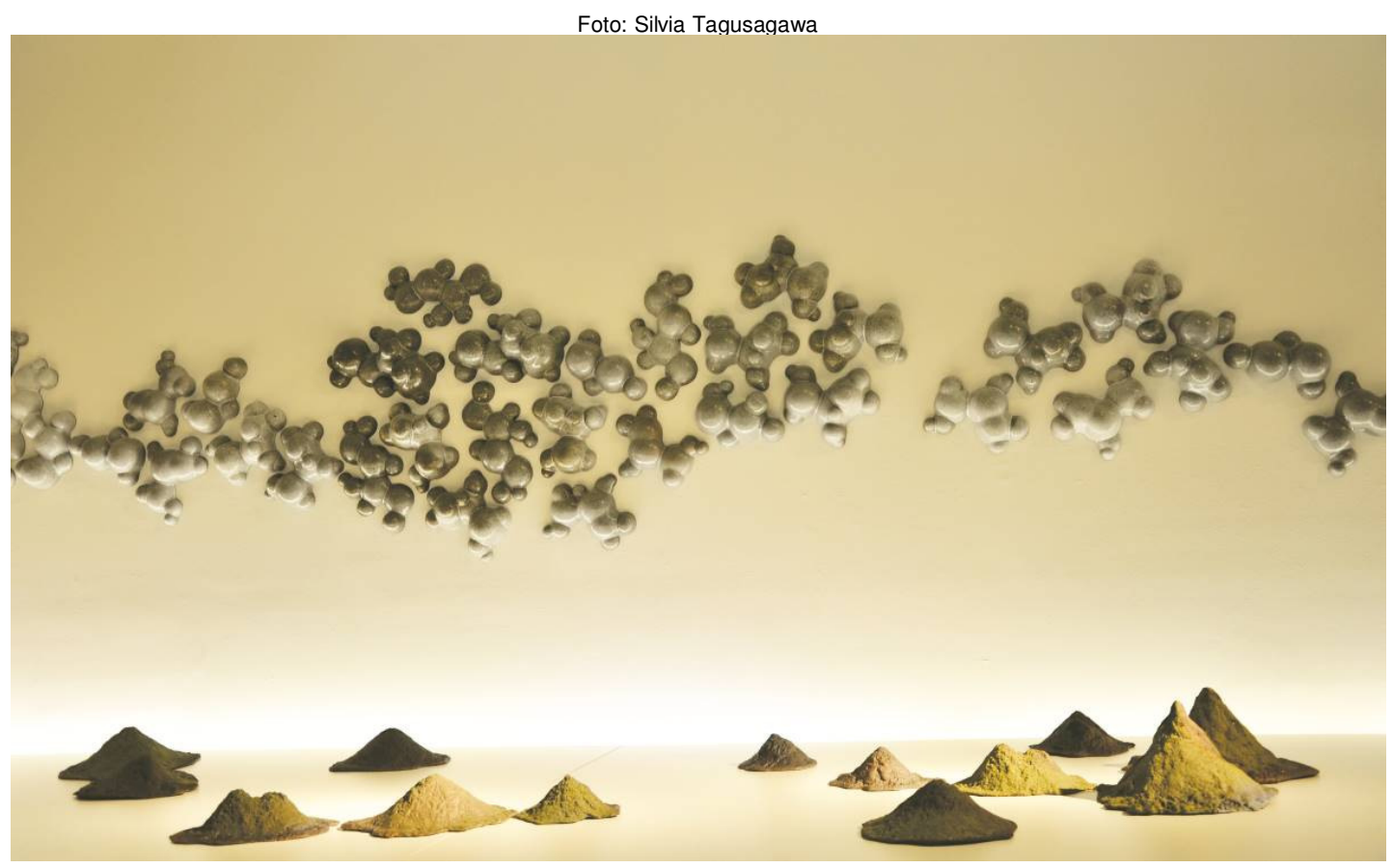

Figura 88

Kimi Niii

Nuvens e ilhas

Dimensões variadas

2014

Instalação em cerâmica (alta temperatura)

Caixa Cultural São Paulo 


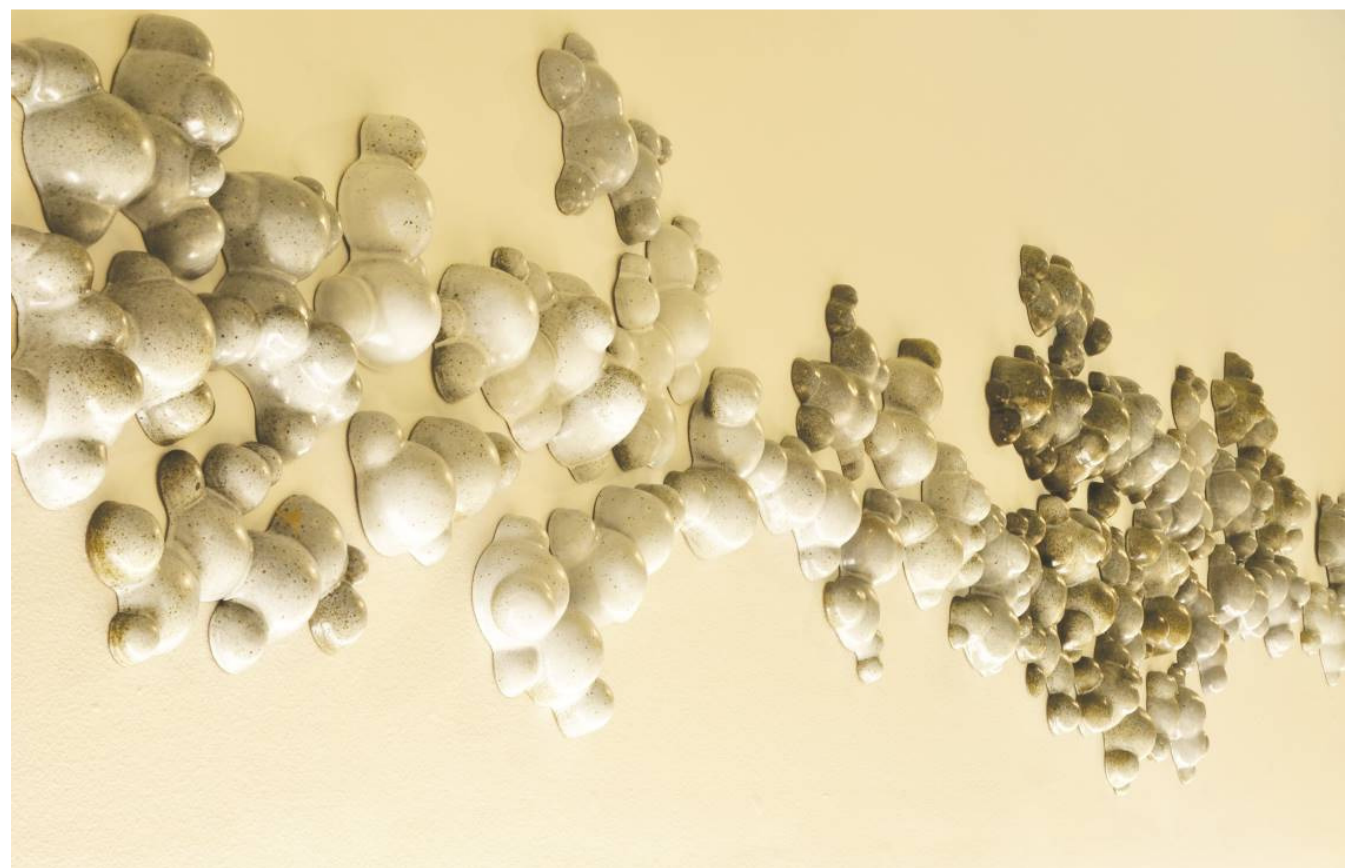

Figura 89

Kimi Niii

Nuvens e ilhas

Dimensões variadas

2014

Instalação em cerâmica (alta temperatura)

Caixa Cultural São Paulo

Foto: Silvia Tagusagawa

\subsubsection{Entrevista com Kimi Nii (São Paulo, 12/06/2013)}

Silvia: Você nasceu em Hiroshima, Japão e veio aos nove anos de idade para o Brasil. Você tem mais irmãos?

Kimi: Somos em cinco irmãos.

Silvia: Houve alguma razão especial para vir ao Brasil?

Kimi: É que a minha mãe nasceu no Brasil. Ela é nissei. Meu pai veio trabalhar aqui no Brasil, conheceu a minha mãe e foram morar no Japão e lá ficaram durante 17 anos. 

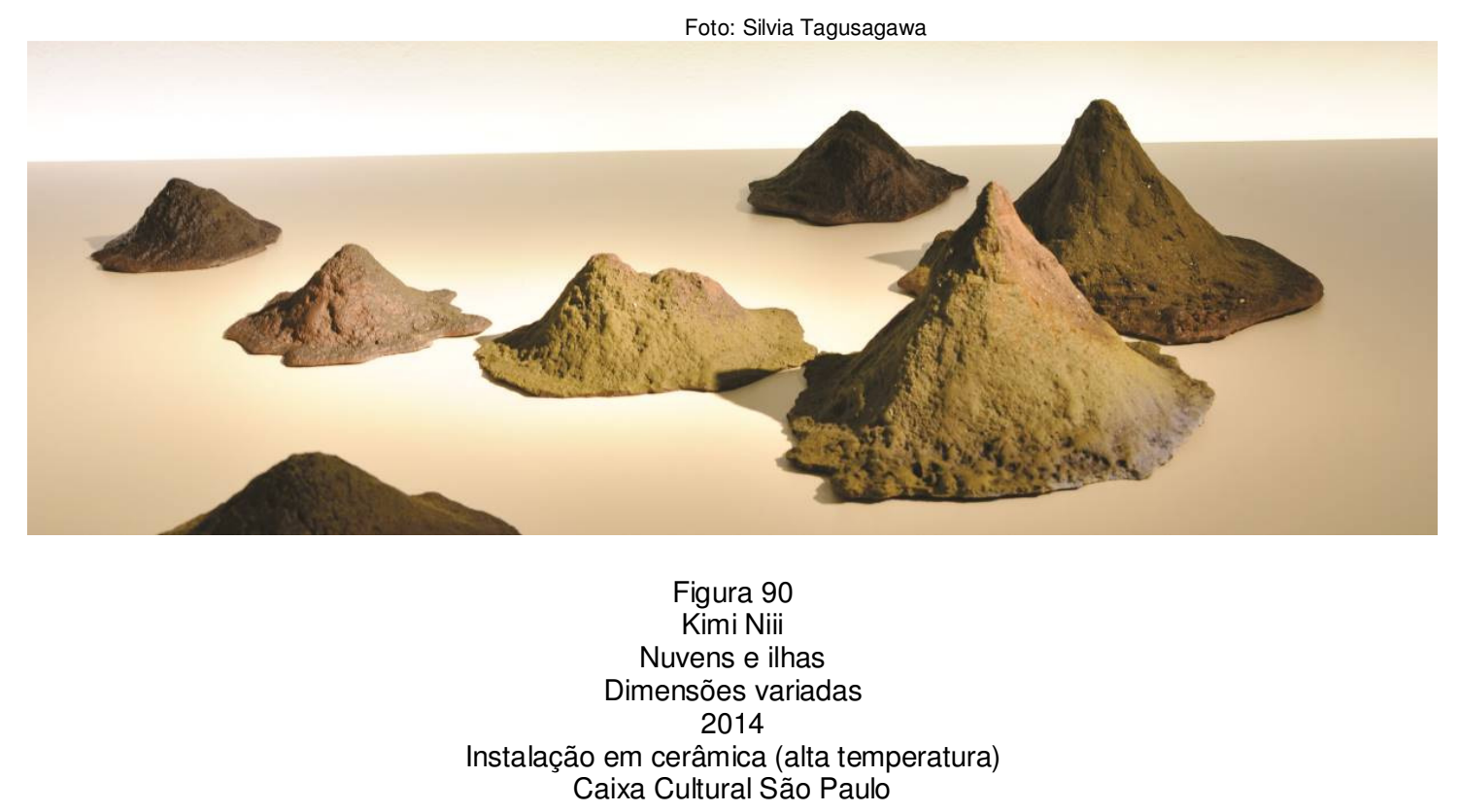

Silvia: Há uma história de que ele trabalhou para a família Matarazzo.

Kimi: Sim. Naquela época, ele era engenheiro, arquiteto e construtor. Ele fez o cálculo do prédio dos Matarazzo, da residência deles e do Hospital Santa Cruz. Meu pai faleceu há muito tempo. Minha irmã conta que quando foram demolir o prédio (a residência dos Matarazzo), não demolia de jeito nenhum (risos)! Ele estava acostumado a calcular de acordo com a geografia do Japão, ele deve ter diminuído nível de segurança, mas mesmo assim, eles tiveram que colocar muita dinamite para demolir. Por isso acho que o Hospital Santa Cruz não vai cair facilmente.

Silvia: Li também que você foi muito motivada pelo seu pai a ter contato com a Arte.

Kimi: É. Ter contato com a Arte era uma coisa normal porque ele sempre gostou, mas não nos educou ou direcionou para isso, do tipo "faça isso ou aquilo". Ele sempre nos deu materiais de desenho e pintura, mostrava exemplos. Nós achávamos aquilo normal e pensávamos que todas as famílias também tinham isso.

Silvia: Quando fui ao Japão percebi que as crianças desenham muito bem. A Educação Artística é muito forte lá. 
Kimi: De fato, era muito normal para mim porque na escola, onde estudei até o $3^{\circ}$ ano do primário no Japão, havia matérias com Artes, Música, Educação Física, Matemática, Linguagem e História. Tudo com a mesma importância. Eu achava que meu forte era Artes, porque eu tinha bastante afinidade e me sentia bem à vontade. Se uma pessoa tem alguma desenvoltura com Artes, isso começa na escola. Aqui no Brasil acredito que não haja tanta ênfase às Artes, principalmente no ensino público. Nas escolas particulares, atualmente, há uma preocupação maior. Por isso, vejo que a maioria que faz a Faculdade de Artes Plásticas vem de escolas particulares.

Silvia: Depois, você se formou pela FAAP (Fundação Armando Álvares Penteado) em Design e trabalhou com publicidade?

Kimi: Na verdade, eu nunca trabalhei com publicidade, mas sim com Comunicação Visual. Por acaso, eu trabalhei em três agências de propaganda fazendo design gráfico, mas nunca fiz propaganda. Na verdade, sentia-me pouco à vontade naquele ambiente de publicitários, pois gostava mesmo era de trabalhar como designer, onde eu misturava o Desenho e a Comunicação Visual. Nesta área, o trabalho era feito com calma e num ambiente tranquilo. Trabalhei num estúdio chamado InDesign, onde havia dois sócios, que eram pessoas mais calmas também. Um era designer chinês chamado David Pond, que fez Desenho Industrial, formado em Chicago. O outro sócio era um austríaco, Gernot Stiegler, que tinha um super bom gosto. Eu e ele ficávamos discutindo sobre música clássica, MPB e sobre os trabalhos de determinados designers gráficos e arquitetos, etc..

Silvia: Onde vocês se conheceram?

Kimi: Um amigo meu da FAAP que trabalhou com eles, estava saindo deste estúdio e me indicou. Foi meu primeiro trabalho e eu adorava.

Silvia: Este trabalho foi em Recife? 


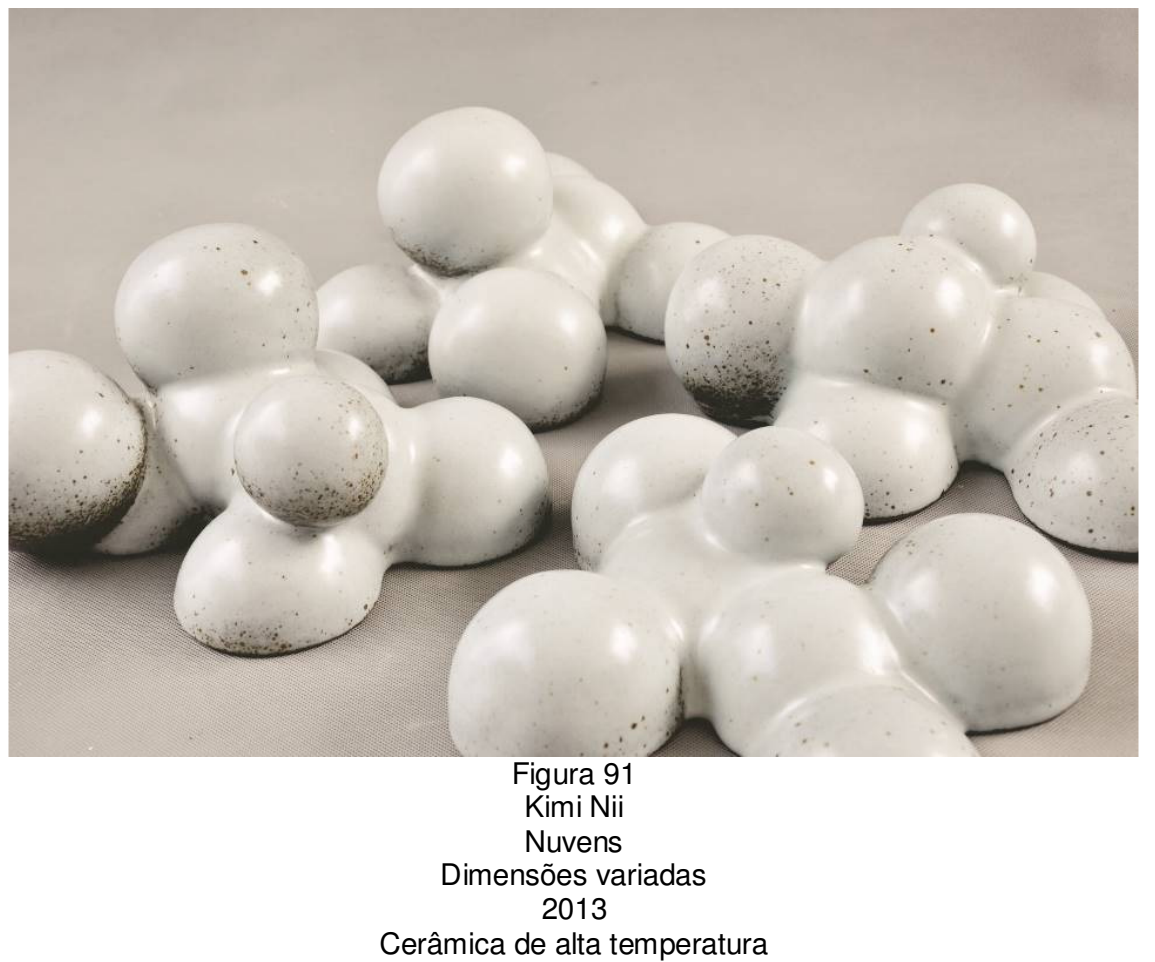

Kimi: Não, foi em São Paulo. Acho que o estúdio existe até hoje. Tenho amizade com o David Pond até hoje. Eles foram muito importantes para mim.

Silvia: Lendo alguns textos sobre a sua carreira, soube que você se encantou com a cerâmica quando viu algumas peças numa feira na Praça da República. É verdade?

Kimi: Sim. Eu tinha um sonho de fazer alguma coisa além do que eu fazia com design gráfico. Pensava: "Quero pintar, fazer arte". Pensava muito no Baravelli, que foi meu professor na FAAP e que dava aulas na Escola Brasil e também no artista Tomoshigue Kusuno ${ }^{169}$. Quando estava no Recife, eu ficava pensando: "Aqui não

\footnotetext{
${ }^{169}$ Tomoshige Kusuno (Yubari, Japão 1935) é artista visual e professor. Iniciou seus estudos em Artes na Universidade de Arte em Tóquio e lá participou de um grupo de vanguarda, ligado ao Dadaísmo. Mora no Brasil desde 1960, onde participou de varias exposições, entre eles no MAM do Rio de Janeiro e MAC-USP. Trabalha principalmente com pintura e sua poética está atrelada às tendências neofigurativas, cuja produção visa comentar criticamente aspectos da realidade do Brasil, dos meios de comunicação de massa. Suas pinturas possuem pinceladas gestuais, porém, voltadas à figuração. (http://enciclopedia.itaucultural.org.br/) data: 08/01/2015
} 
tem essas coisas como aulas de pintura ou algo similar, mas quando eu voltar para São Paulo, voltarei e farei alguma coisa com arte". Outra coisa que eu tinha vontade de fazer era Cerâmica.

Silvia: Então, essa vontade de fazer Cerâmica teve início nesta época?

Kimi: Na verdade, há muito tempo já tinha essa vontade. Acho que como eu estava longe, a vontade ainda era maior. Quando você tem tudo à mão, não dá o devido valor, mas quando você não tem ou está longe, você valoriza.

Um dia, quando eu voltei para São Paulo, estava passeando pela Praça da República, encontrei uma barraquinha de um senhor japonês que produzia utilitários em cerâmica e senti uma identificação, porque era um estilo que eu gostava. $\mathrm{Na}$ verdade, era um estilo japonês de fazer cerâmica. Era uma cerâmica de alta temperatura. Na época, eu nem sabia que existia essas diferenças, alta ou baixa temperatura. Eu já havia visto peças cerâmicas em baixa temperatura e até gostava. mas com a alta temperatura eu fiquei encantada!

Silvia: Foi a partir daí que você começou a estudar cerâmica?

Kimi: Comentei com este senhor que eu queria aprender Cerâmica e perguntei se ele conhecia alguém que dava aulas e ele respondeu: "Eu!" Então, eu peguei um cartão dele e na mesma semana eu fui até o ateliê dele. Chamei uma amiga minha para ir comigo. A partir daí, comecei a fazer aulas cerâmica. Estava amando! No primeiro dia que participei, cheguei em casa eufórica e feliz. Eu pensava: "Eu fiz ! Eu fiz!" Eu fiz algo que eu tinha tanta vontade. Nem consegui dormir direito naquela noite e pensava: "Agora posso fazer isso ou aquilo.". Não via a hora de chegar a próxima aula.

Silvia: O que você aprendeu com ele?

Kimi: Tive aulas de modelagem e era uma vez por semana. Era um processo lento: quando eu terminava uma peça, ele queimava e avisava que havia biscoitado. Então, ele dizia que poderia esmaltar e mostrava as cores disponíveis.

Estava amando fazer cerâmica e nesse meio tempo, chegou uma prima minha do exterior, que passou três anos viajando ao redor do mundo. Ela era publicitária e quando voltou fez a seguinte proposta: "Kimi, estou disposta a mudar de profissão e 
quero ser ceramista. Você não quer ser minha sócia?" Então, eu disse: "Nossa! Que coincidência!" Muito feliz, eu, no auge da minha paixão pela cerâmica e ela vem fazer essa proposta! Disse sim sem titubear.

Depois que veio aquela luta, pois naquele tempo não tinha as facilidades que temos hoje como massas cerâmicas prontas, ferramentas e outros suprimentos para trabalhar com cerâmica como temos hoje.

Silvia: Conte-me um pouco dessa dificuldade, pois muitos ceramistas daquela época passaram por isso também.

Kimi: Eu sou autodidata. Na verdade, frequentei algumas aulas de cerâmica e logo parei. Trabalhando com essa prima, começamos a procurar argila, por conta própria, local para trabalhar e precisava de um forno. Comecei a imaginar como seria o forno, mas eu não tinha a mínima noção e nem sabia o que precisava para ser ceramista. Essa minha prima tinha uma pequena noção, pois ela fez um estágio num ateliê de cerâmica no Japão. Então, ela dizia: "Temos que fazer um forno e eu conheço uma pessoa que trabalha na indústria cerâmica". Então, procuramos essa pessoa, dissemos o que precisávamos, mas ele não conseguia entender o que nós queríamos. Na verdade, ele trabalhava e fabricava itens para instalações elétricas. Um dia, ela conheceu um inglês chamado Jeremy Fiennes, que queria ser ceramista como nós. Conversamos e ele disse que queria montar um ateliê. Ele já tinha um terreno, localizado na cidade de Embu das Artes. Ele queria construir fazer um forno Noborigama. Nós entramos como sócias dele, demos o dinheiro e ele começou a construir o forno. Esse foi o nosso primeiro forno.

Silvia: Vocês já sabiam operar o forno?

Kimi: Nós não sabíamos nada e nem ele. Como o Jeremy era inglês e conhecia a literatura de cerâmica no idioma, por exemplo, coisas do Bernard Leach ajudaram bastante. Além disso, ele era formado em engenharia e acredito que teve algumas aulas de cerâmica na Inglaterra. Ele tem uma mentalidade mais técnica.

Silvia: Então, vocês estavam aprendendo juntos. O Jeremy ficava por conta dessa parte técnica. 
Kimi: Nós queríamos montar um ateliê. Eu achei ótimo porque ele tinha esse lado técnico mais forte, eu e a minha prima tínhamos uma mentalidade artística. Assim, eu tinha uma formação em design, minha prima em publicidade e o Jeremy em engenharia. Cada um estava procurando o seu lugar e passamos por algumas dificuldades. Nessa época, fiquei grávida, tinha dois filhos e achava mais fácil fazer as coisas em casa. Então, abri um atelier provisório no porão da minha casa e a minha prima, na casa dela. Eu morava na Rua Capote Valente, em Pinheiros, e queimava as peças em Embu. O Jeremy dizia: "Vou montar o forno por esses dias." Daí, eu levava as minhas para ele queimar. Um dia levava as peças para biscoitar, no outro me dedicava a esmaltar. Muitas vezes, um dia só não era o suficiente.

Silvia: Como era a sensação e a sua relação com o trabalho?

Kimi: Para mim, era tudo uma novidade. Eu era fanática! Tudo que eu olhava e pensava voltava-se para a cerâmica. Desde uma folha que caía de uma árvore. Tudo me levava a pensar em cerâmica. Não que hoje não pense, mas naquela época, lembro-me de ficar até altas horas da noite fazendo cerâmica. Lembro-me que quando meus filhos eram pequenos, a hora que eles iam dormir, eu ficava trabalhando. Era o melhor período e muito gostoso. No entanto, quando somos apenas alunos, tudo é mais fácil, pois tudo está resolvido: argila bem resolvida, esmalte bem resolvido, queima, etc. Lembro-me quando fui fazer a primeira queima, tudo era novo desde a massa até o esmalte.

Silvia: E vocês que formularam a massa...

Kimi: Sim.

Silvia: Era uma argila local, de Embu mesmo?

Kimi: Na verdade, pegamos um pouco de cada lugar. Fizemos uma mistura, inúmeros testes e quando chegamos a uma conclusão dissemos: "É este." Daí, preparamos certa quantidade desta massa, mas não deu muito certo, pois todas as peças apresentaram algum defeito. Lembro-me que na primeira fornada convidamos várias pessoas amigas.

Kimi: Essa época foi realmente emocionante! (risos) 
Silvia: Na Cerâmica, sempre aprendemos que temos que ter paciência e hoje vejo que tudo é mais acessível: temos várias massas cerâmicas, ferramentas de todos tipos. Imagino como foi a sua persistência em ter que fabricar tudo e fazer vários testes.

Kimi: Na verdade, eu tive sorte. Imagine só, eu querendo fazer cerâmica e de repente aparece uma prima que há tempos não via querendo fazer a mesma coisa. Então, as coisas vão se juntando. Por isso, acho que houve dificuldade, mas tive sorte também. Depois, conhecer esse senhor na praça da República, que dava aulas de cerâmica, eu acho que a vida queria que eu fosse mesmo ceramista.

Silvia: Voltando um pouco, você estava contando da primeira fornada que não deu muito certo.

Kimi: Nossa! Tudo tinha algum defeito.

Sempre fui habilidosa, conseguia fazer as formas que queria, mas eu não conhecia todas as leis da cerâmica. Então, não basta só fazer ou dar a forma. A maneira de fazer, de secar e queimar, tudo isso faz uma grande diferença. Lembrome que eu fazia uma coisa com uma curva ou torcia para um lado ou outro. Ou seja, uma forma cilíndrica na base e quadrada no topo. Daí eu pensava como que ficaria interessante essa forma, mas no final rachava tudo!

Com o tempo, fui vendo que muita coisa que eu fazia não deveria ou estava errado. Até hoje eu tenho perdas.

Silvia: Que faz parte da cerâmica!

Kimi: Será que os grandes mestres do Japão têm perdas? Bem, acho que todo mundo tem. Porque há coisas que não dependem da gente ou, se dependem de nós, somos ignorantes.

Silvia: Em sua opinião você acha que o artista deve ter domínio técnico? No seu trabalho, até que ponto o domínio técnico é fundamental?

Kimi: Tenho minhas dúvidas. Há ceramistas ortodoxos que dizem que tudo tem que ser cerâmica com a própria linguagem da cerâmica. Tenho um olhar um pouco diferente, pois eu gosto do resultado. Acho que porque sou mais ocidentalizada. 
Quando você conhece a técnica e vê uma peça, você logo pensa como a peça foi feita. Então, você consegue gostar ainda mais da peça, porque você a identifica e se identifica com todo o processo.

Silvia: $\mathrm{Na}$ estética japonesa, há uma valorização das marcas das mãos no trabalho. Seus trabalhos possuem superfícies extremamente limpas.

Kimi: Acho que as duas coisas têm valor, tanto o trabalho com as marcas das mãos, como os trabalhos no torno que resulta numa superfície lisa. O olhar, a existência e o ser ceramista, tudo tem o seu valor. Porque no pensamento japonês existe o princípio de que devemos nos aprofundar, nos envolver e até chegar às últimas consequências. Isso eu acho muito importante, muito bonito e profundo, mas acho que ainda não alcancei neste nível.

Silvia: E você pretende chegar?

Kimi: Não sei o que pretendo. Acho que estou caminhando. Talvez eu queira fazer outras coisas também.

Silvia: Por falar em Cerâmica Japonesa. Fale um pouco das suas referências, estilos e artistas que influenciaram o seu trabalho.

Kimi: Na verdade, minhas referências estão fora da Cerâmica. Gosto de alguns artistas plásticos com os quais eu me identifico. Acho que essas influências acabam transparecendo no trabalho. Admirava os Concretistas, Construtivistas e Modernistas. Minha formação é da linha Bauhaus, uma coisa mais objetiva e limpa. Isso ajudou muito a desenvolver minha linha de utilitários. Mas isso de ser objetiva e racional, não dispensa o outro lado, porque eu aprendi que além de ser tudo isso, tem que ter uma linguagem, uma poesia. Em alguns momentos, quando o racional e o sensível trabalham juntos, as coisas terão maior sentido. Cada detalhe terá um sentido de existir.

Silvia: Estudando as suas obras, os primeiros trabalhos eram bem geométricos.

Kimi: Essa era minha admiração pelos construtivistas. Eu gostava era de criar. Sempre trabalhei com criação. Quando estou criando, é como se algo saísse de dentro de mim, mas na verdade, estou preenchida com os outros, com as influências que admiro. Nunca conseguia pensar em fazer um vaso clássico, ou, coisas que já 
tinha visto aos montes só porque estava fazendo cerâmica. Para mim, eu tinha que criar outro vaso que não havia visto. Eu sempre me preocupei com isso, de não fazer algo repetido. Eu tinha que tentar algo novo. Às vezes, eu pensava: "Eu acho que alguém já fez isso em algum lugar." Daí, eu parava de fazer. Um belo dia eu pensei: "Quer saber? Nunca mais vou ficar lendo ou olhando revistas de cerâmica." Vai ficar muito parecido e eu vou ficar pensando que já fizeram ou fazem. Prefiro focar no meu próprio trabalho.

Silvia: Voltando às peças geométricas. Os críticos definem essa série como Morandi.

Kimi: No meu livro, fiz questão de mostrar as primeiras peças. Essas daqui, por exemplo, foram feitas com o segundo lote de argila, pois as que foram feitas com o primeiro, não deram muito certo.

Silvia: Falando em massa, você testou muito antes de obter a massa ideal...

Kimi: Foi uma fase bem difícil, mas eu tive sorte de ter o Jeremy ao nosso lado. Ele é quem dava um Norte na parte técnica. Na verdade, fiquei com a minha prima por pouco tempo e ela passou a trabalhar com outros sócios, montando outro ateliê. Eu firmei uma sociedade com o Jeremy. A partir daí, dediquei-me totalmente à fabricação de utilitários que eu mesma desenhava, produzíamos e queimávamos. Ficou algo bem profissional. Com os desenhos, tínhamos a possibilidade de repetir as peças. Fazíamos dez de cada desenho.

Silvia: E como eram divididas as tarefas?

Kimi: Tínhamos a ajuda de um torneiro. Um torneiro facilitou a nossa vida porque ele fazia melhor, mas antes, eu havia aprendido a tornear, fazia sozinha as minhas peças, produzia minha massa, queimava e tudo mais. Por isso, produzia pouco.

Silvia: Admiro o caminho que vocês tiveram que percorrer antes de fazer firmar uma produção propriamente dita. Descobrir a massa ideal, a queima, os esmaltes. Quanto trabalho!

Kimi: Então, era difícil produzir em escala maior. Produzia-se pouco, quase nada. Por exemplo, se eu quisesse fazer uma dúzia de xícaras, quanto menos se 
esperava, já acabava a semana, pois no início ainda não tinha tanta destreza. Primeiro, fazia as xícaras, depois as alças e colava partes. Além disso, disso, eu ficava bastante tempo fazendo o acabamento, pois eu não queria que fosse somente uma alça colada. Queria que o objeto que eu estava construindo tivesse um reforço na base da alça, mas que formasse uma curva sem que houvesse um rompimento ou rachadura. Isso demandava bastante tempo e era desafiador.

Silvia: As peças retas, mais geométricas, foram feitas com placas?

Kimi: Sim, era na base do pau de macarrão.

Silvia: Essas peças devem ser guardadas, pois são as primeiras.

Kimi: Mas algumas delas eu não guardei, pois eu não sabia que deveria guardá-las. No entanto, muitas coisas deram certo nessa fornada. Participei do $2^{\circ}$ Encontro de Ceramistas de Paraty e foi minha primeira exposição

Silvia: Naquela época essas peças eram bem arrojadas e suas formas eram inovadoras.

Kimi: Era a maneira que eu pensava a Cerâmica. Não conseguia pensar diferente. Para mim, era isso. Quem entendia minha Arte eram os publicitários e os arquitetos, porque eles eram mais arrojados.

Silvia: Como era essa preocupação com o mercado?

Kimi: Realmente, para as lojas de decoração o mais importante era o design clássico, pois aqueles tipos de vaso, até hoje, fazem sucesso. Para mim, as formas clássicas de vasos e utilitários têm o seu mérito, mas não me satisfazia. Por isso, fazia as peças mais geométricas, quadradas.

Silvia: Mas para a época, era algo arrojado...

Kimi: Era difícil de entender, mas hoje em dia é fácil, há mais pessoas que apreciam. Na verdade, sabe aquelas peças Morandi? Tudo isso eu já fazia naquela época.

Tem umas que eu fazia, fazia, e acabava desistindo. Essa peça, por exemplo, que é meio torcidinha, eu fiz umas seis vezes, mas sempre rachava em algum ponto daí eu acabei desistindo. Fazia na base das "cobrinhas", porque era o único jeito. 
Com o passar do tempo, eu pensei que eu poderia fazer uma coisa geométrica, mas foi muita pretensão de minha parte querer fazer tais objetos na base do acordelado, depois queimar e dar tudo certo. Então, eu fiz essa peça em madeira, sobrepondo quadradinhos que eram posicionados em espiral, assim, dando uma sensação de movimento à peça. Ficou geometricamente perfeito. Depois, eu fiz um molde e reproduzi. Isso era uma coisa que eu deveria ter feito desde o começo, mas não passou pela cabeça.

O ceramista ortodoxo acha que tem que fazer peças únicas. Muitas pessoas com quem eu converso acham que com o molde, as peças perdem o seu valor, mas também é melhor ter do que não ter.

Se eu posso reproduzir, um maior número de pessoas pode ter aquela peça. Assim, estou sendo designer industrial, aliás, designer artesanal. Eu digo que estudei design industrial, mas pratico design artesanal, pois o que eu desenho tem o conceito de desenho industrial, só que faço artesanalmente. Porque mesmo fazendo em molde é algo muito artesanal. Com isso, também comecei a ter mais liberdade de fazer mais peças. Um dos conceitos do desenho industrial é de tornar a Arte mais acessível ao um maior número de pessoas, ou seja, uma peça deve ter desenho, lidar com o lado social e cultural. Falar que o design é só para a elite, não está certo.

Silvia: Como você vê essa relação das pinturas de Giorgio Morandi com a série Morandi?

Kimi: Na verdade, eu fiz essas peças porque, tudo que eu faço, penso primeiro na construção.

Silvia: Você faz um desenho preliminar?

Kimi: Sim. Achei interessante pegar o desenho do contorno de um vaso, chapalo e fazer algo meio "cubista". Então, a primeira série chamava-se vasos cubistas e depois achei mais chique chamar de vasos Morandi, pois ele retratava muitos vasos que eram chapados. Para ele, o desenho é mais importante, ele funde o plano de fundo com os objetos. 
Silvia: Suas peças se apresentam tão exatas, sem deformações. Lendo a sua bibliografia, há relatos de que você toma partido dessas deformações para se obter uma peça tão limpa, exata, geométrica, perfeita...

Kimi: Eu sofri muito com as deformações, porque eu desenhava as coisas para ficarem retas e nunca ficavam. Sempre entortavam. Quando projetava uma peça com determinada curva, após a queima, não havia mais curva, pois ela se deformava ficando algo sinuoso. Eu ficava decepcionada e partir daí, comecei a pensar: "eu não posso querer que elas sejam da mesma maneira que os desenhos, não posso fazer essa imposição. Tenho que aceitar a imposição do processo" Então, eu sabia que querer aquelas formas era um desafio muito grande e desisti das formas retas demais. Agora eu tenho um controle um pouco maior sobre as deformações. Sei que a peça pode deformar de um lado, por isso faço uma deformação contrária. Assim, as forças se equilibram e a peça fica do jeito que desenhei. Eu desafiava e explorava os limites e verificava até que ponto poderia entortar.

Silvia: Então, a partir das observações feitas destas deformações, você começou a tirar proveito delas?

Kimi: Sim. Comecei a tirar proveito dessas deformações e desses acidentes.

Silvia: Acredito que muitos que trabalham com cerâmica, o que é mais corriqueiro é desafiar tais deformações. Vendo suas peças, elas são perfeitas. Não percebemos as deformidades.

Kimi: Você acha?

Silvia: No seu livro, você conta um episódio em que seu filho fez "interferências" em algumas peças suas...

Kimi: É, foi até bonitinho, mas na hora fiquei tão brava com ele. Muito aborrecida, comecei a jogar essas peças num balde. Havia feito umas quinze esferas que foram socadas pelas mãozinhas do Kenzo que tinha 2 a 3 anos. Então, comecei a observar e pensei: "Até que essa daqui tem certa graça". Olhei para outra, outra e daí eu comecei a separá-las. Aquelas que não tinham jeito, eu reciclei. Salvei umas quatro peças. 
Silvia: Mesmo sendo acidentais, é admirável como essas formas parecem intencionais.

Kimi: Trabalhar com criação é uma coisa muito incerta. Então, eu sempre trabalhei com isso em design, nas agências. Depois que voltei de Recife, retornei ao antigo estúdio aqui em São Paulo, o InDesign. Percebi que sempre tive algumas dúvidas com relação à criação, tipo: "Será que eu vou conseguir criar algo?", mas depois de muitos anos de prática, percebi que há sempre uma solução e quem a encontra é você mesmo.

Silvia: Durante o seu percurso, há uma transformação das formas geométricas para orgânicas. Mesmo as obras em que você faz referências às flores, folhas apresentam formas exatas e limpas.

Kimi: Eu acho que me identifico com as plantas, pois elas têm certa ordem, uma geometria, uma sequência de proporção matemática.

Silvia: E como é o seu processo de construção?

Kimi: Acho que é mais construção e intuição.

Silvia: Tipo um arquiteto: que desenha, calcula e aquele projeto se materializa?

Kimi: Acho que sou tipo um arquiteto, pois sempre penso nas possibilidades. Às vezes, penso que é possível, mas não dá certo. Quando isso acontece, vou pesquisar e continuo a construir. Por exemplo, as peças que são empilhadas, elas têm encaixes. No caso delas, eu tenho que calcular o diâmetro das partes, tanto externa como interna. Tem que ter uma determinada espessura e uma folga para poder encaixar tudo.

Silvia: Realmente é algo bem pensado e calculado. Toda essa preocupação e planejamento vêm da formação de design?

Kimi: Acho que sim, mas tudo isso é natural para mim. Às vezes, invejo as pessoas que não pensam muito e vão fazendo as coisas, sem ordem ou planejamento e que pode resultar em coisas muito interessantes.

Silvia: Com a prática e anos de experiência você adquiriu grande domínio técnico. 
Kimi: Eu não sei se tenho esse domínio técnico, mas acho que tenho um dom. De certa forma, tenho um domínio técnico, afinal, são mais de 30 anos que faço cerâmica. E cada vez mais, vou adquirindo confiança. O domínio técnico não é completo, pois há muitas coisas que ainda não domino. $E$ eu sofro as consequências.

Silvia: Mas mesmo assim, você é sempre persistente...

Kimi: Ah sim! E também, tem gente que diz que quando não dá certo, quebra o trabalho. Tem coisas que não posso comercializar, mas eu pego aquela peça que "não deu muito certo", eu uso ou dou para as pessoas mais chegadas. A transformação da argila para a cerâmica é uma coisa irreversível, de grande responsabilidade! Então, essa coisa de falar em quebrar o que não gostei, acho que algo "motainai" (desperdício).

Silvia: Você chegou a passar alguma temporada no Japão? Conheceu algum ateliê de cerâmica lá?

Kimi: Fui algumas vezes para lá. Numa delas, eu fui com a minha amiga Hideko Suzuki, da Galeria Deco. Ela me apresentou à dona da galeria Genkai de Tóquio que, a meu pedido, me mostrou os trabalhos dos artistas desta galeria. Selecionei os artistas que mais gostei e decidimos então visitar seus ateliês. Assim definimos nosso roteiro de viagem. Gostei mais dos trabalhos dos ceramistas jovens, eram bem interessantes.

Silvia: Eles encaram a cerâmica de uma forma diferente.

Kimi: São ateliês bem pequenos, produções pequenas, mas são muito compenetrados. Eles vivem de cerâmica. O Japão inteiro consome cerâmica.

Silvia: Você veio do Japão, há uma coisa bem oriental, mas seus trabalhos diferem bastante da Cerâmica Japonesa em si.

Kimi: Eu percebi isso nas viagens e acho que valeu a pena eu estar mais centrada em meu trabalho, sem ir atrás de influências. Acho que há também uma brasilidade em meus trabalhos. 
Silvia: Falamos sobre as obras mais geométricas e agora dos trabalhos que fazem referências às plantas, formas orgânicas.

Kimi: Que para mim, são estilizados. Penso: "Quem sou eu para imitar a Natureza?" Então, eu faço uma interpretação da natureza.

Silvia: No seu processo de criação como fica a questão da cor? Ela é pensada depois ou durante o processo de execução das peças?

Kimi: O que você acha das cores?

Silvia: São equilibradas e vejo que uma relação com a Cerâmica Japonesa, as cores azuis e os tons terrosos. Agora vejo essas cores mais quentes avermelhadas e os lilases.

Kimi: O vermelho foi uma conquista recente, pois não é fácil. No entanto, não foi algo que eu persegui: "Quero o vermelho!" $\mathrm{Na}$ verdade, digo que nós conseguimos, pois eu tenho um assistente que me ajuda, ele deu uma modificada.

Silvia: Eu vi umas peças com tons mais rosados na Galeria Deco.

Kimi: Fiz algumas peças mais rosadas. Na verdade, não gosto muito deste brilho. Gostaria de obter um vermelho, mas não tão brilhante. Vou ver se consigo fazer dele, algo mais acetinado. Na verdade, eu faço esses esmaltes por intuição e tateando, fazendo testes.

Silvia: Para quem está começando na cerâmica, existe um grande desafio de conciliar a forma e cor. Muitas vezes, ambas não se adequam ou, não ficam da maneira imaginada.

Kimi: Normalmente, quando você faz um teste, pode dar um resultado e quando você faz uma quantidade grande não corresponde.

Silvia: Você conseguir conciliar a forma e a cor, é algo desafiador.

Kimi: Eu sei mais ou menos o que eu quero. Às vezes, vem ao meu ateliê algumas pessoas pedindo para que eu faça peças vermelhas. Muitas vezes, eu recuso as solicitações, mas aproveito essas situações para desenvolver alguns esmaltes, assim como foi com o vermelho. Depois que desenvolver um esmalte, é só fazer, usar e repetir a mesma formulação. 
Silvia: Existem formulações de esmaltes vermelhos para alta temperatura que utilizam CMFs que são para baixa temperatura. Ou seja, aumenta-se o ponto de fusão do CMF complementando com outros materiais mais refratários.

Kimi: Eu experimentei, mas não deu certo na queima a gás. O vermelho que estou produzindo foi obtido da maneira mais tradicional, dentro da cerâmica. Consigo o vermelho quando faço queima redutora, pois na oxidante fica verde.

Silvia: É Incrível! Então a relação cor e forma nos seus trabalhos é algo intuitivo?

Kimi: Às vezes eu planejo, às vezes não. Na verdade, eu tenho alguns esmaltes. Na época em que eu trabalhava com o Jeremy, tínhamos uns vinte esmaltes e quando desfizemos a sociedade ainda usava as mesmas receitas. Ele é bom em desenvolver esmaltes. Aos poucos, fui substituindo por formulações próprias. E também, gradualmente, fui reduzindo o número de cores. Até porque se eu faço utilitários, se faço várias cores de esmaltes, nunca será o suficiente para esmaltar uma série de cinco ou seis peças. Um mesmo branco pode ficar cinza numa peça e creme na outra. Então, eu fui reduzindo o número de cores e atualmente trabalho com cinco ou seis cores.

Silvia: No seu percurso, vemos trabalhos tanto na produção de utilitários, esculturas e obras em grandes instituições. Há alguma distinção?

Kimi: Isso é uma polêmica eterna, principalmente no Ocidente. Acho que no Japão, não existe essa diferença do que é arte ou não: uma tigela de um grande mestre é tão valiosa quanto um quadro do Chagal (por exemplo). Certa vez, vi um catálogo de arte japonês em que havia de lado um quadro do Chagal e do outro, um pote de cerâmica.

No Japão, antigamente, todo mundo fazia utilitário e aquele utilitário era uma obra de arte. Aqui no Brasil se pergunta: "Você faz arte ou utilitário?" Eu chamo de escultura, utilitários e vasos, eu separo em três categorias. Na verdade, para mim todos têm o mesmo valor, pois tenho carinho pelos três. A única diferença é maneira como eu produzo cada uma delas. Quero dizer, o quanto eu produzo. No caso do utilitário, eu faço várias vezes (a mesma forma) uma xícara que desenvolvi ou uma 
forma, eu vou continuar fazendo sempre, mas uma escultura é única. Eu costumo usar aquilo que existe nas Artes que é o múltiplo. Há algumas esculturas que eu resolvi repetir para tornar mais acessível, são os múltiplos. Isso não quer dizer que uma coisa tem menos valor que a outra. Pois acho que custou muito para chegar naquela forma. Desenvolvi um desenho para os meus pratos.

Para você viver de Cerâmica, é importante fazer utilitários, isso no meu caso. Eu gosto de fazer utilitários porque eu sou designer. As pessoas entendem um utilitário, mesmo não entendendo uma escultura. $\mathrm{O}$ vaso fica entre os dois. $\mathrm{Na}$ verdade, o vaso é um utilitário, mas está entre o útil e a escultura.

Silvia: Você acha que as pessoas conseguem entender melhor utilitário, então?

Kimi: Sim. Todo mundo entende uma tigela. Alguns não entendem porque essa tigela de cerâmica é diferente de uma tigela de porcelana (produzida industrialmente). Não entendem a diferença de um produto artesanal e industrializado.

Quem vem até aqui, são pessoas que têm informação. Quem vem aqui, veio atrás e conhece.

Eu estou fazendo aulas de gravuras em metal com o professor Evandro Carlos Jardim e que era meu sonho! É difícil! Tem que se dedicar. Ele diz que muitos pensam estar criando algo, mas enganam-se, pois na verdade nós estamos transformando. Também ele diz que o artista tem que entrar no ateliê sem se dar conta que passou a noite trabalhando.

Em 2003, houve uma exposição de vitrines. Fui convidada por uma pessoa que organizava este tipo de evento e que chamou alguns artistas. Cada artista ficou de representar uma empresa e eu peguei a Varig. Pensei e logo tive uma ideia. $\mathrm{Na}$ verdade, fui convidada duas vezes, uma vez representando a Caloi e a outra a Varig. Para a Varig, fiz uma escultura em cerâmica que é um menino apontando o dedo para o céu. Era na mesma época que se falavam dos guerreiros de Xian, as terracotas estavam impressionando todo mundo. Eu também fiquei impressionada. Então, pensei: "Vou fazer uma criança, em tamanho natural assim". Fiz primeiro uma maquete e a escultura maior. 
Silvia: Fale um pouco deste trabalho, que lembra uns macarrõezinhos.

Kimi: Tudo eu fico pensando o que poderia ser. Na verdade, são aqueles fios (de massa cerâmica) que saem da maromba e pensei o que eu poderia fazer com essas coisas. Foi um experimento, fiz várias peças e sempre baseada nas formas de pratos e tigela. Até fiz peças mais fechadas, mas ainda não me concentrei o suficiente para realizar outras peças. Essas peças ficaram muito frágeis, tenho que resolver melhor essa questão da fragilidade.

Silvia: Há sempre essa preocupação com o resultado final e de fazer uma peça resistente.

Kimi: Sim. Tenho que resolver melhor essa questão fragilidade. Realmente, tenho essa preocupação. Vejo que há pessoas que não estão preocupadas com isso e obtêm resultados interessantes, mas você nem pode chegar perto do trabalho.

Silvia: Há sempre uma preocupação com o público em seus trabalhos?

Kimi: Sim. Não faço queima de Raku, por exemplo, porque eu acho que peças ficam muito frágeis. São de baixa temperatura e frágeis. Na verdade, eu acho que eu deveria relevar isso, mas não sei.

Silvia: Talvez não seja o momento.

Kimi: É. Não fui atrás, mas gosto dos efeitos, são bonitos. Fiz algumas coisas, mas daí eu parei, pois achei muito frágil.

Silvia: Desde o início de sua carreira, você sempre trabalhou com alta temperatura, não é mesmo?

Kimi: Sim, mas nós fizemos Raku uma época, eu e Jeremy, mas como era baixa temperatura, frágil, eu parei. Se eu tivesse mais oportunidade, forno e espaço talvez eu voltasse a fazer.

Silvia: Faz bastante fumaça.

Kimi: É. Talvez seja bom como performance. Há alguma coisa de espetáculo no Raku.

Silvia: Percebe-se uma busca constante da "perfeição" das formas no seu trabalho. 
Kimi: É intuitivo, mas também tem seu lado calculado e técnico. Tem o desenho, mas as proporções calculadas intuitivamente. Quando não estou satisfeita com a forma, vou mexendo até ficar do jeito que eu quero. Uma vez, o Edson Tani disse que havia feito um trabalho de Mestrado ou Doutorado, não me recordo exatamente, e queria me mostrar. Era sobre proporção áurea que é algo complexo. Em certo momento do trabalho, aparece uma peça minha. Daí eu disse ao Tani que não havia feito com essa intenção. Isso mostra que devo continuar seguindo minha intuição (risos).

Silvia: Vejo que você é bem decidida. Os cortes, as formas e as cores são parecem ser bem determinados.

Kimi: Isso se adquire com a prática. Já perdi peças várias vezes. Lembro-me quando estava fazendo aqueles Morandis, um ceramista, amigo meu, estava no ateliê fazendo uma visita. Ele olhou o que eu estava fazendo e disse que tinha certeza de que aquilo não daria certo. Perguntei o porquê e ele respondeu que não estava úmido o suficiente. Daí eu joguei para reciclagem. Mas eu já iria colar daquele jeito mesmo. É falta de conhecimento, mas ele já sabia que não iria dar certo por ser mais experiente.

Silvia: O artista percorre um longo caminho e não imaginamos o quanto é árduo para se chegar a determinadas formas.

Kimi: É verdade. Nós vamos fazendo, fazendo até que uma hora, erramos menos. Há tantas coisas que não sei e tenho a aprender. Acredito que devemos aliar conhecimento e intuição. Para mim, há um ponto certo que devo parar, ou elevar a curva ou fazer um bojo que deve ficar de determinada maneira.

Então, se você quer fazer cerâmica e está atrás de uma técnica, você não vai fazer a técnica pela técnica. Você vai expressar algo através desta. Ao mesmo tempo em que você está perseguindo a técnica, você está desenvolvendo a sua própria linguagem.

Silvia: Então, você acha que o aprendizado de uma técnica também é o desenvolvimento da própria linguagem? 
Kimi: Sim, da sua própria linguagem. Por exemplo, eu gosto da técnica da placa. Colocava uma placa na minha frente eu ficava pensando que eu poderia fazer isso ou aquilo. Daí, eu fiz todas as peças já mencionadas aqui. Pensava na placa, como faz uma designer ou um marceneiro, e ela pode ter formas retas como curvas.

Silvia: Acredito que ao trabalhar com placas, o artista deve saber o ponto de secagem exata para cortá-la, senão entorta. Deve haver um domínio.

Kimi: As formas que eu queria eram bem geométricas. Não poderia ficar de qualquer jeito. No entanto, há pessoas que não estão preocupadas com essa precisão, as peças ficam tortas e alcançam bons resultados.

Silvia: Tudo acontece de acordo com o que o artista pretende. No seu caso, há uma preocupação de alcançar determinadas formas geométricas e retas. $\mathrm{Na}$ cerâmica, estamos lidando com fatores da física e da química, transformações ocorridas desde a fase da modelagem até a queima. Assim, as deformações são frequentes e parece que você desafia esses acontecimentos o tempo todo. Mesmo as peças que possuem uma inclinação, parecem ter sido feitas propositalmente como é o caso dos trabalhos que são cones, cortados como espirais e que inclinam para um lado.

Kimi: Ela é um caso que eu aproveitei o defeito, ela caiu tanto que ficou nesse ponto. Pena que eu nunca mais consegui isso. É muito interessante trabalhar com esses acasos. Existe certo suspense.

Silvia: Existem acasos nos seus trabalhos?

Kimi: Na verdade, eu prevejo o acaso. Acho que o meu lado racional também e sensível e vice-versa. Eu acho bonito que no Japão, há uma valorização daquelas formas "tortas". A China adotou as formas perfeitas e os japoneses adotaram a estética do "imperfeito". E eu acho que as peças "imperfeitas" são expressivas.

Silvia: Existe um documentário que foi feito a respeito da cerâmica Raku, utilizada para a cerimonia do chá, na qual valorizam as marcas deixadas pelas mãos do artista, as marcas feitas pelo fogo durante a queima, os acasos, tudo isso é valorizado na estética Raku.

Kimi: Acho que é uma sensibilidade diferente. 
Silvia: Sim, trata-se de uma outra maneira de olhar.

Kimi: Sim, diferente. Eu acho muito bonito, eu me identifico com a sensibilidade zen. Admiro muito.

Silvia: Seus trabalhos que fazem referências às flores trazem a lógica dos encaixes e talvez, sem você querer, as questões da proporção áurea.

Kimi: Mas é tudo muito intuitivo. Enquanto conversávamos, já estava pensando num novo trabalho. Vislumbrei uma forma.

Silvia: O artista é assim: mergulha no trabalho. Artista e trabalho são uma coisa só.

Kimi: Na verdade, eu me divido em várias outras atividades, a gravura, como eu havia dito, o Pilates, o tai chi entre outras coisas. De certa forma, tudo acaba influenciando no meu trabalho. Uma vez, eu fiz uma exposição trocando de mídia com outro artista. O [José Roberto] Aguilar fez Cerâmica e eu fiz pintura. Daí, a Tomie Ohtake viu e disse: "Isso! Faça pintura para inspirá-la na cerâmica!" Achei bonitinho, pois ela deve pensar que tudo a inspira. Ela frequentava muito os espetáculos de dança, teatro, ópera, exposições, concertos porque, creio eu, tudo era inspirador. $O$ que você vive é o que você é. $E$ tudo culmina no processo de transformação dentro de você e depois sai. Tudo faz parte.

Lembrei-me de uma frase interessante que o Aguilar escreveu num folder para uma exposição em que eu estava participando e que dizia: "O artista é um mero telefone de Deus". 


\subsection{Laerte Ramos (São Paulo, São Paulo,1978) : ícones cerâmicos}

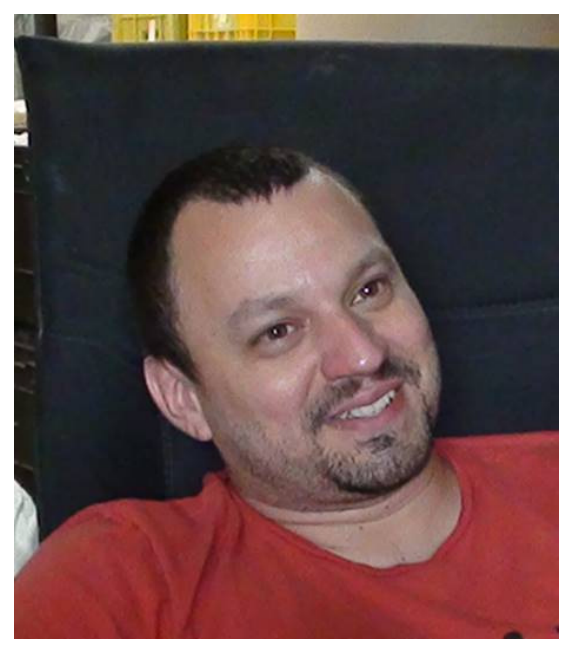

Foto: www.laerteramos.com.br (data: 15/09/2013)

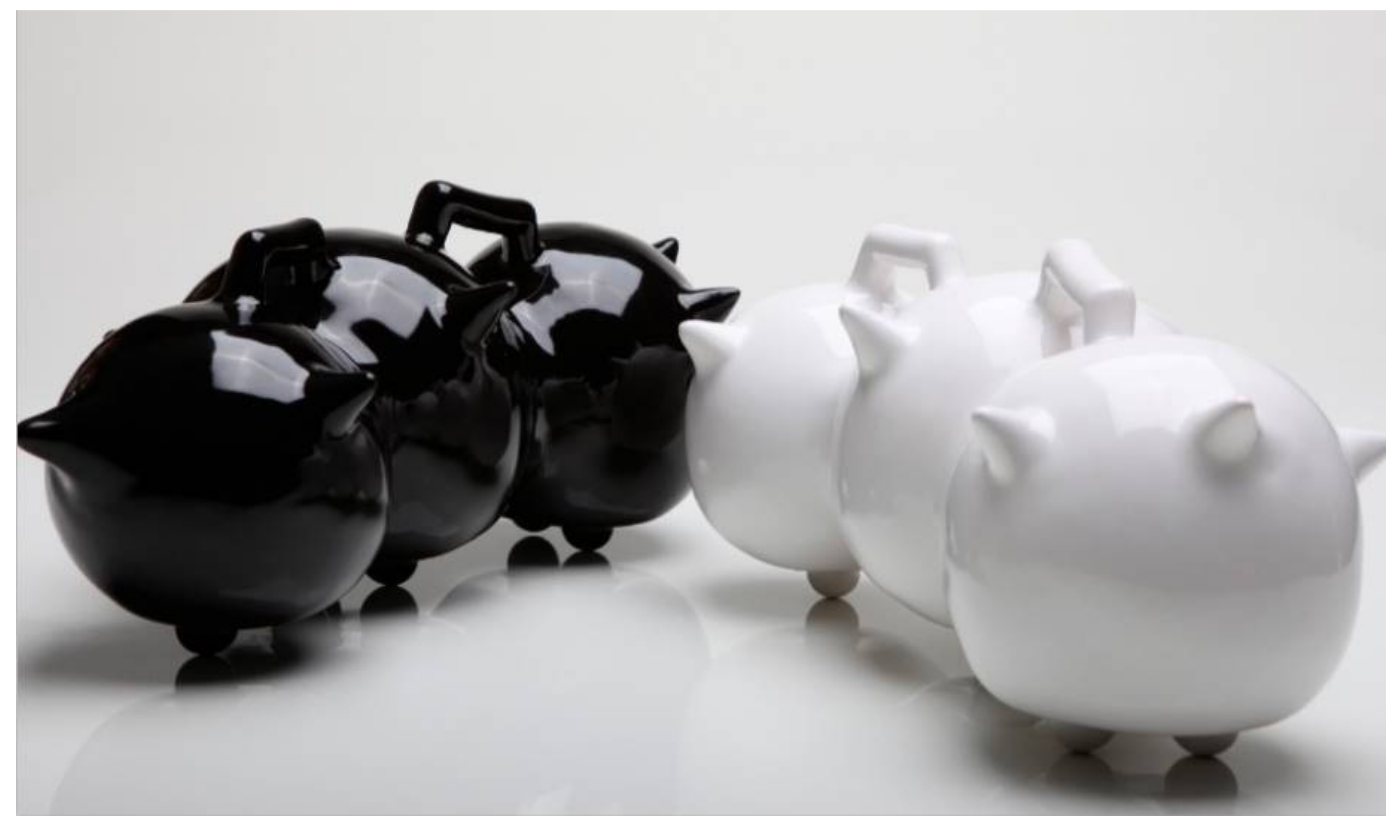

Figura 92

Laerte Ramos

Acesso Negado (peça)

Cerâmica esmaltada

2003-2009 
A primeira vez que vi o trabalho do Laerte Ramos foi através de uma pesquisa apresentada por uma aluna de graduação em Artes Plásticas na ECA-USP, em que ela falava da instalação re.van.che. Trata-se de uma instalação que foi primeiramente apresentada no Paço das Artes da Universidade de São Paulo, em que Laerte expõe uma academia de Artes Marciais com objetos como luvas, saco de pancada, banquinhos entre outros acessórios utilizados para os treinos. A instalação surpreende o espectador, pois tudo é feito em cerâmica. Anos depois, lembrei-me exatamente deste trabalho e comecei a pesquisar outras obras. Fiquei entusiasmada e interessada com sua grande produção artística em cerâmica. Entrei em contato com Laerte e marcamos uma entrevista em seu ateliê localizado no Centro da cidade de São Paulo, no bairro Campos Elíseos, num antigo prédio, próximo a comércios e muito trânsito (típico da Capital paulistana). Logo na entrada do prédio, um simpático senhor perguntou aonde eu iria e eu respondi que marquei um horário com o Laerte Ramos. Depois de autorizar minha entrada, peguei um antigo elevador que me conduziu até o seu ateliê. A porta já se encontrava aberta. Laerte saiu em meio a mesas repletas de moldes de gesso, argila, esculturas e ele logo se desculpa, pois acabara de mudar seu ateliê e havia voltado de uma temporada no exterior e exposições.

Foto: www.laerteramos.com.br (data: 15/09/2013)

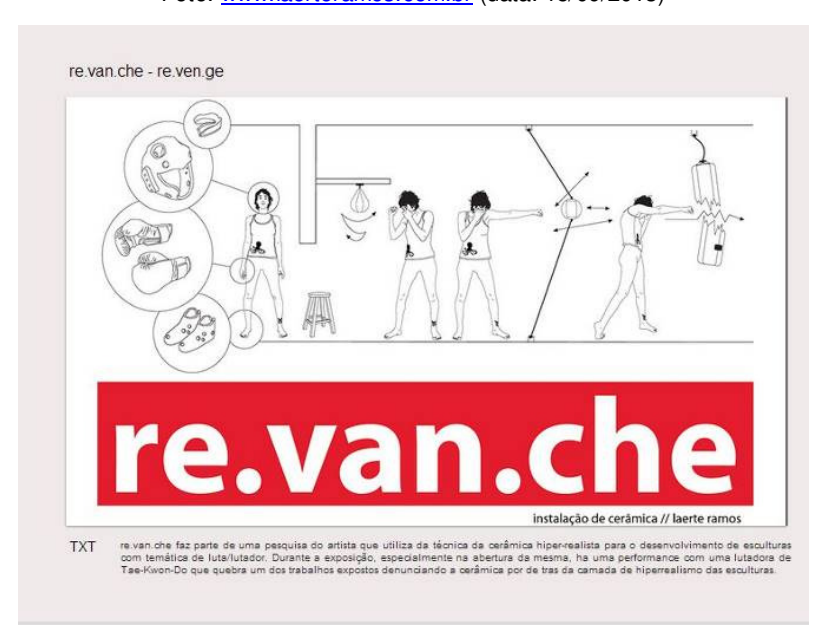

Figura 93

Laerte Ramos

re.van.che

2009

Peças em cerâmica que imitam acessórios utilizados em Artes marciais

Projeto de exposição e instalação apresentado ao Paço das Artes 


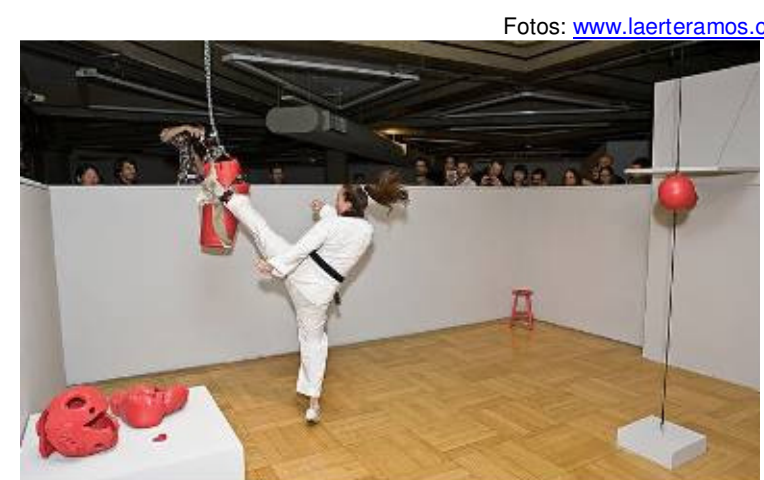

Figura 94

$$
\begin{gathered}
\text { Laerte Ramos } \\
\text { re.van.che }
\end{gathered}
$$$$
\text { Dimensões variadas }
$$$$
2009
$$

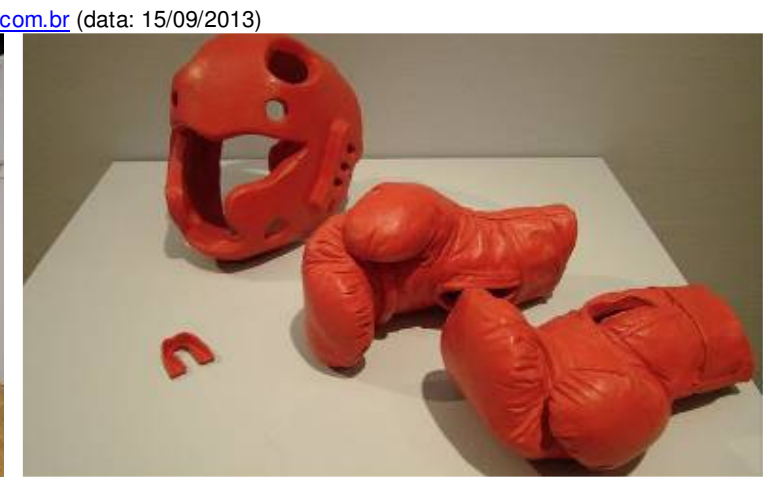

Figura 95

Peças em cerâmica que imitam acessórios utilizados em Artes marciais

Projeto de exposição e instalação apresentado ao Paço das Artes

Laerte contou que desde o início de sua carreira, dedica-se totalmente às Artes Visuais. Nascido na cidade de São Paulo, desde a infância teve contato com a Arte, devendo parte de sua formação artística à escola Waldorf e ao curso de Artes Visuais na FAAP (Fundação Armando Álvares Penteado). Seu pai, hoje falecido, foi engenheiro e artista, realizou exposições e participou de uma bienal em São Paulo, mas por razões de força maior deixou a carreira artística, passando a se dedicar à profissão de engenheiro. Laerte lembra com carinho que seu pai viajava para vários países e costumava trazer livros de maquinários, o que muito lhe inspirou.

"Na verdade, os trabalhos de Artes do meu pai, Adhemar Ramos, eu vi pouquíssimos. Conheci mais o lado engenheiro dele. Eu via muito os livros de engenharia dele. Eram livros incríveis que ele trazia de vários países que ele visitava. Ele costumava ir para a Índia, Japão, Estados Unidos e Alemanha, sempre trazia catálogos de maquinários, umas coisas que não existiam aqui na época. [...] Ele viajava muito para comprar máquinas e ver novas tecnologias. Eu via todo esse material. Então, para mim eram desenhos incríveis e vejo que meu trabalho tem muito esse olhar de uma criança, que olha para alguma coisa e não entende, mas acha tudo lindo. Quando uma criança vê um tanque de guerra pela primeira vez, por exemplo, ela vai achar aquilo fascinante, não importa a sua função, aquilo é bonito. Então, meu trabalho tem muito isso." 
Segundo Laerte, seu olhar de criança é traduzido em seus trabalhos. Manoel de Barros já dizia: "A infância é a melhor fonte de poesia que existe"170. E esse resgate da infância, Laerte faz todo o tempo. Através de suas xilogravuras e esculturas.

"O incentivo ao resgate da infância eu tive muito na escola Waldorf. [...] vários professores meus eram refugiados de guerra. Tinha um professor cujo sapato tinha o bico elevado, pois ele não tinha os dedos do pé, porque foram perdidos congelados e havia outro que construiu um planador para fugir. Tinha também uma professora que foi cantora da Opera de Berlim e se escondeu num bueiro. Então, as experiências de cada um eram tão ricas, e eram histórias tão marcantes e incríveis. Tudo sob o olhar daquela criança. [...] Então, isso influenciou muito o meu olhar infantil, o entendimento do mundo. Claro, eu não passei por essas experiências de guerra, mas essas histórias me deram uma vivência. Talvez por isso eu leve isso para a Arte, pois foi uma vivência bonita. não foi uma coisa horrível que eu vi, sangue, gente sofrendo. Eu trago a força desses vencedores, que sobreviveram, histórias de superação."171

Laerte conta que foi na gravura, especificamente na xilogravura, que sua poética teve um encontro especial e até hoje se dedica a ela. Posteriormente, os trabalhos em xilogravura o impulsionaram para outras manifestações.

"No meu caso, eu tive realmente esse encontro na xilogravura, acho que eu estava no terceiro semestre da faculdade. Eu gostei muito da técnica. Uma coisa é você pegar um lápis e papel para desenhar e ter o poder sobre aquilo, a outra é a gravura que tem vários procedimentos que demoram um pouco."172

\footnotetext{
170 Trecho retirado do documentário "Manoel de Barros - 'Só dez por cento é mentira" - Direção: Pedro Cezar. (http://www.sodez.com.br/). Acesso em: 12/08/2013.

${ }^{171}$ Trecho da entrevista com Laerte Ramos concedida a Silvia Tagusagawa.

172 Idem.
} 


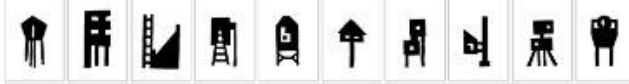

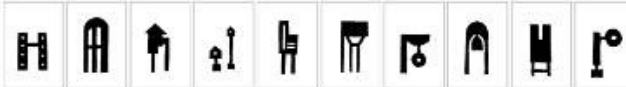

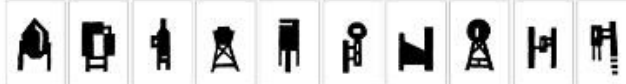

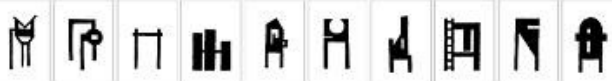

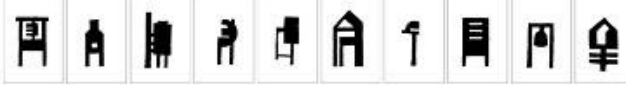

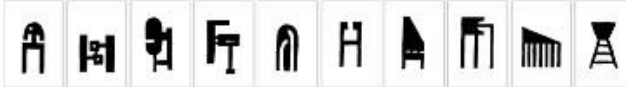

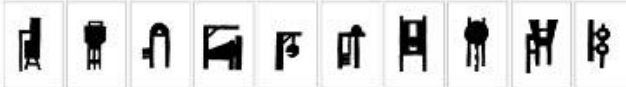

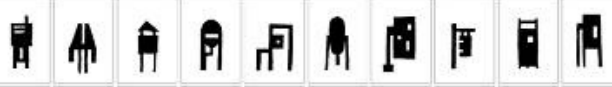

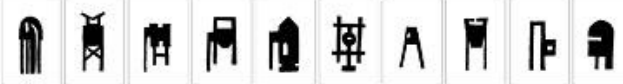

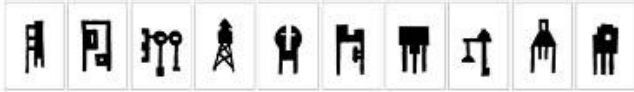

Figura 96

Laerte Ramos

Série Caixa d'água

100 matrizes de xilogravura

1999-2003

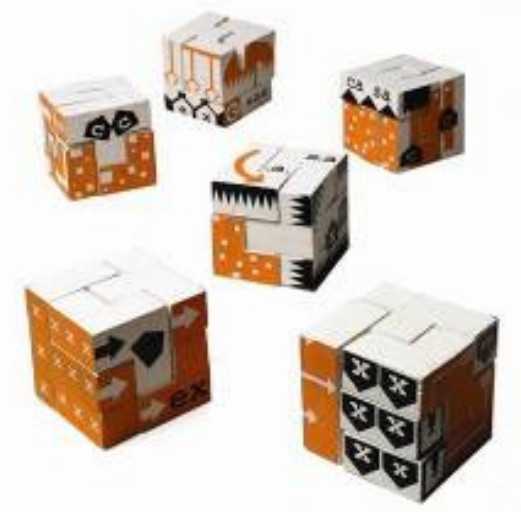

Figura 97

Laerte Ramos

Sem título

Serigrafia sobre madeira

4 cubos de $6,5 \times 6,5 \times 6,5 \mathrm{~cm}$ cada, $1 / 1$

As imagens reproduzidas estão relacionadas com a sua infância: histórias de guerra, maquinários e brinquedos.

"Tive um professor no curso de licenciatura que indagou sobre o meu trabalho e pediu para levar alguns cadernos da minha época de infância, quando levei e abri, era igual! Era a mesma coisa! Tinha soldado, tinha um tanque, tinha um trator que mais lembrava um tanque, tinha um poço. Olhei aquilo (admirado), (pois) são coisas que eu faço hoje. Ou seja, os desenhos que eu encontrei como artista, são os mesmos de quando era criança e eu não usei isso para a pesquisa. Tudo isso estava guardado lá."

As imagens que remetem às coisas de sua infância, livros de seu pai, brinquedos e histórias dão origem às xilogravuras: Sobre rodas, Caixa d'água e Paisagem. As imagens são cuidadosamente elaboradas e possuem regras. 
'[...]Na série Sobre Rodas, todas as matrizes de xilogravura são de $30 \mathrm{~cm} \times 36 \mathrm{~cm}$, são máquinas sobre rodas e tem que ter rodas ou algo do gênero. Então, existem algumas regras e leis. Dentro dessas regras e leis, eu ainda consegui viver várias vezes, mudando de acordo com as mudanças externas. Então, essas coisas que vejo na minha vida, eu vejo também mudando no meu desenho..,173

Essas "regras e leis", certamente, dão uma direção ao seu trabalho. É o fio condutor descrito por Cecília A. Salles:

"Em toda prática criadora há fios condutores relacionados à produção de uma obra específica que, por sua vez, atam a obra daquele criador, como um todo. São princípios envoltos pela aura da singularidade do artista. [...] São gostos e crenças que regem o seu modo de ação: um projeto pessoal, singular e único."174

Além do seu universo particular, suas residências e as exposições das quais participou, suas viagens enriqueceram tanto a sua formação artística, quanto técnica. Durante a faculdade, teve a oportunidade de participar de residências artísticas internacionais na Cité dês Arts, em Paris, e em seguida fez outra residência na laab/Beyeler Foundation, em Basel, na Suíça. Experiências que permitiram o conhecimento de novas culturas e a ampliação do olhar para o desenvolvimento de seu trabalho.

Em 2003, Laerte Ramos foi convidado para um leilão beneficente de pratos em cerâmica promovido Associação Amigos do Museu Lazar Segall, que visa angariar fundos para o Museu. Anualmente, o evento convida vários artistas de renome nacional e internacional para fazer interferências em pratos que são leiloados.

"Certa vez, me chamaram para participar de um leilão de parede usando pratos em cerâmica no Museu Lazar Segall e quem me convidou foi a Juliana Monaschesi. Fui até um ateliê de cerâmica e

\footnotetext{
${ }^{173}$ Idem.

${ }^{174}$ (SALLES, Cecília Almeida. Gesto inacabado: processo de criação artística. São Paulo: Annablume, 2004, p. 37.
} 
havia alguns pratos, fiz o trabalho e eu gostei daquele ambiente, havia uma familiaridade [...]."

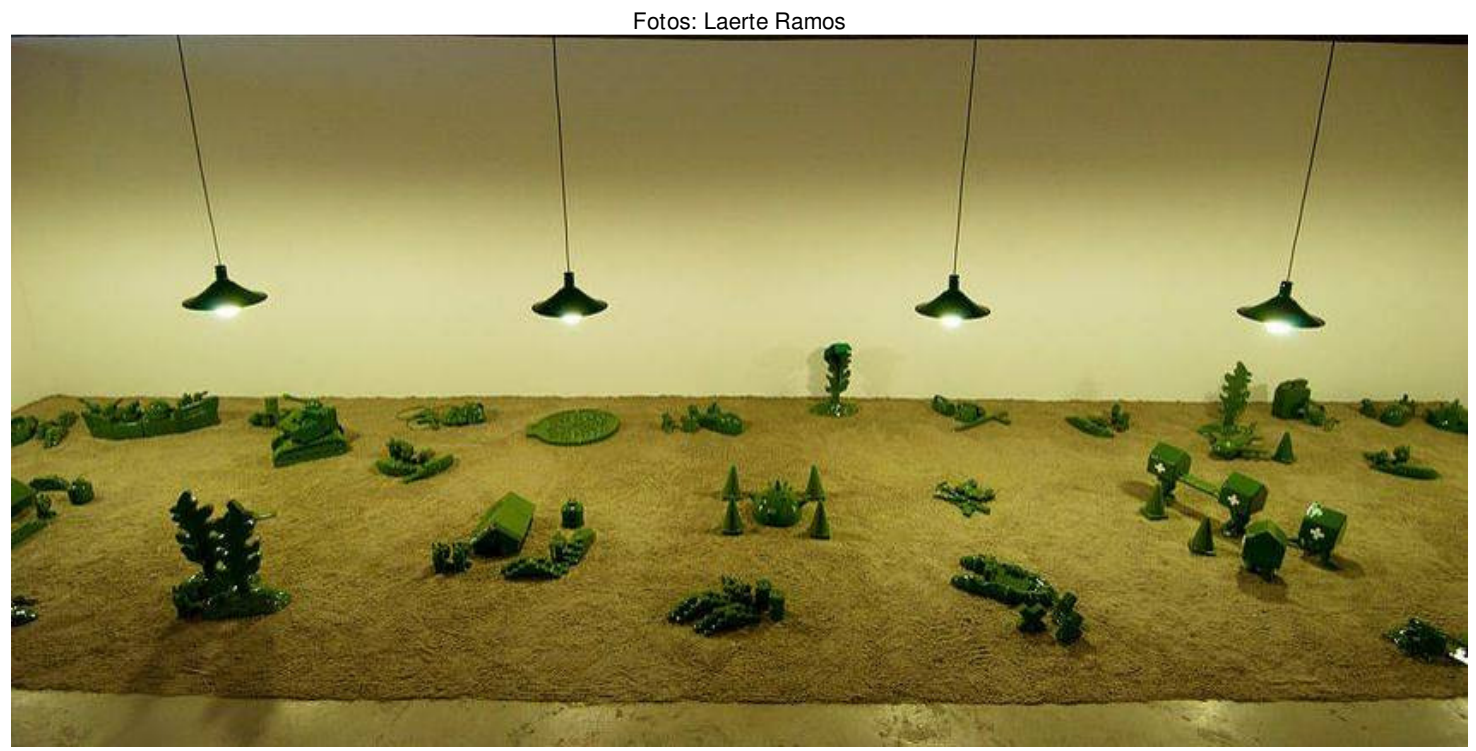

Figura 98

Laerte Ramos

Lastlândia

2013

Dimensões variadas

Instalação com peças cerâmicas esmaltadas

Galeria Emma Thomas

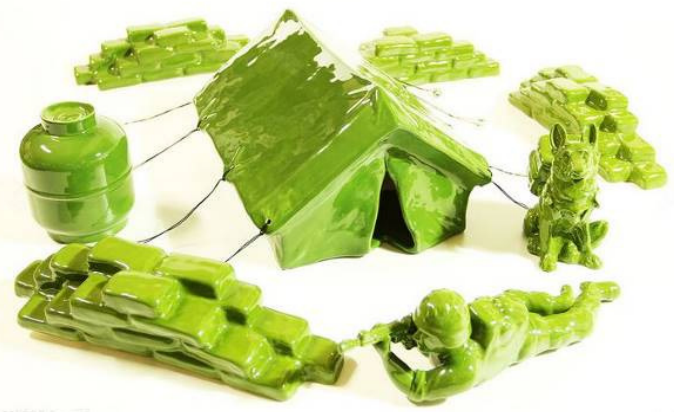

Figura 99

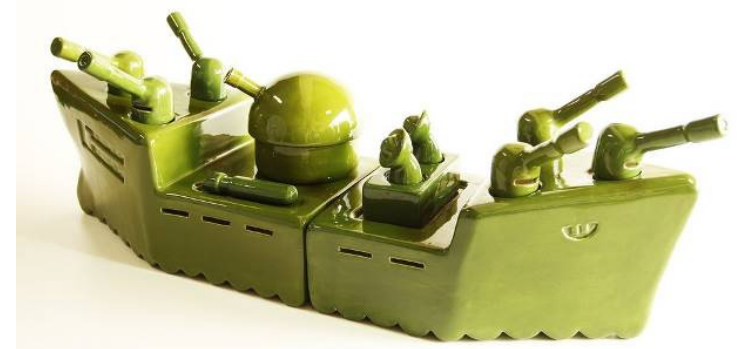

Figura 100

Laerte Ramos

Lastlândia (detalhes)

Dimensões variadas

Instalação com peças cerâmicas esmaltadas

O fascínio que Laerte tem pelo contato direto com a matéria, seja a madeira, a tinta ou a argila, é evidenciado nessa procura por meios que exigem do artista a relação mente/ olhos/ mãos/ matéria.

Na sua retomada da cerâmica, interessa-se pelo molde de gesso como meio de expressão. Laerte vê na cerâmica a possibilidade de tornar o que estava no campo 
bidimensional, tridimensional. As formas tridimensionais são as imagens que já trabalhava na xilogravura.

Em 2007, foi convidado a participar de uma residência na EKWC (European Ceramic Work Centre), por conta do ano do Brasil na Holanda. Segundo Laerte, foi uma grande oportunidade de aprofundamento ao plano tridimensional e às técnicas cerâmicas.

\begin{abstract}
"Nesta última residência, Laerte teve a oportunidade de expandir e aprimorar seus projetos tridimensionais, que tinham como raiz-mãe a xilogravura, e através do paralelo entre a reprodutibilidade e 'tridimensionalidade chapada' que havia em suas gravuras, as quais eram representadas bidimensionalmente em papel estampado, ocorreu o encontro com a cerâmica, graças à maneira de reprodução via molde que esta técnica permite."
\end{abstract}

Entre 2012 e 2013, participou de residências artísticas, ambas em Portugal, uma na fábrica Bordallo Pinheiro e a outra na fábrica de cerâmica que possibilitou tanto o aprimoramento técnico como também conhecer o meio de produção industrial e suas especificidades.

Atualmente, trabalha em seu ateliê o Studium Generale em São Paulo.

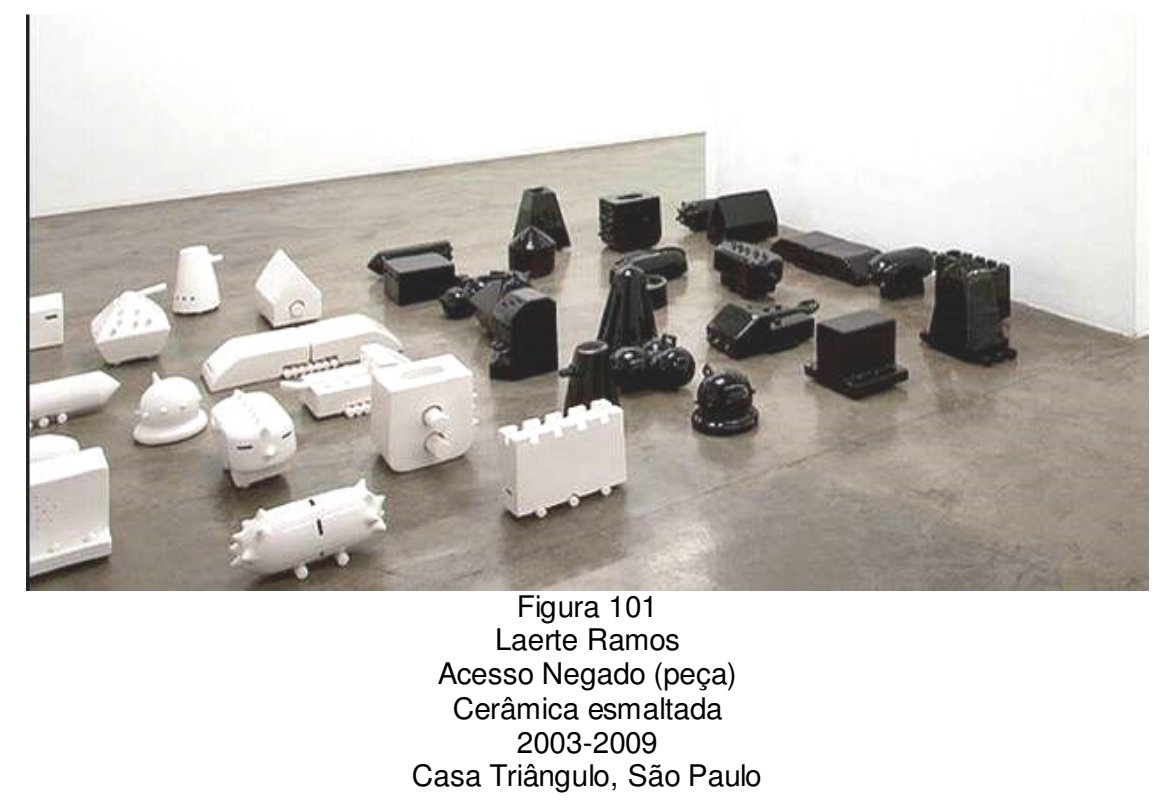

${ }^{175}$ Trecho da biografia de Laerte Ramos em www.laerteramos.com.br 12/07/2013 


\subsubsection{Poética de Laerte Ramos}

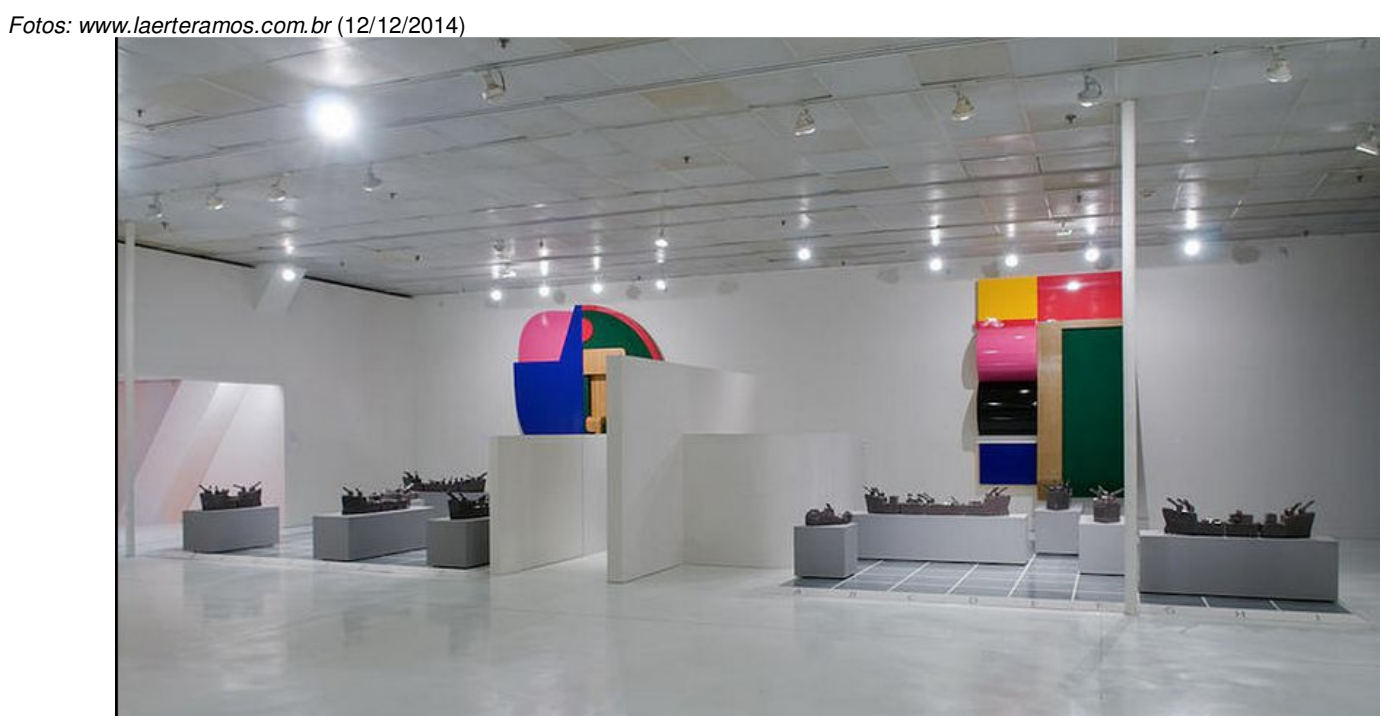

Figura 102

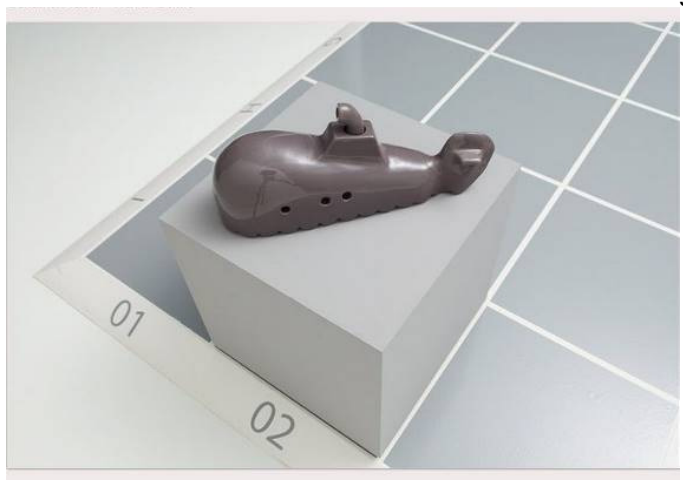

Figura 103

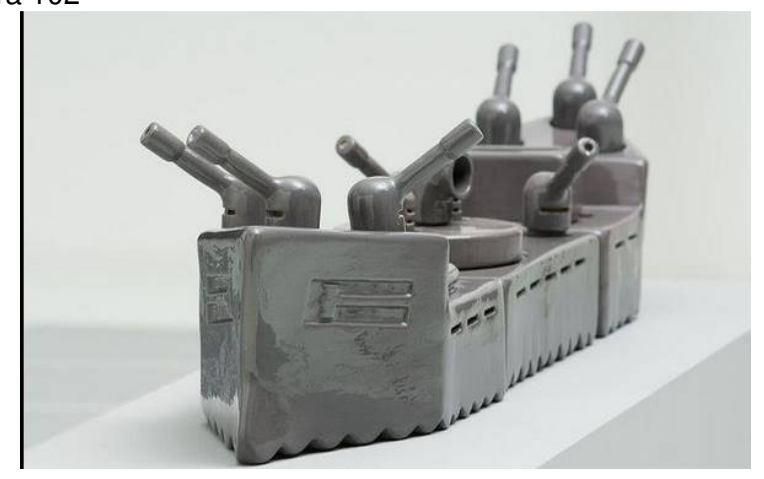

Figura 104

\footnotetext{
Laerte Ramos

Batalha Naval Dimensões variadas 2008

Instalação com peças cerâmicas esmaltadas Itaú Cultural, São Paulo
}

Laerte Ramos utiliza moldes de gesso para reproduzir suas peças. A repetição faz parte de sua poética. Segundo o artista, esse é o recurso que ele traz de suas gravuras. "Os moldes funcionam como matrizes..."176

${ }^{176}$ Trecho da entrevista concedida a Silvia Tagusagawa. 
Dependendo do projeto, ele utiliza molde para colagem (no qual a reprodução é feita com barbotina), em outros, faz uso da massa cerâmica pressionada contra o molde. As peças passam pela queima de biscoito e posteriormente o artista esmalta suas peças com vidrados prontos de baixa temperatura. Além dos vidrados, em alguns projetos ele usa pintura a frio com tintas sintéticas ou acrílicas.

Em seus primeiros trabalhos, como na série Acesso Negado, ele trouxe para o plano tridimensional as figuras trabalhadas na xilogravura. As cores também são baseadas no contraste preto e branco da técnica bidimensional.

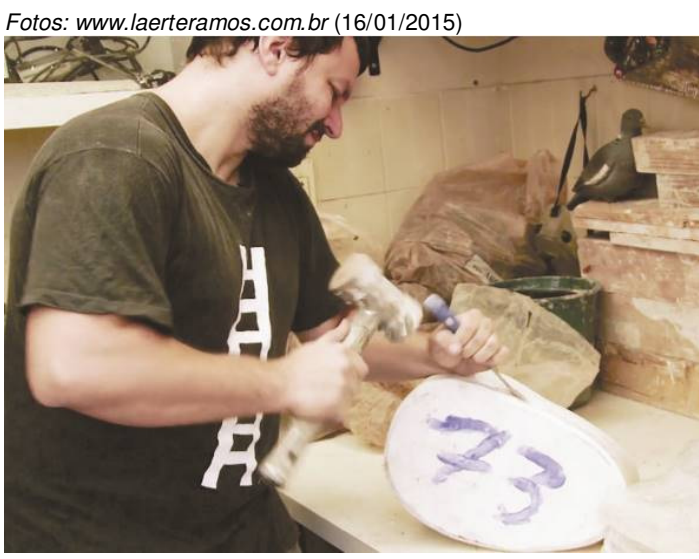

Figura 105

Laerte Ramos fazendo acabamento em um molde de gesso

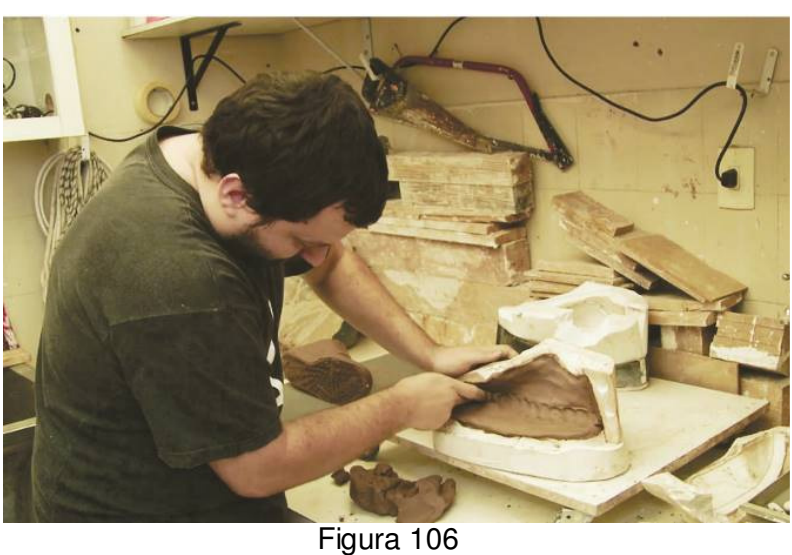

Laerte Ramos construindo uma peça pressionando massa cerâmica em molde de gesso

Laerte ressalta que suas cerâmicas são a continuação de suas gravuras, carregadas com as mesmas leis de reprodução.

"É como se todos os meus desenhos de gravura fossem estudos para eu ir para o tridimensional. A partir daí eu entendi, vi um pouco da técnica da cerâmica e descobri a técnica da argila líquida (barbotina). Você injeta argila líquida num molde de gesso e você consegue reproduções de um mesmo objeto. Que é o mesmo raciocínio da xilogravura, em que há uma matriz que utilizo para imprimir e fazer cópias. Continuo usando a reprodução com poucas tiragens. Por exemplo, as gravuras são três, as esculturas também são três, o que me deixou muito próximo desses dois meios. Por isso que eu falo que a minha cerâmica ainda é minha gravura. A gravura, ainda é a coisa mais importante na minha produção. Criei, então, a série Acesso 
Negado. Ela é praticamente a série Sobre Rodas, mas em escultura.

Por isso, que elas têm o branco e o preto da impressão."

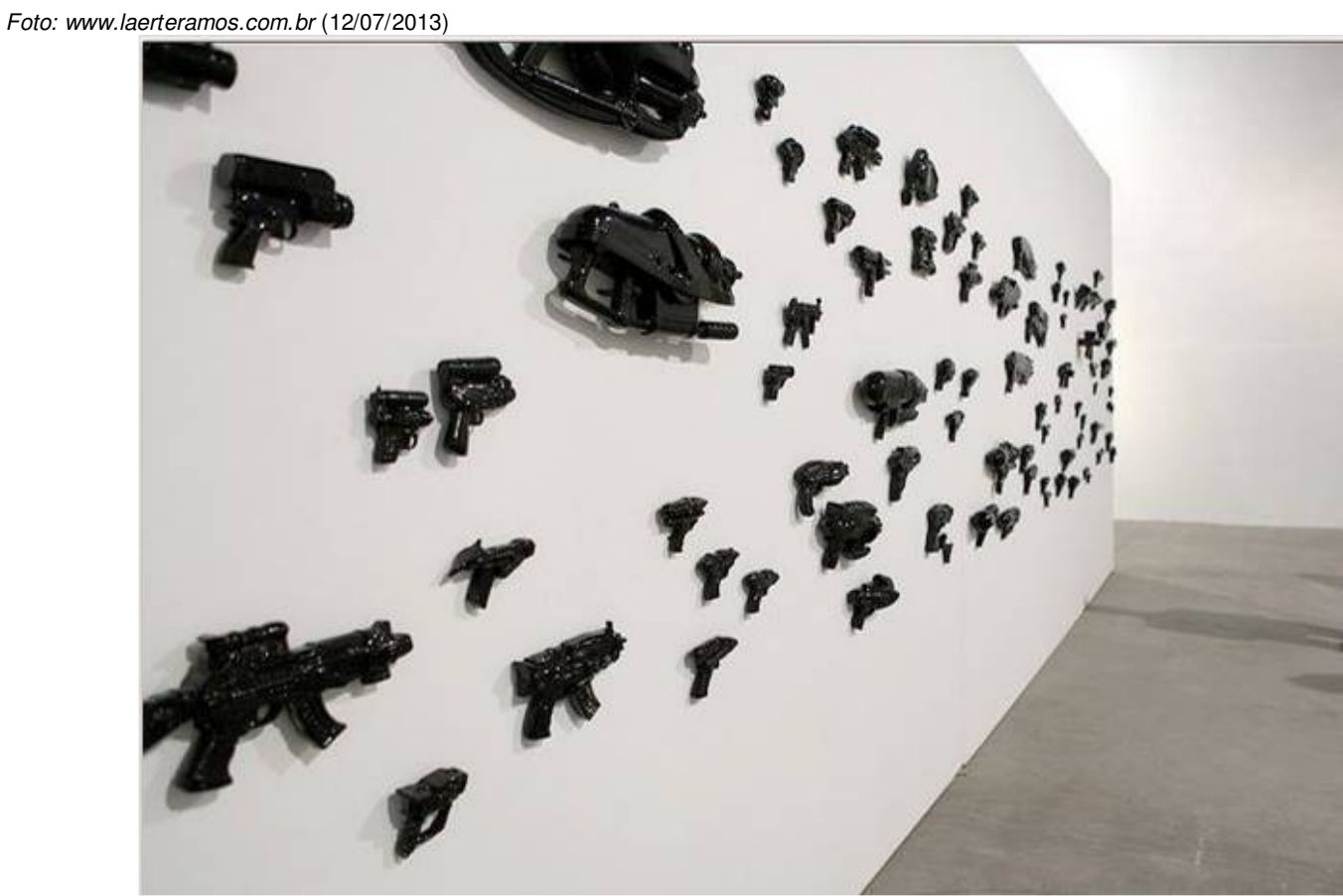

Figura 107

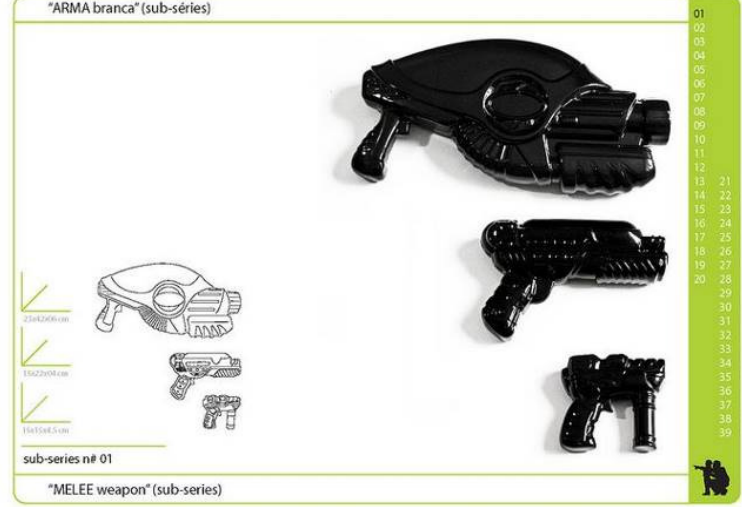

Figura 108

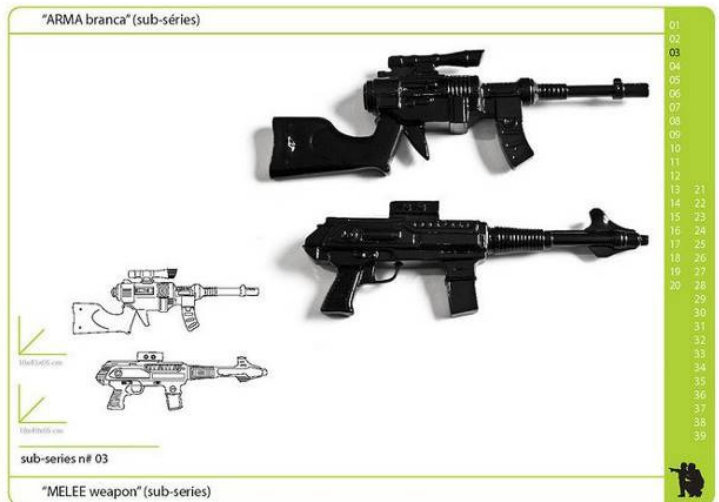

Figura 109

\section{Laerte Ramos}

Arma Branca

Dimensões variadas

2011

Cerâmica Esmaltada 
Em seus outros trabalhos, Laerte se apropria de objetos, assim como na instalação em cerâmica re.van.che (2009), utilizando-os como modelo para a produção de moldes. No caso de 50\% off (2014), Laerte reproduziu, de maneira hiper realista, 300 pares de tênis de várias marcas conhecidas.

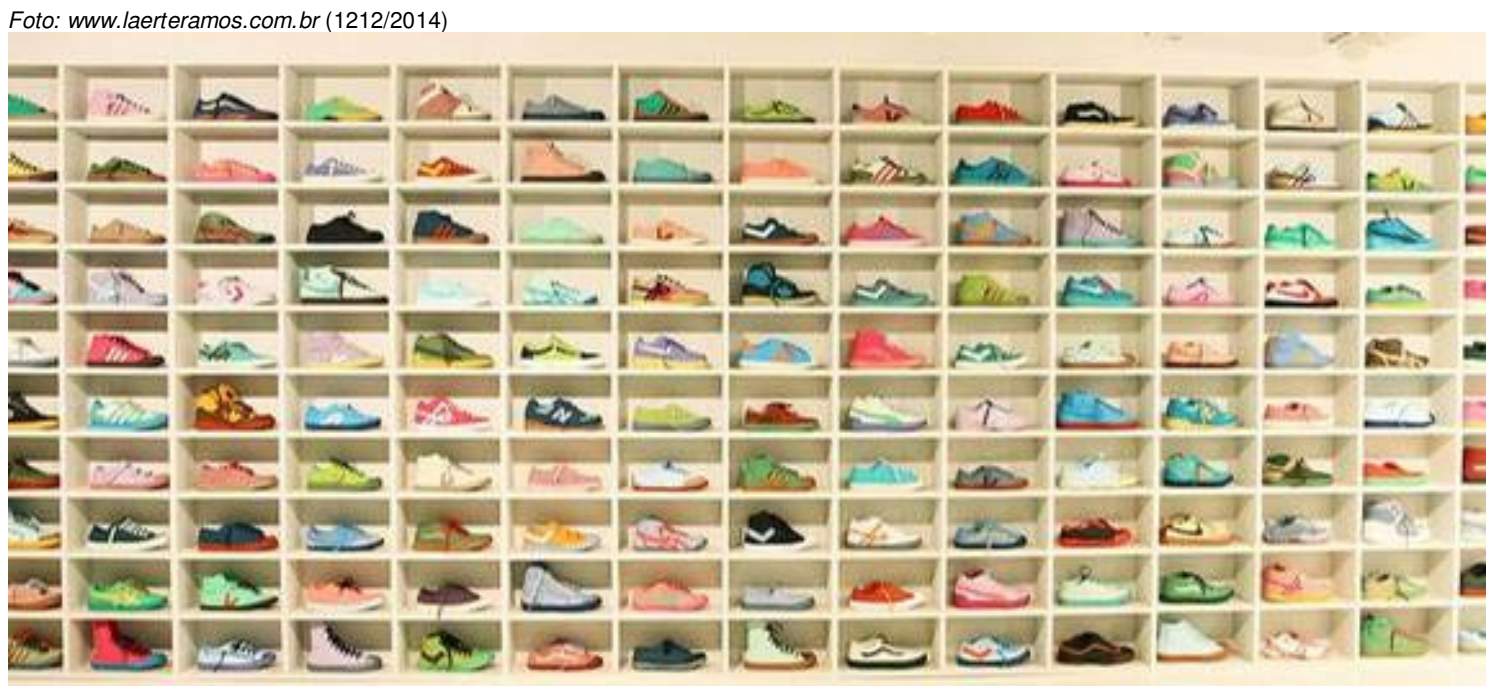

Figura 110

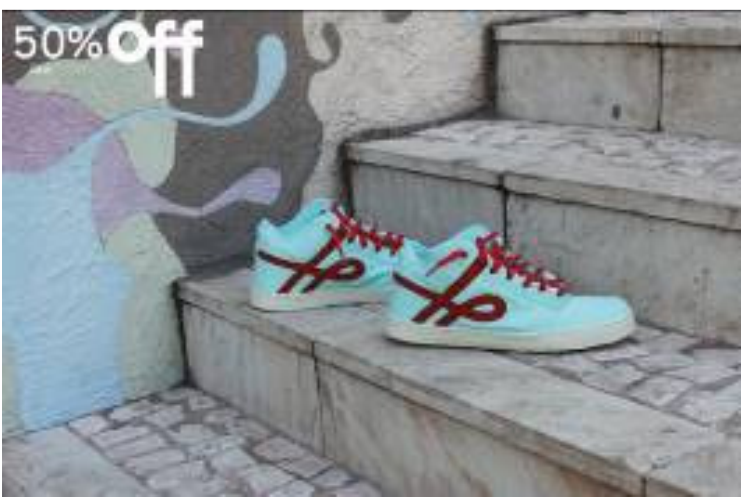

Figura 111
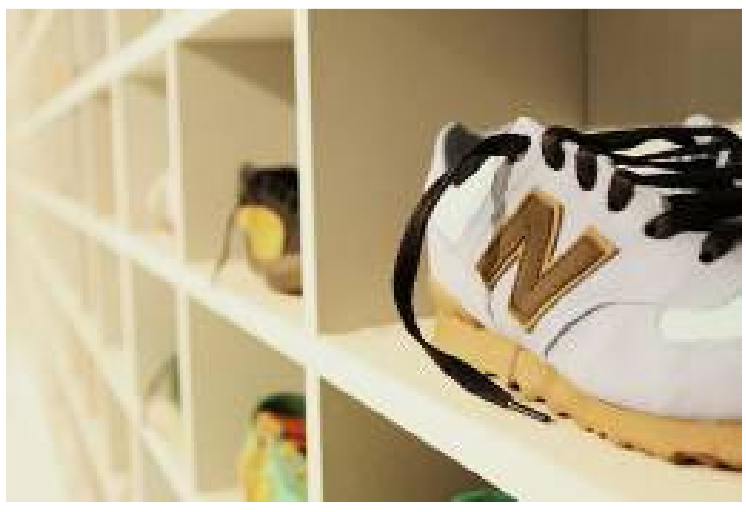

Figura 112

Laerte Ramos

$50 \%$ off

Cerâmica policromada

Dimensões variadas

2014

Itaú Cultural

Assim como nas gravuras, Laerte toma para si alguns desafios pessoais, como por exemplo, fazer determinado número de trabalhos num tempo determinado, como é o caso da instalação $50 \%$ off: 
"[...] é um número que eu determinei para chegar nos 300 e que é um desafio pessoal. Na verdade, eu comparo minha produção com o desempenho de um atleta de olimpíadas, sempre em busca de sua melhor marca $[\ldots]^{1}{ }^{177}$

Além do desafio pessoal, Laerte traz para suas obras questões mais subjetivas. No caso de $50 \%$ off, as reflexões acabam partindo para o que está inserido no tema tênis e suas histórias:

"Não quero tirar fotos dos tênis de vários ângulos e ficar explicando a anatomia dos pés de seus donos. No entanto, esses desgastes das solas são detalhes silenciosos que fui percebendo, para mim fazem sentido e acho interessante, mas não precisa ficar claro. Logicamente que numa conversa isso acaba ficando claro, mas não é uma coisa que quero 'gritar' ao mundo. Pois os tênis novos, não contam histórias de ninguém, mas os outros contam. Eles contam histórias das próprias marcas, por exemplo, se é Nike estou falando da Nike, se é Rainha, estou falando de uma marca brasileira, da Topper, etc.Peguei um Kichute. Por que peguei um Kichute? Porque é uma chuteira que foi muito importante para os meninos dos anos 70/80. Por muitos anos, ele foi utilizado por alpinistas. Eles retiravam as travas, deixavam a sola lisa e depois eles podiam subir nas rochas." ${ }^{178}$

Laerte Ramos mantém viva sua motivação interna e impõe sempre novos desafios. Cada trabalho finalizado dá origem a outro, como é o caso da instalação Casamata. Neste trabalho, Ramos faz referência à arquitetura militar, na qual casamata é uma construção fortificada fechada e abobadada à prova dos projéteis inimigos. Para Ramos, há uma relação também com a casa do pássaro João de barro.

${ }_{178}^{177}$ Trecho da entrevista com Laerte Ramos concedida a Silvia Tagusagawa

${ }^{178}$ Idem. 

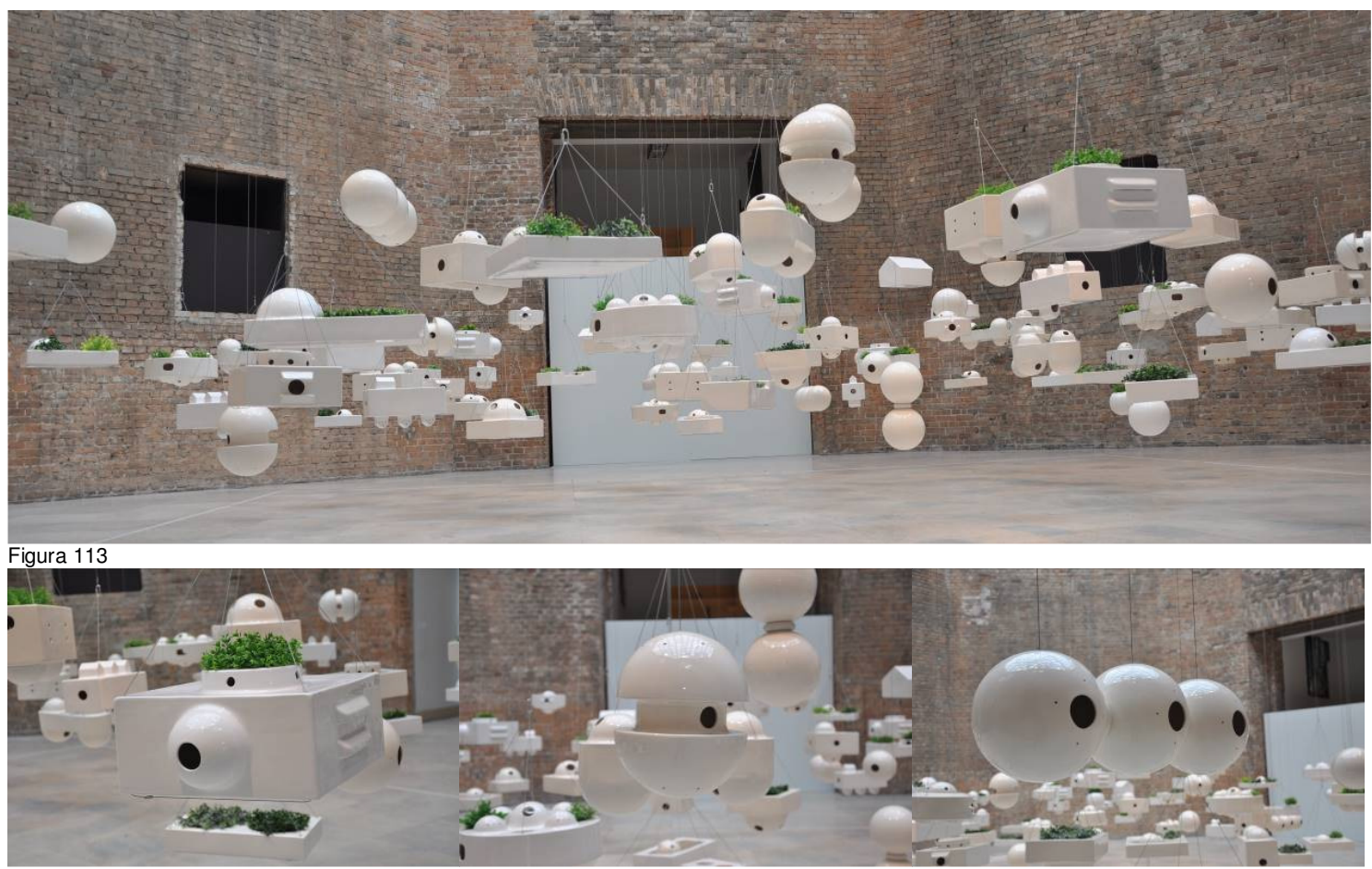

Figura 114

Laerte Ramos

Casamata

Dimensões variadas

2014

Instalação com cerâmicas esmaltadas, fios de aço, areia e plantas artificiais

Pinacoteca do Estado de São Paulo

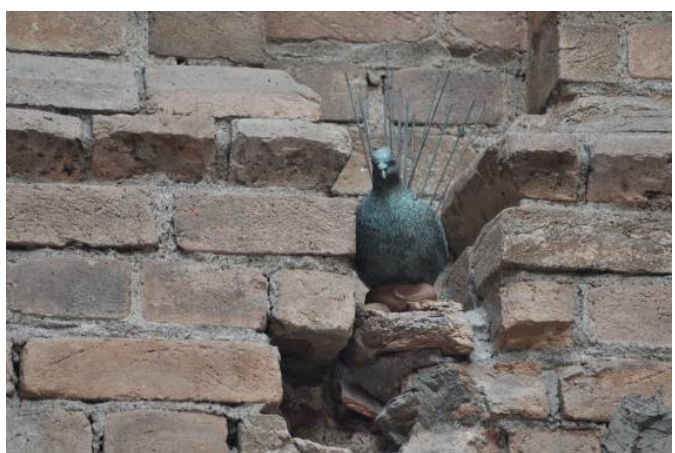

Figura 115

Laerte Ramos

Columbiformes 2014

Bronze patinado

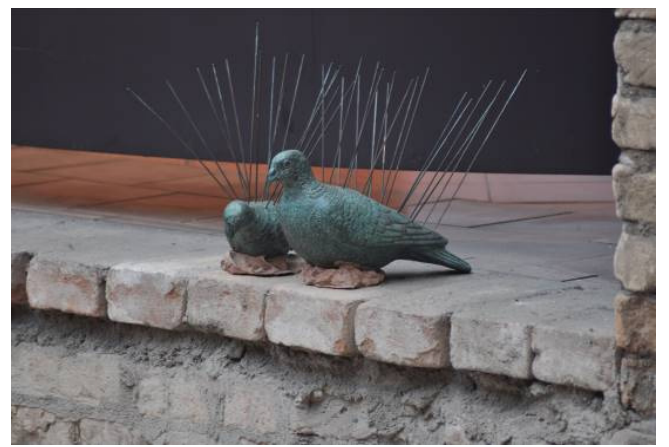

Figura 116

Laerte Ramos

Columbiformes 2014

Bronze patinado

Esculturas em bronze patinado apresentadas na exposição Casamata, na Pinacoteca do Estado de São Paulo 


\subsubsection{Entrevista com Laerte Ramos (São Paulo, 04/12/2013)}

Silvia: Em sua biografia, desde a infância você teve contato com a Arte, estudou na Escola Waldorf o que estimula bastante. Seu pai também foi artista.

Laerte: Meu pai chegou a participar da Bienal de São Paulo. Ele era engenheiro e artista, trabalhava na Volkswagen, lia texturas de metal com lentes absurdamente precisas. Então, ele enxergava um metal que nós não conseguimos ver e eram texturas muito bonitas. Num dado momento, ele quis mostrar isso para o mundo, algo que só ele via. Ele começou a pintar isso. Então, ele lançou uma série de metamorfoses ligada ao que ele via nessas texturas.

Silvia: Qual é o nome dele?

Laerte: Adhemar Ramos. Ele já é falecido. Ele participou de salões de Artes. [Certa vez] saiu uma matéria no jornal que tinha a obra O porco, do Nelson Leiner, ao lado da pintura do meu pai. Mas acontece que ele tinha quatro filhos, era engenheiro e nunca deixou de ser e teve que fazer algumas opções de vida. Ele não concordava com algumas coisas que havia no mundo da Arte, por isso, seguiu a vida como engenheiro.

O tempo da Arte é mais lento. Nós estamos acostumados com coisas de computador, e-mail, celular, internet que é tudo muito rápido e imediato. No entanto, o tempo da Arte é um momento de reflexão, é aprimoramento de uma técnica e de um entendimento. Fazemos um trabalho e só depois entendemos o que é e nem tudo que fazemos, nós sabemos. Vamos nos perguntando e sendo guiados pelas perguntas. Então, é tudo demorado.

Silvia: Você disse que tem mais três irmãos. Algum deles também é artista?

Laerte: Tenho uma irmã que é nutricionista e não desenha bem. Tenho mais dois irmãos que, pelo eu que via, davam de dez a zero em mim no desenho. Eles poderiam ser excelentes artistas hoje, mas um é publicitário e o outro é veterinário. O que é publicitário tem bastante proximidade com a Arte, com esse universo. Até porque a nova tendência da publicidade é fazer propagandas e pegar o consumidor de maneira intensa e profunda. Então, o trabalho da publicidade está encostando 
com a Arte hoje em dia. E o trabalho dos artistas está encostando com as questões da publicidade. Então, está havendo essa troca.

Silvia: Depois, você foi estudar Artes na FAAP. E foi sua primeira opção?

Laerte: Não, foi Administração. Na verdade, eu não sabia o que eu queria mesmo. Prestei Administração, mas nem fui ver o resultado do vestibular. Depois de um tempo, prestei para Artes, mas meio sem saber o que era aquele curso, não conhecia ninguém que estava fazendo, não tinha mais informações e fui fazendo. Mas para mim, o que foi mais determinante na minha carreira e que influencia até hoje isso foi um professor que se chama Toshifumi Nakano que já é falecido. Fazia três meses que estava na faculdade e ele falou para todos os alunos que tinha um salão de Artes na faculdade no segundo semestre. Eu havia entrado na segunda metade do ano. Então, ele disse estavam abertas as inscrições, era para os alunos se inscreverem porque ali dava bolsa. Aí eu falei, "Que legal!". Estava meio sem grana e pensei que se conseguisse uma bolsa seria muito bom. Só que eu só tinha 3 meses de faculdade, ou seja, não tinha nada, eu não sabia o que era aquilo. (De qualquer forma) mandei uns trabalhos de conclusão que tinha feito na Escola Waldorf que eram umas cabeças em argila. Esse trabalho foi premiado. Daí eu ganhei $50 \%$ de bolsa. No dia da premiação eu não fui, pois, na época, não compreendia muito que era aquilo. Depois, eu fui visitar a exposição e vi que tinha uma estrelinha no meu trabalho. Aos poucos, comecei a entender como as coisas funcionavam. Isso foi um motor na carreira e uma das minhas metas era sempre ganhar os concursos na faculdade para poder pagar a faculdade. Consegui quatro bolsas lá. Consegui também uma bolsa residência pela FAAP.

Silvia: Isso foi depois da faculdade?

Laerte: Não, foi durante, em 2001. Tranquei matrícula na FAAP e fui para a Cité Internationale des Arts $^{179}$ em Paris. Depois voltei e continuei a faculdade.

Silvia: Na residência, o que você desenvolveu lá?

${ }^{179}$ Cité Internationale des Arts em Paris, França, é um programa de residência artística oferecido à artistas profissionais no mundo inteiro. 
Laerte: Na verdade, desenvolvi experiência de vida. Numa experiência internacional você conhece vários artistas, lugares e museus. Trabalhei bastante no ateliê, tive contato com várias pessoas e viajei bastante. Fui para a bienal de Veneza pela primeira vez, e em Basel. Fiz também uma exposição individual lá em Paris.

Silvia: Você tem um trabalho de gravura que até hoje você desenvolve. Você iniciou na faculdade? Conte-me sobre o início de sua carreira.

Laerte: Quando entramos na faculdade, não temos a mínima noção do que vai acontecer, ou, preconcebemos ideias sobre isso. Chegamos lá e compreendemos que é um universo extremamente complexo, existem vários setores e segmentos. Um deles é o contemporâneo de museu e galeria. Enfim, não é que temos que escolher um, mas nós acabamos sendo guiados pelos próprios professores para a Arte Contemporânea mesmo, que é o mais sedutor. O que é mais desafiador para um estudante de Artes ou jovem artista que quer realmente desenvolver uma carreira é você encontrar seu próprio trabalho: é você pegar um papel ou pedaço de barro, você construir/fazer um trabalho e você falar que isso é seu. E quando o mundo olhar saber que isso é seu, não precisar de uma assinatura. Aliás, (o conceito de) assinatura caiu há muitos anos. Então, quando você encontra o seu trabalho e sabe dizer quem é você ou o que você quer dizer para o mundo, utilizando técnicas de Arte, isso é o maior desafio. Tem muitas pessoas que conseguem, tem outras que não e há pessoas que encontram isso depois de se formar. Ainda há aqueles que nunca estudaram Artes e já nasceram com isso. Você muda da água para o vinho quando encontra esse caminho e o próprio trabalho também vai mudando assim. No meu caso, eu tive realmente esse encontro na xilogravura, acho que eu estava no terceiro semestre da faculdade. Eu gostei muito da técnica. Uma coisa é você pegar um lápis e papel para desenhar e ter o poder sobre aquilo, a outra é a gravura que tem vários procedimentos que demoram um pouco. Então, você tem que ter um esforço na madeira, tem que cavar, depois passa a tinta e imprime no papel. Quando você imprime, sai invertido. Ou seja, eu acho que esse procedimento mais lento da gravura ensina mais a desenhar, eu aprendi a desenhar com a técnica da gravura, da xilo, no caso. Para mim, a xilo foi minha maior professora, aprendi muito e até hoje aprendo a desenhar com ela. Tenho um projeto, por exemplo, que 
se chama Sobre Rodas que eu desenvolvo desde 2000. Trata-se de 1127 matrizes e ainda está em fase de execução.

Silvia: Quais são as dimensões dessas matrizes?

Laerte: $30 \mathrm{~cm}$ x $36 \mathrm{~cm}$. São 1127 matrizes e é um trabalho só. Daí, vem aquela história de aprender com o trabalho. Eu não quero pegar esse trabalho e, para terminar, dizer que terminarei daqui um mês. Porque eu entendi que é aquilo que eu estava falando, de você aprender com a técnica, permitir que a xilo lhe ensine a desenhar. E o que aconteceu no decorrer destes treze a catorze anos foi que eu mudei. Eu também comecei a trabalhar com escultura, minha mão mudou, ficou mais forte, quebrei a mão uma vez. O mundo mudou e a paisagem também. Eu mudei de casa várias vezes. Existiram vários "EUs" e esses Laertes acabam aparecendo também nesses desenhos. Na série Sobre Rodas, todas as matrizes de xilogravura são de $30 \mathrm{~cm}$ x $36 \mathrm{~cm}$, são máquinas sobre rodas e têm que ter rodas ou algo do gênero. Então, existem algumas regras e leis. Dentro dessas regras e leis, eu ainda consegui viver várias vezes mudando de acordo com as mudanças externas. Então, essas coisas que vejo na minha vida, eu vejo também no meu desenho. Com treze, quatorze anos de carreira, eu consigo voltar e enxergar essas mudanças. Para mim é muito melhor demorar mais tempo para terminar um trabalho grande como esse, do que fazer em 4 ou 6 meses. $O$ aprendizado é muito melhor.

Silvia: É isso que percebemos nas figuras, quando dispostas uma ao lado da outra, que há regras e sequência. Até mesmo nas esculturas cerâmicas.

Laerte: Sim. Há algo que é uma constante. Às vezes, é uma coisa que eu adiciono ou subtraio e crio outra nova. É infinito e também tem aquela coisa de se desafiar. Quando eu terminava 10, eu me perguntava se eu seria capaz de fazer 30. Quando chegava nas 30 , eu pensava que foi legal, gostei do resultado. E aí partia para um número maior. Eu sempre fui exigente comigo mesmo, me desafiar, colocar números grandes e tentar conseguir fazer. E esse trabalho está em andamento.

Ao mesmo tempo em que desenvolvia a série Sobre Rodas eu também estava fazendo a série Caixa D'água, que é algo mais para o retrato. Eu também contextualizava essas imagens em paisagens. Fiz uma série de Paisagens também. 
Certa vez, me chamaram para participar de um leilão de parede usando pratos em cerâmica no Museu Lazar Segall e quem me convidou foi a Juliana Monaschesi. Fui até um ateliê de cerâmica e havia alguns pratos, fiz o trabalho e eu gostei daquele ambiente, havia uma familiaridade, pois já havia frequentado vários ateliês de cerâmica, o contato com a argila.
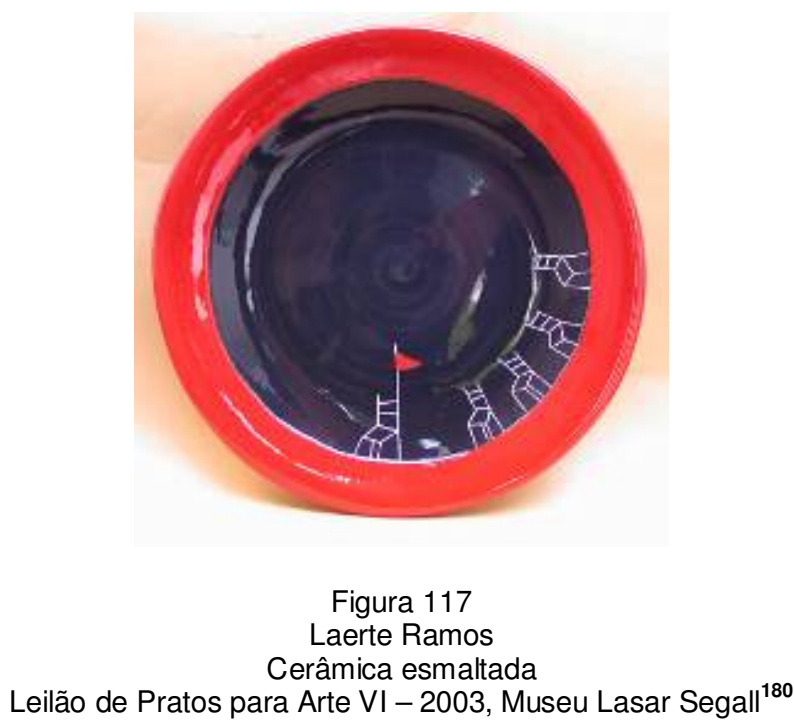

Para mim, a argila é um material que eu tive durante a minha infância. Então, o contato com a argila é uma coisa muito forte. Porém, quando eu descobri o meu desenho na xilo, eu deixei isso de lado. Então, quando eu voltei nesse ateliê, ativou esse lado da minha infância. Uma semana depois, eu estava com a escultura pronta. E meu trabalho do Sobre Rodas e Paisagens, para mim, eram muito esculturais. Então, são formas bem tridimensionais, você olha é bidimensional e por outro lado, é tridimensional.

Do bidimensional para o tridimensional foi muito rápido. É como se todos os meus desenhos de gravura fossem estudos para eu ir para o tridimensional. A partir daí eu entendi, vi um pouco da técnica da cerâmica e descobri a técnica da argila líquida (barbotina). Você injeta argila líquida num molde de gesso e você consegue reproduções de um mesmo objeto. Que é o mesmo raciocínio da xilogravura, em

${ }^{180}$ Imagem disponível em: http://www.museusegall.org.br/mlsLeilao.asp?sLeil=9 Acesso em: $15 / 08 / 2013$ 
que há uma matriz, que utilizo para imprimir e fazer cópias. Continuo usando a reprodução com poucas tiragens. Por exemplo, as gravuras são três, as esculturas também são três, o que me deixou muito próximo desses dois meios. Por isso que eu falo que a minha cerâmica ainda é minha gravura. A gravura, ainda é a coisa mais importante na minha produção. Criei, então, a série Acesso Negado. Ela é praticamente a série Sobre Rodas, mas em escultura. Por isto, que elas têm o branco e preto: o preto da tinta e o branco que vem do papel branco.

A série Acesso Negado possui pequenas esferas e palitos na parte de debaixo, permitindo que as esculturas fiquem mais leves e não encoste sua base na mesa ou em qualquer outro suporte. Permite uma sensação de peças mais infladas, levinhas e ainda quando você olha, tem essa possibilidade de movimento. Além disso, esses elementos dão a possibilidade de questionar se o objeto se movimenta ou não. Gosto de trabalhar com essa coisa da imaginação também. Acabei agregando valores do movimento, do preto e do branco. Mesmo sendo brancas, eu conseguia acrescentar o preto nelas, sem tinta, utilizando as fendas. Nos buracos não há luz, então, sai algo como uma sombra preta de dentro. Então, todas essas coisas vieram da gravura e infestou nas minhas cerâmicas. Para mim, essa série é uma das mais importantes, pois há esse encontro.

E graças a esse leilão de pratos. Talvez se eu não tivesse sido convidado, não despertaria tudo isso.

Silvia: E no prato, você fez um desenho que já tinha sido desenvolvido?

Laerte: Fiz um desenho normal. Na verdade, fiz um prato que compôs um painel de 180 pratos, na qual cada artista convidado fazia um. O resultado das vendas seria revertido para a Associação Amigos do Museu Lazar Segall e é um evento que acontece anualmente até hoje. Nesse tempo também, trabalhei com serigrafia, vídeo e por um tempo acabei me envolvendo com moda. 
Silvia: Tem vários vídeos seus no Youtube em que você mistura os vídeos e as $\operatorname{gravuras}^{181}$.

Laerte: Sim. Lá, eu usei a própria linguagem do vídeo como elemento. Usei a barra de cores e era num tempo em só existia a fita VHS e não tinha nem DVD. Então, essa coisa do looping era quase uma novidade. Naquela época, quando havia uma exposição com vídeo, colocava-se a fita VHS, acabava a fita e tinha que voltar. E aí ficava sempre um tempo sem ter o vídeo passando, a obra de arte. Para mim, era uma falta de respeito com o espectador porque muitas vezes pagava ingresso para ver a exposição. Isso é algo que não acontece com a gravura, ou a pintura ou a escultura, pois as obras são postas ali e estarão sempre presentes. Não tem esse problema. Então eu comecei a pensar nesse outro tempo, de respeito com o espectador. Meu trabalho era sempre sobre a barra de cor. Era sempre sobre essa pausa e hoje não faz mais tanto sentido.

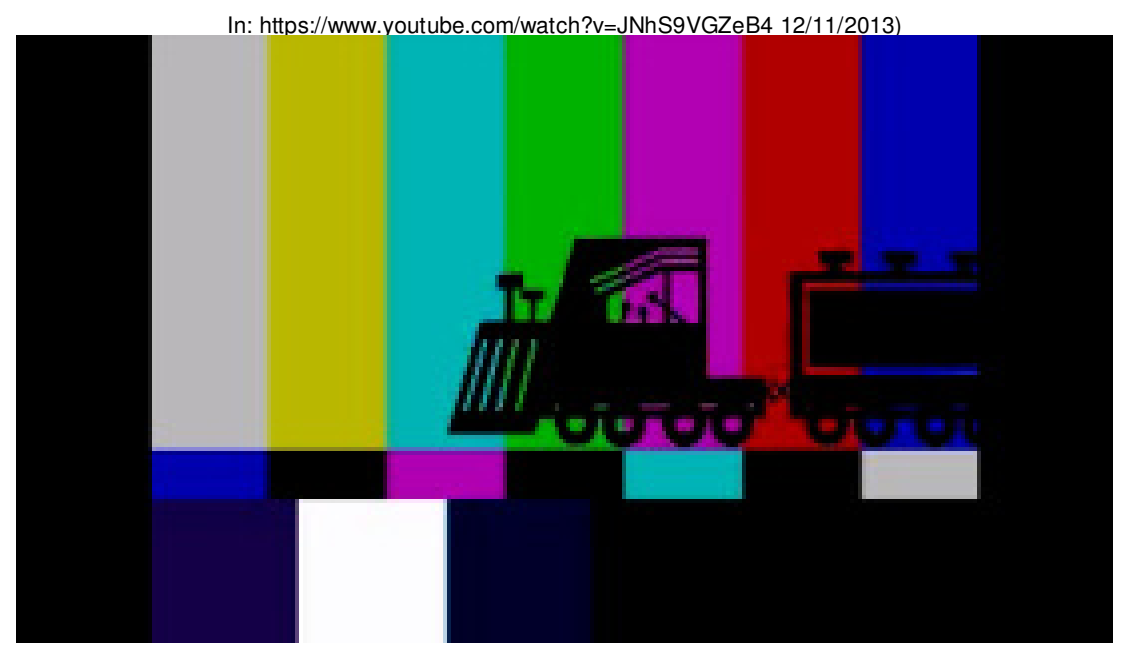

Figura 118

Laerte Ramos

Vídeo produzido por Laerte Ramos

Trem

2006

\footnotetext{
181 Vídeos disponíveis em: https://www.youtube.com/user/laerteramos/videos. Acesso em: 01/12/2014.
} 
Silvia: No percurso artístico, há muitos trabalhos que estão guardados, em execução etc. Quem está de fora, não tem noção do que acontece antes das obras estarem numa exposição, os esforços, as negações, o tempo, etc.

Laerte: Quando eu faço exposições, eu sempre realizo oficinas, conversas e palestras. Há uma troca com o público. Acabei de voltar de Birigui, no SESI (Serviço Social da Indústria), fiz uma oficina e uma palestra. Acho que se vou para uma cidade que ninguém me conhece e não conheço ninguém, e lá eu faço a exposição e volto correndo, sem ter uma relação com a cidade e as pessoas, tudo isso acaba sendo uma mentira, não tem sentido ser feito. Se eu me interessei em fazer uma exposição, eu tenho que me relacionar ao máximo, senão não faz sentido. Fica vazio. Eu sempre coloco isso como uma condição: ficar lá pelo menos dois ou três dias e fazer coisas para haver essa troca, tendo como objetivo aprender sobre a cidade onde eu estou expondo os meus trabalhos e para eles saberem quem sou eu.

Silvia: Essa vivência, além de criar proximidade entre público e artista, possibilita também a valorização ainda maior da obra por parte deste público.

Laerte: $\mathrm{E}$ o retorno disso também é rico. Eles mandam e-mails agradecendo e às vezes fazem perguntas a respeito dos trabalhos entre outras coisas. É super bacana. No meu ponto vista, o artista deveria ter um papel um pouco mais social, além de querer ser famoso. Acredito que com essa onda de facebook, quantas curtidas que você recebe, mostra a necessidade se criar celebridades. E muitos artistas acreditam que tem que ser assim, esquecendo esse lado mais humano mesmo.

As pessoas com quem eu gosto de conversar bastante e que estão bem próximas dos trabalhos nas exposições, muito mais que os curadores, são as faxineiras e os seguranças. Eles têm um olhar que não está viciado em Arte e é um olhar puro e direto. São pessoas normais, comuns e que não têm um estudo direcionado para isso, mas eles têm uma sensibilidade extra. Isso para mim é muito interessante.

Acho que isso fecha um ciclo, pois se você só fica no ateliê trabalhando, não ocorre esse ciclo. Você fica isolado, faz exposição e não se relaciona com as 
pessoas. Não há um retorno e não traz elementos novos para o seu trabalho, nem dá subsídios para dar continuidade a sua pesquisa.

Silvia: Voltando ao seu percurso, na sua poética está presente a questão das máquinas, temas bélicos misturados com brincadeiras de crianças. Fale-me sobre as suas influências.

Laerte: Na verdade, trabalhos de Arte do meu pai, eu vi pouquíssimos. Conheci mais o lado engenheiro dele. Eu via muito os livros de engenharia dele. Eram livros incríveis e ele viajava muito também. Ele ia para a Índia, Japão, Estados Unidos e Alemanha. Sempre trazia catálogos de maquinários, umas coisas que não existiam aqui na época.

Ninguém viajava ou saía do país para trazer esses livros. Ele viajava muito para comprar máquinas e ver novas tecnologias. Quando ele trazia, eu via todo esse material. Então, para mim eram desenhos incríveis e vejo que meu trabalho tem muito esse olhar de uma criança que olha para alguma coisa e não entende, mas acha lindo. Quando uma criança vê um tanque de guerra pela primeira vez, por exemplo, ela vai achar aquilo fascinante, não importa a sua função, aquilo é bonito. Então, meu trabalho tem muito isso. Tem essa coisa de uma experiência vivida por uma criança observadora. Eu não entendia esses livros, não sabia o significado, mas absorvia essas imagens e essas figuras. Só depois que eu entendi tudo isso, quando o meu trabalho estava praticamente feito: meus desenhos, os traços definidos, os tanques de guerra etc. Eu tive muito incentivo na escola Waldorf. Como eu digo em vários depoimentos, vários professores meus eram refugiados de guerra. Tinha um professor cujo sapato tinha o bico elevado, pois ele não tinha os dedos do pé, pois foram perdidos congelados e havia outro que construiu um planador para fugir. Outra professora foi cantora da Ópera de Berlim e se escondeu num bueiro. Sob o olhar daquela criança as experiências de cada um deles eram tão ricas tão marcantes e incríveis. Eu ainda quero entender melhor essas "lendas", com as quais eu realmente convivi. Então, isso influenciou muito o meu olhar infantil, o entendimento do mundo. Claro, eu não passei por essas experiências de guerra, mas essas histórias me deram uma vivência. Talvez por isso eu leve isso para a Arte, pois foi uma vivência bonita. Não foi uma coisa horrível que eu vi, sangue e 
gente sofrendo. Eu trago a força desses vencedores, que sobreviveram, histórias de superação. E é aquilo, sob o olhar de uma criança que está conhecendo o mundo e tudo é belo. Eu uso isso no meu trabalho e eu só fui entender isso muito tempo depois. Tive um professor no curso de licenciatura indagou sobre o meu trabalho e pediu para levar alguns cadernos da minha época de infância, quando levei e abri, era igual! Era a mesma coisa! Tinha soldado, tinha um tanque, tinha um trator que mais lembrava um tanque, tinha um poço. Olhei aquilo (admirado), (pois) são coisas que eu faço hoje. Ou seja, os desenhos que eu encontrei como artista, são os mesmos de quando era criança e eu não usei isso para a pesquisa. Tudo isso estava guardado lá e só depois eu fui resgatar essas histórias a pedido desse professor. Eu me entendi.

Silvia: Fale-me sobre o seu encontro e aprendizado das técnicas.

Laerte: No caso da gravura, eu tive seis meses de aula com o Hermann Tacasey e explorei as técnicas de várias maneiras. Porque estava também encontrando meu desenho e me desafiava. Trabalhei muito e às vezes, quando havia apresentações na sala de gravura, eu tinha que tirar os trabalhos que estavam todos espalhados pela sala. Havia gravuras minhas em todos os secadores, do chão ao teto. Eu estava realmente envolvido, experimentando e produzindo. Parecia até que eu estava correndo atrás de um prejuízo que eu tive de não ter encontrado o desenho antes.

O início na cerâmica foi mais difícil. Comecei fazendo dessa maneira, usando os moldes.

Silvia: Mas você modelava e...

Laerte: No começo eu só modelava a escultura e tinha um técnico que fazia o molde para mim e reproduzia as esculturas, queimava, pintava e tudo.

Silvia: Isso logo depois da experiência dos pratos em 2003 mais ou menos..

Laerte: Sim. Só que para mim era um pouco caro.

Silvia: É um trabalho bem específico, pouca gente faz. 
Laerte: Pouca gente faz e é caro. É demorado. Foram surgindo mais exposições, o orçamento ficou apertado e já não conseguia financiar. Ficou pesado demais e aí aprendi a fazer molde para ficar mais barato e rápido.

Silvia: Fica mais acessível: você modela, constrói o molde e já reproduz.

Laerte: Aprendi a esmaltar também. Eu sei injetar a barbotina, mas como eu não tenho forno, a fundição é feita no mesmo local da queima. Nunca tive interesse de ter um por causa da minha limitação de espaço. Então, eu terceirizo, tanto a injeção de argila líquida como a queima. Eu prefiro concentrar na parte criativa. Eu até poderia terceirizar o molde, mas por questão de tempo, não tem ninguém que poderia fazer a quantidade de moldes que eu tenho e dentro do meu prazo.

Há peças que eu faço a tiragem e há peças que eu não faço, pois é muito frágil transportá-las e é preciso fazer tudo próximo ao forno.

Depois da primeira queima, se precisar esmaltar eu trago tudo para cá, esmalto com pincel e mando para queimar novamente. Uso esmaltes prontos.

Há um vai e volta até o trabalho ficar pronto. Para mim, cada trabalho possui uma história.

Silvia: A que temperatura você queima as peças?

Laerte: Em torno de $1000^{\circ} \mathrm{C}$. Em 2007, estavam selecionando artistas para participar de uma residência no EKWC (European Ceramic Workcentre) na Holanda. Fui indicado, mandei meu portfólio e apresentei para o pessoal. Era o ano do Brasil na Holanda e eles convidaram 5 artistas do Brasil para desenvolver um projeto lá durante 3 meses. Foi nessa época que eu realmente aprendi muito sobre cerâmica.

Eles convidam artistas, arquitetos e designers que são ignorantes na cerâmica, que acham que cerâmica é só xícara ou que não fazem ideia de como trabalhar com cerâmica. Para o EKWC, essas pessoas são as melhores para se trabalhar com cerâmica porque não têm vícios e não teve ninguém na vida previamente falando o que é certo ou errado. São pessoas que não têm carregado a questão da tradição no seu fazer e na sua poética. 
A tradição em Arte e em Cerâmica é incrível por um lado. Por outro lado, tem que ter uma ruptura, senão você não evolui e fica preso a algo já inventado, seja ela uma técnica ou uma maneira de pensar, pois você não cresce, não ousa, não dá um passo além. Você fica preso.

Silvia: Em sua opinião, até que ponto o conhecimento da técnica e o contato com a matéria são importantes para o trabalho artístico?

Laerte: Vejo que muitos jovens artistas estão muito mais preocupados em serem famosos e não há interesse em colocar a mão na massa, mandam fazer suas obras de arte. É coisa de hoje.

Para mim, o mais incrível foi ter esse reencontro com a argila que é um material que eu tenho uma familiaridade grande. A argila é um material que é um bloco de terra molhada, lama, sei lá. Quando nós a tocamos, ela grava a textura da nossa mão. Então, nossa mão fica impregnada lá. E se nós dobrarmos o pedaço de argila, o desenho que ficou ali, fica no seu interior e ganha outra forma. Então isso, acaba virando uma memória dentro do material, algo que é encantador para mim. Por mais que você dobre, aperte, amasse, ele sempre vai ter essas formas, esses volumes dentro dela, essa memória carregada. Uma coisa que eu gosto muito da minha argila é que ela, por mais eu queime parte dela, que eu compre novas argilas, ela sempre será a mesma. Por exemplo, aquela estrutura ali, foi construída com uma argila que teve aquela forma, eu tirei o molde e aí o gesso veio para cá e essa argila foi seca e quebrada, reciclei e ela vai virar outra forma. Cada escultura nova que eu crio tem outra forma e tem essa memória. Acho isso muito poderoso. Por isso eu tenho um respeito muito grande por esse material. É como se todos os meus trabalhos, independente onde eles estão, no mundo, a essência deles estão naqueles pedaços de argila. Eu tento não perder estes pedaços. Evidentemente, sempre perdemos, na confecção de moldes, mas o grosso fica sempre ali.

Silvia: Qual é a importância do conhecimento técnico no seu trabalho?

Laerte: Agora, estou nesta minha pesquisa de cerâmica. O que faço, digo que é pesquisa e não a obra de arte. Estou sempre estudando alguns limites e as possibilidades do que eu vou conseguir fazer com a técnica. O meu primeiro trabalho foi o Acesso Negado, depois fiz a série da Batalha Naval. 
A série Acesso Negado tem os palitos em baixo e a Batalha Naval que tem as bases móveis e as pessoas podem jogar. Normalmente, as pessoas nunca podem mexer em uma obra de arte numa exposição, mas através de um jogo podem movimentar as peças. Então, essa exposição sempre estava em movimento. Tem as questões técnicas, mas também tem a preocupação de como as esculturas se dão no espaço expositivo.

No trabalho re.van.che, por exemplo, eu quis dar uma impressão de couro. Se eu trabalhasse dentro de uma tradição da cerâmica, eu não iria conseguir dar essa textura de couro do jeito que eu queria. Então, eu usei tinta de parede, inventei umas coisas e aí consegui a textura do couro na cerâmica. A maneira que eu construí os moldes possibilitou que eu reproduzisse cada detalhe: a linha (costura) da luva de boxe, do saco de pancada. Existem trabalhos que você consegue ver a linha e trama do tecido ainda, de tão incrível que é esse material. E aí se eu esmaltasse, eu perderia todos esses detalhes, a textura, pois o esmalte infla. Então, eu tive buscar outras soluções, desrespeitando a tradição.

Silvia: Não acho que seja um desrespeito...

Laerte: Desrespeitando no sentido de seguir uma tradição. É mesmo "chutando o balde" e não ligando para nada disso, porque se eu fosse seguir todas as regras não teria feito esse trabalho e fazer esse trabalho, era muito importante para mim. $E$ também chamar uma atleta. Então, é uma união de várias coisas: o trabalho novo, desafiador, eu encosto minha produção com o esporte. Há muitos anos, eu era atleta, estava no tatame, então eu volto para o tatame, e a atleta invade o ateliê.

Silvia: Você fazia Taekwondo também?

Laerte: Não, eu praticava Jiu-jitsu. Fiz Kung fu um tempo também. Para mim, é vital ter esse ciclo e não ficar só no ateliê. Unir minha produção com outras áreas. Daí surgiu esse trabalho de quase um Hiper-realismo, mas de você enganar o olhar e essa coisa de um autodesafio para tentar e conseguir fazer uma luva de boxe parecida com a luva de boxe de verdade, usando cerâmica, sem que as pessoas percebam, ao olhar, que é cerâmica. 
Silvia: Percebe-se o seu grande conhecimento técnico. Você acha que você obteria os mesmos resultados, sem o conhecimento das técnicas?

Laerte: Tudo que eu não sei, eu busco maneiras de tentar aprender. Fora os moldes, eu acabei aprendendo a fazer sozinho. É claro, hoje em dia tem Youtube, então, você consegue informações para fazer o que quiser. Pesquisa-se e daí encontramos um vídeo de alguém que fez e faz. Eu fui pesquisando, eu sempre fiquei muito no ateliê produzindo, mas o que eu não sabia fazer, eu pesquisei e fui na raça fazer.

Esse projeto, por exemplo, fiz com desenho técnico e enviei ao Paço das Artes. Estava tentando entrar nesse projeto, a Temporada no Paço das Artes, há mais de dez anos. Nunca havia conseguido. Tentei com vídeo, gravura e várias outras coisas. Finalmente eu consegui com esse trabalho chamado re.van.che. Ou seja, é uma revanche porque eu estava há dez anos tentando e finalmente consegui. É revanche também porque a cerâmica é um material imprevisível, quando menos se espera, estoura no forno. Eu quis dar essa revanche na cerâmica. Em uma exposição pelo menos, eu quero ter o poder sobre este material e aí que pensei como eu poderia quebrar. Assim, surgiu essa ideia de fazer essa performance, convidar uma atleta de Taekwondo por causa do chute e de fazer um tipo de academia com barquinha de corner e outros elementos. Então, as pessoas que estavam na exposição, viam tudo aquilo e não entendiam direito, indagando tudo sobre tudo aquilo, o porquê de trazer uma academia para um espaço expositivo. Tipo, isso é arte? E de repente chega a atleta quebra e denuncia o material: a cerâmica.

Silvia: Assisti ao vídeo e no momento do chute, fica um silêncio absoluto.

Laerte: É um momento plástico e bonito. E todos descobrem que aquilo tudo é cerâmica. Você olha para a luta e vê que é cerâmica em tudo. Eu aprendi muito com este trabalho e até com a parceria com essa atleta. Fiz esse trabalho várias vezes e ela liga de vez em quando perguntando quando haverá outra apresentação dessa. Aí eu respondo que não, pois já o fiz em vários lugares do Brasil.

E perguntei para a atleta o que ela havia achado da experiência e ela respondeu: "Laerte, para mim foi uma experiência incrível. A minha adrenalina ficou 
mais forte do que quando participo de um campeonato Panamericano. Porque quando vou lutar, eu conheço o meu oponente. O saco de pancada em cerâmica é um elemento totalmente estranho".

Silvia: Essa exposição ocorreu em vários espaços pelo Brasil. E as atletas fizeram algum teste antes da performance?

Laerte: Sim, elas testaram em uma peça no ateliê. Só que não sabemos ao certo como vai ser na hora. As peças são feitas, cada uma com espessura diferente. Algumas peças tinham as paredes mais grossas, outras mais finas. Além dos elementos serem diferentes para a atleta, o público também era. Então, a adrenalina subia. Mais do que um campeonato em que ela depende disso para viver, há as medalhas. Ela não ganhou uma medalha na performance, mas acho que eu poderia ter feito uma medalha para ela (risos).

Eu sabia que se o projeto fosse aprovado e de fato foi, teria outros desafios.

Silvia: Ou seja, você ainda não tinha feito nenhuma das peças antes de apresenta-lo ao Paço. Você mandou somente a ideia antes.

Laerte: Sim, tanto é que no projeto inicial era para ser uma lutadora dando um soco e no final ficou sendo um chute.

Silvia: Ela realmente incorporou todo o contexto, ficou concentrada e tudo mais.

Laerte: De fato, ali é uma luta. Além disso, tem o meu lado, a minha visão. O tempo todo eu fiquei ao lado dela. Teve um preparo antes: um aquecimento e ali eu fazia o papel do técnico. Filmei a situação, ficava dando orientações e falava palavras de motivação.

Silvia: Então, você partiu de algo desconhecido, foi atrás de conhecimento e meios para realizá-lo.

Laerte: Na verdade, a re.van.che não surgiu do nada. Foi um mix de várias vivências. Na época, eu estava morando na Liberdade e lá existem muitas lojas de equipamentos de luta. Passava em frente delas diariamente. Tem também academias de luta. E tive a experiência de ter lutado e então é um resultado de várias coisas. Meu ateliê se localiza no quarto andar e, então, eu era praticamente 
um atleta que subia e descia as escadas, diariamente, com materiais pesados. Essa coisa de treinamento árduo. Minha vida era um pouco isso e essa vivência pessoal ficou muito forte e aí tudo isso se encontrou, resultando nesse trabalho.

Além do trabalho, fiz um mini documentário em que eu entrevisto a atleta e apanho no tatame (risos). Foi exibido durante a exposição, junto como vídeo da performance.

Na exposição havia dois protetores de pé, de cabeça, de boca, banquinho de corner e a pêra. Havia grande parte dos equipamentos de uma academia de luta.

Dos protetores de pés surgiu a pesquisa dos tênis (em cerâmica). Se formos analisar, há uma ligação com todos os trabalhos.

Silvia: Já ocorreu a exposição com os tênis?

Laerte: Todo processo é lento e de entendimento sobre o que é o trabalho. Normalmente, quando eu faço a exposição, às vezes existe algo que o ligue com o próximo trabalho. Quando eu fiz a exposição com as armas, a série Arma Branca, que é um painel de cem armas, eu coloquei alguns tênis camuflados, feitos em cerâmica, para dar a dica para o próximo trabalho, o $50 \%$ off. O interessante é que eu vi ceramista na exposição que olharam para os tênis e não reconheceram como sendo de cerâmica.

Silvia: Então, a proposta é sair da cerâmica, ultrapassar os seus limites mesmo.

Laerte: De transformá-la em outras coisas que a cerâmica não é. Poderia ser em outros materiais sim, mas entra na questão de que eu quero que seja em cerâmica, pois é argila. A argila faz parte de toda a minha vida.

No caso, eu achei super bacana fazer esses tênis. Fiz um estudo de como poderia fazer os moldes. Coloquei os tênis na exposição Arma Branca, comecei a pensar o que seria isso e se faria sentido naquele lugar. Então, foi um teste e acabei apresentando em vários lugares.

Silvia: Então, não necessariamente foi planejada para a exposição com as armas? 
Laerte: Os tênis estavam camuflados ali. Remetiam às armas. E acabei pensando melhor sobre eles. Essa exposição foi em 2010 e continuo fazendo esse trabalho, que resultou no Projeto $50 \%$ off que é composto por 300 pares de tênis. É bem demorado. São pintados um a um.

Silvia: Você tem algum assistente.

Laerte: Na verdade recentemente, estou com uma assistente que está em treinamento agora. Há muito trabalho. De cada modelo de tênis eu faço de 5 a 6 cópias. Então se são seis de cada molde, eu preciso de cinquenta moldes para completar 300 tênis. Como eu pretendo usar cinco modelos, então, são 60 moldes esquerdos e 60 moldes direitos totalizando 120.

Silvia: Esse número de cópias tem alguma relação com o conceito do trabalho ou é numero que você determinou.

Laerte: É um número que eu determinei para chegar nos 300 e é um desafio pessoal. Na verdade, eu comparo minha produção com o desempenho de um atleta de olímpiadas, em que você tem que correr sempre atrás daquele segundo para bater o seu próprio recorde. Então, eu acabo colocando algumas metas e me desafiando, fazendo de tudo para alcançar meus objetivos.

Silvia: Há alguma relação com as regras da gravura? Pois nela, o artista determina um número de tiragens.

Laerte: No caso da gravura, eu faço somente três cópias. Existem regras em outros meios, como por exemplo, na escultura, até seis cópias considera-se edição única.

$\mathrm{Na}$ verdade, sou eu quem determina as regras nos meus trabalhos. Por exemplo, na gravura, eu faço somente três cópias, pois sempre fui eu quem imprimiu e não quero perder tempo fazendo 1000 cópias de uma mesma matriz. Prefiro mil matrizes e uma cópia de cada uma, porque daí eu estarei me desafiando como criador. Por isso, faço somente três cópias e um PA (prova de artista). No caso das cerâmicas, eu faço somente três. No entanto, na série dos tênis é diferente, porque as pinturas são diferentes em cada modelo. Então, serão consideradas únicas.

Silvia: São muitos tênis. Você pediu doações de tênis para este trabalho? 
Laerte: Aprendo muito com cada projeto. Eu acabei comprando mais tênis sim, além de observar mais os pés das pessoas. Também pedi tênis emprestados para alguns amigos. Então, percebi que os tênis, que eu peguei emprestado, eram um retrato da pessoa. Não faço somente um tênis simples, pois existe o desgaste da sola, tem o jeito que a pessoa anda, que são sinais todos os lugares. Acaba tendo as características do dono do tênis e tudo isso acaba aparecendo de maneira extremamente silenciosa.

Não quero tirar fotos dos tênis, sob vários ângulos e ficar explicando a anatomia dos pés de seus donos. No entanto, esses desgastes são detalhes silenciosos que fui percebendo, tem certo sentido para mim e acho interessante, mas não precisa ficar evidente. Logicamente que numa conversa isso acaba ficando mais claro, mas não é uma coisa que quero "gritar" ao mundo. Já os tênis novos, não contam histórias de ninguém, mas os outros contam. Na verdade os novos contam histórias das próprias marcas, por exemplo, se é Nike estou falando da Nike, se é Rainha, estou falando de uma marca brasileira. Outro dia, peguei um Kichute. Por que peguei um Kichute? Porque é uma chuteira que foi muito importante para os meninos dos anos 70/80. Por muitos anos, ele foi utilizado por alpinistas. Eles retiravam as travas, deixando a sola lisa e depois eles podiam subir nas rochas.

Aos poucos, os desafios foram aumentando. Não me pergunte a razão de ter escolhido o número de 300 tênis. Acho que foi loucura, pois dá muito trabalho. Estou neste projeto há mais de dois anos, além de outros. Eu tenho que apresentar este projeto em junho ${ }^{182}$ que será na Passagem Literária da Consolação.

Não são trabalhos para museu ou galeria, pois eu quero causar uma reação diferente nas pessoas que costumam frequentar um espaço de arte. Se for exposto numa galeria, todos vão saber que é uma obra de arte, pois é um espaço viciado em obra de arte. Queria colocar este trabalho num lugar que não tivesse relação tão direta com a arte. Então, o meu olhar foi para as vitrines de lojas. A vitrine de loja acabou determinando como eu iria apresentar este trabalho. Na verdade, escolhi o

\footnotetext{
${ }^{182}$ A Exposição 50\% off foi realizada também no Itaú Cultural em São Paulo de Março a Outubro/2014.
} 
título 50\% off porque seria uma maneira de chamar a atenção, como se fosse uma promoção, tudo pela metade do preço. Também é $50 \%$ off porque eu apresento os tênis numa vitrine de loja, mas só com um pé, ou seja, só metade do trabalho, para as pessoas não roubarem, conceito usado nas lojas.

Então, eu vou expor só uma das metades, pois na verdade estou fazendo dois trabalhos. Ou seja, dois painéis com 300 pés direitos e 300 pés esquerdos que será outro trabalho. Portanto, vou apresentar um trabalho na Passagem Literária e a outra metade vou guardar comigo. Não é a mesma coisa, mas os painéis possuem as mesmas características de fachada de loja. Os monitores da exposição estarão vestidos como se fossem vendedores.

E por que deve ser na Passagem Literária? Porque lá tem uma grande vitrine com 27 metros de vidro. Normalmente, ocorrem exposições de arte lá, mas se eu fizer esse projeto lá, irão ficar zangados comigo. A primeira reação esperada das pessoas seria: "É um espaço que foi vendido e agora pertence a uma loja de tênis multimarcas! Isso aqui virou uma loja, mas era uma espaço cultural !" Com certeza, vai ter essa reação. Ao mesmo tempo, vou colocar um vídeo documentário, falando do processo de criação deste projeto, com um especialista em tênis falando sobre o assunto. O interessante de fazer uma grande quantidade é que convencerá que aquilo tudo não é cerâmica. Além disso, vou colocar um vídeo com todo processo que é árduo, cansativo e que levou cerca de dois anos para fazer. Quem vir o painel, não irá esquecer facilmente deste trabalho.

Silvia: O marcante está em todo o processo. O legal que os tênis, como você havia dito, contam histórias.

Laerte: Além disso, se tiver verba suficiente, tive a ideia de colocar um telefone tipo SAC (Serviço de atendimento ao cliente), onde as pessoas poderão ligar e conversar comigo em alguns horários. Como eu havia dito, alguns trabalhos fazem uma aproximação com o Marketing e Publicidade. Os trabalhos ganham um significado muito maior para mim, pois eles são feitos de acordo com o tempo que 
eles exigem. Como eu digo, a Arte tem seu tempo. Diferentemente de quando há uma pressão de galeria, por exemplo, que propõe encomendas de certa quantidade para determinado tempo, não faz sentido. Então, melhor coisa é eu conseguir trabalhar para a pesquisa, me concentrar, ter esse tempo para a pesquisa, senão perco a oportunidade de ter esse contato com o próprio trabalho e explorar e ver o que o trabalho quer realmente ser. Então, para mim isso é fundamental, esse respeito e carinho. Não ter a pressa dos dias atuais.

Silvia: Há uma pressão grande nos dias de hoje, todos querem tudo para "ontem". O grande desafio é poder ser honesto com o seu próprio trabalho.

Laerte: Sim, claro. Com relação à sua pergunta anterior sobre o acampamento verde (a instalação Lastlândia), eu juntei vários elementos como se fosse uma minirretrospectiva de vários trabalhos. Neste trabalho, existem as armas, diferentes das armas que eu havia feito, mas que remetem à série de armas e tem os barcos, há dois, que são série da Batalha Naval. Acabei me desafiando em outras questões pontuais desses trabalhos, fiz um machado, um binóculo, a máscara e soldadinhos que remetem àqueles brinquedos de plástico de $R \$ 1,99$, mas resgatando algumas coisas pontuais desses trabalhos anteriores.

Silvia: Remetem também às gravuras.

Laerte: Também. Então, tem esses intervalos, esses grupos, coloco aquelas luminárias rebaixadas porque estou questionando, é como se fosse um interrogatório, lâmpada de interrogatório, meio que você não enxerga o rosto da pessoa, algo parecido com filme e estereotipado, porque são símbolos. Então, ilumino a instalação como se fosse um acampamento e coloquei areia no chão com o objetivo evitar que as pessoas invadissem esse espaço, pois se você pisa, fica a marca de sua pegada. Faço uma relação com as questões do Muro de Berlim que tinham várias camadas (de muro) para impedir que as pessoas invadam o outro lado.

Silvia: Realmente, conta um pouco de sua trajetória mesmo.

Laerte: Sim. Em paralelo a esses projetos, eu faço os almanaques. Acabei desenvolvendo um almanaque para cada grande exposição. É um material extra que 
adiciona valor à exposição. Às vezes, isso é distribuído gratuitamente ou é vendido por preços de $R \$ 20,00$ a $R \$ 25,00$, depende da exposição. Para exposição na Pinacoteca farei um almanaque específico. E também tinha vários desenhos que eu usava em projetos, não como obra de arte, mas que foram usados nos almanaques. É outro lado meu. No final, desenvolver uma obra de arte é muito séria e o almanaque dá uma quebrada nisso. É um trabalho que eu consigo ousar mais, um espaço que eu uso para falar algo que não consegui falar com o trabalho. Ele é muito mais eu como pessoa do que como artista. É mais despojado. Eu gosto dessa liberdade que eu tenho nesses almanaques. Esses almanaques têm uma importância muito grande. Esse é o Informação 5 que é um livreco que foi feito para a exposição das armas que já foi, mas ele será lançado nessa mesma exposição que acontecerá em Belém e o painel das cem armas será doado ao museu de lá, a Casa das Onze Janelas. Já desenvolvi o almanaque e agora só falta imprimir, o tema serão os alvos. Realmente é um paralelo, de um lado as armas e nos almanaques têm os alvos. Na Pinacoteca, o almanaque trabalhará o tema Pombo.

Silvia: Na Pinacoteca você vai apresentar o projeto Casamata. Casamata que tem relação com aqueles abrigos ou proteções utilizados em guerras.

Laerte: Sim. Que são essas construções abauladas, que foi também o nome do meu antigo estúdio que atualmente chama-se Studium Generale. Antigamente, chamava-se Casamata Studium generale porque ele ficava num porão com essas formas, mas hoje é só Studium Generale.

O projeto Casamata fala sobre as construções de proteções.

Silvia: No Japão, especificamente num parque onde abriga o Monte Aso, que é na verdade um vulcão, há várias construções em concreto, com paredes bem grossas, com uma entrada e sem janelas. O telhado é do mesmo material, formando assim, uma estrutura parecida com uma cápsula. Esses abrigos lembraram os seus trabalhos, pois são justamente utilizadas para abrigar em caso de erupções vulcânicas.

Laerte: Na verdade, este trabalho teve origem por causa do pássaro João de barro/ Furnarius Rufus. A última exposição que fiz era composto por cupinzeiros ocorreu no Sesi e também teve a mesma origem. 
Com relação às esculturas de pombos, que irão integrar a exposição Casamata, eu estava pensando em fazê-los com um material mais nobre e que conversa com os materiais de esculturas, presentes na Pinacoteca, como o bronze e o mármore.

[Neste momento, Laerte mostra uma fluxograma com todas as atividades que serão realizadas em um determinado projeto]

Silvia: Fale um pouco de sua experiência na Bordollo Pinheiro.

Laerte: Foi um desafio, pois ao chegar na fábrica, conheci as instalações, o museu, a história do Bordallo Pinheiro e sua importância para Portugal. Logo depois, você tem cinco minutos para decidir o que vai fazer.
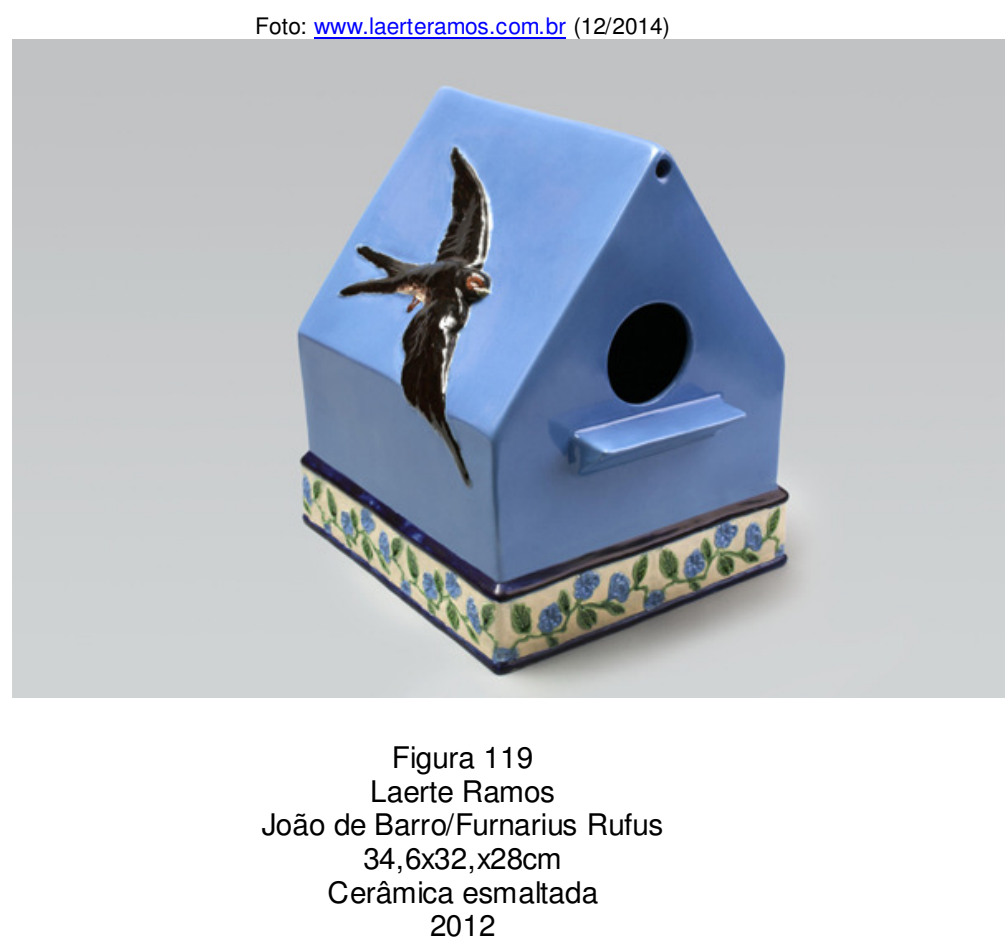

No projeto que seria desenvolvido ali, teríamos obrigatoriamente que utilizar moldes da fábrica. Foi bem desafiador, principalmente aos artistas que nunca haviam trabalhado com cerâmica antes. A sorte que eu tinha um projeto na minha cabeça e eu vi um painel de andorinhas lá, aí decidi que eu iria usá-lo para uma de minhas esculturas. Eu modelei minha escultura, fiz a forma, usei um dos moldes deles, recortei os pássaros e os frisos, colei e construí a escultura. 
Durante minha residência na Bordallo Pinheiro, visitei a fábrica de porcelana em Vista Alegre também.

Silvia: Depois você foi para lá também e como foi a sua experiência lá?

Laerte: Foi bem desafiador também, pois aqui no meu ateliê eu sou dono de tudo, tenho bastante liberdade, faço o que eu quero, domino o espaço e respeito muito o tempo da minha pesquisa. Quando você entra numa fábrica...

Silvia: Você teve que usar os recursos deles também assim como na Bordallo?

Laerte: Não, foi diferente. Na verdade, na Bordallo não são oferecidas residências para artistas, este projeto foi único, bem específico, e terminou. Na Vista Alegre existe um programa de residência. Eles trabalham com porcelana e em cima de algumas linhas de peças. Quando eu fui lá, conheci a fábrica, a marca Vista Alegre o museu e o mais importante: o cliente Vista Alegre. Para eles, o que é fundamental é quem compra, quem é cliente porque é uma fábrica, diferente de uma galeria ou um museu. Eles focam em coisas que sejam viáveis para venda e que sejam capazes de serem reproduzidas em linha de produção. A maioria dos meus trabalhos aqui não é viável para uma linha de produção de uma fábrica e de porcelana que é uma massa mais complicada de trabalhar. Eu acabei desenvolvendo decoração para jogo de mesa. Eles dão os briefings, dizem que tipo de peça precisa ser desenvolvida, seja ela uma luminária ou um jogo de mesa. Então, fiz alguns desenhos e mostrei aos setores de marketing, design e responsável pela fábrica. Eles disseram que poderiam produzir três jogos, pois tratava-se de uma obra artística e que não seria viável um produção em larga escala. Foi um grande aprendizado para mim. Não tive problemas em aceitar o fato de que não pudesse ser produzida em larga escala, não via diferença.

Silvia: É interessante essa união de arte, design e indústria. Há muitos artistas que tentam unir várias áreas.

Laerte: Sim, o Geraldo de Barros, por exemplo, produziu objetos como cama, movéis em geral. Então, quando o pessoal da Vista Alegre viu o projeto, disse que não seria viável, pois tratava de um trabalho de escultura e não poderia ser tratada como uma peça de decoração ou utilitária. Então, eles me promoveram do ID Pool 
para o EVOC que é um projeto para artistas mais experientes, mais velhos, que já tem uma carreira. Desenvolvi uma escultura em porcelana, o biscuit, sem esmalte. Fiz seis esculturas, os moldes, os positivos em gesso e outros moldes para entrar na linha produção. Permaneci lá trabalhando durante um mês na oficina de modelagem da fábrica.

Nem todos os trabalhos produzidos nas residências vão para linha de produção, pois existe a questão de custo envolvido. Pode ser que meu trabalho entre em linha de produção o ano que vem ou não.

Silvia: É muito importante essa parceria indústria e artista - o que deveria ocorrer mais aqui no Brasil também.

Laerte: Sim, é verdade. O SESI agora vai lançar um programa de residência, não sei como vai ser, mas serão selecionados artistas para trabalhar em empresas e indústrias.

Silvia: Só para retomar aquilo que estávamos falando sobre os seus trabalhos e processo criação, você acaba partindo de algo novo e até desconhecido e você vai atrás de conhecimento e meios para atingir seus objetivos.

Laerte: O projeto das armas, por exemplo, era para ser uma exposição de armas de verdade. Contatei uma delegada para viabilidade ao acesso às armas legalmente, mas seria muito complicado. Nunca pretendi conseguir pelo jeito ilegal, comprando arma, pois vai contra os meus princípios. Acabou sendo armas de brinquedo, mas sempre respeitando o tempo do trabalho. E vendo o trabalho pronto, agora vejo que é interessante o fato ser armas de brinquedo, pois abre para várias outras questões. Eu andei muito para conseguir essas armas, muitas lojas não vendem armas de brinquedo.

Silvia: Você optou por serem armas de brinquedo e depois você decidiu que seria em cerâmica?

Laerte: Não, sempre pensei que deveriam ser em cerâmica. Queria um painel com armas negras e outra com armas em branco, seguindo a mesma ideia do Acesso Negado. 
Pensei bastante sobre a questão da branca e negra. Então, decidi que o esmalte seria preto, mas o título seria Arma Branca e por quê? Porque não tem fogo. A faca é uma arma branca. Escolhi este título porque essas armas não têm poder fogo nem disparo. O titulo é importante para o trabalho. Cada arma teve uma tiragem de três cópias. Outro painel tem 100.

Silvia: E as armas foram modeladas?

Laerte: Não, tirei molde a partir das armas de brinquedos. Tem outro lado meu também, eu coleciono brinquedos, tipo Playmobil, por exemplo, entre outros.

Silvia: De fato, as formas dos seus trabalhos remetem também aos brinquedos. A série Sobre Rodas lembra brinquedos.

Laerte: Sim, os meus trabalhos têm muita relação com os brinquedos. Voltando aos painéis, a série Arma Branca possui um painel com 100 armas. E como são vendidos esses trabalhos? São vendidos inteiros. No caso do projeto $50 \%$ off é um trabalho só, não é vendido separadamente. Hoje em dia, eu não vendo os trabalhos separados, mas existem algumas galeria que possuem obras avulsas, mas o que está sendo produzido hoje em dia é um trabalho só, que é um painel só ou uma instalação. Acredito que os trabalhos devam se manter em blocos. No caso do acampamento, uma das edições é vendida separada, em subséries e outras duas o grupo inteiro. Um dos grupos será doado o MARCO (Museu de Arte Contemporânea do Mato Grosso do Sul). E eu costumo doar algum trabalho para o museu que estou expondo fora do eixo Rio-São Paulo, como o trabalho que foi para Belém. Acredito que seja importante incentivar museus fora desse eixo a ter doações de Arte Contemporânea.

Silvia: Acredito que todos se beneficiem: o artista, o museu e o público.

Laerte: Há outro problema: o Brasil é muito grande. Teve lugares que eu queria expor trabalhos, fazer doações, projeto e eu não consegui, pois não atendem nem o telefone ou nem respondem um email. Talvez por não compreenderem a importância dessa troca. 
Atualmente tenho muito trabalho a fazer. No momento, estou trabalhando no $50 \%$ off, fazendo a fundição dos tênis, queima e pintura. É um processo demorado e ocorrem alguns acidentes e perdas.

Silvia: Você consegue ver essa série e as demais em outros materiais?

Laerte: Sim, em madeira, acrílico ou vidro. No entanto, atualmente estou focado na cerâmica porque, assim como havia dito, gosto do material e acho que depois de esmaltada é um material extremamente tátil. Não dá para ver somente com os olhos, você tem vontade de tocar. Isso porque é um material que faz parte do nosso cotidiano como o azulejo, o vaso sanitário. É cerâmica, assim como a pia, a xícara e o prato.

Agora, quando vemos uma escultura, que é uma coisa que está fora desse contexto, é algo que conseguimos entender direito. Por que será que mesmo sendo um material tão familiar, quando você depara com uma escultura isso nos causa um estranhamento? Sendo um material comum, do dia-a-dia, quando é uma escultura, que está fora desse contexto, isso chama a atenção. 


\subsection{Marco Paulo Rolla (São Domingos do Prata, Minas Gerais, 1967) : Simbologias, drama humano e o cotidiano}

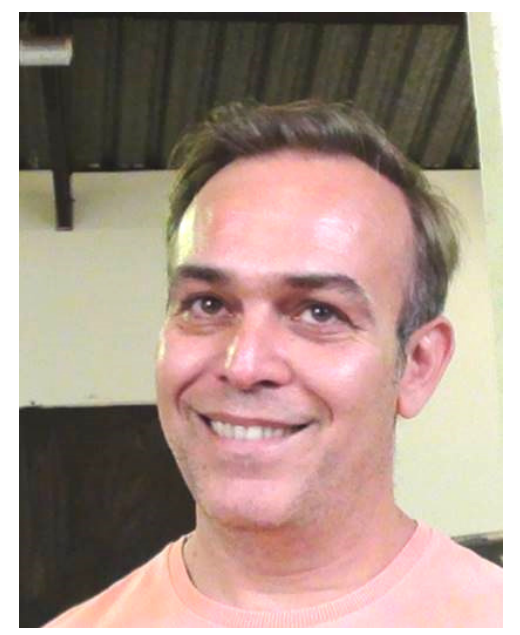

Marco Paulo Rolla é um artista visual que transita pelas áreas da cerâmica, pintura, gravura, escultura, performance e vídeo. Antes de construir sua carreira na área das Artes Visuais, Rolla era pianista clássico. No entanto, Rolla desejava mais, queria expandir suas possibilidade e criar. Então, partiu para o Teatro e Dança e improvisação musical, que o permitiu adquirir ferramentas para seus trabalhos com o corpo em suas performances. Mais tarde, decide partir definitivamente para as Artes Visuais onde encontrou espaço para a sua expressividade.

"Quando entrei na Escola de Belas Artes da UFMG, eu já tinha um conhecimento muito bom de John Cage, Bob Wilson, essa ligação da Arte e outras mídias. Eu acho que a vida foi colocando situações na minha frente em que eu fui engolindo. Foi sempre problema um gostar de tudo ! Na época da faculdade, eu experimentei novas possibilidades. Ao invés de utilizar guache de marca, eu usava café e papel de embrulhar pão para pintar, por exemplo." 183

\footnotetext{
${ }^{183}$ Trecho da entrevista Marco Paulo Rolla concedida à Silvia Tagusagawa
} 


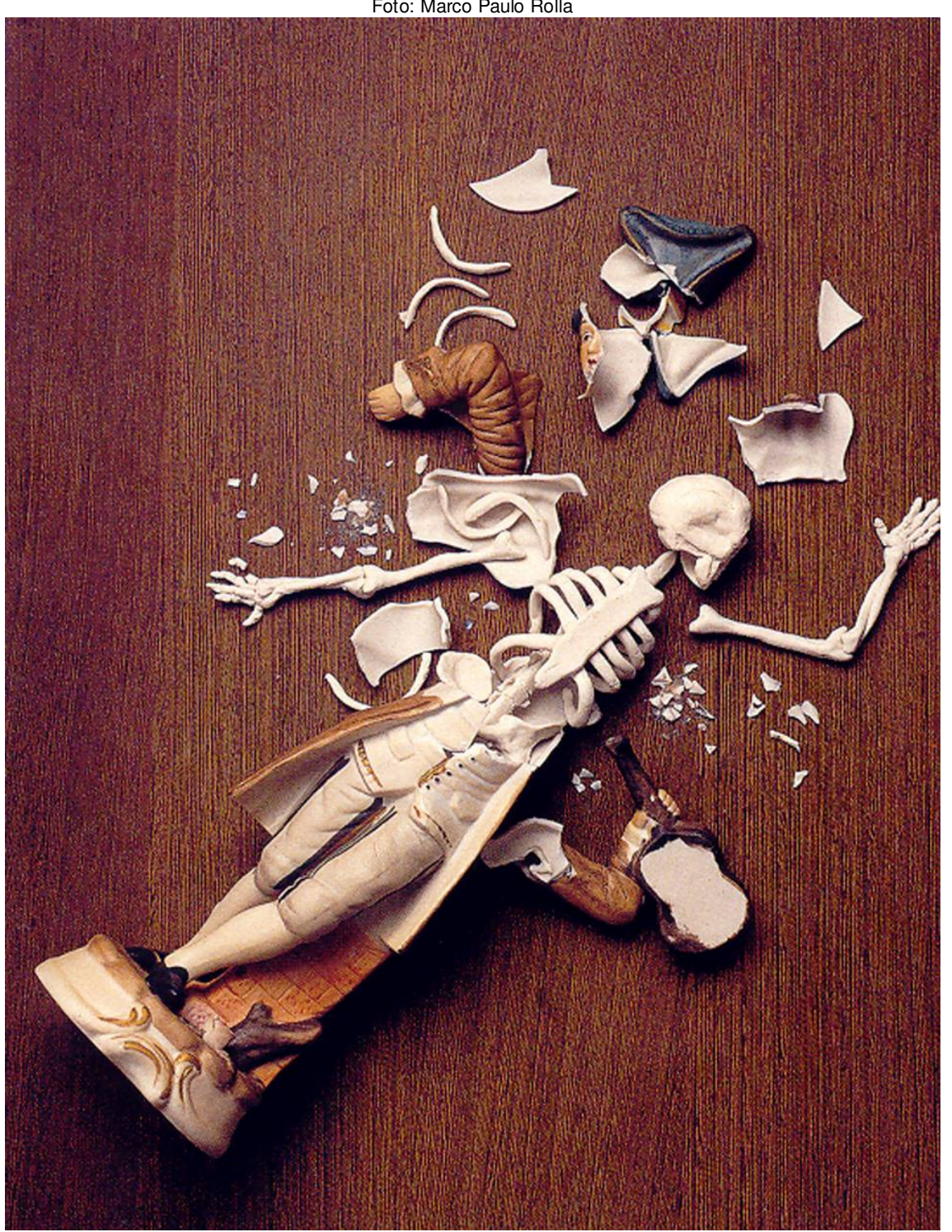

Figura 120

Marco Paulo Rolla

Oráculo

Peças em cerâmica e porcelana esmaltada 1999

O cotidiano, os sentimentos, os prazeres passageiros, as dores e a banalidade ligadas ao ser humano estão presentes em seus trabalhos:

"Desejo, em minha obra, desenvolver um discurso em que fique clara a pluralidade do ser do humano, qualquer tipologia física, pensamentos, filosofias, políticas, identidade sexual, desejos 
materiais, ações, clichês como parte de uma totalidade. Um corpo como forma e linguagem." "184

Suas obras são carregadas de dramaticidade e Marco Paulo Rolla recorre à figuração para se expressar tanto na pintura, nos seus tridimensionais como também em suas performances:

"Acho que ela (a figuração) me possibilita transitar entre a performance e as imagens do corpo dramático. O corpo é a morada do ser.[...] Para mim, o mundo é figurativo, concreto apesar de podermos transgredi-lo, ritualizá-lo e distorcê-lo, até o abstrato que muitas vezes figura o invisível"185

[Ele ainda acrescenta:]

"Em minhas pinturas também mantenho essa intenção de representar do modo mais realista possível os corpos e os objetos para provocar um espelhamento de imagens da realidade." $" 186$

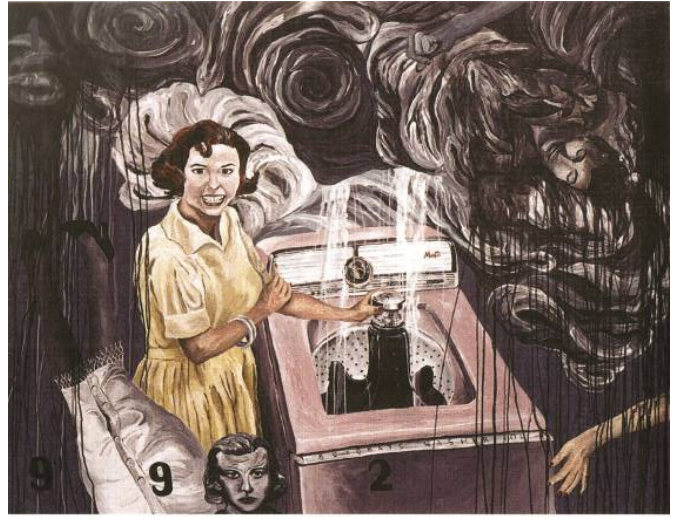

Figura 121

Marco Paulo Rolla

A máquina de lavar

Série Eletrodomésticos

$160 \times 206 \mathrm{~cm}$ 1992

Acrílica sobre tela

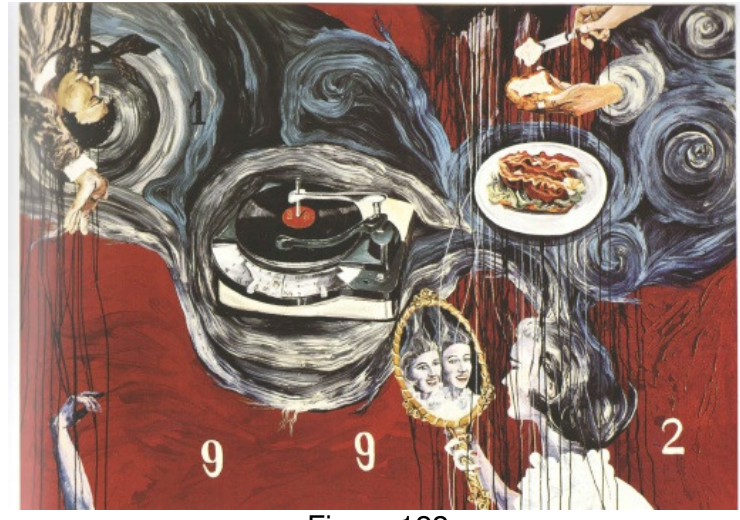

Figura 122

Marco Paulo Rolla

A eletrola

Série Eletrodomésticos

$160 \times 230 \mathrm{~cm}$ 1992

Acrílica sobre tela

${ }^{184}$ ROLLA, Marco Paulo. O corpo e o material: uma reflexão social do desejo na vida através da arte. Dissertação de mestrado apresentada à faculdade de Belas Artes da Universidade Federal de Minas Gerais, 2006, p. 16.

${ }^{185}$ ROLLA, Marco Paulo, HILL,Marcos e TEJO, Cristiana. Vertigem. Belo horizonte: Centro de experimentação e informação de arte, 2012. p. 130

${ }^{186}$ ROLLA, Marco Paulo. Op. cit., 2006, p.57. 
Sobre a série de pintura Eletrodoméstico, diz:

"Para mim, esses antigos objetos transmitem a sensação de venderem um futuro, no entanto, esse futuro já foi vivido. [...] além de tentar vender um futuro, eles surgiram como uma forma de manipular a sociedade, atrair a mulher e por isso possuíam formas que transmitiam a sensação de serem produtos poderosos e com uma cara de supersônico, como se isso fosse resolver os problemas da vida" ${ }^{187}$

Após o período de faculdade, ganhou bolsa da Fundação Vitae e apoio do Ministério da Cultura ( $\mathrm{MinC}$ ) para fazer residência na Rijksakademie van Beeldende Kunsten, Amsterdã, de 1998 a 1999. Lá desenvolveu trabalhos com performance, desenho e pintura.

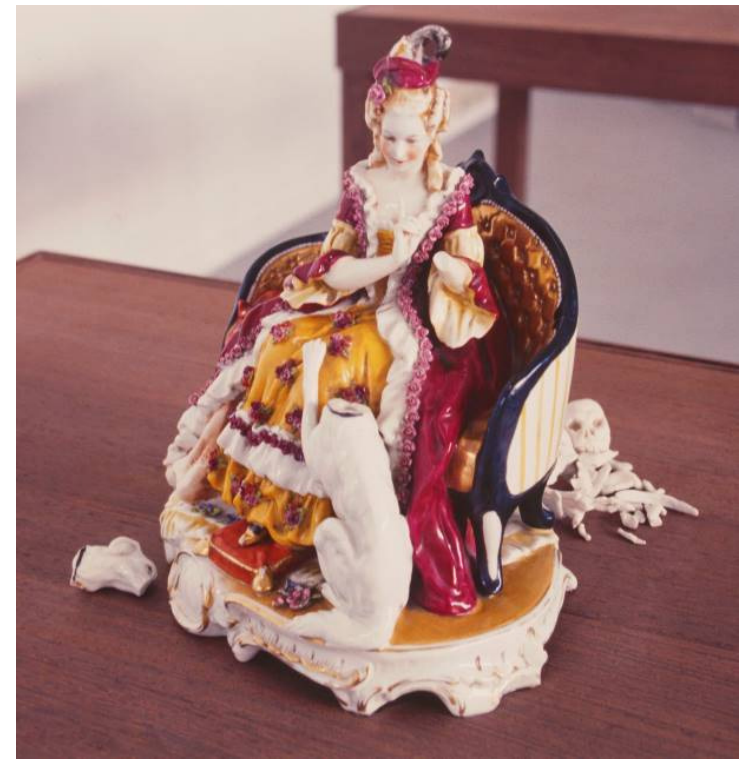

Figura 123

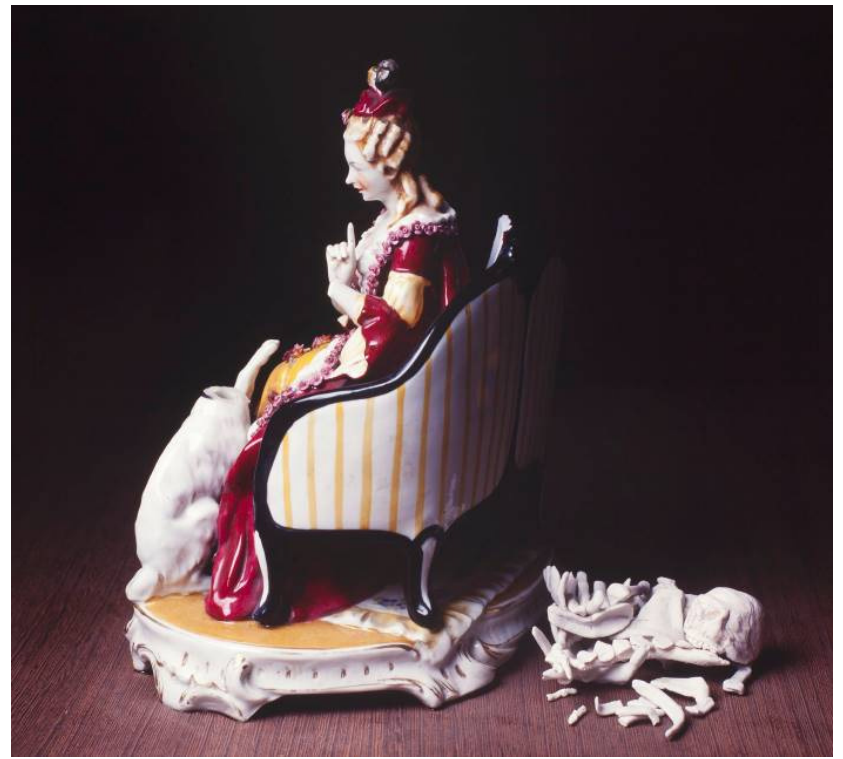

Figura 124

\footnotetext{
Marco Paulo Rolla

Da série Oraculo, 1999

Porcelana pintada

$60 \times 71 \times 75 \mathrm{~cm}$
}

Durante o período em que esteve na Holanda, ficou encantado com as obras de arte presente nos museus holandeses. Marco Paulo Rolla visitava frequentemente o Rijkensmuseum, que abriga um rico acervo de pinturas, esculturas

\footnotetext{
${ }^{187}$ Trecho da entrevista de Marco Paulo Rolla concedida à Silvia Tagusagawa.
} 
e objetos decorativos datados do período medieval em diante. Encantava-se principalmente com os utilitários e mobiliários dos séculos XVII e XVIII, desde pratarias até as porcelanas. Para ele, tais objetos estão relacionados ao cotidiano e ao comportamento humano de uma época.

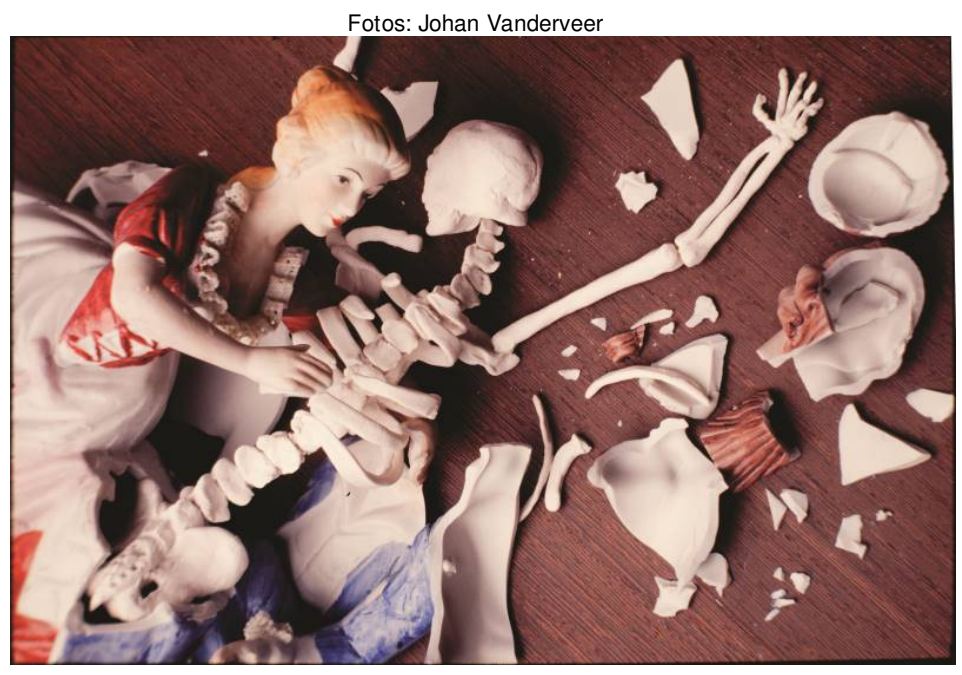

Figura 125

Marco Paulo Rolla

Oráculo, 1999

$64 \times 212 \times 150 \mathrm{~cm}$

Cerâmica esmaltada 1999

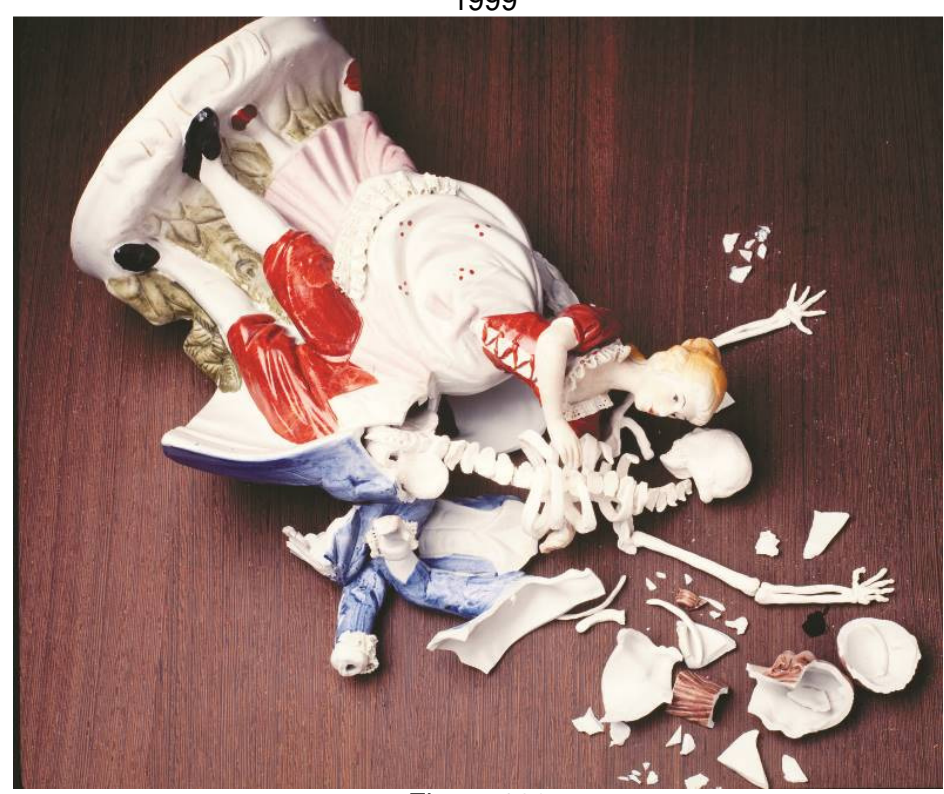

Figura 126

Marco Paulo Rolla

Oráculo

$75 \times 60 \times 71 \mathrm{~cm}$

Bibelô em porcelana

1999 
Marco Paulo Rolla pôde pesquisar e refletir sobre a relação que tem seus trabalhos com o Barroco, Maneirismo e Rococó, principalmente na maneira de retratar com dramaticidade:

"Uma das fortes características do Maneirismo é fazer uso da composição para criar efeitos de movimentos que funcionam dramaticamente e vão construindo perspectivas espaciais na imagem. Esse é um dos pontos em que detecto uma conexão com o trabalho que desenvolvo. Buscar a sensação do movimento é uma característica muito importante de minha obra, usada para provocar uma sensação viva."188

Um dos meios em que Marco Paulo Rolla atua com frequência é a performance. Recurso que utiliza para expressar os dramas humanos e a experiência de vida:

"Hoje a performance é, talvez, uma das técnicas artísticas que mais consegue provocar esse impacto na sociedade, porque trabalha com a matéria corpo e muitas vezes expõe a carne em situações a criar simbologias e analogias, muitas vezes ainda vistas como tabus." 189

Ainda no período que se encontra na Holanda, Rolla une todas as suas experiências adquiridas Pintura e performance para construir a primeira obra tridimensional da série Oráculo. Trata-se de uma escultura em cerâmica esmaltada que representa uma figura masculina do século XVIII :

"Essa série, desde o início, chama-se Oráculo por causa deste sentido de segredo, do segredo humano, que é a nossa caveira e que iguala a todos nós. Há o sentido do oráculo que também revela o segredo. É uma ironia que a morte é o futuro que todos têm. É um futuro que ninguém foge".

\footnotetext{
${ }^{188}$ ROLLA, Marco Paulo. O corpo e o material: Uma reflexão social do desejo na vida Através da arte. Dissertação de mestrado apresentada à faculdade de Belas Artes da UFMG, 2006. p.31

${ }^{189}$ Idem, p.55
} 
A primeira escultura cerâmica Oráculo foi motivação para dar prosseguimento a outras séries. O seu interesse e curiosidade pelos objetos em porcelana foi motivador para a sua pesquisa com bibelôs em porcelana. Aliás, Marco Paulo Rolla interessa-se pelos símbolos presentes nestes pequenos objetos, pois para ele, estão relacionados com o cotidiano:

"Para mim, a porcelana é um material do cotidiano e possui uma afetividade, algo amoroso e popular. É o objeto cerâmico mais comum na sociedade. Quando eu tive a ideia que quebralas, imaginei aquela reação das pessoas ou da vovó: "Nossa! Que dó!" Essa relação de "amorzinho" pela coisa."190

Posteriormente, foi convidado pela EKWC (European Ceramic Workcentre), na Holanda, a participar de uma residência artística, onde desenvolveu uma instalação cerâmica. Nesta instituição teve a oportunidade de aprimorar seus conhecimentos técnicos da Cerâmica.

Em 2006, Marco Paulo Rolla desenvolveu em sua dissertação de mestrado um memorial descritivo de suas obras, fazendo relação com algumas correntes artísticas. Ele traça um paralelo entre o desenvolvimento de suas poéticas artísticas e as ações ocorridas nessa história, buscando entender a contemporaneidade como uma causa ou um resultado de cada realidade.

${ }^{190}$ Trecho da entrevista de Marco Paulo Rolla concedida à Silvia Tagusagawa. 


\subsubsection{Poética de Marco Paulo Rolla}

Foto: Johan Vanderveer

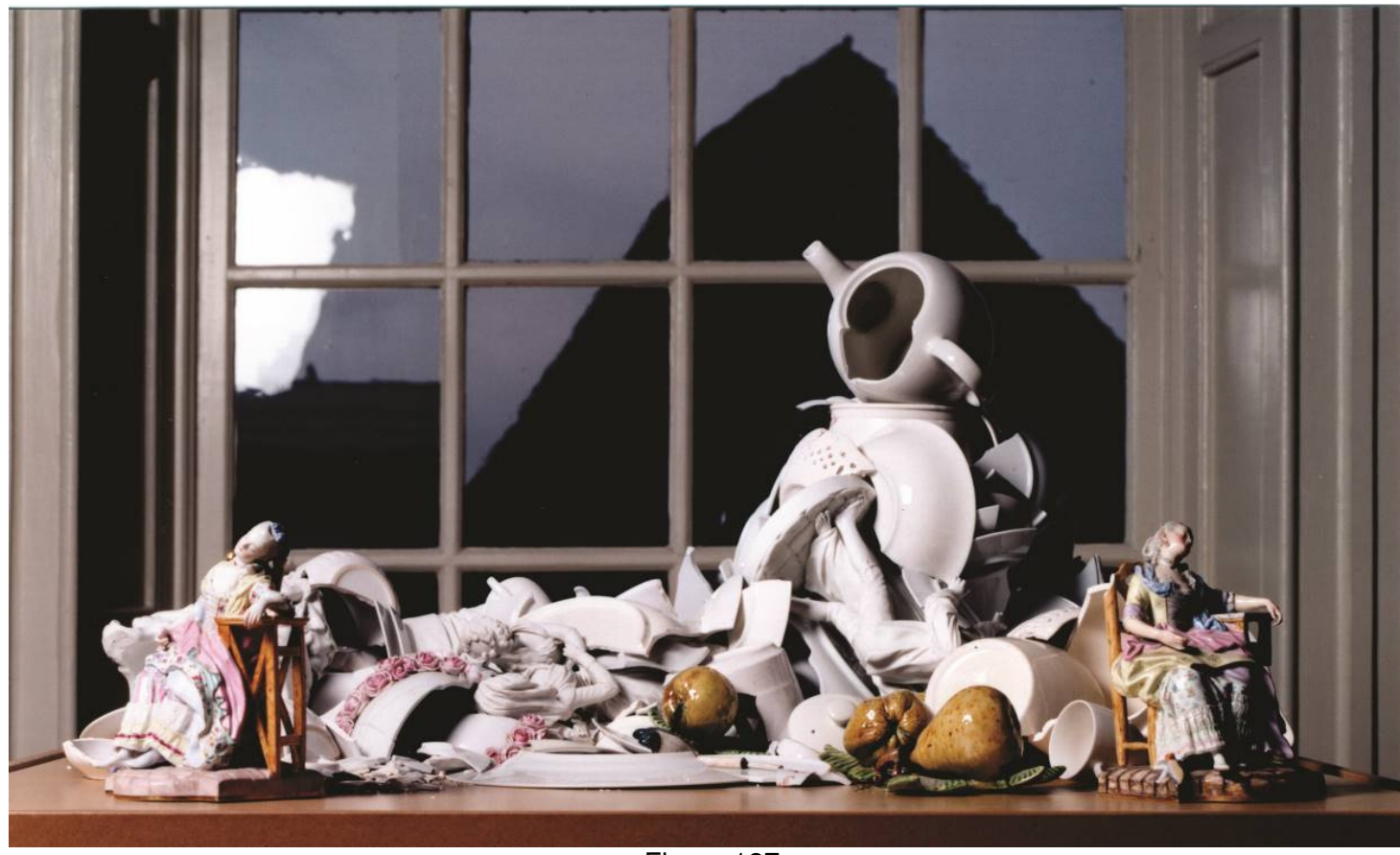

Figura 127

Marco Paulo Rolla

Vanitas

Instalação: louças quebradas e bibelôs de porcelana pertencentes ao museu de cerâmica de Leeuwarden, Holanda

1999

Marco Paulo Rolla trabalha de maneira diversa dentro da cerâmica, recorrendo ás técnicas de modelagem, esmaltação e também se apropriando de objetos industrializados em porcelana para materializar sua poética.

O que chama a atenção nas obras de Rolla é a maneira como se apropria de tais peças para construir sua poética, mais conhecidas como bibelôs, principalmente aquelas que rementem às figuras do século XVIII. Aliás, no século XVIII, a porcelana era muito apreciada, principalmente, pela elite europeia e países como Alemanha, Inglaterra e Holanda foram grandes produtores destes produtos. Rolla acrescenta:

"Assim como alguns objetos de casa, os bibelôs são os objetos mais conhecidos e consumidos, que no processo de industrialização, criou-se um estigma de objetos de baixa qualidade. Isso também aconteceu com a simbologia que existe nelas. Elas são cheias de simbologias e se você olhar no 
mundo antigo existe coisas que ainda temos que refletir sobre o Humano"191.

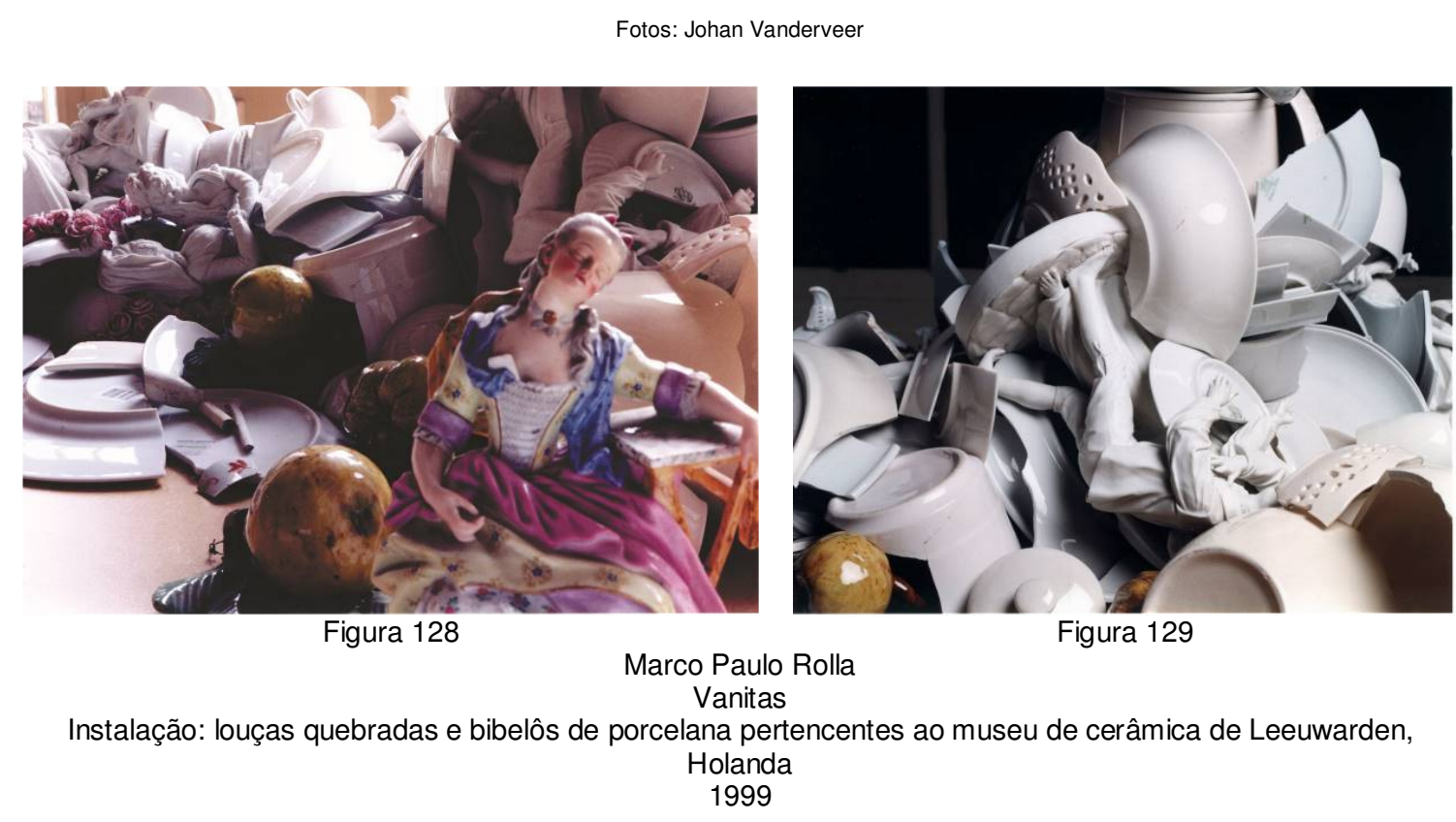

Segundo, Erin J. Campbell, o século XVIII foi o período denominado "a Idade da Porcelana" na Europa. As peças comercializadas nesta época estavam próximas ao estilo Rococó ${ }^{192}$. De acordo com Howart Coutts $^{193}$, as primeiras figuras em porcelana, conhecidas como bibelôs, produzidas na Europa são datadas aproximadamente de 1735 e foram fabricadas no principal polo de porcelana em Meissen, Alemanha, desenvolvidas por Johann Joachim Kändler que retratavam personagens do teatro cômico, como o Arquelim, por exemplo.

Outros países como a França, Holanda e Inglaterra, também aderiram à moda de criar bibelôs em porcelana, muito similares aos de Meissen, sendo que temas alegóricos tornaram-se cada vez mais populares. Além de personagens teatrais, grupos de deuses e deusas, representações das Quatro Estações e dos Cinco Sentidos eram comuns. O século XVIII também foi cenário para o desenvolvimento de novos estilos pictóricos, sendo que as cenas criadas pelo pintor francês Jean-

\footnotetext{
191 Trecho da entrevista de Marco Paulo Rolla concedida à Silvia Tagusagawa.

192 CAVANAUGH, Alden; YONAN, Michael E. org. The cultural aesthetics of eighteenth- century porcelain. Guildford: Ashgate Publishing Limited, 2010, p.87.

${ }_{193}$ COUTTS, Howard. The art of ceramics: European ceramic design 1500-1830. New York: Yale University Press, 2001, p. 97.
} 
Antoine Watteau (1684-1721) foram grandes inspirações para a elaboração de figurações e bibelôs em porcelana.

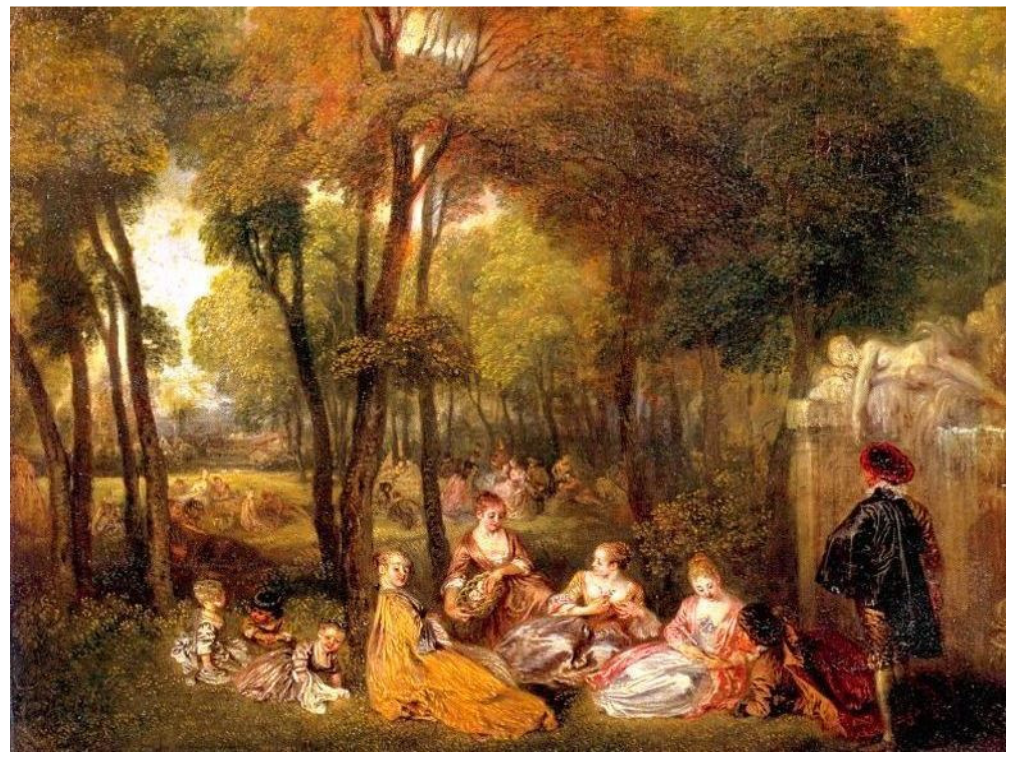

Figura 130

Antoine Watteau (1684 - 1721)

Fête galante in a Wooded Landscape (França)

$1719-1721$

Oil on canvas

$127.2 \times 191.7 \mathrm{~cm}$

Foto: http://wallacelive.wallacecollection.org/ (01/12/2014)

Rolla diz:

"Fiquei muito interessado nas simbologias dessas figuras, dos bibelôs, e que muito têm a ver com as pinturas de Watteau e com a Natureza Morta, que são cheias das mesmas simbologias ligadas à vacuidade, da eroticidade e da busca. Tanto nos bibelôs como nas pinturas holandesas, há a figura do músico e seus elementos que para mim estão relacionados ao prazer passageiro." ${ }^{194}$

Assim, Marco Paulo Rolla interfere sobre a peça de porcelana e como numa performance a quebra com uma ponta metálica e martelo, criando cenas de grande dramaticidade.

${ }^{194}$ Trecho da entrevista de Marco Paulo Rolla concedida a Silvia Tagusagawa. 
Fotos: Marco Paulo Rolla

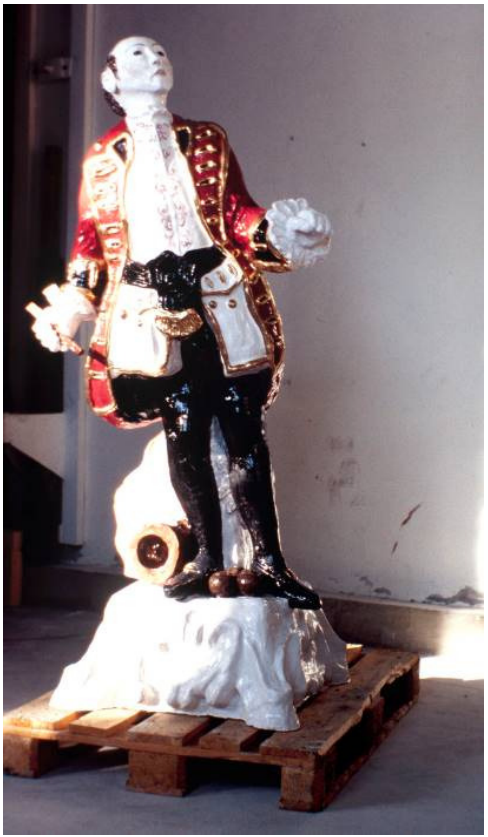

Figura 131

Marco Paulo Rolla

Oráculo

Cerâmica com vidrados

Alta Temperatura

1999

Primeira peça em cerâmica da série Oráculo

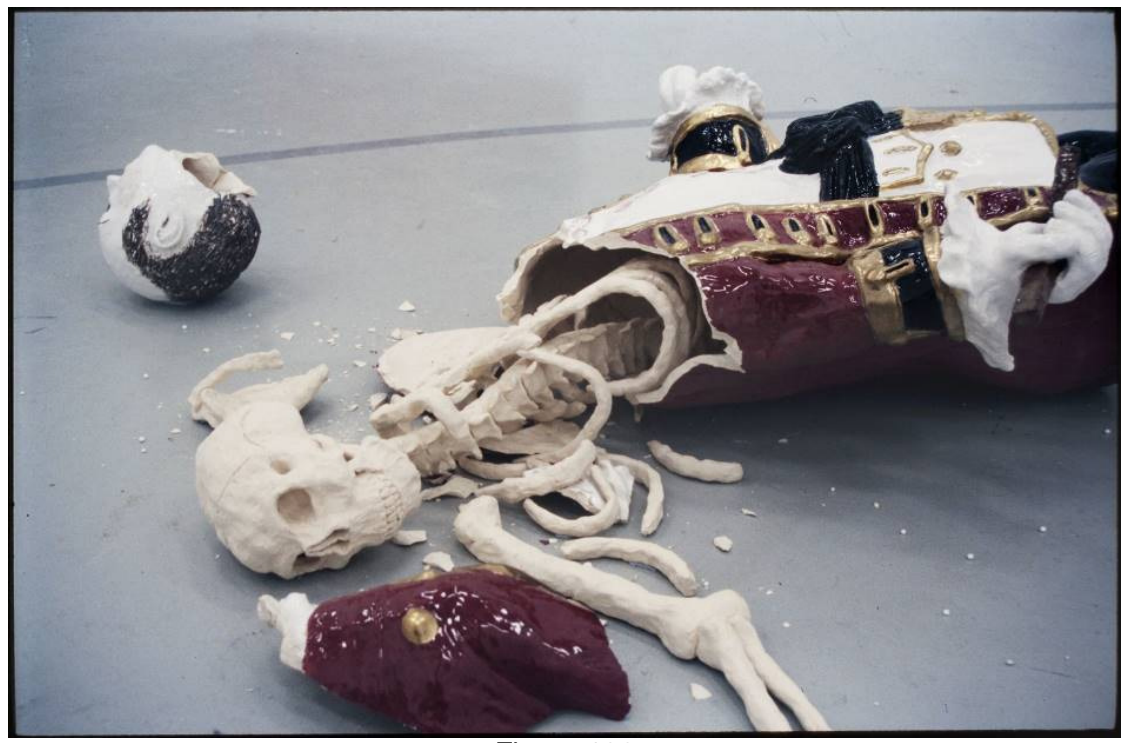

Figura 132

Marco Paulo Rolla

Oráculo

Cerâmica com vidrados

Alta Temperatura

1999

Primeira peça em cerâmica da série Oráculo 


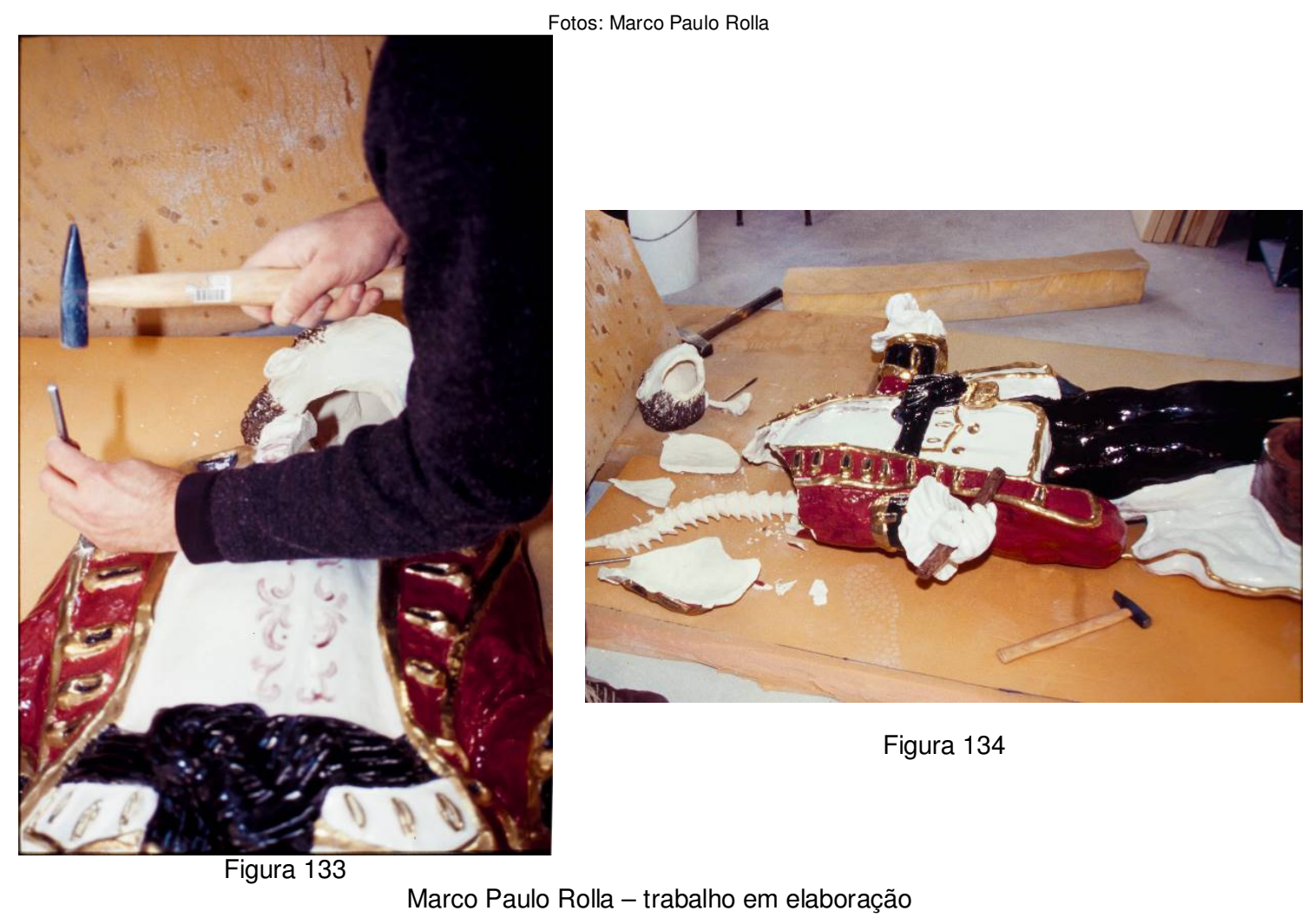

"O material faz parte do conceito. Em outra técnica seria ruim, seria falso. Quando você se aproxima de uma técnica, de um material, aquilo Ihe trará uma série de outras ideias. Talvez ela até influencie em outras técnicas." 195

Marco Paulo Rolla traz suas experiências vividas com a Pintura em toda a sua trajetória artística. Assim, utilizou este potencial para a realização da instalação em cerâmica chamada Pic Nic. Esta instalação foi desenvolvida durante a sua residência na EKWC (European Ceramic Workcentre). Marco Paulo Rolla o desenvolveu através da modelagem manual em placa, rolo e bloco, além de molde de gesso. Depois de biscoitada as peças foram pintadas com vidrados cerâmicos. $O$ maior desafio era adequar as cores imaginadas para as cores presentes nos vidrados cerâmicos:

\footnotetext{
${ }^{195}$ Trecho da entrevista de Marco Paulo Rolla concedida à Silvia Tagusagawa.
} 
"Sou guiado muito pelos testes de esmaltes para eleger as cores mais adequadas aos trabalhos. A técnica da Cerâmica exige isso. Por exemplo, o vermelho, antes da queima é um pó branco. Há uma aliança entre uma sensibilidade pictórica e os testes, mesmo assim, existe certo grau de cegueira, ou seja, só vou saber depois da queima. O bolo de chocolate do Pic Nic, antes da queima, era verde!"196

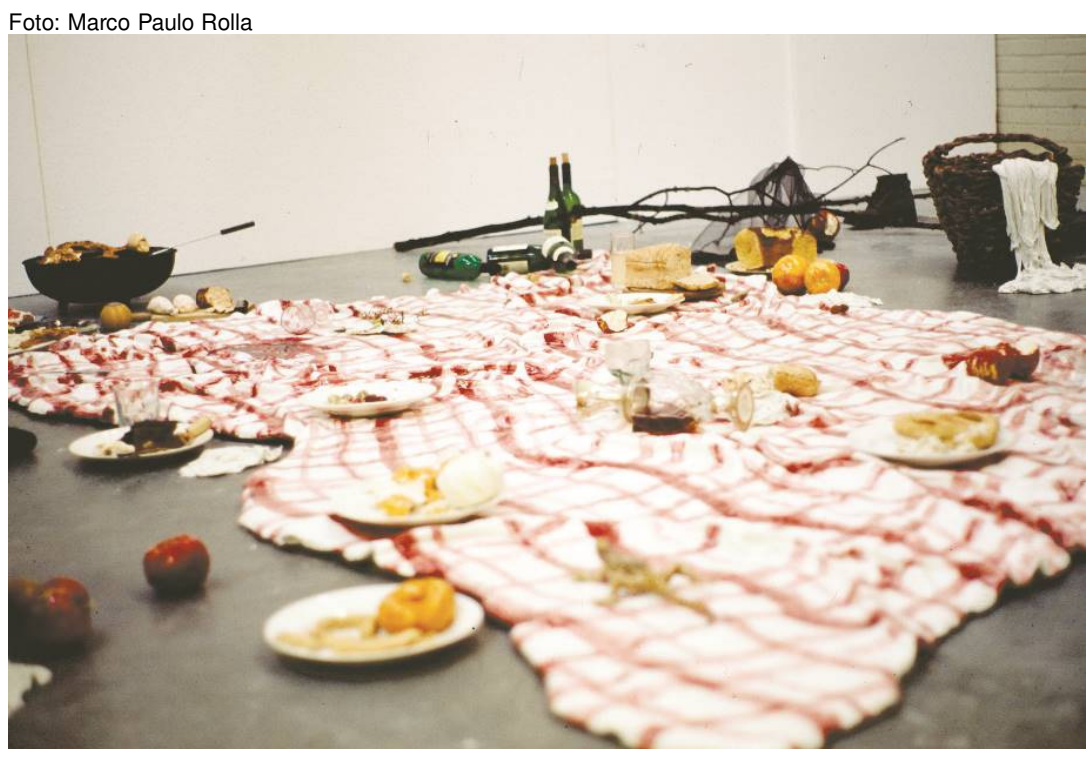

Marco Paulo Rolla

$\mathrm{Pic} \mathrm{Nic}$ $400 \times 350 \mathrm{~cm}$

Cerâmica esmaltada e objetos 2000

Figura 135
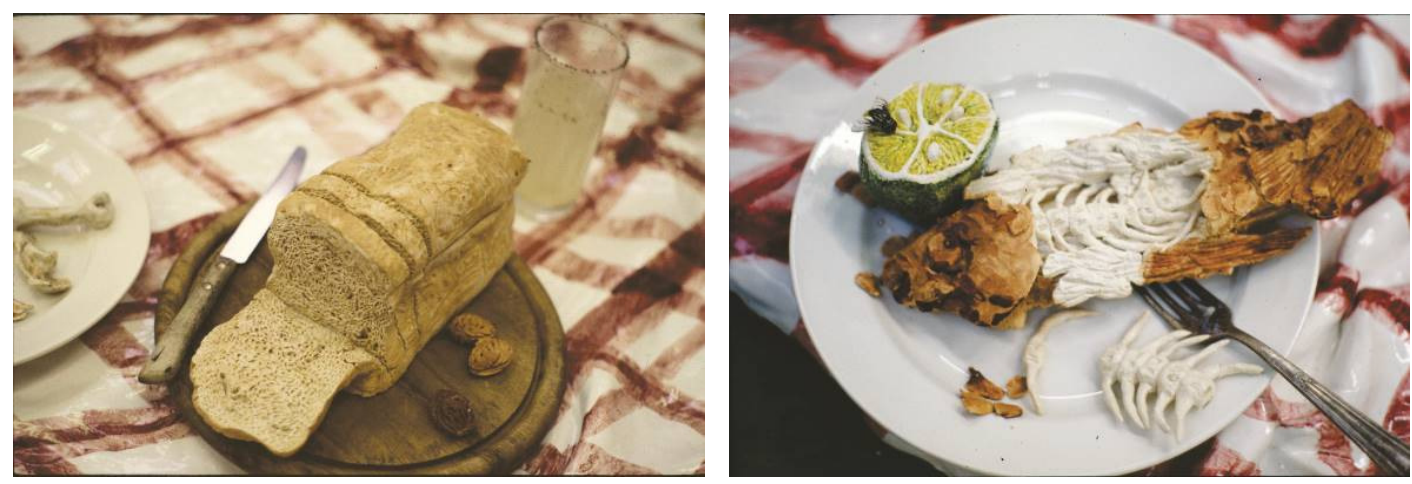

Figura 136

Marco Paulo Rolla

Pic Nic (detalhes)

$400 \times 350 \mathrm{~cm}$

Cerâmica esmaltada e objetos

2000

EKWC

196 Trecho da entrevista de Marco Paulo Rolla concedida à Silvia Tagusagawa. 
O aprimoramento técnico na cerâmica faz com que Marco Paulo Rolla dê seguimento a outros projetos como é o caso das obras compostas pela série Vanitas, onde constrói peças hiper realista retratando pedaços de carne fazendo referência aos encartes de supermercado. Rolla diz :

"O interessante é que essas carnes aparecem "enfeitadas", assim como os bibelôs. O que me motivou a fazer essas carnes cruas foi essa ideia de criar um objeto decorativo, utilizando essa ideia da porcelana como algo relacionado ao luxo, como um objeto de consumo. Eu queria criar algo que se pudesse ser visto, usado e comprado, assim como os objetos de decoração. A pintura também é feita com a tinta para porcelana. Essas alfaces me remetem as rocalhas barrocas" ${ }^{\prime 197}$

O que chama a atenção é a maneira como os vidrados são aplicados. Após modelar e biscoitar, Rolla acrescentou vidrados.

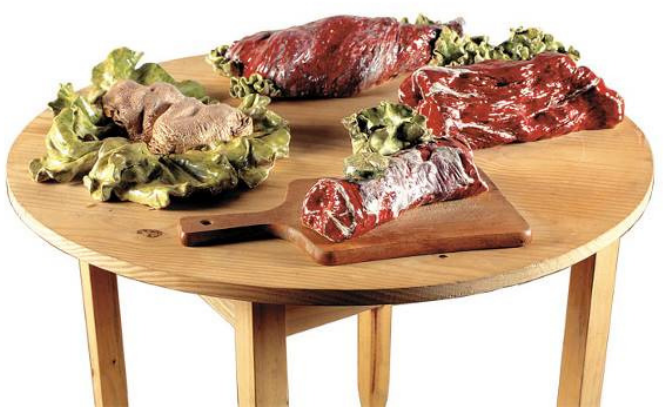

Figura 137

Marco Paulo Rolla Vanitas - Mesa de carne Cerâmica esmalta e mesa de madeira 2003

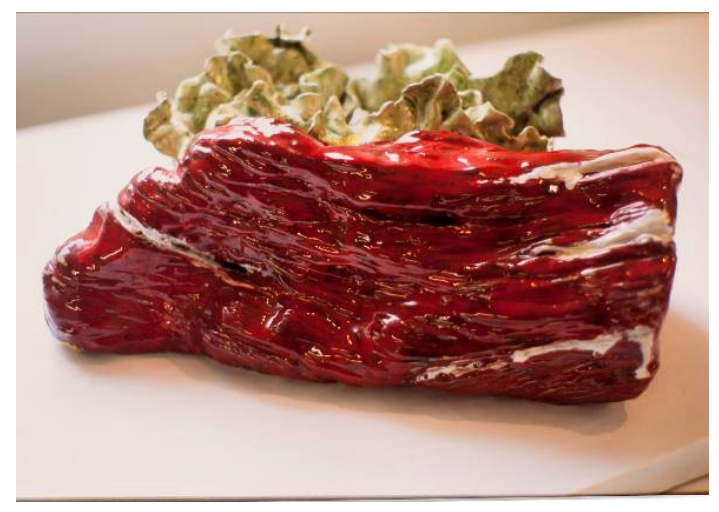

Figura 138 Marco Paulo Rolla Vanitas - Filé de Alcatra Cerâmica esmalta e mesa de madeira 2003

\footnotetext{
197 Trecho da entrevista de Marco Paulo Rolla concedida à Silvia Tagusagawa.
} 


\subsubsection{Entrevista com Marco Paulo Rolla (Belo Horizonte, 22/05/2013)}

Silvia: Em sua dissertação de mestrado, você inicia com a história, cujo título é O menino guloso, que deseja experimentar de tudo e explorar o mundo. Na verdade, este menino seria você mesmo. Essa relação com a Arte vem desde a infância?

Marco: Acho que sim. Minha mãe pintava, era muito habilidosa, mas não teve a oportunidade de estudar Artes. Além de pintar, ela tocava piano. Inclusive, nós aprendemos a tocar piano também.

Com uns sete anos de idade, a minha irmã começou a ter aulas de piano. Então, um belo dia, eu me sentei ao piano e comecei a tocar o que ela tocava. Eu tinha cinco anos de idade e a minha família entendeu que eu também deveria estudar piano, mas aos sete, a professora me abandonou, pois eu não seguia o seu método. Dos sete aos treze eu ficava tirando as músicas de ouvido e tocava.

Eu venho do interior e tive contato com o barro na infância. Recentemente, eu estava trabalhando com a porcelana, veio lembranças da infância. Em casa, havia uma eletrola e lembro-me que eu construí uma parecida. Esse objeto aparece em vários trabalhos meus, na pintura e até performance.

Quando eu era criança, experimentei várias coisas e teve um dia em que construí umas coisas com barro, pintei com tinta de tecido e tentei queimar no forno da cozinha.

Silvia: Conte-me sobre a sua formação artística.

Marco: Quando eu mudei para Belo Horizonte, entrei para uma escola de música para estudar piano clássico e fiquei lá até os vinte e dois anos. Eu tinha um dom para a música, mas não tive um professor ou um sistema que me ajudasse a criar no piano, ou me liberar da técnica. Então, eu tive a sorte de encontrar o Eduardo Guimarães Alvares, que tinha um grupo de músicas cênicas, vocal e de improvisação. Eu aprendi demais com ele. Eu acho que toda noção de composição que aprendi foi adquirida com esse grupo. Toda essa acuidade e ironia com o mundo vêm desse grupo também. Ele faleceu em 2013 e era jovem. Eu tenho certeza que é dali que veio tudo o que sou hoje. 
Quando entrei na Escola de Belas Artes da UFMG, eu já tinha um conhecimento muito bom de John Cage, Bob Wilson, essa ligação da Arte e outras mídias. Eu acho que a vida foi colocando situações na minha frente em que eu fui engolindo. Foi sempre problema um gostar de tudo ! Na época da faculdade, eu experimentei novas possibilidades. Ao invés de utilizar guache de marca, eu usava café e papel de embrulhar pão para pintar.

Durante a faculdade, tive uma professora de litogravura e um professor de desenho que contribuíram muito para o meu desenvolvimento técnico. Ela colocava os exercícios realizados em varais e analisávamos as imagens. Era para ver o que cada trabalho transmitia e o que significava. Então, me senti motivado e fiquei encantado em pesquisar melhor a litogravura, adorava lidar com o "fantasma" que ficava na pedra e achava isso fascinante. A litogravura foi o ponto de partida para outros trabalhos bidimensionais.

Depois da faculdade, eu fui para Holanda fazer o que seria uma pós-graduação na Rijksakademie ${ }^{198}$, onde o foco é o trabalho do artista. Certa vez, eles me perguntaram, muito admirados, onde eu havia aprendido a desenhar e porque ainda desenhava daquele jeito. Posteriormente, percebi que o sistema de educação em Arte, desde a década de 70, em alguns países europeus como a Alemanha e Holanda, por exemplo, deixaram de dar prioridade ao aprendizado de Desenho e de outras técnicas básicas. Para mim, o desenho é um diferencial enorme no meu trabalho e nunca parei de desenhar. Sigo o meu olhar quando desenho ou estou pintando e gosto quando meu olho distorce as coisas. Através desta distorção eu descubro outras possibilidades. O olhar deforma a figura, ficando esquisita e eu acho isso uma riqueza.

Silvia: A sua trajetória artística é bem rica, pois você transita pela Cerâmica, pintura, escultura, vídeo e performance entre outros meios.

Marco: Meu caminho de prospecção no meio da Arte foi lento, mas nunca deixou de existir uma abertura, sempre expus meus trabalhos e o que eu consegui

\footnotetext{
${ }^{198}$ Rijksakademie van Beeldende Kunsten, Amsterdã,1998-1999
} 
foi através do meu esforço. Em 1992, me mudei para São Paulo para tentar ficar mais presente aos movimentos artísticos e era a cidade onde eu via uma profissionalização maior no campo artístico. Na minha época, não havia projetos incentivos ou bolsas destinados à jovens artistas como existe atualmente. Havia os salões onde você mandavam três trabalhos que, para mim, é um número insuficiente para avaliar ou conhecer a obra do artista. Teve uma época em que eu me voltei para a pintura e as pessoas achavam que eu só pintava. Nos anos 80 , o artista era estigmatizado se não fosse específico, pois isso dava a impressão de que se um artista utilizava muitas técnicas, ele queria atirar para todos os lados, era assim que se dizia. Na verdade, eu era assim, já trabalhava com vários materiais. Nesta mesma época, eu até escondi parte do que fazia, dando a entender que só pintava, mas isso não ajudou a colocar meu trabalho em evidência. Não significa que eu quisesse ser o superstar, mas eu queria alcançar algo e poder fazer mais pela minha Arte.

Silvia: Acho que todo artista tem esse anseio.

Marco: Hoje eu vejo que essa necessidade de se jogar na sociedade, mostrando o meu trabalho, é também uma maneira "de contaminá-los" com a minha Arte.

Compreendo que o lugar do artista é o local do questionamento à sociedade ou às coisas arraigadas na cultura. $O$ artista trabalha com esses subsídios, a sociedade e a cultura, para transmutar e descobrir outras maneiras de desenvolver o humano. No entanto, hoje a sociedade acha que o Humano é desenvolvido, sobretudo pelo fator Econômico e isso não é verdade. A riqueza intelectual, cultural e sensível são extremamente importantes para o lado Humano.

Silvia: Como você vê o cenário da Arte Contemporânea com os meios de utiliza?

Marco: Acredito que o meu trabalho confronta a Arte Contemporânea, usando técnicas tradicionais misturadas a operações contemporâneas. Porém, ele vive o contemporâneo, pois nasci e estou aqui. Não fico preocupado com que as pessoas vão pensar ou nos preconceitos que irão gerar ao verem um trabalho meu em cerâmica, por exemplo. 
Para mim, os materiais são ricos de possibilidades, há algo poderoso neles. $O$ que eu acho de mais rico nos materiais é que existem muitas possibilidades de representações e ligações históricas.

Quando toco esses materiais, como a argila, a tinta e a pedra, por exemplo, eu sei que estou me conectando com o passado. Assim acontece quando eu toco um material como a cerâmica, que está presente na nossa História e percebemos, com o tempo, a perda de seu valor e que existe um grande preconceito, assim como há sobre a pintura também por ter sido um meio que dominava o curso de uma história da arte.

Silvia: Você acha que existe, então, um preconceito? Como vê esse preconceito dentro das áreas que atua?

Marco: Sim. Existem preconceitos em todos os setores da Arte e até mesmo na dança, mas tudo vai depender da sua acuidade, do conhecimento da história que todas as mídias têm. Há um conjunto de conhecimentos, estéticos, técnicos e históricos, que contribuem para a evolução e a quebra de preconceitos.

Apesar de haver uma grande produção tanto na pintura como na cerâmica, elas são, muitas vezes, relacionadas com uma arte inferior, para os anseios da denominada arte contemporânea. Neste sentido, acredito que sou um artista corajoso, pois para mim essas coisas são o nosso cotidiano. Não nego que há "o brega" em nossa sociedade.

Silvia: Em seu catálogo Vertigem, que reúne algumas de suas obras, e na sua dissertação de mestrado, percebemos que através das técnicas, ditas "tradicionais", você utiliza uma linguagem contemporânea, quebrando essa ideia de que há limitações ao se expressar com elas.

Marco: Eu tenho uma grande atração pelos materiais que foram levados à decadência estética, na maioria das vezes de "mau gosto". Este dado cria essa dificuldade de aceitação do objeto. Acredito que esses materiais carregam uma realidade e conseguem nos aproximar de elementos sociais verdadeiramente, trazendo uma série de memórias. Não só a sociedade artística, mas também uma forte carga de estímulos vindos da sociedade em geral. Esses materiais (como a 
tela, a tinta, a argila e o próprio corpo) são portas para o Ser comum, aquele que não tem conhecimento artístico. Acho que uma pessoa vai chegar perto de determinado trabalho como a série feita com os bibelôs de porcelana quebrados, com um dó imenso, mas ele vai ver uma transformação ali. Então os materiais podem ter esse poder de cativar também. O público em geral é atraído pelo emocional.

Quanto às quebras dos bibelôs em porcelana, há uma escolha estética. No plano de ação, existe a ideia de quebrar o objeto, mas para quem vê pela primeira vez, aquilo foi um acidente. É como se fosse a memória deixada pela performance. A memória da quebra.

Silvia: Além de suas próprias vivências e visões, o público também coloca as suas próprias experiências na obra que vê na sua frente.

Marco: Sim, claro. Ele vai entrar de outra forma. Acho que uma obra está livre e tem um potencial de transformação. O conceito de uma obra, muitas vezes, não está concluída nela mesma.

Silvia: As obras são construídas com a realidade do artista e então as pessoas de fora constroem outra.

Marco: Muitas vezes, as obras me surpreendem, pois elas contam coisas que eu anteriormente não sabia. Como é o caso das pinturas da Série Eletrodomésticos em que eu faço retratos desses objetos dos anos 50. Para mim, esse antigos objetos transmitem a sensação de venderem um futuro, no entanto, esse futuro já foi vivido. Quando fiz essa série eu achava interessante e tinha uma atração por esses objetos antigos, cujo design transmite essa ideia do novo e de um futuro moderno. Tempos depois, fui analisar melhor esses objetos que estava pintando e conclui que além de tentar vender um futuro, eles surgiram como uma forma de manipular a sociedade, atrair a mulher e por isso possuíam formas que transmitiam a sensação de serem produtos poderosos e com uma cara de supersônico, como se isso fosse resolver os problemas da vida.

Claro que essas conclusões não foram obtidas imediatamente, eu fui aprendendo e escutando. Por isso acho que quando escutamos nossa intuição, 
muitas vezes, trazemos coisas que estão presentes no arquétipo social. Você faz algo intuitivamente, mas aquilo tudo já estava à sua volta, mas ainda não tem consciência. Por isso tem que ter calma, pois você não precisa entender tudo que está fazendo. Aliás, acho que se você entender de imediato, isso significa que está criando uma obra muito racional e premeditada. Acredito que o ser humano ainda tem muito a aprender, a sentir os poderes além do pensamento racional. Acho que o meu inconsciente é muito mais inteligente do que o meu racional. Ele dá ao meu trabalho algo não percebo racionalmente, como nos trabalhos com cabelos. Eles surgiram inconscientemente e que eu achei incrível: no primeiro momento, é como se a ideia e os cabelos estivessem conectados. É como se englobassem muitas realidades ao mesmo tempo. Mais tarde, entre 1998/99 outra série surgiu e que se chama de Peludos. São instalações, pinturas e esculturas que são trabalhados com cabelos sintéticos, veludo preto e pelúcias. Nesta série, eu volto para questão da máquina oprimindo o humano, subtraindo-o, como na escultura Enceradeira.

Para mim, eu não preciso trabalhar com o cabelo de verdade, são cabelos sintéticos e de plástico, do material do simulacro, contemporâneo.

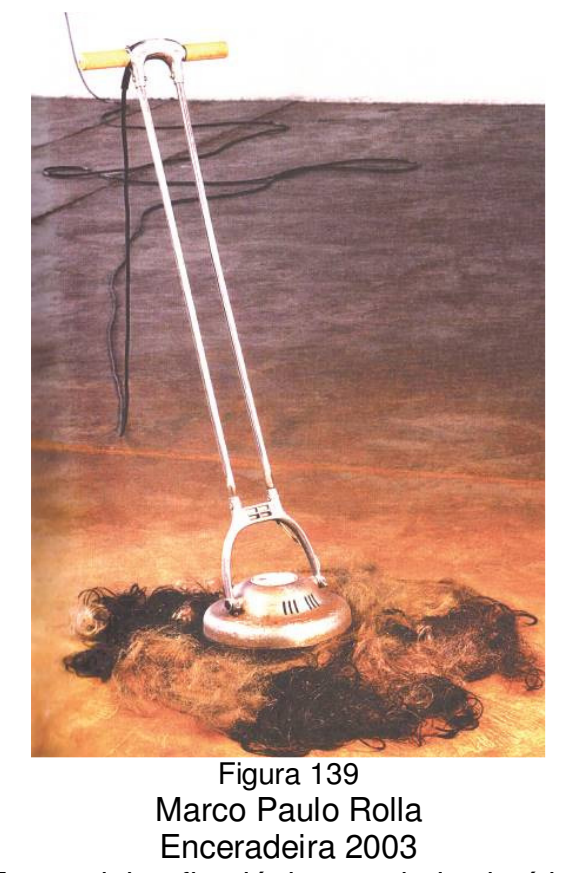

Enceradeira, fio elétrico e cabelo sintético $80 \times 180 \times 800 \mathrm{~cm}$ 
Silvia: De qualquer forma, remete ao cabelo humano.

Marco: Eu acho que o de plástico tem mais força, pois acredito que a nossa realidade é "plastificada", sendo algo que remete ao industrial na aparência. Quando estava morando em Amsterdam, encontrei algumas lojas de perucas e apliques de Surinameses, onde eu comprei apliques loiros, ruivos e pretos. Eu gosto do material sintético que remete à pele e ao mundo das coisas falsas.

Atualmente, no meu processo criação, sou mais paciente e paro um trabalho durante o processo e deixo-o sem terminar. Por um bom tempo, ele fica dormindo e respirando ao meu olhar. Depois, volto a ele. Para mim, cada trabalho tem sentido único, por mais que seja parte de uma série, isso não importa, é a coisa do artífice e essa tentativa de melhorar e aprimorar. Assim, você acaba melhorando o outro e a sociedade.

Não concordo com essa história de que o artista não deve ser importar com quem olha o seu trabalho ou que ele não tem que ser entendido. Acredito que não precisa ser entendido, mas ser sentido. Ou seja, pode ser que não seja compreendido no racional, na lógica, mas quando você faz algo artístico e pensa que não deve se importar com quem vai ver, você está sendo ingênuo. Você tem a capacidade, por exemplo, de analisar como essa pessoa vai sentir o seu trabalho, se pondo no lugar dela. Isso é uma técnica muito utilizada no teatro e na dança, onde tentamos colocar o nosso olhar lá fora e tentar imaginar neste ponto de vista.

Silvia: No seu processo de criação, como ocorre essa ligação entre a poética e a materialização dela? Ou ainda, como você adequa as técnicas e os materiais com as suas ideias?

Marco: Muitas vezes, a ideia vem exatamente para aquela técnica. De certa forma, a técnica está relacionada com o potencial poético. O material faz parte do conceito. Em outra técnica, de repente, seria ruim ou falso. Quando você conhece uma técnica ou um material, aquilo Ihe trará uma série de outras ideias e até influencie em outras técnicas. Por exemplo, nas performances, há uma série de coisas relacionadas à Pintura e Escultura. 
Além disso, a técnica é uma ferramenta para o artista e também é estímulo. Os trabalhos com os bibelôs não teriam sentido em outro material. Se fosse construído em outro material eu não teria contato com as imagens contidas neles.

Países como a Holanda e Alemanha foram grandes produtores de porcelana no século XVIII. No auge da produção, eram objetos consumidos pela Realeza e a elite. Eles fabricavam esses bibelôs em tiragens limitadas, assim como nas séries de gravuras, que eram assinados e com carimbo. Essas duas peças, apresentadas na obra Vanitas, são da mesma tiragem, mas possuem cores diferentes. São peças alemãs. Este trabalho faz parte do acervo do Museu de Cerâmica Princessehof, onde a série Oráculo inaugurou a primeira exposição de arte contemporânea no museu.

Como me interesso pelas questões e símbolos do cotidiano antigo, eu frequentava muito a Rijkensmuseum que possui um grande acervo de utilitários domésticos: pratarias, louças, etc. e eu costumava visitar a sala que tinha esses objetos da casa e havia cerâmicas incríveis. Um dia deparei com um desses trabalhos e que me encantou: um bibelô que retrata um salão de cabeleireiros que tinha três ou quatro figuras de porcelana e que estavam montando o cabelo de uma senhora usando uma escadinha! Voltei umas dez vezes lá e me perguntava como fizeram isso, com tantos detalhes, uma coisa tão delicada e dava medo de quebrar. Você conseguia ver os dedinhos o que me impressionou, principalmente a delicadeza e a fragilidade.

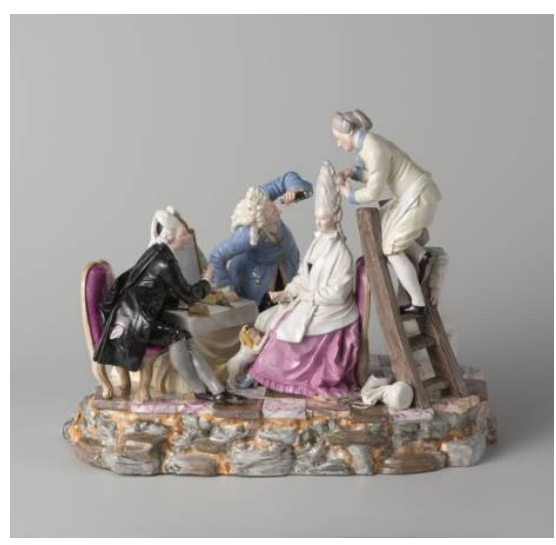

Foto:https://www.rijksmuseum.n|Acesso: 01/01/2015

Figura 140

Penteado alto Höchst, Carl Ries, c. 1780

$27 \mathrm{~cm}$ altura

Porcelana

Rijkensmuseum 
Silvia: Vamos falar um pouco dos trabalhos que você desenvolveu em cerâmica que tiveram início no final dos anos $90 \mathrm{com}$ a série Oráculo. As primeiras obras em cerâmica foram feitas na Rijksakademie?

Marco: Na verdade, a série Oráculo continua até hoje. Ela foi criada em conjunto com dois trabalhos: uma revista e um vídeo-instalação com o mesmo título.

Teve um dia em que eu encontrei com o técnico de cerâmica da faculdade (Rijksakademie) numa viagem e perguntei para ele se ele sabia fazer porcelana e ele respondeu que sim. De repente, veio uma imagem na minha cabeça dessa primeira escultura cerâmica com um esqueleto saindo de dentro dela. Imaginei a questão da fragilidade, da quebra e esse esqueleto que saia.

Atualmente essa primeira escultura cerâmica, da série Oráculo, a que foi agigantada para ao nosso tamanho de corpo, pertence a Inhotim. O fato de ele estar próximo daqui é muito interessante para mim. Quando eu o fiz, busquei referências em livros de história de Arte e encontrei um bibelô inglês que representava um personagem que de fato existiu, o Sir Manners. Ao redor dele, é possível ver as armas e espadas. Eu gostei desta figura, pois não era bonita, era careca e não tinha nada de Rococó, era um retrato de alguém. Eu o construí baseado numa foto preto e branca e ele foi pintado de acordo com o que eu imaginava e com base no Barroco Brasileiro. Ele tem a cor do vermelho utilizado na época do barroco daqui.

Silvia: Você poderia falar sobre outras peças da série Oráculo?

Marco: As obras posteriores possuem dimensões menores. Há uma peça, por exemplo, que eu adquiri numa feira de na rua na Holanda. Essa figura aqui, eu não consegui tombar e criei outra solução de acontecimento. Então, podemos notar que cada figura tem que ser tratada com respeito. Assim como os materiais, a imagem possui sua especificidade e você em que esperar a resposta dela. Eu acho que temos que respeitar o tempo e a energia que o trabalho possui.

Eu comprei essa figura num dia de muito frio e na rua só tinha uma barraca. Esta peça estava lá sem a cabeça do cachorro. Ela era bem diferente das outras peças que havia visto, pois fiquei inquieto com ela e com a sua relação com o cachorro e essa chamada dela com ele. Como eu havia dito, não tive coragem de 
tombar ela, pois há um sofá maravilhoso com pernas que fundem com as da mulher. Os sapatinhos dela estão numa almofada e a bolsinha dela está "derramada" no sofá.

Teve uma ocasião em que fui à casa de um amigo e lá havia uma pintura de uma menina do século XVIII. Esse quadro tinha uma história de que ela havia feito um aborto. Ela estava desmaiada e o cachorro estava sobre a saia dela. Então, compreendi que a cena. O cachorro, que é símbolo de fidelidade, estava pulando na saia da mulher e isso significa que ela saiu da regra social, ou, fez sexo antes do casamento, ou traiu ou foi desvirginada. Então, ali existia um segredo. E essa série, desde o início, chama-se Oráculo por causa deste sentido de segredo, do segredo humano, que é a nossa caveira e que iguala a todos nós. Há o sentido do oráculo que também revela o segredo. É uma ironia que a morte é o futuro que todos têm. É um futuro que ninguém foge.

Adorei essa relação e por isso não fez mais sentido não tomba-la, obedecendo a sua condição. Eu consegui quebrar as costas dela e quando você vê o seu interior, você consegue ver as pernas dela e atrás do sofá está os ossos dela escondidos. Então, você rodeia e vê as verdades escondidas.

Com este trabalho, tive a honra de abrir uma exposição no único museu de cerâmica, de Princessehof, na Holanda. Foi uma exposição que reuniu vários grandes ceramistas. Era um museu de cerâmica antiga e que tinha interesse em iniciar sua coleção com peças da cerâmica contemporânea. Eles abriram uma sala para trabalhos contemporâneos e eu fui convidado para abri-la porque eu estava exatamente trabalhando que eles mais conservavam e evitavam, que era a quebra das peças. Eu estava transmutando eles. E eu fiz, em todo museu, uma instalação sonora com gravações de sons de peças cerâmicas sendo quebradas juntamente com uma música de Bach tocada no cravo. Então, de quinze em quinze minutos, ouvia-se o som da quebra e da música. A exposição também era composta por outros trabalhos meus como fotografias relacionadas ao tema.

Outro trabalho que eu havia comentado anteriormente e que faz parte da série Vanitas foi apresentado após esta exposição. Eles me ofereceram as coisas quebradas do museu e também emprestaram as duas peças alemãs e as frutas em 
porcelana. Quando eu as vi, notei que poderia trabalhar com essa questão do espelhamento e sua simbologia. Além disso, percebi que havia um forte cunho erótico. Elas, por exemplo, estão sem os sapatinhos e só de meias. Acabou de ler uma cartinha de amor. Elas têm algo aqui entre os seios e com a face rubra. Você vê que a mãozinha posicionada na parte intima e estão, ao mesmo tempo, totalmente inconscientes, num momento de êxtase. Eu quis construir esse desastre atrás delas, uma dimensão do holocausto e elas não percebem. Acho que isso é algo muito de hoje. Nós estamos restritos à nossa realidade e temos dificuldade de encontrar um sentido.

Silvia: Há uma beleza na destruição e no drama presentes nos seus trabalhos.

Marco: Para mim, a série Oráculo não teria sentido, se o material não fosse quebrado. Junto com o trabalho, existe a vontade de que o outro o complete, assim como fala de Duchamp.

Silvia: E o Outro está exercitando sobre a obra.

Marco: Isso é essencial. Quando eu estava fazendo uma exposição na galeria Vermelho, ganhei de uma pessoa, que foi ver a exposição, um presente. Era uma caixa linda com um laço e dentro havia um bibelô de um casal, que pertencia à sua avó. Era um bibelô de marca, parecia caro, uma peça histórica e ela disse que eu não devia nada a ela. Ela disse que havia se lembrado de mim e estava dando este bibelô de presente. Logo, fiquei com vontade de fazer uma animação com ele, mas demorei demais para fazer, até alguém me pediu um trabalho para uma exposição e eu já tinha o storyboard dessa animação. O trabalho que se chama Com muito amor.

Certo dia, uma pessoa na Austrália me escreveu dizendo que ele estava fazendo uma exposição, cujo titulo era "It's not a love Song". Então, apresentei este trabalho e que lá passou a ser chamado "With much love". Inclusive uma imagem deste trabalho virou cartaz da exposição. Daí, para fazer o trabalho, eu montei um cenário que era uma espécie de teatro, fiz toda uma animação. É um casal que se corteja, passa de um lado vai para outro. Eu utilizo uma câmera e uma lâmpada para filmar, utilizando o recurso de stop motion. Durante as filmagens, descobri que a lâmpada produzia sombras. Fazendo jogos com essas sombras, fiz com que o casal se beijasse. No final, o casal cai e eu entro com uma ferramenta de esculpir e 
quebro. Há um silêncio que quebra o som da música. As músicas executadas durante a animação foram criadas por mim. O interessante foi que a quebra ocorreu de forma controlada e durante o processo o homem se solta totalmente. Daí, a caveira aparece para o homem e começo algo carnal com a morte e eles desparecem através dos estilhaços.

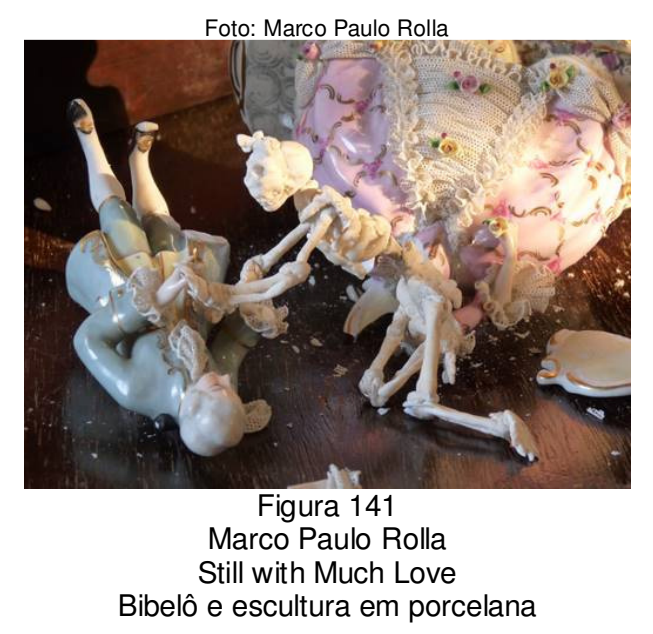

Tenho vários trabalhos em desenvolvimento. Tem um que fala do drama amoroso. Trata-se de um casal também, que tem uma iluminação teatral. É um trabalho que tem que estar num lugar mais escuro, por isso o nome deste trabalho é Ópera.

Silvia: Há um trabalho chamado Êxtase em que você utiliza uma escultura em argila. Após construí-la, ela passa por uma destruição durante uma performance.

Marco: Este trabalho eu construí a escultura em argila de uma mulher que passei a chama-la de Verônica. Eu criei um molde dela com vários tacelos. Para as exposições, eu utilizei o molde para reproduzi-la. Guardo a peça original dela maciça que possui uma estrutura de ferro dentro. Ela não para de rachar e sua superfície está repleta de pó!

Silvia: Ela foi construída para sofrer a degradação do tempo ?

Marco: Sim. O objetivo de construir o molde dela é para que a presença dela seja uma aparição, como num êxtase, é um momento de acontecimento. Ela foi apresentada em suas ocasiões. Hoje em dia eu olho para o molde dela e eu acho 
incrível que parece um sudário da presença da Verônica, pois é assim que eu a chamo.

Uma vez me perguntaram se ela tinha nome e aí imediatamente respondi que era Verônica. Há uma longa história que tem tudo a ver com o trabalho. A Verônica é uma personagem bíblica e que revela a marca de Cristo num sudário e nome dela tem esse significado que é "Ver através da verdade". A questão do êxtase momentâneo se relaciona com a argila crua e a fragilidade, demonstrada através das rachaduras. Ela não é cerâmica porque não está queimada, mas trabalha com a matéria que é a argila e utiliza o molde. Então, o molde tem a função de produzir essa escultura oca, o que facilita o seu transporte. Quando ela é construída para uma exposição, ela é posta no chão e sua secagem é feita sem os devidos cuidados. Além disso, pego uma argila qualquer. Quando a exposição termina, eu a destruo. Neste sentido, tem o mesmo significado da destruição de uma coisa preciosa como nos bibelôs e que faz analogia às relações humanas.

Acabei criando uma performance com ela, onde eu literalmente quebro a escultura com o meu corpo. A primeira performance com a Verônica, não foi em público, pois queria fazer algo mais íntimo com ela e que resultou num vídeo que se chama Atravessando Verônica. Eu acredito que nesse atravessamento, eu recrio o Mito do Andrógeno. A primeira improvisação ocorreu meio aleatoriamente, onde eu abra a perna dela, quebro o que eu posso, eu entro nela como uma paisagem. Logo depois eu volto para reconstrui-la através de seus pedaços unidos ao meu corpo, existe um momento em que eu entro com o rosto dela e daí fica um corpo masculino numa mulher e tento quebrar os sapatinhos dela. Esta sequencia improvida acabou virando uma linha de construção cênica da performance. Na segunda vez, aconteceu algo meio parecido, percorri o mesmo caminho, mas é claro que a escultura da Verônica era outra. Tive que quebrar de forma diferente e foi bem estranho, mas resultou em algo bonito também.

Com essas partes quebradas, juntei outros tipos de argila e acabei modelando alguns ossos, refiz um pedaço tido como o interior dela. Este trabalho chama-se o Êxtase rompido. Ele é composto também por uma câmera super 8 e um cantil, que eu acho tem forma de um útero e é bem feminino e a câmera faz referência ao 
masculino. Então, assim como Atravessando Verônica tinha ver com androgenia, o Êxtase rompido é criado como um Ser ambíguo.

O Êxtase rompido está montado numa mesinha de centro mas não sei ainda se vou usar uma base de metal ou madeira para suportar o peso. Essas peças não serão coladas e deverão ser desfeitas e refeitas como uma instalação.

Existe um artista chamado Jannis Kounellis ${ }^{199}$ que trabalha muito com essa questão da destruição. Ele é performer e trabalha com seres da mitologia.

Silvia: O figurativo é presença forte no seu percurso. A relação com as cenas do cotidiano, do presente e do passado, é forte em seus trabalhos.

Marco: Sim acredito que meu interesse pelo figurativo tem haver com o próprio ser humano. Meu objetivo é analisar nossas necessidades de existir.

Silvia: Você desenvolveu uma instalação chamada Pic Nic no EKWC e como foi essa experiência?

Marco: A EKWC me convidou porque eles haviam visto a escultura cerâmica grande, Oráculo. O instrutor da Rijksakademie levou um dos responsáveis do EKWC para ver o meu trabalho e sugeriu que me convidassem para participar da residência lá. Imediatamente, me fizeram o convite e ganhei uma bolsa para passar uma temperada lá. Desde o início, veio a cena de um piquenique. Primeiramente, fiz um pequeno draft deste piquenique. Há uma história interessante que deste trabalho surgiram as séries Panos de mesa e Panos de chão. Tem o vinho derramado sobre eles. Estes trabalhos surgiram de uma maneira muito engraçada, pois fazendo o draft do trabalho, comecei a olha-la de cabeça para baixo. Pensei então que naquela posição o vinho derramaria. Daí surgiu a ideia de derramar o vinho sobre a porcelana, tendo assim, um embate com a matéria orgânica. O interessante na cerâmica esmaltada é que, em alguns casos, ocorrem pequenas rachaduras e que

\footnotetext{
199 Jannis Kounellis (Pireu, Grécia, 1936) é artista visual que participa de movimentos como o Informalista europeu, utilizando figuras simples para criar imagens de caráter simbólico e a Arte Povera, recorrendo a materiais simples e consideradas pobres para produzir objetos que ultrapassam a limitação da pintura. Posteriormente, começa a fazer uso de elementos vivos, vegetais e animais, para criar instalações, exprimindo a ideia de transformação e energia, Disponível na Internet: http://www.infopedia.pt/\$jannis-kounellis . Acesso em: <23/01/2015>
} 
às vezes são imperceptíveis até o momento que alguma coisa penetre como gordura, por exemplo. Ali, o vinho sempre deixa esses trincados evidentes.

Foi graças a experiência dos tecidos em cerâmica feitos para a instalação Pic Nic que eu aprendi a utilizar bem a barbotina com os tecidos rendados, que resultaram nas séries Pano de mesa e Pano de chão.

Foi uma experiência riquíssima. Cheguei lá com uma ideia bem pretensiosa de fazer algo bem real.

Quando eu fiz a instalação cerâmica Pic Nic eu não conhecia Watteau, mas eu tinha a questão dos bibelôs. Para mim, as cenas de piquenique mostram certa malícia. Então, imaginei uma cena em que as pessoas pudessem completa-la.

Tirei todo mundo de lá para que nossa imaginação pudesse completar a imagem das pessoas que antes estavam ali naquela cena através de certos vestígios como luvas, sapatos, garrafas vazias, frutas e vários outros elementos.

Silvia: Como você executou a instalação Pic Nic?

Marco: O grande pano é em oito placas de formas orgânicas em cerâmica e que foram montadas como um quebra-cabeça. É toda em cerâmica esmaltada. Tem uma questão da pintura, que é muito colocado. Há o cuidado de pintor para fazer todos os detalhes da esmaltação.

Silvia: Você já era um pintor com bastante experiência. Como foi essa experiência de se pintar sobre a cerâmica, já que as tintas são diferentes e as cores reais você só consegue ver após a queima.

Marco: É como na gravura que há inversão e você não sabe direito como vai ficar. Existe certo tipo de cegueira, mas fizemos vários testes. Trabalhei bastante nos testes das cores das frutas. Comprei um tecido para ver como ficaria e a partir daí fui pintando, tendo como parâmetro os testes que havia feito. Eu tive bastante ajuda técnica, principalmente para fazer a cesta, por exemplo, que são trançados. Fiz os Rolinhos trançados que eram bem complicados e que foram conformados num molde de gesso para ganhar a forma. O interessante que no EKWC, o pessoal encara o desafio do que não sabemos fazer como uma oportunidade. Eles querem que os artistas levem desafios com o intuito de aprimoramento técnico do local. 
Silvia: Quanto tempo você demorou em concluir todo o trabalho?

Marco: Levei três meses. Utilizei massa cerâmica de alta e porcelana. Os tecidos foram feitos em porcelana. Utilizamos várias técnicas de construção e queima. Por exemplo, para construir e queimar a toalha, foram feitos grandes placas finas de porcelana sobre uma manta de tecido e areia. Para ser transportada até o forno, as placas foram arrastadas sobre a areia até a base do forno composto por pequenas manilhas refratárias. $O$ forno era uma grande cúpula que descia até base do forno. Fiz a primeira queima em biscoito e depois esmaltei.

Silvia: É um trabalho que desafia os limites da resistência mecânica. Desafia todas as regras no que se referem às dimensões e as espessuras das placas.

Marco: Eu trabalho bastante no limite entre o controle e a sensibilidade. Por exemplo, trabalhei as questões das manchas, as deixei fluir, mas, ao mesmo tempo, tive um controle.

Silvia: Ele está aonde agora?

Marco: Ele pertence ao MAM de São Paulo.

Silvia: Depois do Pic Nic surgiram outros trabalhos, utilizando a cerâmica?

Marco: Com a experiência que obtive ao fazer os tecidos em cerâmica para a instalação Pic nic, eu aprendi a utilizar bem a barbotina. Então fiz uma mistura com tecidos rendados e barbotina, o que resultou nas séries Pano de mesa e Pano de chão.

Silvia: Gostaria de saber mais sobre a série Vanitas em que você faz referência aos anúncios de supermercado?

Marco: Essa série é inspirada nessas propagandas de carne que vemos em jornal. O interessante é que essas carnes aparecem "enfeitadas", assim como os bibelôs. O que me motivou a fazer essas carnes cruas foi essa ideia de criar um objeto decorativo, utilizando essa ideia da porcelana como algo relacionado ao luxo, como um objeto de consumo. Eu queria criar algo que se pudesse ser visto, usado e comprado, assim como os objetos de decoração. A pintura também é feita com a tinta para porcelana. Essas alfaces me remetem as rocalhas barrocas. 
Silvia: Se pensarmos bem, carne crua não é nada atraente. Nos encartes de supermercado eles tentam seduzir o consumir enfeitando essas peças.

Marco: A carne também não costuma ser consumida por todas as classes sociais aqui no Brasil. De certa forma, é um produto de luxo. A maneira de como está exposta, é uma tentativa de decorar o grotesco, o animal morto.

Silvia: O interessante é realmente esse recorte, um retrato de uma época. Lembra muito aquilo que você já havia comentado sobre as naturezas mortas que possuem simbologias que contam sobre uma época e do cotidiano. $E$ tudo isso também é o nosso cotidiano.

Marco: Com certeza. Essas pinturas são como açougues da época e esses encartes fazem o mesmo papel.

Silvia: É como se você trouxesse algo do cotidiano para outro patamar, como uma obra de arte.

Marco: E eu montei estes trabalhos em tábuas de carne usadas para dar mesmo essa sensação do real.

Silvia: Os detalhes destes trabalhos são impressionantes, parecem reais. Como fez para obter as cores desejadas?

Marco: Sou guiado muito pelos testes de esmaltes para eleger as cores mais adequadas aos trabalhos. A técnica da Cerâmica exige isso. Por exemplo, o vermelho, antes da queima é um pó branco. Há uma aliança entre uma sensibilidade pictórica e os testes, mesmo assim, existe certo grau de cegueira, ou seja, só vou saber depois da queima. O bolo de chocolate do Pic Nic, antes da queima, era verde!

Sempre acreditei que o conhecimento pictórico, poderia também ser alcançado na cerâmica. Assim como o exercício do desenho de observação me faz ter maior habilidade para fazer esculturas, para entalhar uma pedra, por exemplo. Existem pessoas que não conseguem enxergar uma deformidade, por exemplo, pois não exercitam o olhar. Se você faz uso da deformidade na cerâmica de maneira intencional é uma coisa, mas se você não consegue enxergar a deformidade, isso é um grande problema. A acuidade só vem com desenho de observação. 
É a coisa que eu trago do piano: O treino. Quando eu tinha 13 para 14 anos, eu tocava sonatas e tinha que treinar. De tanto treinar, tinha a impressão de que não era eu mesmo, parecia que havia saltado e atravessado uma barreira. 


\subsection{Máyy Koffler (Assunção, Paraguai, 1952): O sublime e delicado}

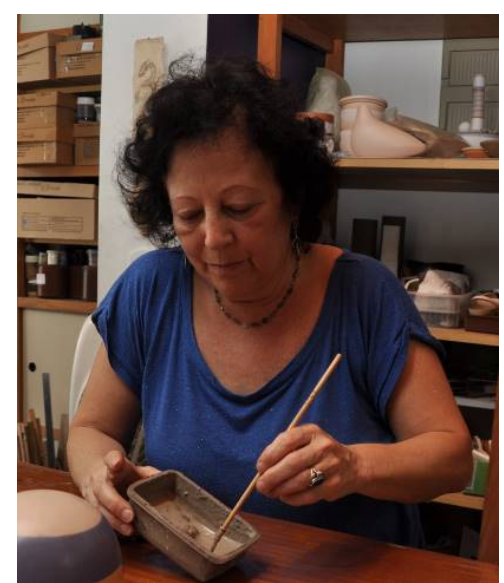

Os trabalhos de Máyy Koffler não passam despercebidos pelo nosso olhar e nem pelo nosso tato, pois tanto as formas como a superfície lisa e acetinada nos seduzem. São delicados, aparentemente frágeis, mas quando tocamos suas cerâmicas percebemos que possuem resistência mecânica, uma força.

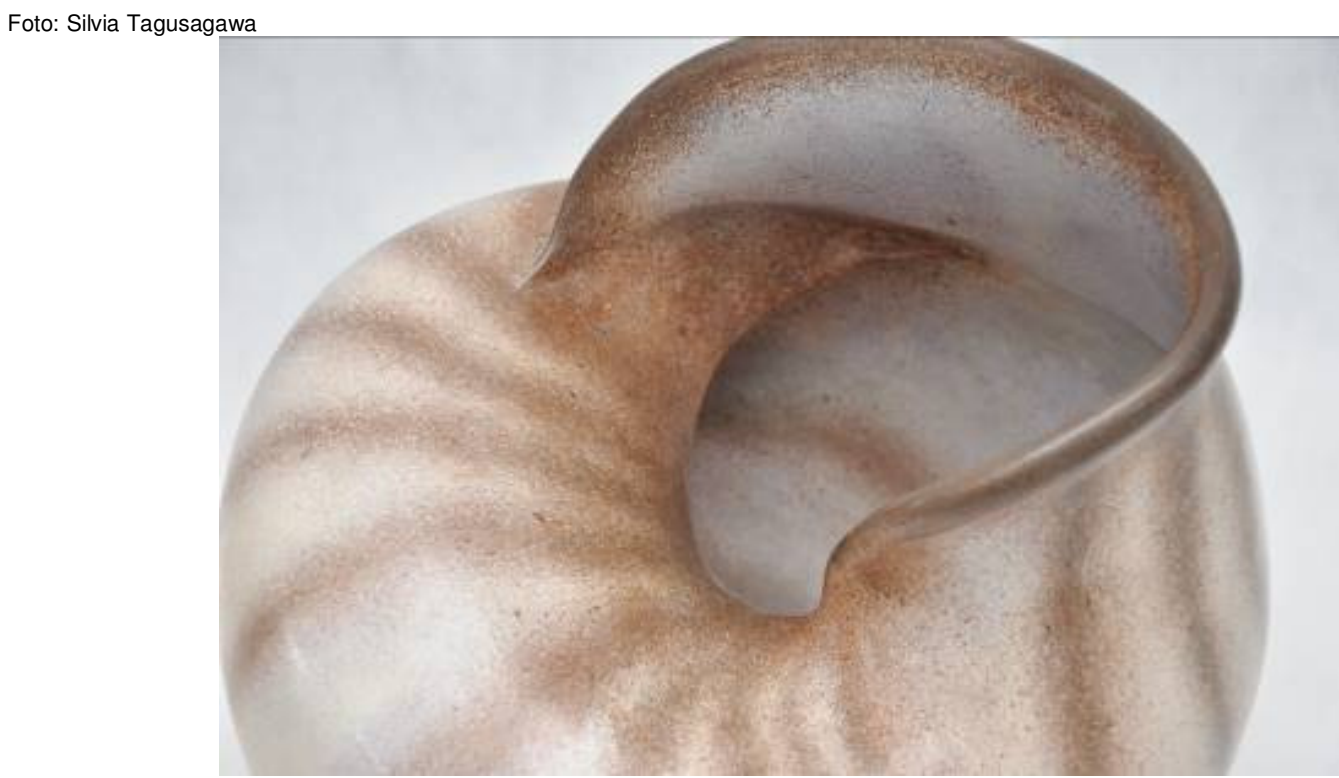

Figura 142

Máyy Koffler

Concha

1998

$40 \mathrm{~cm} \times 35 \mathrm{~cm}$ aprox.

Cerâmica paleteada com engobe - baixa temperatura 
Com mais de 30 anos de carreira, Máyy Koffler se dedica a cerâmica com paixão e devoção. Ela prontamente aceitou conceder uma entrevista e durante os nossos encontros falou de maneira muito espontânea sobre seu percurso, história de vida, a cerâmica e sua poética. A delicadeza e a força são refletidas na sua história de vida também. Falou sobre a sua família, sua vida no Peru, suas descobertas na cerâmica e suas inquietações.

Máyy Koffler utiliza o paleteado, uma técnica pré-colombiana de modelagem manual em cerâmica.

"O Paleteado é um método de modelagem manual de uma peça cerâmica que utiliza como ferramenta uma paleta e uma pedra. A peça é modelada golpeando-se ritmicamente a parede de argila com uma paleta de madeira (espécie de raquete pequena e sólida) e uma pedra redonda e lisa (seixo rolado de rio)." ${ }^{200}$

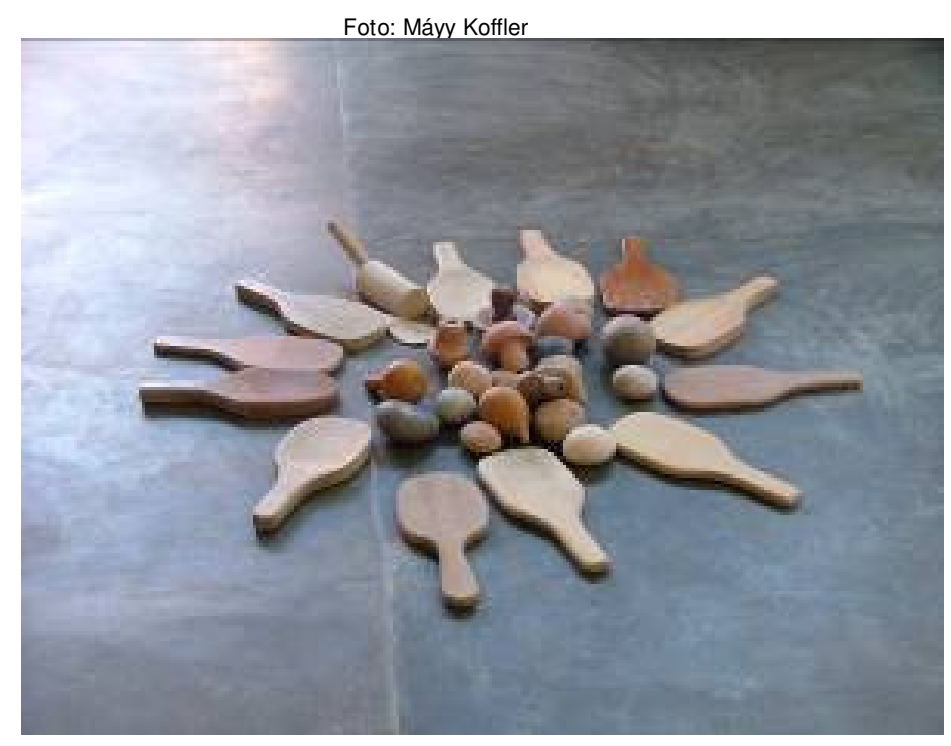

Figura 143

Paletas e pedras

De acordo com Koffler, o paleteado é uma técnica complexa e que exige dedicação disciplinada para se superar as dificuldades de cada etapa. Isso se dá

\footnotetext{
${ }^{200}$ Trecho de texto de autoria de Máyy Koffler no site www.mayykoffler.com. Acesso em: 12/03/2013.
} 
através da observação de cada resultado obtido, dos erros e acertos conseguidos a cada momento da ação da paleta e da pedra. ${ }^{201}$

Além do paleteado, Máyy Koffler utiliza engobes, terra sigilata e lustra suas peças, deixando suas peças com superfície lisa e acetinada. Além disso, utiliza a queima primitiva.

Nascida no Paraguai, Koffler morou em várias cidades na América Latina: Montevidéu, Tacuarembó, Colônia, Porto Alegre, Florianópolis, São Paulo e Lima. Atualmente vive e trabalha em seu ateliê em São Paulo. Seu pai era austrohúngaro, judeu que morou em vários dos países Europa e sua mãe, argentina. Tem mais três irmãos. A família viajou por várias cidades, passando um período em cada uma delas e fixa-se aos 15 anos no Brasil com a família em 1968.

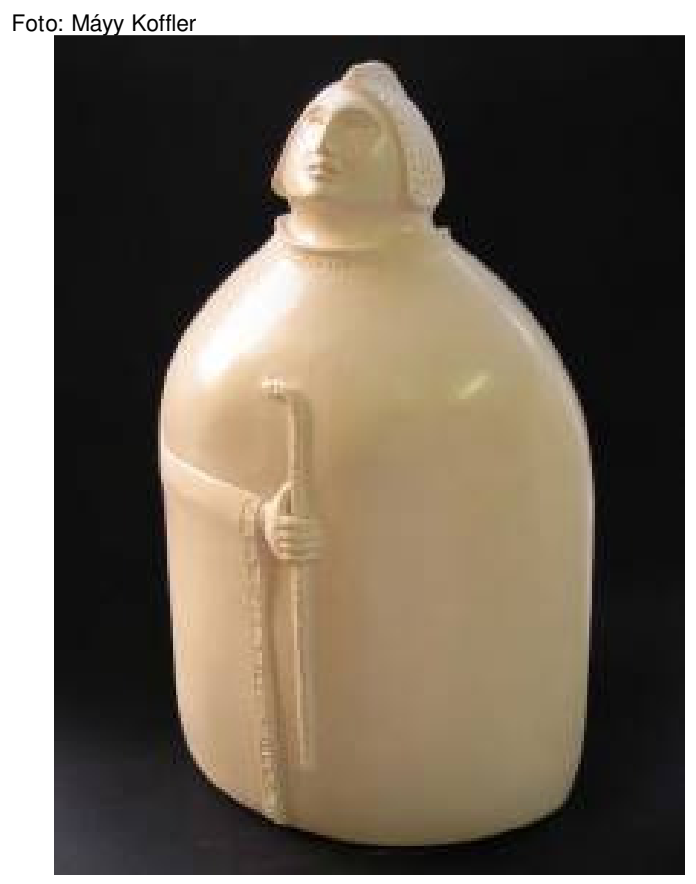

Figura 144

$$
\begin{gathered}
\text { Máyy Koffler } \\
\text { Guerreira } \\
30 \mathrm{~cm} \text { de altura } \\
2002 \\
\text { Cerâmica paleteada, engobe - baixa temperatura }
\end{gathered}
$$

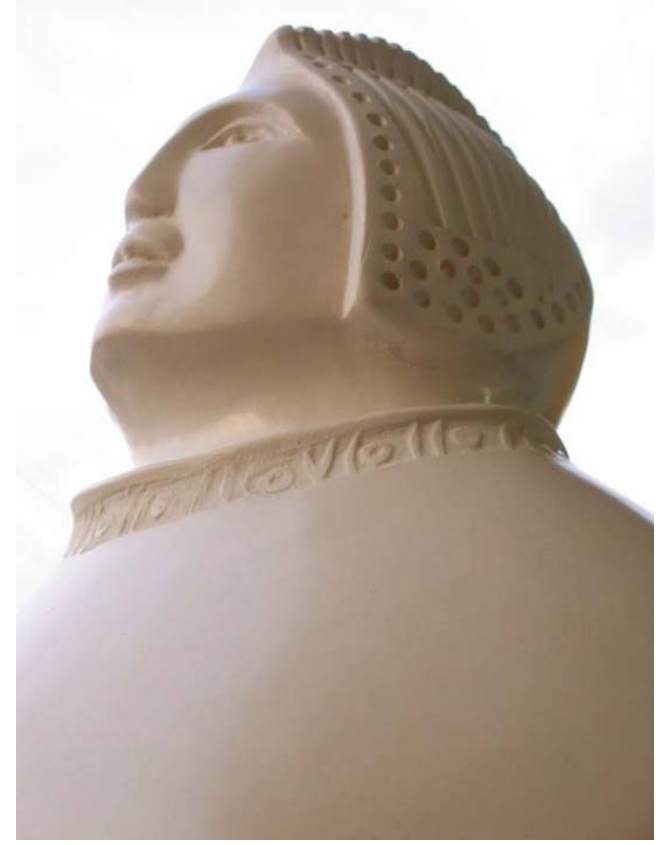

Figura 145

201 Idem, Ibidem 
Iniciou sua formação em música no Uruguai com aulas de piano. Aliás, sua relação com a música é muito forte desde a sua infância. Quando veio para o Brasil, foi morar primeiro em Porto Alegre, onde iniciou sua formação artística no Ateliê o Ponto, onde teve aulas de gravura e história da Arte. Em 1979 se formou pela Faculdade de Belas Artes de São Paulo, na época em que a sede era na Pinacoteca do Estado de São Paulo. Depois da faculdade, foi ministrar cursos de Artes para alunos de Terapia Ocupacional na faculdade de Medicina da USP e confeccionou brinquedos educativos em madeira. Nessa época, viajava muito para Lima, Peru, onde sua irmã, mais velha, tinha uma livraria. Em 1986, sua irmã a convida para passar uma temporada lá e a partir deste momento teve a oportunidade de se dedicar inteiramente à Arte. No Peru, Máyy teve a oportunidade de conhecer a riqueza cultural dos povos pré-hispânicos, em especial a Cerâmica, pela qual Máyy fica complemente fascinada e apaixonada.

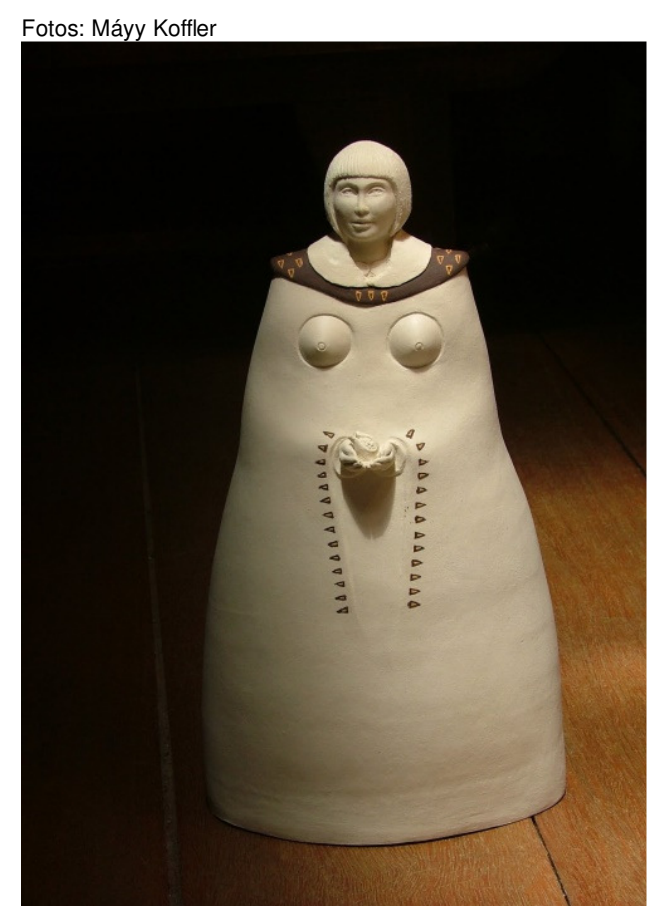

Figura 146

Máyy Koffler Senhora do fruto $30 \mathrm{~cm}$ de altura 2005 Cerâmica paleteada e engobes

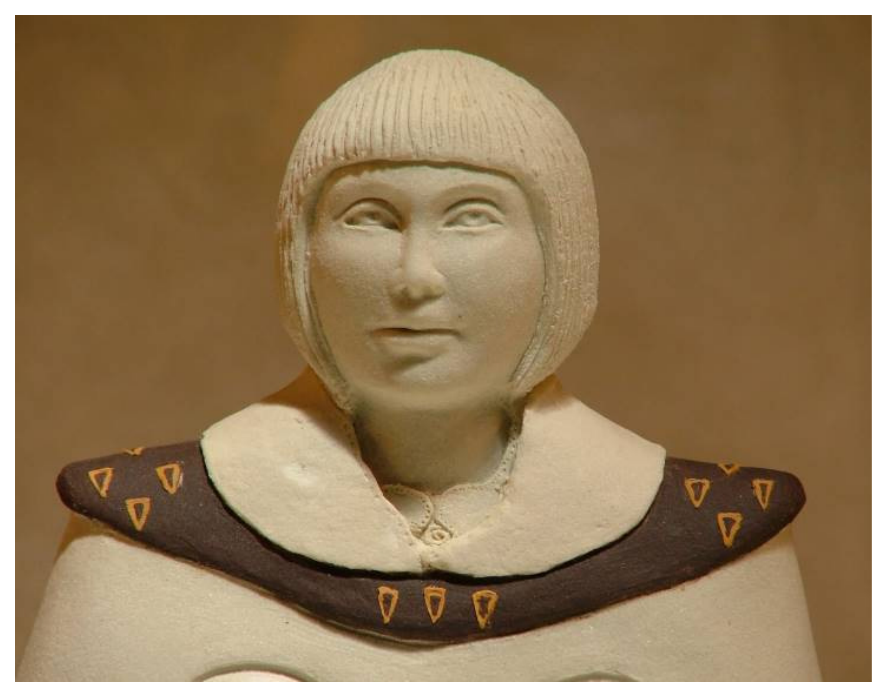

Figura 147

Máyy Koffler Senhora do fruto (detalhe) $30 \mathrm{~cm}$ de altura 2005

Cerâmica paleteada e engobes 
"No passado andino, encontrei meu presente"po2

Conhece um artista chamado Hernando Soares, filho de um famoso pintor peruano, Germán Suaréz-Vértizy. Hernando possuía um ateliê de joalheria em Lima e posteriormente inaugurou um importante espaço cultural de acolhia artistas dos mais variados meios e onde se produziam peças de arte vendidas em sua loja chamada Warike. Neste momento, Máyy Koffler percebe as possibilidades plásticas do material cerâmico, se entusiasma e decide estudar cerâmica.

Foto:Máyy Kóffler
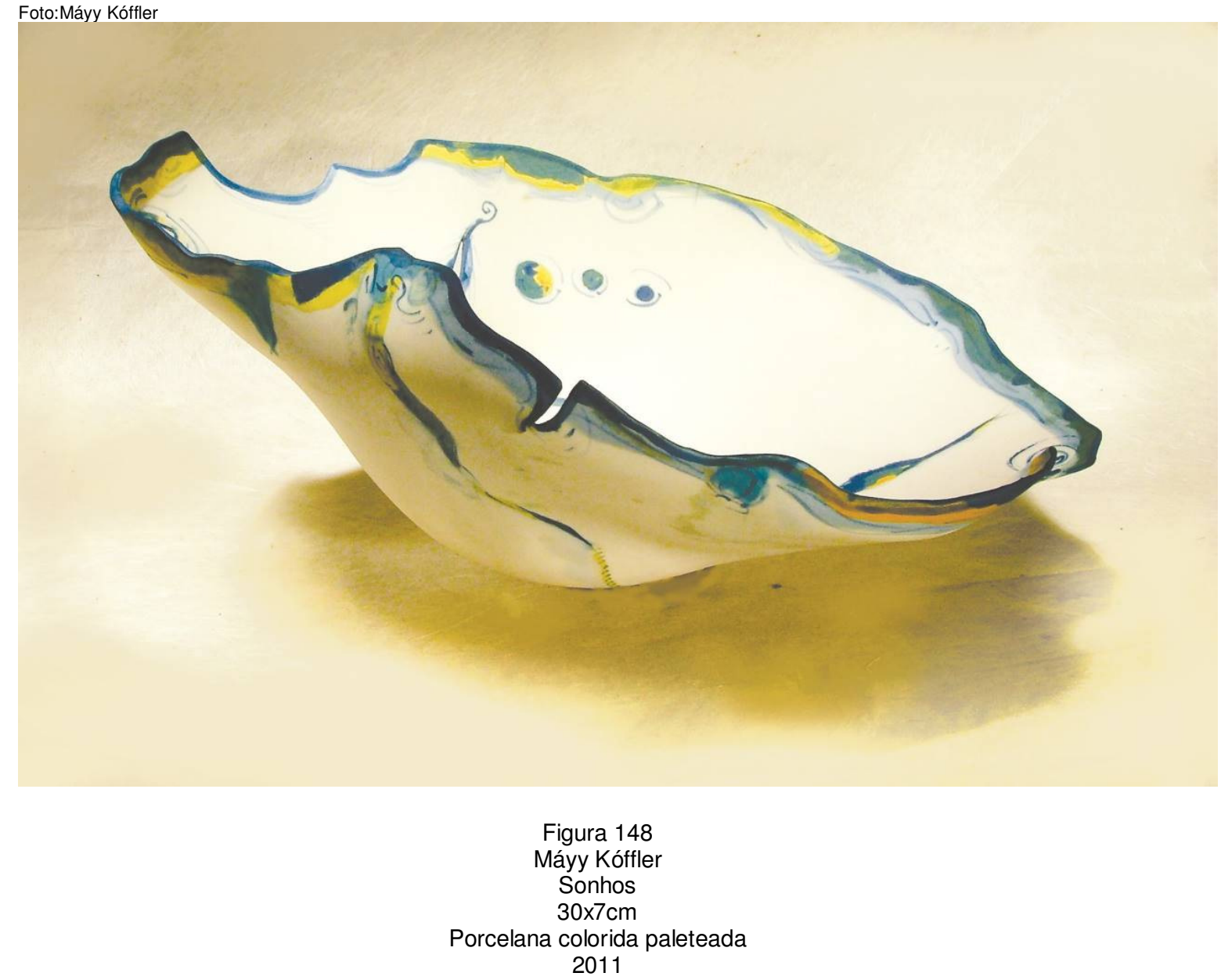

A artista se deu conta da riqueza da Cerâmica, pois é um suporte que conta a história de todos os povos. Todas as culturas trabalharam com este meio e ele está presente nos museus do mundo do todo.

${ }^{202}$ Depoimento colhido em uma conversa informal com Máyy Koffler.. 
"A Cerâmica contém todas as outras Artes, nos oferece múltiplas possibilidades, desde a tridimensionalidade na escultura, o desenho até a realização de utilitários. Além do conhecimento sobre as matérias-primas que se utilizam para a preparação de massas cerâmicas, há os corantes minerais que nos brindam com a infinita variação de cores que se podem utilizar sobre a superfície cerâmica e os esmaltes. E há ainda a criação de murais artísticos, pisos e instalações. As possibilidades plásticas que a cerâmica oferece são infinitas." 203

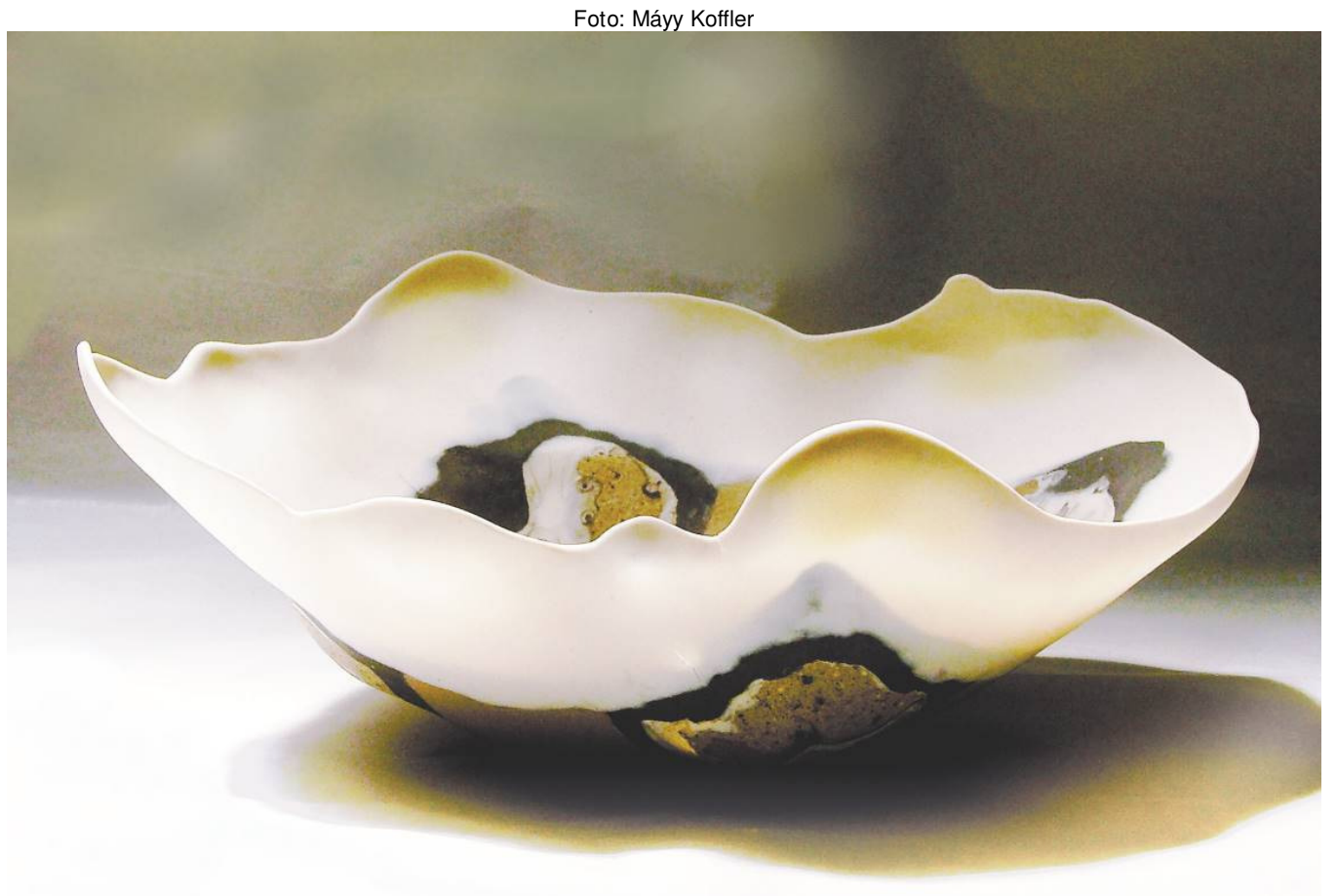

Figura 149

Máyy Koffler

Historinha

Porcelana e argila marrom com filito grosso paleada (Alta temperatura)

$30 \times 7 \mathrm{~cm}$

2004

${ }^{203}$ Trecho da entrevista de Máyy Koffler concedido à Silvia Tagusagawa. 


\section{Através do ceramista peruano Jose Luis Yamunaquéen ${ }^{204}$, uma das referências do paleteado no Peru, Máyy Koffler tem seu primeiro contato com as técnicas utilizadas pela Cultura Tallán ou Vicús ${ }^{205}$ :}

"Daí, ela me levou ao ateliê Jose Luiz Yamunaqué que foi o meu mestre. Ele me iniciou na Arte Cerâmica. Foi a ponte para esse encontro tão significativo na minha vida. Ele é de Chulucanas. Fiquei encantada com a história que tinha por trás de sua obra: a cultura Vicus. Um povo de riqueza ímpar com expressões artísticas de grande beleza e profundidade simbólica, onde o legado que eles deixaram transmitia a profundidade e intimidade com que eles se relacionavam com a natureza, suas crenças e costumes. Naquele momento, tudo se clareou e passou a ter um sentido na minha vida."206

A partir do momento em que entra em contato com a técnica, Máyy Koffler se impõe um desafio pessoal de atingir a excelência técnica primeiramente. Koffler lembra:

"No início, tive bastante dificuldade e minhas peças saíam tortas e quando pintava com engobes, ao retirar as peças do forno, constatava que as peças não estavam bem cobertas, era frustrante."207

\footnotetext{
204 Jose Luis Yamunaqué (1951) é artista e professor. Nascido em Chulucanas, região norte do Peru,é um remanescente da cultura Vicús e trabalha com o paleteado e desenvolveu de forma peculiar a técnica da preparação dos engobes. Trabalhou como professor de cerâmica e atuou como artista residente em seu país e em universidades americanas como o Wellesley College, Cranbook College e Harvard. Desenvolve trabalho artístico utilizando várias técnicas em cerâmica, mas principalmente o paleteado e os engobes com acabamento acetinado. (Fonte: http://joseyamunaque.blogspot.com.br/ Acesso em: 26/12/2014)

${ }^{205}$ A artista Máyy Koffler tem uma forte conexão poética e histórica com a técnica que utiliza. Por isso, há um texto complementar sobre a história do paleteado que se encontra nos Anexos.

206 Trecho da entrevista de Máyy Koffler concedida a Silvia Tagusagawa.

207 Idem.
} 


\subsubsection{Poética de Máyy Koffler}

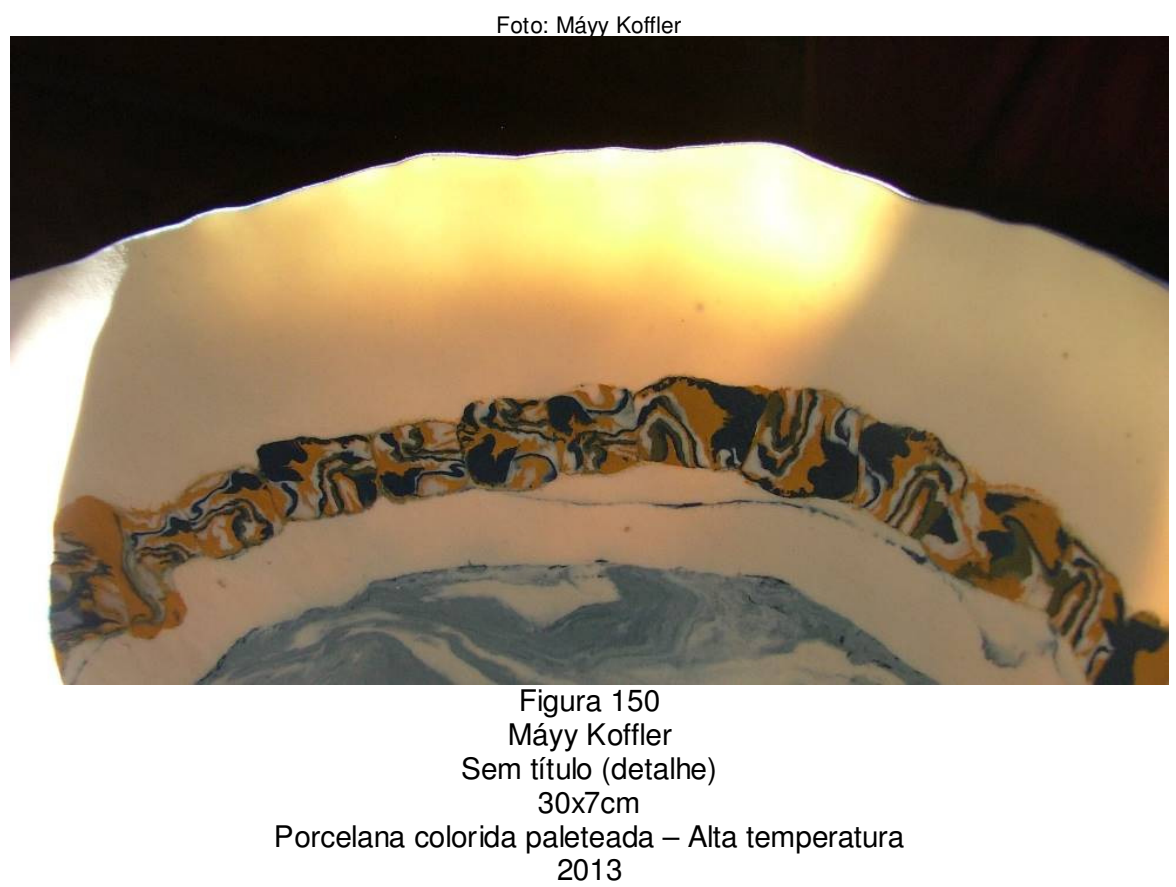

Em sua entrevista, Máyy fala de seu fascínio pela figura feminina. Desde criança, ela diz retratar essa admiração, pois sempre foi atraída pelas formas curvilíneas, delicadeza dos gestos e a força simbólica que a mulher representa. Assim como para Miró, o corpo da mulher é exaltado como possibilidade de criar outras formas:

"O que chamo de Mulher não é a criatura mulher, é um universo" 208

"Para mim, o sexo feminino é como planetas ou estrelas cadentes. Faz parte do meu vocabulário.,209

${ }^{208}$ MIRÓ, Joan e RAILLARD, Georges. A cor dos meus sonhos: entrevistas com Georges Raillard/Joan Miró. São Paulo: Editora Estação Liberdade, 1992.p. 32 ${ }^{209} / d$ dem ,p. 81. 
Foto: Máyy Koffler

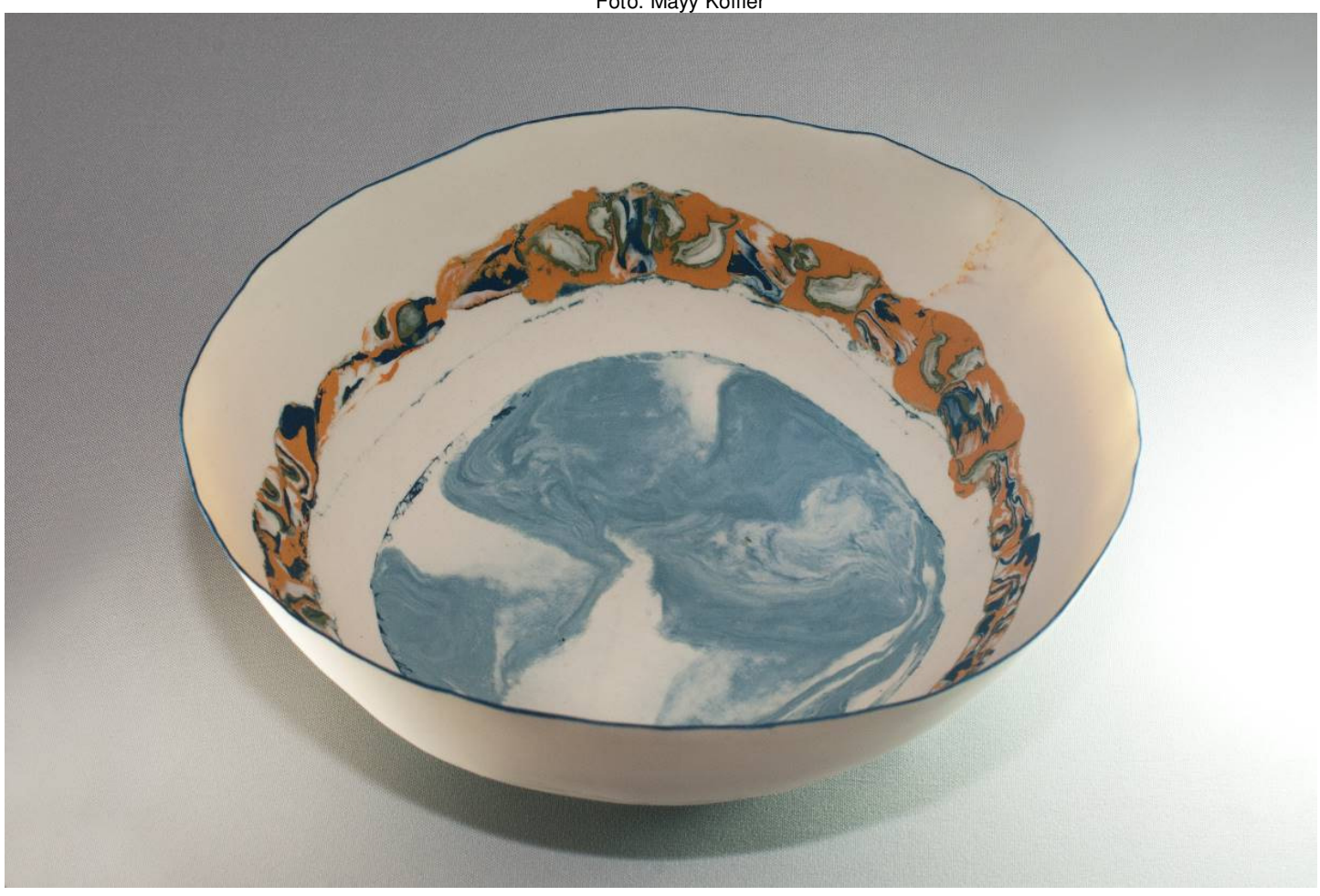

Figura 151

Máyy Koffler

Sem título

$26,5 \times 11 \mathrm{~cm}$

Porcelana colorida paleteada - Alta temperatura

2013

Sobre admiração que tem pela força e atitude de algumas mulheres, em especial as mulheres talhanes, Máyy diz:

“[...] Essas mulheres carregam personalidades que eu admiro.

Era mulheres muito especiais com posturas de liderança quando seus homens iam realizar outras tarefas. Existem várias crônicas tanto de cronistas indígenas como espanhóis que ressaltam essas características de forma explícita. Frei Reginaldo Lizárraga, por exemplo diz: "à margem do rio Motupe encontrei um povo governado por mulheres que eram as Capullanas, chamadas assim pelos espanhóis por causa de seu vestido que tinha uma espécie de capuz. Mas para a historiadora Maria Rostworowski de Diez Canseco, a palavra Capullana é de origem Tallán que significa filha. Quando se 
falam de Capullanas se faz referência ao governo de certa mulheres talhanes, governo que existiu na costa norte do peru dentro da cultura pré-hispânica dos talhanes,210

Máyy também faz referência à autora Maria Rostworowski de Diez Canseco lembrando trecho de seu livro:

"O poder não é privilégio do homem no mundo andino: Em numerosas regiões existiam "senhorios" governados por mulheres curacas (lideres). ${ }^{, 211}$

Fotos: Máyy Koffler

llustração 1 - Técnica do paleteado
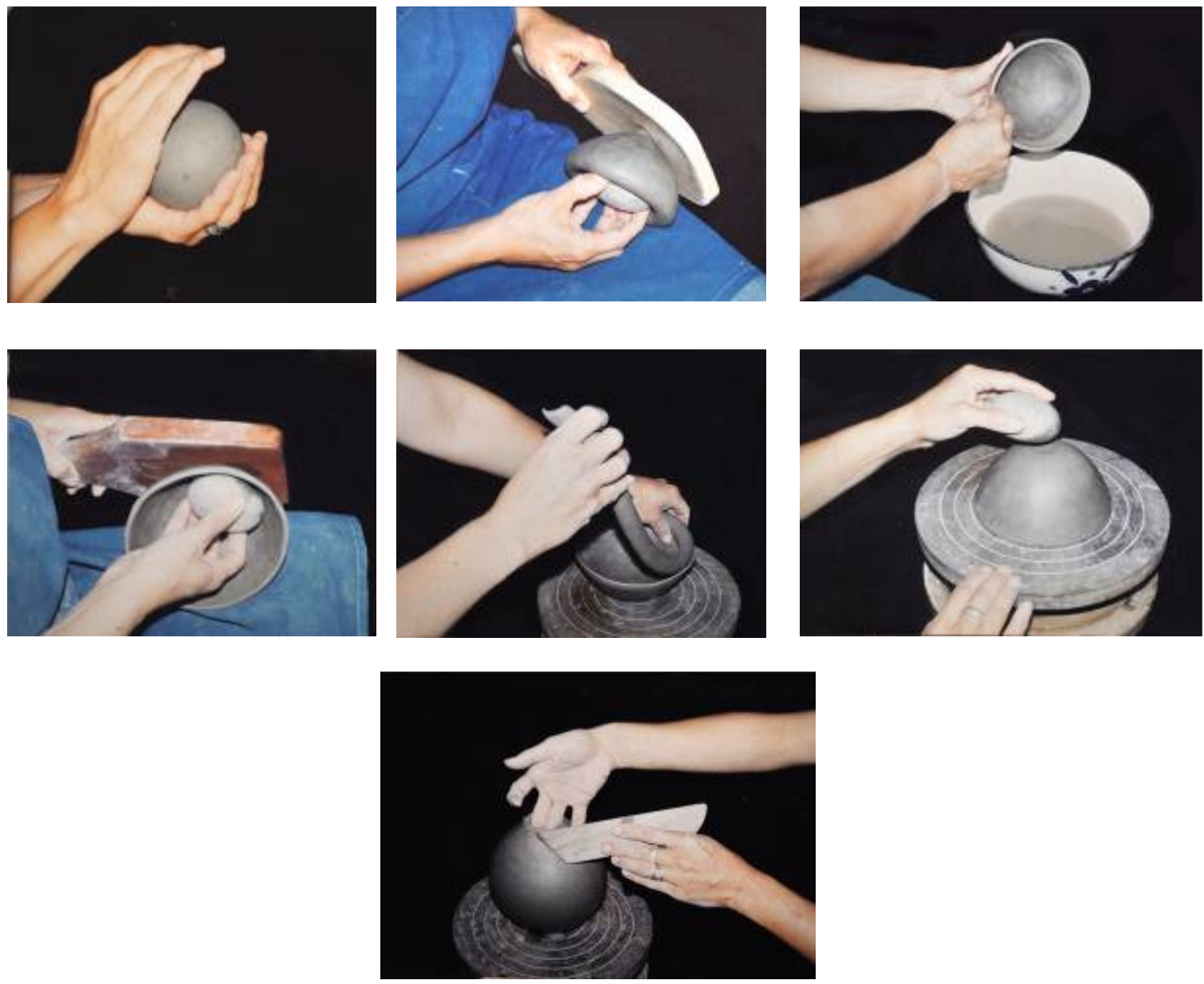

210 Trecho da entrevista realizada com Máyy Koffler por Silvia Tagusagawa em 24/05/2013

${ }^{211}$ CANSECO, Maria Rostworowski de Diez. Historia del Tahuantinsuyu. Lima: IEP, Instituto de Estudios Peruanos1988. 
Máyy Koffler acrescenta:

"Muitos anos depois, podemos ver que a posição social da mulher dentro da comunidade passou a perder totalmente $o$ prestigio e ser considerada pelo homem em segundo plano à sua sombra, mesmo que sua labor seja indispensável. Provavelmente, fruto do domínio da colônia espanhola."

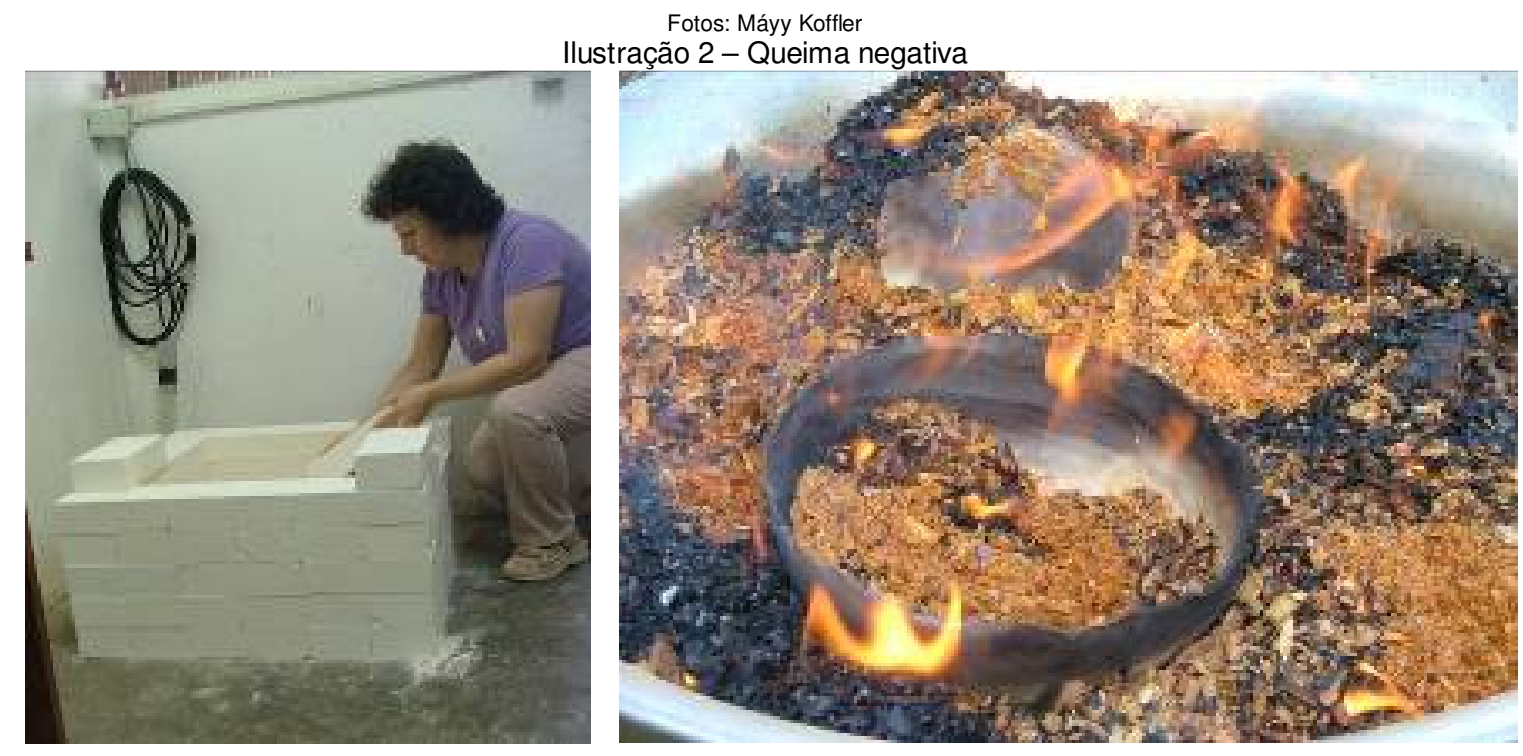

Figura 152

Figura 153

A vivência de Máyy Koffler com a cultura peruana traz outros elementos para a suas obras, nos quais há uma mistura de fascínio pelas as formas e linhas femininas, pela história das mulheres talhanes que possuíam força de decisão e autoconfiança entre outras características admiradas por ela.

"Inspiro-me muito nas leituras de livros sobre história, o mundo mágico religioso e lendas desta cultura maravilhosa. Existe uma história sobre as mulheres incas que quando morriam se transformavam em pedras e que depois, como era um povo guerreiro, eles acreditavam que durante a guerra, elas poderiam voltar à vida na forma de mulher novamente para ajudar os homens a derrotar os seus inimigos. E depois, cumprida a missão, retornavam a sua forma de pedras Esta 


\section{lenda ${ }^{212}$, junto com uma outra, foram inspiração para a criação de duas obras "Mama Huaco e Mama Ocllo."213}

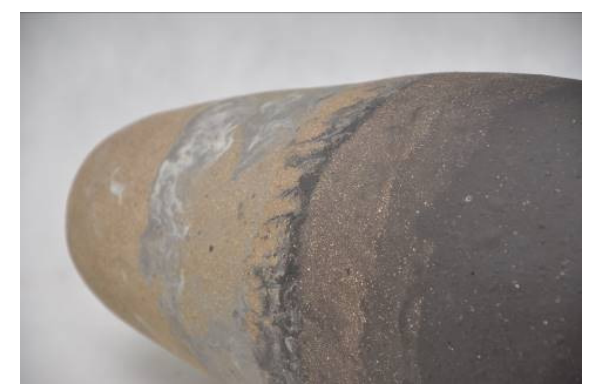

Figura 154
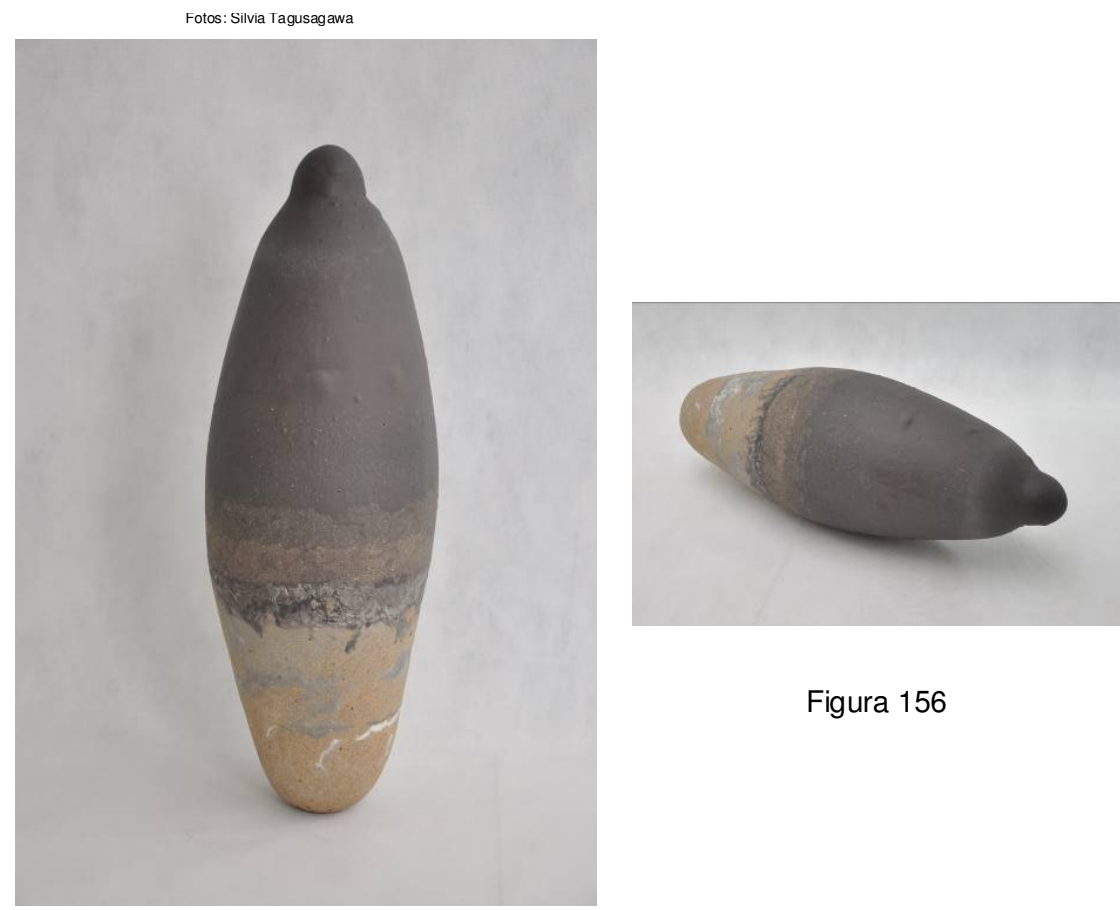

Figura 156

Figura 155

Máyy Koffler

Mama Huaco

$60 \mathrm{~cm}$ de altura

Porcelana e massa cerâmica preta paleteada (alta temperatura) 2004

${ }^{212}$ É a lenda que conta de como surgiu a região, de Cuzco, a capital Inca. Há uma crônica Sarmiento de Gamboa que diz que Mama Huaco foi a mulher que arremessou uma vara de ouro inúmeras vezes até fincar-se em um assentamento definitivo que fundou a cidade de Cuzco.

${ }^{213}$ Trecho da entrevista concedida por Máyy Koffler a Silvia Tagusagawa 


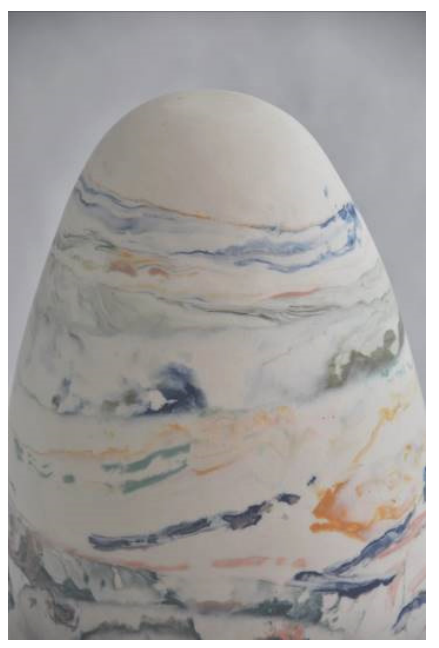

Figura 157

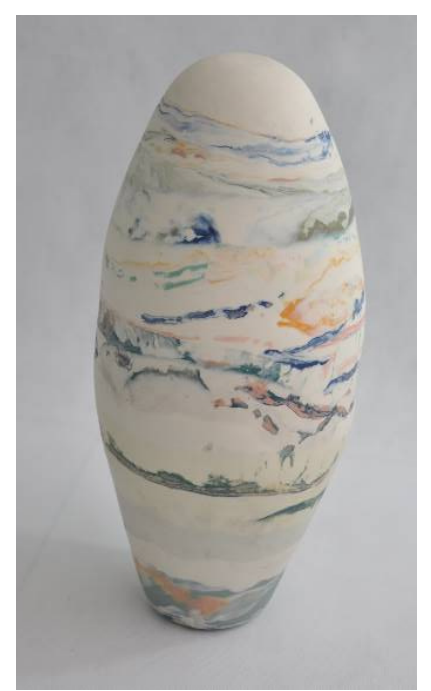

Figura 158

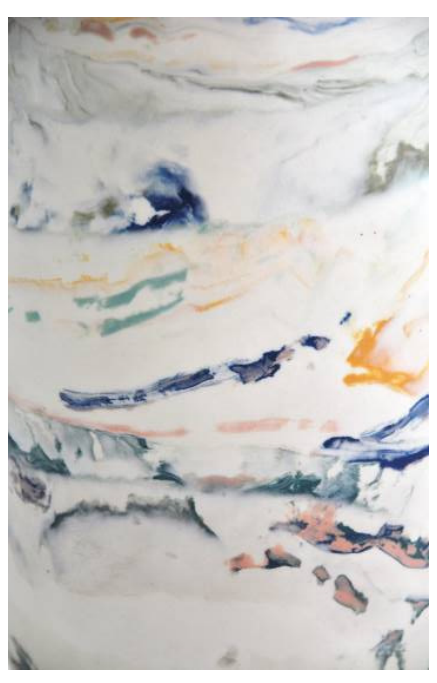

Figura 159

Mama Ocllo

$45 \mathrm{~cm}$ de altura

Porcelana e massa cerâmica preta paleteada (alta temperatura) 2004

Máyy busca uma constante perfeição para formas que produz e explora todas as possibilidades do paleteado, engobe e terra sigilata. Essa busca pode ser vista em suas obras que possuem superfícies lisas e acetinadas.

Para Máyy, o domínio técnico é importante para o seu processo de criação e ela acredita que isso também lhe dá maior liberdade para se expressar. Com sua sensibilidade, percebe que as paletas estão se movimentando corretamente quando cria uma batida ritmada. Seus dedos são sensíveis ao ponto de sentir o ponto ideal para que a porcelana possa ser manipulada. Não há palavras que expliquem tais fenômenos, pois é algo que somente a experiência do toque sobre a massa e o diálogo interno entre a artista e a matéria pode propiciar. 


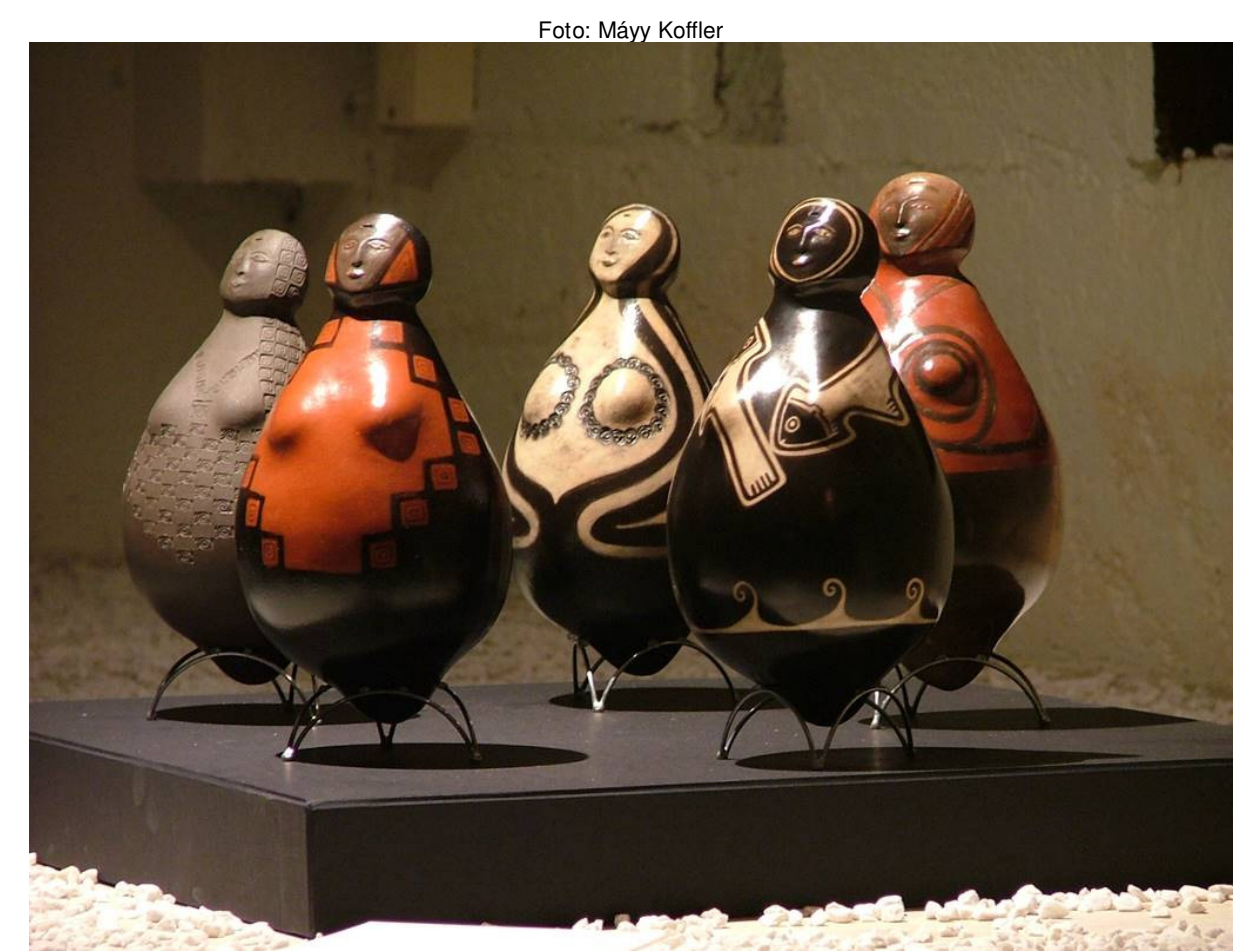

Figura 160

Máyy Koffler

Mulheres Talhanes

$26 \mathrm{~cm}$ de altura

Cerâmica paleteada e engobes

Queima Negativa - Baixa Temperatura

$2004 / 2013$

Máyy busca uma constante perfeição para formas que produz e explora todas as possibilidades do paleteado, engobe e terra sigilata. Essa busca pode ser vista em suas obras que possuem superfícies lisas e acetinadas.

Para Máyy, o domínio técnico é importante para o seu processo de criação e ela acredita que isso também the dá maior liberdade para se expressar. Com sua sensibilidade, percebe que as paletas estão se movimentando corretamente quando cria uma batida ritmada. Seus dedos são sensíveis ao ponto de sentir o ponto ideal para que a porcelana possa ser manipulada. Não há palavras que expliquem tais fenômenos, pois é algo que somente a experiência do toque sobre a massa e o diálogo interno entre a artista e a matéria pode propiciar.

"[...] Quando você está aprendendo uma técnica, você está presa e sente que falta adquirir uma intimidade suficiente com a matéria- 
prima para que se possa manifestar com uma expressão pura e natural. $E$ isso é como um limite que interfere na liberdade de expressão. É como um poeta que quando escreve, as palavras fluem livres expressando um sentimento."214

Processo de mescla de massas de porcelana coloridas - utilização de corantes cerâmicos de alta temperatura

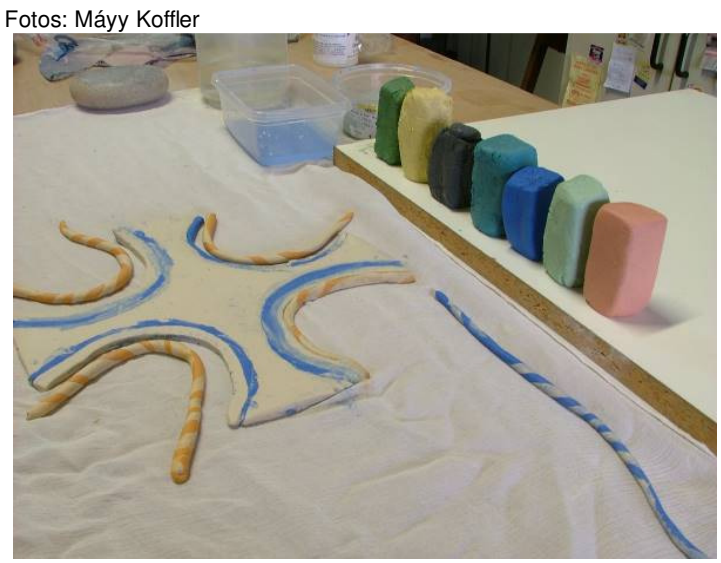

I 1

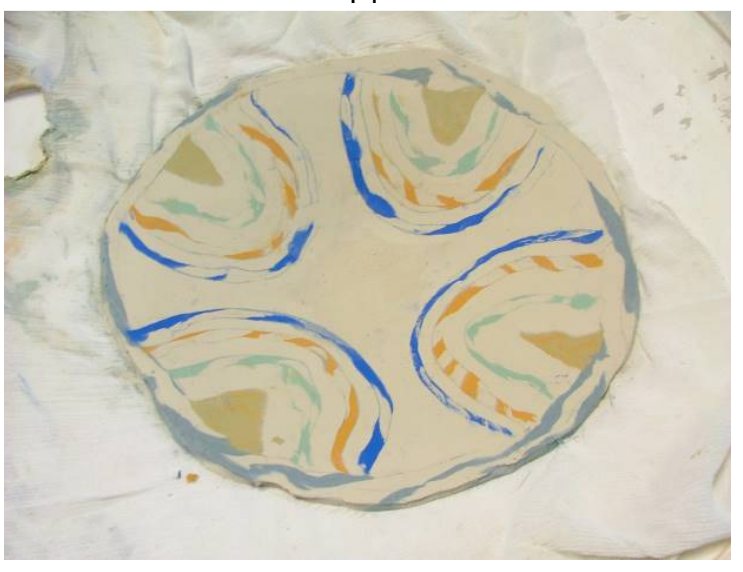

13

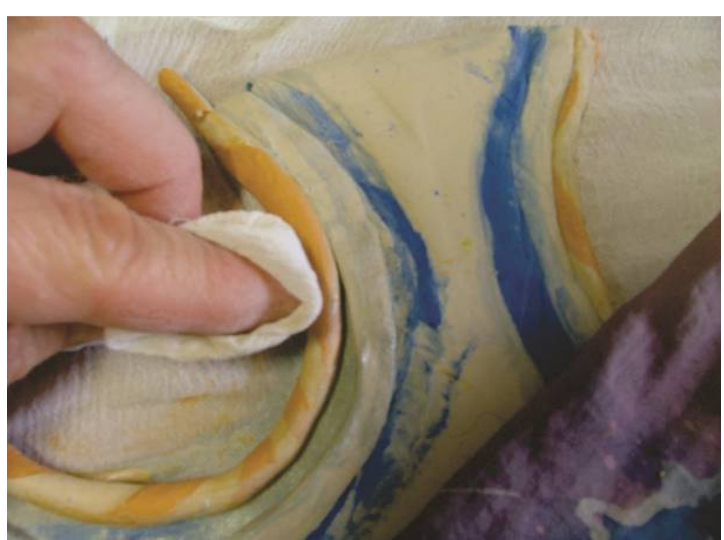

12

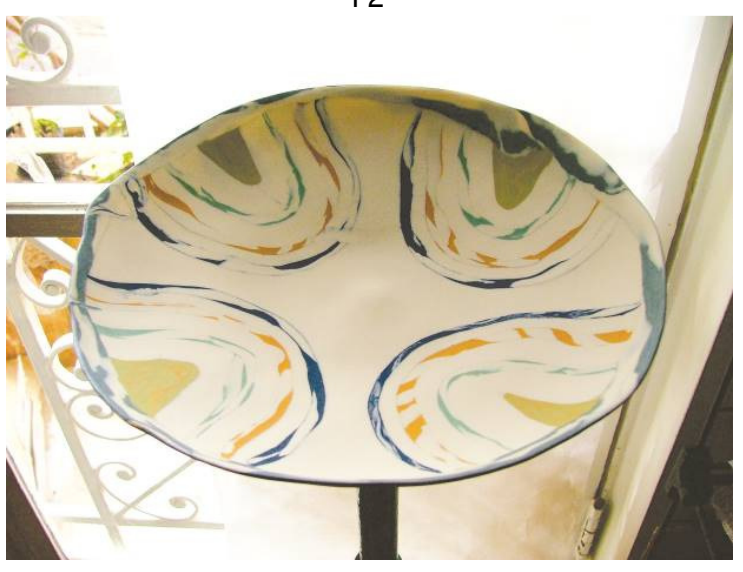

14

${ }^{214}$ Trecho da entrevista concedida por Máyy Koffler a Silvia Tagusagawa 


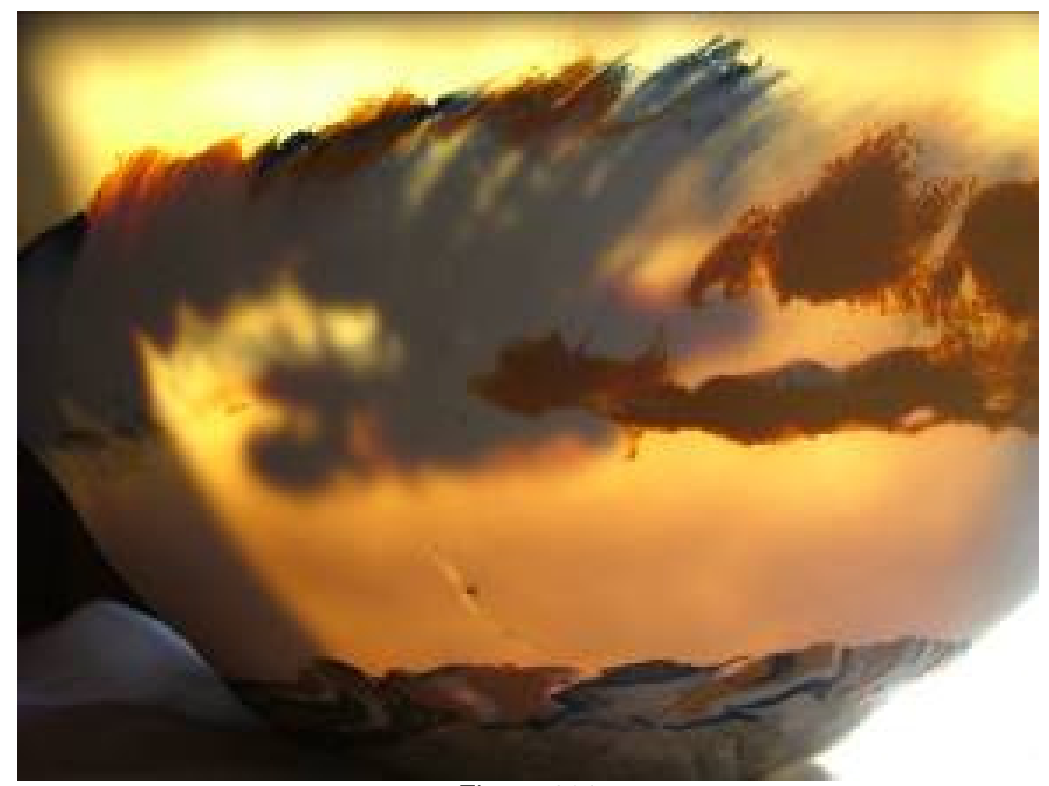

Figura 161

Máyy Koffler

Bela Adormecida (detalhe)

Porcelana paleteada e corantes cerâmicos

2013/2014

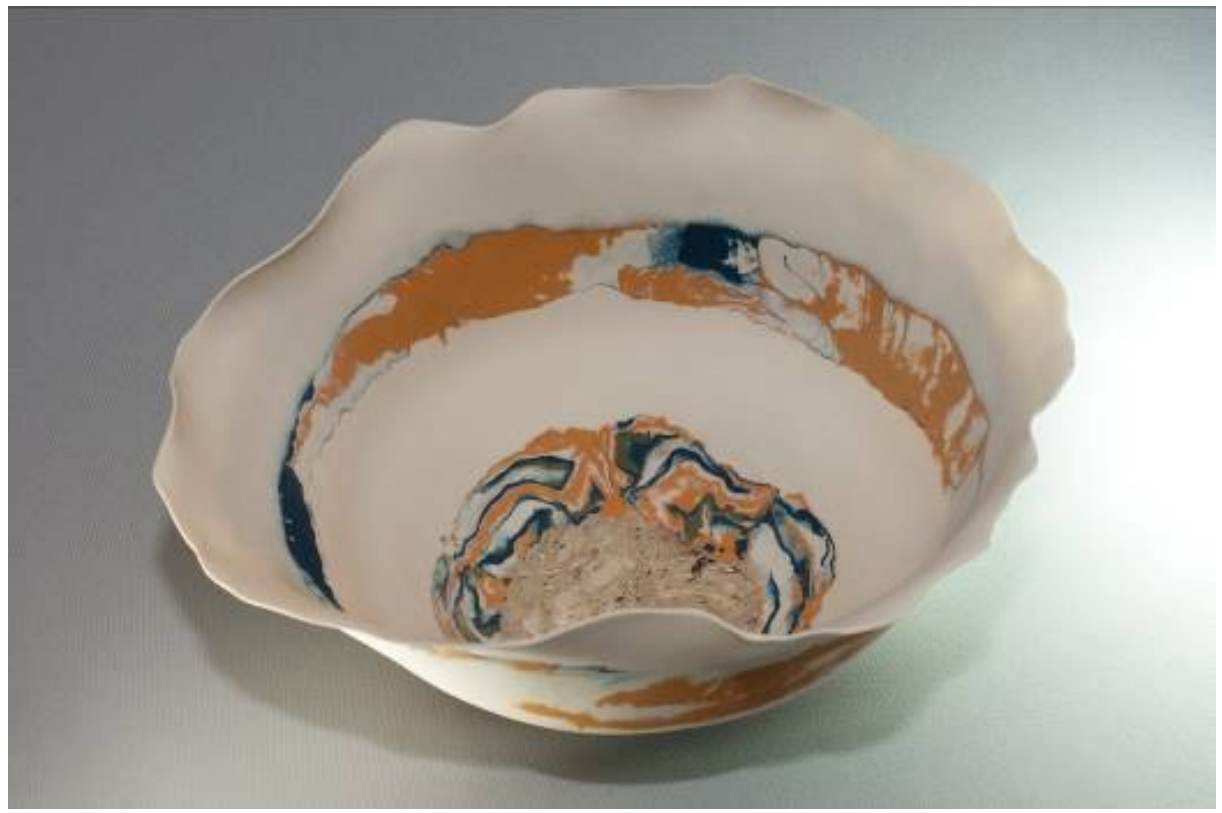

Figura 162

Máyy Koffler

Bela Adormecida

Porcelana paleteada e corantes cerâmicos

$2013 / 2014$ 


\subsubsection{Entrevista com Máyy Kóffler (São Paulo, 19/08/2013)}

Silvia: Então Máyy, vamos falar sobre quando tudo começou. Sei que você nasceu no Paraguai, morou uma época em Lima, Peru. Por favor, vamos voltar um pouco no tempo.

Máyy: Eu não tenho lembrança alguma do Paraguai, pois eu era muito criança quando sai de lá. Eu nasci em Assunção, meu pai era Austro-húngaro e minha mãe era argentina, assim como sua família. Meus três irmãos também. Meu pai era judeu e viajou o mundo, falava sete línguas e ele chegou aqui fugido da perseguição aos judeus. A Suíça concedeu-lhe uma carta de Salvo-conduto.

Lá, ele conheceu a minha mãe e se casaram. Ele era técnico em eletrônica e muito inteligente. Quando ele estava no Paraguai, ele trabalhou numa emissora de rádio chamada Radioteleco e era responsável técnico pela transmissão das programações. Inclusive tenho fotos desta época. Costumávamos fotografar muito naquela época, mas muitas fotos acabaram se perdendo.

O Paraguai estava passando por várias turbulências político-sociais e por questões de segurança, meu pai achou melhor nos mudarmos para um país mais tranquilo. Fomos para o Uruguai, que era considerado a "Suiça" da América. Ele pensava: "Eu acho que está acontecendo alguma coisa interessante lá. Então, vamos para lá." No Uruguai, vivi até os 15 anos, primeiro em Montevidéu, depois fomos à uma cidade chamada Tacuarembó, cujo nome tem origem da palavra taquara que é um tipo de bambu. Tempos depois, nos mudamos para uma cidade chamada Colônia, próximo a Buenos Aires. Colônia é uma cidade maravilhosa, antiga, que foi colonizada pelos portugueses e que se chamava Colônia do Sacramento. Depois, ela passou a ser a Colônia de Espanha. Uma graça de cidade que vale a pena conhecer! De Colônia, nós viemos ao Brasil.

Desde criança, eu gostava de desenhar, meus cadernos eram cheios de desenhos. Já admirava as formas do corpo humano.

Silvia: O gosto pelo desenho tinha influência da família? 
Máyy: Não, era algo meu mesmo. Minha família admirava esse dom do desenho que eu tinha, mas não tive uma motivação ou estímulo externo para desenvolvê-lo.

Para mim, o corpo feminino tem algo muito especial com relação as suas formas curvas e as linhas plásticas. Sempre olhava revistas de moda, estava atenta às roupas. Adorava desenhar pequenas mulheres e inventava roupas variadas para elas. Naquela época, eu observava e ficava fascinada com os sapatos de salto. Olhava atentamente na rua as mulheres andando com os seus sapatos de salto. Observava o movimento e achava lindo quando o salto se levantava, mostrando a base. Isso ficou muito marcado na minha memória.

Eu era uma criança muito distraída, vivia num mundo de sonhos. Nesta época, eu me trancava no banheiro e brincava de faz-de-conta, imaginando que aquele espaço era a minha casa. Queria ter privacidade.

Ficava imaginando onde eu poderia pôr a minha cama, por exemplo. Outra coisa que eu gostava muito era o cinema e que até hoje é uma das minhas paixões. Na minha imaginação infantil, a cama ficava na posição vertical, assim como no filme do Gordo e o Magro.

Silvia: Qual era a sua idade, nesta época?

Máyy: Acho que uns seis ou sete anos de idade. O interessante é que até o Gastón Bachelard fala dessa questão da criança, em que o adulto não imagina o universo rico que a criança vive, onde ela se esconde e o que pensa. Atualmente, há uma preocupação maior com a criança e suas necessidades, mas antigamente não era assim, pois não se pensava nos desejos que possuíam ou em suas potencialidades.

Então me identifico muito com o discurso do Bachelard, na qual ele afirma que quando a criança se esconde, está acontecendo muita coisa e talvez, um dia, ela se esqueça de tudo isso.

Silvia: Fale-me sobre a formação artística. 
Máyy: Meu pai costumava projetar filmes em casa e lembro-me do som da projeção. Assistia desenhos animados e foi nessa época que comecei a gostar de Jazz e do Blues, que eram trilhas sonoras dessas animações.

Assim como a Arte, a música é para mim uma necessidade. Uma coisa boa que meu pai cultivou em nós foi o gosto pela música e leitura. Ele costumava comprar livros para nós e frequentávamos shows musicais. Lembro-me que íamos almoçar em um restaurante com música ao vivo. A minha família era muito alegre e fazíamos muitas festas. As pessoas traziam instrumentos musicais como harpas e violões. Amigos do meu pai vinham para jogar bridge e reuniam-se aos finais semanas e eu costumava brincar com os filhos desses amigos.

O primeiro momento que eu tive contato com a Música e a Arte foi quando eu estudei piano no Uruguai.

Silvia: Acredito que seja extremamente importante, além de ver a obra, conversar com o artista. Ver como ele começou e de onde vêm seus anseios, suas paixões, medos e fascínios.

Máyy: O fascínio pela figura humana vem desde a infância, quando desenhava aquelas pequenas mulheres, as recortava e manipulava, fazendo com que se sentassem ou se abraçassem. Estavam envolvidos ali os comportamentos humanos.

Durante a adolescência, por volta dos quinze anos de idade, nós nos mudamos de Colônia rumo a Porto Alegre. Foi uma fase de grandes mudanças, houve um choque cultural grande com um novo idioma e, além disso, estava numa idade de rebeldia. Contudo, hoje sou agradecida. O Uruguai é país muito conservador, apesar de ser muito culto. Hoje, eu sinto que sou uruguaia, mas amo o Brasil e não vivo sem ele.

Silvia: Em que ano foi?

Máyy: Foi em 1968. Com o tempo, fui me adaptando, aos poucos aprendi o português e fiz novos amigos. Em Porto Alegre, entrei em contato com um ateliê chamado $O$ Ponto, que até hoje, me parece, é um espaço importante de Arte. Eu fiz aulas de gravura e havia cerâmica lá, mas neste momento, eu não dei muita 
importância. Com este ateliê, vim pela primeira vez para São Paulo visitar uma das bienais de Arte. Eu fiquei encantada por São Paulo.

Depois de algum tempo meu pai decidiu se mudar para Florianópolis. Eu estava com vinte anos. Então, eu decidi que não queria me mudar mais. No entanto, meu pai acabou me convencendo. Quando cheguei lá, eu vi aquelas luzes, o pôr do sol e a ponte de ferro, daí, eu me encantei!

Eu estava vivendo uma época de grandes transformações. Eram os anos 70. Com alguns amigos, comecei a cantar músicas de protesto e me envolvi com as questões sociais. Eu era uma jovem que queria mudar o governo e o mundo. Eu sabia músicas da guerra civil espanhola e outras canções relacionadas com questões políticas, estávamos vivendo a ditadura. A música fez com que eu tivesse uma aproximação maior com as pessoas, pois quando você canta ou toca algum instrumento, você acaba ficando popular e rodeada de amigos. Minha mãe ficava preocupada com algumas das minhas atividades e me criticava bastante.

Nesta mesma época, eu fazia esculturas em madeira e colares com sementes de vários tipos. Envernizava os colares e vendia. Além disso, desenhava retratos de meus amigos e era divertido.

Meu primeiro trabalho em Florianópolis foi na área de publicidade. Eu fazia desenhos, past-up, diagramação e tudo isso foi importante.

Fiquei morando em Florianópolis durante dois anos. Minha irmã estava de mudança de Buenos Aires para São Paulo, aproveitei a oportunidade e vim para cá (São Paulo), pois meu sonho era fazer a faculdade de Artes e em Florianópolis não havia um curso desta natureza.

Ao mesmo tempo em que fazia a faculdade, eu dava aulas de espanhol, violão e trabalhava numa agência de publicidade. Nesta agência, eles editavam revistas de eletrônica e os desenhos eram feitos à base de bico de pena para desenhar e isso fez com que meu pulso ficasse mais firme. O engenheiro passava para mim um draft e eu redesenhava com precisão.

Fiz a faculdade de Belas Artes, no antigo prédio da Pinacoteca do Estado, e cursei Educação Artística. Eu me formei em 1979. 
Logo que saí da faculdade, fui dar aulas de artes para terapeutas ocupacionais na faculdade de medicina da USP. Trabalhei lá durante dois anos. Nesta mesma época, conheci um rapaz que estava interessado em vender alguns trabalhos na feira da Praça da República. E junto com ele, fomos fazer o teste. Entre 2000 pessoas, nós conseguimos uma vaga. No entanto, ele mudou os planos e queria trabalhar com joalheria. Fiquei sozinha com a vaga e iniciei um trabalho de construção de brinquedos educativos em madeira.

Silvia: O que você produzia?

Máyy: Confeccionava móbiles, brinquedos educativos, caixinhas, quebracabeças em madeira, tudo para crianças. Inicialmente, eu cortava e pintava as caixinhas com motivos construtivistas com tinta a óleo. Era bem trabalhoso. Posteriormente, consegui uma pessoa que cortava a madeira e eu pintava. Fazia coisas bem coloridas. Eu vendia bem e o ganho de um final de semana era o suficiente para custear meu aluguel. A partir daí, passei a ter meu próprio ateliê, mas ainda não estava satisfeita com o que fazia. Para mim, o que eu estava fazendo ainda não era arte. Trabalhei na Praça da República durante três anos. Neste período, com a morte do presidente Tancredo Neves, mudou a economia e a situação ficou difícil. Então, tive que sair da Praça da República.

Meus pais estavam morando em São Paulo, mas mudaram-se várias vezes antes disso: de Florianópolis foram morar em Vitória, no Espírito Santo, Belo Horizonte, Minas Gerais e Salvador, na Bahia. Após uma reunião com os meus irmãos, devido à idade avançada dos meus pais e como minha mãe estava com arteriosclerose, decidimos trazê-los para mais perto de nós. Então, eles foram morar em Itu.

Silvia: Você foi morar em Itu?

Máyy: Não. Como a situação do Brasil estava difícil, minha irmã, que estava morando em Lima, no Peru, me convidou para passar uma temporada lá. Ela e meu cunhado tinham uma livraria famosa em Lima, chamada El Virrey. Lá, costumavam se reunir políticos, escritores e intelectuais, havia lançamentos de livros e as pessoas jogavam xadrez. Isso foi em 1986. 
O Peru é um país rico em arte e eu sempre buscava algo para fazer em Lima. Numa das ocasiões, conheci grupo chamado Yuyaschkan215 que confeccionava máscaras e faziam apresentações artísticas, pirotécnicas trazendo várias referências folclóricas regionais. Fiquei encantada com as máscaras que eles faziam. No Peru, há uma tradição grande de máscaras, assim como em muitas culturas que se desenvolveram naquele país. Eram máscaras ritualísticas, festivas e que contam a história do povo. A maioria das festas têm máscaras. Fiquei, então, motivada em fazer uma máscara do meu rosto.

Então, consegui uma pessoa que me ajudou a confeccionar e utilizamos ataduras gessadas. Você corta as ataduras em quadradinhos, molha na água e coloca sobre o rosto lubrificado com vaselina. Queria fazer outras máscaras, experimentações e alterações, mas não tinha muito conhecimento técnico. Fui tentando e explorando.

Silvia: Quem ajudou você a confeccionar sua máscara?

Máyy: Minha irmã sugeriu que eu entrasse em contato com Hernando Soares, dono do ateliê La Araña e que eu levasse minha máscara. Quando cheguei lá, o Hernando e sua esposa, chamada Pili, me receberam calorosamente. Imediatamente, o Hernando já chamou um rapaz, pediu para trazer o gesso, fizeram o molde e já tiraram a primeira cópia da minha máscara, tudo no mesmo dia. Fiquei encantada!

Esse ateliê possui uma loja chamada Warike, que é um nome de origem indígena. Todas as cerâmicas comercializadas na loja eram fabricadas neste ateliê. Era um local em que você não tem vontade de sair de tão lindo e bem montado que era. Tudo ali era de bom gosto, objetos feitos com palha de arroz em tons de terra. Assim, tudo era tão perfeito, as xícaras em pires, tudo. Eles faziam todos os tipos de utilitários, além de outros objetos com plantas, tapetes e objetos indígenas.

\footnotetext{
${ }^{215}$ Yuyaschkani é um grupo teatral com centro cultural fundado em 1971 que tem como objetivo divulgar a Cultura Peruana no que se refere ao teatro, dança e artes. Promove laboratórios e workshops que ajudam na formação de atores.
} 
E sabe por que se chama La Araña? Porque havia uma escultura em forma de uma aranha gigantesca bem na entrada do ateliê. Era uma casa toda branca e havia algumas estruturas de ferro que eram as pernas da aranha e corpo era composto por dois cestos indígenas, um para o corpo e o outro para a cabeça. Era suntuoso.

O Hernando Soares acolheu muitos artistas e foi importantíssimo. Recentemente, consegui resgatar um pouco da história do La Araña através de um site. Eu cheguei a morar lá, produzia minhas peças e em troca, produzia suportes para plantas em bambu com macramê. Lá, havia muito material e outras pessoas também produziam. Havia uma artista que tingia lãs de lhama, fazia tecelagem, tinha um fotógrafo, enfim, tinha de tudo. Era lugar muito especial.

Logo que conheci o ateliê La Aranã, comecei a frequenta-lo e na mesma ocasião, eles me convidaram para uma bienal de máscaras. Fiquei surpresa e apreensiva, pois eu ainda estava começando e conhecendo as técnicas de modelagem. Pensei: "Nossa! Imagine! Que ousadia aceitar o convite!" Sem ter estudado antes, peguei a argila, fiz uma máscara e participei da bienal. Quando fiz minha máscara, a esposa do Hernando viu, percebeu minha obsessão pelo o acabamento, pois as minhas peças ficavam com a superfície brunida, ou seja, extremamente lisa e acetinada. Ficava horas com uma ferramenta alisando a peça. Descobri o brunido por acaso. Então, ela disse: "Você tem conhecer o Jose Luís Yamunaqué. Seu trabalho tem tudo a ver com ele!"

Silvia: Foi neste momento que você entra em contato com o paleteado?

Máyy: Então, a Pili, esposa do Hernando, me levou ao ateliê Jose Luiz Yamunaqué que é o meu mestre. Ele é de Chulucanas. Fiquei encantada com a história que tinha por trás de sua obra: a cultura Vicus. Um povo de riqueza ímpar com expressões artísticas de grande beleza e profundidade simbólica, onde 0 legado que eles deixaram transmitia a profundidade e intimidade com que eles se relacionavam com a natureza, suas crenças e costumes. Naquele momento, tudo se clareou e passou a ter um sentido na minha vida.

A Cerâmica contém todas as outras artes, nos oferece múltiplas possibilidades, desde a tridimensionalidade na escultura ao desenho e realização de utilitários. 
Conhecimento sobre as matérias-primas que se utilizam para a preparação de massas cerâmicas, os corantes minerais que nos brindam com a infinita variação de cores que se podem utilizar sobre a superfície cerâmica e os esmaltes. E ainda a criação de murais artísticos, pisos e instalações, etc. As possibilidades plásticas que a cerâmica oferece são infinitas.

Eu realmente estava muito feliz e encantada. Foi um encontro muito especial com a cerâmica.

Então, comecei a frequentar o ateliê do Yamunaqué uma vez por semana.

O José Luís demonstrava a técnica do paleteado e era muito bom em engobes. O primeiro contato com as técnicas, tanto do paleteado como dos engobes, foi bem desafiador, pois tive bastante dificuldade e minhas peças saíam tortas e quando pintava com engobes, ao retirar as peças do forno, constatava que as peças não estavam bem cobertas, era frustrante. Aos poucos, fui percebendo que as batidas no paleteado são ritmadas, cada força tem um som. Com a prática, fui sentindo e apreendendo cada detalhe das técnicas.

Lá, havia um grupo maravilhoso de artistas e há dois deles que são meus amigos até hoje: o Noriaki e o Tuco. Com eles e mais outros artistas, formamos o grupo Integración. Juntos, fazíamos exposições e chegamos a alugar uma casinha em frente ao ateliê do José Luís. Ali, fazíamos nossas peças e vendíamos. As aulas eram muito divertidas. O José Luís era mestre em paleteado e engobes. Fiquei no ateliê dele durante cinco anos.

Silvia: Conte-me um pouco de José Luís Yamunaqué.

Máyy: Ele nasceu e viveu em Chulucanas, cidade localizada no Norte do Peru quase divisa com o Equador. Nos 60, iniciaram-se algumas escavações e várias peças em paleteado foram descobertas num sítio arqueológico. Havia peças em abundância, tanto é que as pessoas comuns escavavam terrenos onde haviam antigos cemitérios soterrados. Como era um povo muito pobre, saía vendendo. Esse fato chegou aos ouvidos dos arqueólogos que foram imediatamente para lá em busca dessas peças para pesquisá-las. 
http://joseyamunaque.blogspot.com.br/

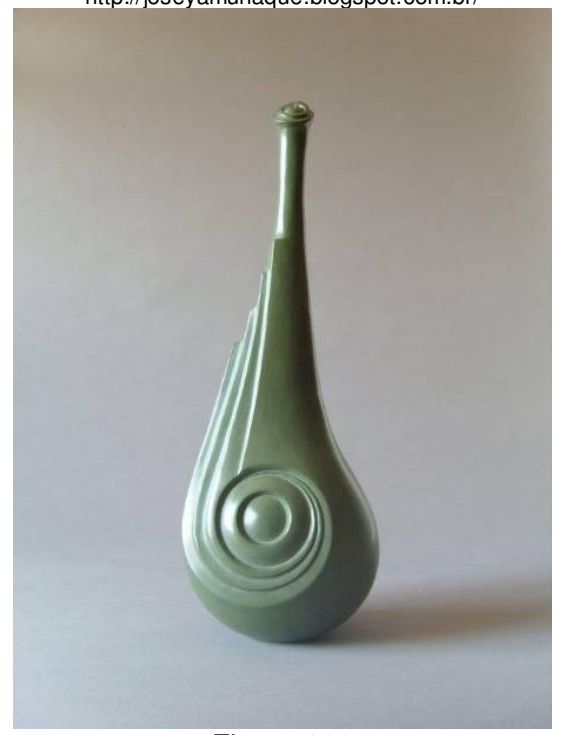

Figura 163

Jose Luís Yamunaqué 2011

Cerâmica paleteada com engobe

Baixa temperatura

Os pesquisadores iniciaram suas investigações e constataram que a técnica utilizada nas peças encontradas era a mesma que os artesãos locais utilizavam naquele momento. Nos sítios arqueológicos, eles encontraram as peças paleteadas e as ferramentas, tais como paleta, pedras e brunidores (pedras negras lisas e brilhantes). Eles descobriram que o povo que viveu ali era pertencente à cultura Tallán. Os arqueólogos denominaram a cultura como Vicús, pois o maior achado de peças foi feito no morro Vicús. Assim como em outras civilizações antigas, na cultura Vicús enterravam os mortos com os seus pertences.

Os arqueólogos convidaram alguns ceramistas entre eles o Jose Luis, Gerósimo Sosa, Pólo Ramirez, Segundo Moncado e Max Inga. Juntos, iniciaram uma pesquisa sobre os desenhos contidos nas peças encontradas. Eram desenhos elaborados e obtidos através de uma queima decorativa. Posteriormente, denominada queima positiva e negativa.

Primeiramente, eles pintam a peça em ponto couro, fazem o brunido e uma vez seca, levam ao forno à lenha. Depois, é feito o desenho com barbotina. A camada de barbotina não pode ser muito fina, mais ou menos $1 \mathrm{a} 2 \mathrm{~mm}$ aproximadamente $e$ deve cobrir as partes que se quer proteger da carbonização. A segunda queima é 
feita em ambiente redutor, onde as peças são queimadas com material orgânico como folhas de manga. O tempo pode variar, pois depende de inúmeros fatores: isolamento do forno, quantidade material orgânico e está se ventando demais.

Posteriormente, essa pesquisa teve grande repercussão. Então, esse grupo de ceramistas foi divulgar as técnicas em vários lugares no mundo.

Nesta época, o Jose Luís conseguiu sair de Chulucanas e foi para Lima, além de outras localidades como Buenos Aires, Itália com o intuito de divulgar a técnica. Ele recebeu convites para palestras e exposições, pois seu trabalho é maravilhoso! Morou por vários anos nos Estados Unidos. Atualmente, possui um ateliê em Lima.

Em 1987, frequentei seu ateliê em Lima.

Silvia: Em seus primeiros trabalhos, as influências da cultura Vicús e a maneira de como utilizavam a técnica do paleteado, a aplicação dos engobes e a queima negativa aparecem com bastante força. Como você vê essa influência?

Máyy: Certamente eu fui influenciada, mas naquela época não parava para racionalizar essas coisas. Estava vivendo, vendo e tudo me encantava: as argilas, os tons terra, tudo. Os museus de Lima possuem um acervo riquíssimo que conta a história da cultura peruana.

Em 1986, ainda se falava dessa grande descoberta que eram as peças da cultura Vicús. Era tão novidade que o pessoal de Lima não tinha consciência do que era o paleteado.

Eu decidi, então, mergulhar no paleteado. Queria trabalhar no Museu de Arqueologia e Etnologia de Lima, pois eu pretendia entender melhor a cultura e a história da cultura Vicús. Então, apresentei uma carta interesse para fazer uma parceria com a equipe de arqueólogos. Eu via que eles tinham habilidade de datar, catalogar e analisar sob outros aspectos uma cerâmica, mas não sabiam como preparar um engobe nem conheciam as características e o comportamento das matérias-primas, por exemplo. Então, minha proposta era trocar conhecimento: eu passaria tudo que sabia de cerâmica, enquanto técnica, e eles, o conhecimento de restauração. Eles aceitaram a proposta. Aprendi muito sobre restauração de peças cerâmicas. Por exemplo, aprendi que essas peças absorveram muito sal e assim os 
cristais vão se formando no interior de suas paredes, provocando sua quebra. Aprendi também a técnica de retirar esse sal, na qual a peça é colocada em várias piscinas pequenas com químicas especiais, para dessalinização. Eles tinham muitas peças em seu acervo, cerâmicas que foram saqueadas e devolvidas ao museu e outras que, por algum motivo, foram entregues. Muitas se quebraram e foram restauradas inadequadamente. Tinha muito coisa para restaurar e eu ficava horas, e muitas vezes dias, sobre uma mesma peça.

Foi emocionante, pois eu estava rodeada dessas peças pré-hispânicas! Eu pude também fazer algumas peças, inclusive tive privilégio de utilizar um dos moldes originais da cultura Chancai e fazer uma queima numa réplica de forno préhispânico, construído pelos arqueólogos. Posteriormente, tive a oportunidade de fazer uma exposição neste museu juntamente com o grupo Integración.

Atualmente, consigo pensar melhor em tudo que aconteceu na minha vida e o que influenciou o meu trabalho, quando fui convidada a dar uma palestra cujo tema era a influência da Cultura Vicús no meu trabalho poético. Foi muito bom resgatar tudo o que aconteceu no Peru.

Em 1991, decidi voltar ao Brasil.

Silvia: E como foi esse retorno? Foi definitivo?

Máyy: Quando eu voltei para o Brasil, tive que recomeçar do zero em São Paulo. Não fazia ideia de onde poderia encontrar argila e como iria iniciar na cerâmica aqui. Eu tinha uma amiga, a Karen, que também fazia parte do grupo Integración e que esteve em Buenos Aires para um encontro com o Chiti ${ }^{216}$. Neste encontro, ela conheceu a escultora austríaca, Signe Möbus, que morava em São Paulo. A Karen enviou uma carta para mim de Buenos Aires, falando da Signe e me passou o contato dela. A Signe foi até a minha casa e me convidou a frequentar seu ateliê, localizado no Jardim Marajoara. Eu caminhava diariamente até lá, pois onde eu morava era relativamente próximo. Depois de certo tempo, devido as constantes

\footnotetext{
216 Jorge Fernandez Chiti (Buenos Aires, 1940) é ceramista, professor e escritor. É considerado uma das referências no ensino das técnicas cerâmicas, publicou vários livros sobre a história e as técnicas. Ministra cursos de esmaltação e modelagem em cerâmica periodicamente.
} 
viagens dela, fui convidada para morar e trabalhar no seu ateliê, onde produzia meus trabalhos. Fiquei lá por dois anos. Era um local muito agradável, onde se podia ver, do meu quarto, a paisagem. Era um ateliê com paredes de vidro e um forno alemão.

Depois disso, eu montei meu ateliê no Butantã. Meu primeiro ateliê após meu retorno de Lima. Era num lugar que eu tinha que subir 51 degraus. O local pertencia a um médico alemão que praticava medicina natural e seu consultório era no mesmo local. Posteriormente, ele se mudou para Brasília. No quintal do ateliê tinha um pomar: havia abacate, pêssego, limão e amoras. Era um lugar que dava a sensação de estarmos fora de São Paulo, num sítio. A casinha em que eu estava era uma graça! Fiquei quatro anos neste local.

Posteriormente, montei outro ateliê na Lapa. Em 1993, tive a oportunidade de fazer minha primeira exposição individual em Curitiba pela Associação Brasileira de Cerâmica, graças a ceramista Nilziete de Mello, que foi minha madrinha, pois ela me apresentou ao pessoal do museu Alfredo Andersen. Além disso, ela abriu as portas me colocando no universo da cerâmica aqui. Foi a primeira apresentação do paleteado no Brasil. Isso consta nos anais da Associação. Fiz também uma palestra para mostrar a técnica. Naquela ocasião, conheci minha amiga e ceramista Sueli Massuda, que é minha sócia no ateliê hoje.

Em 1995, tive a oportunidade de implantar um curso de cerâmica na Fundação Cultural Cassiano Ricardo na cidade de São José dos Campos, São Paulo. Trabalhei lá durante cinco. Em 1997, comecei a dar aulas de escultura no Liceu de Artes e ofícios de São Paulo. Anos mais tarde, houve um corte de profissionais no Liceu. Então, a Sueli propôs de montarmos um ateliê juntas. Eu achei que em duas, ficaria mais fácil e melhor. E estamos juntas até hoje, há quatorze anos.

Em 2007, eu implantei um curso em Diadema no Centro Cultural Clara Nunes, onde montei um forno inclusive.

Após meu retorno ao Brasil, tive a oportunidade partilhar todos os conhecimentos que tive em cerâmica, implantei cursos e montei fornos. Fiz vários trabalhos neste sentido com comunidade carente. Além disso, participei de muitas exposições e em 2004, desejei fazer uma homenagem ao povo de Chulucanas. 
Então, voltei para lá e fiz um registro fotográfico dos ceramistas e dos ateliês que trabalham com o paleteado.

Silvia: Lembro-me que você apresentou uma palestra a respeito deste registro no CONTAF em 2005.

Máyy: Sim. Eu apresentei várias palestras lá. Lembro-me que na primeira, eu fui aplaudida de pé, pois acho que eu estava apresentando algo novo e eu fiz uma demonstração com um fundo musical, foi muito legal.

Com relação ao registro fotográfico realizado em Chulucanas, convivi com os ceramistas e visitei vários ateliês. Nos dias que fiquei lá, me hospedei na casa do ceramista Maneno Juarez. Uma vez, eu o convidei para dar uma oficina no Liceu. A apresentação fotográfica resultante desta viagem foi apresentada juntamente com as fotos dos meus trabalhos e teve como objetivos, além de homenagear Chulucanas, mostrar que uma técnica cerâmica pré-hispânica, pode ser utilizada como uma linguagem contemporânea.

Depois disso, de todas essas experiências, práticas e maturidade, percebo que criei minha própria linguagem dentro do paleteado. Comecei então a desenvolver trabalhos em porcelana.

Meus trabalhos anteriores tinham muita influência da queima negativa e das cores terra.

Com a porcelana, iniciei algumas experimentações tingindo a massa com corantes cerâmicos. Então, chegou um momento que percebi que aquilo era realmente a minha linguagem. Era uma pesquisa minha.

Silvia: Tradicionalmente, o paleteado é feito em massas de baixa temperatura.

Máyy: Em Chulucanas, eles não trabalham com alta temperatura. Alguns, como o irmão do Maneno, estão começando algumas pesquisas com queima de alta.

Silvia: Lembro-me que você havia comentando sobre a necessidade que você tinha em trabalhar com alta temperatura por questões de resistência mecânica. 
Máyy: Se não tomar os devidos cuidados, os trabalhos feitos em baixa temperatura podem se quebrar. É de grande responsabilidade e devemos nos preocupar com a fragilidade.

Lembro-me que quando iniciei minhas pesquisas com massas cerâmicas de alta temperatura, a Nilziete havia me dado uma massa de porcelana Limóges, mas já usava o grês creme como filito grosso que resultou nesta peça aqui a Mulher Dragão. Fiz um molde dela. Sei que até a sétima peça, é considerada original, como na gravura. Quanto maior o número de cópias, menor é o valor.

Silvia: Você acredita que a obra vai perdendo sua "aura" à medida que é reproduzida, assim como diz Walter Benjamin?

Máyy: Não, as peças que as pessoas mais gostam, eu acabei repetindo. As pessoas encomendavam esta peça especificamente. Como eu havia feito o molde dela, então fiz outras mulheres. Aquelas mulheres ali foram feitas em homenagem às mulheres tallánes. Há uma série de estudos publicados em livros sobre as mulheres tallánes, entre eles, conta que quando Pizarro veio ao Novo Mundo pela primeira vez, ele não viu os homens, mas sim as mulheres. Os homens tinham outras tarefas como pescar, por exemplo. Houve trocas de presentes. Então, a destruição da cultura e do povo indígena foi algo gradual. A história deste povo foi contada pelos cronistas espanhóis e indígenas. É interessante ler a versão de ambos os lados. Um destes cronistas é o Guaman Poma, um índio que falava espanhol e era muito culto. Ele conta a história através de seus desenhos.

Nessas histórias, essas mulheres eram muito especiais. Elas tinham um domínio de si próprias, decidiam com que homem iria ficar e participavam ativamente na cultura de seu povo. Sempre fico interessada por esses assuntos ligados às mulheres e a sua atuação na sociedade. Como havia dito no início, o aspecto feminino está sempre presente nos meus trabalhos. Não só pela forma figurativa em si, mas também simbólica. Inspiro-me muito em lendas. O Peru é riquíssimo de lendas e mitos, que eram passados de geração a geração pelo povo indígena. Existe uma história sobre as mulheres incas que quando morriam se transformavam em pedras e que depois, como era um povo guerreiro, eles acreditavam que durante a guerra, elas poderiam voltar à vida na forma de mulher 
novamente para ajudar os homens a derrotar os seus inimigos. E depois, retornavam a sua forma de pedra.

Essas histórias muito me fascinam. Por isso, eu fiz essas mulheres aqui parecendo rochas (mama Huaco e Ocllo) . Quando eu vi as rochas na paisagem eu ficava imaginando: "Nossa! Isso aqui é uma mulher!"

Atualmente, chamo essas mulheres talhanes de mulheres que assobiam porque elas podem emitir um som de suas cabeças.

A primeira mulher que eu fiz, não havia gostado e por isso eu a escondi por muitos anos. Um belo dia, pensando em homenagear as mulheres talhanes, eu comecei a vasculhar as coisas, para fazer uma exposição e daí eu reencontrei a peça escondida e pensei: "Nossa! Que peça bonita! Tem uma força! Eu acho que vou fazer um molde dela!".

Estou lembrando que fiz uma exposição na Livraria Cultura chamada Expressões da Natureza. Fiz uma série de peças que tinham relação com as coisas da Natureza, os bichos, conchas e os fósseis.

Houve uma época em que me voltei para a psicologia na tentativa encontrar as razões nas quais eu estava fazendo determinadas formas. Costumo conversar com pessoas da área e uma amiga minha analisando meu trabalho, trouxe essa questão do feminino nas formas da concha, por exemplo, é a coisa do acolher. Então, realmente essas formas de conchas vêm da coisa do útero e há um questionamento sobre a origem.

Senti a necessidade de fazer conchas novamente para resgatar essas questões da origem.

Houve uma época em que me interessei em estudar as formas dos fósseis. Fiz até alguns estudos modelando essas formas de conchas, nautilus e trilobitas, ouriços e quitons. 


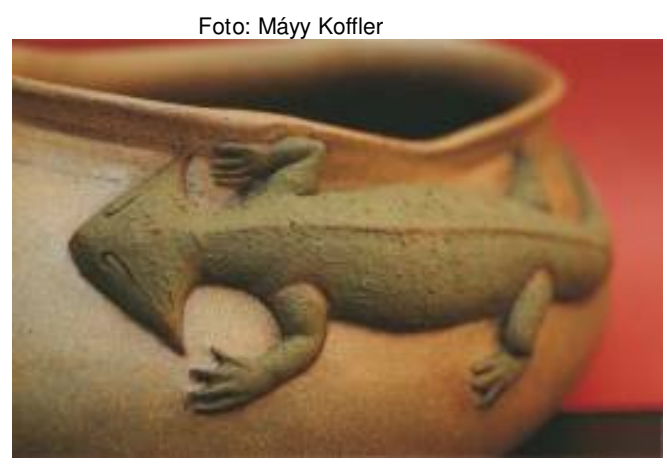

Figura 164

Máyy Kóffler

Cerâmica paleateada e engobes

Agora, retomei as formas mais limpas. Gosto das linhas, sem rugosidades, da espacialidade ou algo que está no ar. Por isso, penso que há uma necessidade de colocar as mulheres (talhanes) no ar. Então, encontrei uma pessoa que está montando um suporte para essas mulheres.

Silvia: Há um envolvimento grande de sua parte desde o início até o final do processo de trabalho. Há o contato direto das mãos, a mente e os olhos atentos aos movimentos. Fale-me um pouco dessa experiência.

Máyy: Além de tudo há uma pesquisa. Para alguns trabalhos eu tenho o apoio de um torneiro, que faz as peças. O acabamento, assim como a aplicação de desenhos e engobes são feitos por mim. Para agilizar no processo de produção, fui procurar possibilidades como o molde e o torno elétrico, pois o paleteado é algo demorado.

Silvia: A leveza está presente em quase todos os seus trabalhos.

Máyy: Sim. Há peças que trabalho desde 1993/94. Na série dos Caracóis, quando estou construindo as peças, sempre aparece um trinco no mesmo local. Insistentemente, continuei a fazer e o problema persistia. Então, percebi que os movimentos contrários, para dentro e para fora, criavam essas tensões.

Com relação aos detalhes da pesquisa, quando comecei com a porcelana eu não queria uma peça totalmente branca, queria tirar proveito de outras possibilidades e de colorir. Iniciei com a massa creme com filito grosso e colocava com a porcelana. Percebi, então, que a união de duas massas com retrações 
diferentes, só seria possível com o paleteado. A partir daí, me atrevi mais e fiz uma peça. Separei pedaços de porcelana colorindo-os, um por um, em amarelo, azul, todas as cores possíveis na porcelana. Primeiro, adiciono corante em pedaços de porcelana e organizo em forma de bloquinhos retangulares, em sequência, cada um de uma cor.

Com os pedaços de massas de porcelana coloridos, o próximo passo seria esticar os bloquinhos em forma de placas, depois decidiria qual seria as formas que iria recortar. Assim como no processo de marchetaria vou colando com a barbotina colorida. Essas pequenas plaquinhas recortadas são encrustadas sobre outra placa. Para começar a paletear uma placa de porcelana, ela deve estar em ponto de couro com uma pedra do tamanho da minha mão. Não é fácil. Muitas peças não ficaram boas. Depois eu me apaixonei por esse trabalho. É um desafio.

Então, o processo da idealização do trabalho, pensar nas formas das peças, nas cores, nas mesclas, ficar imaginando o que fazer para construir uma forma de nuvem, por exemplo, tudo isso é movido pela emoção. Geralmente, essa emoção é gerada, por exemplo, por um livro que li ou música que escutei ou por uma cor ou imagem. Todas as coisas ao meu redor são estímulos que me fazem sentir e que eu quero plasmar no meu trabalho. Fico olhando o que acontece fora, percebo que os artistas são como um termômetro do que acontece na sociedade. No entanto, eu acho que eu não me encaixo nisso, apesar de saber o que acontece com a sociedade, de me interessar pelo que acontece, acho que eu não trago isso para o meu trabalho. Não sou uma artista que quer fazer uma denúncia. Houve uma época em que eu fazia, mas acho que agora não.

Silvia: Talvez não seja o momento, pois está trabalhando questões bem pessoais. As questões trazidas pelos artistas devem ser verdadeiras e são coisas que fazem do trabalho, da obra de arte, algo singular.

Máyy: O que me completa e me satisfaz se encontra no próprio fazer, em conseguir determinada plasticidade, conseguir colocar as cores que queria e depois que acabar pensar em outros trabalhos.

O momento mágico do fazer, é como um parto, até chegar o final do trabalho é muito sofrido. O fazer é o momento mais importante. 
Logicamente sempre há um estímulo, no caso das mulheres, as lendas trouxeram motivação. As questões de certos animais também trazidas, como é o caso da salamandra. A salamandra é um bicho forte e simbolicamente é tão forte que, segundo a lenda, se jogada no fogo não morre e renasce com força. Eu li isso em algum lugar. Aqui no ateliê tem muitas lagartixas e eu sei muitas coisas sobre elas, pois fico observando, elas põe ovos nas peças que ficam por aqui, conheço o barulho delas, como andam e olham.

Por isso, elas estão sempre presentes no meu trabalho.

Silvia: Há muita feminilidade e sensualidade na forma, na superfície de cada peça. É forte isso. São muito sedutoras.

Máyy: É verdade, as pessoas falam que querem senti-las e tocá-las. Tem pessoas que custam em acreditar que sejam cerâmicas (risos).

Silvia: Essa questão do feminino e do útero está presente nos contêineres e nas suas mulheres.

Máyy: Acredito que é bem forte essa questão do feminino e do masculino. Gosto de analisar os diferentes comportamentos, eu leio bastante a respeito e busco referências.

Silvia: O que chama a atenção em seus trabalhos é essa superfície lisa. É quase obsessiva essa busca por uma superfície perfeita.

Máyy: Na verdade é a busca pela plasticidade e volume. Busco conseguir a curva, leveza e o movimento. Se você pudesse filmar, perceberia que há algo lúdico no movimento dessas peças. Elas podem ser vistas sob vários ângulos.

Quando eu termino uma peça, ela não pertence mais a mim. Gosto de ficar olhando para ela, mas isso, para mim, não é narcisismo. Persigo uma forma que é bonita e bem instalada. No entanto, quando estou fazendo não sei se estou seguindo uma proporção. Acredito que as proporções áureas estão dentro nós. Aliás, tudo na natureza parece seguir essas proporções, como uma folha por exemplo. Não fico medindo, as coisas saem naturalmente. Por isso, eu digo que eu 
nasci com a escultura dentro mim, pois quando penso no volume eu tenho uma intimidade com ele.

Silvia: Então, esse é o seu processo: você pensa e vai modelando?

Máyy: Não. Tenho tudo isso desenhado, mas pode mudar no meio do caminho. Separo as obras por temas. Há os objetos que estão relacionados com a natureza e as Mulheres. Tem a Mulher Guerreira, Mulher Dragão, Silvadora, a Mulher do Leite, a Sacerdotisa e a Senhora do Fruto. De guerreiras, tenho duas que fiz. Enfim, essas mulheres carregam uma personalidade que está relacionada com coisas que admiro nas pessoas. A mulher guerreira é a que vai atrás, batalha para se manter.

Silvia: Tem algo relacionado com você.

Máyy: Acho que sim. Quando eu as desenho, elas são bem figurativas. Durante o processo de modelagem, elas mudam.

Silvia: Os objetos que têm a forma de um pote, você tem a preocupação de serem utilizadas para esta função?

Máyy: Não. Na verdade, elas são formas escultóricas. Essas peças ainda estão no começo de um processo. Espero que se transformem em outras coisas, tenho muito trabalho pela frente. Não consegui pensar na peça como um utilitário, embora seja um contêiner e podem conter outras coisas.

Há uma batalha interna sobre essa questão das formas das peças. As questões técnicas, em alguns momentos, interferem quando você deseja em querer dar sequencia à sua expressão. O tempo todo eu tenho que experimentar e verificar como uma argila vai se comportar com a outra e isso tira um pouco a liberdade de deixar fluir. Eu percebo que ainda não dei tudo de mim. Gostaria muito de me dedicar mais.

Silvia: Fica sempre aquela dúvida quando está terminada uma peça.

Máyy: É. Sempre continua. Tanto é que costumo repetir as peças, modelo da mesma forma várias vezes.

Silvia: O interessante que você registra muitas de suas ideias em seu caderno de desenho. 
Máyy: Tem muitas coisas que leio também e que estimulam. Estava estudando questões de religião como o judaísmo. Apesar de meu pai não ter passado nada da religião, tive necessidade de buscar algo.

Silvia: Tem a ver com as raízes.

Máyy: Apesar de meus pais terem me ensinado muitas coisas a respeito de suas respectivas culturas e valores, por vezes, sinto-me sem raízes. Talvez seja pelo fato de ter morado em vários lugares diferentes. A Cerâmica fez com que eu encontrasse a artista que há em mim e encontrar o meu caminho. Além disso, foi através de uma cultura antiga, que não tinha nada haver comigo, é que eu me encontrei. Tive que ir até o Peru para me encontrar. Muito louco isso, né?!

$\mathrm{Na}$ verdade, em minha busca sempre quis ser eu mesma. Eu acho que ainda estou iniciando, tenho muitas coisas para fazer. Na Arte, tudo é tão demorado que ainda vou começar a trabalhar aquilo que eu acredito que domino. Atualmente, me sinto tranquila quanto ao domínio da técnica, se posso misturar os materiais, se vai dar certo ou não. Não me preocupo mais com essas coisas. Sinto-me livre para deixar as coisas fluírem e ser mais autêntica.

Silvia: E você sente a necessidade de ter domínio total da técnica para poder se expressar?

Máyy: Acredito que o caminho e a técnica que escolhi me deixavam presa e senti a necessidade de dominar a técnica. Quando você está aprendendo uma técnica, você está presa a ela; deve entendê-la, pesquisar suas possibilidades e limitações, tudo isso é uma interferência. Assim, você não está totalmente livre para criar. Como um poeta. Ele está livre para se expressar quando tem o domínio das palavras. Ele se sente livre em dizer o que seu inconsciente está lhe falando, vai se expressar através de sua poesia com naturalidade.

Acho que agora me sinto livre e começo a trilhar esse caminho. Sinto-me mais livre com a técnica.

Silvia: Normalmente, o fato de sermos artistas causa nas pessoas um estranhamento. Fico feliz pelos artistas que conheço, pois eles lutam diariamente 
para serem eles mesmos. Fico honrada também com a oportunidade que vocês estão dando de abrir o universo de vocês.

Máyy: Eu sempre acho que a força do trabalho gera outros trabalhos e compensações. Quando você mergulha em alguma coisa, as respostas virão. Falar sobre o seu trabalho, e estar dentro dele mostrará caminhos e o guiará para lados que você nem imaginava. Pode ser que você até mude completamente o foco daquilo que você estava fazendo.

Silvia: Além de conhecer o trabalho do artista, acho importante conversar e poder escutar o que ele tem a dizer. Mesmo que a obra fale por si só, ouvir o que o artista tem a dizer enriquece o entendimento de tudo que ele faz.

Máyy: Na verdade, nós nunca conseguimos explicar tudo sobre nosso trabalho e nem paramos muito para pensar o que estamos fazendo.

Silvia: Talvez não haja necessidade dessas explicações.

Máyy: Acredito que quando falamos do nosso próprio trabalho, temos a oportunidade organizar nossas ideias. Não que seja o objetivo ficar falando, pois na verdade, não é essa a pretensão, mas quando organizo minhas ideias é como se eu estivesse olhando para mim mesma. Começo então a me compreender e reestruturar, o que me ajuda a dar continuidade ao meu trabalho.

Silvia: E também quando você reestrutura as ideias, verbalizando-os, se tem a oportunidade de refletir sobre certos pontos e pensar: "Eu acho que estava equivocada nisso ou naquilo."

Máyy: Isso mesmo. Ter a liberdade de dizer: "eu estava enganada".

Silvia: Um elemento forte no seu trabalho é a própria emoção demonstrada em algumas de suas cerâmicas. E revendo a sua história de vida, vejo que há uma procura de suas próprias origens, mas tudo é muito instintivo e está ali guardado em algum lugar.

Máyy: Eu olho os trabalhos e penso que é uma grande mistura. Atualmente, dedico-me a um tema, estou focada em fazer determinada forma e agora sinto essa 
necessidade. Eu preciso começar e terminar. Explorar ao máximo determinada ideia que certamente vai gerar outras, produzindo outros frutos.

Silvia: Todos os artistas têm seus questionamentos e desafios. As coisas são muito dinâmicas e ocorrem todas ao mesmo tempo. Em meio a esse turbilhão de coisas, temos que encontrar um momento próprio para a produção artística.

Vejo que no seu percurso, há uma busca pela perfeição, assim como a necessidade de encontrar um momento perfeito para a realização dos seus trabalhos.

Máyy: Sempre achamos que devemos fazer o melhor e ir atrás. E posso afirmar que estou inteira, de corpo e alma, em todos os trabalhos que faço. E, de certa forma, está plasmado nas obras, o meu ser. 


\subsection{Miguel dos Santos (Caruaru, Pernambuco 1944): Totens e guerreiros}

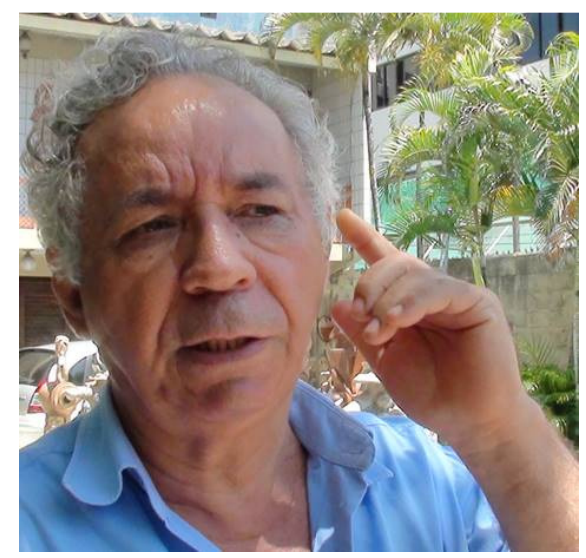

Miguel dos Santos é um artista autodidata que transita com bastante liberdade entre a cerâmica, escultura, desenho, pintura e gravura. Tem mais de quarenta anos de carreira. Nas palavras de seu amigo, Dorian Gray Caldas:

"Miguel dos Santos vibra sua arma de guerra nas tintas, no barro, com pincel e escopo, cinzel da ponta do metal recriando o sonho em seu universo artístico. Surge de sua inventiva o guerreiro e a donzela, os pássaros emplumados, a armadura do príncipe, o gestual arcaico, a consagração da arte, na qual se evidencia a sagração que o eleva." ${ }^{217}$

Conhecer pessoalmente Miguel dos Santos foi uma experiência incrível. Tive a oportunidade de conhecer sua casa-ateliê, alguns de seus trabalhos de perto e ouvir suas histórias desde sua infância em Caruaru até seus grandes desafios como artista.

\footnotetext{
${ }^{217}$ Depoimento de Dorian Gray Caldas - artista plástico do Rio Grande do Norte e ensaísta disponível no site: http://www.migueldossantos.com.br/ . Acesso em: 28/01/2015.
} 


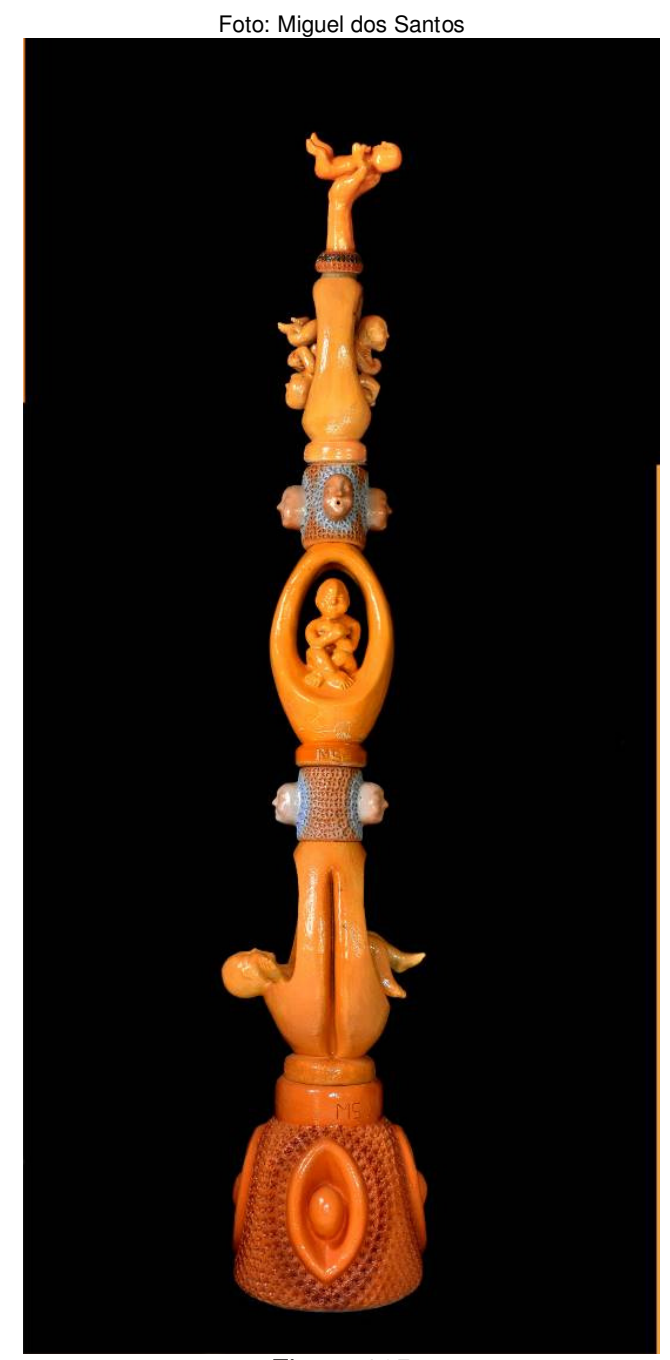

Figura 165

Miguel dos Santos

A Vida

2012
$3,15 \mathrm{~m}$

Cerâmica esmaltada de alta Temperatura

Logo que entro em seu ateliê deparo-me com um cenário repleto de tótens e seres fantásticos feitos de cerâmica. Havia entrado no mundo de Miguel dos Santos: singular, alegre, cheios de história e lições de vida.

Nascido em Caruaru, Pernambuco em 1944, Miguel dos Santos, teve seu primeiro contato com a Arte visitando duas vezes por semana a feira de Caruaru e seus olhos de menino brilhavam diante dos trabalhos de Mestre Vitalino. Durante a sua infância, lembra-se que passava horas no sítio de seu avô, onde a tia lhe dava argila e ele ficava modelando coisas de seu imaginário de menino. 


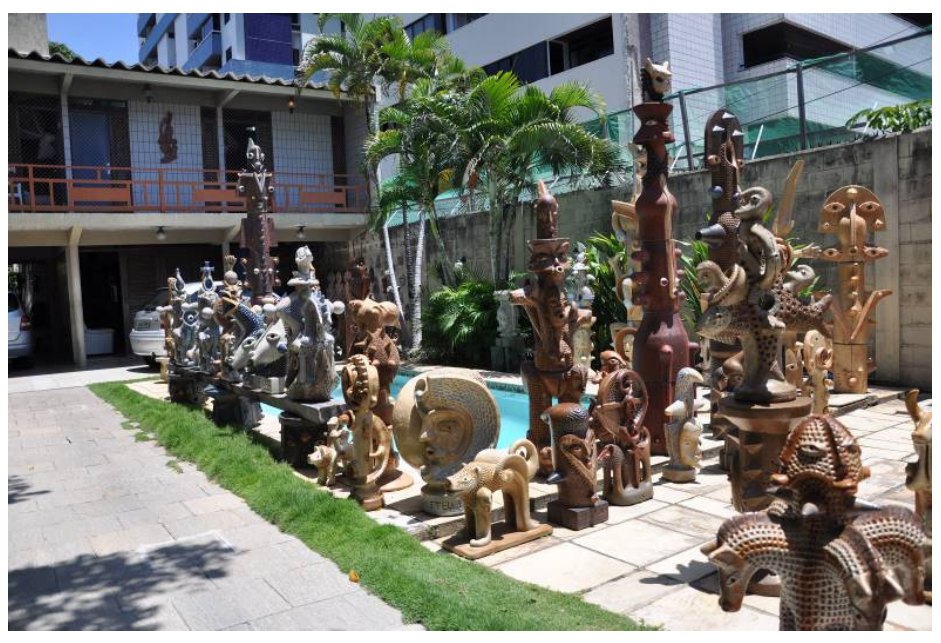

Figura 166

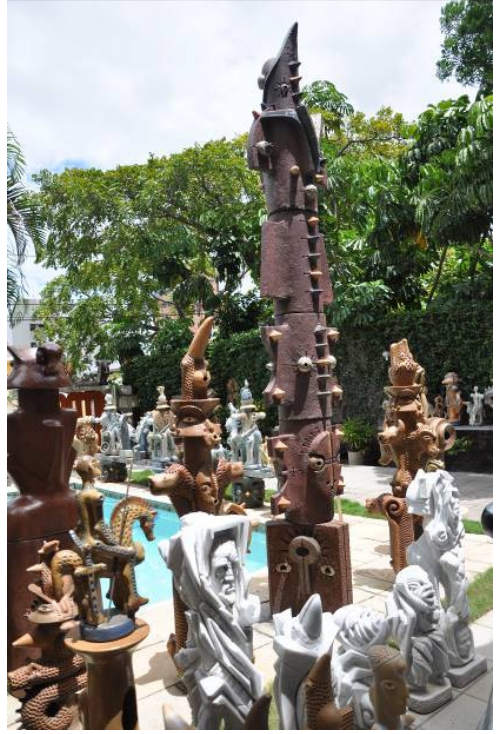

Figura 167

Ateliê Miguel dos Santos

Miguel dos Santos é um artista que se expressa através da cerâmica, pintura, escultura e gravura. Seu conhecimento em Arte foi adquirido através de muita leitura, experiências e contatos em exposições que realizou pelo Brasil, Estados Unidos e Europa. Foi descobrindo e experimentando os diversos materiais, criando sua própria linguagem. Além da Cerâmica, Miguel dos Santos se expressa através da Pintura, Gravura, Escultura, Desenho, Serigrafia e Computação Gráfica. Teve seus trabalhos expostos em importantes museus como o MASP e galerias de arte do Brasil, bem como exposições internacionais. Para ele, a Arte é algo sagrado, um dom. 


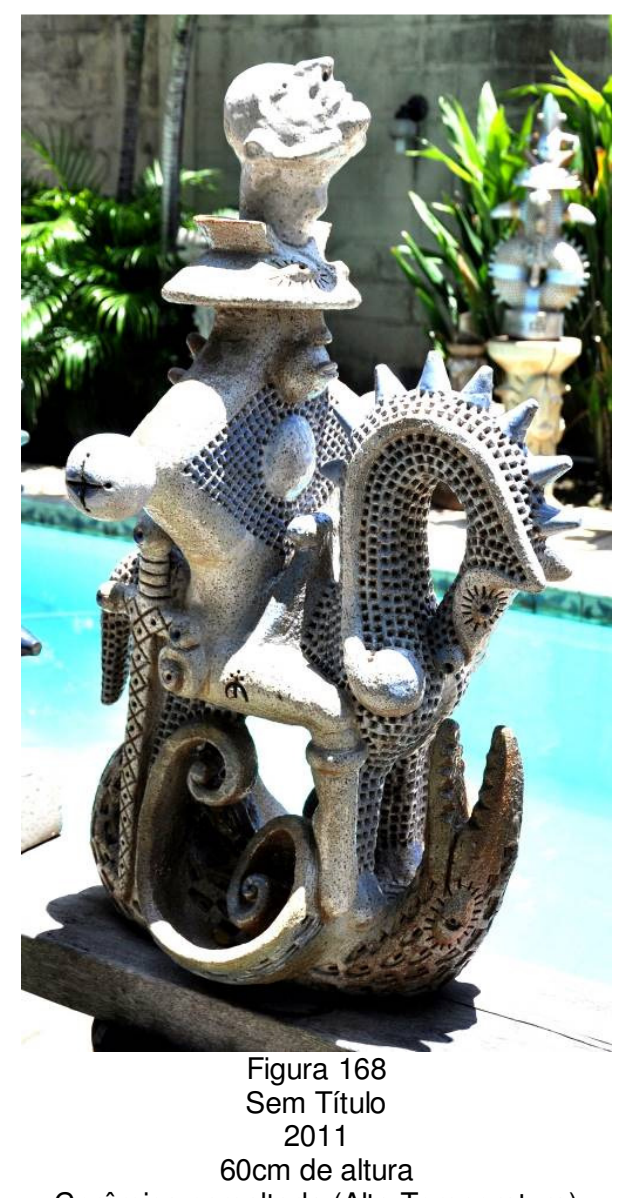

Cerâmica esmaltada (Alta Temperatura)

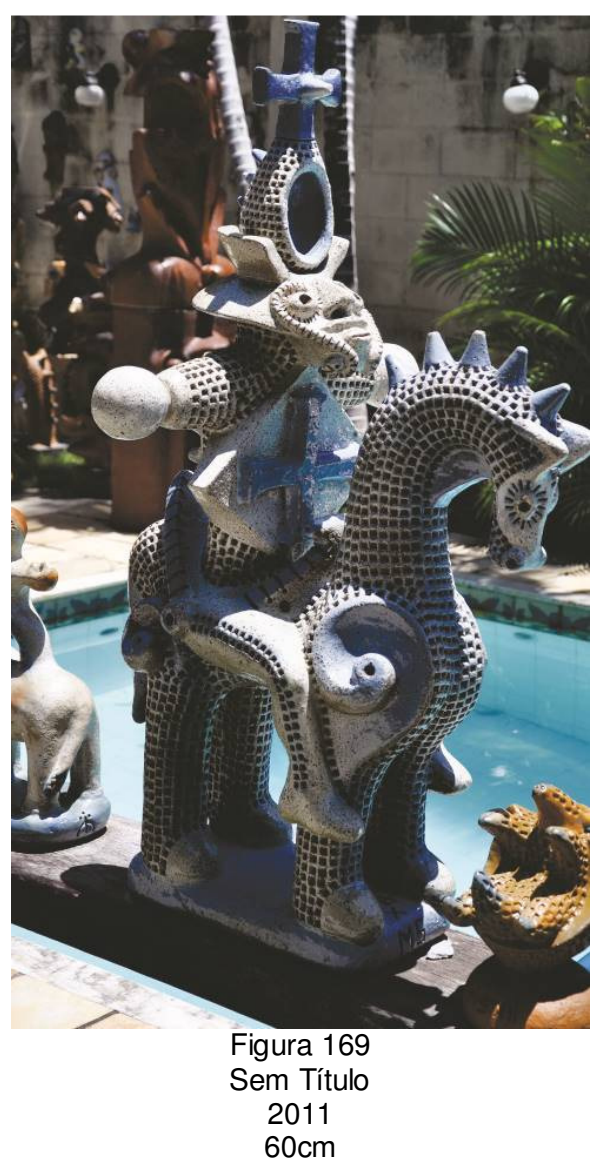

Cerâmica esmaltada (Alta Temperatura)

Segundo Miguel dos Santos, houve vários epísodios interessantes que o inspiraram a dedicar sua vida à Arte. Sua fonte está nas lembranças de menino que guarda de sua cidade natal, Caruaru, e tudo que o cerca. Porém, pode-se dizer que Mestre Vitalino inspiriou Miguel dos Santos a ser inventivo, a procurar a sua própria essência, pois a arte de ambos é completamente distinta:

"Além da feira de Caruaru, uma forte imagem que guardo de minha infância é o garajau de galinhas. A imagem do galo pedrês com todas as cores e o movimento que nenhum outro bicho tem, é algo parecido com um dinossauro. [...] $E$ até hoje, a galinha é um elemento de grande importância no meu trabalho e que tento traduzilo. ${ }^{218}$

\footnotetext{
${ }^{218}$ Trecho da entrevista de Miguel dos Santos concedida a Silvia Tagusagawa.
} 


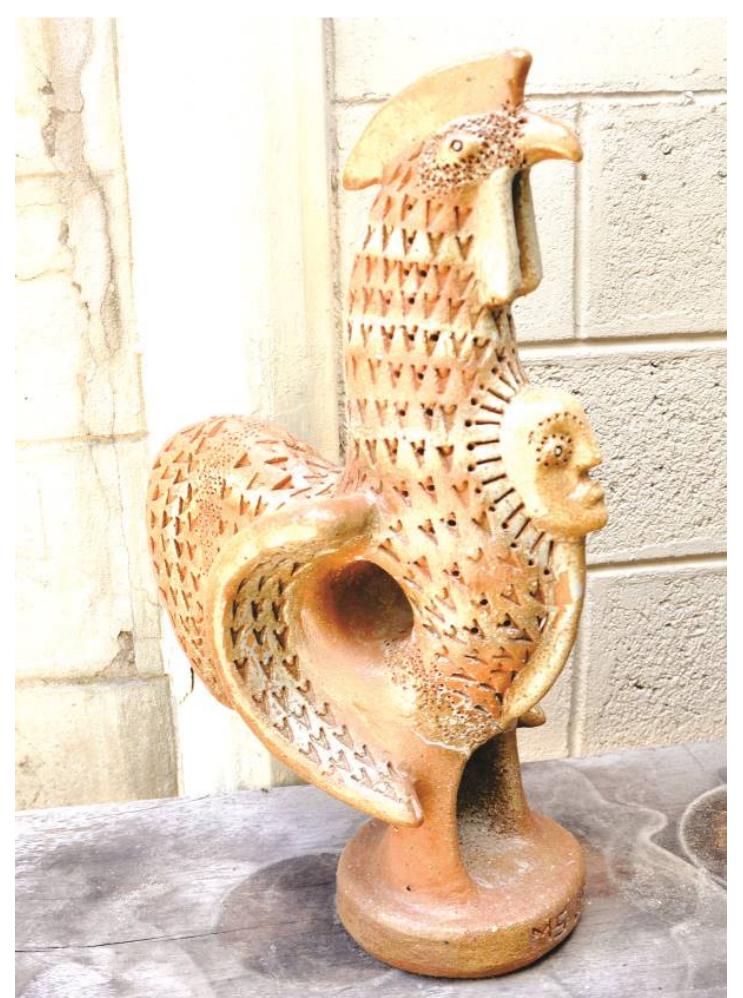

Figura 170

Miguel dos Santos

Galo Dourado

Cerâmica esmaltada de alta temperatura 2009

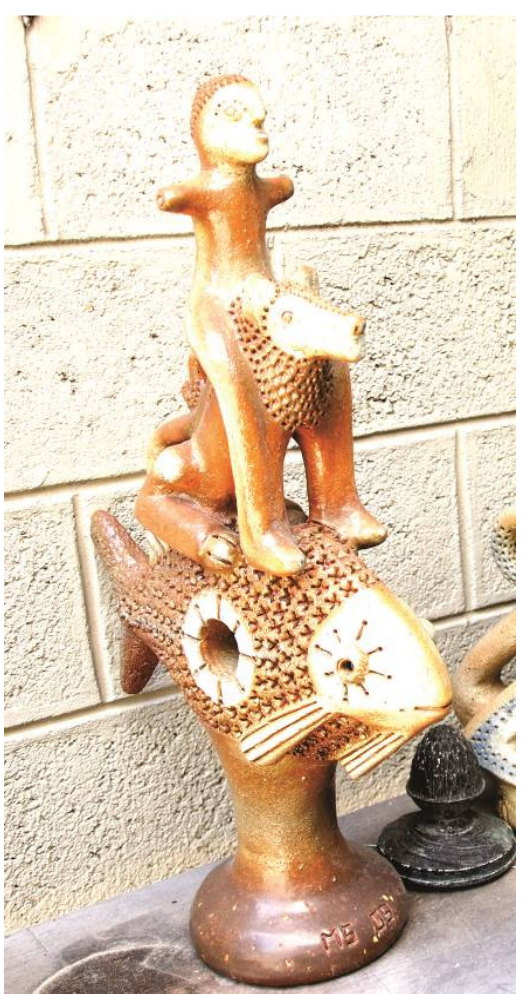

Figura 171

Miguel dos Santos

Sem título

Cerâmica esmaltada de alta temperatura 2009

Ainda jovem, estudou Ferramentaria no SENAI de Palmares, e lá teve bastante contato com as técnicas de desenho. Posteriormente, foi trabalhar em uma biblioteca e segundo ele foi uma rica oportunidade que teve para adquirir conhecimento, pois tinha que ler os livros para poder fazer a catalogação. Apaixona-se pela História da Arte, Filosofia, entre outros assuntos.

Durante toda a sua vida, experimentou vários materiais e se identificava com eles. A Cerâmica, de certa forma, sempre esteve presente no seu universo infantil até a fase adulta, quando aprimora suas técnicas frequentando uma fábrica de cerâmica. Na juventude, conhece Francisco Brennand com quem mantém amizade até hoje. Foi com o pai de Brennand, Ricardo, que Miguel dos Santos adquiriu conhecimento dos vidrados cerâmicos. 


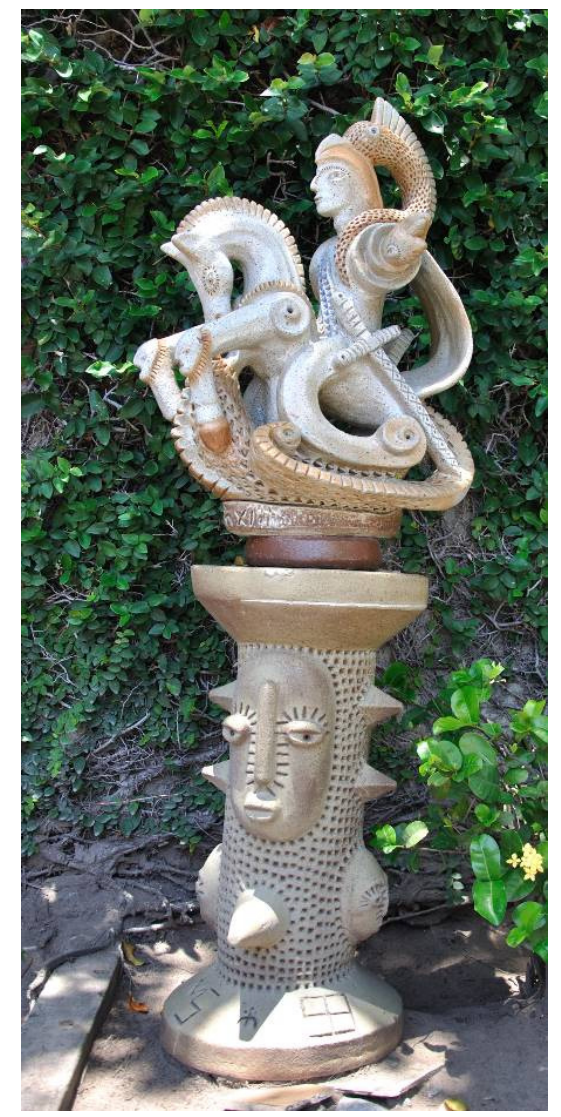

Figura 172

Miguel dos Santos

São Jorge

$130 \mathrm{~cm}$ de altura

2012

Cerâmica esmaltada (Alta Temperatura)

Miguel dos Santos tem na sua essência artística o encantamento pela cultura nordestina. Suas obras fazem referências à cultura que é uma mistura das influências européias, indígenas e africanas, ricas de lendas, representações de animais regionais e personagens fantásticos. Características valorizadas pelo Movimento Armorial.

O Movimento Armorial foi fundado em 1970 pelo escritor paraibano Ariano Suassuna, e teve início na Universidade Federal de Pernambuco, com apoio de artistas e escritores da região Nordeste do Brasil. Tendo como princípio básico realizar uma arte erudita e autenticamente brasileira, abrangendo as áreas das Artes Visuais, música, literatura e teatro. 
Antes mesmo da fundação do Movimento, a Arte Armorial já estava presente e segundo Costa $^{219}$ tinha como premissa uma arte culta que recorria à obra popular como fonte de expressão e comunicação. De acordo com Idelette Santos:

"O Movimento não reúne artistas populares, mas artistas cultos que recorrem à obra popular como a um "material" a ser recriado e transformado segundo modos de expressão $e$ comunicação pertencentes a outras práticas artísticas. Esta dimensão culta e até erudita manifesta-se tanto na reflexão quanto na multiplicidade das referências culturais. "220

Foto: Miguel dos Santos

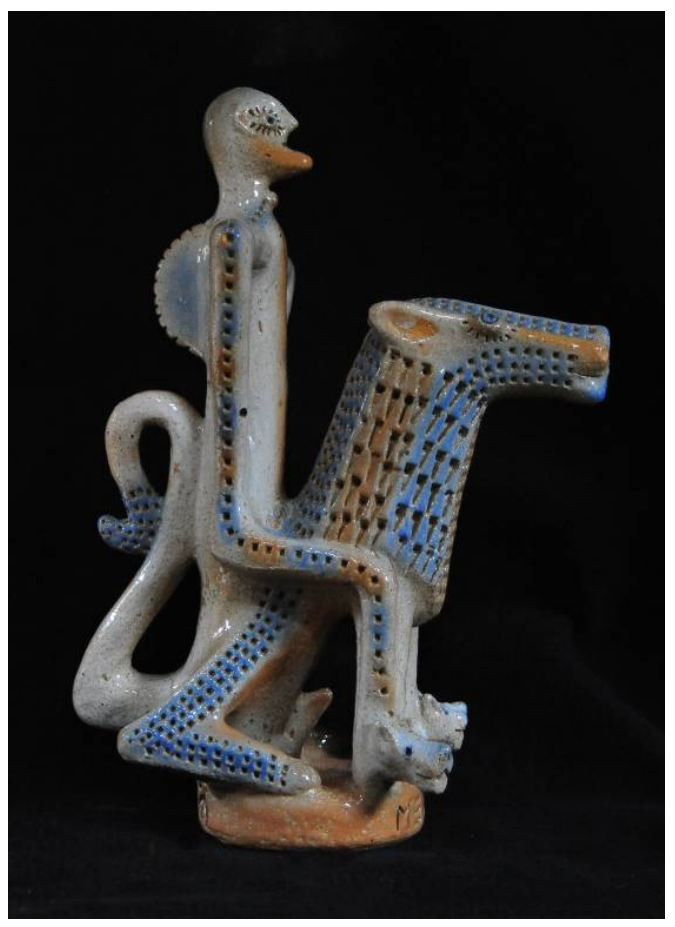

Figura 173

Miguel dos Santos

Leão Azul Montado

$60 \mathrm{~cm}$ altura

2012

Cerâmica esmaltada de alta temperatura

${ }^{219}$ COSTA, Luís Adriano Mendes Costa. Antonio Carlos Nóbrega em acordes e textos armoriais. Campina Grande: Eduepb, 2011. P.31

${ }^{220}$ SANTOS, Idelle M. Fonseca Apud COSTA.Op. cit.2011, p.31. 
No Movimento Armorial fundado por Suassuna a arte popular era igualmente valorizada à arte erudita:

"a arte popular não é inferior ou superior à erudita; são categorias diferentes, cada uma com seu valor próprio". 221

"O fazer artístico seria uma atividade para elites, sejam elas, popular ou erudita, uma vez que a arte não é algo democrático, com oportunidade igual para todos. Para Suassuna, existiria uma elite popular formada por artistas populares". 222

De acordo com Newton Júnior, Miguel dos Santos atua fortemente na primeria fase do movimento, juntamente com os artistas como Gilvan Samico e Francisco Brennand. No entanto, o que o movimento pregava sempre fizeram parte da filosofia de vida de Miguel dos Santos.

Miguel dos Santos traz no seu conceito de vida um pouco daquilo que Ariano Suassuana um dia afirmou:

"Arte pra mim não é produto de mercado. Podem me chamar de romântico. Arte pra mim é missão, vocação e festa."223

${ }^{221}$ SANTOS, Idelle M. Fonseca Apud COSTA.Op. cit.2011, p.31.

${ }^{222}$ Idem, p.18.

${ }^{223}$ Depoimento disponível em http://www.elfikurten.com.br/2013/09/ariano-suassuna.html. Acesso em 01/11/2013. 
Foto: Miguel dos Santos

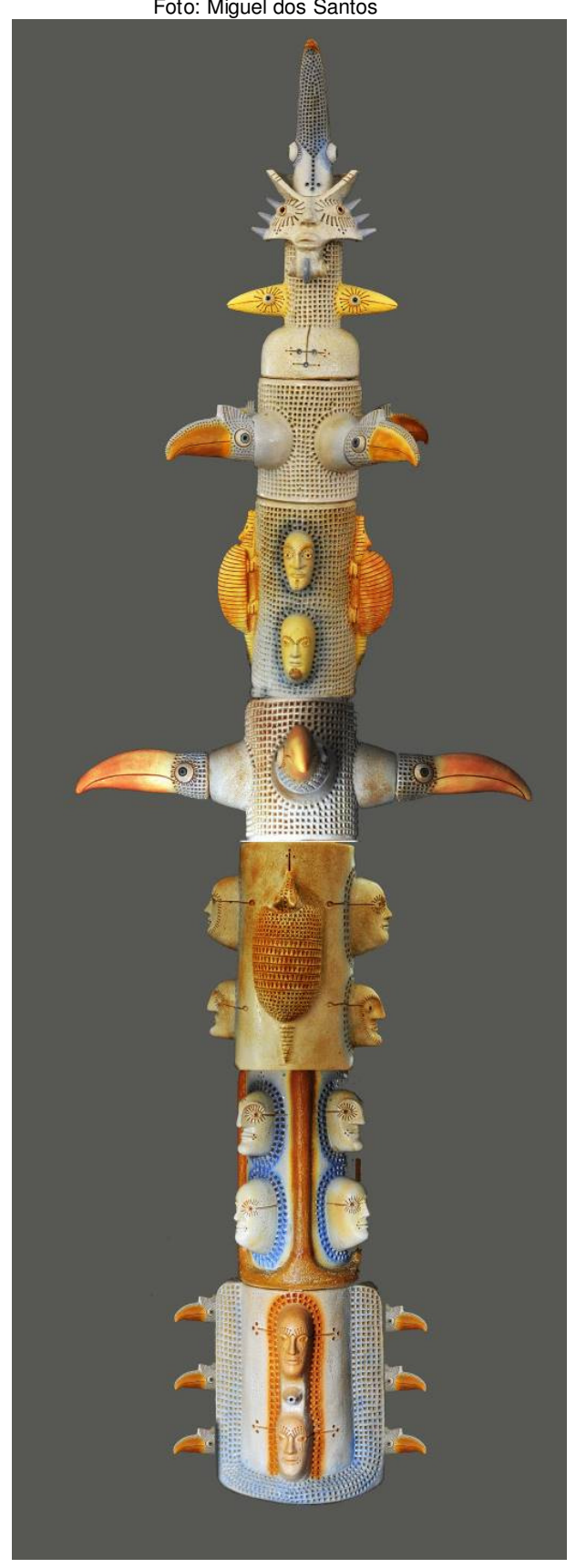

Figura 174

Miguel dos Santos

A Fauna

$5,4 \mathrm{~m}$ de altura

2013

Ceramica esmaltada (alta temperatura) 


\subsubsection{Poética de Miguel dos Santos}

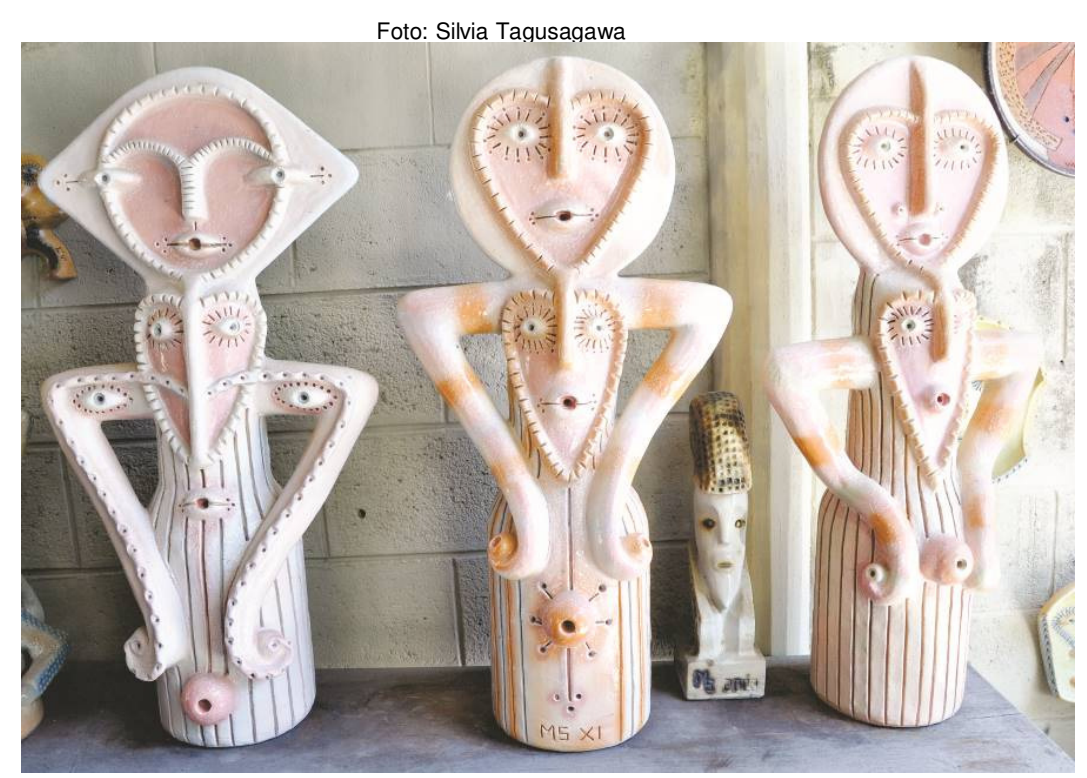

Figura 175

Miguel dos Santos

Verônicas

$90 \mathrm{~cm}$ de altura

2012

Cerâmica esmaltada (alta temperatura)

As obras em cerâmica de Miguel dos Santos trabalham os opostos: de um lado existe a percepção sutil e a sensibilidade perante o mundo que o cerca, do outro, temos a força bruta materializada sob as formas de seres fantásticos, alguns com aparência grotesca, ricas de texturas e desenhos, através manipulação de grande quantidade de massa cerâmica.

Utilizando argilas de diversas regiões da Paraíba, Miguel dos Santos prepara sua própria massa. Ele modela manualmente recorrendo às técnicas de placa, acordelado e até torno elétrico para alguns tipos de trabalhos. Muitas de suas obras possuem grandes dimensões e ocupam locais públicos.

Miguel dos Santos recorre à queima oxidante em fornos elétricos e neles são feitas as queimas de biscoito e, posteriormente, dependendo do projeto, utiliza vidrados cerâmicos de alta temperatura. As cores variam de projeto a projeto e segundo ele, são selecionadas durante o processo de execução: 
"Penso em Cobalto, ferro e titânio [como fossem idiomas]. As formas das peças vão pedindo determinadas texturas e cores."224

As queimas são feitas em fornos elétricos de alta temperatura.

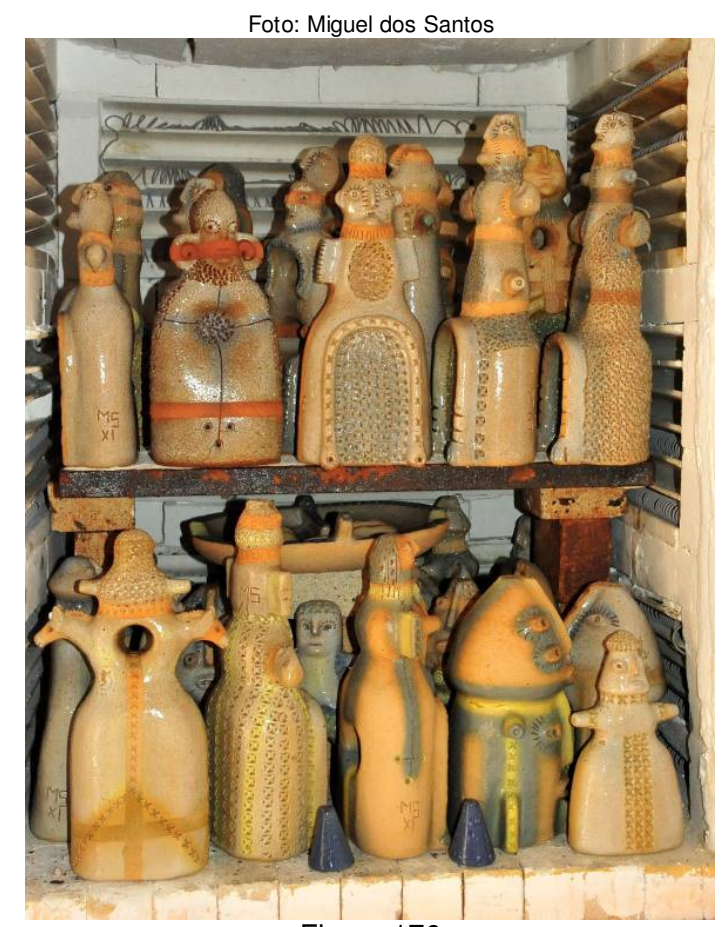

Figura 176

Miguel dos Santos

Peças cerâmicas esmaltada de alta temperatura - Abertura de forno Queima elétrica

No início de sua carreira, trabalhou com cerâmica de baixa temperatura, mas logo sua produção artística devota-se à alta temperatura, principalmente porque parte de suas obras possuem grandes dimensões e muitas delas ficam expostas às intemperes. Nesta mesma época, nos anos 70 e 80 , suas obras exploram as potencialidades cromáticas das argilas, predominando os tons terrosos.

Em trabalhos posteriores, Miguel dos Santos explora outras possibilidades cromáticas utilizando óxidos corantes, além de descobrir outras fontes de argilas, explorando as argilas brancas.

\footnotetext{
${ }^{224}$ Trecho da entrevista de Miguel dos Santos concedida a Silvia Tagusagawa.
} 


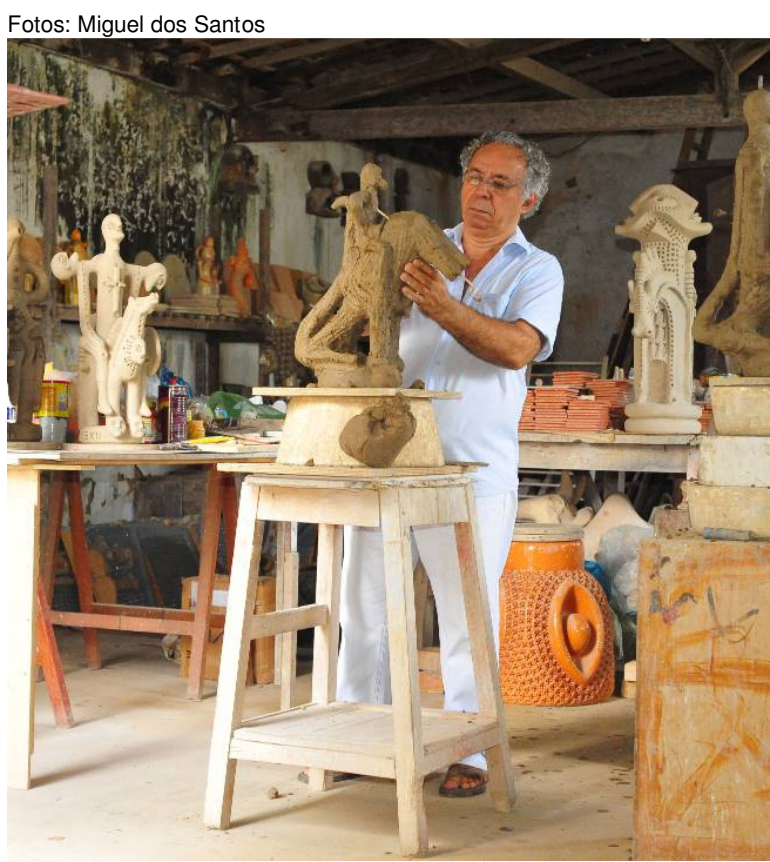

Figura 177

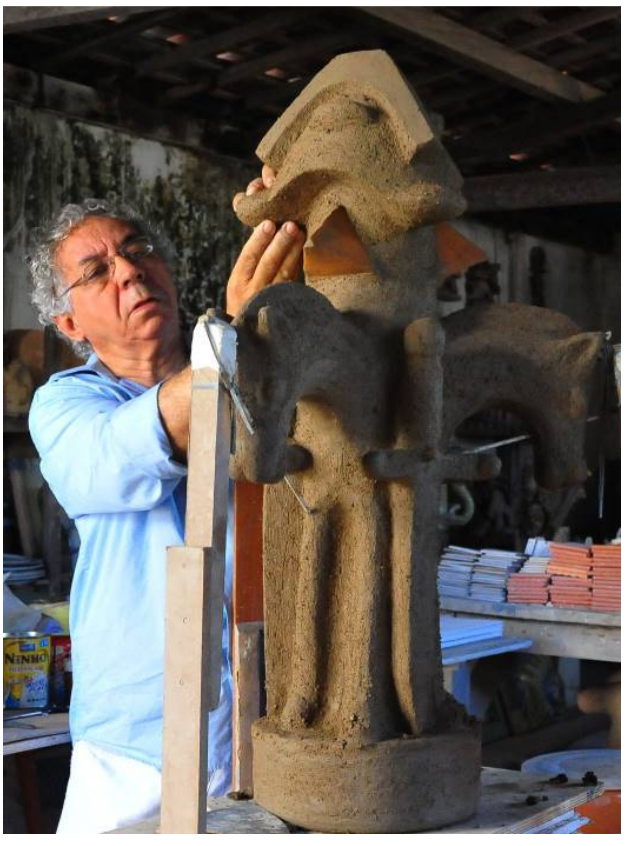

Figura 178

Miguel dos Santos em seu ateliê Modelagem por placa e bloco

O universo explorado por Miguel dos Santos possui deuses como Cronos e santos como São Jorge e São Francisco, não se esquecendo dos animais como o cavalo ou o tamanduá. No entanto, retratar figuras que fazem parte de uma cultura, para Miguel, não tem nada de imitativo, pois ele procura dentro de seu repertório criar uma nova interpretação. Ele não segue uma tradição, assim como na arte popular, em que a estética e a maneira de trabalhar é passada de pai para filho. Miguel dos Santos possui uma linguagem própria. 


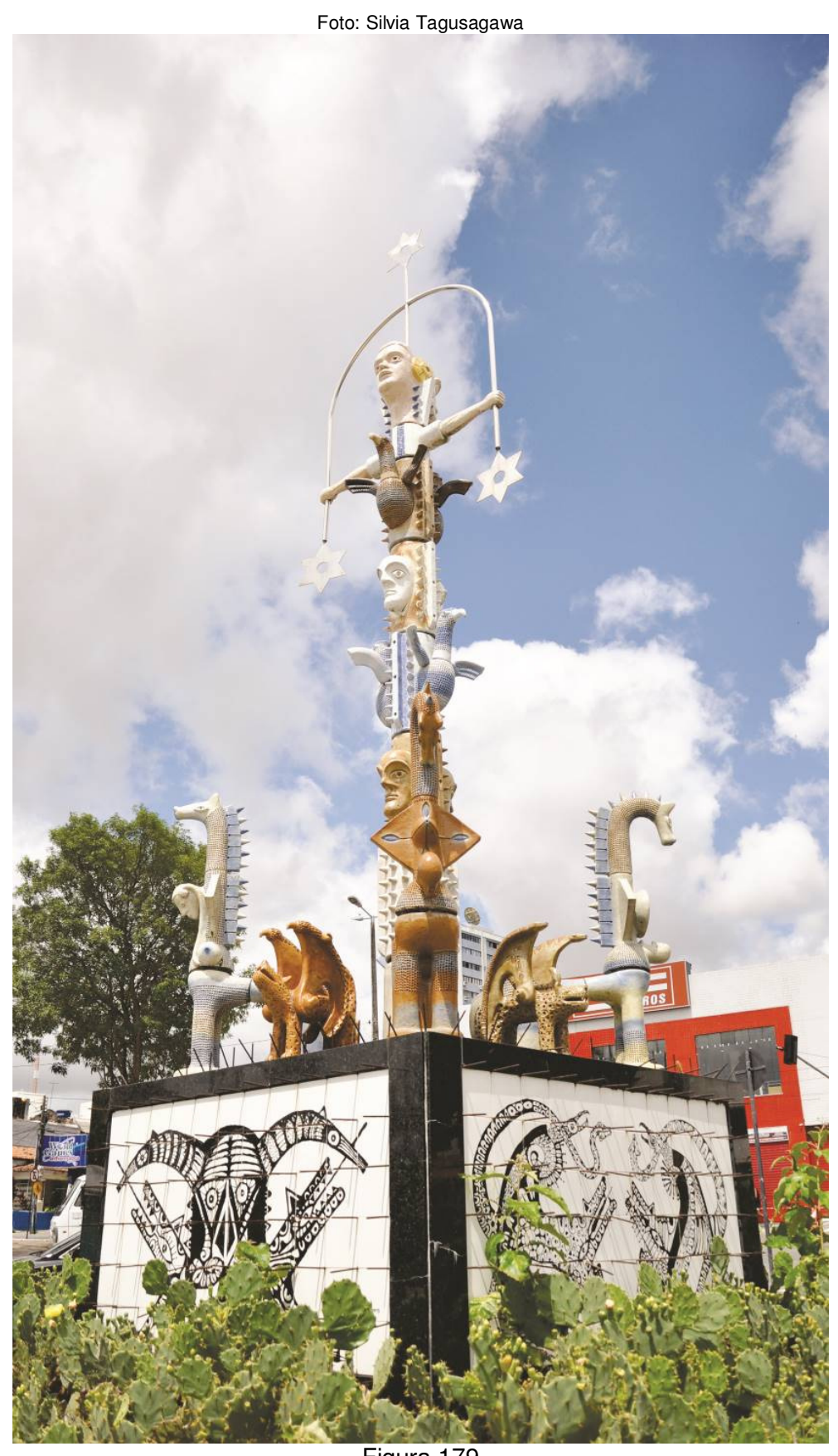

Figura 179

A Pedra do Reino

(Monumento dedicado à Ariano Suassuna)

Cerâmica de alta temperatura, concreto e aço $8,55 \times 3,0 \times 3,0 \mathrm{~m}$

2009

Parque Sólon de Lucena - João Pessoa, Paraíba 


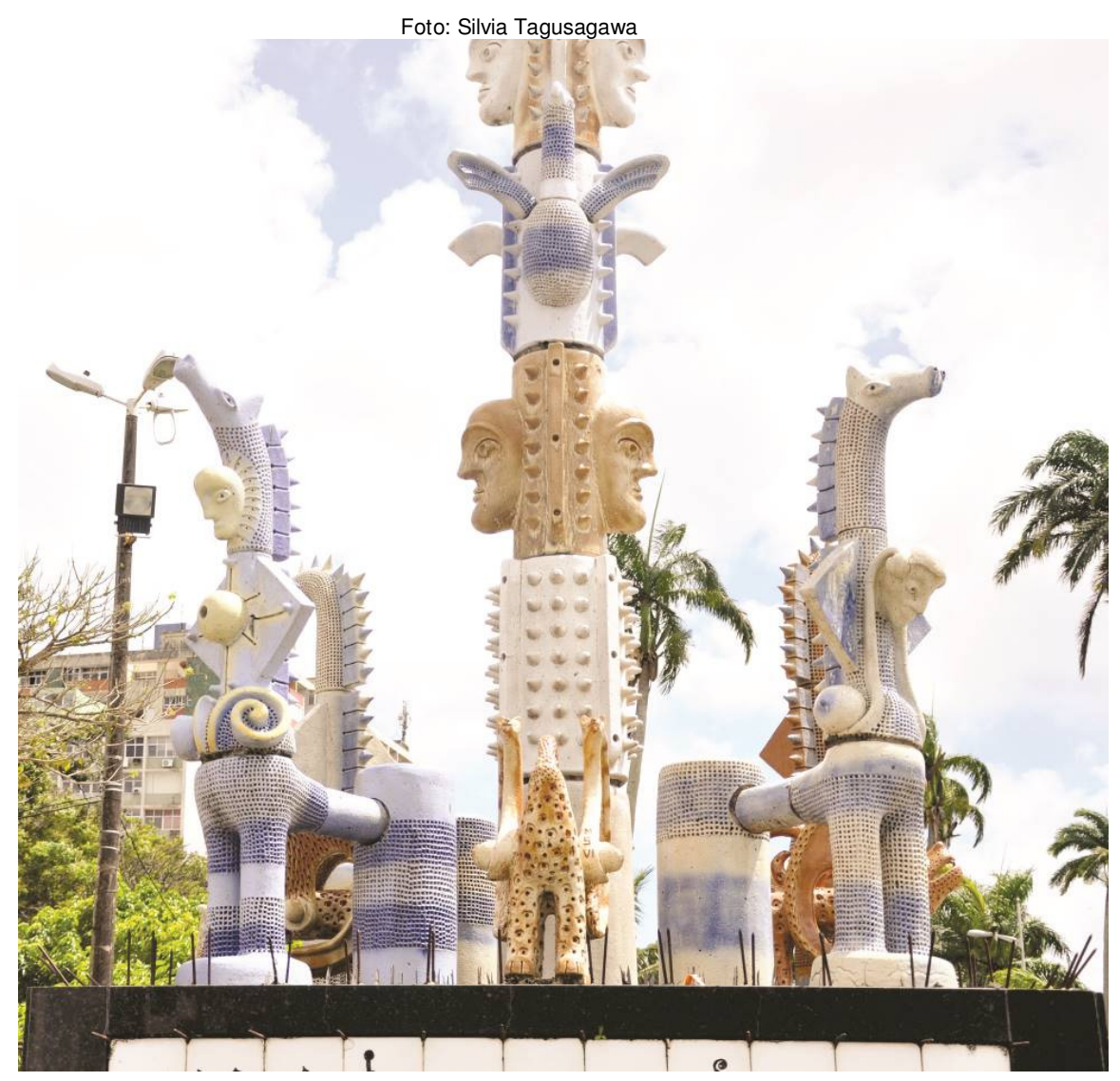

Figura 180

A Pedra do Reino (Detalhe)

(Monumento dedicado à Ariano Suassuna)

Cerâmica de alta temperatura, concreto e aço

$8,55 \times 3,0 \times 3,0 \mathrm{~m}$

2009

Parque Sólon de Lucena - João Pessoa, Paraíba

Em 2009, foi inaugurada na capital paraibana, João Pessoa, o monumento construído por Miguel dos Santos.

De acordo com Miguel dos Santos ${ }^{225}$, o monumento A pedra do Reino é uma homenagem ao escritor Ariano Suassuna. Newton Júnior disse em entrevista que o monumento simboliza a reconciliação entre Suassuna e a capital paraibana João Pessoa. Seu pai, João Suassuna era senador da Paraíba e foi assassinado em conflitos políticos em 1930. Sua família se vê obrigada, então, a se mudar para a cidade de Itaperoá, sertão paraibano. "Mesmo sem saber mensurar o quanto o peso da morte de João Suassuna contribuiu para moldar o Ariano Suassuna escritor, eu 
creio que de certa maneira ele realizou a sua "vingança" através dos seus escritos."226 O monumento tem o mesmo título de umas principais obras de Suassuna, A Pedra do Reino.

$\mathrm{Na}$ Pedro do Reino de Miguel dos Santos, ele constrói uma espécie de tabuleiro de xadrez utilizando elementos da fauna e outros elementos da cultura nordestina. Quer unir os elementos da cultura nordestina e da fauna brasileira, como onças, cascavéis, tamanduás. Para o professor e estudioso das obras de Ariano Suassuna, Carlos Newton, a obra de Miguel dos Santos, baseada no conto que leva o mesmo nome, simboliza a reconciliação de Ariano Suassuna com a cidade de João Pessoa. Neste monumento, Miguel dos Sanos uniu todos os elementos que sempre estiveram presentes em seu meio e na infância.

\subsubsection{Entrevista com Miguel dos Santos (João Pessoa, 27/09/2013)}

Miguel dos Santos sempre faz referência às suas ações utilizando o pronome pessoal na primeira pessoa do plural, "nós", pois diz que suas conquistas são obtidas também com apoio, seja da família, ou de um funcionário.

Silvia : Miguel, fale-me de sua trajetória artística, começando pela sua infância.

Miguel: Eu nasci em Caruaru e abri os olhos para o mundo com quatro anos de idade. Mestre Vitalino ${ }^{227}$ era uma figura que eu visitava na feira de tabuleiro duas vezes por semana, às quartas e aos sábados. Às seis horas da manhã estava eu com o meu avô diante do tabuleiro de Vitalino. Há coisas que Vitalino repetia, mas também tinham as novidades. As novidades apareciam esporadicamente e poderia ser um boi diferenciado ou uma composição diferente. Isso era em 1948. Eu ouvia

\footnotetext{
225 Documentário" Do barro à A Pedra do Reino", Miguel dos Santos,2010.

${ }_{226}$ MEDEIROS, Rostand. http://tokdehistoria.com.br/2014/08/02/ Data: 11/11/2014)

${ }_{227}$ Mestre Vitalino (Caruaru, Pernambuco 1903-1963) ou Vitalino Pereira dos Santos foi um ceramista autodidata que tinha um forte senso estético e criou obras em cerâmica que retratam de forma expressiva e singular a vida no campo e nas vilas do nordeste pernambucano. Das mãos de Vitalino surgiram bois, cabras, cavalos e a realidade em que vivia. Suas obras são conhecidas mundialmente. "Ele arrancava as coisas da terra, sem impelir a ela suas figuras. Muito pelo contrário, ele sempre trazia as figuras da terra", definiu certa vez o sociólogo Gilberto Freyre.( Algo Mais. Revista de Pernambuco, Julho/2009 nº 40, p. 66)
} 
muitas coisas sobre ele através do meu avô. Na época não compreendia, mas muitas coisas que ele dizia ficaram em minha memória, principalmente a sua essência. Mestre Vitalino foi o meu ponto de partida.

Naquela época, Caruaru era muito mais mágica do que é atualmente. Outro dia, fomos para lá e vimos que a cidade se transformou numa Nova lorque, Los Angeles, cheia de edifícios e dois shoppings. Aliás, a feira de Caruaru é precursora dos shoppings, pois ela era um grande shopping, o primeiro do Nordeste brasileiro. Junto com Vitalino estava Zé Caboclo ${ }^{228}$ e Manoel Eudócio ${ }^{229}$, na feira de Caruaru. Entre eles, havia muita humildade e troca de ideias, como por exemplo, partilhavam o conhecimento do uso de arame para facilitar na construção dos bonequinhos, para fazer o triângulo e instrumentos musicais. A cerâmica deles era queimada a $600^{\circ} \mathrm{C}$ e não deformava o arame.

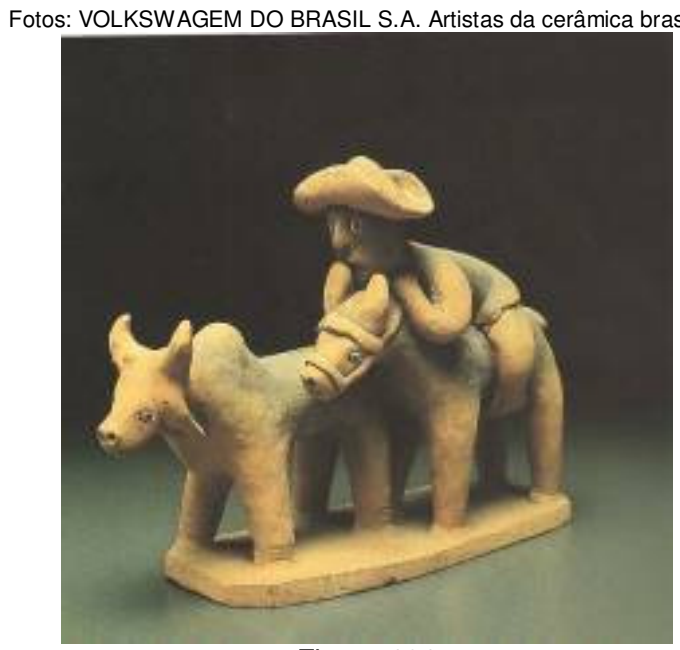

Figura 181

Mestre Vitalino

Sem título s/d

Cerâmica

$17 \times 26 \mathrm{~cm}$

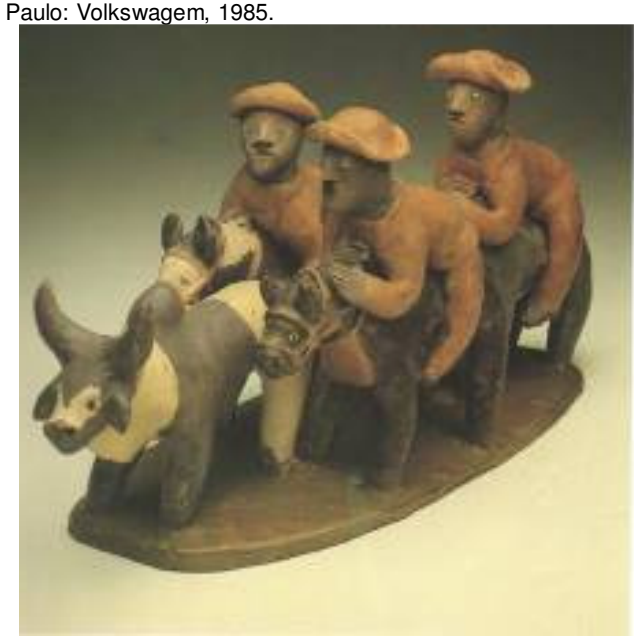

Figura 182

Mestre Vitalino

Vaquejada 1950

Escultura em barro cozido

$11 \times 21 \mathrm{~cm}$

228 José Antonio da Silva (Alto do Moura, PE 1921-1973) ou Zé Caboclo foi ceramista e junto com Mestre Vitalino e Manuel Eudóxio, seu cunhado, deixou sua marca na Arte Cerâmica Nordestina. Retratava de maneira irônica e singela algumas profissões liberais como a figura do dentista ou o advogado (http://www.popular.art.br/. Acesso em 02/11/2014).

${ }^{229}$ Manoel Eudócio (Alto do Moura, PE 1931-) é ceramista nordestino e junto com o cunhado de Zé Caboclo e Mestre Vitalino desenvolveram trabalhos em cerâmica que retratavam de maneira única o seu povo (http://www.popular.art.br/ . Acesso em 02/11/2014). 
Silvia: Essa paixão pela Arte é de família?

Miguel: Meu pai era marceneiro e de vez em quando exercia o ofício de luthier. Ele fazia violões aos grandes violonistas de Pernambuco e do interior da Paraíba. Por intuição, ele tinha um conhecimento de acústica e afinava os violões nas fábricas. Ele pegava os violões defeituosos de fábrica e literalmente quebrava-os e os reaproveitava, por exemplo, o braço, que ele não gostava fazer. E a partir daí, construía um violão novo. Seus pais e tios eram ciganos. A família de minha mãe é afrodescendente, de origem lorubá230.

Lembro-me muito bem do barulho dos pés dela pisando a argila. Um dia, ela me deu um pedaço de argila e saiu para fazer o almoço. Mais à tardinha, meu avô chegou, eu ainda estava lá e disse: "Teresa, venha ver. Esse menino é um artista". Ainda essa palavra é muito misteriosa para mim, artista.

Em todas as oportunidades, eu sempre estava lá e minha tia sempre preparava a argila para que eu pudesse me entreter.

Silvia: Suas obras trazem a cultura nordestina, suas lendas e histórias. Fale mais sobre as suas influências artísticas.

Miguel: No meu caminho há outras referências além do Vitalino. Tem o Galdino ${ }^{231}$ que é, para mim, mais "Gaudi" do que qualquer outra coisa. Até os nomes são parecidos. Ele era um pagão e irreverente. Para dar um exemplo, ele fez um altar suntuoso e no lugar do santo maior, fez um macaco. E tem todos os bichos ao redor do macaco, inclusive a cobra, todos de mãos postas. Eles descobriram que o

\footnotetext{
${ }^{230}$ A civilização lorubá também é conhecida como Yorubá constitui um dos maiores grupos étnicos da África Ocidental. Habitam a região da Nigéria,Guiné e o Reino de Benim. (http://civilizacoesafricanas.blogspot.com.br/2009/10/civilizacao-ioruba.html. Acesso em: 02/02/2014) ${ }^{231}$ Manuel Galdino de Freitas (1929, São Caetano -1996 Alto Moura, Caruaru) foi ceramista, escultor, poeta de cordel e músico. Seu trabalho caracteriza-se por duas grandes séries: a das figuras alongadas de cangaceiros e a das figuras fantásticas, simbioses de humano e animal De acordo com a crítica de arte Lélia Coelho Frota, a superfície das esculturas de Galdino, formada por uma espécie de espinhado como se fosse um cacto, é provocadora e aguerrida. Suas figuras vão se desdobrando em pernas, braços, cabeças. São seres ameaçadores, às vezes antropofágicos, ou híbridos, como o Lampião-sereia." (OLIVEIRA, Albino. http://basilio.fundaj.gov.br/) Acesso em: 01/12/2014)
} 
macaco estava fazendo milagres. Essa imagem é uma ironia sobre as religiões ocidentais.

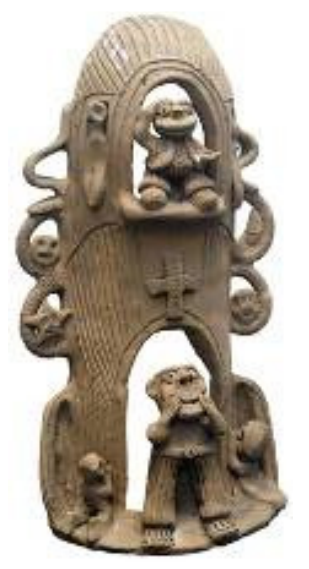

Figura 183

Mestre Galdino

Manoel pãozeiro em seu castelo imaginário

Cerâmica

Foto: livro Em Nome do Autor, Proposta Editorial, São

Paulo, SP.

Além da feira de Caruaru, uma forte imagem que guardo de minha infância é o garajau de galinhas. A imagem do galo pedrês com todas as cores e o movimento que nenhum outro bicho tem, algo parecido com um dinossauro.

Havia um sujeito que fazia a feira em Capoeira e que trazia os seus garajaus. Ele fazia a feira de Itabaiana. E até hoje, a galinha é um elemento de grande importância no meu trabalho e que tento traduzir.

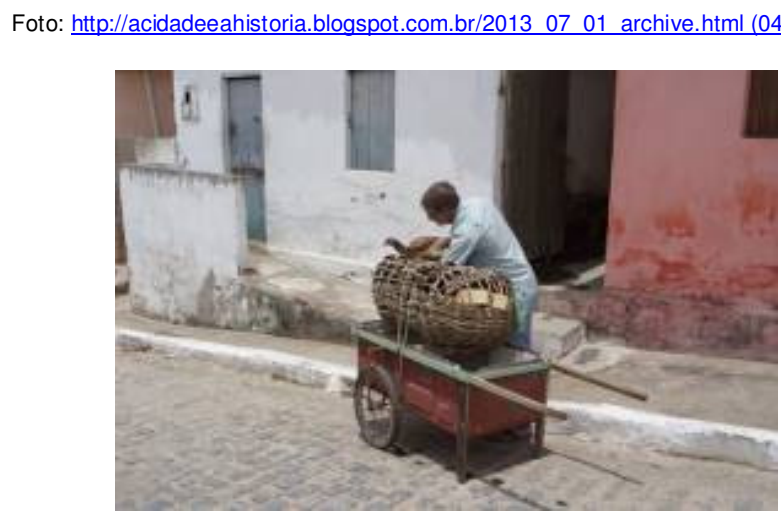

Figura 184

Garajau de galinhas - uma espécie de cesto de carregar galinhas

Além disso, há também um sequencial de sonhos que guardo em minha mente e às vezes, quando estou viajando ou passeando, eu casualmente encontro essas imagens desses sonhos. Em várias ocasiões, passei em feiras, ou em algum outro 
lugar, eu as vi diante de meus olhos objetos ou tive a sensação de tê-las visto. Há uma identificação inexplicável.

No entanto, não fico procurando influências e acredito que não tenho que olhar lá fora. Eu estou aqui, vivi e vivo. As influências em minha volta estão no cheiro, na comida, nas vestimentas, nos modos e em tudo.

Eu já era moço e teve um período em que fui funcionário de uma universidade, cuja função era de leitor da biblioteca. Fora doze anos trabalhando como leitor, o que possibilitou uma formação autodidata de cultura universal. Li todos os filósofos, escritores, de Karl Marx a Celso Furtado. Eu tinha que ler para classificar e catalogar os livros da biblioteca. Eu tinha um mestre que me ajudava e discutíamos aspectos do Capitalismo, por exemplo. Então, essa estrutura autodidata que tenho e todas essas informações sobre diversos assuntos me deram confiança de poder dialogar com os outros, no lugar em que eu estivesse, seja na Alemanha ou África, de igual para igual.

Silvia: Lendo e assistindo algumas reportagens sobre seus trabalhos, sempre mencionam as influências Arte Africana em suas obras. Como você vê isso?

Miguel: Durante a infância, lembro-me das minhas primeiras manifestações no desenho e que foi em Palmares, cidade da zona da Mata Sul de Pernambuco, que é a região açucareira. Depois de Caruaru, eu morei lá dos 10 aos 12 anos. Eu tinha a função de levar o almoço para um serrador que cortava madeira. Eu costumava andar uns $6 \mathrm{~km}$ para chegar até ele. E um dia, eu estava chutando uma bolinha na estrada, tinha chovido, parei e pegue um graveto. Comecei a desenhar no areal. Aliás, eu sempre desenhei. De repente, aproximou-se um carro de boi e um homem negro bem velho. Nessas regiões, os homens costumavam usar um facão para cortar cana, parecido como uma espada. Quando eu estava terminando, o homem disse: "Isso tá bom!" Mal eu termino, fico admirado com o primeiro elogio. Ele olhou, olhou e depois disse para mim: "Você é perverso! Você é um menino mal! Você é ruim. E sabe de uma coisa, vou te dar uma surra!" E já descendo do carro de boi e com facão em punho para me dar a tal da surra, eu mais que depressa saí correndo canavial adentro. E somente após 20 anos, é que eu fui entender aquela atitude. 
Depois de pesquisar Gilberto Freire ${ }^{232}$, descobri que na região de Palmares, um dos redutos dos Quilombos, os ex-escravos faziam pontos de macumba para quebrar o carro de boi do outro e foi isso que aquele homem identificou no meu desenho. Era uma raiz africana no meu trabalho.

As formas africanas, na verdade, vieram até mim. Lembro-me que fiz uma exposição em Lagos, em 1977, no Segundo Festival Mundial de Arte Negra, onde resgataram algumas teorias de Clarival Prado Valadares ${ }^{233}$, nas quais ele fala sobre arquétipos de culturas extintas africanas e que se manifestam no meu trabalho. Acredito que há fatos de que não se tem escapatória, pois de repente se eu tivesse nascido nos países nórdicos, talvez minhas imagens fossem algo dos vikings. Assim, os arquétipos se assemelham, pois tudo que está na aura do Homem são formas essenciais ao existencial, elas estão muito próximas.

Silvia: Miguel, você é um artista que utiliza várias técnicas e materiais. Fale-me um pouco sobre os seus trabalhos.

Miguel: Eu tenho a Cerâmica e a Pintura como uma constante em meu trabalho. Porém, tenho passagens pela madeira e o mármore. Meu pai era marceneiro e essa também foi minha primeira profissão. Na realidade, não sou bem um ceramista, mas sim, um artista. Os materiais chegam até a mim. Houve uma ocasião em que fizemos um trabalho em aço que era composto de seis guerreiros de dois metros e meio de altura, que hoje está nos Estados Unidos.

No meu caso, quando troco de material é como se eu estivesse trocando a roupagem porque o conteúdo é o mesmo, mas sabemos que cada um dos materiais tem seu vocabulário específico.

Silvia: Então, vem primeiro a ideia e depois a escolha dos materiais?

\footnotetext{
${ }^{232}$ Gilberto Freyre (Recife, PE 1900-1987) foi sociólogo, antropólogo e escritor. Considerado um dos pioneiros da Sociologia no Brasil, também publicou vários livros, entre os mais conhecidos estão Casa-grande \& senzala, traduzidos para vários idiomas. Fundou em 1946 a Fundação Joaquim Nabuco (http://basilio.fundaj.gov.br/ . Acesso em: 02/02/2014).

${ }^{233}$ Clarival Prado Valadares (1918 Salvador, Bahia -1983 Rio de Janeiro, Rio de Janeiro), foi médico, historiador e crítico de arte. Publicou vários livros sobre história da arte brasileira e escreveu sobre os trabalhos de vários artistas, entre eles Portinari, Di Cavalcanti e Miguel dos Santos (http://basilio.fundaj.gov.br/ Acesso em: 15/11/2014).
} 
Miguel: Não. Por exemplo, eu recebi uma encomenda para fazer uma escultura de um arquétipo em madeira para uma capela de Pernambuco. Naquele momento eu estava trabalhando com cerâmica e pintura, então, tive que limpar tudo e montar as bancadas de marceneiro.

Na realidade, não há uma programação prévia, um rascunho, nem posturas intelectuais com relação às estratégias. Para mim, tem que deixar as coisas acontecerem. Há obras que levam um tempo maior para a sua conclusão, então, a cada dia que passa, o seu conteúdo é revelado. Você sabe que há uma sequencia e às vezes, quando você se apressa, pode atrapalhar o andamento. Racionalmente, você entra num processo de criação e por ser criação, ele está acontecendo pela primeira vez. Então, como é o novo, ele irá subverter até o artista. O tempo é longo e cada coisa ocorre no momento certo. Você sabe que a tarefa do dia é cavar um pouco mais, dez centímetros a mais, aprofundar ali e no dia seguinte a obra em andamento vai pedir outra intervenção e assim, a cada dia, há uma transformação.

Silvia: Então você respeita o tempo de cada material?

Miguel: Sim. Para mim, os caminhos são mostrados pelos materiais e como eles querem ser trabalhados. Cada material tem o seu caminho e o que fica é a intimidade entre a matéria física e o espiritual. Há um ponto em que você tem que dialogar com o divino na madeira, na argila, no mármore ou na pintura. $\mathrm{O}$ divino habita aquele material. Nesse diálogo ocorre a intimidade com a obra em si porque ela vai conduzir. Há uma frase do Mestre Vitalino, que eu gosto muito, dito a Ariano Suassuna: "Eu trabalho na cadência, faço o que eu vejo e faço também o que não vejo."

Então, Mestre Vitalino tinha um compromisso com a realidade, na qual ele retratou parte do Nordeste Brasileiro através de figurinhas feitas na ponta do dedo, mas também tinha a liberdade de criar. Há um compromisso com a realidade e a imaginação. Ariano Suassuna gostou tanto disso que tomou isso como ponto de referência.

Silvia: Então, você me falou dos primeiros estímulos. Você poderia me contar sobre como se deu o aprendizado formal das técnicas. 
Miguel: Quando eu terminei o curso ginasial, fiz um curso técnico de ferramentaria na Escola SENAI que atendia às usinas de Palmares, PE. No curso conheci vários equipamentos como o torno industrial, a serralheria, etc. Era um curso bem específico para o manuseio de máquinas industriais. Fiz esse curso, pois sabia que tinha algo relacionado com o artesanal, de ajustes e de projetar determinado objeto. Havia uma matéria de Desenho Técnico. Foi nessa disciplina, que pela primeira vez tive material farto para desenhar e que me ajudou muito. $O$ diretor da escola era formado em Belas Artes e tinha um desenho bom. Os primeiros livros que causaram grande impacto na minha vida foram escritos pelo historiador chamado Hendrik Willem van Loon. Seus livros possuíam ilustrações incríveis. Depois tem outro, escrito por um autor francês, que faz parte de um conjunto de seis ou sete volumes, cujo título é $O$ espírito das formas. Este último lida com o ponto mágico entre a matéria e o espírito da Arte.

Silvia: O aprendizado formal em Cerâmica, você teve no SENAI também?

Miguel: Não. Tudo isso foi em Caruaru. Não teve escola nenhuma de cerâmica.

Silvia: Então, você aprendeu as técnicas da cerâmica, conforme você foi experimentando?

Miguel: Durante a minha infância, experimentei a cerâmica em Caruaru. Depois eu a retomei numa fábrica de filtros, onde eu pegava material para trabalhar. Trabalhava e me deslocava para a fábrica nos finais de semana quando não havia ninguém. Ficava criando as coisas e o forno à lenha para fazer as queimas.

Silvia: A Cerâmica é um meio que exige, entre outros atributos, força física. Ela trabalha os dois extremos a força e a sutileza.

Miguel: Para construir minhas peças em cerâmica, eu uso o torno para peças pequenas e, esporadicamente, as formas maiores são feitas no processo do rolo e placa. Uma vez, eu obtive uma bolsa da Fundação Vitae para desenvolver uma massa cerâmica compactada, com adição de chamotes em granulometrias maiores. Para assim, poder desbastar ou esculpir a massa compacta como se fosse um bloco de mármore, sem ter os riscos de rachaduras ou explosões. 
Hoje em dia, eu não trabalho somente com um tipo de argila. Faço uma mistura de argilas de vários lugares. A argila Lhandra é branca e muito utilizada para fazer bocais de lâmpada que não pode conter ferro em sua composição, senão leva choque.

$\mathrm{Na}$ época em que fiz minha primeira exposição no Rio, eu trabalhava com cerâmica de baixa temperatura, engobes e costumava brunir as peças.

Silvia: Como aprendeu a trabalhar com os vidrados cerâmicos?

Miguel: Quando conheci Francisco Brennand, eu fiz também amizade profunda com o pai dele, o Ricardo Brennand. Certa vez, os Brennand vieram para a Paraíba em função de um feldspato que havia aqui na região. Toda vez que eu ia para Recife, eu também visitava o velho Ricardo e ele me deu os mesmos ensinamentos que ele deu para Francisco. Então, chegou alguém aqui e perguntou se há coisas de Francisco aqui e eu respondo que fomos siameses. Ele me ensinou sobre o uso do chamote, dos esmaltes baixa e as fritas. Posteriormente, comecei a trabalhar com alta, que são matérias-primas cruas.

Silvia: Como você planeja as cores em suas obras. Já que, como se sabe, há uma diferença significativa nos esmaltes antes e depois da queima.

Miguel: No meu caso, trabalho os esmaltes a partir de bases transparentes e brancas em forma de fritas. $\mathrm{O}$ uso das cores não é algo muito planejado.

Depois que a peça está pronta, no processo secagem, nós vamos estabelecendo um diálogo com a forma. Na hora você descobre que vai ser azul. Aqui você tem o cobalto, aqui temos $2 \%$ de óxido de ferro. É bem intuitivo. Uso a mesma liberdade que há para se chegar à forma, assim como as cores com os esmaltes.

Houve uma ocasião que saiu uma série de cabeças, bem arcaicas e os esmaltes que casavam com essas formas eram à base de cinzas. Quando eu queimei uma vez, eu imediatamente pensei nas grandes esculturas de pedra da llha de Páscoa ou algo mais antigo. Esmaltei e queimei novamente. O resultado foi algo mais envelhecido ainda, percebi então que era aquilo mesmo e que não deveria interferir mais. $O$ esmalte pertencia já àquela entidade e ao espírito daquela peça. 
Silvia: Então você tem isso na sua cabeça?

Miguel: Penso em cobalto, ferro e titânio. As formas das peças vão pedindo determinadas texturas e cores. Cada tema pede determinadas nuances. Como nos trabalhos Cronos ou Saturno, o tempo é o Deus que come os filhos - determinou tons mais secos, para que se obtivesse a unidade, que é mais difícil para se fazer uma leitura da forma com poucas cores, ao contrário da abundância de cores que é encantatória. Pela cor a pessoa pode dizer que gosta de tal forma, mas na verdade só vê a cor e não a forma.

Silvia: Há uma frequência maior de elementos surpresas na cerâmica, não é mesmo?

Miguel: A prática de você estar pintando com um material cru e já prever como vai ficar depois da queima, é a mesma de quem pinta a óleo em grandes dimensões e tem que aprender a ver sob certa distância. Você está perto, mas precisa imaginar essa pintura vista de longe.

Silvia: Sob o aspecto técnico, você utiliza queima à lenha ou gás, pois algumas delas têm efeitos de esmaltes queimados em ambiente redutor.

Miguel: Faço queima em forno elétrico. Para alcançar esses efeitos é tudo controlado. As manchas acontecem onde é necessário. Não é aleatório. Gosto de controlar, diferentemente de alguns ceramistas que gostam algo mais livre.

Uma coisa que Brennand nos define como escultures, e não como ceramistas, pois somos escultores que utilizamos a cerâmica. Talvez se utilizássemos outros materiais, o resultado poderia ser o mesmo. A força reside na forma e independe do material.

Silvia: Então, essas formas poderiam ser construídas em outros materiais?

Miguel: Sim, poderiam.

Silvia: Mas o que o atrai a fazer em cerâmica?

Miguel: Por ser um material mais abundante. Historicamente, a cerâmica está presente em todas as regiões brasileiras como um material de mais fácil manipulação. O Vale do Jequitinhonha é um dos núcleos mais fortes em cerâmica. É 
um material abundante. Por exemplo, o Brennand que já vinha de uma tradição da indústria cerâmica, se apropria disso para fazer o próprio trabalho, forte e legítimo.

Silvia: Gostaria que você falasse um pouco da relação da poética, a matéria e a prática. Como é o seu processo de criação?

Miguel: Eu trabalho no ateliê de domingo a domingo, sem nenhuma preocupação de que deixei uma praia ensolarada de lado. Porque a vida está no ateliê, o que deve ser feito ali não será feito em nenhum outro lugar.

Luto diariamente com três tipos de brancos: zinco, titânio e chumbo. Vejo que, por exemplo, o desenho do renascentista Leonardo da Vinci, não era feito em menos de três dias e o que está incutido nele é a humildade diante da criação. Ele se transportava ao desenho, doava-se por inteiro.

Por isso que eu digo, que há diferença entre a emoção e o conceito. Devemos passar por todo o processo de compreensão, de sentimento e isso envolve dor e sofrimento na base de nossa alma. Então, você gera um produto da alma, importante e necessário. Quando um trabalho é feito destituído dela, é feito num processo artificial e às vezes repetitivo. Em algumas entrevistas eu digo que o Brasil é muito estranho, pois premia o similar e pune o original.

Então, prefiro não pensar muito. Eu fico mais à vontade não pensando. A criação acontece naturalmente e sempre funcionou assim.

Não adianta tentar mudar, fazer rascunhos ou qualquer coisa. Tem que deixar a alma livre.

Silvia: É nesse dia-a-dia, a luta com os materiais e outros desafios também ajudam a construir o artista.

Miguel: Para mim, o que atrapalha no processo criativo é o conceito, ou seja, racionalizar e pensar demais, porque a Arte é a linguagem mais elevada. Ela é o extrato da alma em busca da própria evolução. Ela trabalha com aspectos metafísicos e da alma. Então, não adianta tentar alcançar tais aspectos com conceitos ou inteligência racional porque ela é mais que isso, é algo sagrado. Sempre que alguém tentar interferir, levar esses valores aos mundos dos fatos, só irá corromper e corroer esse sagrado. Que está acima de tudo é está no campo da 
intuição. Saiu disso e entrou o conceito, você pode ter o melhor discurso, mas ele é frio.

Deixe-me citar uma frase Machado de Assis, que define tudo isso com relação à escrita, mas que serve para todas as artes: "existe no mundo dois tipos de escritas [entenda aqui Arte]. Há a escrita do predestinado e a do outro. Do predestinado é vibrante, natural, genuína e feiticeira. Já a do outro é tesa, engomada e chocha." Isso é uma frase atual. Na minha vida, o que eu mais encontro são os tesos, engomados e chochos.

O aspecto que mais gosto na Arte é quando nós sentimos, em determinados momentos, que não é mais o material. Já é o espirito vestido de material, já houve a transmutação. Já é o desconhecido e sagrado diante de você. E feito com o quê? De óxido de ferro, argila, com madeira, óleo, etc..

Silvia: Então, quando o artista materializa a obra, esta já não pertence a ele.

Miguel: Exatamente. Além disso, o que literalmente acontece no processo é o rompimento do elo entre o artista e a obra, a partir do momento que a ideia é materializada. Para mim, é o fim do trajeto do sagrado para o profano. Atingiu o profano [o público] não é mais sagrado. Ou seja, intrinsecamente, não pertence mais ao artista.

Assim, o artista volta-se sempre para o sagrado que é essa região onde, às vezes, eu falo que existe apenas uma obra de arte composto de todas as formas e feita que material nenhum. Esse é o absoluto. Para abrir as portas deste lugar sagrado é necessário generosidade, caridade, compaixão e servidão. Sem essas forças de negação da primeira pessoa, do "Eu", as chaves não funcionam.

Para mim, o verdadeiro artista deve se dar por inteiro e não cultivar a personalidade, utilizando o sagrado da Arte para enaltecer a si próprio.

Silvia: Você participou de grandes exposições. Fale-me um pouco de algumas delas.

Miguel: Houve uma exposição que fiz na Galeria Bonino, no Rio de Janeiro, apresentei cerâmicas e pinturas. Durante muito tempo, ela foi considerada a melhor galeria do Brasil e foi assim até a década de 80 . Quando foi inaugurada a exposição, 
me disseram que foi a primeira vez que a cerâmica entrou em salões nobres. Até então, a cerâmica era vista como arte menor.

A primeira exposição que fiz em São Paulo, foi também a primeira vez que fui à cidade, conheci a Avenida Paulista e o MASP (Museu de Artes de São Paulo). Antes disso, nunca havia visto, nem por foto. O que eu conhecia era minha realidade de ateliê e não ligava muito para essas coisas. Isso há quase quarenta anos.

Pela primeira vez que entrei no MASP, vi uma exposição enorme e uma obra minha, um painel de 2,20 por $6,60 \mathrm{~m}$, que era um tríptico.

Silvia: Quando foi?

Miguel: 1974. Eu fui com um amigo que era muito próximo do Alfredo Volpi. Fomos à casa do Volpi e ele fez questão de ir ao vernissage. Volpi ${ }^{234}$ me deu as receitas de têmpera, que eram as mesmas utilizadas na Idade Média! Quando ele viu a exposição, eu me surpreendi com a reação dele e que até agora não entendi. Ele disse: "Se você pensa que pode fazer tudo, está muito enganado." E eu respondi: "Mas a intenção não é essa, mas faço o que posso". Mas depois eu tive essa mesma manifestação aqui no ateliê quando Babinski ${ }^{235}$ veio há uns 10 anos. Essas reações estão relacionadas às obras e não à minha pessoa.

Silvia: De certa forma, houve um reconhecimento e isso é um motivo de orgulho para um artista.

Miguel: Há no Nordeste vários artistas com grandes talentos, mas que não têm o devido reconhecimento como Nhô Caboclo ${ }^{236}$, que é um elo entre a arte indígena e

\footnotetext{
${ }^{234}$ Alfredo Volpi (Lucca, 1896- São Paulo - 1988) Artista plástico autodidata, foi um dos principais pintores da segunda geração da Arte Moderna Brasileira. Suas obras exploravam as cores e formas geométricas, que retratavam de maneira singular temas como festas juninas e fachadas de casas. (http://enciclopedia.itaucultural.org.br/pessoa1610/alfredo-volpi. Acesso em: 12/01/2014) ${ }^{235}$ Maciej Antoni Babinski (Varsóvia, Polônia 1931). Gravador, ilustrador, pintor, desenhista e professor. Em virtude da Segunda Guerra Mundial, Babinski muda-se de seu país de origem para Inglaterra e lá inicia sua carreira artística. Suas obras fazem referências às suas viagens Em 1953, muda-se para o Brasil.

${ }^{236}$ Nhô Caboclo (1910 Águas Belas, PE - 1976 Recife, PE) ou Manoel Fontoura, pouco se sabe sua origem, mestiço de índio e negro, desce criança construía objetos em barro e outros materiais como madeira e até raízes. Foi para Caruaru e trabalhou com Mestre Vitalino. De origem humilde, Nhô Caboblo materializou o seu universo através de formas que remetem à arte africana e retrata de forma singular o povo que vivia à sua volta. (http://artenaescola.org.br/dvdteca/catalogo/dvd/131/ Acesso em: 01/12/2014).
} 
negra. Chico da Silva ${ }^{237}$,no Ceará, e Severino de Tracunhaém ${ }^{238}$. Como havia dito, acredito que há uma valorização do que vem de fora, punindo o que é original.

Foto: http://animacultura.com.br/ (data: 01/12/2014)

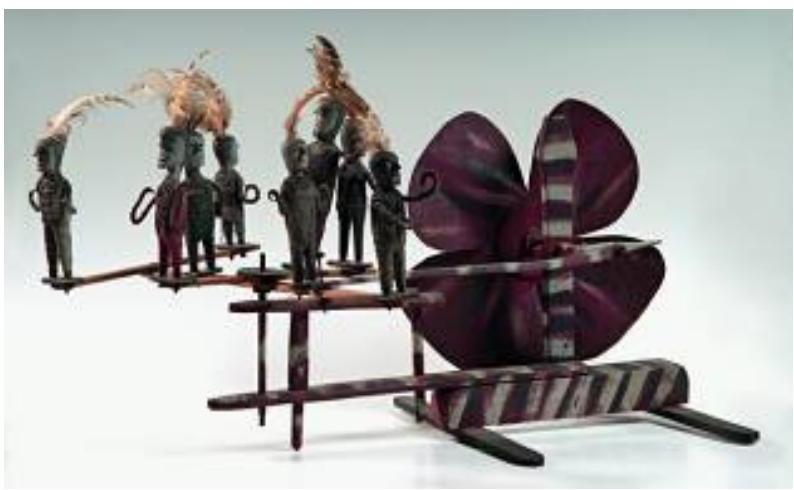

Figura 185

Nhô Caboclo

Madeira, penas, metal

década de 1960, Recife, PE.

Acervo Museu Casa do Pontal.

Exposição Máquinas Poéticas, Museu Casa do Pontal, RJ.
Foto: http://www.espacoarte.com.br/obras/6667-dragaofantastico (Data:01/12/2014

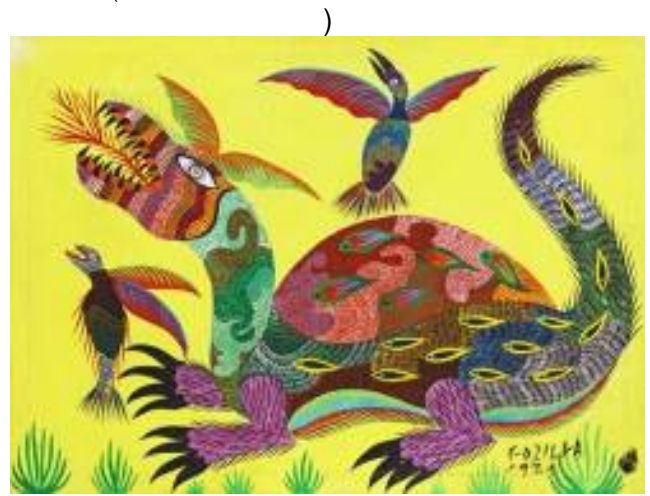

Figura 186

Chico da Silva

$50 \times 70 \mathrm{~cm}$

1971

Óleo sobre tela

Em minha opinião, o Brasil nunca expôs o Brasil, esteticamente falando. Acho que uma das exposições mais significativas sobre a Arte brasileira foi ao início da década de 70 de aconteceu no MASP e que me tocou demais chamada $A$ Mão do povo brasileiro ${ }^{239}$, com curadoria da Lina Bo Bardi.

${ }^{237}$ Chico da Silva ou Francisco Domingos da Silva (Cruzeiro do Sul - Alto Tejo, Acre, 1910 Fortaleza, 1985) foi um artista autodidata e que atuou na área da Pintura e tinha como referência e inspiração as paisagens amazônicas. Utilizava em suas telas cores variadas e com riqueza de detalhes retratava a fauna e flora da Amazônia e suas lendas.

(http://www.pinturabrasileira.com/artistas bio.asp?cod=156\&in=1 Acesso em: 01/12/2014)

${ }^{238}$ Severino Gomes de Freitas, o Severino de Tracunhaém, (1916-1965) foi um dos mais representativos ceramistas de Trachunhaém, cidade onde nasceu e onde trabalhou nos engenhos de cana-de-açúcar até casar com Lídia Vieira, na época uma das mais famosas ceramistas nordestinas (faleceu em 1974). De tanto observar a mulher modelando seus bonecos, deixou o trabalho na agricultura e entrou para o negócio do barro. Logo desenvolveu estilo próprio e ganhou fama como artista popular. Esculpia bichos e figuras estranhas, frades, beatas, estatuetas de Padre Cícero e outros. Suas peças, em geral medindo entre $30 \mathrm{~cm}$ e $50 \mathrm{~cm}$, integram coleções particulares e acervos de alguns museus pernambucanos. Morreu em decorrência de esquistossomose adquirida na zona rural onde viveu ( fonte:

http://www.pe-az.com.br/index.php?option=com content\&view=article\&id=653:severino-detracunha\%C3\%A9m\&catid=78\&ltemid=225 Acesso em: 01/12/2014)

${ }^{239}$ A exposição $A$ mão do povo brasileiro foi realizada no MASP em 1969 com curadoria da arquiteta Lina Bo Bardi, apresentou vários elementos dos mobiliários, vestimentas, adornos, cerâmica, esculturas, figuras religiosas e brinquedos no Brasil (http://ieffcelophane.wordpress.com/2012/01/30/a-arte-popular-coletada-por-lina-bobardi-revive-emexposicao-na-bahia/ Acesso em 01/12/2014). 
Silvia: Você comentou que algumas pessoas confundem os seus trabalhos com o Brennand.

Miguel: Sou amigo dele. Eu vejo Francisco Brennand de três em três anos ou cinco em cinco. Haverá sempre um diálogo que só poderá haver entre mim e ele. Quando eu fui a primeira vez à sua casa, ele não fazia ainda o Bestiário, havia os vasos e os painéis e eu levei uma pintura, uma cerâmica e uma caixa de slides. Quando ele viu a cerâmica ele tomou da minha mão e arrebatou. Logo depois, voltou e na sala estavam presente sua filha e seu genro, então Brennand disse: "Estou diante do maior artista do Brasil." E aí eu disse: "E eu também".

Nós nos conhecemos nessa época e isso é mantido até hoje. Um respeito e uma admiração profunda.

Silvia: Talvez por falta de conhecimento, há quem confunda suas obras com as cerâmicas de Francisco Brennand, principalmente com relação às figuras totêmicas.

Miguel: Acho que porque trabalhamos com o mesmo material que é a cerâmica de alta temperatura, mas nosso vocabulário é diferente. No entanto, não podemos obrigar que as pessoas compreendam as diferenças em nossos trabalhos. Talvez, falte informação. Os trabalhos de Francisco Brennand têm algo orgânico.

Para as pessoas apreciarem uma obra de arte não precisa ser altamente culta, ela precisa ter sensibilidade. Pode ser a menos instruída, mas se tem a sensibilidade ela consegue chegar à obra. Às vezes, com mais propriedade do que um crítico. Assim como eu havia dito, se é um produto da alma, a alma reconhece.

Uma vez, eu fiz uma pintura baseada no mito de Ariano Suassuna, que no consenso popular se chama Bruzacã ${ }^{240}$, que é um símbolo de totalidade. É um

\footnotetext{
${ }^{240}$ Quaderna é o personagem do romance A pedra do reino de Ariano Suassuna,e também descendente do líder da seita da pedra do reino, que existiu de fato entre 1835 e 1838. A seita produziu um mar de sangue no sertão.( http://felipepimenta.com/2014/03/26/resenha-romance-dapedra-do-reino-de-ariano-suassuna/ data: 05/12/2014). "[...] Quaderna descreve para o Juiz Corregedor a visagem de um vaqueiro Manuel Inácio, sertanejo do Seridó, que teria visto Bruzacã (uma das muitas formas assumidas pelo demônio) sair do Mar, perto da praia de Touros, no Rio Grande do Norte." (Apud Newton Jr..., Carlos. O pai, o exílio e o e o reino: a poesia armorial de Ariano Suassuna. Recife: UFPE, 1999, p. 114). Assim, Ariano Suassuna descreve Bruzacã: "São sete chifres turvos e amolados! Ai, a fuça peluda. E a corcova cerúlea! No Cabelouro espesso, Cabeleira
} 
animal com sete chifres, lombo de leão, rabo de onça, genitálias humanas. Um belo dia, uma pessoa entrou no ateliê, que foi levar um pedaço de madeira, viu aquela pintura e disse: "Esse é o pai do mundo". Parei o rapaz e pedi que ele repetisse o que havia dito e ele novamente disse que aquela pintura era o pai do mundo. $E$ perguntei o porquê e ele respondeu: "Porque quer ser tudo e ainda sobra".

Muitas pessoas também dizem que sou doido. Você abraçar algo que não é profissão, e sim uma missão, na esperança de que aquilo tenha importância na vida das pessoas, é algo, para muitos, impensável. Se eu fosse uma pessoa ajuizada e eu estaria fazendo coisas das pessoas ajuizadas, talvez, atrás de um balcão vendendo qualquer coisa.

Silvia: Muito corajoso!

Miguel: Ser artista é você dar mais do que receber. O artista depura um produto da alma. $\mathrm{O}$ artista é a síntese do mundo e a essência. $\mathrm{O}$ que é a essência do Renascimento? É Leonardo, Michelangelo. E a essência do século XVIII? Mozart.

Silvia: A maioria de suas obras têm grandes dimensões. Como são seus fornos?

Miguel: Atualmente, nós estamos construindo um forno que vamos ter que alterar toda a estrutura do espaço lá. Vamos ter que queimar um monobloco de dois metros largura e 10 metros. Precisaremos uma empilhadeira e estruturar também a sua saída.

Silvia: Os trabalhos têm desenhos preliminares?

Miguel: A escultura não é desenho, pois a escultura quer ser escultura. A pintura também não tem um esboço.

É muito mais convincente você partir direto para construção do volume do que fazer um desenho dele antes. Muitas vezes, se tivermos o desenho e darmos para

de conchas entrançadas![...]" (SUASSUNA citado em Newton Jr.., Carlos. O pai, o exílio e o e o reino: a poesia armorial de Ariano Suassuna. Recife: UFPE, 1999, p. 116). 
alguém executá-lo no plano tridimensional, não há o prazer de desfrutar seus desdobramentos durante o processo de criação.

Silvia: Então, é importante esse contato com a matéria?

Miguel: Sem dúvida.

Silvia: Fale um pouco do monumento que está num dos principais pontos de João Pessoa, A Pedro do Reino.

Miguel: Há uma conotação política ali. O pai de Ariano, que era governador do Estado da Paraíba, foi assassinado. Ariano Suassuna e a sua família foram banidos daqui de João Pessoa por conflitos políticos. O monumento é uma homenagem aos dois e é um cartão postal eleito pelo povo.

Para mim, A Pedra do Reino é grande tabuleiro de cerâmica da feira de Caruaru, das figurinhas de Vitalino. É um monumento inteiramente de cerâmica e a raridade dele está aí.

Há outras obras públicas em cerâmica. Tem outro que foi construído recentemente monumento inteiro de cerâmica que está em Niterói. Ele será montado numa praça, mas atualmente ele está, provisoriamente, no Museu Janete Costa de Arte Popular, em Niterói. Devido a mudança de gestão da prefeitura, houve uma interrupção temporária de sua montagem. Neste monumento há quatro cavaleiros que representam chegadas das diferentes etnias ao continente americano, começando pelo índio Arariboia, Mem de Sá ou a política, a raça negra, o futebol, Pelé e o mestiço. O monumento tem aproximadamente $2,70 \mathrm{~m}$ de altura. Já em cima de uma superfície de 2,50 m de largura. Há uma torre de $6 \mathrm{~m}$ no meio. Se somarmos tudo isso dá 10 metros. 
Foto: http://mapadecultura.ri.gov.br/manchete/museu-janete-costa-de-arte-popular Acesso em: 29/12/2014

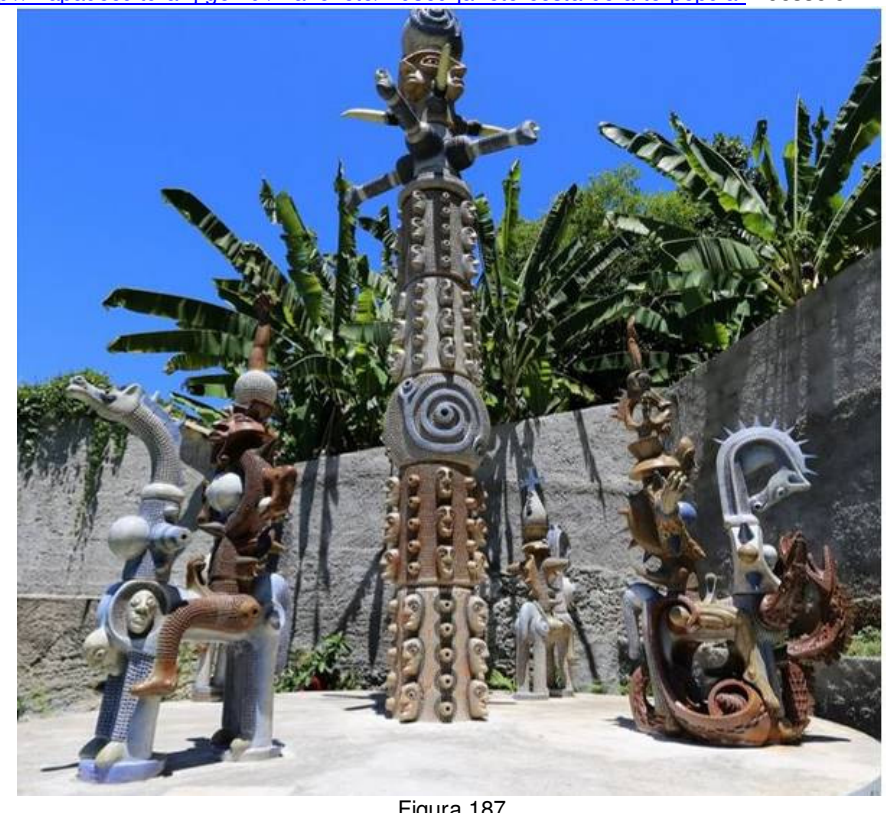

Figura 187

Miguel dos Santos

Homenagem às Artes

Totem de cerâmica (Alta temperatura)

$10 \mathrm{~m}$ de altura

Museu Janete Costa de Arte Popular - Niterói, Rio de Janeiro 


\subsection{Norma Grinberg (Cochabamba, Bolívia, 1951): Formas em infinita metamorfose}

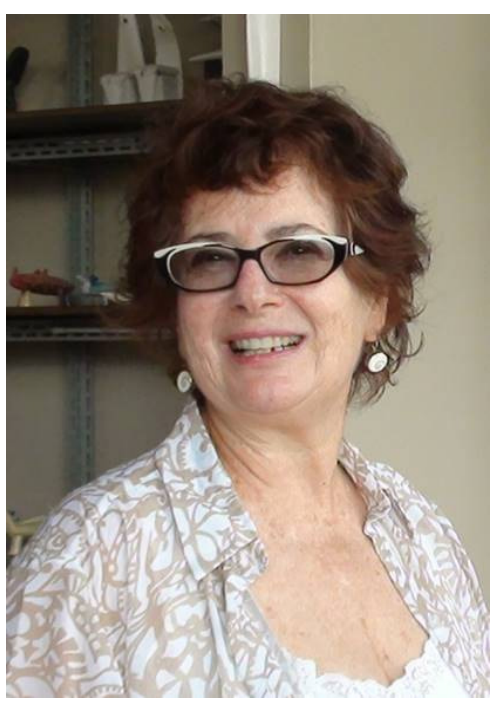

Lembro-me que conheci os trabalhos de Norma Grinberg na época em que eu cursava Artes na UNESP e foi durante as aulas de cerâmica. Certo dia, foi exibido um vídeo sobre o seu trabalho e processo criação: Percursos de um módulo ${ }^{241}$. Pesquisei sobre seus trabalhos e fiquei entusiasmada e admirada com as possibilidades que a cerâmica poderia oferecer.

Em 2004 conheci Norma pessoalmente durante um curso que ela estava ministrando na pós-graduação da ECA-USP. Na ocasião, participei como sua aluna ouvinte. A partir desta época, tive várias oportunidades de conhecer melhor o seu trabalho, percurso artístico e generosamente, ela partilhou suas opiniões e visões sobre a Cerâmica, a Arte e a vida.

\footnotetext{
241 Percursos de um módulo foi o título de uma exposição individual de Norma Grinberg que aconteceu no Centro Cultural São Paulo em 1985 na qual mostrou obras produzidas entre 1977 a 1985 (www.normagrinberg.com.br, acesso em 05/01/2015.)
} 


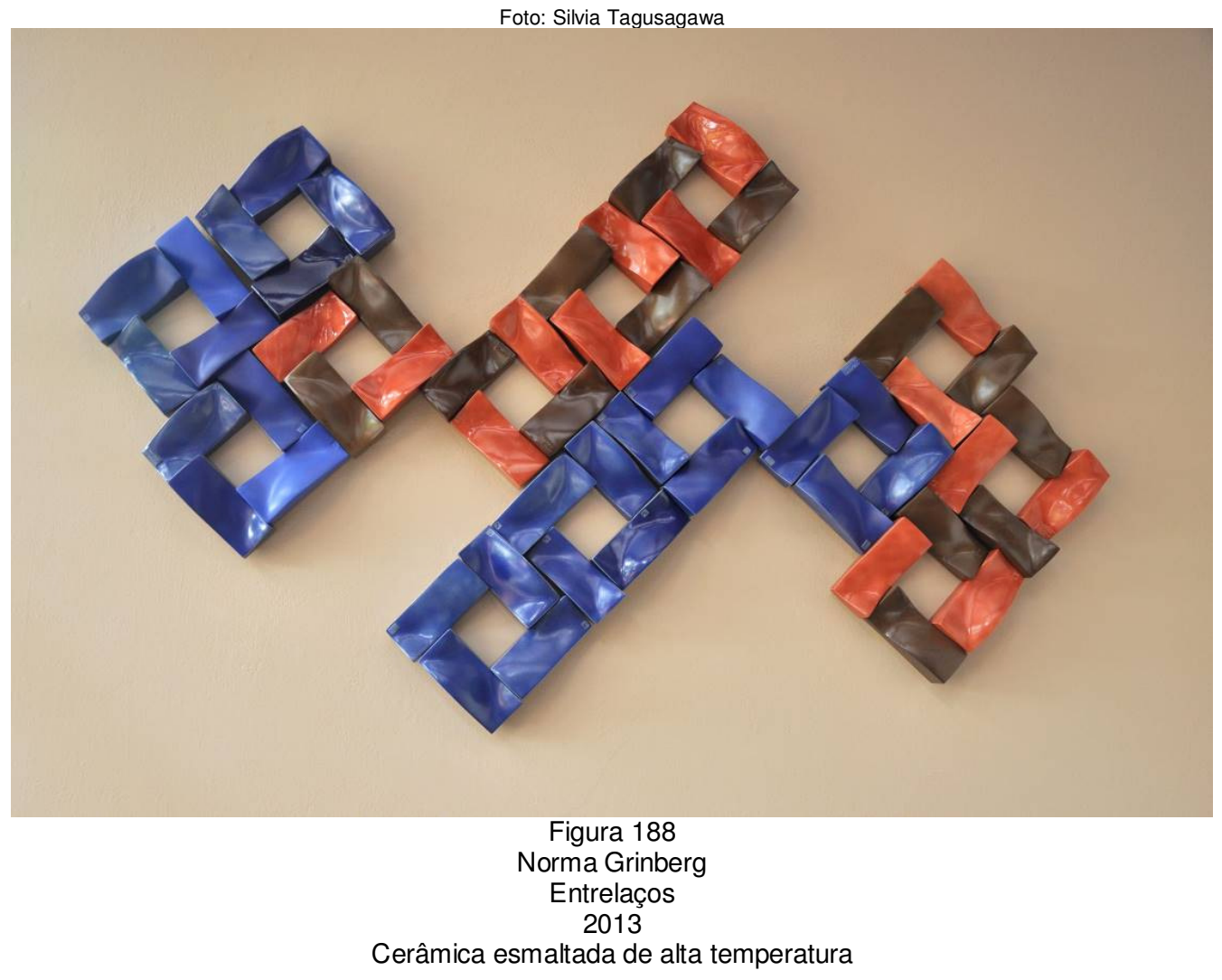

Norma Grinberg, nasceu em Cochabamba, na Bolívia em 1951, veio aos nove anos de idade para o Brasil. Família de origem judaica que foi marcada por histórias da guerra vividas pelo seu pai, que sobreviveu ao holocausto e migrou para a América do Sul. Seu pai refez sua vida na Bolívia, onde conheceu a sua mãe. Norma é a caçula da família e lembra-se de seus primeiros contatos com Arte, na escola em que tinha aulas de balé, onde ela observava os alunos das aulas de desenho e pintura. 


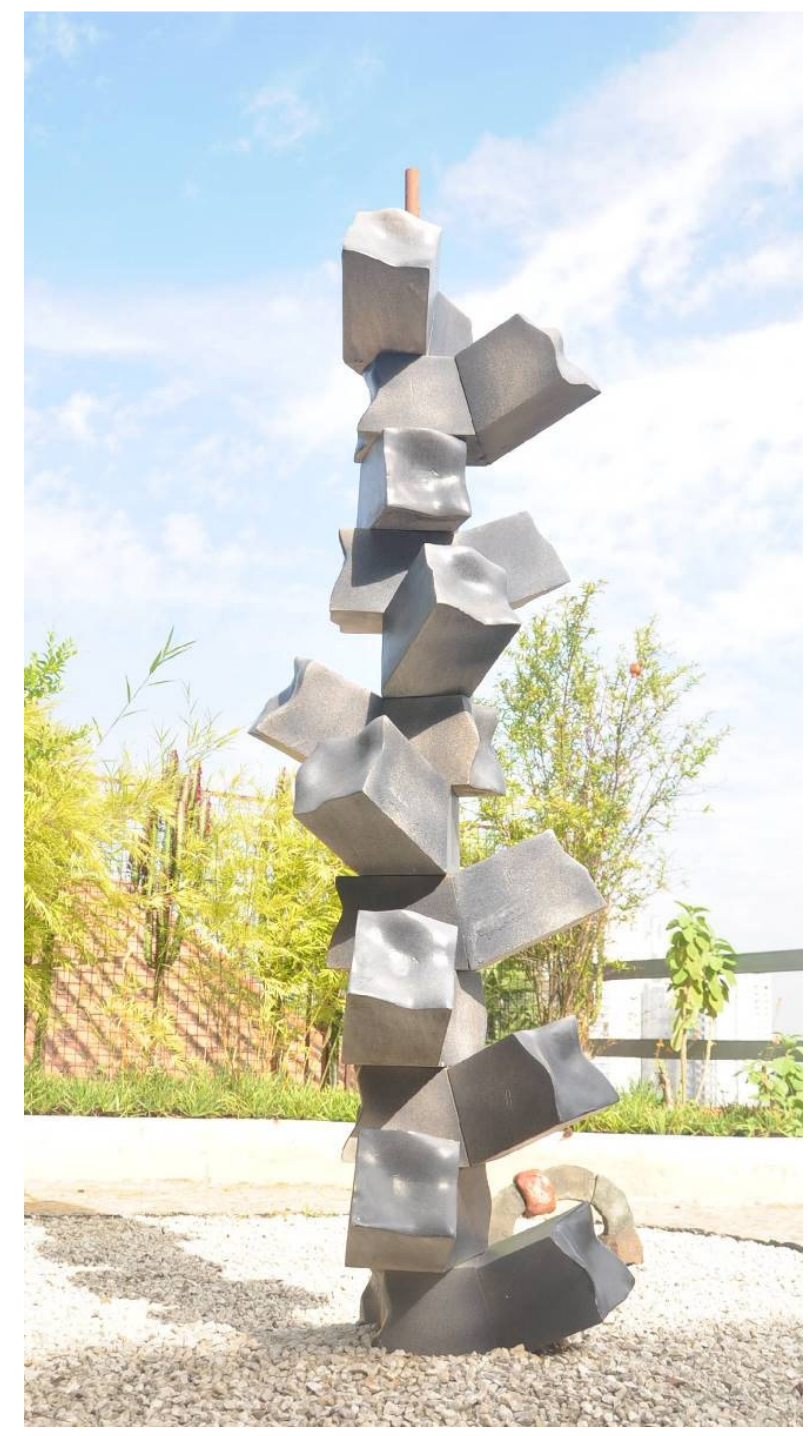

Figura 189

Norma Grinberg

Blocos

$1,6 \mathrm{~m}$ de altura

Cerâmica esmaltada (alta temperatura) e estrutura de metal

Na sua adolescência, Norma começa a fazer desenhos de estamparia e vendia aos fabricantes de tecidos. Também deu aulas de Artes para crianças o que permitiu que ela estudasse e conhecesse melhor as fases da infância e seus comportamentos. Quando terminou o colegial (ensino médio), decidiu fazer Arquitetura, mas não se identificou com o curso e em 1970 prestou para Artes Plásticas na FAAP (Fundação Álvares Penteado). 


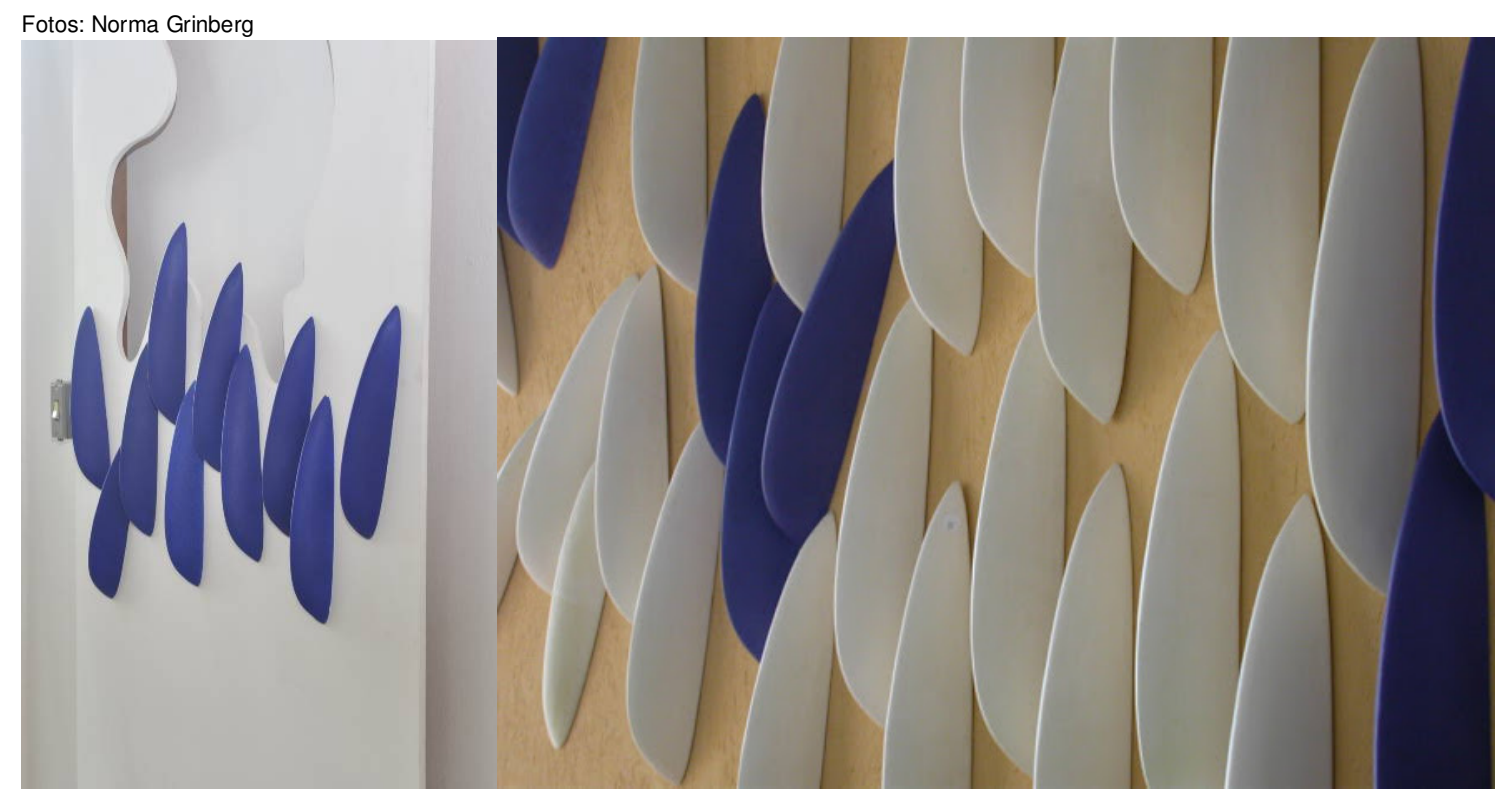

Figura 190

Norma Grinberg

Pingos

2012

Cerâmica esmaltada (alta temperatura)

Em 1972, conheceu o ceramista uruguaio Alberto Lema Pires que Ihe ensinou as técnicas básicas da Cerâmica e a ajudou construir seu primeiro forno. Neste mesmo ano, Norma abriu seu ateliê numa garagem, escondida de seus pais que encaravam com bastante reserva a ideia de ver a filha artista. Iniciou assim sua produção em cerâmica. Ela diz:

"Eu tinha que dar uma resposta aos meus pais. Conscientemente ou inconscientemente, nós damos respostas aos nossos pais, porque eles são os nossos parâmetros. ${ }^{, 242}$

A maior preocupação de seus pais era a sua formação e de como levaria a vida no futuro, pois desejavam um futuro melhor do que eles tiveram. Ela conta que seus pais não compreendiam o seu desejo de ser artista. Ela conta houve uma ocasião em que seu pai foi visitá-la em seu ateliê e se deparou com uma de suas esculturas, que era composta por módulos sobrepostos. Com certo ar de lamentação seu pai

\footnotetext{
${ }^{242}$ Entrevista de Norma Grinberg concedida a Silvia Tagusagawa.
} 
diz: "Coitada da minha filha, não consegue vender os trabalhos e tem que ficar empilhado aqui."

Mesmo com a incompreensão, Norma Grinberg persistiu e foi buscar o seu caminho. Para ajudar em suas pesquisas artísticas dentro da Cerâmica, Norma Grinberg fez um estágio na Escola SENAI, cujo foco é o aprendizado das técnicas da Cerâmica.

Na sua busca, elege a cerâmica como meio de expressão, pesquisa e cria sua primeira forma base que posteriormente transformaram-se em uma série de trabalhos que foram apresentados na exposição "Percursos de um módulo: 19771985" no Centro Cultural São Paulo. A forma base era o Grão que até hoje, Norma Grinberg cria novas possibilidades e obras.

Participando de exposições e dando prosseguimento às suas pesquisas, Grinberg é convidada a ser professora do Departamento de Artes Plásticas da USP para ministrar as aulas de Modelagem e Cerâmica. Posteriormente, com suas pesquisas artísticas em andamento, suas peças voltam-se para as questões humanas e têm como resultado a instalação apresentada ao Museu de Arte Contemporânea da USP, chamada Humanóides - Transmutações da forma e da matéria . Esse trabalho foi resultado de sua pesquisa de Mestrado, apresentada à Escola de Comunicações e Artes da USP, sob orientação do Prof. Dr. João Evangelista Silveira. 


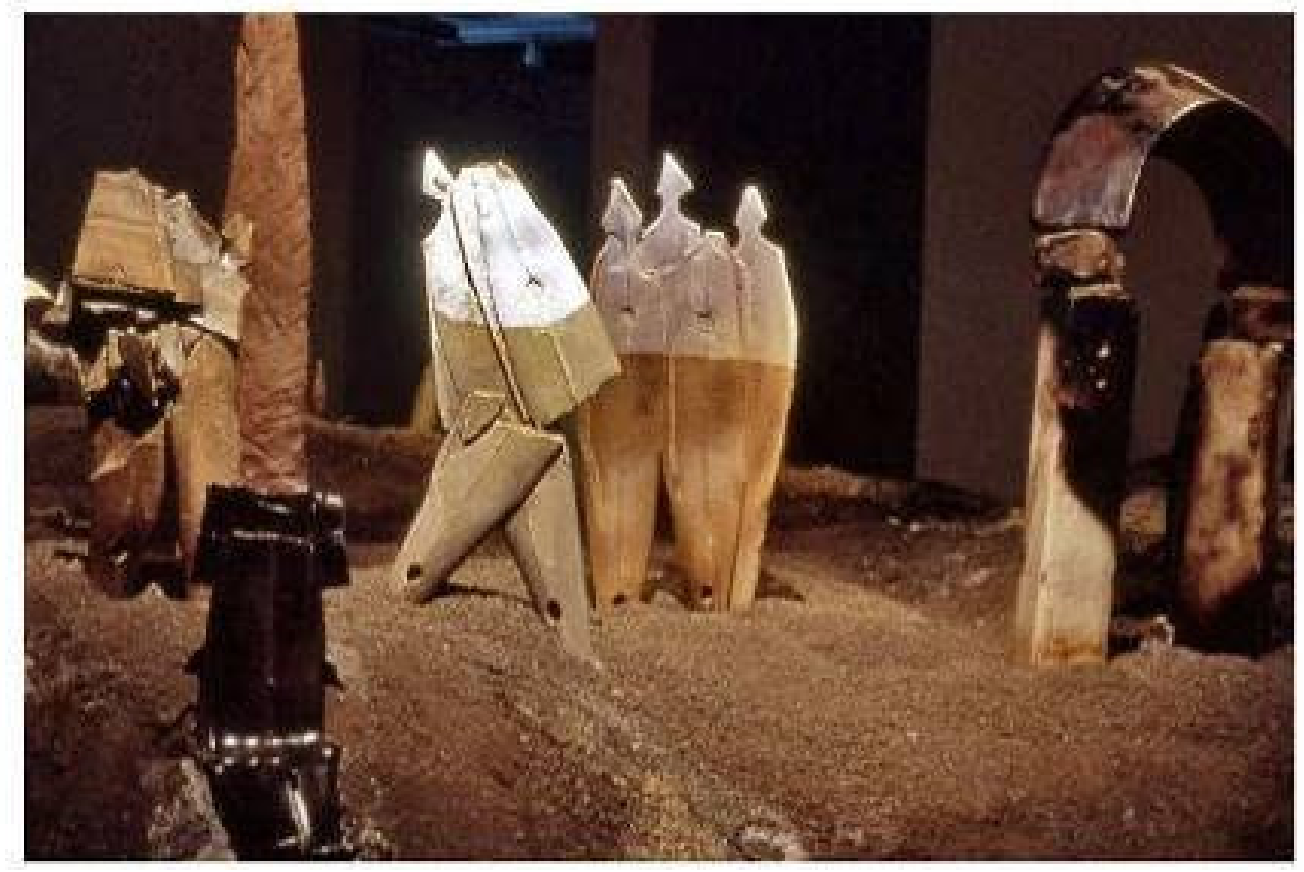

Figura 191

Norma Grinberg

Humanóides - Transmutações da forma e matéria (detalhe) 1994

Instalação em Cerâmica

Museus de Arte Contemporânea da USP

Norma Grinberg deu prosseguimento às suas experiências poéticas que resultou em sua tese de doutorado Lugar com Arco, sob orientação do Prof. Dr. Evandro Carlos Jardim. Nesta pesquisa, Norma Grinberg traz a questão do arco e seu significado tanto na história da Arte e como na Arquitetura. Com este trabalho, Norma Grinberg criou o monumento Lugar com Arco que está localizado no campus da Universidade de São Paulo em frente à Escola de Comunicações e Artes.

Além de ser artista atuante, Norma Grinberg tem contribuído na formação de artistas e outros profissionais da área de Artes. 


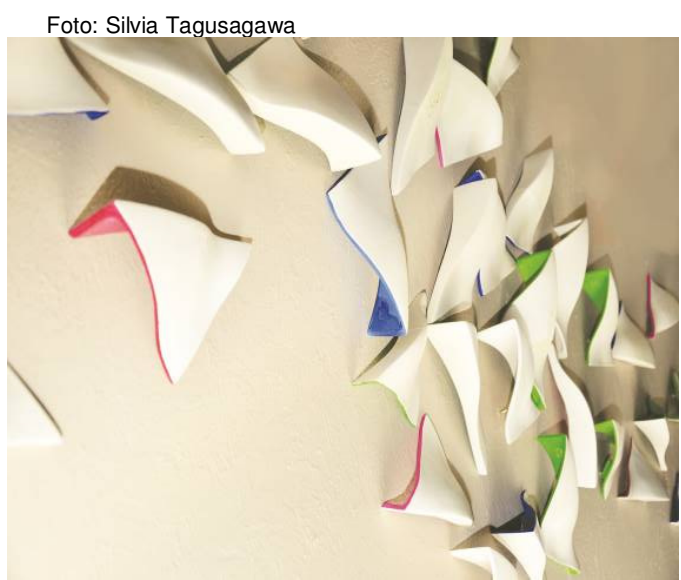

Figura 192

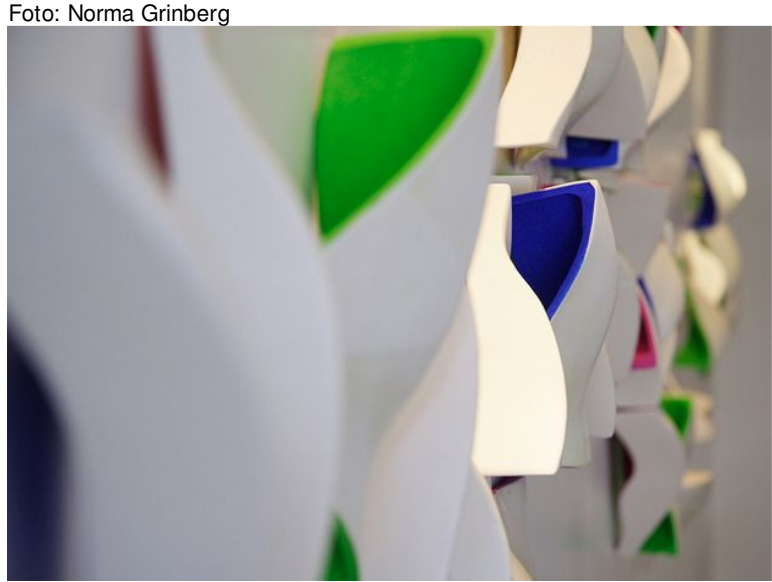

Figura 193

Norma Grinberg

Catacores

Cerâmica policromada (alta temperatura)

2012

Em virtude de seu destaque como artista que utiliza a cerâmica como meio expressão, desde 2010, Norma Grinberg é a primeira e única representante brasileira do IAC (International Academy of Ceramics) que tem como objetivo representar os interesses relacionados à Cerâmica. Seus membros são compostos por artistas, colecionadores, críticos, instituições educacionais, museus e escritores que têm contribuído ou tem se destacado na Arte Cerâmica em seus países.

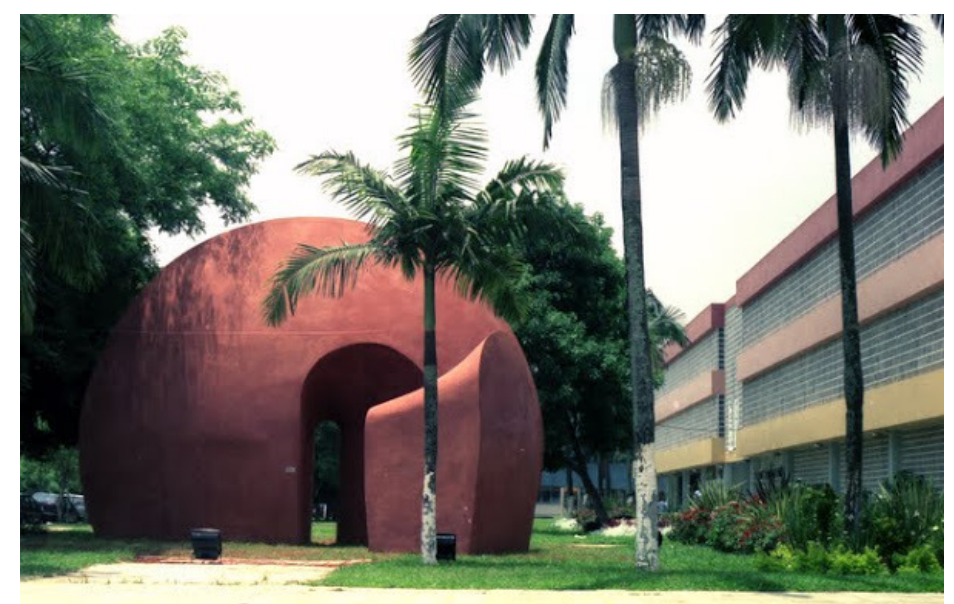

Figura 194

Norma Grinberg

Lugar com Arco

Concreto armado (Monumento localizado em frente à Escola de Comunicações e Artes da USP)

$9 \times 6,20 \times, 2,16 m$ 2000 


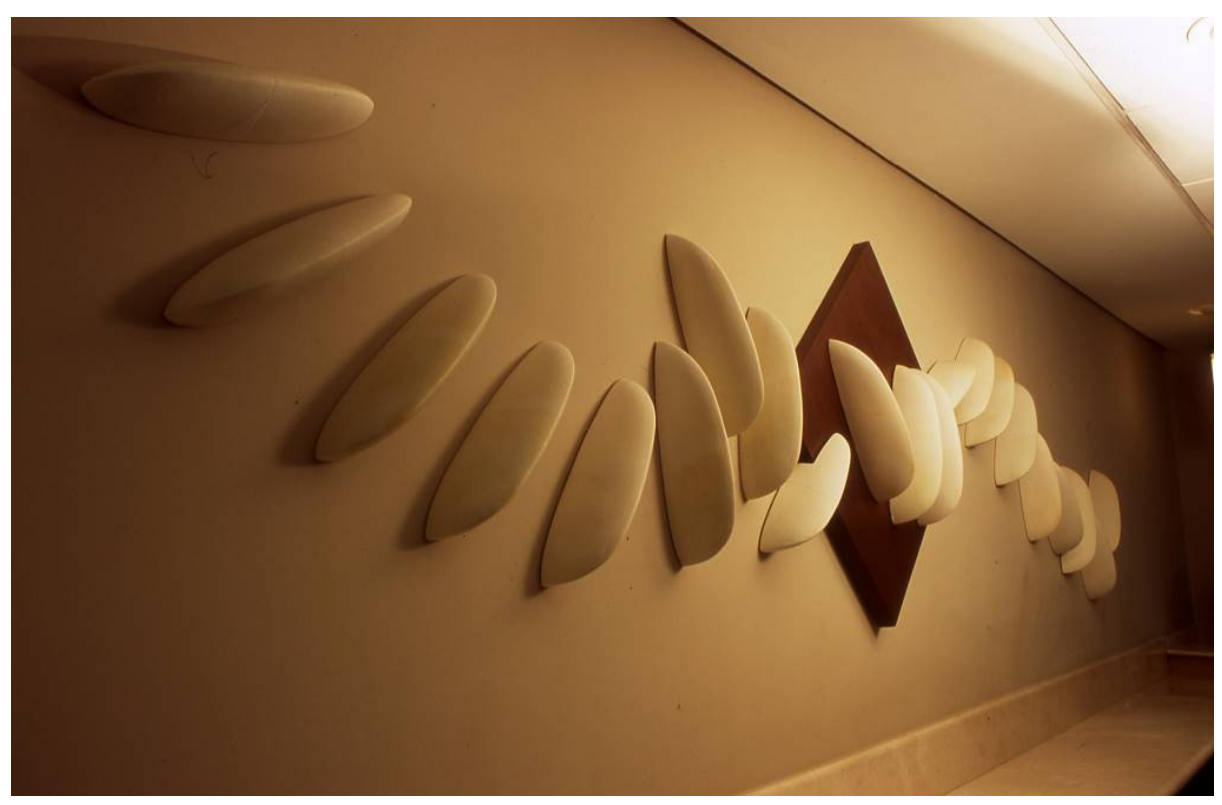

Figura 195

Norma Grinberg

Grãos

$3 m \times 0,50 \mathrm{~m}$ aprox...

Cerâmica Esmaltada

1997

\subsubsection{Poética de Norma Grinberg}

"Hoje vejo que realmente é um desafio chegar a um bom resultado poético e técnico na cerâmica, pois tudo depende da combinação entre a elaboração da ideia, a percepção, uma profunda compreensão do trabalho e da arte. Há ainda a técnica, a tecnologia e a sua utilização duramente adquirida por meio da disciplina pessoal do olho, da mão e da mente, numa linguagem que o artista desenvolve e pela qual evidencia o seu mundo sensível. ${ }^{243}$

${ }^{243}$ GRINBERG, Norma Tenenholz. Memorial de um percurso: Pesquisa, produção e ensino. Memorial apresentado a Escola de Comunicações e Artes da USP. São Paulo: 2007, p.7. 
Nos anos 70 , nascem às primeiras formas que até hoje continuam em transformação, como os Grãos, por exemplo. Para Norma, a cerâmica, a princípio, era seu suporte de pintura e desenho, mas logo foi vista como forma e volume. ${ }^{244}$

Foto: Norma Grinberg
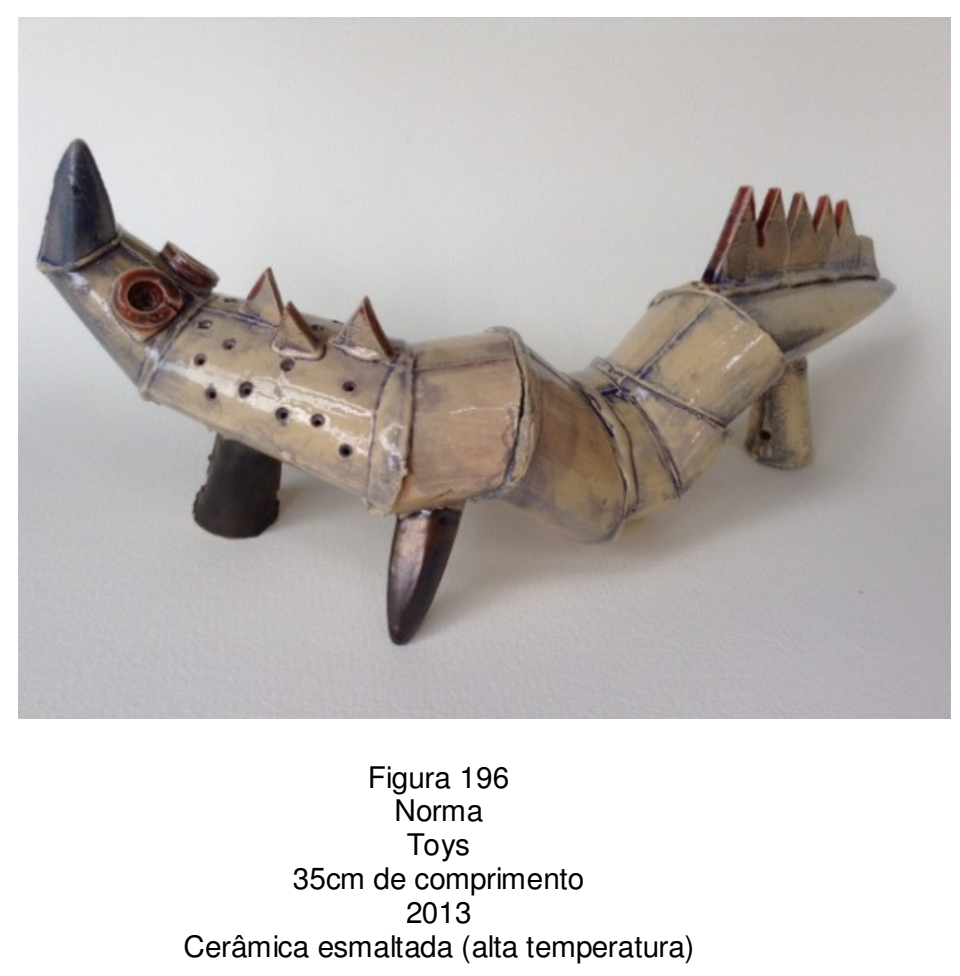

No início, Norma trabalhava a ideia de formas como utilitários e objetos escultóricos. Por exemplo, no caso dos Grãos: quando a forma não era interferida, mantida fechada, ela não tinha função determinada, era uma escultura. Segundo ela, quando recortava o "Grão", este se transformava num contêiner, tendo a partir deste momento, uma funcionalidade.

Incessantemente, Norma Grinberg poetiza sobre o espaço, criando a partir de um módulo, novas combinações. Um módulo é reproduzido, através do molde de gesso, inúmeras vezes, mas são interferidas de formas diversas, criando sempre novas combinações. As peças cerâmicas são reproduções criadas a partir de um molde de gesso, que por sua vez, foi gerado através de um modelo feito em argila.

${ }^{244}$ GRINBERG, Norma Tenenholz. Op. cit. 2007, p.6 
Então, Norma Grinberg faz inúmeras inferências, decompondo e recompondo as formas geradas de maneiras diversas, criando obras únicas.

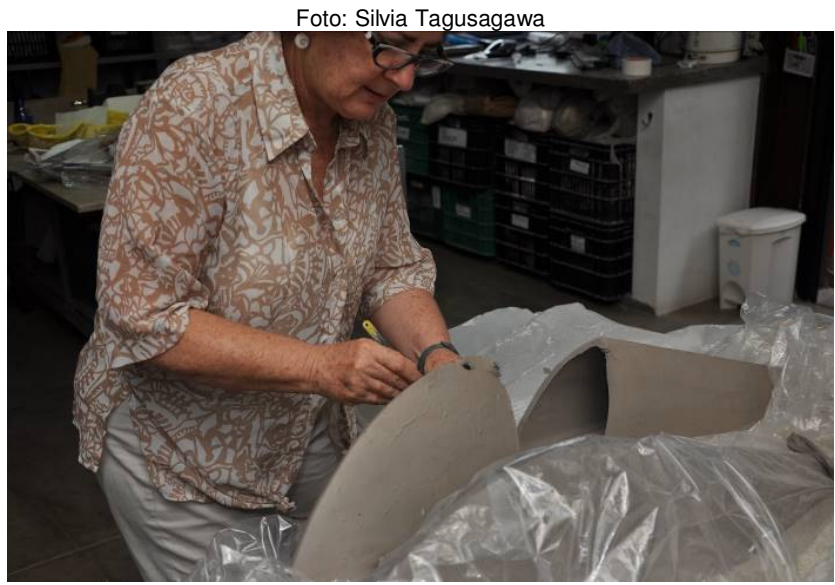

Figura 197

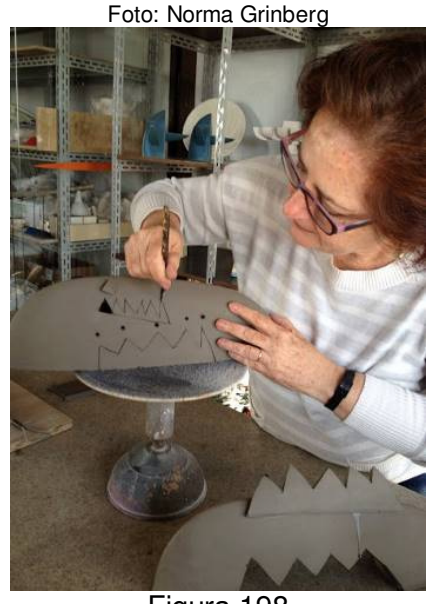

Figura 198

Norma Grinberg em seu ateliê - interferência sobre peça fundida úmida

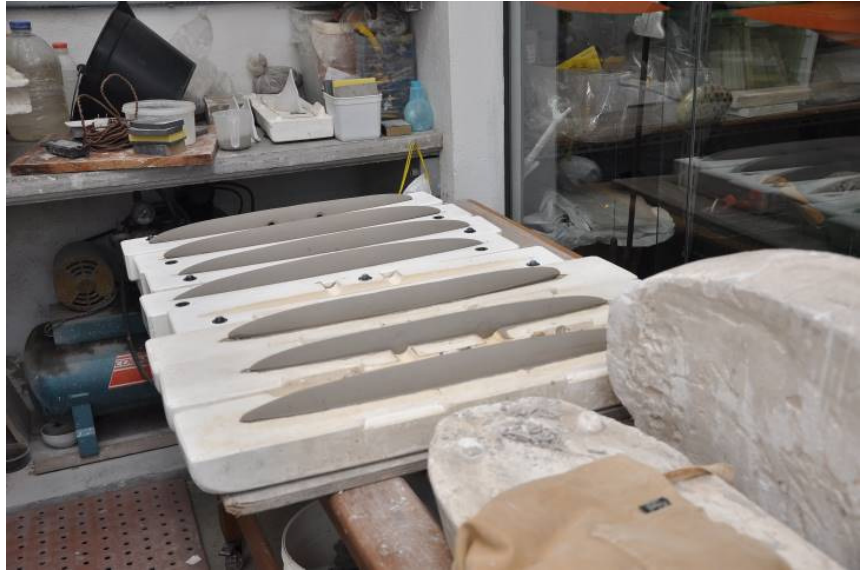

Figura 199 - Moldes com peças fundidas

Então, essas foram geradas a partir de desenhos resultantes de decomposições de formas. "[...] eu desenhava manequins e essas imagens eu sobrepunha e decompunha, eram movimentadas no espaço bidimensional e posteriormente no tridimensional."245

${ }^{245}$ Trecho da entrevista de Norma Grinberg concedida à Silvia Tagusagawa 

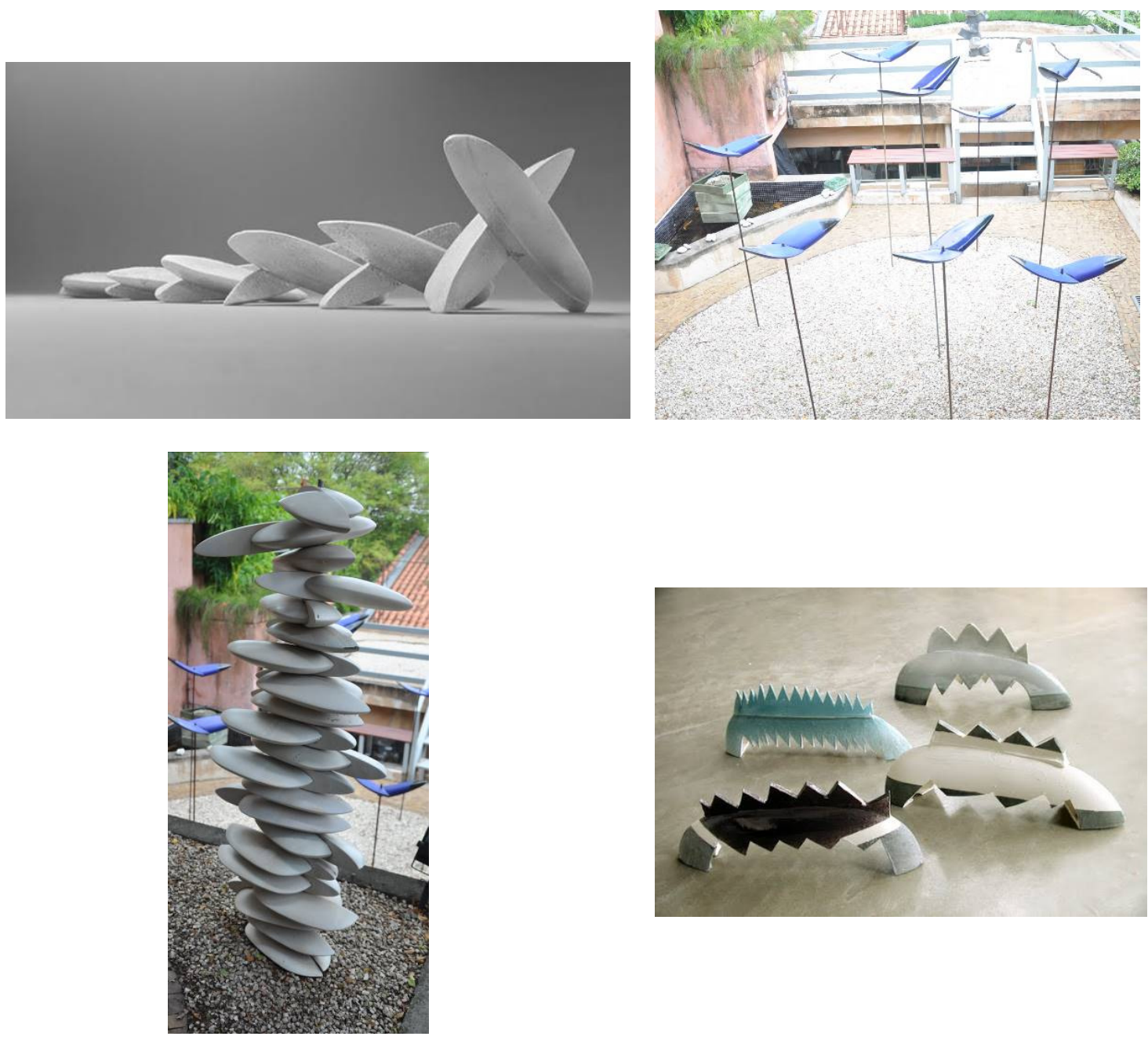

Da forma-base "grão", Norma cria metamorfoses - Rotativas , Vôos, Estrutura Vertical e Cururus

Decompondo as formas geradas através de desenho, Norma elegeria uma nova forma, transportando-o para o mundo tridimensional. Um molde de gesso era construído a partir do modelo de argila para assim gerar os múltiplos. No caso dos Grãos, eles se transformaram em outros trabalhos como as obras: Rotativas, Vôos, Estrutura Vertical e Cururus.

"'Em 1977, comecei a criar uma série de módulos com material cerâmico, curiosamente percebi que eles podiam ser manipulados num fascinante jogo aberto e lúdico. Meu envolvimento foi tal que não consegui mais controlar o desejo de continuidade e de 
desenvolvimento desse trabalho. $\mathrm{E}$, à medida que eu jogava, tudo se tornava mais amplo, mais complexo, desafiador e envolvente.

Notei que até mesmo o caminho que eu percorria não era sequer previsível: ele simplesmente acontecia.

$E$ é isso que eu quero mostrar. Mostrar um percurso que começa na criação dos módulos, a princípio sem interferências, onde exponho a sua plasticidade e conceitualidade, para logo em seguida entrar no mundo da abertura criativa que me permita interferir, justapor, aglomerar, cortar, juntar, construir...,246

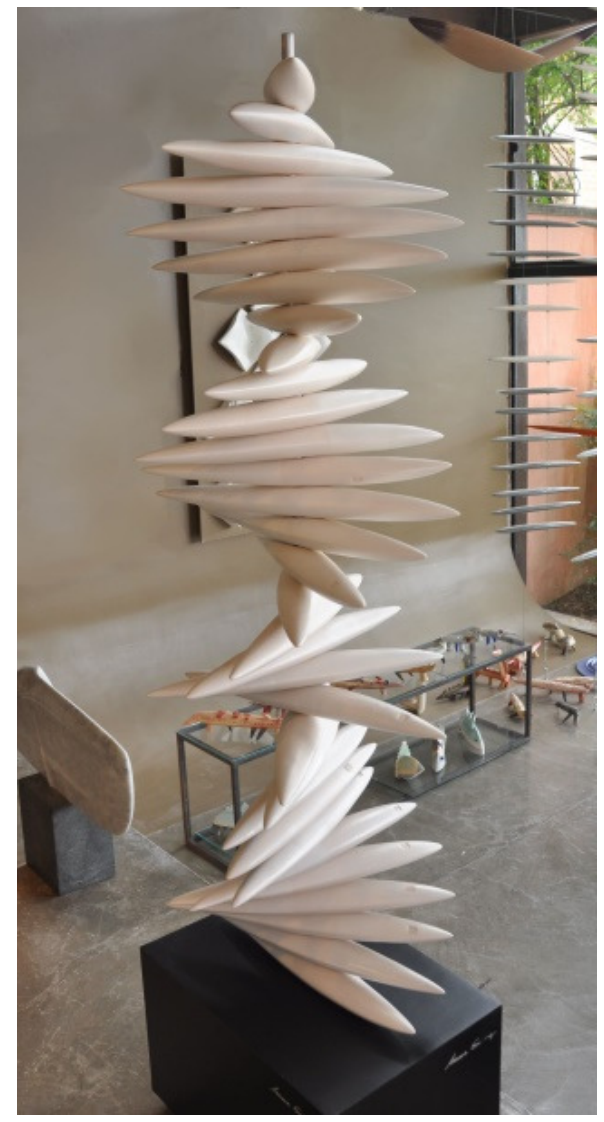

Figura 200

Norma Grinberg

Vertical Flauta

$1,65 \times 60 \times 60 \mathrm{~m}$ de altura

Cerâmica esmaltada, estrutura de madeira e aço $1980-$

${ }^{246}$ GRINBERG, Norma Tenenholz. Humanóides: Transmutações da forma e da matéria. Dissertação de Mestrado apresentada a Escola de Comunicações e Artes da USP, São Paulo, 1994, p.10 
Assim, ocorre com outras formas que elegeu. No início essas formas eram para serem vistas sobre uma base plana. Com o decorrer de suas experiências, Norma Grinberg os transporta para outros planos, como é caso dos Humanóides. Grinberg havia partido das flautas. Essas formas começaram a ser deformadas e foram tomando características humanas.

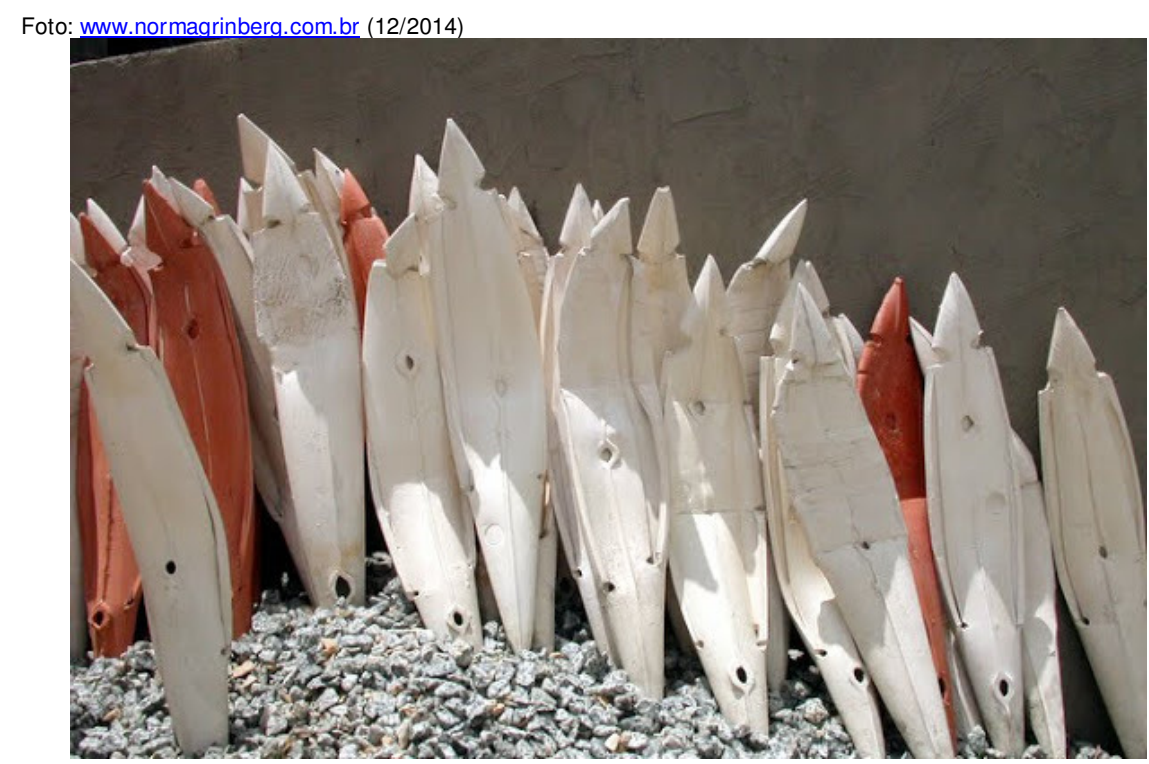

Figura 201

Norma Grinberg

São Paulo

$160 \times 90 \times 80 \mathrm{~cm}$

Instalação cerâmica

\subsubsection{Entrevista com Norma Grinberg (São Paulo, 08/04/2013)}

Silvia: Norma, vamos começar falando uma pouco da sua infância e o seu primeiro contato com a Arte.

Norma: Minha relação com a Arte se iniciou na infância, na escola de balé que eu frequentava na Bolívia. Na verdade, era uma escola de Belas Artes, mas que havia também balé, música, ou seja, era multidisciplinar. Antes de ir à aula de balé, eu via o pessoal desenhando e ficava observando como as coisas funcionavam, depois, seguia para a minha aula. Então, esse foi o meu primeiro contato com a Arte.

Silvia: Fale-me, então, sobre sua formação. 
Norma: Quando estava no ginásio (Ensino Fundamental), eu estava encantada pelo desenho. Então, eu procurei uma escola de Artes aqui no Brasil. Comecei a frequentar um curso de desenho, no Centro da cidade de São Paulo, uma vez por semana. Era um curso de desenho de observação. Depois disso, quando entrei no científico (antigo Ensino Médio), pedi para a minha mãe que me inscrevesse na Escola de Belas Artes, no bairro da Luz, onde é a Pinacoteca do Estado hoje. Nossa! Imagine! Frequentava aquele edifício magnífico naquela época! Inscrevi-me e frequentei duas disciplinas, Modelagem e Desenho de Criação, como aluna especial. Foi o meu primeiro contato com o barro. Tinha 17 anos. Fazia desenho de observação, pintura, guache e aquarela. A minha mãe não era a favor e achava que era somente um passatempo. Quando ela me via desenhando, perguntava: "Você não tem o que fazer?"

Com o passar do tempo, procurei fazer muitos desenhos. Comecei a criar também desenho para estamparias, motivada pelas confecções e estamparias que via no Bom Retiro, bairro onde eu morava. As empresas do bairro utilizavam estampas copiadas de revistas e que eu criticava tanto pelos desenhos como pela falta de estética. Então, descobri que criar desenhos para estamparia de tecidos poderia ser um meio de ganhar dinheiro e investir em cursos e material para desenho e pintura. Então, passei a vender essas estampas para empresas de estamparia.

Além de produzir os desenhos, eu também fui dar aulas de Artes para as crianças numa escola no bairro do Bom Retiro. Uma escola chamada Lubavitch ${ }^{247}$. Era uma aula extracurricular e tive vários alunos dos seis a oito anos de idade. Como era algo novo para mim, fui até a Biblioteca Mário Andrade e comecei a pesquisar, ler livros que mostravam vários aspectos sobre o ensino da arte para criança, além do significado do universo do papel para uma criança. Aprendi muito sobre a psicologia e a arte. A criança se expressa através do desenho e o papel é encarado como seu próprio mundo, onde ela se posiciona da mesma forma que sua

\footnotetext{
${ }^{247}$ Lubavitch é uma instituição educacional que trabalha com crianças e adolescentes, do ensino infantil ao médio. Localizada no bairro do Bom Retiro na cidade de São Paulo, a instituição foi fundada em 1960 pelos rabinos Jacob e Henrique Begun.
} 
realidade. Por exemplo, se você pede para ela desenhar a família, ela pode desenhar a mãe maior e o pai menor ou ele muito grande e o irmão pequenininho. Foi uma experiência muito positiva.

Desta forma, mostrava para a minha mãe que com essa profissão "artista", eu poderia me sustentar, porque era essa grande preocupação da minha mãe e ela perguntava: "Você vai viver do quê?"

Meu maior contato com a Cerâmica foi na faculdade de Artes Plásticas na FAAP (Fundação Armando Álvares Penteado). O currículo tinha ênfase no bidimensional: no desenho, pintura e gravura. Tive uma excelente formação nestas áreas, além da fotografia. Antes do curso de Artes, eu havia começado a cursar Arquitetura, mas não houve uma identificação e então parti para o curso de Artes. Eu me formei em 74 .

Silvia: Logo depois da faculdade, você montou seu ateliê?

Norma: Em 1972, conheci um ceramista uruguaio chamado Alberto Lema Pires e fiquei muito influenciada pelo trabalho dele. Passei a frequentar seu ateliê. Ele foi a primeira pessoa com quem eu tive um contato mais próximo com a cerâmica. Ele também utilizava moldes e foi ele quem me ensinou o processo de reprodução com moldes.

Por questões políticas, o Alberto havia se refugiado aqui no Brasil. Ele é formado pela Escola de Belas Artes do Uruguai, que era totalmente voltada para uma socialização da Arte, ou seja, a Arte deveria ser também para o povo. Tanto assim, que os alunos eram estimulados a apresentarem seus trabalhos em praças públicas e onde poderiam comercializar suas obras. Eles achavam que essas ações incentivavam a produção e o contato com o povo. Essa era também uma ideia de um conhecido artista uruguaio, Torrez-Garcia, que tinha esse conceito como princípio. Além disso, os alunos eram incentivados a aprender e a construir seus próprios instrumentos de trabalho.

Foi ele quem fez o meu primeiro forno elétrico para cerâmica, o qual eu tive a sorte de presenciar e de ajudar na construção. Era um forno de uso impressionamente amplo. Cavamos os tijolos, enrolamos as resistências. Neste 
mesmo período, eu aluguei uma garagem, montei meu primeiro ateliê e dei continuidade à Cerâmica.

Silvia: Quando surgiram as primeiras formas tridimensionais?

Norma: No início, a cerâmica era o suporte dos meus desenhos. Posteriormente, percebi que a cerâmica era volume e deveria ser tratada como tal. Deixei, então, de desenhar sobre a Cerâmica e parti para o volume. Mesmo nos desenhos que eu fazia, já havia algum sinal do que eu iria fazer no tridimensional. Teve uma época em que eu desenhava manequins e essas imagens eu sobrepunha e decompunha, eram movimentadas no espaço bidimensional e posteriormente no tridimensional.

Iniciei as formas tridimensionais na cerâmica que eram vistas como contêineres e não contêineres. Por exemplo, a forma chamada Grão, quando eu não interferia nela, era uma forma fechada, sem uma função determinada ou era uma escultura. Quando eu recortava, ela se transformava num contêiner, ou seja, era uma cerâmica na sua funcionalidade.

As formas que trabalho até hoje não são formas complexas, mas sim essencialistas e que vêm do pensamento da Bauhaus, que eu gosto muito. Mies van der Rohe dizia "O menos é mais". Assim como o menos fosse a essência de um excesso. Eu comecei a fazer essas formas que até hoje continuo utilizando. Penso: "Nossa!", mas sempre encontro outras possibilidades.

Silvia: Conte-me sobre o seu processo de criação

Norma: Meu processo de criação está atrelado à questão do múltiplo e a essa transformação do múltiplo. Percebo que reproduzir uma mesma forma e depois interferir de maneira diversa me dá uma liberdade muito grande, porque eu interfiro nele sem receio, porque ele é múltiplo. Eu transformo que para que esse multiplo seja único.

Silvia: Como você vê a sua relação entre a sua poética e a cerâmica?

Norma: Eu acho que é perfeita, ou seja, eu acho que a cerâmica é um material que possibilita a concretização do meu trabalho tridimensional. Eu vejo que tenho uma tendência maior ao tridimensional. 
Quando encontrei a cerâmica e o barro, percebi que minha expressão fluía e de uma maneira muito mais intensa, agradável e realizadora. Fui desenvolvendo o conhecimento dentro da Cerâmica que, para mim, é uma questão de encontros e respostas. Ou seja, se você tem uma resposta boa a uma ação, com certeza você vai gostar dela. Assim foi meu encontro com a cerâmica.

Para mim, a Cerâmica tem uma grande vantagem, já que é um material que pode ser utilizado em áreas externas como internas. Tanto o projeto como a materialidade devem ser observadas e levadas em conta. Teoricamente, todo barro, transformado em cerâmica, resiste às intempéries. Obviamente, temos que nos ater às questões de temperatura, do acabamento entre outros cuidados, mas isso vem depois. O mais importante a levantar é que se trata de um material plástico e impressionantemente amplo. Tão amplo quanto à sua flexibilidade como à sua plasticidade. E também é um material que se adapta a qualquer meio, tanto países quentes como os frios. No entanto, necessitamos conhecer os materiais para que possamos adaptá-los aos diversos ambientes. Porque as massas cerâmicas são diversas com relação às suas formulações e finalidades, assim como os esmaltes. Enfim, é um universo.

Silvia: Por que você optou pela Cerâmica e por utilizar este método de trabalho?

Norma: A opção pelos múltiplos se deu pelo fato, de quando eu entrei na faculdade de Artes, que foi nos anos 70, havia sido declarada à morte a Pintura. Nesta época, Marcel Duchamp tinha uma grande evidência no Brasil e o fazer já era uma coisa obsoleta. O que importava ao artista era o pensar, o conceito. Com isso, eu fiquei uns dois anos sem produzir, pois tinha sido contaminada por esse conceito e acreditei que já não havia sentido no criar e fazer manualmente ou lidar com a matéria. Como contei anteriormente morava no Bom Retiro, local de muitas fábricas do setor de vestuário e a produção em série estava presente no meu dia a dia. Acredito que isto tenha me motivado a optar também pela multiplicação no meu trabalho artístico e esta foi a minha saída.

Naquela época, havia um preconceito com relação à habilidade manual e acredito que não era somente no meio artístico, mas também na sociedade. Eu 
percebia isso nos meus pais também, o preconceito com o fazer manual, mas por outros motivos. Eles tinham esse preconceito, porque eles estavam voltados para a questão da Revolução Industrial, não para a questão da conceptualização da Arte. São coisas diferentes, mas havia sim esse preconceito pela manualidade. Então, eles diziam que quem fazia essas coisas manuais, não tinha muitas condições de desenvolver um trabalho e sobreviver a partir dele. A máquina era preponderante por motivos diversos. Eu tinha que dar uma resposta aos meus pais. Conscientemente ou inconscientemente, nós damos respostas aos nossos pais, porque eles são os nossos parâmetros. Então, quando eu vi a possiblidade de multiplicação, eu fiquei fascinada. Mesmo não sendo uma multiplicação mecânica ou eletrônica, ela pode ser feita por outros, não só por mim. No entanto, as transformações destes objetos são resultantes da minha poética, do meu resultado artístico. Então, o fato de utilizar o molde que é um processo industrial na minha produção, está relacionado também a uma resposta que eu queria dar a eles, meus pais.

Silvia: Nos seus trabalhos as repetições ocorrem e a partir delas, você recria sobrepondo, cortando, recombinando, colando e amassando.

Norma: No início da década de 80, Pietro Maria Bardi me convidou para participar de uma exposição no Museu de Artes de São Paulo. Para esta ocasião, eu enviei a primeira obra da série Estrutura Vertical. É neste trabalho que começo a perceber que poderia realmente manipular os módulos. Além de criar, eu poderia multiplicar, seccionar e sobrepor. Conversando com um amigo, percebi que deveria explorar outros tamanhos e fazer obras maiores.

A série Estrutura Vertical, teve início com o desenvolvimento na horizontal dos elementos que a compunha e houve uma transformação para a verticalidade. Então, por exemplo, eu tenho uma série chamada Rotativas, que eu fiz para uma exposição na Galeria Arte Aplicada e que ganhou uma crítica favorável do Jacob Klintowitz ${ }^{248}$ no Jornal da Tarde. Foi um grande estímulo para continuar produzindo.

248 Jacob Klintowitz (Porto Alegre, 1941) é critico de Arte e curador. Escreveu vários artigos e textos para jornais, livros e revistas sobre importantes exposições e artistas brasileiros. 
Em 1987, fiz uma exposição no Centro Cultural São Paulo chamado Percurso de um módulo: 1977 a 1985. Apresentei em torno de quarenta esculturas com este mesmo módulo, o Grão.
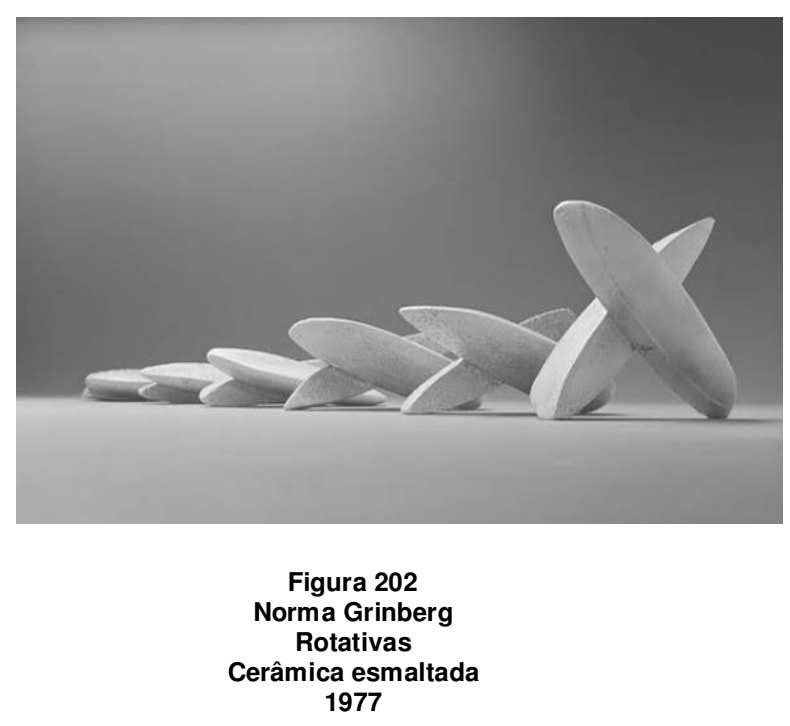

Com relação ao processo de criação, há uma transformação radical em 1987 quando iniciei a criação dos Humanóides. Neste, eu amassava o múltiplo Flauta, e o transformava em figuras humanas. Estas obras estavam relacionadas à transformação facial principalmente, pois tive um problema de saúde. Portanto, posso afirmar que cada trabalho apresenta um momento da minha vida.

Silvia: Os Humanoides são um dos seus trabalhos mais conhecidos e foram tema do seu mestrado. Conte-me mais sobre esta série e sobre as séries posteriores.

Norma: Desenvolvi as séries com os Pingos e as Flautas. A partir delas, criei outros trabalhos e delas surgiram os Humanoides. É nesta fase que meu interesse pela figuração aumenta. Algo que não estava presente na minha produção. Isso foi na década de 1990, pois, até então, eu recorria mais à abstração. Sinto que nesta fase eu quase me transformei numa "Barroca", por causa das dobras presentes nestes elementos.

Quando esses elementos saem dos moldes, eles estão maleáveis e plásticos. Então, eu comecei a cortar e a recortar, mas de uma maneira orgânica, sem ser tão 
racional ou projetar. Eu batia a forma, ela dobrava e se transformava, até quando está queimado e rígido, você tem um blasé da matéria.

Certa vez, fiz um trabalho chamado Dobras da terra, no qual eu peguei todas as peças as séries Humanoides e filmei as dobras. As séries não apareciam diretamente, mas só os detalhes. Essas dobras têm a ver com Deleuze e com Bachelard. O que é uma dobra? Numa dobra você tem uma parte escura e outra clara. O escuro corresponde às entranhas, são as coisas do inconsciente e a partes claras são aquelas que levam à razão. Desenvolvi muito essa questão das dobras e que eu levo posteriormente para o meu trabalho de Mestrado. Neste momento, eu começo desenvolver esses Humanoides, numa situação geográfica e numa situação de cidade. Como se fossem ninhos para eles. No início, os Humanoides eram dispostos horizontalmente em gavetas. Essas gavetas foram elaboradas num primeiro momento para que as pessoas pudessem abri-las e se deparar com surpresas, mas depois resolvi criar uma cidade para eles.

A cidade foi construída com os arcos que comecei a construir em 91. Foi numa primeira viagem, no mesmo ano, que fiz à Europa. Lá, eu vi aquelas construções austro-húngaras e fiquei impressionada com os arcos. A cidade húngara de Pecs é considerada a segunda cidade barroca. Linda!

De maneira geral, fiquei impressionada com as construções arquitetônicas deste local e fui atraída para isso, pois exatamente o que eu precisava era de uma cidade para os Humanoides. Esses arcos faziam parte da instalação exposta no MAC USP por ocasião do Mestrado e faz uma referência ao tempo e espaço. A partir daí, comecei a estudar os arcos na arquitetura, engenharia e as suas funções. Sem os arcos não haveria, por exemplo, os aquedutos que transportavam água de um lugar para o outro e os vãos das construções ficariam reduzidos, como por exemplo, na Grécia Antiga. Quem vê tais construções fica maravilhado. Havia quantidade de pilares para a sustentação dos telhados e tetos. Com os arcos os espaços tornavamse mais amplos.

Na parte interna dos arcos, que forma um túnel, suas entradas têm larguras diferentes, uma menor que a outra, que para mim forma um arco com entrada em perspectiva, ou seja, é o espaço em perspectiva e que dá sensação de passagem. 
Recentemente, esses Humanoides se transformaram nos Toys que fazem parte dos Bichos, obras que iniciei em 1998. Em 2008, eu fui convidada a participar, juntamente com outros artistas do IAC (International Academy of Ceramics) da América Latina, a residência artística que aconteceu numa grande fábrica de cerâmica em Fuping/Xian, na China. O resultado foi a instalação em cerâmica chamada Brazilian Pantanal, que faz parte do acervo permanente do FLICAM (Fule International Ceramic Art Museums). Esta instalação faz referência à fauna do Pantanal brasileiro, que fazem referência, então, aos Bichos.

Norma: Normalmente, a Cerâmica está restrita ao tamanho do forno, mas podemos utilizar de outros artifícios ou técnicas para ampliar as possibilidades. Neste caso para que pudesse ser criada uma obra de dimensões maiores. Tais técnicas acabam fazendo parte de uma linguagem artística. Então, esse foi meu grande desafio: como poderia transformar os elementos que tinham mãos em obras monumentais. Essa questão me perseguiu e eu dei as respostas. Atualmente, só trabalho com obras em grandes escalas, mas utilizando elementos menores.

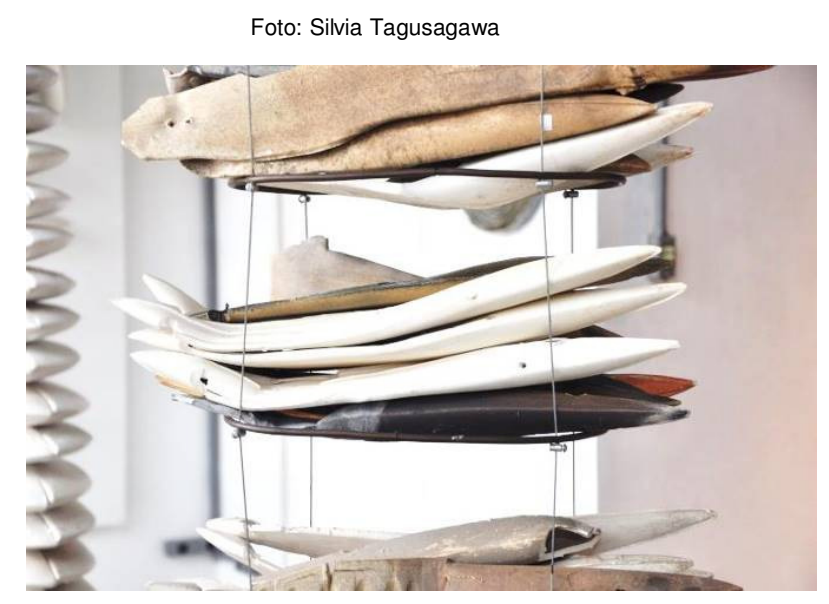

Figura 203

Norma Grinberg Humanóides (detalhe)

Cerâmica, cabos de aços e metal 2011

Nesta decomposição das formas, algumas das formas resultantes me encantam mais e aí eu transformo em outras possiblidades. Os Voos, por exemplo, têm origem de uma peça que eu chamei de Januária Mulher Negra e era uma forma 
ovalada e que tinha uns sulcos. Eu recortei e deste recorte saíram duas formas que me interessaram e que deram início uma seriação. As séries Voos e Leques são resultados desta seriação.

Então, a partir de uma forma outras vão surgindo, eu me encanto, modelo e secciono. Então, uma única forma pode dar várias seriações.

Entrelaços é um dos trabalhos mais recentes e que deriva de uma transformação das Nuvens. As partes se apoiam uma a outra. Fiz este trabalho a pedido de uma Sinagoga, em homenagem aos seus benfeitores e que traz esse sentido de um apoiar o outro como uma comunidade deve ser. Ela também foi capa de uma revista de cerâmica chinesa em 2013.

Além da obra Entrelaços, da série nas Nuvens surgiram outras como as obras Paisagem de nuvem e Catacores.

No caso da série Catacores, são formas brancas na frente e coloridas atrás com engobes e tintas frias, dependendo das cores aplicadas. É um trabalho que deve ver visto pela lateral e não de frente, pois as cores se apresentam na parte de trás de cada peça, algo que se vai desvendando e causa uma curiosidade. Houve uma ocasião em que uma pessoa disse que haviam montado o trabalho do lado errado, eu disse que estava certo e achei engraçada a reação da pessoa.

Silvia: Só retomando um pouco as questões técnicas, você costuma fazer trabalhos com os moldes de gesso - também modelagem, torno - mas predomina o molde. Primeiro você faz a queima de biscoito, utiliza os vidrados e faz a ultima queima. No caso das cores, elas já foram determinadas antes de construir as peças?

Norma: Sim. Eu sempre penso nas propostas, formas e cores simultaneamente. Eu acho que faz parte. Eu ultimamente tenho utilizado uma gama maior de cores. Eu acho que tem haver com o momento que estou vivendo, com os Toys (Bichos)

Silvia: No início, os trabalhos eram apresentados nas cores brancas e seus derivados, partindo para os azuis e dos verdes. 
Norma: Acontece que no começo eu queria que as formas estivessem em evidência, mais do que as cores. porque a cor é algo muito fascinante, se você acrescenta cores, muitas vezes, ela chama a atenção mais do que a forma.

O que eu queria era o desenvolvimento e a valorização da forma, no seu significado, no volume.

A cor é mais um complemento e se ela for muito forte, sinto que ela poderia enganar o meu desenvolvimento formal e até o significado.

Comecei a usar cores em 1998. Foi na ocasião para uma exposição na Galeria Toki chamada Módulo: multiplicação, decomposição e recomposição. Comecei a usar tanto o azul como o preto, além do branco.

Silvia: Comente sobre as questões das cores aplicadas nos seus trabalhos.

Norma: No caso dos Entrelaços, as cores foram selecionadas de acordo com a temática de cada andar da sinagoga, onde estão instalados. O prédio possui três andares: o térreo que corresponde à Sinagoga, o segundo é o andar da Juventude, terceiro é o Pátio de estudos e o quarto é o andar Polivalente.

Por isso, no térreo utilizei marrons opacos acetinados e marrons-avermelhados translúcidos e brilhantes. Os marrons opacos estão relacionados com a terra e os marrons-avermelhados translúcidos que refletem luz, dando a sensação de leveza e transcendência e espiritualidade.

O verde significa o que está em desenvolvimento. Está relacionado com "aquilo que está verde, não está maduro". São jovens em desenvolvimento. Logicamente, sempre estamos em desenvolvimento, mas com o jovem há uma necessidade maior e ocorre com mais evidência essa procura em crescer e desenvolver-se.

Os azuis são as séries localizadas no terceiro andar e que fazem relação com a espiritualidade. Quando Goethe fala sobre os sentidos das cores, os azuis, os lilases e os arroxeados estão relacionados à espiritualidade.

No quarto andar é o polivalente. Por isso, colori as peças com cada uma das cores trabalhadas nos outros andares, pois é onde tudo se encontra.

Há uma questão da forma e da cor que também tem um sentido. 
Na questão da cor, como eu havia dito, eu me baseio nas teorias de Goethe e na Antroposofia. Ou seja, quando se fala em Antroposofia com relação à cor, remete-se à Goethe. Cada cor tem o seu sentido. É claro que o conteúdo da cor e seus significados mudam de acordo com cada cultura, assim como na cultura Ocidental o vermelho é Yang, o sangue. Na Oriental é o Yang, mas também é a realeza. Para os chineses, a noiva se veste de vermelho, pois é uma cor da Realeza.

Silvia: Nas obras Enredadas e Eróticas saem desta linha mais limpa e geométrica.

Norma: É verdade. As Enredadas foram feitas depois de uma viagem que eu fiz à Índia. Visitei as construções hindus e os castelos dos marajás. Por volta do século XVII e XVIII, as janelas não tinham vidros, para se poder ver através delas, pois são vazadas com contornos de motivos florais e simétricos. As mulheres raramente saíam e ficavam olhando as ruas pelas janelas, mas as pessoas de fora não conseguiam vê-las. Fiquei maravilhada com toda a riqueza de formas e estética, o Taj Mahal. Então, quando voltei de viagem, desses vazados, os vazios me interessaram e tive uma vivência com um grupo amigos de sensibilização e mexendo na argila, comecei a fazer furos e a partir disso surgiu essa série.

No caso das Eróticas, as formas são sugestivas, são sensuais, mas não fiz com esse intuito. Quando faço um trabalho, não penso exatamente o que vai ser, ou de forma racional, ou do mundo real. Penso sempre numa decomposição da forma, numa gramática visual e numa conceituação. Por exemplo, os Humanoides têm uma relação forte comigo, a maneira que eu os mostrei estava relacionada com histórias da minha vida.

Atualmente, estou trabalhando estas formas, com fragmentos que se justapõem, mas sem uma organização exata quantos às verticais, mas para mim orgânicas, dentro um caos que ao mesmo tempo tem uma ordem própria.

Silvia: Você tem alguns trabalhos em outros materiais e tem um que eu vi que é em mármore.

Norma: Este trabalho eu fiz em cerâmica e depois pedi para um escultor para que transferisse esta mesma forma para o mármore. Ela é de 78. Eu comecei a 
talhar o mármore, mas eu não tive paciência porque não é só uma questão de força, mas é de prática. Eu necessito de um material que dê resultados rápidos, pois é uma necessidade que tenho ao criar. Ver o trabalho o pronto quanto antes! Mesmo que para quem trabalha com a argila o processo todo não é tão rápido assim, amassar, modelar, secar e queimar... tudo leva tempo, não só pela nossa ação mas pelo tempo que o material exige para domá-lo e termos um resultado desejado.

Com a argila eu me sinto livre, ela responde. Não digo que eu tenho controle sobre ela, mas ela tem sobre mim. É ilusão achar que temos total controle sobre os materiais, mas é possível um dialogo.

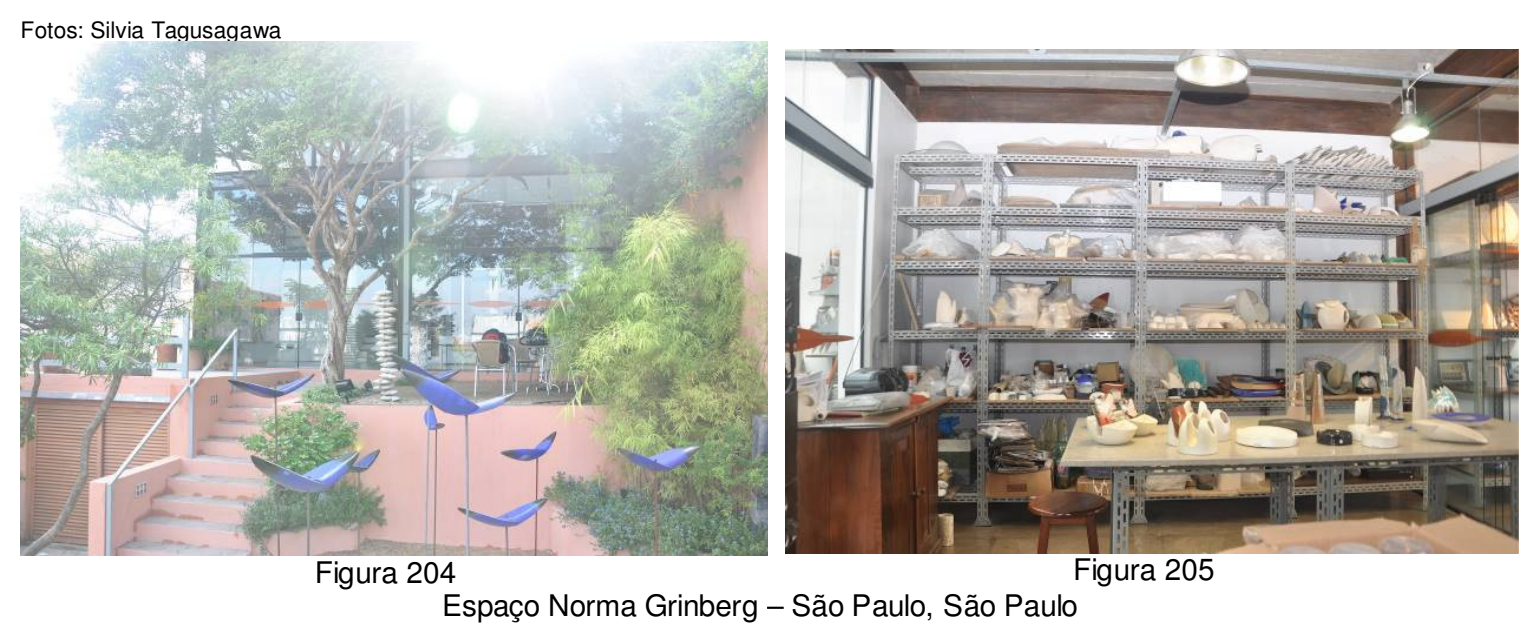

Silvia: O Espaço Norma Grinberg é o seu local de trabalho e também um espaço para exposições e eventos, inclusive há cursos de cerâmica. Conte um pouco da história e o significado deste lugar.

Norma: O meu ateliê é um espaço que havia sonhado há vários anos. Então, é um sonho realizado! Isso é maravilhoso. Acredito que vivemos de sonhos e realizações, principalmente numa área em que atuamos que é Arte. $O$ arquiteto Gilberto Nascimento foi quem fez o projeto do meu ateliê. Meu antigo ateliê era numa garagem junto com a casa em que eu morava com minhas filhas e marido. Era uma casa-ateliê. Que se transformou em ateliê-casa! Cada pedacinho do meu atual ateliê, assim como cada obra, tem um sentido e uma história. 


\section{Capitulo 4: Conexões}

Primeiramente, é importante esclarecer que esta pesquisa não visa julgar ou criticar as obras dos artistas, mas sim refletir sobre suas experiências de vida. Levamos em conta o envolvimento com a cerâmica e outras artes, a importância o conhecimento técnico e seu domínio, o processo de criação e tudo o que faz com que criem novas possibilidades expressivas para a Cerâmica. Percebemos que os artistas André Yassuda, Kimi Nii, Laerte Ramos, Máyy Kóffler, Marco Paulo Rolla, Miguel dos Santos, e Norma Grinberg respeitam os limites da matéria, mas criam meios para transcendê-la.

Através do contato com cada um dos artistas, percebi que possuem um universo único a ser explorado com profundidade, merecendo um espaço especial dentro de uma pesquisa acadêmica. Dedicaram parte de seu percurso ao aprendizado das técnicas cerâmicas, mas não deixaram de lado a experimentação. No entanto, o que diferencia cada um deles, além de suas histórias de vida, suas experiências e sua formação é a visão poética. Sempre com o intuito de materializar suas obras, procuram fazer com que os limites técnicos não sejam barreiras ou restrições. Ao contrário: tomam partido desses limites, chegando a ultrapassá-los.

Esses artistas determinam seus próprios critérios e não se restringem às regras pré-estabelecidas. Para eles o tempo da Arte é lento, onde cada instante é para aprender, sentir e buscar o incompreensível que habita cada um.

A busca por sanar suas inquietações faz com que se dediquem 24 horas do dia pensando, desenhando, fazendo analogias entre fatos cotidianos com o seu trabalho, relacionando seja um objeto ou uma obra de outro artista com sua própria produção. Durante a entrevista, todos relataram já estar pensando em suas próximas produções ou em como poderia resolver um problema que enfrentavam naquele momento.

A Cerâmica exige do artista muito além da teoria ou rascunho. Com ela, o artista necessita o contato direto com a matéria. Aliando o desejo de materializar suas ideias e desse contato físico com os materiais da cerâmica surgem novas possibilidades. 
Refletimos sobre como a Cerâmica possui técnicas específicas que auxiliam na produção das obras e, portanto, conhecê-las e dominá-las possibilita ao artista a base para ousar desafiá-las. Os entrevistados fazem isso muito bem, pois a poética de cada um impõe desafios cada vez maiores que implicam, inevitavelmente, na transcendência dos limites das "regras da cerâmica".

Por meio das histórias de cada um deles, percebemos que a descoberta, o aprendizado das técnicas e o contato com os materiais da cerâmica fizeram com que tomassem caminhos diversos para chegar aos seus objetivos. Esses objetivos também, muitas vezes, não estavam tão claros desde o início, mas o esforço, a persistência, a intuição e a emoção auxiliaram nessa caminhada.

Com este trabalho, tive a oportunidade de mostrar uma pequena parte de um rico universo e constatei que há um vasto campo de pesquisa. Infelizmente, pelas limitações de prazo e espaço para registro, não pude trazer tudo que gostaria de mostrar sobre cada um deles e me vi obrigada a me contentar com o desenvolvimento de um trabalho de cunho introdutório, ou pelo menos, relativamente "panorâmico".

Cabe considerar que nesses processos para chegar a determinados resultados, seja aprendendo a manusear certa ferramenta ou simplesmente experimentando tipo novo de argila, reconhecemos o que Cecília Almeida Salles diz:

"Lidar com a matéria-prima está diretamente relacionado às técnicas. Há uma série de manuais que se dedicam à apresentação dessas técnicas [...]. No entanto, sabemos que a busca do artista se apoia no espaço pessoal que encontra para lidar com essa espécie de gramática básica; seguindo na analogia linguística, o artista, ao longo de seu processo, procura a construção de uma sintaxe pessoal, a partir do diálogo com a tradição e seus contemporâneos [...].".249

\footnotetext{
${ }^{249}$ SALLES, Cecília A. Redes da criação: Construção de uma obra de arte, São Paulo: Editora Horizonte, 2006, p. 85.
} 
Além de tudo isso, quando apreciamos verdadeiramente as suas obras, é possível verificar em que ponto ou medida estes artistas ultrapassam ou transcendem os limites técnicos conhecidos.

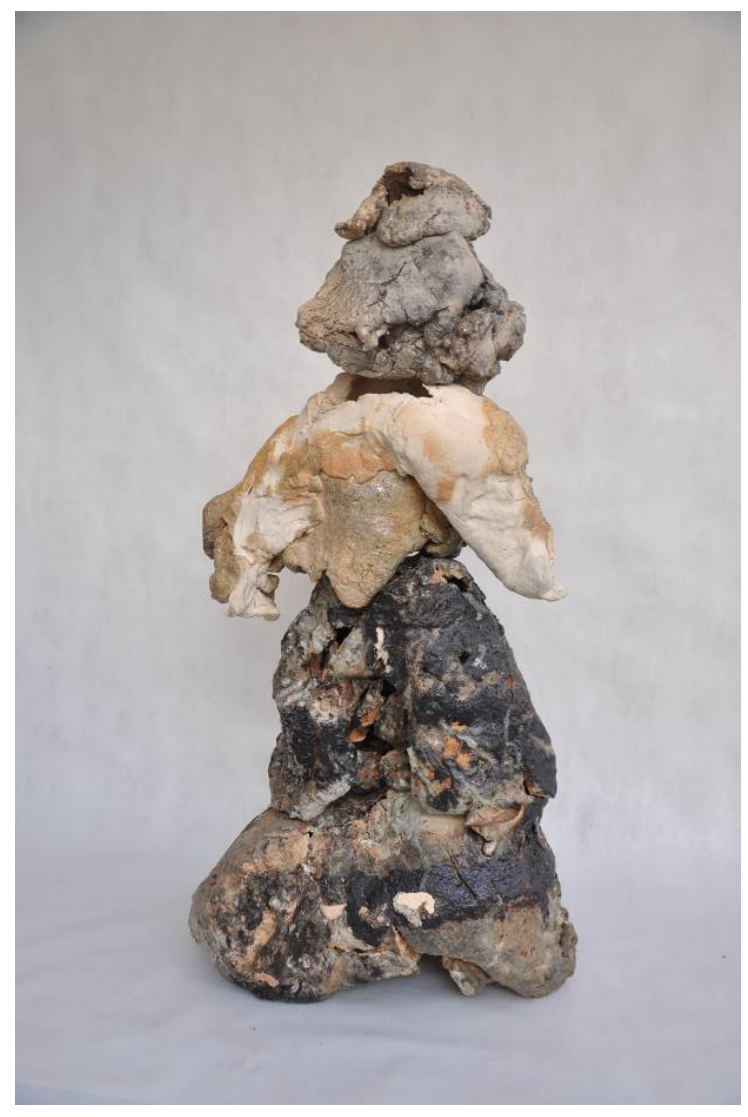

Figura 206

André Yassuda

$1,10 \mathrm{~cm} \times 30 \mathrm{~cm} \times 30 \mathrm{~cm}$ (aprox.)

2013

Cerâmica de Alta Temperatura

Assim, vimos nos trabalhos de André Yassuda o modo como utiliza a sua gestualidade na construção de suas cerâmicas: abrindo grandes placas grossas de argila, acomodando-os em galhos cujas formas traduzem as linhas que têm identidade com seu universo e colocando energia de seu corpo sobre elas, fazendo com que corpo, movimento e alma se conectem com a vitalidade da massa cerâmica. As paredes de um forno não são empecilhos para ele, pois constrói fornos de acordo com cada projeto que realiza. 


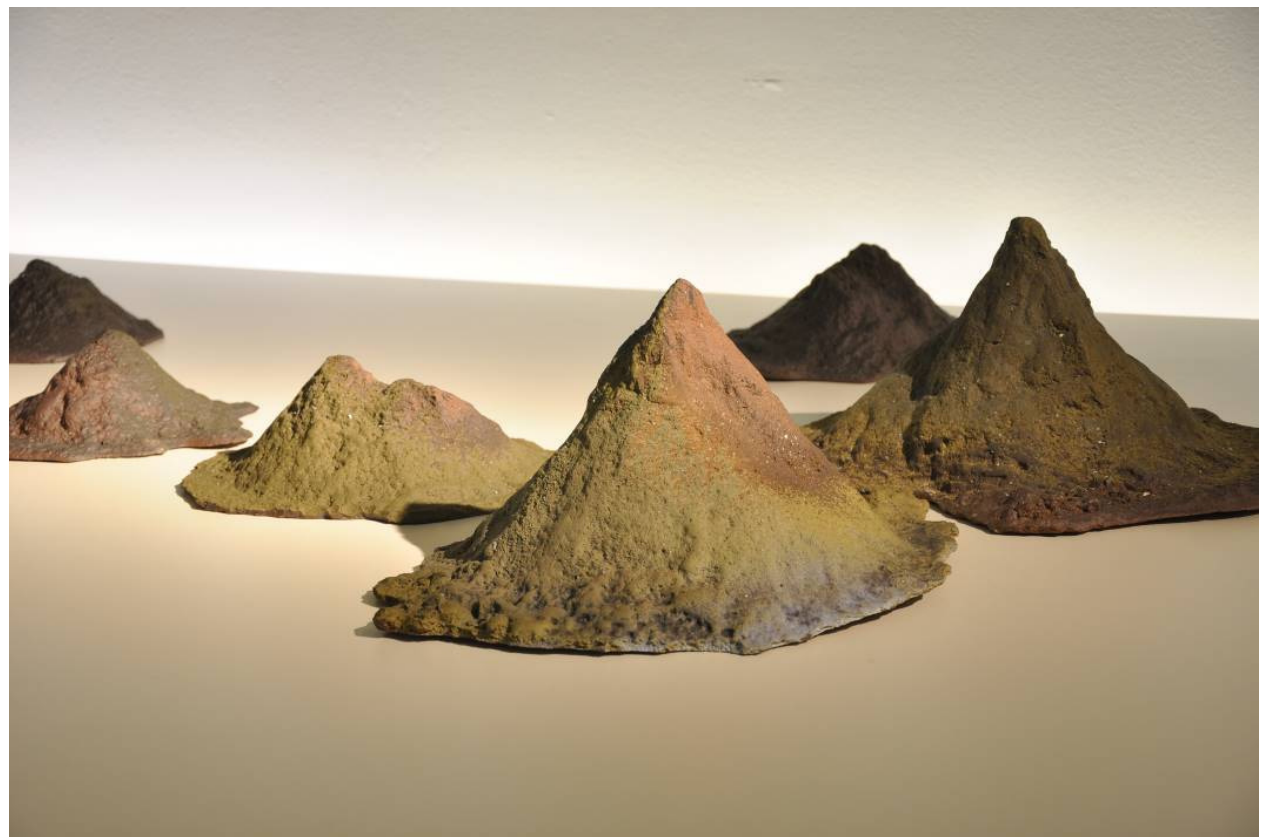

Figura 207

Kimi Nii

Detalhe da Instalação "Nas Nuvens"

2014

Cerâmica de alta temperatura

Caixa Cultural São Paulo

$\mathrm{Na}$ disciplina do aprendizado das técnicas e na dedicação em dominar parte delas, Kimi Nii conhece e sente cada mudança ocorrida desde a modelagem até a queima de suas peças. Foi graças a essa sensibilidade que pôde compreender os limites da matéria cerâmica, para ultrapassar os seus limites. Os desafios em querer uma reta, curva, uma forma cilíndrica perfeita e exata foram vencidos quando a artista percebeu que deveria trabalhar com as forças contrárias da matéria, na combinação certa das matérias-primas para a elaboração de uma massa e no controle da temperatura, Também quando quer uma determinada cor de esmalte, Kimi Nii sabe como combinar cada matéria-prima com a maestria de um pianista. Sabe quais tons utilizar para que todas as matérias-primas entrem em sintonia para obter o tão desejado vermelho. Ela desafiou os limites, mas respeitando-os, pois desenvolveu a habilidade de prever o que para muitos parecia imprevisível. 


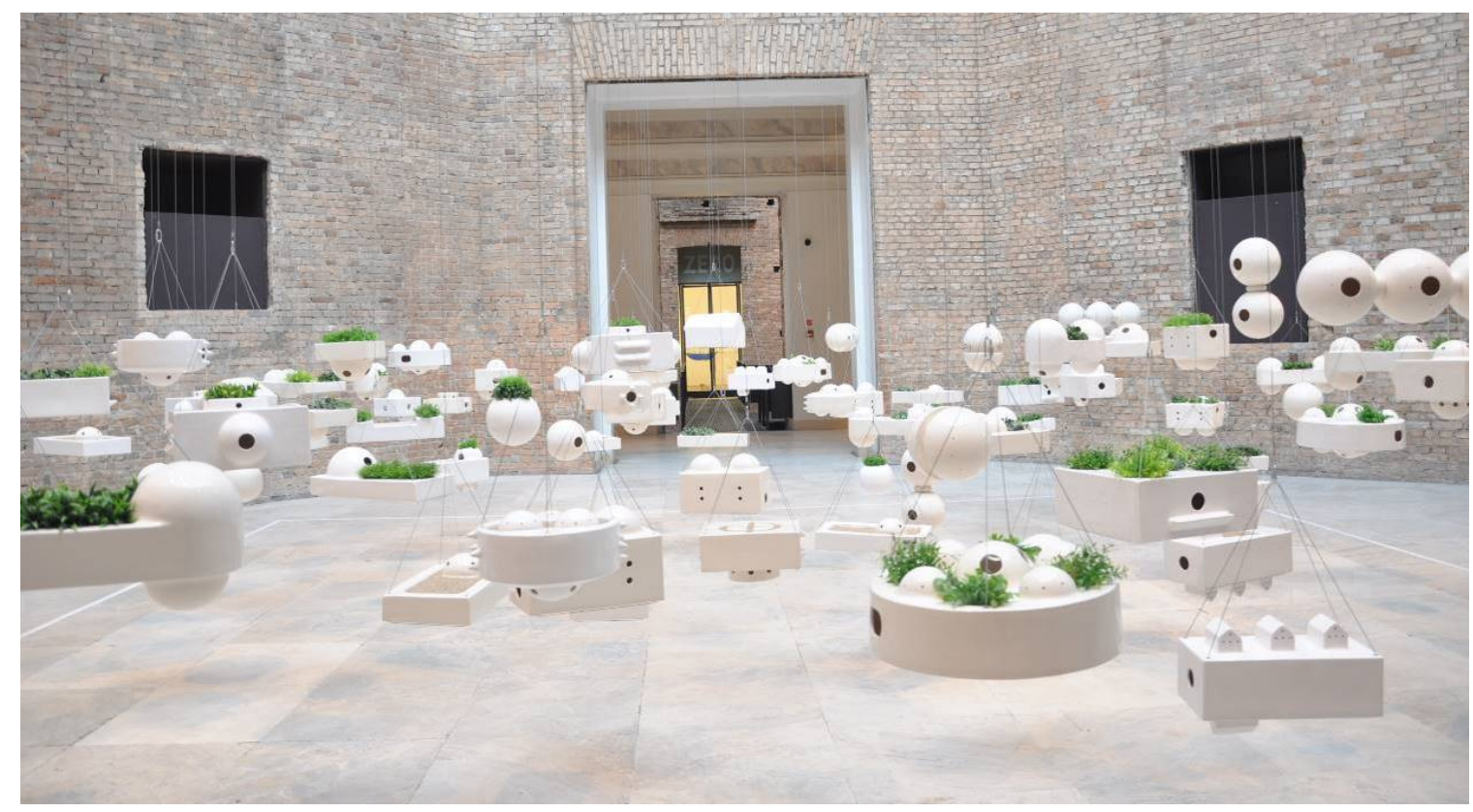

Figura 208

Laerte Ramos

Casamata

2014

Instalação com cerâmica esmaltada, fios de aço, areia e plantas artificiais

Pinacoteca do Estado de São Paulo

Laerte Ramos impõe regras próprias quando determina um número de peças que deseja reproduzir para a construção de suas instalações. Faz intervenções em grandes espaços e para isso reproduz grandes quantidades de peças cerâmicas. $O$ que fascina o nosso olhar é essa invasão de inúmeros elementos num espaço tridimensional, ressaltando o lado sedutor da superfície brilhante e lisa de suas cerâmicas e atraindo o espectador a refletir sobre as reais intenções daquelas peças estarem ali. 


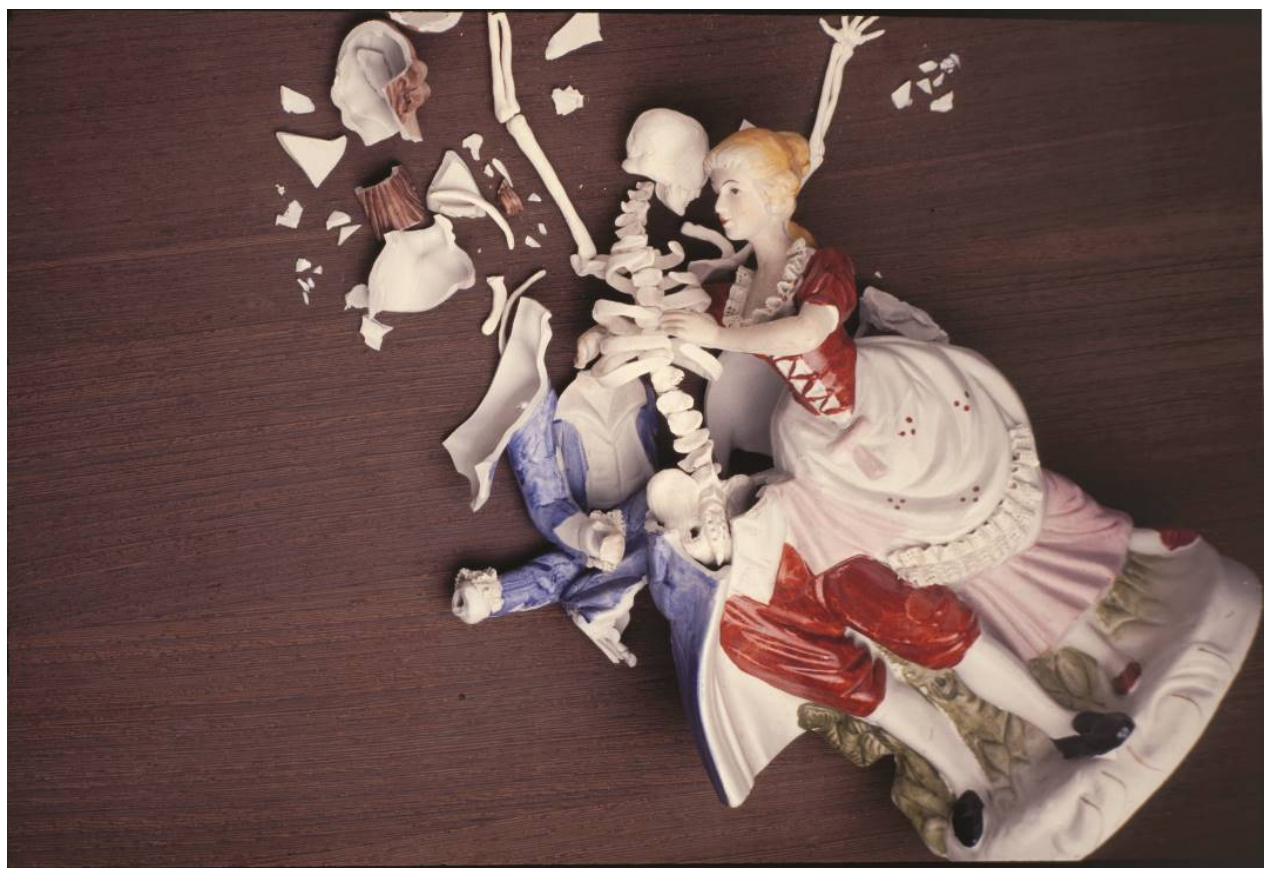

Figura 209

Marco Paulo Rolla

Oráculo

$75 \times 60 \times 71 \mathrm{~cm}$

Bibelô em porcelana 1999

As simbologias e os temas trabalhados por Marco Paulo Rolla na pintura e na performance são trazidos para a cerâmica de uma maneira a ultrapassar paradigmas. É o que acontece no ato de quebrar um delicado bibelô de porcelana e dele sair uma caveira, contrastando o singelo e o grotesco da cena de morte. Ou quando faz uma ironia com o próprio caráter decorativo muitas vezes imposto a algumas peças cerâmicas - como faz na série Vanitas, na qual recria peças de carne em cerâmica. 


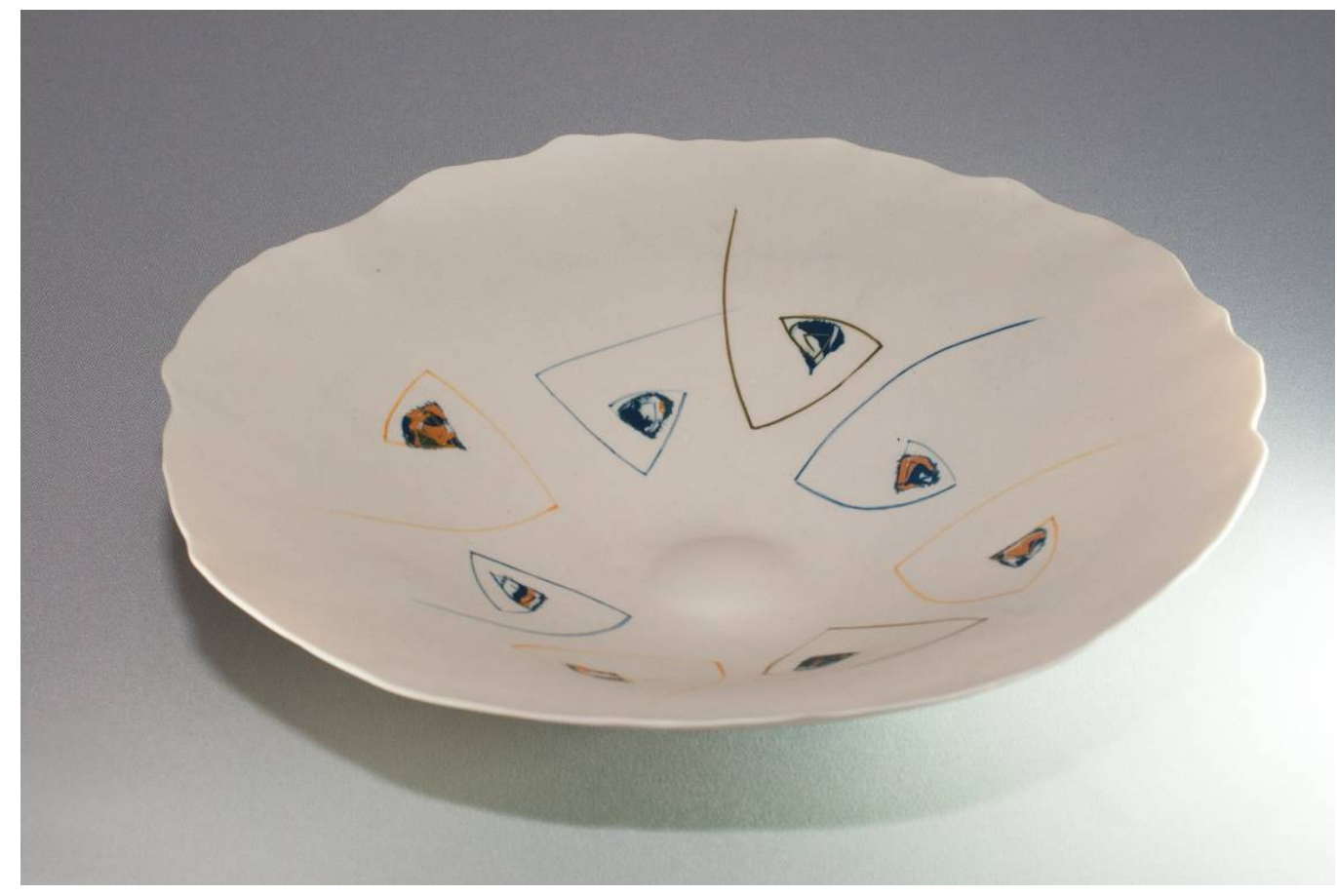

Figura 210

Máyy Koffler

A Bela Adormecida

$29,7 \times 15 \mathrm{~cm}$

2013

Porcelana Paleteada

Adquirir o domínio técnico é para Máyy Koffler parte de seu processo de criação. É através dele que Máyy vê possibilidades de ultrapassar os limites impostos pela matéria. A própria técnica do paleteado exige que a artista entre em sintonia com a matéria. Ao misturar os corantes com a porcelana e 0 ato de manipular os materiais fazem com que Máyy Koffler crie um diálogo poético. A matéria e a artista criam um universo entre ambas, não havendo mais nada ao redor.

Koffler dedica muito tempo a cada obra e quando o resultado não sai como deseja, ela, pacientemente, recomeça esse diálogo. Ela mergulha de corpo e alma no diálogo com a massa em uma busca quase obsessiva pela perfeição, assim Máyy Koffler cria uma obra singular, onde cada cor, a superfície de suas peças são palavras registradas desse diálogo com a matéria. 


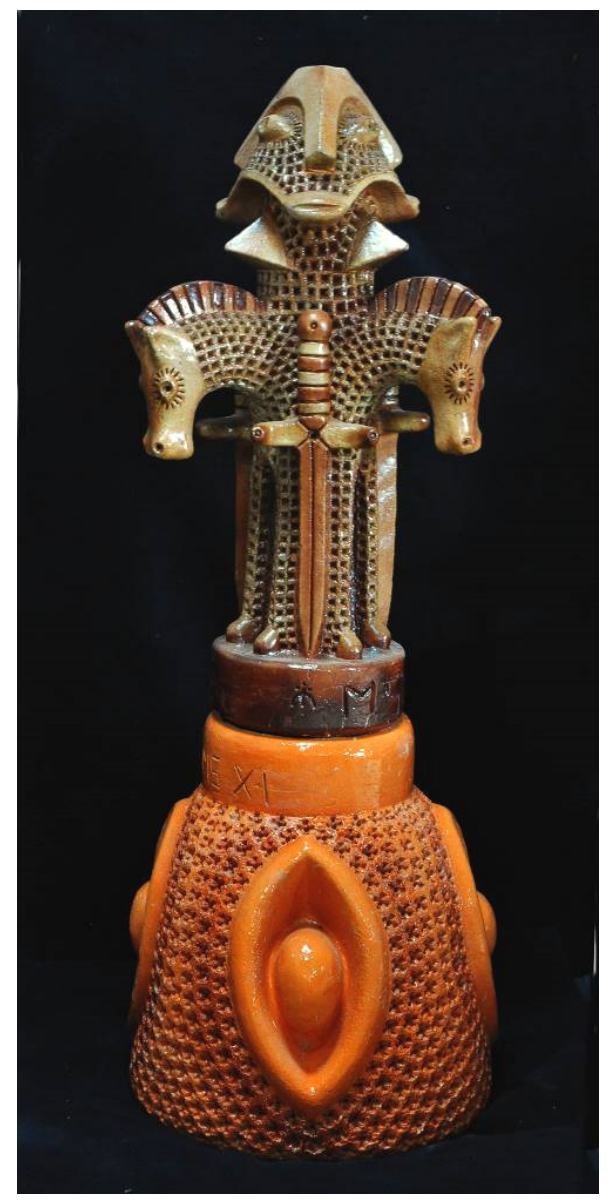

Figura 211

Miguel dos Santos

Capadócia

$105 \mathrm{~cm}$

2012

Cerâmica esmaltada (Alta Temperatura)

Miguel dos Santos é um artista que não tem a pretensão de seguir modismo ou fazer de sua arte algo para imitar ou seguir uma tradição. Procura na riqueza da cultura nordestina novas possibilidades. O domínio da cerâmica faz com que possa materializar esse universo rico que está presente e tão próximo de todos nós. Seu fascínio pelas coisas do Brasil o motiva a criar um universo fantástico de grandes peças cerâmicas. Ele utiliza a cerâmica para criar um universo que possui um idioma próprio. 


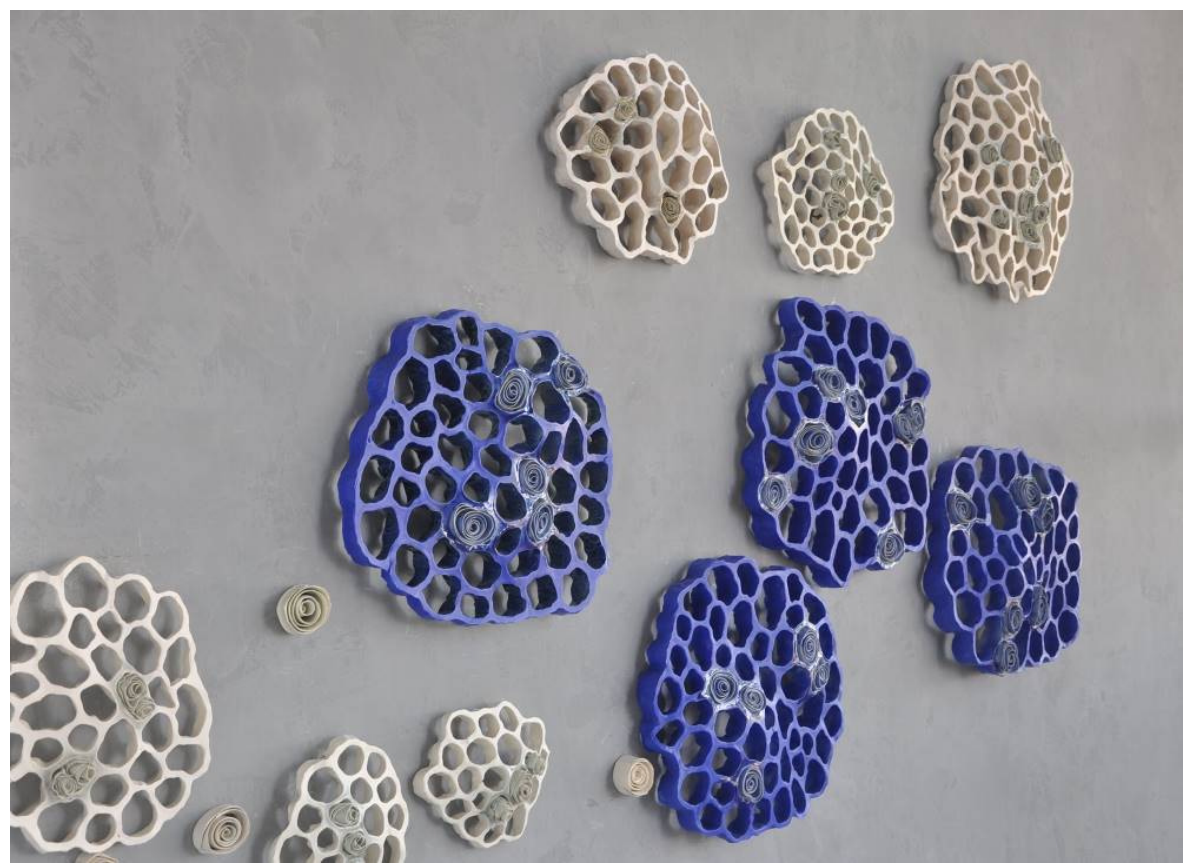

Figura 212

Norma Grinberg

Enredadas

Dimensões variadas

Cerâmica esmaltada ( alta temperatura)

2012

Norma Grinberg cria formas básicas e, a partir delas, são feitas reproduções transformadas através da decomposição, recortes e disposições. Recombina uma mesma forma para criar outras. Até hoje encontra novas possibilidades de combinações, recortes e disposições, criando novos trabalhos. Ela encara a função do molde não só como mero reprodutor de uma mesma imagem, a medida de uma peça fundida sai dele. A cada trabalho, ela enxerga aquela forma de outra maneira, criando assim uma obra singular. Norma ultrapassa os limites da técnica quando organiza de diferentes formas, as formas já existentes. A transformação não cessa. 
Esses artistas são como o menino que carregava água na peneira, da poesia de Manoel de Barros que enxerga o mundo de uma maneira diferente. Às vezes são incompreendidos por muitos, mas são convictos da sua missão de serem artistas.

\section{O Menino que carregava água na peneira}

Tenho um livro sobre águas e meninos.

Gostei mais de um menino

que carregava água na peneira.

A mãe disse que carregar água na peneira

era o mesmo que roubar um vento e

sair correndo com ele para mostrar aos irmãos.

A mãe disse que era o mesmo

que catar espinhos na água.

O mesmo que criar peixes no bolso.

O menino era ligado em despropósitos.

Quis montar os alicerces

de uma casa sobre orvalhos.

A mãe reparou que o menino

gostava mais do vazio, do que do cheio.

Falava que vazios são maiores e até infinitos.

Com o tempo aquele menino

que era cismado e esquisito,

porque gostava de carregar água na peneira.

Com o tempo descobriu que

escrever seria o mesmo

que carregar água na peneira.

No escrever o menino viu

que era capaz de ser noviça,

monge ou mendigo ao mesmo tempo.

O menino aprendeu a usar as palavras.

Viu que podia fazer peraltagens com as palavras.

E começou a fazer peraltagens. 
Foi capaz de modificar a tarde botando uma chuva nela.

O menino fazia prodígios.

Até fez uma pedra dar flor.

A mãe reparava o menino com ternura.

A mãe falou: Meu filho você vai ser poeta!

Você vai carregar água na peneira a vida toda.

Você vai encher os vazios

com as suas peraltagens,

e algumas pessoas vão te amar por seus despropósitos!

(Manoel de Barros ${ }^{250}$ )

${ }^{250}$ BARROS, Manoel. Poesia Completa.São Paulo: Editora Leya,2013. 


\section{Anexos}

\section{Anexo I}

\section{Cartas de Iberê Camargo enviadas à André Yassuda:}

\section{Carta 1}

"Porto Alegre, 8-1-94.

Caro André,

Demorei em responder sua carta por motivo de saúde. Agora estou bem.

André, quando a noite é escura e a 'diritta via é smarrita' (o caminho a seguir está nebuloso: nota dos autores), como diz Dante, deve-se seguir a intuição, que é a bússola do pintor nato.

A sociedade de consumo produz arte de consumo, digo, suposta arte. A preocupação atual é a novidade, mesmo que nada expresse, que nada diga: arte de 'shopping center'.

Como deve ter observado, minha preocupação é bem outra. Como não inventei a pintura, continuo aprendendo com os grandes pintores.

Não dou conselhos. Cada um é responsável pelo seu destino e, consequentemente, pelo caminho que escolhe.

Uma grande obra sempre ensina a quem sabe ver.

Um pintor precisa viver a pintura e trabalhar quarenta e oito horas por dia.

Repito o que disse Rilke: trabalha, trabalha, que um dia o sol te encontrará entre os primeiros.

Boa caminhada, André.

Cordialmente,o Iberê". 


\section{Carta 2}

[Uma segunda troca de correspondências se deu, pela última vez, pouco antes do mestre "fazer a Passagem":]

"Caro André Luiz,

Espero não ser 'o último pintor', como diz a 'Folha de São Paulo' (referência ao título de uma matéria de capa do caderno 'Mais' onde foi publicada uma entrevista com lberê, no início daquele ano: nota dos autores).

Continue, você que é moço.

Não procure atalhos, caminhe pela estrada real da pintura.

Bom trabalho.

Abraço, o lberê.

P.A., 17-3-94". 


\section{Anexo II}

\section{O paleteado}

A técnica do paleteado consiste em golpear a parte externa da peça ritmicamente com a paleta, enquanto que no seu interior uma pedra arredondada é posicionada, funcionando como uma bigorna - o que ajuda a afinar as paredes da peça e dar forma a ela. Para decorar as peças paleteadas, quando estão em ponto de couro, são utilizados os engobes que podem ser coloridos. Nesta fase, as peças são brunidas ou lustradas com pedras ou pedaços de plásticos lisos. Depois da secagem, as peças são queimadas até $980^{\circ} \mathrm{C}$.

As peças são retiradas do forno. Depois, é feito uma segunda queima, desta vez, num ambiente redutor. Com o auxílio de um pincel, é passada argila líquida ou barbotina sobre a superfície cerâmica para efeito de isolamento nas partes que não se deseja enegrecer. Assim, as peças são colocadas novamente no forno à lenha, onde são depositados, durante a queima, materiais orgânicos que podem ser galhos e folhas secas. No caso das cerâmicas de Chulucanas, os ceramistas utilizam folhas de mangueira secas, que são abundantes na região. ${ }^{251}$ Os materiais orgânicos produzem grande de quantidade de fumaça, favorecendo o escurecimento das peças. Após a queima e o resfriamento, as peças são retiradas do forno, limpas, e é dado um acabamento com ceras e alguns tipos de óleo. As peças cerâmicas ficam, assim, com brilho acetinado e extremamente liso.

De acordo Karina Cáceres ${ }^{252}$, com as primeiras mostras destas peças cerâmicas produzidas pelas culturas pré-hispânicas Tallán, foram encontradas nas regiões de Piura, La Encantada e Chulucanas, sendo todas localizadas na região Norte do Peru.

Alguns pesquisadores denominam como cultura Vicús, já que essas as primeiras peças foram encontradas no morro Vicús,. A cultura Vicús ou Tallán,

\footnotetext{
${ }^{251}$ El Encanto de Chulucanas - Documentário sobre a Cerâmica de Chulucanas (disponível em https://www.youtube.com/watch?v=vHIOhmkxTRo. Acesso em 28/12/2014).

${ }^{252}$ CÁCERES, Karina M. Tolentino. Estudio de pre-factibilidad para la producción y comercialización de cerámicas de chulucanas. Tese apresentada à Pontifícia Universidade católica do Peru, 2007, p.25 .
} 
segundo Luís Portillo ${ }^{253}$, que se desenvolveu entre os anos de 100 a.C. até 400 d.C. tinha uma complexa organização social baseada na classe social formada por indivíduos com diferente poder político, social e econômico. A julgar pela sua representação frequente na arte, os guerreiros desempenharam um papel central nesta sociedade. A existência de tais ofícios complexos atesta a presença de artesãos e em tempo integral. Certamente, na base da sociedade era uma grande massa de camponeses e pescadores.

A cultura Vicús contribuiu no desenvolvimento da decoração "em negativo", que se transformou na principal característica de cerâmica das regiões mencionadas, principalmente em Chulucanas. A cultura Tallán foi desenvolvida nas proximidades para atual cidade de Piura que herdou a técnica do paleteado, uma maneira única de modelar peças cerâmicas utilizando uma paleta de madeira e uma pedra arredondada.

De acordo com Eduardo Merido ${ }^{254}$, a cerâmica Vicús ou Tallán era decorada e modelada com motivos relacionados à vida cotidiana deste povo, refletindo a fauna local como cervos, roedores, répteis e felinos, além de características místicas destes animais. Também eram retratados guerreiros, personagens lendárias, cenas eróticas e crenças sobre a fertilidade.

Segundo Traverso ${ }^{255}$, as tradições do paleteado e da queima negativa haviam sido esquecidas. Somente a partir dos anos 70 e 80 , do século $X X$, elas foram resgatadas graças às pesquisas arqueológicas realizadas nas cidades onde se encontraram peças da antiga cultura Tallán. A enfermeira e religiosa americana Gloria Joyce iniciou suas pesquisas com 0 intuito de resgatar as técnicas, juntamente com José Luis Yamunaqué, Roso Alamo e Max Inga e que formam o primeiro movimento artístico de região. Eles realizaram durante várias

\footnotetext{
253 PORTILLO, Luis. Cultura Vicús. Artigo sobre a Cultura Vícus (disponível em http://www.historiacultural.com/2009/04/la-cultura-vicus-intermedio-temprano.html. Acesso em 23/12/2014).

${ }^{254}$ Artigo: La Cultura Tallán de Eduardo Merido (disponível em http://pt.calameo.com/read/00050286525d100d264fd Acesso em 16/12/2014).

255 TRAVERSO, Karla A. Valderrama. Planificación de la estratégia Operativa para la producción de cerámica de Chulucanas. Tese apresentada à Faculdade de Engenheria da Universidade de Piura, 2004. (p.15)
} 
experimentações, tentando resgatar a antiga técnica de negativo-positivo de Tallanes-Vicús. Por fim, Gerásimo Sosa conseguiu reconstituir as técnicas perdidas e juntamente com Juan Vilchez e Segundo Moncada formam outro grupo de ceramistas. Finalmente, nos anos 80 surge o terceiro movimento artístico, completamente modernista, cujos representantes são Polo Ramirez e Santodio $\mathrm{Paz}^{256}$.

\section{Anexo III}

\section{Matérias-primas e fundentes}

Tabela 1 - Matérias-primas (utilizadas em massas cerâmicas e vidrados cerâmicos)

\begin{tabular}{|c|c|}
\hline Tabela de matérias-primas & Descrição \\
\hline $\begin{array}{l}\text { Feldspato sódico ou albita } \\
\left(\mathrm{Na}_{2} \mathrm{O} \cdot \mathrm{Al}_{2} \mathrm{O}_{3} \cdot 6 \mathrm{SiO}_{2}\right)\end{array}$ & $\begin{array}{l}\text { Funciona como fundente nas massas cerâmicas. } \\
\text { Seu derretimento inicia a } 800^{\circ} \mathrm{C} \text { podendo volatizar a } \\
1200^{\circ} \mathrm{C} \text {. }\end{array}$ \\
\hline $\begin{array}{l}\text { Feldspato potássico } \\
\left(\mathrm{K}_{2} \mathrm{O} \cdot \mathrm{Al}_{2} \mathrm{O}_{3} \cdot 6 \mathrm{SiO}_{2}\right)\end{array}$ & $\begin{array}{l}\text { É um dos feldspatos mais comuns. Também pode ter a } \\
\text { função de baixar a temperatura da massa cerâmica. } \\
\text { Seu ponto de fusão se inicia a } 1200^{\circ} \mathrm{C} \text {. }\end{array}$ \\
\hline Sílica ou quartzo $\left(\mathrm{SiO}_{2}\right):$. & $\begin{array}{l}\text { E uma das substâncias mais importantes em vidrados e } \\
\text { está presente nas argilas. Trata-se de um material vítreo } \\
\text { bastante resistente, cujo ponto de fusão é de } 1710^{\circ} \mathrm{C} \\
\text { aproximadamente. Quando adicionado em uma massa } \\
\text { cerâmica tem a função de dar dureza, deixando-a refratária. }\end{array}$ \\
\hline Oxido de alumínio ou Alumina (Al2O3) & $\begin{array}{l}\text { A alumina é um elemento que dá sustentação ao vidrado } \\
\text { cerâmico, pois que se houver somente a sílica e o } \\
\text { fundente, essa mistura torna-se fluida e não se prenderá à } \\
\text { superfície cerâmica. As fontes de alumina são: os } \\
\text { feldspatos e caulim. }\end{array}$ \\
\hline
\end{tabular}

${ }^{256}$ TRAVERSO, Karla A. Valderrama. Planificación de la estratégia Operativa para la producción de cerámica de Chulucanas. Tese apresentada à Faculdade de Engenheria da Universidade de Piura, 2004. (p.15) 


\section{Tabela 2 - Fundentes}

\begin{tabular}{|c|c|}
\hline Fundentes & Descrição \\
\hline $\begin{array}{l}\text { Oxido de sódio }\left(\mathrm{Na}_{2} \mathrm{O}\right) \\
\text { Carbonato de sódio }\left(\mathrm{Na}_{2} \mathrm{CO}_{3}\right)\end{array}$ & $\begin{array}{l}\text { Ponto de fusão: } 800 \text { - acima de } 1200^{\circ} \mathrm{C} \\
\text { É um dos fundentes mais fortes e utilizados em } \\
\text { vidrados, tendo a função de baixar o ponto de fusão, a } \\
\text { contração e dar solubilidade. Produz cores brilhantes. } \\
\text { Combinado com: } \\
\text { Óxido de cobre, produz tons azulados. } \\
\text { Óxidos de cobalto e manganês produz tons malva e } \\
\text { pink. } \\
\text { Favorece o craquelado. } \\
\text { Fontes de sódio: Carbonato de sódio, Feldspato sódico } \\
\text { (Albita), Bóraxe borato de cálcio }\left(720^{\circ} \mathrm{C}-1100^{\circ} \mathrm{C}\right) \text {. }\end{array}$ \\
\hline $\begin{array}{l}\text { Óxido de lítio }\left(\mathrm{Li}_{2} \mathrm{O}\right) \\
\text { Carbonato de lítio }\left(\mathrm{Li}_{2} \mathrm{CO}_{3}\right) \\
\text { Feldspato de lítio } \\
\left(\mathrm{Li}_{2} \mathrm{O} . \mathrm{Al}_{2} \mathrm{O}_{3} .4 \mathrm{SiO}_{2}\right)\end{array}$ & $\begin{array}{l}\text { Ponto de fusão: } 800^{\circ} \mathrm{C}-1200^{\circ} \mathrm{C} \text {. } \\
\text { É um dos fundentes mais potentes. Seu resultado é } \\
\text { semelhante ao sódio. Normalmente, utiliza-se o lítio sob a } \\
\text { forma de carbonato ou feldspato. } \\
\text { Cores: combinado com cobre produz tons azulados e } \\
\text { rosados com cobalto. } \\
\text { Favorece a resistência contra o choque térmico tanto nas } \\
\text { massas como também de vidrados. } \\
\text { Fontes de lítio: Carbonato de lítio, espodumênio ou } \\
\text { feldspato de lítio, ambligonita e lepidolita. }\end{array}$ \\
\hline Óxido de potássio $\left(\mathrm{K}_{2} \mathrm{O}\right)$ & $\begin{array}{l}\text { Ponto de fusão: } 750^{\circ} \mathrm{C} \text { - acima de } 1200^{\circ} \mathrm{C} \\
\text { É um tipo de sal solúvel muito utilizado em vidrados e fritas. } \\
\text { O feldspato potássico está presente na maioria das argilas. } \\
\text { O potássio deve ser utilizado em conjunto com outros } \\
\text { minerais, pois é quebradiço. Produz vidrados brilhantes } \\
\text { Fontes: Feldspato potássico, carbonato de potássio, } \\
\text { Nefelina sianita e bicromato de potássio. }\end{array}$ \\
\hline Oxido de berílio (BeO) & $\begin{array}{l}\text { Aqui no Brasil, não é um óxido comum de ser utilizado. E } \\
\text { extremamente fundente em altas temperaturas. Ideal na } \\
\text { utilização de vidrados para porcelana e como opacificante. }\end{array}$ \\
\hline
\end{tabular}




\begin{tabular}{|c|c|}
\hline $\begin{array}{l}\text { Oxido de magnésio }(\mathrm{MgO}) \\
\text { Carbonato de magnésio }\left(\mathrm{MgCO}_{3}\right)\end{array}$ & $\begin{array}{l}\text { Na utilização para compor um vidrado, pode ser utilizado } \\
\text { em forma de óxido ou carbonato. É um material refratário, } \\
\text { funcionando como opacificante e matizante em vidrados de } \\
\text { alta temperatura e durante a queima inicia seu derretimento } \\
\text { a } 1170^{\circ} \mathrm{C} \text {, atingindo seu ponto de fusão a } 1300^{\circ} \mathrm{C} \text {. Entre } \\
1190^{\circ} \mathrm{C} \text { a } 1230^{\circ} \mathrm{C} \text {, o magnésio, quando inserido num } \\
\text { vidrado, funciona como fundente, produzindo vidrado mate. } \\
\text { O talco é uma das fontes mais comuns de magnésio. Além } \\
\text { do tom mate, o magnésio produz uma superfície } \\
\text { semiopaca. }\end{array}$ \\
\hline $\begin{array}{l}\text { Óxido de cálcio }(\mathrm{CaO}) \\
\text { Carbonato de cálcio }\left(\mathrm{CaCO}_{3}\right)\end{array}$ & $\begin{array}{l}\text { Pode ser encontrado na forma de óxido ou carbonato. } \\
\text { Encontra-se sob a forma da matéria-prima calcita. Nos } \\
\text { vidrados, é um dos fundentes mais utilizados. Sua ação } \\
\text { fundente inicia entre } 1000^{\circ} \text { podendo chegar a } 1300^{\circ} \text { C. De } \\
\text { acordo com Hamer ( } 2004, \text { p. } 47 \text { ) abaixo de } 1100^{\circ} \mathrm{C} \text { o cálcio } \\
\text { não é um fundente ativo. Para alcançar seu ponto de fusão } \\
\text { é necessária a interação com outros fundentes como: o } \\
\text { sódio, potássio e chumbo. Além disso, o cálcio oferece } \\
\text { resistência e dureza ao vidrado, por isso, é importante a } \\
\text { sua adesão. } \\
\text { Para vidrados de baixa, quando introduzido até } 10 \% \text {, pode } \\
\text { ser absorvido com uma pequena perda de brilho, mas } \\
\text { melhorando a resistência. } \\
\text { Acima de } 35 \% \text { quando adicionado em esmalte de baixa, } \\
\text { pode ocorrer a formação de cristais na superfície da peça } \\
\text { cerâmica. } \\
\text { A presença deste elemento no borato de cálcio faz com que } \\
\text { os vidrados fiquem com aparência leitosa e "escorrido". Em } \\
\text { alguns casos, funciona também como um "branqueador", } \\
\text { dando resultante interessante quando misturados a óxidos } \\
\text { colorantes. Combinado com óxido de cobre produz um azul } \\
\text { acobreado e com uma pequena quantidade de cobalto } \\
\text { obtêm-se tons de azuis malva. Quando trabalhado com } \\
\text { adição acima de } 3 \% \text { de óxido de ferro, o efeito alvejante é } \\
\text { bem evidente, produzindo uma superfície rajada de tons } \\
\text { entre amarelos e ocres. }\end{array}$ \\
\hline
\end{tabular}




\begin{tabular}{|c|c|}
\hline Oxido de zinco (ZnO) & $\begin{array}{l}\text { Encontrado sob a forma de óxido, o zinco é um pó } \\
\text { branco que adicionado ao vidrado oferece opacidade e } \\
\text { proporciona o aparecimento de cristais. É utilizado } \\
\text { como fundente ativo acima de } 1085 \text { C que proporciona } \\
\text { ao vidrado estabilidade e dureza. } \\
\text { Misturado com potássio e cálcio, o zinco produz } \\
\text { vidrados transparentes brilhantes e se tiver adicionado } \\
\text { cobalto e cobre em sua mistura. } \\
\text { Não há um limite de temperatura exato para o uso de } \\
\text { zinco, mas normalmente ele é utilizado entre } 1150^{\circ} \mathrm{C} \text { e } \\
1250^{\circ} \mathrm{C} \text { funcionando como um fundente, abaixo de } \\
1085 \text { C essa função não é ativada. }\end{array}$ \\
\hline $\begin{array}{l}\text { Óxido de estrôncio (SrO) } \\
\text { Carbonato de estrôncio }\left(\mathrm{SrCO}_{3}\right)\end{array}$ & $\begin{array}{l}\text { É um eficiente fundente para todas as temperaturas. O } \\
\text { estrôncio é utilizado em vidrados cerâmicos sob a forma de } \\
\text { carbonato. Seu ponto de fusão se inicia a } 650^{\circ} \mathrm{C} \text {, mas sua } \\
\text { ação é efetiva a partir de } 1090^{\circ} \mathrm{C} \text {. Geralmente, é utilizado } \\
\text { em vidrados de média temperatura (de } 1100^{\circ} \mathrm{C} \text { a } 1200^{\circ} \mathrm{C} \text { ) }\end{array}$ \\
\hline $\begin{array}{l}\text { Oxido de bário }(\mathrm{BaO}) \\
\text { Carbonato de bário }\left(\mathrm{BaCO}_{3}\right)\end{array}$ & $\begin{array}{l}\text { Sob a forma de carbonato, o bário funciona como um } \\
\text { fundente para fritas de baixa temperatura e vidrados de } \\
\text { alta. Produz também excelentes vidrados mates. Deve- } \\
\text { se ter cuidado ao manuseá-lo devido à sua toxicidade. } \\
\text { Acima de } 1175^{\circ} \mathrm{C} \text { funciona como um eficiente fundente, } \\
\text { já abaixo desta temperatura tem a função de opacificar } \\
\text { um vidrado. }\end{array}$ \\
\hline $\begin{array}{l}\text { Óxido de chumbo }(\mathrm{PbO}) \\
\text { Carbonato de chumbo }\left(\mathrm{PbCO}_{3}\right)\end{array}$ & $\begin{array}{l}\text { É um dos mais populares fundentes. Pode ser utilizado } \\
\text { em forma de bisilicato ou de frita ou ainda CMF. Por ser } \\
\text { extremamente tóxico, é recomendado oseu uso em } \\
\text { forma de frita ou CMF(ver CMFs-Composto moído de } \\
\text { fritas pXX). Quando introduzido nos vidrados, a } \\
\text { temperatura de queima ideal pode variar de } 900^{\circ} \mathrm{C} \text { a } \\
1200^{\circ} \mathrm{C} \text {, dependendo a porcentagem de outras matérias- } \\
\text { primas utilizadas. Entretanto, seu ponto de fusão pode } \\
\text { iniciar a partir de } 700^{\circ} \mathrm{C} \text {. }\end{array}$ \\
\hline
\end{tabular}




\begin{tabular}{|c|c|}
\hline Oxido de boro $\left(\mathrm{B}_{2} \mathrm{O}_{3}\right)$ & $\begin{array}{l}\text { E um formador de vidro muito utilizado em vidrados de } \\
\text { baixa temperatura, atuando também como um fundente. O } \\
\text { óxido de boro é muito utilizado na fabricação de fritas e é } \\
\text { uma alternativa para substituir o uso do chumbo (que é } \\
\text { tóxico). Pode ser encontrado sob a forma de Borato de } \\
\text { cálcio, bórax e ácido bórico. }\end{array}$ \\
\hline $\begin{array}{l}\text { Óxido de manganês (MnO) } \\
\text { Carbonato de manganês }\end{array}$ & $\begin{array}{l}\text { O manganês é um eficiente fundente e quando utilizado } \\
\text { acima de } 15 \% \text { em massas grês (alta temperatura) auxilia na } \\
\text { vitrificação. É um óxido corante muito utilizado e produz } \\
\text { tons marrons, tabacos e com efeitos de cristais dourados } \\
\text { nas superfícies dos vidrados. }\end{array}$ \\
\hline Óxido de ferro (FeO) & $\begin{array}{l}\text { Sob a forma de óxido, nas cores vermelha e preta, o ferro } \\
\text { além de ter ação fundente é um utilizado para dar cor aos } \\
\text { vidrados, produzindo tons terrosos avermelhados, ocres, } \\
\text { laranjas e marrons em ambiente oxidante. Em ambiente } \\
\text { redutor, produz efeitos como o tenmoku, o celadon. }\end{array}$ \\
\hline Óxido de cobalto (CoO) & $\begin{array}{l}\text { Auxilia na baixa da temperatura em massas cerâmicas. } \\
\text { Além disso, é um poderoso óxido corante produzindo azuis } \\
\text { intensos a lilases. }\end{array}$ \\
\hline Óxido de níquel (NiO) & $\begin{array}{l}\text { É um óxido corante que produz tons acinzentados e } \\
\text { marrons. Quando combinados com bário, pode produzir } \\
\text { tons rosados, mas isso dependerá da quantidade utilizada } \\
\text { num vidrado. }\end{array}$ \\
\hline Óxido de cobre (CuO) & $\begin{array}{l}\text { Além de baixar o ponto de fusão em massas e vidrados, o } \\
\text { cobre é um poderoso óxido corante. Produz verdes escuros } \\
\text { metalizados, azuis turquesa, dependendo a formulação e } \\
\text { combinação com outras matérias-primas. Em ambiente } \\
\text { redutor, produz cores avermelhados metálicos. }\end{array}$ \\
\hline
\end{tabular}




\section{Tabela 3 - Cones pirométricos}

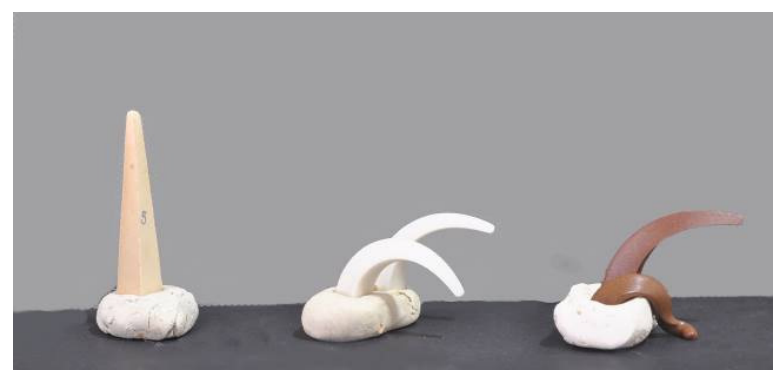

Figura 213 - Cones pirométricos

Hamer $^{257}$ explica que os cones pirométricos que têm a forma de pirâmides alongadas de dois a oito $\mathrm{cm}$ de altura. São posicionados no forno de cerâmica para medir a temperatura de queima.

Os cones pirométricos são produzidos com os materiais cerâmicos similares aos dos vidrados e identificados com números que correspondem a uma determinada temperatura. Com o aquecimento do forno, os cones tendem a amolecer e curvar-se, indicando que o forno chegou à temperatura desejada. Isso ocorre, pois cada cone possui uma composição de minerais distinta e sensível à determinada temperatura. Tantos os cones pirométricos como os termopares são utilizados para a medição de temperatura interna dos fornos cerâmicos. No mercado, existem algumas marcas de cones e seus fabricantes determinaram um padrão de temperatura para cada cone, como o exemplo abaixo:

\begin{tabular}{|c|c|c|c|}
\hline \multicolumn{4}{|c|}{ Fonte: Hamer e Hamer, 2004. P. 399} \\
\hline Cone $\mathrm{n}^{0}$ & $\begin{array}{l}\text { Velocidade da queima } \\
\quad\left({ }^{\circ} \mathrm{C} / \mathrm{h}\right) 150^{\circ} \mathrm{C} / \mathrm{h}^{*}\end{array}$ & Cone $\mathrm{n}^{\circ}$ & $\begin{array}{l}\text { Velocidade da queima } \\
\left({ }^{\circ} \mathrm{C} / \mathrm{h}\right) 150^{\circ} \mathrm{C} / \mathrm{h}\end{array}$ \\
\hline 022 & $586^{\circ} \mathrm{C}$ & 05 & $1046{ }^{\circ} \mathrm{C}$ \\
\hline 021 & $614^{\circ} \mathrm{C}$ & 04 & $1060^{\circ} \mathrm{C}$ \\
\hline 020 & $635^{\circ} \mathrm{C}$ & 03 & $1101^{\circ} \mathrm{C}$ \\
\hline 019 & $683^{\circ} \mathrm{C}$ & 02 & $1120^{\circ} \mathrm{C}$ \\
\hline 018 & $717^{\circ} \mathrm{C}$ & 01 & $1137^{\circ} \mathrm{C}$ \\
\hline 017 & $747^{\circ} \mathrm{C} \mathrm{C}$ & 1 & $1154^{\circ} \mathrm{C}$ \\
\hline 016 & $792 \stackrel{\circ}{ } \mathrm{C}$ & 2 & $1162^{\circ} \mathrm{C}$ \\
\hline 015 & $804^{\circ} \mathrm{C}$ & 3 & $1168^{\circ} \mathrm{C}$ \\
\hline 014 & $838^{\circ} \mathrm{C}$ & 4 & $1186^{\circ} \mathrm{C}$ \\
\hline 013 & $861^{\circ} \mathrm{C}$ & 5 & $1196^{\circ} \mathrm{C}$ \\
\hline 012 & $872^{\circ} \mathrm{C}$ & 6 & $1222^{\circ} \mathrm{C}$ \\
\hline 011 & $883^{\circ} \mathrm{C}$ & 7 & $1240^{\circ} \mathrm{C}$ \\
\hline 010 & $890^{\circ} \mathrm{C}$ & 8 & $1263^{\circ} \mathrm{C}$ \\
\hline 09 & $923^{\circ} \mathrm{C}$ & 9 & $1280^{\circ} \mathrm{C}$ \\
\hline
\end{tabular}

${ }^{257}$ HAMER, F. e HAMER J., 2004, p.77 


\begin{tabular}{|l|l|l|l|}
\hline 08 & $955^{\circ} \mathrm{C}$ & 10 & $1305^{\circ} \mathrm{C}$ \\
\hline 07 & $984^{\circ} \mathrm{C}$ & 11 & $1315^{\circ} \mathrm{C}$ \\
\hline 06 & $999^{\circ} \mathrm{C}$ & 12 & $1326^{\circ} \mathrm{C}$ \\
\hline
\end{tabular}

${ }^{*}$ Se a temperatura de queima subir a $150^{\circ} \mathrm{C}$ por hora.

Tabela 4 - Receitas de engobes (Fonte: RHODES, Daniel, 1973, p. 252)

\begin{tabular}{|c|c|c|c|c|c|c|c|c|c|}
\hline Temperatura & \multicolumn{3}{|c|}{$\begin{array}{c}\text { Cone } \\
\text { 08-1 }\end{array}$} & \multicolumn{3}{c|}{$\begin{array}{c}\text { Cone } \\
\text {-6 }\end{array}$} & \multicolumn{3}{c|}{ Cone } \\
\hline $\begin{array}{c}\text { Ponto de } \\
\text { secagem da } \\
\text { peça }\end{array}$ & Úmido & Seco & Biscoito & Úmido & Seco & Biscoito & Úmido & Seco & Biscoito \\
\hline & \multicolumn{3}{|c|}{$\%$} & & & & & & \\
\hline Caulim & 25 & 15 & 5 & 25 & 15 & 5 & 25 & 15 & 5 \\
\hline Argila Branca & 25 & 15 & 15 & 25 & 15 & 15 & 25 & 15 & 15 \\
\hline $\begin{array}{c}\text { Caulim } \\
\text { Calcinado }\end{array}$ & 0 & 20 & 20 & 0 & 20 & 20 & 0 & 20 & 20 \\
\hline $\begin{array}{c}\text { CMF sem } \\
\text { chumbo }\end{array}$ & 15 & 15 & 15 & 0 & 0 & 5 & 0 & 0 & 5 \\
\hline Talco & 5 & 5 & 15 & 5 & 5 & 5 & 0 & 0 & 0 \\
\hline $\begin{array}{c}\text { Quartzo } \\
\text { Oxido de } \\
\text { zircônio }\end{array}$ & 5 & 5 & 5 & 5 & 5 & 5 & 5 & 5 & 5 \\
\hline Bórax & 5 & 5 & 5 & 5 & 5 & 5 & 5 & 5 & 5 \\
\hline $\begin{array}{c}\text { Nefelina } \\
\text { Sianita }\end{array}$ & 0 & 0 & 0 & 15 & 15 & 20 & 0 & 0 & 0 \\
\hline Feldspato & 0 & 0 & 0 & 0 & 0 & 0 & 20 & 20 & 20 \\
\hline
\end{tabular}

\section{Glossário}

Ácido: Na cerâmica, é a qualidade de algumas matérias-primas. Quimicamente, trata-se de um componente que libera prótons no centro dos átomos, agindo na solução com materiais não ácidos, formando sais.

Álcalis: é oposto de ácido. São assim definidos os óxidos que interagem com a sílica num vidrado ou numa massa cerâmica.

Alcalino: qualidade de álcalis (ver álcalis).

Devitrificação: é a cristalização de um vidrado durante seu resfriamento, formando cristais sobre a superfície. A formação de cristais é ocasionada devido à combinação de óxidos, juntamente com o controle do resfriamento, que deve ser lento. Um dos óxidos que favorece o aparecimento de cristais é o óxido do zinco. 
Fundente: é um óxido que abaixa o ponto de fusão da sílica no vidrado ou numa massa cerâmica quando atua também com outros óxidos.

\begin{tabular}{|l|l|l|}
\hline Fundentes & Oxido de sódio $(\mathrm{Na2O})$ & Óxido de potássio $(\mathrm{Na2O})$ \\
\hline Oxido de líto $(\mathrm{Li2O})$ & Oxido de berílio $(\mathrm{BeO})$ & Óxido de cálcio $(\mathrm{CaO})$ \\
\hline Oxido de magnésio $(\mathrm{MgO})$ & Oxido de bário $(\mathrm{BaO})$ & Óxido de chumbo $(\mathrm{PbO})$ \\
\hline Oxido de estrôncio $(\mathrm{SrO})$ & Oxido de zinco $(\mathrm{ZnO})$ & Oxido de manganês $(\mathrm{MnO})$ \\
\hline Oxido de boro $(\mathrm{B} 2 \mathrm{O} 3)$ & Oxido de bismuto $(\mathrm{Bi2O}$ & Oxido de cobalto $(\mathrm{CoO})$ \\
\hline Oxido de ferro $(\mathrm{FeO})$ & Oxido de níquel $(\mathrm{NiO})$ & \\
\hline Oxido de cobre $(\mathrm{CuO})$ & & \\
\hline
\end{tabular}

Opacificante: são os óxidos ou matérias-primas que tiram a translucidez dos vidrados, deixando um aspecto "leitoso" que impede a passagem de luz. Esses elementos quando derretidos durante a queima não se dissolvem no vidrado e as partículas que restaram formam cristais que não permitem a passagem de luz. As matérias-primas mais utilizadas para opacificar um vidrado cerâmico são: óxido de estanho, óxido de zircônio, caulim e talco.

Raku: De acordo com Watkins e Wandless ${ }^{258}$, o Raku é um processo de queima de vidrado de baixa temperatura (980 a $\left.1000^{\circ} \mathrm{C}\right)$. Durante a queima a peça é submetida a variações de atmosfera e resfriamento que criam texturas e efeitos surpreendentes e peculiares. Originalmente, esse tipo de queima foi criado no Japão no século XVI d.C. e está diretamente ligada à Cerimônia do Chá e ao Zen Budismo. A palavra Raku tem origem do ideograma chinês cujo significado engloba conceitos como prazer, felicidade, simplicidade, intimidade e rusticidade. O Raku japonês terminava o processo de queima quando removia a peça de dentro do forno, permitindo que na superfície do vidrado fossem criadas rachaduras, resultante do choque térmico. Para ressaltar ainda mais tais rachaduras eram mergulhadas em chá.

\footnotetext{
${ }^{258}$ WATKINS, James C. e WANDLESS, Paul A. Alternative kilns \& firing techniques.New York: Lark books, 2004, p. 13.
} 
O método de queima de Raku utilizado atualmente foi criada na década de 60 nos Estados Unidos e difere do método japonês, pois quando a temperatura chega de 980 a $1000^{\circ} \mathrm{C}$, a peça é retirada forno, ainda incandescente, sofre choque térmico, é colocada em um tambor com serragem e imediatamente é abafada, criando assim um ambiente redutor. As peças devem ser previamente biscoitadas e esmaltadas.

Refratário: resistente à altas temperaturas. $\mathrm{Na}$ indústria cerâmica, refratário é considerado o material que resiste a $1700^{\circ} \mathrm{C}$, mas para a cerâmica de ateliê considera materiais como massas ou argilas refratários a $1300^{\circ} \mathrm{C}$ sem deformações.

Vitrificação: é o estágio mais avançado na queima, sem que haja deformação à peça cerâmica. No ponto de vitrificação, o corpo geralmente está em estado maleável, isto é, pode ser deformado por pressão, mas um pote mantém a sua forma por causa da força da sua estrutura. A vitrificação é o resultado do derretimento dos elementos derivados dos feldspatos e sílica livre presentes na massa cerâmica. Este silicato fundido flui para os interstícios entre as partículas de argila, derretendo e unindo-os. 


\section{Bibliografia}

ADAMSOM, Glenn. Thinking through craft. New York: Berg, 2007.

ANDRADE, Mário de. 0 baile das quatro artes. Rio de Janeiro: Editora Nova Fronteira, 2012. (Livro eletrônico)

AUN, Cristiane Rodrigues. Proposta de uma metodologia de projeto para a louça utilitária de uso doméstico. Dissertação de Mestrado apresentada à Faculdade de Arquitetura e Urbanismo da USP, São Paulo, 2000.

AUN, Cristiane Rodrigues. Proposta de uma nova linguagem de projeto para o revestimento cerâmico aplicado às fachadas para o uso doméstico e/ou comercial. Tese de Doutorado apresentada à Faculdade de Arquitetura e Urbanismo da USP, São Paulo, 2005.

BACHELARD, Gastón. A terra e os devaneios da vontade. São Paulo: Editora Martins Fontes, 2008.

BACHELARD, Gastón. A terra e os devaneios do repouso. São Paulo: Editora Martins Fontes, 1990.

BACHELARD, Gastón. Psicanálise do fogo. São Paulo: Editora Martins Fontes, 1994.

BARDI, Pietro Maria, 1900-1999. Arte da cerâmica no Brasil. São Paulo: Banco Sudameris Brasil, 1980.

BARROS, Manoel de. Poesia Completa Brochura. São Paulo: Editora Leya, 2013.

BELTING, Hans. The end of the History of Art? Chicago: The University of Chicago Press, 1987.

BENGISU, Murat. Engineering ceramics. Berlim: Springer Verlag, 2001.

BERNARD, Rob; DAINTRY, Natasha \& TWOMEY, Claire. Breaking the Moulds: New approaches to ceramics. London: Black Dog Publishing, 2007.

BIRKS, Tony. The Potter's Companion: The complete guide to pottery making. New York: E.P. Duttton \& Co., 1977. 
BONATO, Ernesto. Imanência. Dissertação de Mestrado apresentada à Escola de Comunicações e Artes da USP, 1999.

BRANCANTE, Eldino da Fonseca. O Brasil e a cerâmica antiga. São Paulo: Cia. Lithografica Ypiranga, 1981.

BRENNAND, Francisco. Testamento I: Oráculo contrariado. Recife: Bagaço, 2005.

CÁCERES, Karina M. Tolentino. Estudio de pre-factibilidad para la producción y comercialización de cerámicas de chulucanas. Tese apresentada à Pontifícia Universidade católica do Peru, 2007.

CANSECO, Maria Rostworowski de Diez. Historia del Tahuantinsuyu. Lima: IEP, Instituto de Estudios Peruanos1988.

CAVANAUGH, Alden; YONAN, Michael E. The cultural aesthetics of eighteenthcentury porcelain. Guildford: Ashgate Publishing Limited, 2010.

CHAVARRIA, Joaquim. Moldes. Barcelona: Parromón Ediciones, 2008.

CHIPP, H.B. Teorias da Arte Moderna. São Paulo: Editora Martins Fontes, 1999.

CHITI, Jorge Fernández. Curso práctico de cerámica: artística e artesanal, v. 1,2 e

3. Buenos Aires: Ediciones del Taller Condrhuasi, 1995.

CHITI, Jorge Fernández. Manual de esmaltes cerámicos - el libro de las formulas, TOMO I, II e III. Buenos Aires: Ediciones del Taller Condrhuasi, 1976.

CLARK, Garth (org.). Ceramic Millennium. Nova Scotia: The press of the Nova Scotia, 2006.

CLARK, Garth, STRASS, Cindy. Shifting paradigms in contemporary ceramics: the Garth Clark and Mark Del Vecchio collection. Houston: The Museum of Fine Arts of Houston, 2012.

CLAYTON, Pierce. The clay lover's guide to making molds. North Caroline: Lark Ceramics book, 1998.

COLI, Jorge. O que é Arte? São Paulo: Editora Brasiliense, 1995.

COOPER, Emmanuel. Ten thousand years of pottery. Philadelphia: University of Pennsylvania, 2000. 
COSENTINO, Peter. The Encyclopedia of pottery techniques. Philadelphia : Running press, 1990.

COSTA, Luís Adriano Mendes Costa. Antonio Carlos Nóbrega em acordes e textos armoriais. Campina Grande: Eduepb, 2011.

COUTTS, Howard. The art of ceramics: European ceramic design 1500-1830. New York: Yale University Press, 2001

DALGLISH, Lalada. Noivas da Seca: Cerâmica Popular do Vale do Jequitinhonha. São Paulo: Editora UNESP, 2006.

DANTO, Arthur C. Após o fim da Arte: a arte contemporânea e os limites da história. São Paulo: Edusp, 2010.

DEL VECCHIO, Mark. Postmodern Ceramics. New York: Thames \&Hudson, 2001.

EARLE, Joe. Ceramica clay: Japanese ceramics for the new century. Boston: MFA Publications, 2005.

ECWC (European Ceramic Work Centre) / REIJNDERS, Anton. The ceramic process: a manual and source of inspiration for ceramic art and design. London: A\&C Black, 2005.

FILHO, Antônio Gonçalves. Kimi Nii. São Paulo: Editora Instituto Tomie Ohtake, 2011.

GABBAI, Miriam B. Birmam. Cerâmica: Arte da Terra. São Paulo: Callis, 1987.

GIL, Antonio Carlos. Como elaborar projetos de pesquisa. São Paulo: Atlas editora, 2010.

GOLEMAN, Daniel. Inteligência emocional. Rio de Janeiro: Editora Objetiva, 1995.

GRINBERG, Norma Tenenholz. Humanoides: Transmutações da forma e da matéria. Dissertação de Mestrado apresentada à Escola de Comunicações e Artes da USP, São Paulo, 1994.

GRINBERG, Norma Tenenholz. Lugar com Arco. Tese de Doutorado apresentada à Escola de Comunicações e Artes da USP, São Paulo, Brasil, 1999. 
GRINBERG, Norma Tenenholz. Memorial de um percurso: pesquisa, produção e ensino. Memorial apresentado à Escola de Comunicações e Artes da USP. São Paulo: 2007.

GRINBERG, Norma Tenenholz; AUN, Cristiane Rodrigues; LIMA, Patrícia Miranda; TAGUSAGAWA, Silvia Noriko. Desenvolvimento de massas cerâmicas com características visuais diversas para utilização em trabalhos artísticos. Projeto de pesquisa prática e teórica apresentado à Escola de Comunicações e Artes da USP. São Paulo: 2008.

GULLAR, Ferreira. O universo de Francisco Brennand. Rio de Janeiro: G. Ermakoff Casa Editorial, 2011.

HAMER, Frank e HAMER, Janet. The potter's dictionary of materials and techniques. Philadelphia: University fo Pennsylvania Press, 2004.

HAMILTON, David. Manual of pottery and ceramics. Pennsylvania: Thames and Hudson, 1974.

HELD, Maria Sílvia Barros de. Cerâmica urbana: entre a arte e o artesanato (estudo sobre a cerâmica urbana na cidade de São Paulo), Tese de Doutorado apresentada à Escola de Comunicações e Artes da USP, São Paulo, 1988.

HOPPER, Robin. The ceramic sprectrum. Ohio: The American Ceramic Society, 2004.

LEACH, Bernard. A potter's book, London: Faber \& Faber, 1976.

LIMIA, Beth e LIMA, Valfrido. Em nome do autor: artistas artesãos do Brasil. São Paulo: Proposta editorial, 2008.

MACHADO, Marília Novais da Mata. Entrevista de pesquisa: a interação pesquisador/entrevistado. Belo Horizonte: Editora C/ Arte, 2002.

MATOS, Carolina. Mulheres jornalistas no telejornalismo: a cidadania das que constroem cidadania. Dissertação de Mestrado apresentada à Escola de Comunicações de Artes da USP, São Paulo, 2006.

MILLS, Maureen. Superface design for ceramics. New York: Lark Books, 2008. 
MIRÓ, Joan \& RAILLARD, Geoges. A cor dos meus sonhos: entrevistas com Georges Raillard/Joan Miró. São Paulo: Editora Estação Liberdade, 1992.

MOREIRA, Fernanda. 0 uso de modelos físicos na indústria cerâmica durante o processo de projeto de produto e as possiblidades da inserção de tecnologias digitais nesse processo - estudo de caso. Dissertação apresentada à Faculdade de Arquitetura e Urbanismo da USP, São Paulo, 2014.

MORGENTHAL, Deborah \& TOURTILLOTT, Suzanne J.E. The penland book of ceramics: masterclasses in ceramic techniques. New York: Lark Ceramics Book, 2003.

NAKANO, Katsuko. Terra fogo homem. São Paulo: Aliança Cultural Brasil-Japão, 1989.

NEWTON JÚNIOR, Carlos. O pai, o exílio e reino: a poesia armorial de Ariano Suassuna. Recife: Editora Universitária UFPE, 1999.

NII, Kimi e GONÇALVES FILHO, Antônio. Kimi Nii. São Paulo: Instituto Tomie Ohtake, 2011.

NORTON, F. H. Ceramics for the artist potter. Massachusets: Addison-Wesley Publishing Company, 1956.

OSTROWER, Fayga. Acasos e criação artística. Rio de Janeiro: Elsevier Editora, 1999.

OSTROWER, Fayga. Criatividade e processos de criação. Petrópolis: Editora Vozes, 2012.

PAIM, Gilberto. Cerâmicas da Série o Horla. Rio de Janeiro: Imprinta Gráfica e Editora, 1990.

PERRYMAN, Jane. Naked clay: ceramics without glaze. London: A \& C Black, 2004. PESSOA, F. "Caracterização individual dos heterônimos". In: Obras em Prosa. $1^{\circ}$ Ed. Rio de Janeiro: Nova Aguilar, 1974.

PETERSON, Susan. Contemporary Ceramics. New York: Watson-Guptill Publications, 2000. 
PETRIE, Kevin. The new ceramics: ceramic transfer printing. London: A \& C Black, 2011.

PEVSNER, Nikolaus. Os pioneiros do desenho moderno. São Paulo: Martins Fontes, 2002.

PILEGGI, Aristides. Cerâmica no Brasil e no mundo. São Paulo: Ed. Martins Fontes, 1958.

QUINN, Anthony. Ceramic Design Course. London: Barron's, 2007.

READ, Herbert. The meaning of art. London: Pinguin books, 1967.

REALE, Giovanni. Para uma nova interpretação Platão. São Paulo: Edições Loyola, 1997.

REIJNDERS, Anton. "The ceramic process: a manual and source of inspiration for ceramic art and design". In: ECWC - European Ceramic Work Centre. London: A\&C Black, 2005.

RHODES, Daniel. Clay and glazes for the potter. Pennsylvania : Chilton,1973.

RHODES, Daniel. Pottery form. New York: Dover Publications Inc., 1976-2010.

RHODES, Daniel. Kilns. Philadelphia: Chilton Book Company, 1968.

ROLLA, Marco Paulo. O corpo e o material: uma reflexão social do desejo na vida através da arte. Dissertação de mestrado apresentada à faculdade de Belas Artes da Universidade Federal de Minas Gerais, 2006.

ROLLA, Marco Paulo. Vertigem. Belo Horizonte: CEIA (Centro de Experimentação e Informação em Arte), 2012.

SALLES, Cecília Almeida. Gesto inacabado: processo de criação artística. São Paulo: Annablume, 2001.

SALLES, Cecília Almeida. Redes da criação: construção da obra de arte. São Paulo: Editora Horizonte, 2006.

SARAMAGO, José. A caverna. São Paulo: Companhia das Letras, 2000.

SAVAGE, George. An ilustrated dictionary of ceramics. London: Thames \& Hudson, 1976. 
SCHWARTZ, Judith S. Confrontational ceramics. London: A \& C Black, 2008.

SCOTT, Paul. Ceramic and print. London: A\&C Black, 1994-2002.

SENNETT, Richard. O artífice. Rio de Janeiro: Editora Record, 2012.

TAGUSAGAWA, Silvia N. Articulações: Poéticas do corpo. O corpo expressado através da cerâmica. Dissertação de Mestrado apresentada à Escola de Comunicações e Artes da USP, 2009.

TATAY, Helena. Anna Maria Maiolino. São Paulo: Cosac Naify, 2012.

TAYLOR, Louisa. The ceramics bible. San Francisco: Chronicle Books, 2011.

TOURTILLOT, Suzanne J. E. $\mathbf{5 0 0}$ Ceramic Sculptures: Contemporary Practice, singular works. New York: Lark ceramics book, 2007.

TOURTILLOT, Suzanne J. E. The figure clay: contemporary sculpting techniques by master artists. New York: Lark ceramics book, 2006.

VERA, Genaro Maza. La Cultura Tallán. Piura: Centro Editorial Tallán, 2004.

VERA, Genaro Maza. La Cultura Tallán: Los Tallanes fueron expertos navegantes. Piura: Centro Editorial Tallán, 2002.

VOLKSWAGEM DO BRASIL S.A. Artistas da cerâmica brasileira. São Paulo: Volkswagem, 1985.

WAAL, Edmund de \& CLARE, Claudia. The pot book. London: Phaidon, 2011.

WAAL, Edmund de. 20th Century Ceramics. London: Thames \& Hudson world of art, 2003.

WANDLESS, Paul Andrew. Image transfer on clay. New York: Lark Ceramics Book, 2006.

WATKINS, James C. \& WANDLESS, Paul Andrew. Alternative kilns \& firing techniques. New York: Lark Books, 2004

YASSUDA, André L. Passagens. Dissertação de Mestrado apresentada à Escola de Comunicações e Artes da USP, 2011.

ZAKIN, Richard. Electric Kiln Ceramics. Wiscosin: Krause Publication,1994. 


\section{Periódicos}

LA REVUE DE LA CERÁMIQUE ET DU VERRE, Vendin-le-Vieil, França.

HBM PRINT PTY. Ceramics Arts and Perception Magazine. Sydney, Australia.

THE AMERICAN CERAMIC SOCIETY. Ceramics Monthly Magazine. Ohio, USA.

THE AMERICAN CERAMIC SOCIETY. Studio Pottery. Ohio, USA

\section{Apostilas}

Apostilas SENAI "Mário Amato".

CORDEIRO, Vicente de Fábio. Vidrados cerâmicos. Centro Nacional de Tecnologia - SENAI "Mário Amato" - Núcleo de Cerâmica, s.d.

PRACILDELLI, Sebastião e WATANABE, Helena. Serigrafia Industrial, Centro Nacional de Tecnologia - SENAI “Mário Amato" - Núcleo de Cerâmica, 2001.

SILVA, Elton Gourlart. Fôrmas de gesso. Centro Nacional de Tecnologia - SENAI "Mário Amato" - Núcleo de Cerâmica, s.d.

VANDERLINDE, Flávia. Esmaltes Cerâmicos. Centro Nacional de Tecnologia SENAI "Mário Amato" - Núcleo de Cerâmica, s.d.

\section{Sites}

Entrevista com Jun Kaneko para a Net Nebraska televison: <https://www.youtube.com/watch?v=HvmU5Vm6iol> Acesso em: 16/06/2011.

Vídeo: Entrevista com LaerteRamos:

<https://www.youtube.com/watch?v= b1bYWE6C7Q> Acesso: 01/07/2011

EKWC <http://sundaymorning.ekwc.nl/ > Acesso: 10/10/2011

Norma Grinberg. <http://www.normagrinberg.com.br> Acesso em: 09/08/2011.

Kimi Nii. <http://www.kiminii.com.br> Acesso em: 02/02/2012. 
Brian Peters e impressão 3D: <http://www.dezeen.com/2012/10/31/building-bytes3d-printed-bricks-brian-peters/> 02/02/2013.

Marco Paulo Rolla. <http://marcopaulorolla.blogspot.com.br/> Acesso em: 23/03/2013.

Entrevista com Marco Paulo Rolla.

<http://www.itaucultural.org.br/aplicExternas/enciclopedia_IC/index.cfm?fuseaction=a rtistas_biografia\&cd_verbete=2636\&cd_idioma=28555> Acesso em: 08/05/2013.

Biografia de José Yamunaque.

<http://joseyamunaque.blogspot.com.br/2011_07_01_archive.html> Acesso:em 22/05/2013.

Artigo da Craft Horizons July / August 1961 (Volume 21, Number 4) Vol21No04_Jul1961 31. The New Ceramic Presence by Rosa Slivka:

<http://digital.craftcouncil.org/cdm/ref/collection/p15785coll2/id/2693> Acesso em $01 / 06 / 2013$

Texto de Marcos Hill sobre Marco Paulo Rolla.

<http://www.galeriavermelho.com.br/pt/artista/97/marco-paulo-rolla/textos > Acesso em: 06/08/2013.

Laerte Ramos. <http://www.laerteramos.com.br> Acesso em :12/08/2013.

Máyy Koffer:< www.Máyykoffler.com.br > Acesso em: 01/09/2013

Miguel dos Santos. <www.migueldossantos.com.br> Acesso em: 08/09/2013.

Biografia de Ernst Barlach:

$<$ http://www.moma.org/collection_ge/artist.php?artist_id=335> Acesso em:

08/01/2014.

Entrevista com Jun Kaneko série: Nebraska Masterpieces: Arts Education Series Jun Kaneko.<http://www.youtube.com/watch?v=-T9QLpTxnzo> Acesso em: 18/02/2014.

Documentário Laerte Ramos. "Casamata". <http://www.youtube.com/watch?v=QrOAADGIdDg> Acesso em 22/05/2014. 
Rijksmuseum <https://www.rijksmuseum.nl > Acesso em: 30/12/2014.

Documentário Laerte Ramos. "Casamata".

<http://www.youtube.com/watch?v=QrOAADGldDg> Acesso em 22/05/2014.

Fornos Noborigama: < http://www.ateliesj.com.br/> (02/01/2015)

Documentário: Do barro à Pedra do Reino, Miguel dos Santos, 2010.

Documentário "Manoel de Barros - 'Só dez por cento é mentira" - Direção: Pedro Cezar. (http://www.sodez.com.br/). Acesso em: 12/08/2013. 